\title{
Hypercoordinated Oxazoline and Ethyl Pyridyl Organotin Compounds: Potential Routes to Stable Polystannanes
}

\author{
By \\ Desiree Bender \\ Honours Bachelor of Science in Chemistry, \\ Western University, London, Canada, 2012
}

A thesis presented to Ryerson University

in partial fulfillment of the

requirements for the degree of

Master of Science

in the program of

Molecular Science

Toronto, Ontario, Canada, 2018

(C) Desiree Bender 2018 


\section{Author's Declaration}

I hereby declare that I am the sole author of this thesis. This is a true copy of the thesis, including any required final revisions, as accepted by my examiners.

I authorize Ryerson University to lend this thesis to other institutions or individuals for the purpose of scholarly research.

I further authorize Ryerson University to reproduce this thesis by photocopying or by other means, in total or in part, at the request of other institutions or individuals for the purpose of scholarly research.

I understand that my thesis may be made electronically available to the public. 


\title{
Hypercoordinated Oxazoline and Ethyl Pyridyl Organotin Compounds: Potential Routes to Stable Polystannanes
}

\author{
Desiree Bender, Master of Science - Molecular Science, Ryerson University, 2018
}

\begin{abstract}
Tetraorganotin chelating tin (IV) compounds containing a rigid (10) and a semi-flexible (18) oxazoline ligand were synthesized by a reaction between the lithiated oxazoline and $\mathrm{Ph}_{3} \mathrm{SnCl}$ in good yields. Conversion into their corresponding dihalide species by reaction with two equivalents of bromine was undertaken to yield the dibromide species, $\mathbf{1 3}$ and $\mathbf{2 0}$ respectively. Xray crystallography of these compounds revealed relatively short tin-nitrogen bond distances (10: 2.762 13: $2.383,18: 3.234 \AA$ ). These all fall within the Van der Waal radii of a tin-nitrogen bond and all adopt a distorted trigonal bipyramidal geometry in the solid state. Compounds $\mathbf{1 3}$ and 20 were converted into the corresponding dihydrides by reaction with $\mathrm{NaBH}_{4}$. Polymerization of the corresponding tin dihydrides produced low molecular weight polymers, 10,100 Da for the rigid species (16) and 3,200 Da for the semi-flexible tin species (22). A tetraorganotin compound containing a chelating ethyl pyridyl ligand (23) was synthesized by reacting 2-vinyl pyridine with triphenyltin hydride via a hydrostannylation reaction which was further reacted with two equivalents of bromine to yield the dibromide species (24). The X-ray crystallographic data of 23 and 24 showed relatively short $\mathrm{Sn}-\mathrm{N}$ bond lengths of 2.888(2) $\AA$ and 2.363(5) $\AA$ respectively. Compound 24 will be investigated in the future for the stabilization of polystannanes following the synthesis of the dihydride species.
\end{abstract}




\section{Acknowledgements}

I would like to thank my supervisors Drs. Foucher and Gossage for taking me on as a Master's student. They both have been instrumental in my development as a chemist and have provided a lot of guidance and assistance over the last two years. They both always had an open door to answer any questions, provide insightful conversations and order chemicals.

I would also like to thank my committee members, Dr. George, Dr. Rousseau and Dr. Adler for providing me with feedback and pointing me in the right direction with suggestions. I would also like to thank Dr. Koivisto and Dr. Viirre's labs for allowing me to borrow chemcials.

I would like to thank my lab mates, past and present: Jeff, Joe, Jas, Julie, Gloria, Kristy, Rachel, Alex, Kathy, Jeanette, and Tristan. I would like to specifically thank Joe for always having my back and talking sports with me, Gloria, who I dedicate this thesis too, for being my best friend. Rachel, my fume hood mate, for gossiping with me, making a mess of my fume hood, clogging my needle the first week and running all my GPC samples, Kathy AKA mom for always making sure we are taken care of, and Jeff and Julie who taught me the tin ways. Thank you all for going to McDonald's and going to Blue Jay's games with me, as well as playing games and basketball! I really enjoyed my two years here, I have many fond memories and will miss all of you.

I would like to give a big thank you to my mom, all my siblings and Jack for all the love and support while being away from home. 
Table of Contents

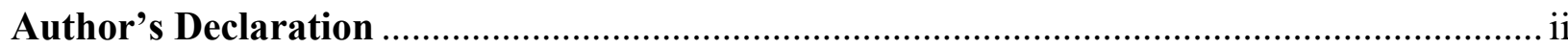

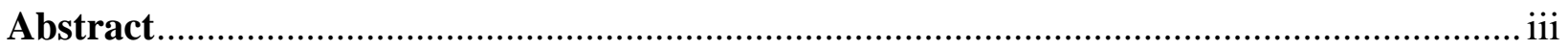

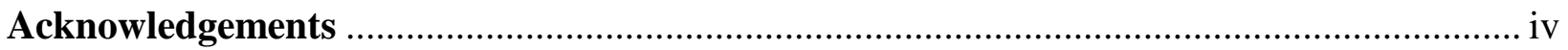

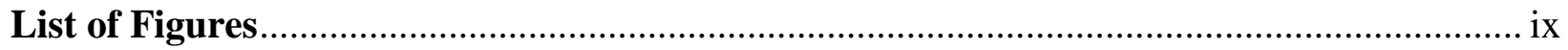

List of Schemes

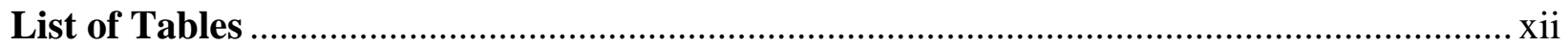

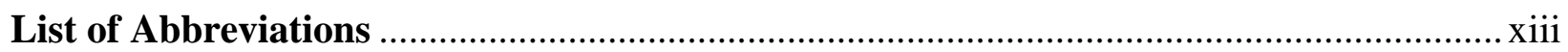

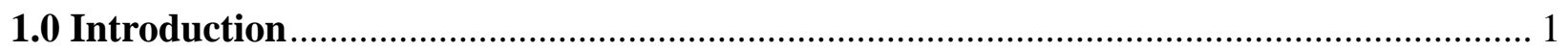

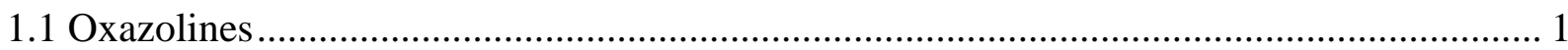

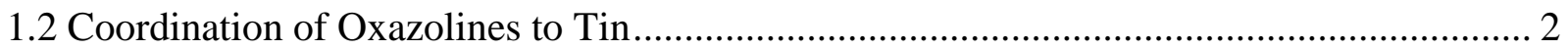

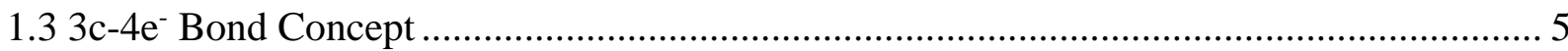

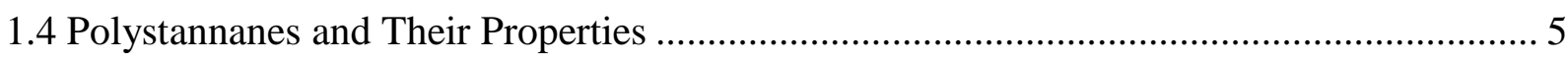

1.4.1 Challenges with Polystannanes ................................................................................. 7

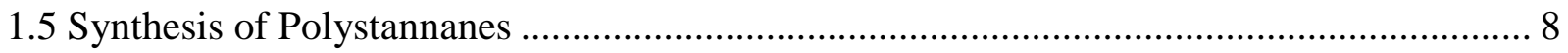

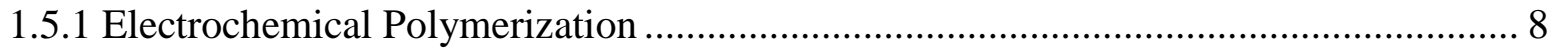

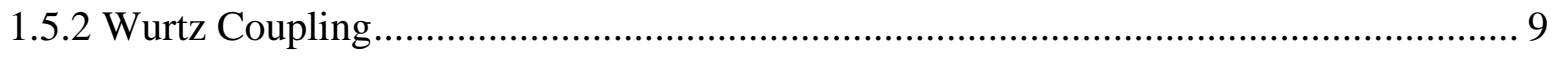

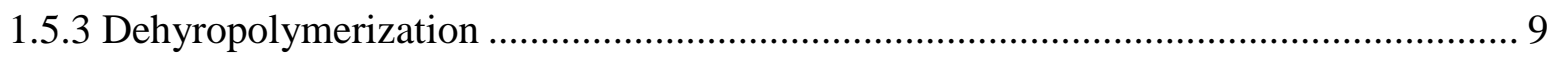

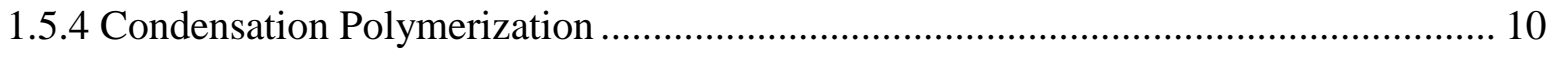

1.6 Previous Work 


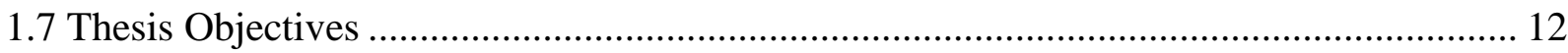

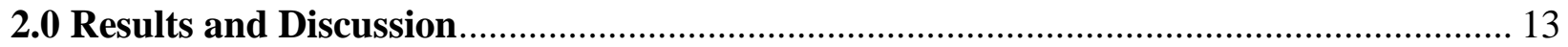

2.1 Synthesis of 2-(2'-bromophenyl)-4,4-dimethyl-4,5-dihydrooxazole 8 ……………......... 13

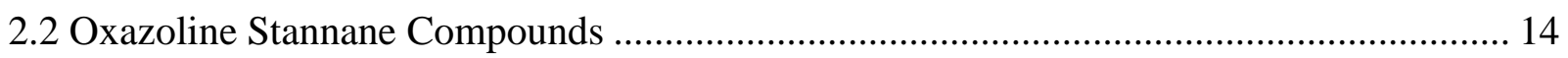

2.2.1 4,4-dimethyl-2-(2-(triphenylstannyl)phenyl)-4,5-dihydrooxazole $\mathbf{1 0} \ldots \ldots \ldots \ldots \ldots \ldots \ldots \ldots \ldots . . . . . . . . .14$

2.2.2 2-(2-(chlorodiphenylstannyl)phenyl)-4,4-dimethyl-4,5-dihydrooxazole 11 ............... 16

2.2.3 Attempted synthesis of 2-(2-(dichloro(phenyl)stannyl)phenyl)-4,4-dimethyl-4,5-

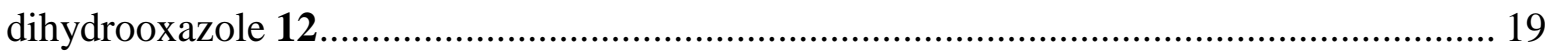

2.2.4 Synthesis and characterization of compound 13 ................................................ 20

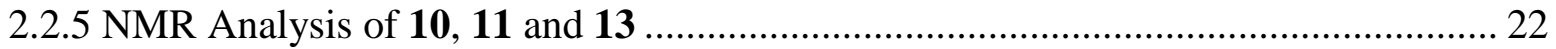

2.3 Synthesis of 4,4-dimethyl-2-(2-(phenylstannyl)phenyl)-4,5-dihydrooxazole $\mathbf{1 4}$............... 24

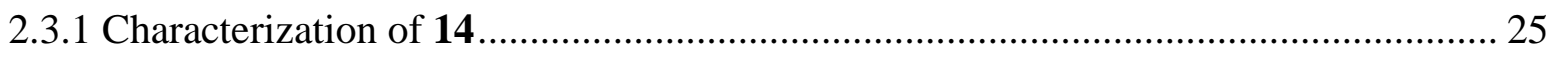

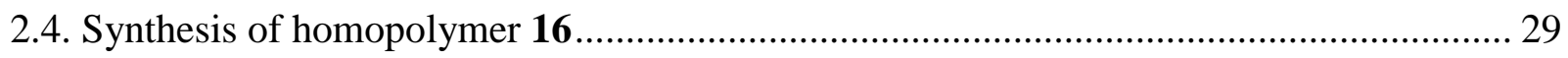

2.4.1 Dehydropolymerization using Wilkinson's catalyst.................................................... 29

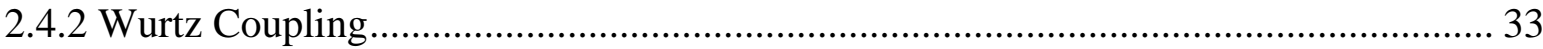

2.5 Synthesis and characterization of 4,4-dimethyl-2-(2-((triphenylstannyl)methyl)phenyl)-4,5-

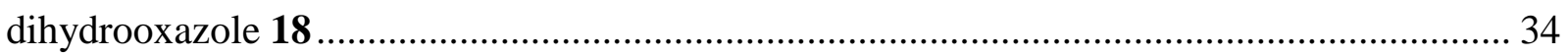

2.5.1. Attempted synthesis of semi-flexible oxazoline stannane halides............................. 37

2.5.2 Synthesis of 4,4-dimethyl-2-(2-((phenylstannyl)methyl)phenyl)-4,5-dihydrooxazole

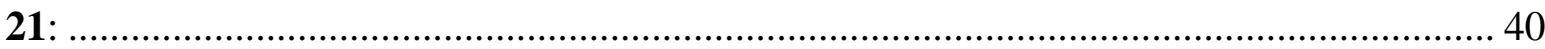


2.5.3 Synthesis of polymer $\mathbf{2 2}$ :

2.6 Synthesis of of 2-(2-(triphenylstannyl)ethyl)pyridine $\mathbf{2 3}$ : 43

2.7 Synthesis of 2-(2-(dibromo(phenyl)stannyl)ethyl)pyridine $\mathbf{2 4 :}$ 45

3.0 Conclusions 49

4.0 Future Work 51

5.0 Experimental 52

5.1 Synthesis of 2-(2-bromophenyl)-4,4-dimethyl-4,5-dihydrooxazole (8): 53

5.2 Synthesis of 4,4-dimethyl-2-(2-(triphenylstannyl)phenyl)-4,5-dihydrooxazole (10): 55

5.3 Synthesis of 2-(2-(chlorodiphenylstannyl)phenyl)-4,4-dimethyl-4,5-dihydrooxazole (11):

5.4 Synthesis of 2-(2-(dibromo(phenyl)stannyl)phenyl)-4,4-dimethyl-4,5-dihydrooxazole (13):

5.5 Synthesis of 4,4-dimethyl-2-(2-(phenylstannyl)phenyl)-4,5-dihydrooxazole (14): 59

5.6 Synthesis of polymer (16): 60

5.7 Synthesis of 4,4-dimethyl-2-(o-tolyl)-4,5-dihydrooxazole (17): 61

5.8 Synthesis of 4,4-dimethyl-2-(2-((triphenylstannyl)methyl)phenyl)-4,5-dihydrooxazole (18) 63

5.9 Synthesis of 2-(2-((dibromo(phenyl)stannyl)methyl)phenyl)-4,4-dimethyl-4,5-

dihydrooxazole (20): 64

5.10 Synthesis of 4,4-dimethyl-2-(2-((tribromostannyl)methyl)phenyl)-4,5-dihydrooxazole (19): 
5.11 Synthesis of 4,4-dimethyl-2-(2-((phenylstannyl)methyl)phenyl)-4,5-dihydrooxazole (21): 66

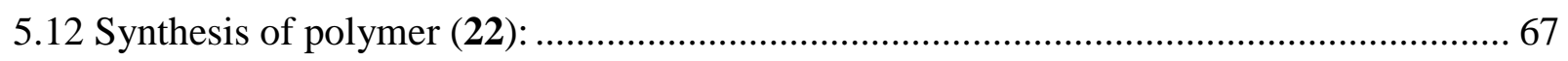

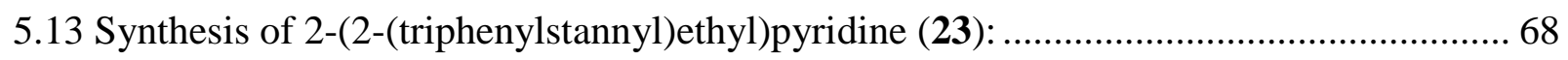

5.14 Synthesis of 2-(2-(dibromo(phenyl)stannyl)ethyl)pyridine (24): ............................. 69

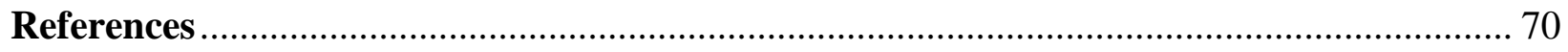

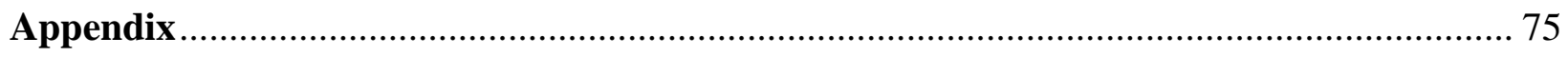




\section{List of Figures}

Figure 1: Structure and numbering system of 2-oxazolines. 1

Figure 2: Structures of ortho (A), para (B) substituted tin oxazoline and 2-pyridine (C), 4pyridine (D) ethyl tin compounds 3

Figure 3: ${ }^{15} \mathrm{~N}$ NMR spectra of $\mathbf{5 , 1}$ and $\mathbf{3}$ respectively. Asterik denotes ${ }^{117 / 119} \mathrm{Sn}$ Satellites. Used with permission from Elsevier. 4

Figure 4: Examples of hypercoordinate tin structures. ........................................................ 5

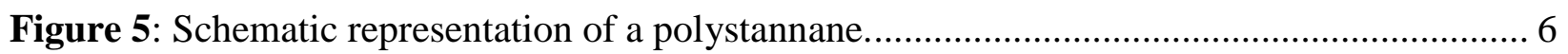

Figure 6: Degradation of polystannanes under light and moisture conditions. ............................ 7

Figure 7: Rigid (A) and flexible (B) hypercoordinate tin structures......................................... 12

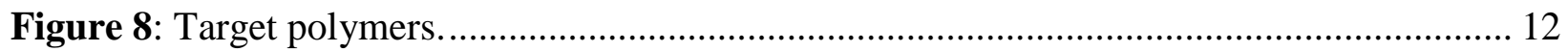

Figure 9: ORTEP representation of 10. Thermal ellipsoids drawn at the $30 \%$ level.................. 15

Figure 10: ORTEP representation of 11. Thermal ellipsoids drawn at the $30 \%$ level................ 17

Figure 11: ORTEP representation of a unit cell molecule of 13. Thermal ellipsoids drawn at the $30 \%$ level. 21

Figure 12: ORTEP representations of rigid hypercoordinate dimethylammino stannanes. Used

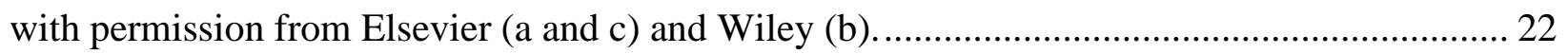

Figure 13: ${ }^{119} \mathrm{Sn}$ NMR spectra $\left(\mathrm{CDCl}_{3}\right)$ of compounds 10, 11, and 13.................................. 23

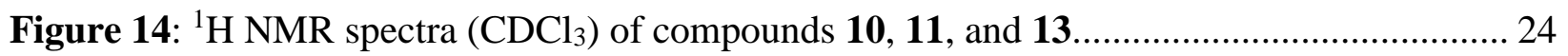

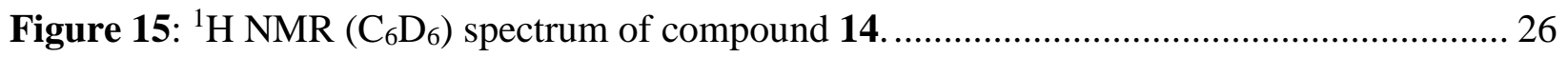

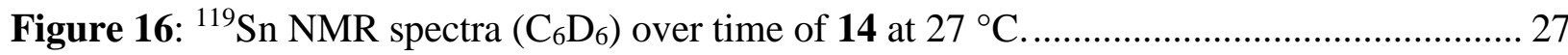

Figure 17: ${ }^{119}$ Sn NMR spectrum of a synthetic attempt to synthesize compound 14................. 28

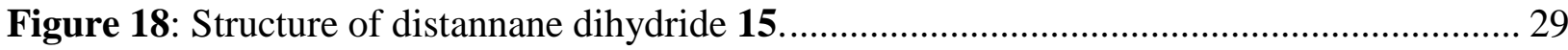


Figure 19: GPC chromatogram of polymer 16.

Figure 20: ${ }^{119} \mathrm{Sn}$ NMR spectrum of crude samples of $\mathbf{1 6}$ at RT (a), RT after cleaning four times (b), doing the polymerization at $-30{ }^{\circ} \mathrm{C}$ for $4 \mathrm{~h}(\mathrm{c})$, and doing the polymerization at $-30{ }^{\circ} \mathrm{C}$ for 6

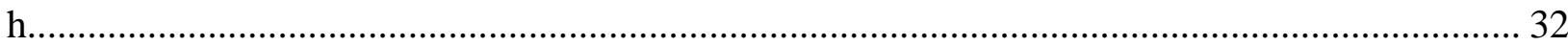

Figure 21: ${ }^{119}$ Sn NMR spectrum of the attempted Wurtz coupling reaction of 13.................. 34

Figure 22: ORTEP representation of two molecules of compound $\mathbf{1 8}$ found in the unit cell.

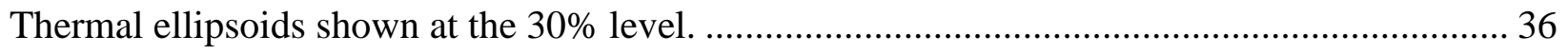

Figure 23: ${ }^{119} \mathrm{Sn}$ NMR spectrum $\left(\mathrm{CDCl}_{3}\right)$ of the reaction with compound $\mathbf{1 8}$ and $\mathrm{Br}_{2} \ldots \ldots \ldots \ldots . \ldots . \ldots$

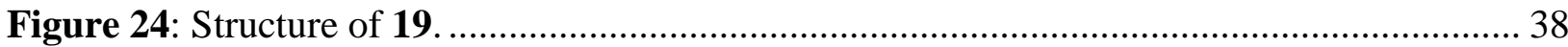

Figure 25: ${ }^{119} \mathrm{Sn} \mathrm{NMR}$ spectrum $\left(\mathrm{CDCl}_{3}\right)$ of the reaction with compound $\mathbf{1 8}$ and $\mathrm{HCl} / \mathrm{Et}_{2} \mathrm{O}$.... 39

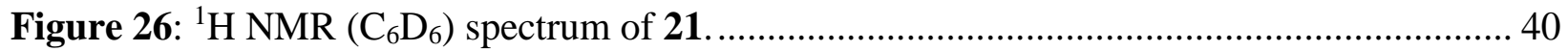

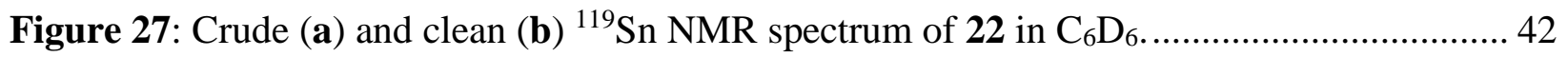

Figure 28: Crude GPC (top), after cleaning GPC (bottom) chromatogram of 22. ................... 43

Figure 29: ORTEP representation of unit cell molecule of 23. Thermal ellipsoids drawn at the 30

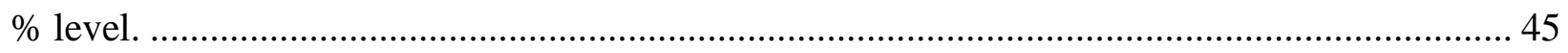

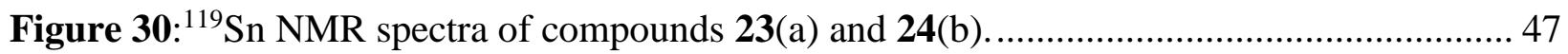

Figure 31: ORTEP representation of two molecules of compound $\mathbf{2 4}$ found in the unit cell.

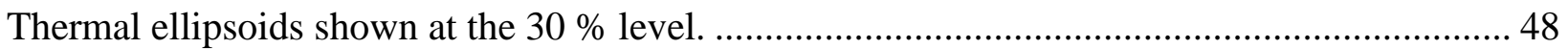




\section{List of Schemes}

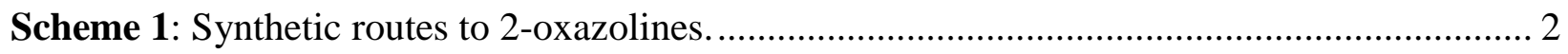

Scheme 2: Electrochemical polymerization of a dialkyltin dihalide.......................................... 8

Scheme 3: Wurtz coupling of a tin dihalide species............................................................... 9

Scheme 4: Dehydropolymerization of a tin dihydride species using a transition metal (TM)

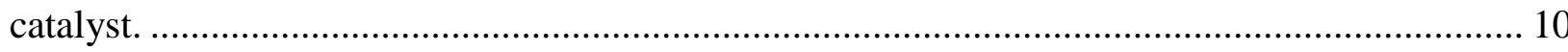

Scheme 5: Condensation polymerization of a tin dihydride and a tin diamide............................ 11

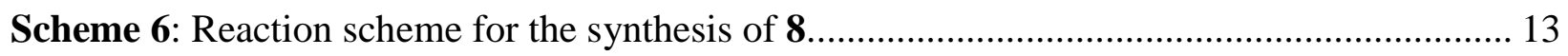

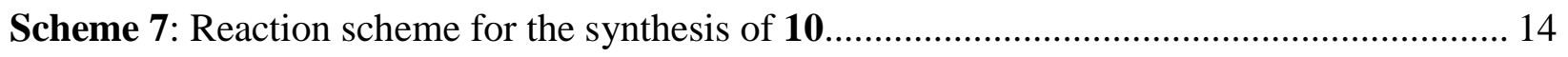

Scheme 8: Reaction scheme of the synthesis of polymer 16.................................................... 30

Scheme 9: Reaction scheme for the synthesis of $\mathbf{1 6}$ via Wurtz coupling.................................... 33

Scheme 10: Reaction scheme for the synthesis of oxazoline stannane 18 …………................. 35

Scheme 11: Reaction scheme for the synthesis of 20.............................................................. 39

Scheme 12: Reaction scheme for the synthesis of 21.............................................................. 40

Scheme 13: Reaction scheme for the synthesis of polymer 22 ............................................... 41

Scheme 14: Reaction scheme for the synthesis of compound 23.............................................. 44

Scheme 15: Reaction scheme for the synthesis of compound 24........................................... 46 


\section{List of Tables}

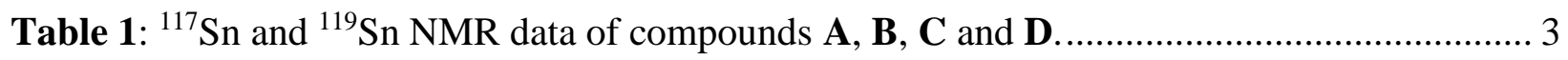

Table 2: Relevant parameters obtained from the crystal data of compound 10...................... 15

Table 3: Relevant parameters obtained from the crystal data of compound 11...................... 18

Table 4: Relevant parameters obtained from the crystal data analysis of compound 13........... 21

Table 5: Relevant crystal structure data analysis of 18 .................................................. 36

Table 6: Relevant parameters obtained from the crystal data analysis of 23......................... 45

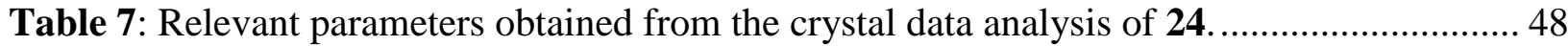




\section{List of Abbreviations}

$\AA$

BHT

b.p.

$\mathrm{CDCl}_{3}$

$\mathrm{C}_{6} \mathrm{H}_{6}$

$\mathrm{C}_{6} \mathrm{D}_{6}$

DCM

$\mathrm{Et}_{2} \mathrm{O}$

$\mathrm{eV}$

$\mathrm{Da}$

DMF

GPC

$\mathrm{HCl}$

$\mathrm{Hz}$

K

$\mathrm{kDa}$

$\mathrm{LiAlH}_{4}$

$\mathrm{Me}$

$\mathrm{MeOH}$

m.p.

$\mathrm{NaBH}_{4}$

NBS
Ångström

butylated hydroxytoluene

Boiling point

hexa-deuterated chloroform

benzene

deuterated benzene

dichloromethane

diethyl ether

electron volt

Daltons

$N, N$ - dimethylformamide

gel permeation chromatography

hydrochloric acid

hertz

Kelvin

kilodaltons

lithium aluminum hydride

methyl

methanol

melting point

sodium borohydride

$N$-bromosuccinimide 


\begin{tabular}{|c|c|}
\hline $\mathrm{nm}$ & nanometer \\
\hline$n$-BuLi & $n$-butyl lithium \\
\hline NMR & nuclear magnetic resonance \\
\hline PDI & polydispersity index \\
\hline $\mathrm{Ph}$ & phenyl \\
\hline ppm & parts per million \\
\hline RT & room temperature \\
\hline $\mathrm{Scm}^{-1}$ & Siemens per centimetre \\
\hline sec-BuLi & sec-Butyllithium \\
\hline $\mathrm{SOCl}_{2}$ & thionyl chloride \\
\hline THF & tetrahydrofuran \\
\hline Tol. & toluene \\
\hline UV-Vis & ultraviolet-visible \\
\hline$\sigma$ & sigma \\
\hline $3 c-4 e^{-}$ & 3-centered-4-electron \\
\hline
\end{tabular}




\subsection{Introduction}

\subsection{Oxazolines}

Oxazolines, also known as 4,5-dihydro-2-oxazoles, are a subclass of azole heterocycles containing a nitrogen and an oxygen atom bonded by an $\mathrm{sp}^{2}$ hybridized carbon in a five-membered ring (Figure 1). ${ }^{1}$ Oxazolines can be derivatized via positions 2,4 and/or 5 to add versatility and to change the properties of the heterocyclic ring. Oxazolines are generally resistant to hydrolysis, oxidation, nucleophiles, bases and radicals, however, oxazolines are generally sensitive to most acids. $^{2}$

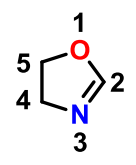

Figure 1: Structure and numbering system of 2-oxazolines.

2-Oxazolines can be synthesized by a variety of different methods including the WitteSeeliger reaction which employs a nitrile group, an amino alcohol and a zinc catalyst at high temperatures in a one pot synthesis ${ }^{3}$ (Scheme 1a), or using an aldehyde and amino alcohol to form an oxazolidine which is then oxidized using $N$-bromosuccinimide to form the oxazoline (Scheme $^{4}$ 1b). Other methods include utilizing a carboxylic acid in an Appel reaction followed by the addition of the amino alcohol and lastly the addition of a base to close the ring (Scheme 1c) ${ }^{5}$ Alternatively, an acid chloride can be reacted with an amino alcohol to the form the amide intermediate followed by ring closure using $\mathrm{SOCl}_{2}$ (Scheme 1d). ${ }^{6}$ A microwave mediated synthesis of oxazolines has also been reported. ${ }^{7}$ 


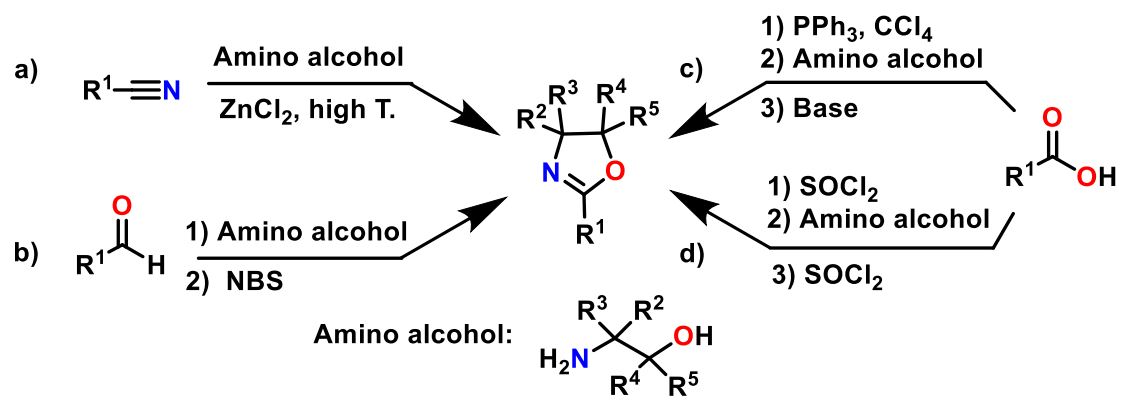

Scheme 1: Synthetic routes to 2-oxazolines.

Oxazolines have also been used as monomers for the synthesis of poly (2-oxazolines) with biomedical applications, ${ }^{8}$ as protecting groups during synthesis, ${ }^{2,6}$ and are able to be coordinated to a variety of metals and non-metals and can be used in symmetric and asymmetric catalysis reactions. $^{5}$

\subsection{Coordination of Oxazolines to Tin}

There have been limited number of tin materials bearing oxazoline ligands reported in the literature. ${ }^{9-12}$ Specifically, 2-phenyl-2-oxazolines are particularly interesting as they allow a five membered chelate ring when the tin center is bonded at the ortho position of the phenyl ring. The first reported complex of this nature was by Jastrzebski et al. in 1991 in which [2-(4,4-dimethyl2-oxazoline)-5-methyl-phenyl]methylphenyltin bromide was synthesized. It was determined through X-ray crystallography of this species that the nitrogen preferentially datively bonds to the tin center over the oxygen atom. ${ }^{13}$ Due to the presence of dative bonding in tetraorganotin species, it essentially changes the geometry around the tin center from tetrahedral to distorted trigonal bipyramidal geometry.

The Staliński group in Poland published a series of papers detailing organotin complexes bearing a chiral 2-phenyl-2-oxazoline to present evidence of an intramolecular Sn-N interaction through the use of ${ }^{1} \mathrm{H},{ }^{13} \mathrm{C},{ }^{15} \mathrm{~N}$, and ${ }^{117} \mathrm{Sn}$ NMR studies. ${ }^{14-17}$ Synthesis of these compounds was 
carried out via a bromine-lithium exchange of the ortho position of the phenyl ring using $n$-BuLi and further reacting with a corresponding tin halide species. As a result of the effect of dative bonding on the electronics of the tin, the chemical shift values in the tin NMR spectra can help identify if dative bonding is present in solution. Staliński et al. probed this effect by synthesizing a series of ortho- (Figure 2A) and para- (Figure 2B) substituted tin complexes consisting of the same 2-phenyl oxazoline derivatives and then compared ${ }^{117} \mathrm{Sn}$ NMR chemical shifts (Table 1). The same trends were seen by Molloy et al. ${ }^{18}$ with an ethyl pyridyl chain bonded to the tin. When the nitrogen was in position -2 (Figure 2C), dative bonding is able to occur while when the nitrogen is in position -4 (Figure 2D), it was unable to bond to the tin. This was shown in Table 1 by comparing the ${ }^{119}$ Sn NMR chemical shift values of these two compounds, showing a more upfield shift of $\mathbf{C}$ in both instances.

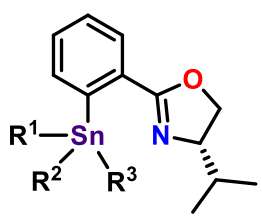

$\mathbf{A}$

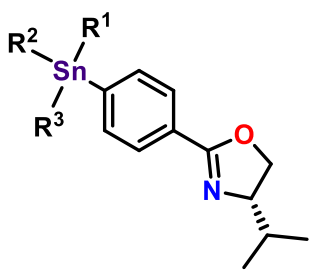

B

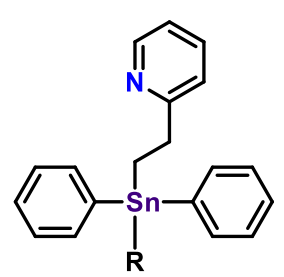

C

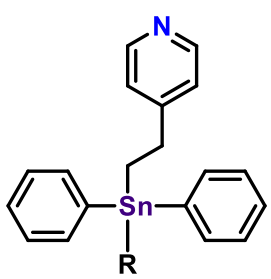

D

Figure 2: Structures of ortho $(\mathbf{A})$, para $(\mathbf{B})$ substituted tin oxazoline and 2-pyridine $(\mathbf{C}), 4$ pyridine (D) ethyl tin compounds.

Table 1: ${ }^{117} \mathrm{Sn}$ and ${ }^{119} \mathrm{Sn}$ NMR data of compounds $\mathbf{A}, \mathbf{B}, \mathbf{C}$ and $\mathbf{D}$.

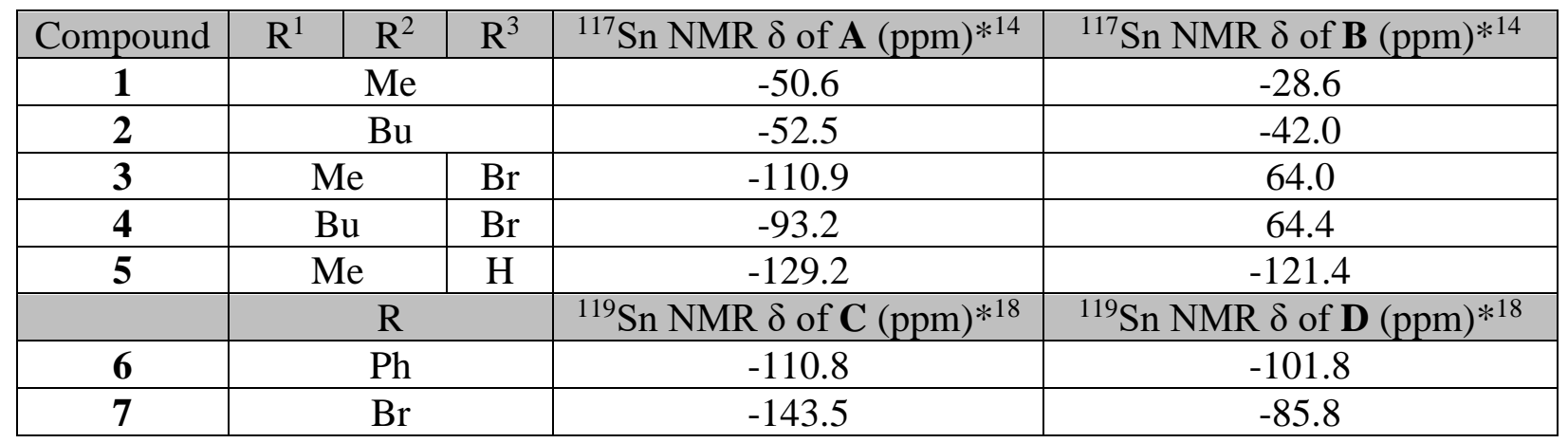

*All values are relative to $(\mathrm{Me})_{4} \mathrm{Sn}$ in $\mathrm{CDCl}_{3}$ at $30^{\circ} \mathrm{C}$. 
As shown in Table 1, all ${ }^{117} \mathrm{Sn}$ NMR chemical shifts in structure $\mathbf{A}$ are shifted more upfield relative to the corresponding $\mathbf{B}$ structures. This is a result of the dative bonding from the lone pair of the ring nitrogen to the tin center, which adds electron density, leading to chemical shifts upfield in the tin NMR. Staliński et al. was also able to present evidence of the dative interaction in solution through ${ }^{15} \mathrm{~N}$ NMR spectroscopy. Shown in Figure 3 are compounds $\mathbf{1 ,} 3$ and $\mathbf{5}$ with all three compounds containing a single nitrogen resonance accompanied by ${ }^{117 / 119} \mathrm{Sn}$ satellites. This indicates the presence and the strength of the tin-nitrogen interaction. Single X-ray crystallography was performed on compounds $\mathbf{1}$ and $\mathbf{3}$ which clearly show dative interactions in the solid state.

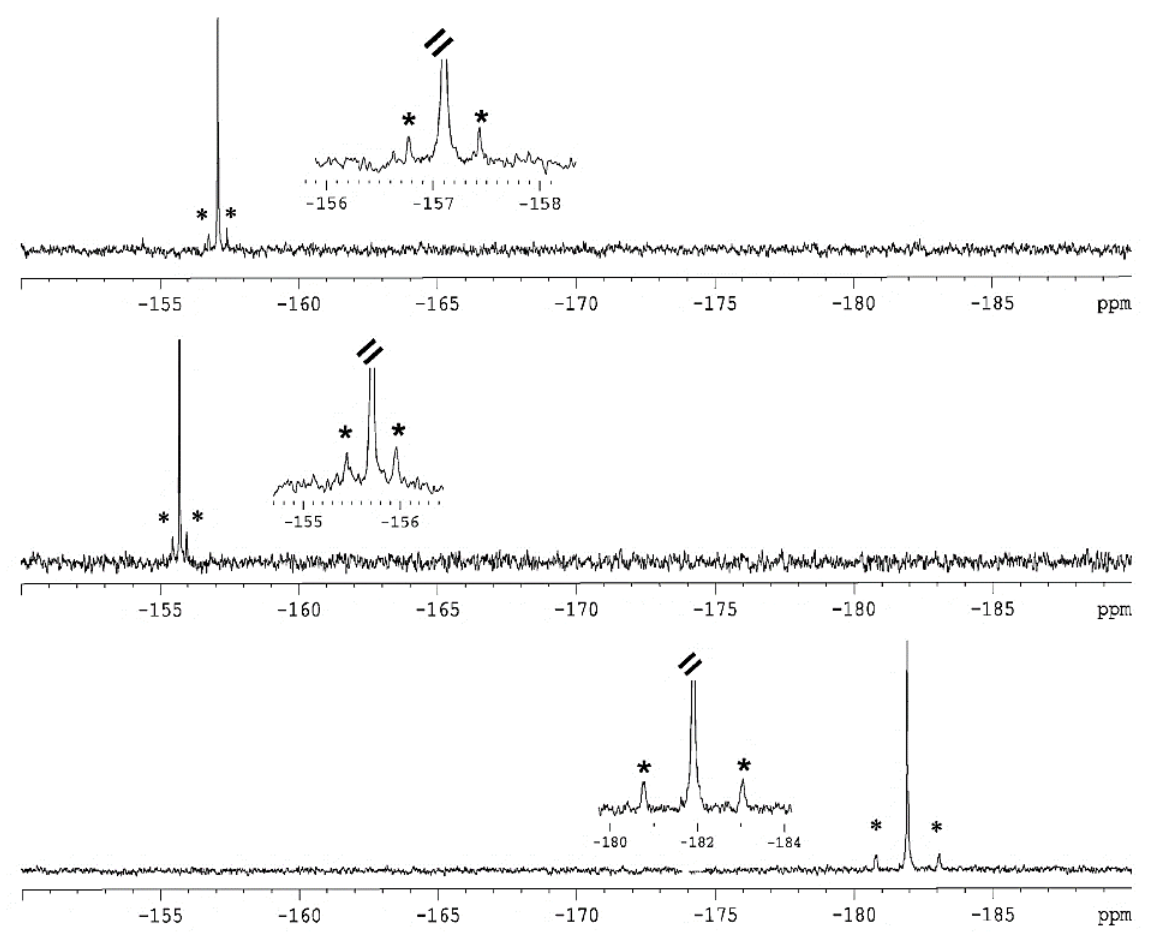

Figure 3: ${ }^{15} \mathrm{~N}$ NMR spectra of 5, 1 and $\mathbf{3}$ respectively. Asterik denotes ${ }^{117 / 119} \mathrm{Sn}$ Satellites. Used with permission from Elsevier.

Compound 1 has a Sn-N bond distance of 2.89(9) Å, while compound 3 had a shorter Sn$\mathrm{N}$ bond distance of 2.39(2) $\AA .{ }^{14}$ These bonds lengths are within the Van der Waals radii of a tin- 
nitrogen bond distance ( $3.72 \AA$ ). The shorter bond distance in compound $\mathbf{3}$ is likely a result of the electron withdrawing effects of the bromine which pulls electron density away from the tin and draws the nitrogen atom closer, likely due its more electropositive nature.

\section{$1.33 \mathrm{c}-4 \mathrm{e}^{-}$Bond Concept}

The $3 \mathrm{c}-4 \mathrm{e}^{-}$bond is a concept used to describe hypervalent compounds which exceed the standard octet of valence electrons. ${ }^{19-21}$ In a tin (IV) compound containing a ligand capable of hypercoordination, trigonal bipyramidal geometries are preferred where the $3 \mathrm{c}-4 \mathrm{e}^{-}$bonds are typically observed in the axial position (Figure 4). ${ }^{20}$ The lone pair of electrons on $\mathrm{Y}$ are donated into the non-bonded molecular orbitals of the tin. This also decreases the Lewis acidic nature of the tin center. Hypercoordinate bonding is more favourable when $\mathrm{X}$ is an electronegative atom such as a halide. ${ }^{20}$

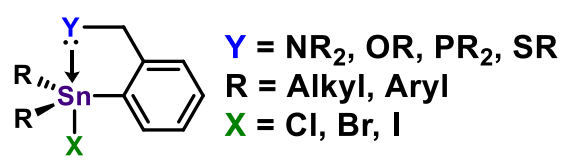

Figure 4: Examples of hypercoordinate tin structures.

The first example of a hypercoordinate tin structure was reported in the literature by van Koten et al. in which a crystal structure $\left(\mathrm{R}=\mathrm{Ph}, \mathrm{Y}=\mathrm{NMe}_{2}, \mathrm{X}=\mathrm{Br}\right)$ was obtained to confirm the hypercoordinate bond. ${ }^{22}$ Other Group 14 atoms ( silicon $^{23-24}$, germanium ${ }^{24}$ and lead $^{25}$ ) are capable of hypercoordination and have been reported in the literature.

\subsection{Polystannanes and Their Properties}

Polystannanes are polymers consisting of a backbone of covalently bonded tin atoms (Figure 5) and the first example was reported by Löwig in $1852 .{ }^{26}$ Polystannanes possess unique 
and interesting chemical, optical, thermal and electronic properties due to delocalization of electrons along the backbone. This is a result of the very diffuse tin $\sigma$ orbitals. $^{26}$

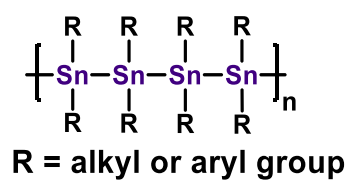

Figure 5: Schematic representation of a polystannane.

The degree of delocalization of electrons is greater than other Group 14 polymers (polysilanes and polygermanes) which leads to a smaller band gap, greater metallic character and a larger red shift in the UV-Vis spectra. ${ }^{27}$ The $\sigma$-delocalization of polystannanes is seen in the UVVis spectra by a significant detectable absorption above $390 \mathrm{~nm} .{ }^{28}$ Polystannanes containing aromatic side chains will also exhibit $\sigma-\pi$ conjugation, which results in a further bathochromic shift in the UV-Vis spectra. ${ }^{29}$

Through computational calculations, the band gaps of polystannanes, polygermanes and polysilanes were calculated to be $2.68,3.10$ and $3.72 \mathrm{eV}$ respectively. ${ }^{29}$ These values agree with previously reported values. ${ }^{30}$ The addition of bulky aryl side groups can further reduce this band gap. $^{29}$

Imori et al. ${ }^{31}$ cast films of poly(di- $n$-butylstannane) and poly(di-n-octylstannane) on glass films and doped with $\mathrm{SbF}_{5}$ and found conductivities of $1 \times 10^{-2}$ and $0.3 \mathrm{Scm}^{-1}$ respectively. Conductivity studies were also done by Choffat et $a .^{32}$ on undoped poly(di(3propylphenyl)stannane) and found the conductivity to be $3 \times 10^{-8} \mathrm{Scm}^{-1}$ at $300 \mathrm{~K}$, which increased with temperature. 


\subsubsection{Challenges with Polystannanes}

Tin forms a long weak covalent metal-metal bond with a bond dissociation energy of typically between $140-183 \mathrm{kJmol}^{-1}$ relative to germanium and silicon which have bond dissociation energies between 197-261 and 239-319 $\mathrm{kJmol}^{-1}$ respectively. ${ }^{33}$ Due to the weak bond strength between tin atoms, polystannanes are extremely sensitive to ambient light and moist air and will thus degrade. ${ }^{33}$ In the presence of light, polystannanes will readily homolytically cleave to form radicals and these typically recombine to form five or six membered cyclic rings (Figure 6). ${ }^{34}$ In the presence of water, polystannanes will undergo a nucleophilic attack and break down into oligomeric stannoxane structures (Figure 6). These undesirable cyclic and stannoxane structures lose the interesting properties that polystannanes possess and are no longer conductive.

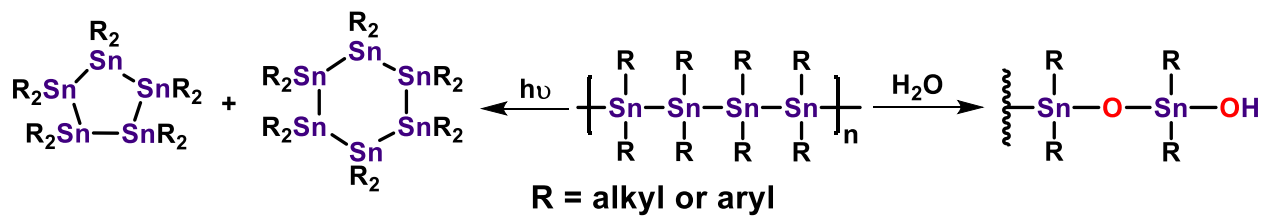

Figure 6: Degradation of polystannanes under light and moisture conditions.

Trummer et al. ${ }^{35}$ performed light stability studies on poly(dibutylstannane) and poly[bis(4butylphenyl)stannane] by running UV-Vis spectra of both polymers separately in solutions of unstabilized THF and DCM. It was reported that the diaryl polymer was far more stable towards light than the dialkyl polymers in both solutions. In the presence of BHT, which is a radical scavenger found in THF, a reduced rate of degradation of both polymers was observed suggesting these degradation processes occur through a radical mechanism in the presence of light. Although polystannanes are typically light and moisture sensitive, they are known to be thermally stable typically up to $200{ }^{\circ} \mathrm{C} .{ }^{34}$ 


\subsection{Synthesis of Polystannanes}

Various methods have been reported in the literature for the synthesis of polystannanes. This includes electrochemical or Wurtz coupling of tin(IV) dihalides, catalytic dehydrogenation of tin(IV) dihydrides using a transition metal catalyst, or a metal-free condensation route using tin(IV) dihydrides and tin(IV) diamides which can both be used to synthesize homo- and copolymers. ${ }^{36}$

\subsubsection{Electrochemical Polymerization}

Electrochemical polymerization of organotin dihalides to produce polystannanes was reported by Okano et al. in $1998 .{ }^{37}$ The authors described the synthesis of poly(dibutylstannane) and poly(dioctylstannane) using a one-compartment cell containing a syringe port, a Pt cathode, Ag anode, TBAP, and dry DME as the solvent with a constant voltage of $20 \mathrm{~V}$ (Scheme 2). Yields ranged from $27.9-56.1 \%$ with moderate molecular weights ranging from $0.59-1.09 \times 10^{4} \mathrm{Da}$ with a PDI value ranging from 1.3 -2.6 depending on the current applied.

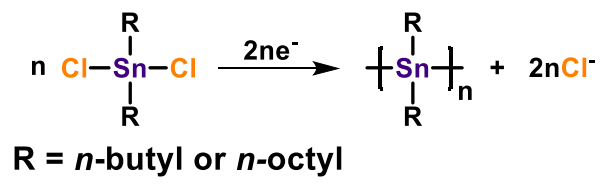

Scheme 2: Electrochemical polymerization of a dialkyltin dihalide.

Okana et $a l .^{38}$ also reported the copolymerization of tin with both organo- silicon and germanium dihalides. Higher molecular weights up to $25 \times 10^{4} \mathrm{Da}$ were obtained depending on the ratios compared to the homopolymers however, yields were fairly poor. There has been no reported synthesis of poly (diarylstannanes) via electrochemical polymerization, which is likely a result of poly (diarylsilanes) and poly (diarylgermanes) being more difficult to synthesize than the dialkyl tin dihalides. ${ }^{39}$ 


\subsubsection{Wurtz Coupling}

Wurtz coupling has been a useful method to synthesize both organic and inorganic polymers. ${ }^{26}$ In the case of polystannanes, it involves a tin(IV) dihalide species in the presence of a fine sodium metal dispersion and a crown ether typically at $60{ }^{\circ} \mathrm{C}$ (Scheme 3). Cyclic stannanes are a common by-product of Wurtz coupling, but have a higher tolerance of functional groups than the previously mentioned electrochemical polymerization of dihalide species.

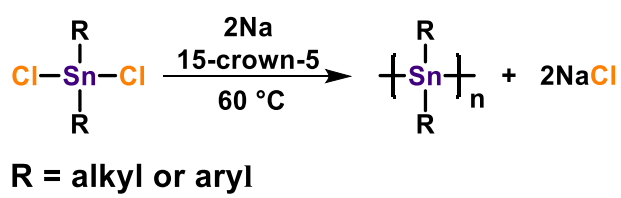

Scheme 3: Wurtz coupling of a tin dihalide species.

Molloy et $a .^{40}$ first reported the synthesis of high molecular weight poly (di- $n$ butylstannane) of molecular weights of $1.09 \times 10^{6}$ Da with PDI of 1.4 via Wurtz coupling of the corresponding tin dichloride species in 1996. Since then Molloy et al. ${ }^{27}$ has reported the synthesis of asymmetric polystannanes with high molecular weights of $2.5-3.0 \times 10^{5}$ Da with PDI values of 1.30-1.96. In 2010, Foucher et al. ${ }^{41}$ reported the synthesis of fluorinated diaryl polymers with molecular weights of $1.73 \times 10^{4}$ and $1.47 \times 10^{5}$ Da with PDI values of 1.4 and 3.8 , respectively.

\subsubsection{Dehyropolymerization}

Many transition metal catalysts have been utilized for the synthesis of polystannanes via dehydropolymerization (Scheme 4). Tin dihydrides can readily be synthesized from the corresponding dihalide species via hydrogenation using a hydride source such as $\mathrm{NaBH}_{4}$ or $\mathrm{LiAlH}_{4}{ }^{31,42}$ 


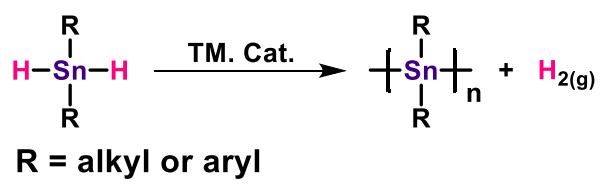

Scheme 4: Dehydropolymerization of a tin dihydride species using a transition metal (TM) catalyst.

Tilley et $a l . .^{31,42}$ reported the dehydrogenative coupling of a dialkyl tin dihydride using a zirconium based catalyst in 1993 obtaining molecular weights of $\sim 1.7 \times 10^{4} \mathrm{Da}$ of linear polymers. However, cyclic products were always obtained as a by-product. Other catalysts incorporating Zr, Ti, Hf, Rh, or Pt have been used to produce high molecular weight polystannanes, which also include a considerable amount of cyclic impurities. ${ }^{43-46}$

Choffat et al. ${ }^{32,} 47-49$ tested over thirty transition metal complexes for the dehydropolymerization of dialkyltin dihydride of which Wilkinson's catalyst $\left(\mathrm{RhCl}\left(\mathrm{PPh}_{3}\right)_{3}\right)$ was found to be the most suitable. Using Wilkinson's catalyst, they were able to achieve high molecular weight dialkyl polymers $\left(\times 10^{4} \mathrm{Da}\right)$ and PDI values ranging from $1.4-2.7$. There was no detectable amount of cyclic by-products and monomer conversion was essentially $100 \%$. However, they reported that the catalyst was limited to alkyl substituents on the tin atom and a tertiary carbon was needed to be at least two methylene carbons away from the tin center for polymerization to occur. ${ }^{49}$

\subsubsection{Condensation Polymerization}

In 2015, Foucher et al. ${ }^{50}$ developed a new method which utilizes a metal-free condensation polymerization to synthesize homopolymers $\left(R^{1}=R^{2}\right)$ or unprecedented alternating $\left(R^{1} \neq R^{2}\right)$ polystannanes (Scheme 5). This method produces volatile diethyl amine as a by-product which can be easily removed in vauco after the reaction. Molecular weights upwards of $2.43 \times 10^{5} \mathrm{Da}$ with a PDI of 2.03 were obtained when $\mathrm{R}^{1}=\mathrm{Ph}$ and $\mathrm{R}^{2}=\mathrm{Me}$. 


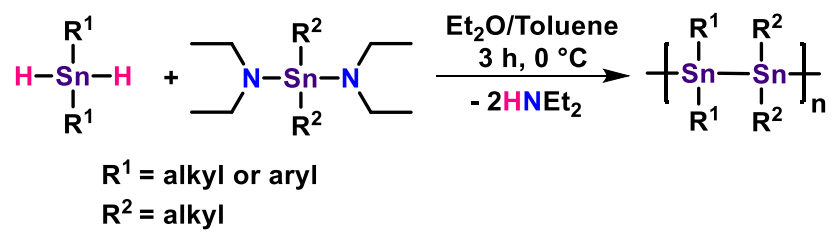

Scheme 5: Condensation polymerization of a tin dihydride and a tin diamide.

\subsection{Previous Work}

As mentioned in sections 1.1 and 1.2, oxazolines are useful ligands for main group metals as they are readily synthesized from commercially available reagents and are inert to a variety of reaction conditions. Staliński et al. have synthesized a variety of tin complexes bearing hypercoordinate oxazoline ligands. ${ }^{14-17}$ They also synthesized tin dihydrides which are an important monomer in the synthesis of polystannanes via dehydropolymerization using a transition metal catalyst, however the authors did not report any attempted synthesis of polystannanes from these tin dihydrides bearing oxazoline substituents.

Molloy et al. ${ }^{18}$ reported the synthesis of triphenyl and a monohalide tin containing the ethyl pyridyl ligand which is an important step in the synthesis of polystannanes, however they did not synthesize any tin dihalides nor tin dihydride species containing the ethyl pyridyl grouping which have also been shown to be nitrogen donors through dative interactions.

The Foucher group has reported the synthesis of asymmetric polystannanes incorporating ligands capable of hypercoordination, specifically propyl alkoxy chains containing a hydroxy group, phenyl, biphenyl or an azo-benzene moiety. ${ }^{36,51-52}$ The incorporation of these propyl alkoxy chains has shown an increase in stability to both light and moisture. Both these examples were flexible (Figure 7B) rather than rigid (Figure 7A) and both employed oxygen donor atoms. In this work, the polystannanes were reported to have two ${ }^{119} \mathrm{Sn}$ NMR chemical signals presumably 
associated with the bound and unbound tin centers. This is attributed to the ability of the flexible side chain containing the oxygen atom to move freely to and away from the tin center. A polymer containing rigid ligands would not have this ability to freely move out of the way, resulting in a stronger dative interaction and steric bulk around the tin center. To date, there have been no reported hypercoordinate rigid or flexible nitrogen based polystannanes reported in the literature.

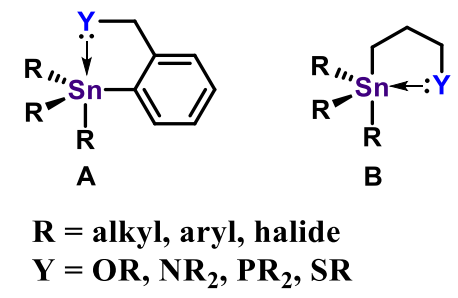

Figure 7: Rigid (A) and flexible (B) hypercoordinate tin structures.

\subsection{Thesis Objectives}

This thesis focuses on synthesizing a series of stabilized nitrogen based hypercoordinate polystannanes, specifically continuing the work done by Staliński et al. with the oxazolines and with Molloy et al. with the tin ethyl pyridine small molecules respectively (Figure 8). This will be done by synthesizing the necessary ligands, the triphenyl, dihalide, and dihydride tin species and polymerize these species primarily using Wilkinson's catalyst.

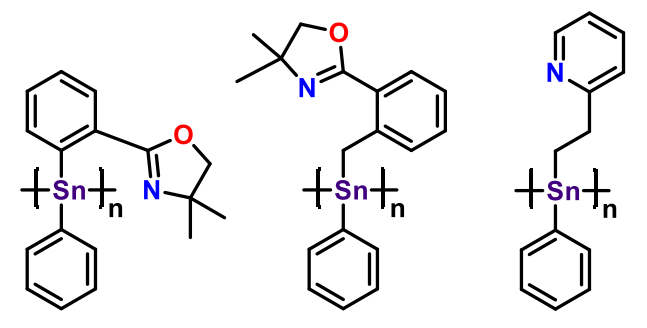

Figure 8: Target polymers. 


\subsection{Results and Discussion}

\subsection{Synthesis of 2-(2'-bromophenyl)-4,4-dimethyl-4,5-dihydrooxazole 8}

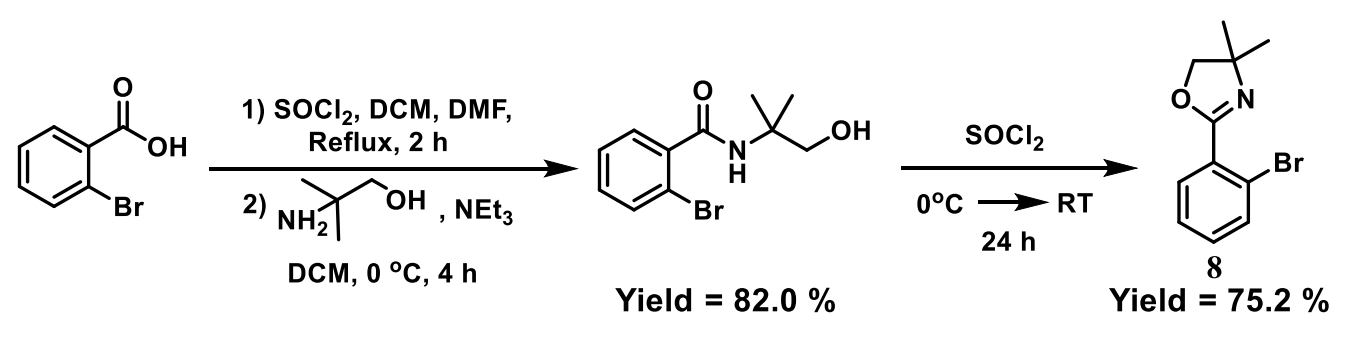

Scheme 6: Reaction scheme for the synthesis of 8 .

Oxazoline $\mathbf{8}$ was synthesized using two different methods as reported in the literature. In the first method, known as the Witte-Seeliger method, ${ }^{3}$ 2-bromobenzonitrile is used in the presence of 2-amino-2-methyl-1-propanol and a catalytic amount of anhydrous $\mathrm{ZnCl}_{2}{ }^{53}$ This reaction yielded oxazoline 8 in a $74.2 \%$ yield. However, the 2-bromobenzonitrile starting material is fairly expensive and alternate methods were explored. This was achieved by (Scheme 6) converting 2bromobenzoic acid into an acid chloride using $\mathrm{SOCl}_{2}$ as the chloride source and DMF as a catalyst. The acid chloride was further reacted with 2-amino-2-methyl-1-propanol in a Schotten-Baumann reaction ${ }^{54}$ to form the benzamide intermediate and finally reacted directly with excess thionyl chloride. In this step, the terminal alcohol is converted into a chloride which is followed by an intramolecular $\mathrm{S}_{\mathrm{N}} 2$ reaction with the nucleophile being the carbonyl oxygen. After $24 \mathrm{~h}, \mathrm{Et}_{2} \mathrm{O}$ is added which results in the precipitation of the oxazoline salt, which is collected and re-dissolved in DCM and subsequently washed with a weak base $\left(\mathrm{NaHCO}_{3}\right)$. After separation and DCM removal, $\mathbf{8}$ was obtained as a white powder and no further purification was required. The NMR data collected correlated to data from the literature for this compound. ${ }^{55}$ This synthetic route was the one that was primarily used in this research. 


\subsection{Oxazoline Stannane Compounds}

\subsubsection{4,4-dimethyl-2-(2-(triphenylstannyl)phenyl)-4,5-dihydrooxazole 10}

a)

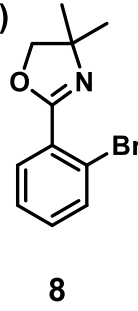

1) $n-B u L i, \mathrm{Et}_{2} \mathrm{O}$ $-84^{\circ} \mathrm{C}, 2 \mathrm{~h}$

2) $\mathrm{Ph}_{3} \mathrm{SnCl}, \mathrm{Et}_{2} \mathrm{O}$ $0^{\circ} \mathrm{C}, 1 \mathrm{~h}$ $+\mathrm{BuBr}(\mathrm{a}) / \mathrm{BuH}(\mathbf{b}), \mathrm{LiCl}$

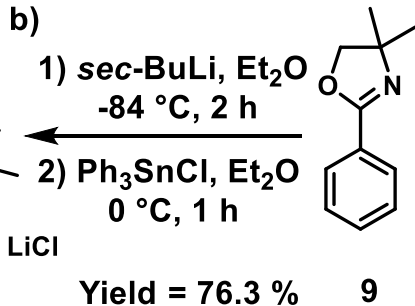

Scheme 7: Reaction scheme for the synthesis of $\mathbf{1 0}$.

Two different methods were employed to synthesize compound 10 (Scheme 7). The first method (Scheme 7a) took 8 in $\mathrm{Et}_{2} \mathrm{O}$ with $n$-BuLi added at $-84{ }^{\circ} \mathrm{C}\left(\mathrm{EtOAc}_{\mathrm{O}} \mathrm{N}_{2(1)}\right)$. This was allowed to react for $2 \mathrm{~h}$, after which the EtOAc bath was switched to an ice bath and allowed to warm up to $0{ }^{\circ} \mathrm{C}$ before the addition of $\mathrm{Ph}_{3} \mathrm{SnCl}$ in $\mathrm{Et}_{2} \mathrm{O}$ for $1 \mathrm{~h}$. After the solvent was removed, toluene was added resulting in the precipitation of the $\mathrm{LiCl}$ by-product. The salt was filtered off and the solvent was removed under reduced pressure to afford a yellow coloured powder of crude 10. Purification from trituration with $\mathrm{MeOH}$ resulted in the isolation of pure $\mathbf{1 0}$ as a white coloured powder.

The second method (Scheme 7b) was adapted from Gschwend et al. ${ }^{56}$ in which they reported the lithiation using sec-BuLi of $\mathbf{9}$ and reacted with a variety of non-tin containing electrophiles. Fortunately, when this synthesis was attempted with $\mathrm{Ph}_{3} \mathrm{SnCl}$, it was successful and compound $\mathbf{1 0}$ was obtained in a slightly higher yield than stated in Scheme 7a. Oxazoline $\mathbf{9}$ is commercially available and therefore synthesis of this is not required. The authors reportedly lithiated 9 using $n$-BuLi, however $15 \%$ of the reported products involved the addition of the $n$ BuLi to the oxazoline. They found this was mitigated by the use of sec-BuLi.

The ${ }^{119} \mathrm{Sn}$ NMR $\left(\mathrm{CDCl}_{3}\right)$ spectroscopic analysis of $\mathbf{1 0}$ showed only a single resonance $\left(\delta_{119 \mathrm{Sn}}=-157.13 \mathrm{ppm}\right)$. Although compound $\mathbf{1 0}$ has not been previously synthesized in the 
literature, Staliński et al. synthesized a similar compound previously shown in Figure 2, (compound A where $\left.\mathrm{R}^{1}, \mathrm{R}^{2}, \mathrm{R}^{3}=\mathrm{Ph}\right)$ and reported ${ }^{117} \mathrm{Sn} \mathrm{NMR}\left(\mathrm{CDCl}_{3}\right)$ chemical shift of -155.5 ppm. ${ }^{16} \mathrm{~A}$ crystal of compound $\mathbf{1 0}$ suitable for single crystal X-ray diffraction was obtained (Figure 9). The relevant bond lengths and bond angles are shown in Table 2.

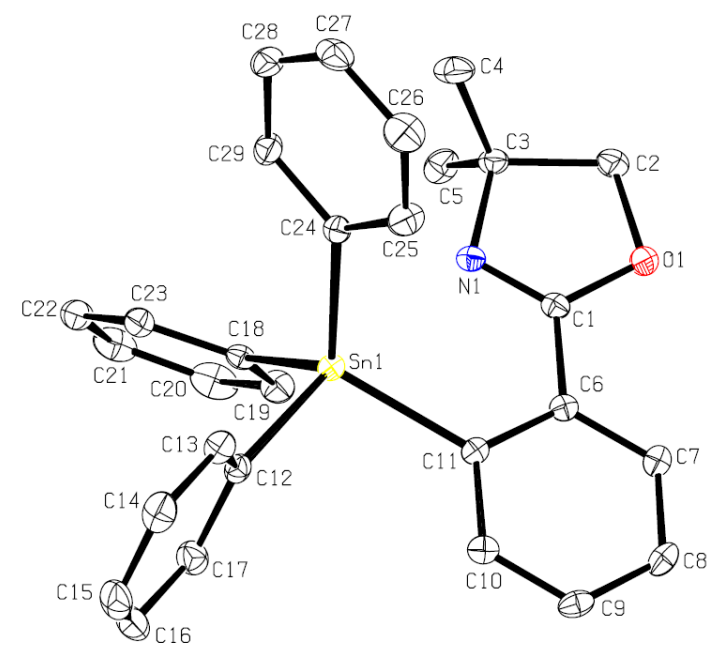

Figure 9: ORTEP representation of $\mathbf{1 0}$. Thermal ellipsoids drawn at the $30 \%$ level.

Table 2: Relevant parameters obtained from the crystal data of compound $\mathbf{1 0 .}$

\begin{tabular}{|c|c|}
\hline Bond & Bond Lengths $(\AA)$ \\
\hline Sn1-N1 & $2.762(1)$ \\
\hline Sn1-C11 & $2.1602(16)$ \\
\hline Sn1-C12 & $2.1752(17)$ \\
\hline Sn1-C18 & $2.1378(16)$ \\
\hline Sn1-C24 & $2.1425(17)$ \\
\hline Angle & Bond Angles $\left(^{\circ}\right)$ \\
\hline N1-Sn1-C12 & $172.20(6)$ \\
\hline
\end{tabular}

The geometry of this compound around the Sn center is distorted trigonal bipyramidal ( $\tau_{5}$ $=0.92)^{57}$ with the equatorial bond angles around the tin center ranging from $102^{\circ}$ to $117^{\circ}$ (Table A1) and the axial bond angle being $172.20(6)^{\circ}$. The structural parameter $\left(\tau_{5}\right)$ is a value that ranges from 0 to 1 which is calculated by using angles from the crystallographic data. This value indicates 
the geometry of the metal of interest. When $\tau_{5}=$ zero, the geometry of the coordination center is square pyramidal and when $\tau_{5}=$ one, the geometry of the coordination center is trigonal bipyramidal $\left(\tau_{5}=(\beta-\alpha) / 60^{\circ}\right.$, where $\beta$ is the axial angle and $\alpha$ is the largest equatorial angle) ${ }^{57}$ The Sn1-C12 bond is slightly longer than the other Sn-C bonds likely a result of it being para to the donating nitrogen as a result of $3 \mathrm{c}-4 \mathrm{e}^{-}$sharing. The tin nitrogen bond distant is relatively short, it is not as short as a covalent Sn-N bond which is typically $2.15 \AA^{58}$ but it is within the sum of the van der Waals radii of tin and nitrogen $(3.72 \AA)$. This bond distance is comparable to a related rigid triphenyltin species with a benzyl amine donor (Figure 7A, $\mathrm{R}=\mathrm{Ph}, \mathrm{Y}=\mathrm{NMe}_{2}$ ) collected by a member of the Foucher group which has a Sn-N bond distance of $2.917 \AA .^{59}$ Staliński et al. did not report crystal structure data of their triphenyltin oxazoline containing a chiral oxazoline, however they did collect a crystal structure of the complimentary trimethyltin oxazoline in which they reported a Sn-N bond distance of 2.888(9) $\AA .{ }^{16}$ Even though this compound is less sterically hindered around the tin, the Sn-N bond distance may be longer due to the isopropyl group on the oxazoline ring (Figure 2A) being more sterically encumbering than the two analogous methyl groups in compound $\mathbf{1 0 .}$

\subsubsection{2-(2-(chlorodiphenylstannyl)phenyl)-4,4-dimethyl-4,5-dihydrooxazole 11}
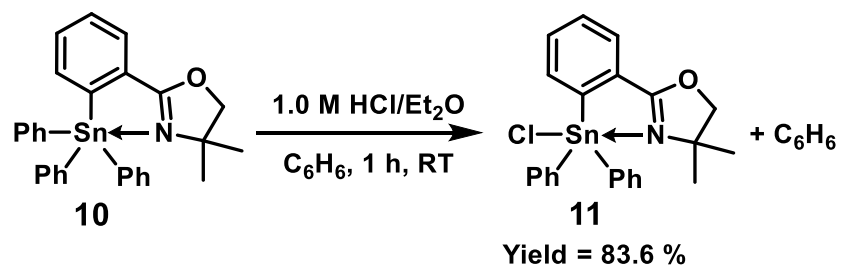

Scheme 8: Reaction scheme for the mono chlorination to synthesize 11.

In a method first described by Pannell et al. to synthesize tin halides from the corresponding triphenyl species, compound $\mathbf{1 0}$ was treated with one molar equivalent of a $1.0 \mathrm{M}$ solution of $\mathrm{HCl}$ / $\mathrm{Et}_{2} \mathrm{O}$ for $1 \mathrm{~h}$ at $\mathrm{RT}$. The crude ${ }^{119} \mathrm{Sn}$ NMR spectrum of the reaction mixture showed a single tin 
resonance $\left(\delta_{119 \mathrm{Sn}}=-225.99 \mathrm{ppm}\right)$. However, the ${ }^{1} \mathrm{H}$ NMR spectrum revealed some unidentified impurities which were removed by trituration with hexanes to yield pure $\mathbf{1 1}$ as a white coloured powder in an $83.6 \%$ yield. Staliński et al. never synthesized a monochloride tin oxazoline, however they did synthesize a monobromide species which has a similar ${ }^{117} \mathrm{Sn}$ NMR chemical shift $\left(\delta_{117 \mathrm{Sn}}=-222.1 \mathrm{ppm}\right)$. In our case, the integration of the aromatic region relative to the oxazoline methylene and two methyl groups in the ${ }^{1} \mathrm{H}$ NMR spectrum confirmed that one phenyl group was replaced by a chloride. A crystal of compound $\mathbf{1 1}$ suitable for single crystal X-ray diffraction was thereafter obtained (Figure 10). The relevant bond lengths and bond angles are shown in Table 3. Two unique molecules were obtained within the unit cell of the crystal that differ in terms of some bond lengths and angles.

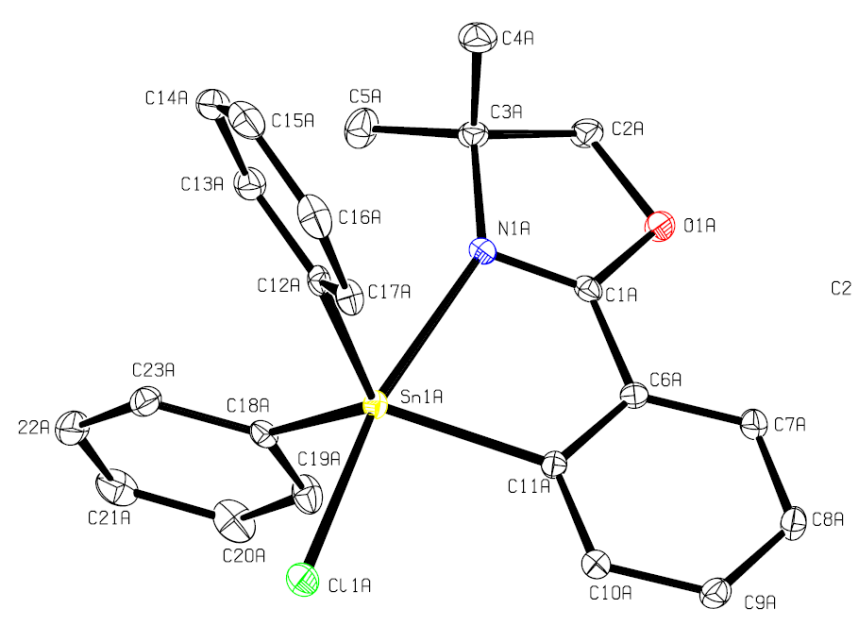

A

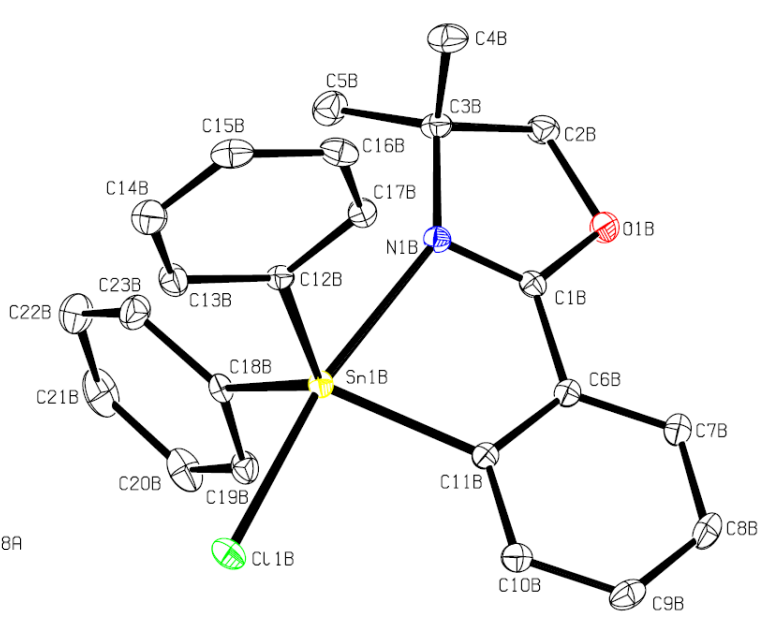

B

Figure 10: ORTEP representation of 11. Thermal ellipsoids drawn at the $30 \%$ level. 
Table 3: Relevant parameters obtained from the crystal data of compound $\mathbf{1 1 .}$

\begin{tabular}{|c|c|c|c|}
\hline Bond & Bond Lengths of A $(\AA)$ & Bond & Bond Lengths of B $(\AA)$ \\
\hline Sn1A-N1A & $2.4658(14)$ & Sn1B-N1B & $2.4502(14)$ \\
\hline Sn1A-C11A & $2.1401(16)$ & Sn1B-C11B & $2.1422(17)$ \\
\hline Sn1A-C12A & $2.1322(16)$ & Sn1B-C12B & $2.1330(17)$ \\
\hline Sn1-C18A & $2.1250(17)$ & Sn1B-C18B & $2.1232(17)$ \\
\hline Sn1-C11A & $2.4832(5)$ & Sn1-C11B & $2.4955(5)$ \\
\hline Angle & Bond Angles of A $\left(^{\circ}\right)$ & Angle & Bond Angles of B $\left(^{\circ}\right)$ \\
\hline N1A-Sn1A-C11A & $169.33(3)$ & N1B-Sn1B-C11B & $170.40(4)$ \\
\hline
\end{tabular}

The geometry around the tin center in both molecules is distorted trigonal bipyramidal (A: $\left.\tau_{5}=0.81, \mathbf{B}: \tau_{5}=0.82\right)^{57}$. For both structures, the angles of N1-Sn-Cl are almost $180^{\circ}$, while the angles between the equatorial ligands range from $117-121^{\circ}$. While the angles between the axial and the equatorial phenyl ligands range between $90-95^{\circ}$. The $3 \mathrm{c}-4 \mathrm{e}^{-}$sharing between the nitrogen, tin and chlorine atoms is evident by result of the $\mathrm{Sn}-\mathrm{Cl}$ bond is elongated relative to the average Sn-Cl bond length of $2.414 \AA{ }^{58}$ This also results in a shorter Sn-N bond length relative to the triphenyltin analogue likely due to the increased Lewis acidity at the tin center as a result of the presence of an electronegative chlorine atom. Staliński et al. did not report crystal structure analysis of their diphenyltin bromide species containing the chiral oxazoline, however they did collect a crystal structure of the dimethyltin bromide oxazoline complex. They reported a Sn-N bond distance of 2.39(2) $\AA^{14}$ which, comparing to the solid state structure of compound $\mathbf{1 1}$, has an average Sn-N bond distance of $2.458 \AA$. This distance is obviously longer. This is likely due to the greater steric hindrance of the phenyl substituents relative to methyl substituents on tin.

Van Koten et al $^{22}$ also collected crystal structure data of the related compound $C, N-(2-$ ((dimethylamino)methyl) phenyl)diphenyltin bromide (Figure 12a) which is more closely related to the structure of 11. The former material has a Sn-N bond distance of 2.511(12) $\AA$. The Sn-C bonds in this structure are also comparable to that found in the solid state structure of $\mathbf{1 1}$. 


\subsubsection{Attempted synthesis of 2-(2-(dichloro(phenyl)stannyl)phenyl)-4,4-dimethyl-4,5- dihydrooxazole 12}

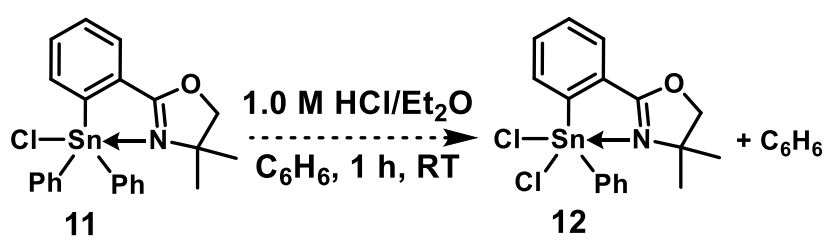

Scheme 9: Reaction scheme of the attempted synthesis of $\mathbf{1 2}$.

A successive chlorination was attempted with another molar equivalent of $1.0 \mathrm{M}$ of $\mathrm{HCl} / \mathrm{Et}_{2} \mathrm{O}$ using compound $\mathbf{1 1}$ (Scheme 9). However, ${ }^{1} \mathrm{H}$ and ${ }^{119} \mathrm{Sn}$ NMR analysis of this mixture showed that no reaction had occurred. Additional equivalents were added but again, no reaction was observed through NMR analysis. Next, a stronger chlorinating source, $\mathrm{SOCl}_{2}$ was utilized. The addition of $\mathrm{SOCl}_{2}$ in $\mathrm{C}_{6} \mathrm{H}_{6}$ for $1 \mathrm{~h}$ to the triphenyl compound $\mathbf{1 0}$ did successfully synthesize compound 11. This same procedure was then applied to $\mathbf{1 1}$ in hopes of synthesizing the dichloride species however, $\mathrm{SOCl}_{2}$ was unable to substitute an additional phenyl ring for a second chlorine.

These unsuccessful attempts at synthesizing the dichloride species may be a result of the shorter, stronger Sn-C bond, therefore less reactive and less labile. It could also be a result of increased steric hindrance around the tin because of the short Sn-N and Sn-C bonds, which may cause the tin center to be inaccessible to a chloride anion.

Another possible method to synthesize the dichloride species is via direct route by reacting the lithiated $\mathbf{8}$ with phenyltin trichloride. After removal of the salt by-product and solvent, ${ }^{119} \mathrm{Sn}$ $\mathrm{NMR}\left(\mathrm{CDCl}_{3}\right)$ analysis revealed three tin resonances were present: $-117.1,-225.9$ and $-237.5 \mathrm{ppm}$. The appearance of $-225.9 \mathrm{ppm}$ in this spectrum was previously confirmed to be the monochloride species, 11. This suggests the chlorine and phenyl groups underwent redistribution at the tin center and therefor this is likely not a good route to take to synthesize a dihalide species. 


\subsubsection{Synthesis and characterization of compound 13}

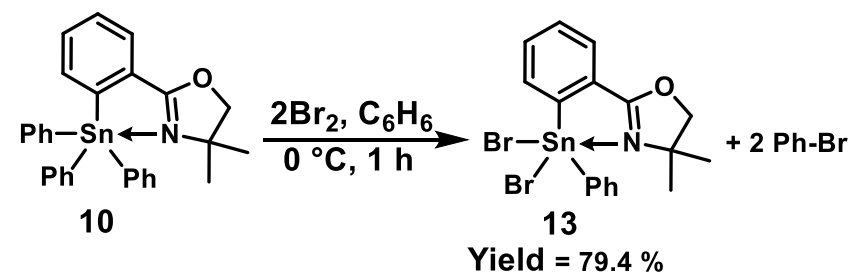

Scheme 10: Reaction scheme for the synthesis of $\mathbf{1 3}$ via bromination.

Having failed to successfully chlorinate compound 11, bromination was investigated as a possible alternative route to the desired dihalide species. Therefore, compound $\mathbf{1 0}$ was reacted with two equivalents of $\mathrm{Br}_{2}$ to yield $\mathbf{1 3}$ (Scheme 10). As the reaction proceeded, the colour faded from a dark red solution to a yellow solution and after the solvent was removed, a yellow coloured powder remained. A crude NMR $\left(\mathrm{CDCl}_{3}\right)$ analysis showed only a single ${ }^{119} \mathrm{Sn}$ resonance at -290.63 ppm, however the ${ }^{1} \mathrm{H}$ NMR showed some impurities, specifically quantities of bromobenzene (b.p. $\left.=156{ }^{\circ} \mathrm{C}\right)$. Removal of this under reduced pressure is a slow process. However, the bromobenzene and other impurities could be easily removed by the addition of methanol to the solution. The product, $\mathbf{1 3}$ immediately precipitated out of solution as a white coloured powder and the methanol, which became yellow, was carefully decanted off. This process was repeated until the resulting methanol layer ran colourless. The aromatic signals in a subsequent ${ }^{1} \mathrm{H}$ NMR spectrum integrates for the correct number relative to the methylene and two methyl group protons on the oxazoline. The NMR chemical shift $\left(\delta_{119 \mathrm{Sn}}=-290.6 \mathrm{ppm}\right)$ also corresponds closely to the shift reported by Staliński et al. $\left(\delta_{117 \mathrm{Sn}}=-288.5 \mathrm{ppm}\right) .{ }^{17} \mathrm{~A}$ crystal of compound $\mathbf{1 3}$ suitable for single crystal X-ray diffraction was thereafter obtained (Figure 11). 


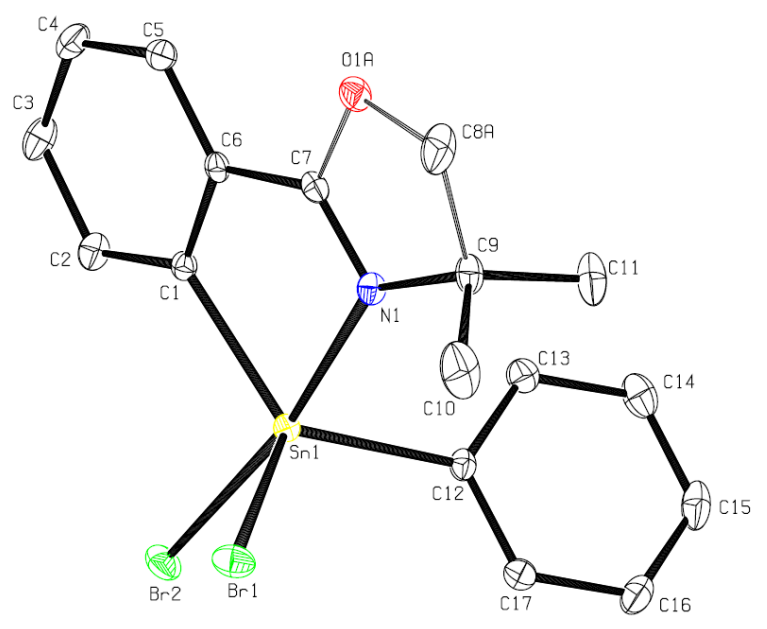

Figure 11: ORTEP representation of a unit cell molecule of 13. Thermal ellipsoids drawn at the $30 \%$ level.

Table 4: Relevant parameters obtained from the crystal data analysis of compound $\mathbf{1 3 .}$

\begin{tabular}{|c|c|}
\hline Bond & Bond Lengths $(\AA)$ \\
\hline Sn1-N1 & $2.383(3)$ \\
\hline Sn1-C1 & $2.137(2)$ \\
\hline Sn1-C12 & $2.127(2)$ \\
\hline Sn1-Br1 & $2.4943(3)$ \\
\hline Sn1-Br2 & $2.6180(3)$ \\
\hline Angle & Bond Angles $\left(^{\circ}\right)$ \\
\hline N1-Sn1-Br2 & $171.36(5)$ \\
\hline N1-Sn1-Br1 & $87.98(5)$ \\
\hline Br1-Sn1-Br2 & $91.994(11)$ \\
\hline
\end{tabular}

The geometry around the $\mathrm{Sn}$ center of $\mathbf{1 3}$ is distorted trigonal bipyramidal in nature $\left(\tau_{5}=\right.$ 0.74). ${ }^{57}$ The angle between the axial atoms (N1-Sn1-Br2) being $171.36(5)^{\circ}$ and the angles between the three equatorial atoms $(\mathrm{Br} 1, \mathrm{C} 12$ and $\mathrm{C} 1)$ ranging from $112.14(7)-126.73(9)^{\circ}$. The angles between the axial and the equatorial atoms range from $76.06(8)-98.14(6)^{\circ}$. The $3 \mathrm{c}-4 \mathrm{e}^{-}$sharing is evident in the solid-state structure due to the relatively short Sn1-N1 bond length and the elongated Sn1-Br2 bond length. The average covalent $\mathrm{Sn}-\mathrm{Br}$ bond length is $2.562 \AA{ }^{58}$ In the solid state structure of $\mathbf{1 3}, \mathrm{Br} 1$ is in the equatorial position and presumably not participating in the $3 \mathrm{c}-4 \mathrm{e}^{-}$ 
sharing. This is evident due to the shorter bond length of the $\mathrm{Sn} 1-\mathrm{Br} 1$ relative to that of $\mathrm{Sn} 1-\mathrm{Br} 2$ and that of the average covalent length of a $\mathrm{Sn}-\mathrm{Br}$ bond. Since $\mathrm{Sn} 1-\mathrm{Br} 2$ in the axial position, it is presumably participating in the $3 \mathrm{c}-4 \mathrm{e}^{-}$sharing and the $\mathrm{Sn}-\mathrm{Br}$ bond length is significantly longer than Sn1-Br1 and that of an average Sn-Br bond length. The electron withdrawing effects of the bromine atoms are likely involved in drawing the nitrogen closer to the tin atom, with a Sn-N bond length of $2.383 \AA$. Novák et al. ${ }^{60}$ reported a related hypercoordinate tin structure, with a chelating rigid benzyl amine substituent (Figure 12b) with a reported Sn-N bond length of 2.444(5) Å. Švec et al. ${ }^{61}$ later synthesized the diiodo analogue (Figure 12c) which was reported to have a Sn-N bond distance of 2.476(3) $\AA$. The Sn-C bonds for both structures are also comparable to those obtained for the solid-state structure of 13. In the latter two structures of Figure 12, the $3 \mathrm{c}-4 \mathrm{e}^{-}$sharing is evident with elongated Sn-Cl1 and Sn-I1 bonds relative to the Sn-Cl2 and Sn-I2 bond lengths respectively.
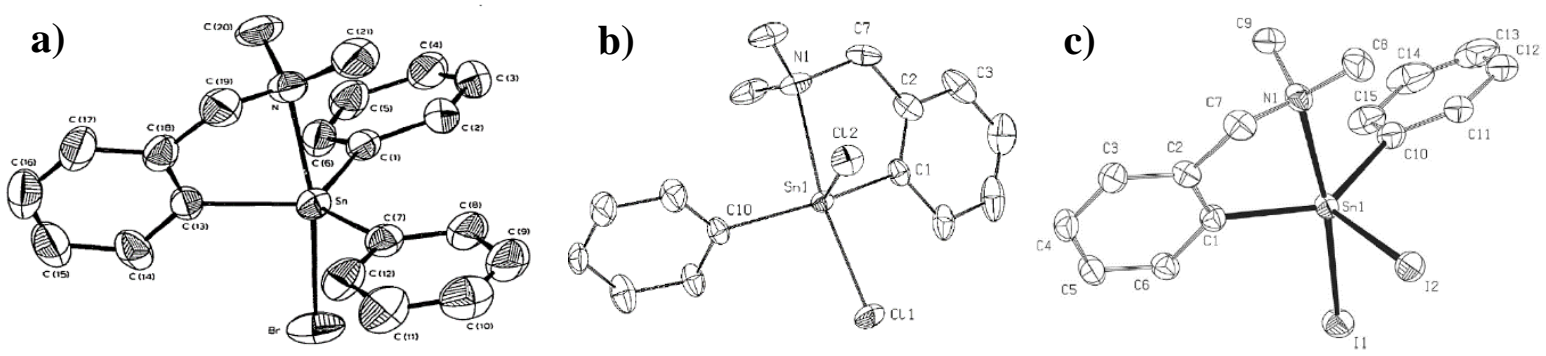

Figure 12: ORTEP representations of rigid hypercoordinate dimethylammino stannanes. Used with permission from Elsevier (a and c) and Wiley (b).

\subsubsection{NMR Analysis of 10, 11 and 13}

Upon the replacement of an alkyl or aryl group by the addition of an electronegative atom to a tin center such as a halide, it is expected to cause a downfield shift in the ${ }^{119} \mathrm{Sn}$ NMR spectrum because of the deshielding effect of the halides. However, in the case of $\mathbf{1 0}, \mathbf{1 1}$ and $\mathbf{1 3}$, the opposite effect is in fact, observed (Figure 13). 

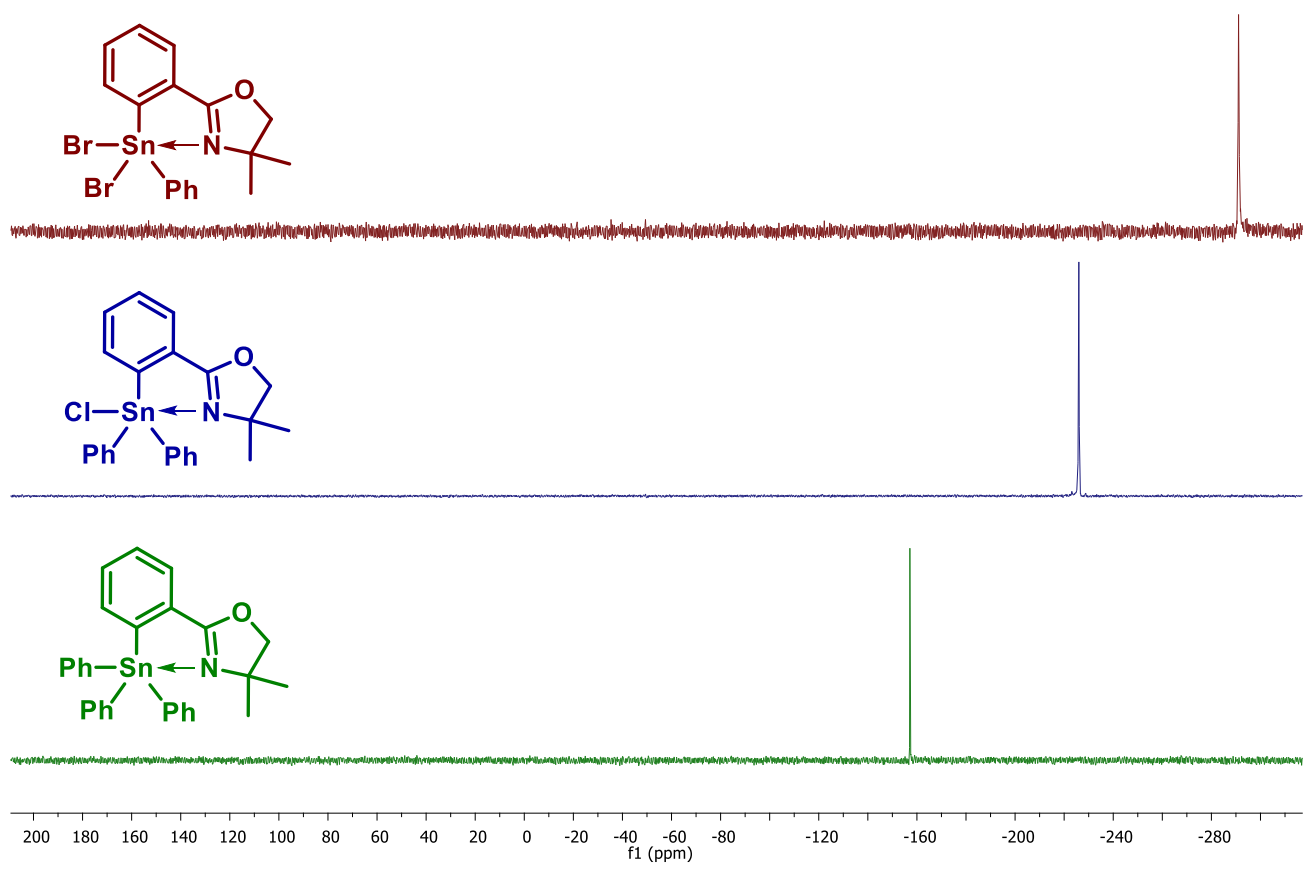

Figure 13: ${ }^{119} \mathrm{Sn}$ NMR spectra $\left(\mathrm{CDCl}_{3}\right)$ of compounds $\mathbf{1 0}, \mathbf{1 1}$, and $\mathbf{1 3 .}$

This observation might be a result of a change in geometry around tin from tetrahedral to trigonal bipyramidal and entails a stronger interaction between the nitrogen and the tin as it drawn closer with each addition of a halide. Similar results have been reported in literature for other hypercoordinate tin compounds. ${ }^{14,16,18}$ In the ${ }^{1} \mathrm{H}$ NMR spectra of compounds $\mathbf{1 0}, \mathbf{1 1}$ and $\mathbf{1 3}$ (Figure 14), the methylene protons of the oxazoline (marked by an asterisk) are shifted downfield with each additional halide, possibly as a result of the inductive effects. This same effect can also be seen with both methyl groups of the oxazoline and all aromatic protons. 


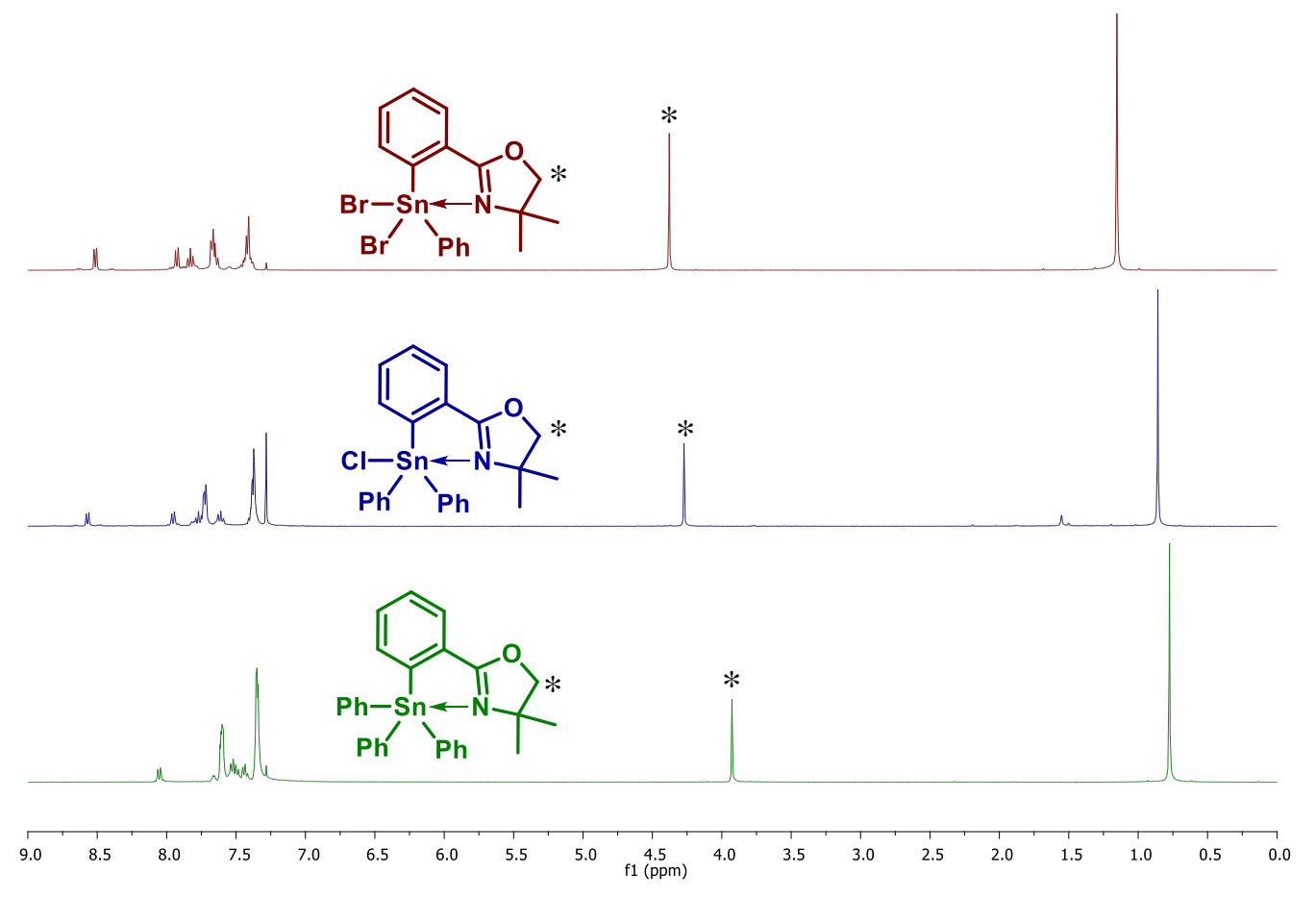

Figure 14: ${ }^{1} \mathrm{H} \mathrm{NMR}$ spectra $\left(\mathrm{CDCl}_{3}\right)$ of compounds 10,11 , and 13.

\subsection{Synthesis of 4,4-dimethyl-2-(2-(phenylstannyl)phenyl)-4,5-dihydrooxazole 14}

The synthesis of dihydride 14 (Scheme 11) proved quite difficult. In the Foucher group, hydrides are typically synthesized from $\mathrm{NaBH}_{4}$ in a large excess ( 10 mol equivalents $)$ or $\mathrm{LiAlH}_{4}$ in slight excess ( $1 \mathrm{~mol}$ equivalent $)$ at $0{ }^{\circ} \mathrm{C}$ for $1-3 \mathrm{~h}$ followed by an aqueous work-up. However, neither of these conditions worked to give product $14 ;{ }^{119} \mathrm{Sn}$ NMR analysis showed many unidentifiable resonances. Staliński et $a l .{ }^{16}$ reported the synthesis of a very similar dihydride utilizing a $10 \mathrm{~mol}$ equivalent of $\mathrm{NaBH}_{4}$ in $\mathrm{EtOH}$ at $0{ }^{\circ} \mathrm{C}$ for $5 \mathrm{~min}$ with an aqueous work-up. These synthetic conditions did not work in this case and immediately after the removal of solvent, the product was isolated as a viscous bright yellow coloured oil, indicative of oligomerization. ${ }^{119} \mathrm{Sn}$ NMR analysis showed many unidentifiable resonances. After many trials, it was established that using 1.5 mol equivalent of $\mathrm{NaBH}_{4}$, at $-84{ }^{\circ} \mathrm{C}$ for $1 \mathrm{~h}$ with an aqueous work up was the best, reproducible procedure. 

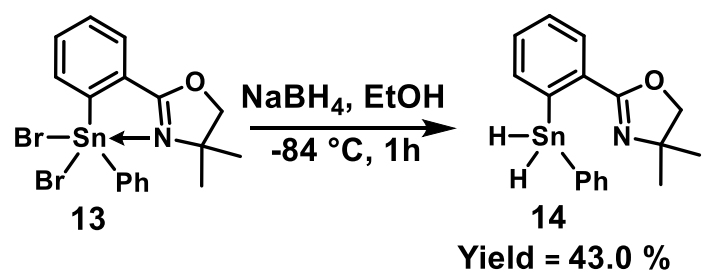

Scheme 11: Reaction scheme for the synthesis of 14.

During the work-up, the product is kept at $-84{ }^{\circ} \mathrm{C}$ as much as possible to slow decomposition as $\mathbf{1 4}$ appears to be very temperature sensitive. Stalisnki et al. reported the analogous compound to be sensitive above $-20{ }^{\circ} \mathrm{C}$. Compound $\mathbf{1 4}$ was isolated as a colourless viscous oil and when in the NMR tube dissolved in $\mathrm{C}_{6} \mathrm{D}_{6}$, the mixture quickly ( $\sim \mathrm{min}$.) turned from a colourless solution to a bright yellow solution with precipitate forming after a few hours.

\subsubsection{Characterization of 14}

In the ${ }^{1} \mathrm{H}$ NMR spectrum of $\mathbf{1 4}$ (Figure 15), the appearance of a singlet at $6.79 \mathrm{ppm}$ has ${ }^{117 / 119} \mathrm{Sn}$ satellites equidistant from this singlet, which is indicative of a hydride bound to a tin atom. These coupling constants shown in Figure 15 are comparable to other tin hydrides, specifically the ones reported by Staliński et al. ${ }^{16}$ It is also seen relative to Figure 14, the chemical shifts of the methylene and methyl protons of the oxazoline are shifted back upfield likely because the hydrides are electron donating. 


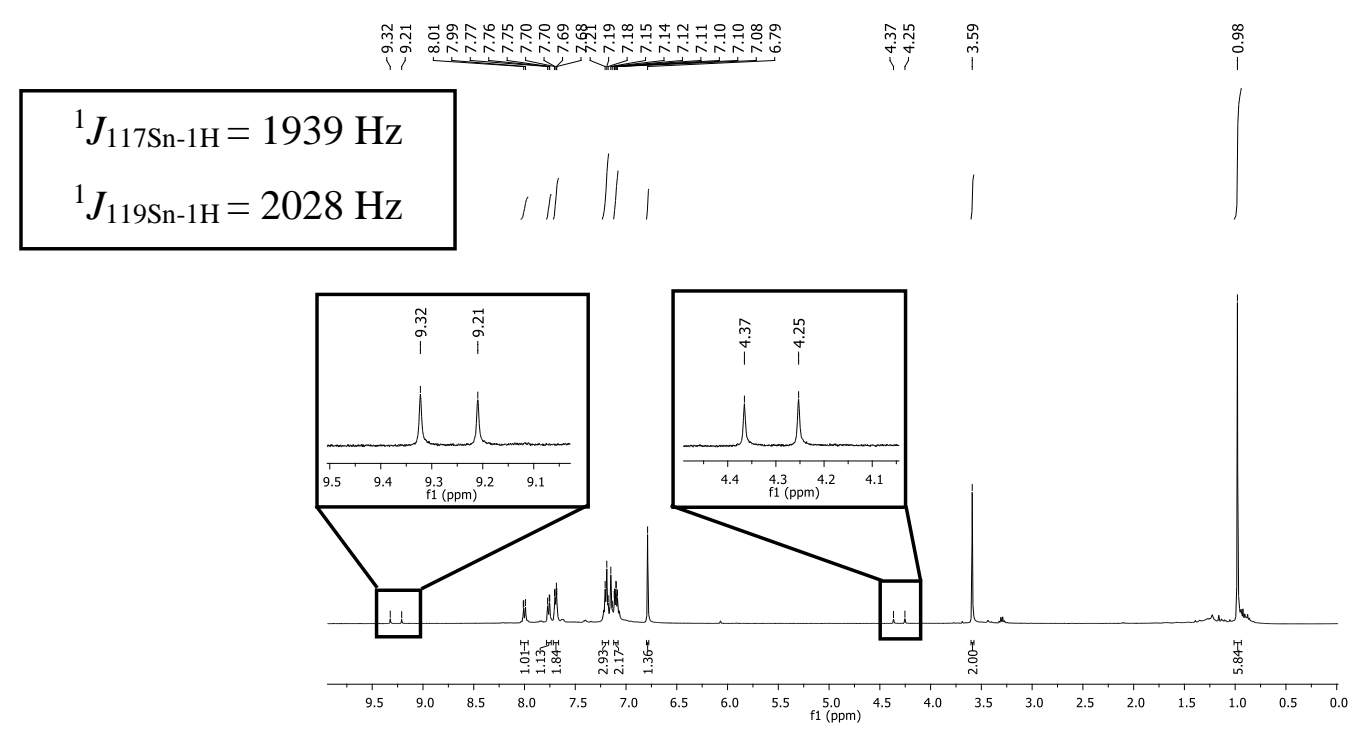

Figure 15: ${ }^{1} \mathrm{H}$ NMR $\left(\mathrm{C}_{6} \mathrm{D}_{6}\right)$ spectrum of compound 14.

The ${ }^{119} \mathrm{Sn}$ NMR shows a single resonance at -249.5 (Figure 16, $\mathrm{t}=0$ ) $\mathrm{ppm}$ which is relatively close to that reported by Staliński et al. of their related phenyltin dihydride (IV) species containing an oxazoline substituent $\left(\delta_{117 \mathrm{Sn}}=-244.5 \mathrm{ppm}\right.$ in toluene- $\left.\mathrm{d}_{8}\right)$. Chemical shifts in the ${ }^{119} \mathrm{Sn}$ NMR spectrum of reported flexible hypercoordinate tin dihydrides typically appear from approximately -200 to -220 ppm..$^{51-52,62}$ The upfield shift of compound $\mathbf{1 4}$ relative to these others may be a result of the close proximately of the nitrogen to the tin center. ${ }^{119} \mathrm{Sn}$ NMR spectrum were collected consecutively for $13 \mathrm{~h}$. After $2 \mathrm{~h}$, the appearance of two other signals, -42 and -173 ppm is detected in the ${ }^{119} \mathrm{Sn}$ NMR spectrum. These two resonances frequently appear through all the trials of the attempted syntheses of compound 14. After $8 \mathrm{~h}$ (not shown below), there is no evidence of starting material $14(\delta=-249.5 \mathrm{ppm})$. The NMR tube was left untouched and was hidden from light using aluminum foil for a week and another ${ }^{119} \mathrm{Sn}$ NMR spectrum was collected of the sample. After a week, the disappearance of the resonance at -42 and -173 ppm had occurred with the appearance of several new unidentified resonances $\left(\delta_{119 \mathrm{Sn}}=-192,-210,-211,-215,-223\right.$, -228, -231 and -233 ppm) as shown in Figure 16. 


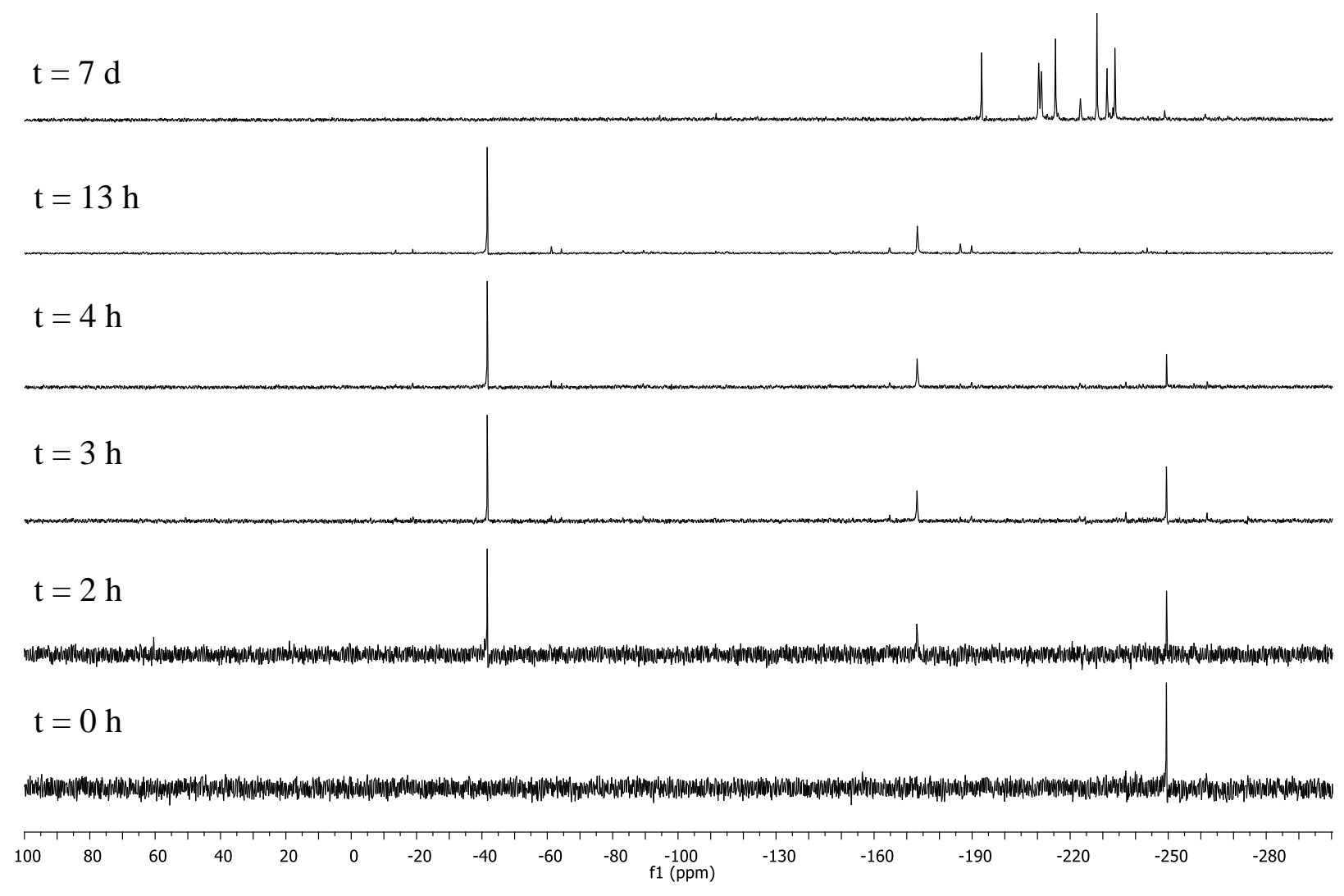

Figure 16: ${ }^{119} \mathrm{Sn}$ NMR spectra $\left(\mathrm{C}_{6} \mathrm{D}_{6}\right)$ over time of 14 at $27{ }^{\circ} \mathrm{C}$.

In Figure 16, specifically at $\mathrm{t}=3 \mathrm{~h}$, the appearance of satellite resonances are noted equidistant from the resonance at $-249.5 \mathrm{ppm}$ (these signals are not likely seen in $\mathrm{t}=0 \mathrm{~h}$ and $2 \mathrm{~h}$ : likely due to less scans being run on these spectra resulting in decreased spectral resolution). These satellites are indicative of tin satellites, suggesting that there are two tin atoms directly attached to each other; the coupling constant of these satellites is large $(3713 \mathrm{~Hz})$. This result has been previously seen in two of the attempts to synthesize compound 14. During these attempts, the reaction was carried out at $-84{ }^{\circ} \mathrm{C}$, with two molar equivalents of $\mathrm{NaBH}_{4}$ for $1 \mathrm{~h}$ in $\mathrm{EtOH}$. The workup was done in the absence of water and instead, after $1 \mathrm{~h}$, a large excess of hexane was added. This causes the excess of $\mathrm{NaBH}_{4}$ to be precipitated out of solution. This could be filtered off leaving a solution containing ethanol, hexane and compound $\mathbf{1 4}$. The majority of the solvent 
was then removed under reduced pressure. As a result, the ${ }^{1} \mathrm{H}$ NMR spectrum largely consisted of signals corresponding to EtOH and hexanes, while the signals for $\mathbf{1 4}$ were unable to be clearly identified. The ${ }^{119} \mathrm{Sn}$ NMR spectrum of this clearly showed the satellites equidistant of the resonance at $-249 \mathrm{ppm}$ with a small impurity at $-42 \mathrm{ppm}$ evident immediately upon running the ${ }^{119}$ Sn NMR (Figure 17).

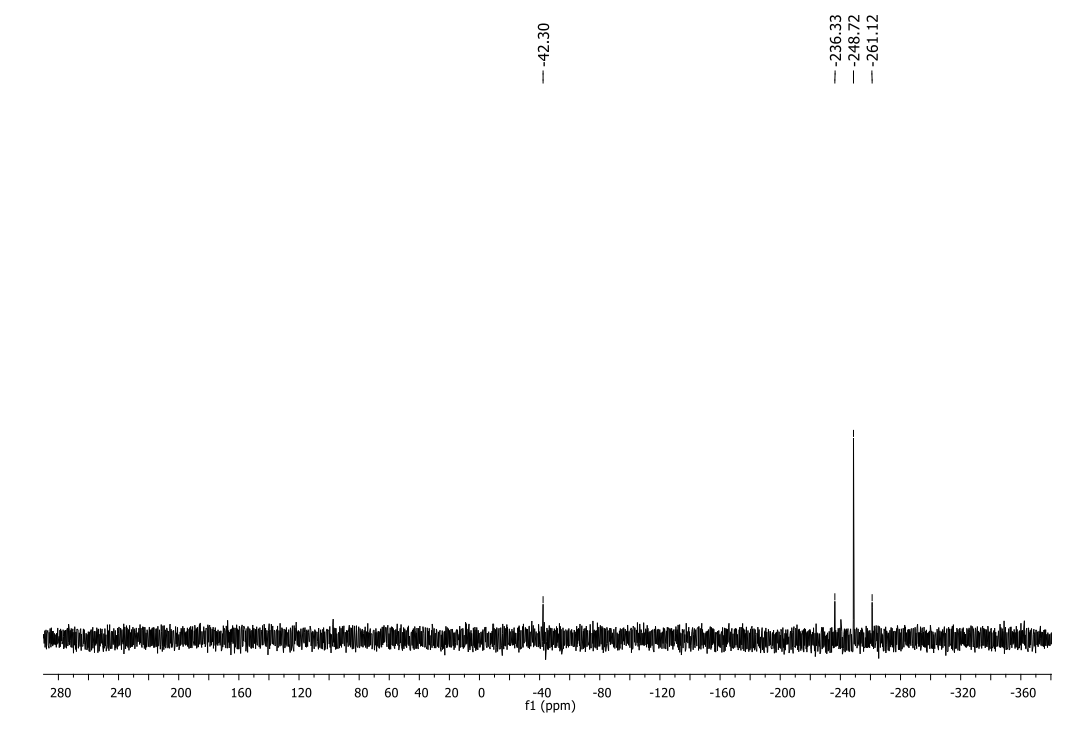

Figure 17: ${ }^{119} \mathrm{Sn}$ NMR spectrum of a synthetic attempt to synthesize compound $\mathbf{1 4}$.

In the ${ }^{1} \mathrm{H}$ NMR spectrum, a presumed hydride resonance with the corresponding to ${ }^{117 / 119} \mathrm{Sn}$ Satellites are present. Typical tin dihydrides are reported to resonate at $\delta_{1 \mathrm{H}}=5.5 \mathrm{ppm}$. Staliński et al. reported their very similar tin dihydride at approximately $6.7 \mathrm{ppm}$, with confirmation of the compound by HRMS, however they did not report any tin satellite signals. Tin monohydrides typically show up more upfield, such as $\mathrm{Ph}_{3} \mathrm{SnH}\left(\delta_{1 \mathrm{H}}=6.93 \mathrm{ppm}\right)$. There is a possibility in combination with the tin satellites and the chemical shift of the $\mathrm{Sn} \underline{H_{2}}$, that the compound might be compound 15 (Figure 18) rather than compound 14 that is being isolated and analyzed. 


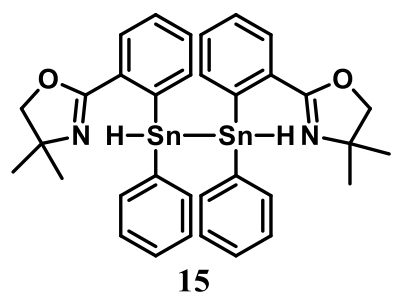

Figure 18: Structure of distannane dihydride 15.

There is little to no studies or prevalence of distannane dihydrides in the literature, probably due to their presumed instability and the likely difficult synthesis of these compounds. HRMS of this product was collected and a $[\mathrm{M}-\mathrm{H}]^{-}$was observed which could be a result of either compound $\mathbf{1 4}$ or $\mathbf{1 5}$ ionizing. There was evidence in the HRMS spectrum of compound $\mathbf{1 5}$, however resolution was inadequate, so an accurate mass could not be determined. However, due to the integration of the hydride signal (int. $=2 \mathrm{H}$ ) plus the corresponding ${ }^{117 / 119} \mathrm{Sn}$ satellites in the ${ }^{1} \mathrm{H} \mathrm{NMR}$ spectrum, it is believed that compound $\mathbf{1 4}$ is being isolated. If $\mathbf{1 5}$ was being isolated this hydride signal at $6.79 \mathrm{ppm}$ should integrate to one relative to the methylene protons on the oxazoline, however the integration of the ${ }^{1} \mathrm{H}$ NMR shows the expected 2:2 ratio, giving evidence for 14 . The assignment of these apparent tin satellites is currently undetermined and conclusive evidence for $\mathbf{1 5}$ was therefore not revealed.

\subsection{Synthesis of homopolymer 16}

\subsubsection{Dehydropolymerization using Wilkinson's catalyst}

Since dihydride $\mathbf{1 4}$ is temperature sensitive and starts reacting readily in an NMR tube, the tin dihydride is carried through to the polymerization without spectroscopic confirmation. Typically, dehydropolymerization of this type are performed at room temperature, however in this

case a temperature of $0{ }^{\circ} \mathrm{C}$ was used (Scheme 8). This was done to try and slow down the 
decomposition reaction of $\mathbf{1 4}$, seemingly with itself before it would interact with Wilkinson's catalyst and initiate polymerization.

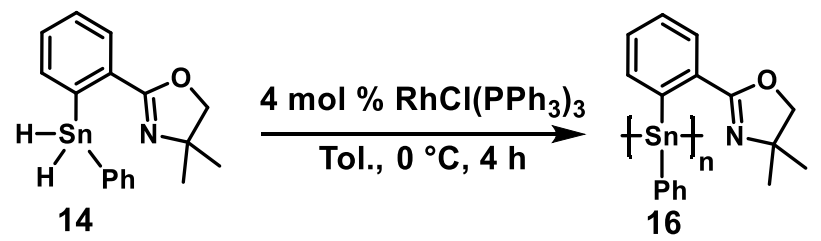

Scheme 8: Reaction scheme of the synthesis of polymer 16.

The crude ${ }^{119} \mathrm{Sn}$ NMR spectrum of product $\mathbf{1 6}$ showed a few unidentified resonances so the crude polymer was cleaned by dissolving it in a minimal amount of THF and dropping the solution into cold stirring hexanes $(3 \times 75 \mathrm{~mL})$ and heptane $(1 \times 75)$ which results in the polymer being isolated as a pale-yellow powder. A single broad tin resonance at $-268.09 \mathrm{ppm}$ in the ${ }^{119} \mathrm{Sn} \mathrm{NMR}$ spectrum is obtained of this material. This is about a $20 \mathrm{ppm}$ upfield shift relative to that of the dihydride. Polymer 16 is only partially soluble in $\mathrm{C}_{6} \mathrm{D}_{6}$ and therefore is difficult to get a concentrated sample. The ${ }^{1} \mathrm{H}$ NMR spectrum showed the disappearance of the $\mathrm{Sn}-\underline{\mathrm{H}}$ signal $\left(\delta_{1 \mathrm{H}}=\right.$ $6.79 \mathrm{ppm}$ ) and a broadening of the other resonances, a characteristic of polymers. The integration of the methylene protons of the oxazoline correspond relative to the aromatic signals however, the methyl groups overlap with residual hexane/ heptane and therefore accurate integration value for that signal is likewise problematic.

Triple detection gel permeation chromatography (GPC) was performed to determine the absolute molecular weight of 16. Polymer $\mathbf{1 6}$ has low solubility in THF in which the GPC is performed but a chromatogram was still able to be collected at this low concentration $(<10 \mathrm{mg} /$ $\mathrm{mL}$ ). The chromatogram (Figure 19) shows a bimodal distribution. From the $18-19 \mathrm{~mL}$ retention volume is indicative of the higher molecular weight chains than those represented by the peak between 20-20.50 mL. Low molecular weight chains are likely represented in the signal at 
approximately $20.00 \mathrm{~mL}$. The molecular weight determined from this distribution will not be precise as a result of the bimodal distribution, but preliminary results show a molecular weight of $\sim 10,100 \mathrm{Da}$, which corresponds to approximately 27 repeat units. A PDI value of 1.73 is likewise obtained.

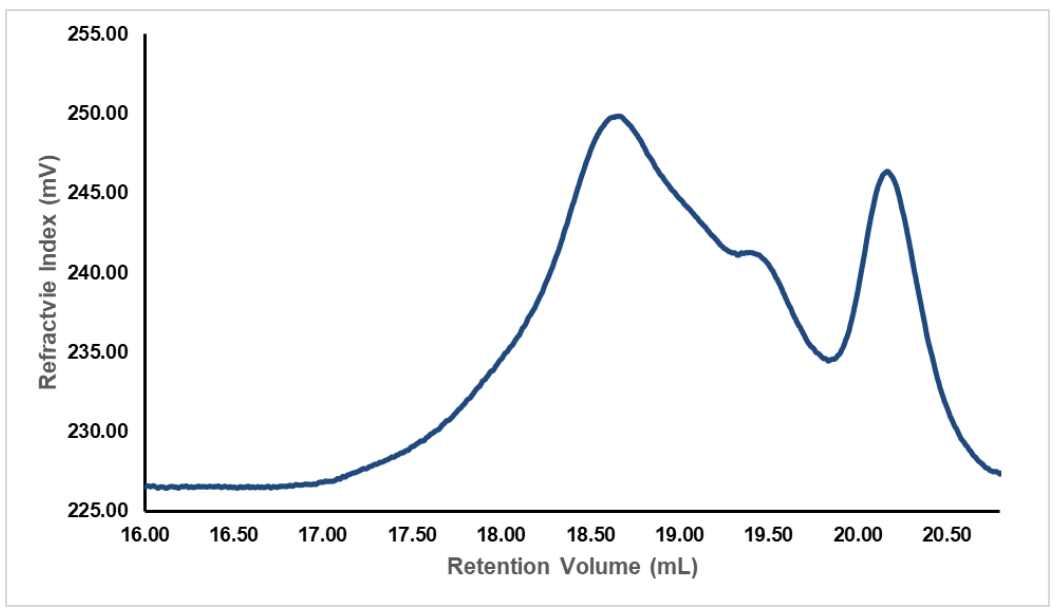

Figure 19: GPC chromatogram of polymer 16.

A second attempt at the polymerization was done, however this time it was performed at $\mathrm{RT}$ in hopes in increasing the molecular weight by increasing the rate of reaction of Wilkinson's catalyst. However, upon ${ }^{119} \mathrm{Sn}$ NMR analysis showed complete consumption of $\mathbf{1 4}$ and the appearance of several sharp resonances and a small broad signal at $-268 \mathrm{ppm}$ resembling polymer 16 (Figure 20a). After cleaning several times, solubility further decreased, and several sharp signals are still present (Figure 20b). No detectable amount of polymer was present when GPC analysis was performed. Due to the reactive nature of $\mathbf{1 4}$, proceeding at RT may cause $\mathbf{1 4}$ to react irreversibly with itself forming cyclic and other unreactive oligomers before interacting with Wilkinson's catalyst.

An attempt at the polymerization of $\mathbf{1 4}$ at $-30{ }^{\circ} \mathrm{C}$ for $4 \mathrm{~h}$ was under taken to try and limit undesired side reactions. No evidence of the previously obtained polymer $\left(\delta_{119 \mathrm{Sn}}=-268 \mathrm{ppm}\right)$ was 
observed, however a broad signal was noted $\left(\delta_{119 \mathrm{Sn}}=-280 \mathrm{ppm}\right)($ Figure 20c). Unfortunately, GPC analysis showed no evidence of polymer under these conditions.

Another attempt at the polymerization of 14 was conducted at $-30{ }^{\circ} \mathrm{C}$ for $6 \mathrm{~h}$. A longer reaction time was attempted to due to the decreased reactivity of Wilkinson's catalyst at a lower temperature. However, upon cleaning of the resulting products, no polymer was detected via ${ }^{119} \mathrm{Sn}$ NMR spectroscopy (Figure 20d). After these attempts, it was assumed that the polymerization of 14 likely yielded only short oligomeric chains.

a)

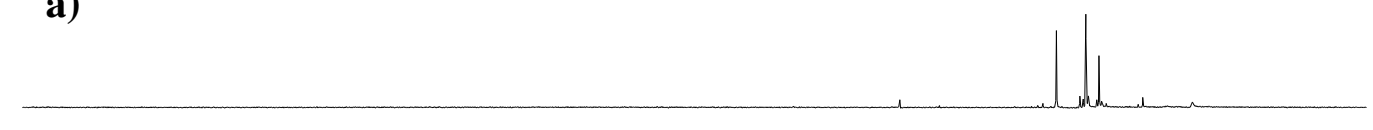

b)

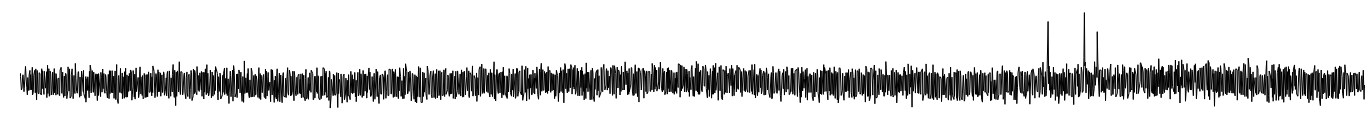

c)

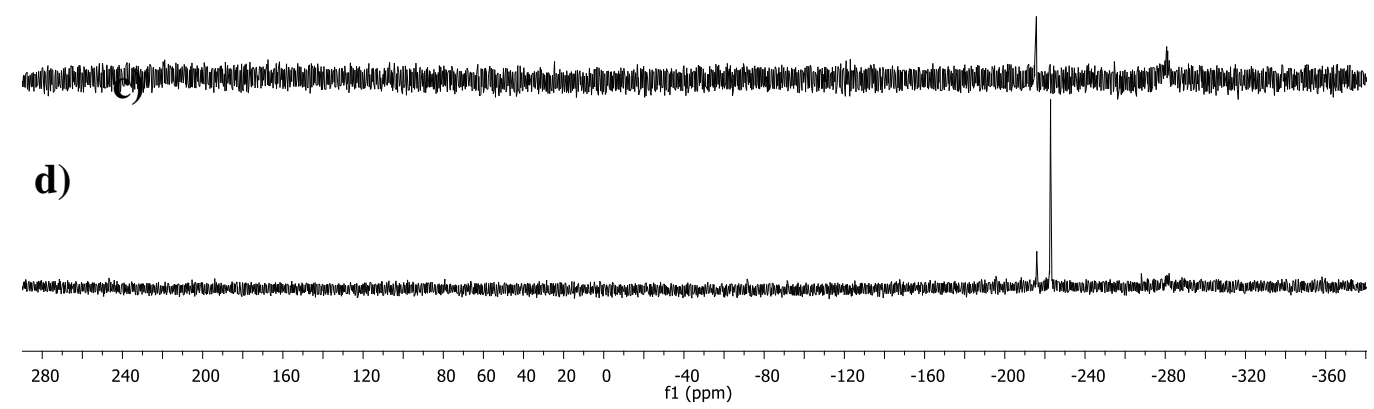

Figure 20: ${ }^{119} \mathrm{Sn}$ NMR spectrum of crude samples of $\mathbf{1 6}$ at RT (a), RT after cleaning four times (b), doing the polymerization at $-30^{\circ} \mathrm{C}$ for $4 \mathrm{~h} \mathrm{(c),} \mathrm{and} \mathrm{doing} \mathrm{the} \mathrm{polymerization} \mathrm{at}-30{ }^{\circ} \mathrm{C}$ for 6 h. 


\subsubsection{Wurtz Coupling}

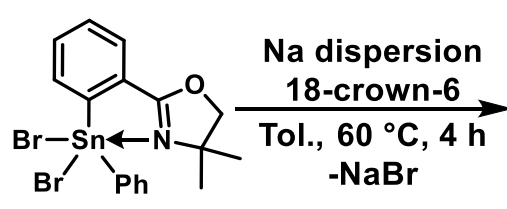

13

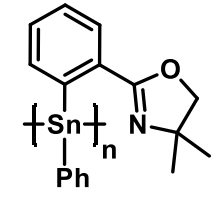

16

Scheme 9: Reaction scheme for the synthesis of $\mathbf{1 6}$ via Wurtz coupling.

A Wurtz coupling reaction using dibromide 13 to yield polymer 16 was attempted. In the Wurtz coupling, clean, shaven Na metal was dispersed into toluene and refluxed at $110{ }^{\circ} \mathrm{C}$ for $1 \mathrm{~h}$. After which, the Na dispersion was cooled down to RT, followed by the addition of a mixture of 13 and 18-crown-6. This was further allowed to react for $4 \mathrm{~h}$ at $60{ }^{\circ} \mathrm{C}$. After $4 \mathrm{~h}$, the reaction mixture was filtered in an inert atmosphere to dispose of the Na metal. After removal of the solvent, of a bright yellow coloured gel was obtained. ${ }^{119} \mathrm{Sn}$ NMR analysis showed a small broad resonance at -268 ppm similar to that previously obtained by dehydropolymerization, however the major resonance was starting material $\left(\delta_{119 \mathrm{Sn}}=-268 \mathrm{ppm}-286.7\left(\mathrm{C}_{6} \mathrm{D}_{6}\right)\right)$ (Figure 21a). No further analysis was done of this material. A second attempt was likewise performed, however after NMR analysis, it was determined that only compound 13 was present and hence no reaction had occurred (Figure 21b).

A third attempt was performed, however in this attempt 15 -crown-5 was used rather than 18-crown-6. This reaction yielded a white coloured powder; the yellow colour indicative of polystannanes were not visible. In this attempt, a small broad resonance at -268 ppm similar to what was previously obtained with both the Wurtz coupling and dehydropolymerization was noted (Figure 21c). Upon cleaning with the same method previously described, all species present seemingly precipitated out of solution after NMR analysis. GPC analysis was performed on this mixture; however no evidence of polymer was detected. The lack of significant polymer formation 
via these three attempts might be a result of the difficulty in obtaining finely dispersed good sodium metal before $\mathbf{1 3}$ is added into the solution.

a)

b)

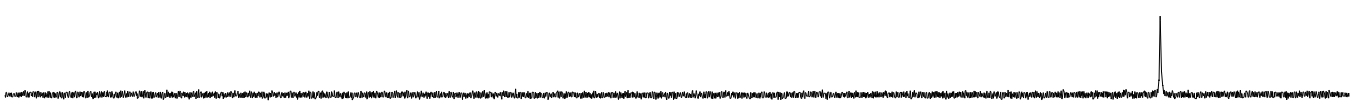

c)

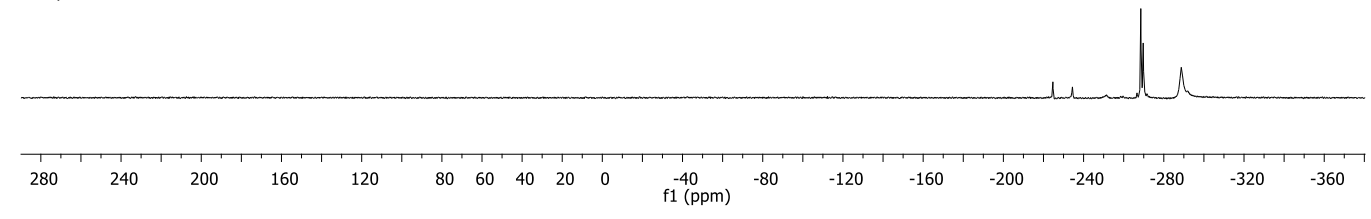

Figure 21: ${ }^{119} \mathrm{Sn}$ NMR spectrum of the attempted Wurtz coupling reaction of $\mathbf{1 3 .}$

2.5 Synthesis and characterization of 4,4-dimethyl-2-(2-((triphenylstannyl)methyl)phenyl)4,5-dihydrooxazole 18

As mentioned previously by Choffat et $a l .{ }^{49}$, diaryl tin hydrides were determined to be incompatible with Wilkinson's catalyst. However, it has been recently shown that diaryl species can be dehydrogenative coupled using Wilkinson's catalyst. ${ }^{63}$ Unfortunately, only low molecular weight polymer is obtained. A more flexible version of the previously mentioned oxazolines was sought in the dehydropolymerization to hopefully yield high molecular weight polystannanes.

Gschwend et al. ${ }^{56}$ demonstrated that the methyl group of the phenyl ring in 4,4-dimethyl2-(o-tolyl)-4,5-dihydrooxazole (17) can be lithiated at $0{ }^{\circ} \mathrm{C}$ and then reacted with various 
electrophiles, however no examples with tin as the electrophile are present in literature. This oxazoline 17 (Scheme 10) was synthesized using the same method mentioned earlier (section 2.1) for the synthesis of $\mathbf{8}$, however $\boldsymbol{o}$-toluic acid was used instead of 2-bromobenzoic acid. Lithiation of this oxazoline was performed as reported ${ }^{56}$ and after the addition of $n$-BuLi, the clear colourless solution turned a cloudy deep red colour. After the addition of $\mathrm{Ph}_{3} \mathrm{SnCl}$, the solution turned an opaque yellow. Following removal of the reaction solvent $\left(\mathrm{Et}_{2} \mathrm{O}\right)$, precipitation of the salt $(\mathrm{LiCl})$ was carried out with the use of toluene. Gravity filtration was carried out, and removal of the toluene, a yellow coloured powder was obtained. The ${ }^{119} \mathrm{Sn}$ and ${ }^{1} \mathrm{H}$ NMR spectra showed impurities, but these could be easily removed through trituration using methanol to afford compound 18 as white crystals.

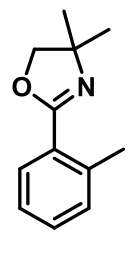

17

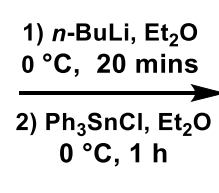

$0^{\circ} \mathrm{C}, 1 \mathrm{~h}$

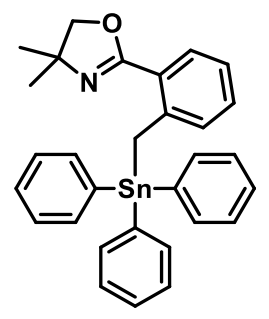

18

Scheme 10: Reaction scheme for the synthesis of oxazoline stannane $\mathbf{1 8 .}$

The ${ }^{1} \mathrm{H}$ NMR spectrum of $\mathbf{1 8}$ showed similar chemical shifts to that of compound $\mathbf{8}$ with the addition of the signal corresponding to the methylene protons between the tin and oxazoline. This signal displays ${ }^{119} \mathrm{Sn}$ satellites $\left({ }^{2} J_{1 \mathrm{H}-119 \mathrm{Sn}}=75.5 \mathrm{~Hz}\right)$. A crystal of compound 18 suitable for single crystal X-ray diffraction was obtained (Figure 22). 
a)

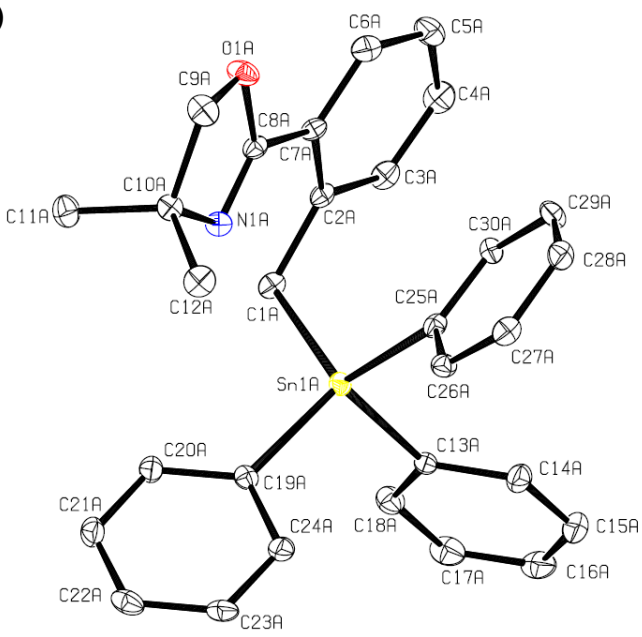

b)

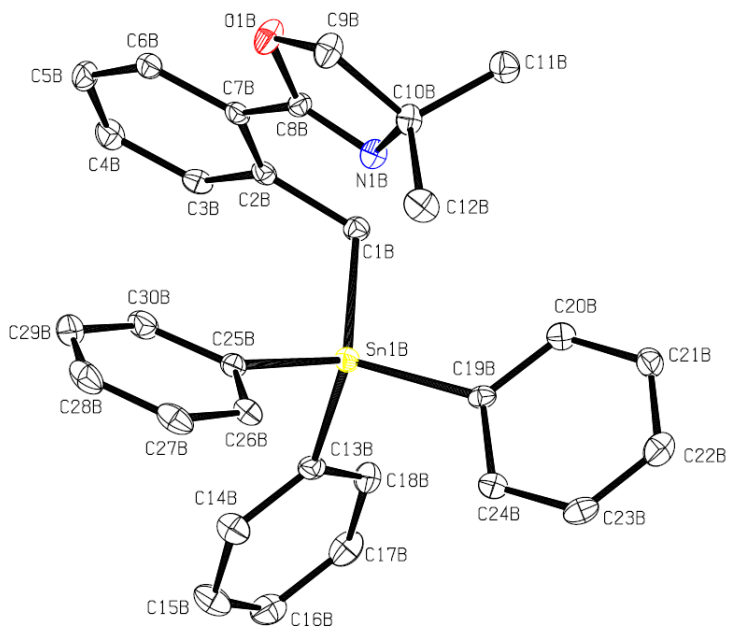

Figure 22: ORTEP representation of two molecules of compound $\mathbf{1 8}$ found in the unit cell. Thermal ellipsoids shown at the $30 \%$ level.

Table 5: Relevant crystal structure data analysis of $\mathbf{1 8 .}$

\begin{tabular}{|c|c|c|c|}
\hline Bond & Bond Lengths of A $(\AA)$ & Bond & Bond Lengths of B $(\AA)$ \\
\hline Sn1A-N1A & $3.176(4)$ & Sn1B-N1B & $3.234(4)$ \\
\hline Sn1A-C1A & $2.162(4)$ & Sn1B-C1B & $2.153(4)$ \\
\hline Sn1A-C13A & $2.158(4)$ & Sn1B-C13B & $2.155(4)$ \\
\hline Sn1-C19A & $2.150(4)$ & Sn1B-C19B & $2.139(4)$ \\
\hline Sn1-C25A & $2.143(4)$ & Sn1-C25B & $2.144(4)$ \\
\hline
\end{tabular}

Two unique molecules of $\mathbf{1 8}$ are found within the unit cell, each with slightly different bond lengths and angles. The geometry around the tin center of these molecules is a distorted trigonal bipyramidal ( $\tau_{5}=0.80,0.76$ respectively). The equatorial angles around the tin center for both structures are between $103.6^{\circ}$ and $116.1^{\circ}$. With the axial angles around the tin centers being 163.2(1) and $162.0(1)^{\circ}$ respectively. The $\mathrm{Sn}-\mathrm{N}$ bond distance is significantly longer than in compound 10 which is expected due to the $\mathrm{CH}_{2}$ group present between the tin and the oxazoline. However, it is still within the sum of the van Der Waals radii of tin and nitrogen bond (3.72 $\AA$ ). Comparing the solid state structures of $\mathbf{1 0}$ and $\mathbf{1 8}$, the Sn-C bond lengths are similar however the 
elongation of the $\mathrm{Sn}-\mathrm{C} 13$ in compound $\mathbf{1 8}$ bond isn't as prevalent as it was in compound $\mathbf{1 0}$ for the related Sn-C12 bond. This is likely a result of the $3 \mathrm{c}-4 \mathrm{e}^{-}$sharing being less prominent in these molecules due to the longer distance between the tin and the nitrogen leading to a weaker dative interaction.

\subsubsection{Attempted synthesis of semi-flexible oxazoline stannane halides}

The addition of bromine was added stoichiometrically and done under the same reaction conditions as reported for $\mathbf{1 0}$. Upon addition of the one equivalent of $\mathrm{Br}_{2}$ (to try and synthesize the monobromide species), three tin resonances were present in the ${ }^{119}$ Sn NMR spectrum (Figure 23a) of the resulting mixture. Compound $\mathbf{1 8}$ is assigned to the major resonance at $\left(\delta_{119 \mathrm{Sn}}=-125 \mathrm{ppm}\right)$ with two others at -215 and $-248 \mathrm{ppm}$. Assuming the resonance at $-215 \mathrm{ppm}$ is the monobromide and the resonance at -248 represents the dibromide, another equivalent of $\mathrm{Br}_{2}$ was added to this mixture. ${ }^{119} \mathrm{Sn}$ NMR spectrum of this mixture is shown in Figure 23b. Although it appears in the ${ }^{119} \mathrm{Sn}$ NMR spectrum that there is only one tin species, the ${ }^{1} \mathrm{H}$ NMR shows two sets of resonances corresponding to the oxazoline signals and for this reason another equivalent of $\mathrm{Br}_{2}$ was added. This then resulted in the appearance of only a single set of oxazoline signals in the ${ }^{1} \mathrm{H}$ NMR being present and a single resonance in the ${ }^{119} \mathrm{Sn}$ NMR spectrum $\left(\delta_{119 \mathrm{Sn}}=-449 \mathrm{ppm}\right.$ : Figure 23c). This presumably corresponds to the tribromide species, 19 (Figure 24). The ${ }^{1} \mathrm{H}$ NMR spectrum integration values also show this as being the likely product due to the integration of the aromatic protons equalling four, and no evidence of the other phenyl substituents is observed. Attempts to separate the mixture represented in Figure 22a was deemed unsuccessful as these compounds would not elute on a TLC plate using polar or non-polar solvents. 


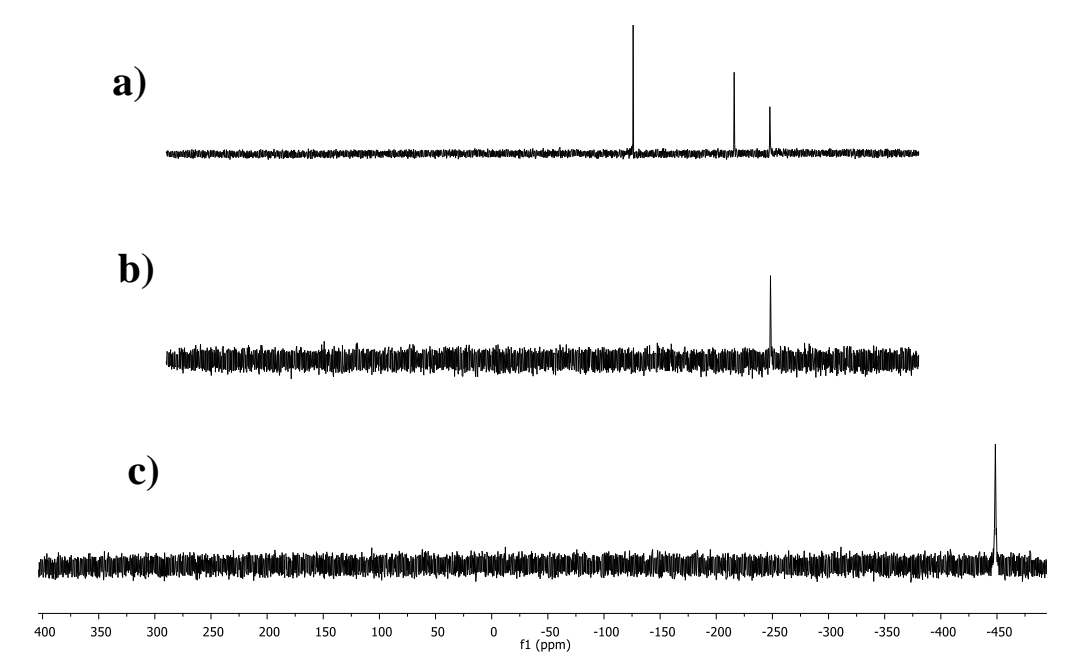

Figure 23: ${ }^{119} \mathrm{Sn}$ NMR spectrum $\left(\mathrm{CDCl}_{3}\right)$ of the reaction with compound $\mathbf{1 8}$ and $\mathrm{Br}_{2}$.

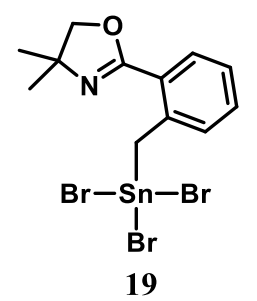

Figure 24: Structure of 19.

Attempts were also undertaken to perform a step-wise chlorination of compound $\mathbf{1 8 .}$ However, the results weren't comparable to that of the attempted bromination. A broad ${ }^{119} \mathrm{Sn}$ resonance appears at $-60 \mathrm{ppm}$ with a smaller resonance at $-206 \mathrm{ppm}$ (Figure 25a) in this experiment. A second equivalent of $\mathrm{HCl} / \mathrm{Et}_{2} \mathrm{O}$ was added to this same reaction mixture which resulted in two different tin resonances, -90 and -233 ppm (Figure 25b). The resonance at -233 ppm might correspond to the dichloride however no separation was attempted. The order of 
addition, temperatures and the speed of addition of the $\mathrm{HCl} / \mathrm{Et}_{2} \mathrm{O}$ were all varied, however similar results were observed $v i a^{119}$ Sn NMR spectroscopy.

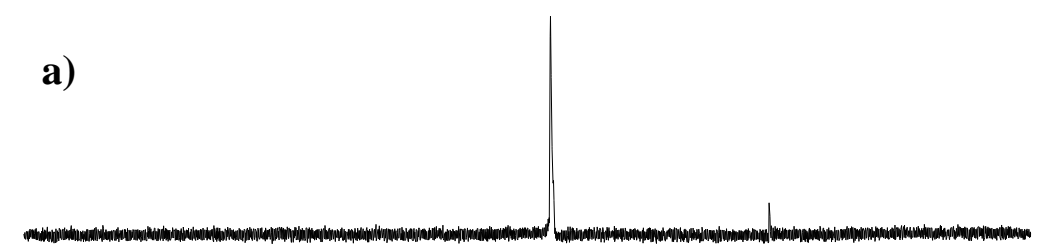

b)

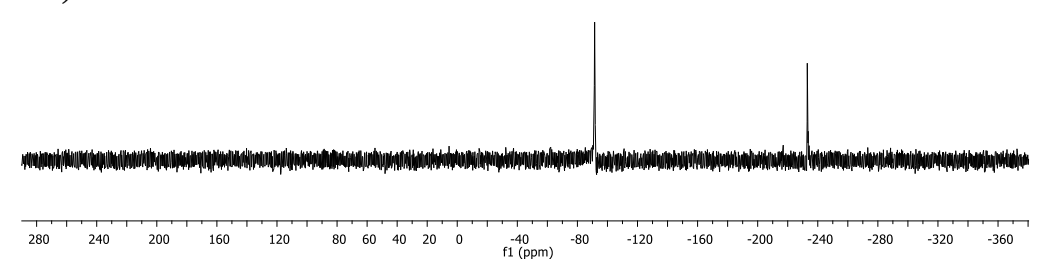

Figure 25: ${ }^{119} \mathrm{Sn} \mathrm{NMR}$ spectrum $\left(\mathrm{CDCl}_{3}\right)$ of the reaction with compound 18 and $\mathrm{HCl} / \mathrm{Et}_{2} \mathrm{O}$.

Bromination of organotin (IV) compounds have been reported in literature in solvents such as $\mathrm{CCl}_{4}, \mathrm{CHCl}_{3}$ and $\mathrm{CH}_{2} \mathrm{Cl}_{2}$ so the attempted synthesis of $\mathbf{2 0}$ was performed in dry DCM (Scheme 11). This resulted in the observation of a single tin resonance was seen in the ${ }^{119} \mathrm{Sn}$ NMR spectrum at $-248.2 \mathrm{ppm}$ in $\mathrm{CDCl}_{3}$ and no additional bromine was needed for this reaction. The upfield shift of about $120 \mathrm{ppm}$ may be due to the increased interaction between the nitrogen and the tin atoms. The ${ }^{1} \mathrm{H}$ NMR showed some impurities, but these could be removed through trituration with $\mathrm{MeOH}$ to yield $\mathbf{2 0}$ as a white coloured powder.

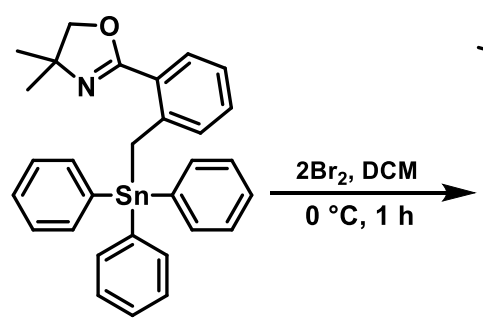

18

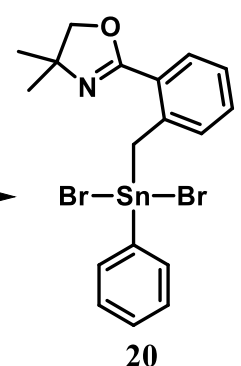

20

Scheme 11: Reaction scheme for the synthesis of 20. 


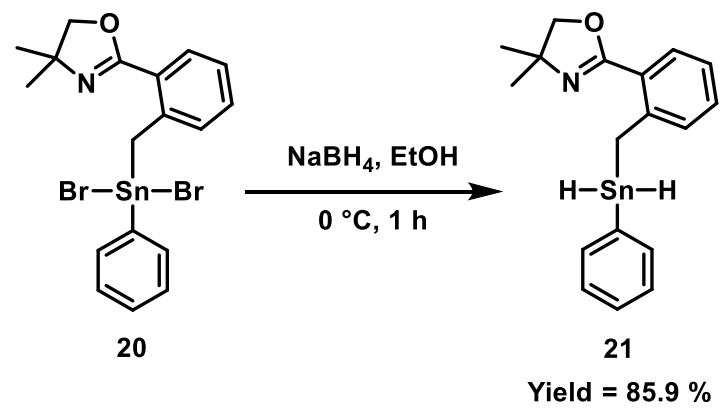

Scheme 12: Reaction scheme for the synthesis of 21.

The synthesis of $\mathbf{2 1}$ was carried out through a more traditional route that is often used to synthesize tin dihydrides from tin dihalides. A large excess of $\mathrm{NaBH}_{4}$ in $\mathrm{EtOH}$ for $1 \mathrm{~h}$ at $0{ }^{\circ} \mathrm{C}$ was used in this case (Scheme 12) to yield hydride 21 after work-up as a colourless viscous oil in good yield. This compound also quickly started turning yellow in colour, however, NMR analysis was still able to be carried out.

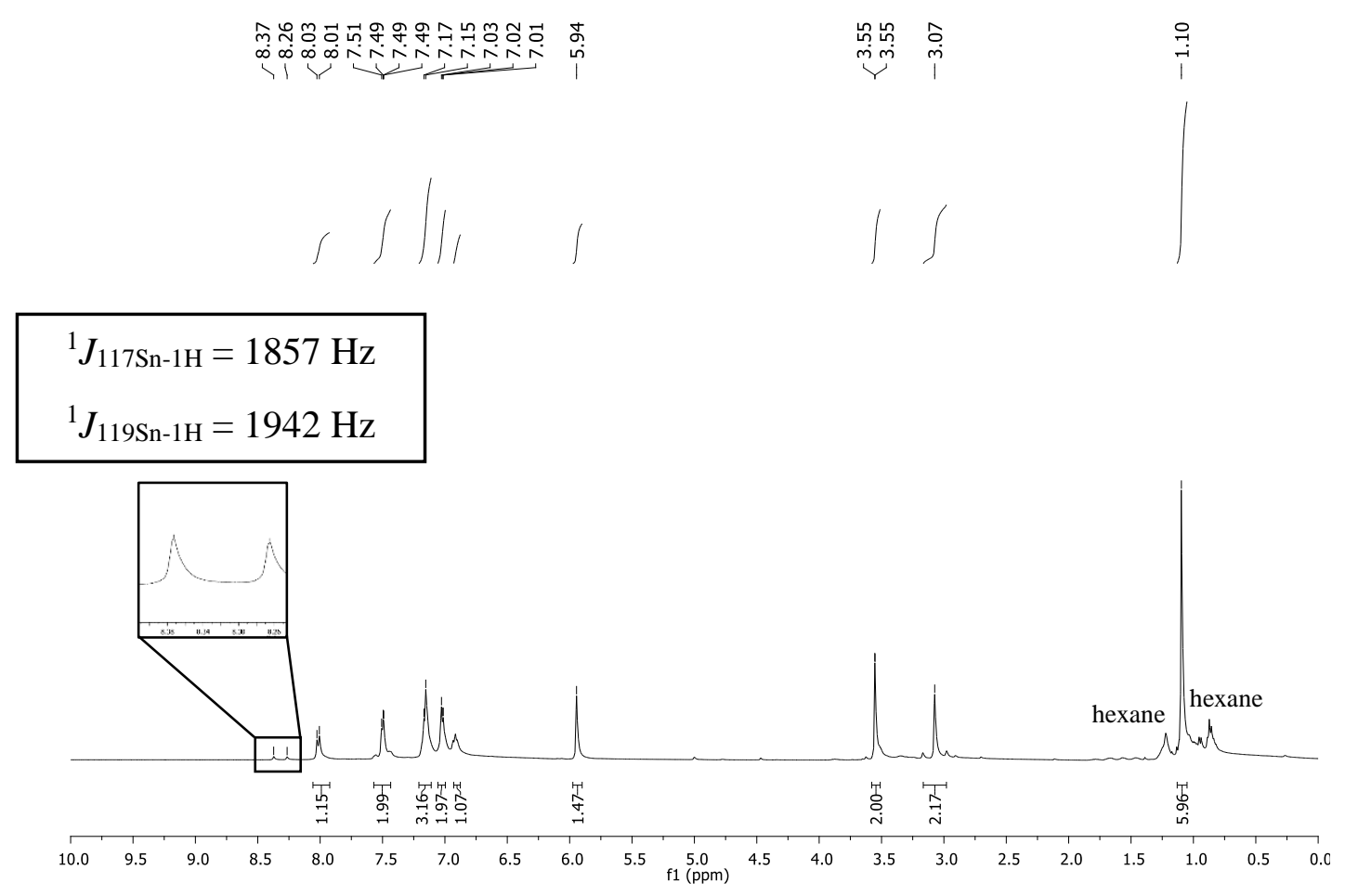

Figure 26: ${ }^{1} \mathrm{H}$ NMR $\left(\mathrm{C}_{6} \mathrm{D}_{6}\right)$ spectrum of 21. 
In the ${ }^{1} \mathrm{H}$ NMR spectrum (Figure 26), the hydride signal appears at $\delta_{1 \mathrm{H}}=5.94 \mathrm{ppm}$ which has ${ }^{117 / 119} \mathrm{Sn}$ satellites equidistant from this singlet, however only one set is visible with the other set being overlaid by the signal at $\delta_{1 \mathrm{H}}=3.55 \mathrm{ppm}$. A single resonance was seen in the ${ }^{119} \mathrm{Sn} \mathrm{NMR}$ spectrum $\left(\delta_{119 S n}=-221.02\right)$. This is about a thirty ppm downfield shift relative to dihydride 14 . This difference in shift is likely a result of $\mathbf{2 1}$ being more flexible than $\mathbf{1 4}$ allowing the nitrogen to be at a greater distance away from the tin which is less Lewis acidic when hydrides are bonded to it relative to halides.

\subsubsection{Synthesis of polymer 22:}

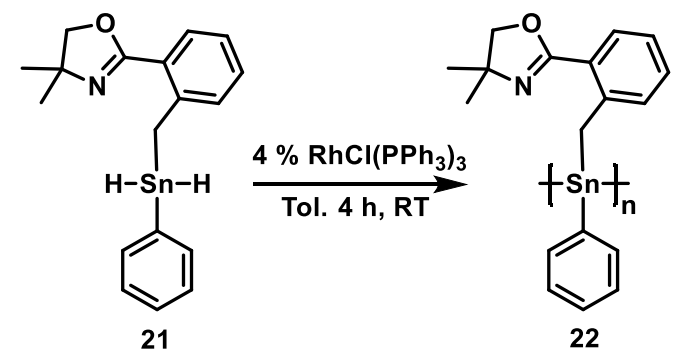

Scheme 13: Reaction scheme for the synthesis of polymer 22.

Due to the better stability of $\mathbf{2 1}$ compared to 14, the synthesis of polymer 22 was carried out using Wilkinson's catalyst for $4 \mathrm{~h}$ at RT (Scheme 13) to yield a yellow coloured powder after work up. Preliminary ${ }^{119} \mathrm{Sn}$ NMR analysis showed five tin resonances $\left(\delta_{119 \mathrm{Sn}}=-186.6,-204.8\right.$, 217.9, -220.9, and -268.8 ppm) in the crude NMR spectrum (Figure 27a). It is unclear what signal corresponds to 22 until cleaning is done. The crude polymer was cleaned by dissolving it in a minimal amount of THF and dropping the solution into cold stirring hexanes $(2 \times 75 \mathrm{~mL})$ and heptane $(2 \times 75)$ which results in the polymer being isolated as a pale-yellow powder. After cleaning, a single resonance is present $\left(\delta_{119 \mathrm{Sn}}=-183.8 \mathrm{ppm}\right.$ : Figure 27b). This chemical shift 
indicates that the oxazoline substituent is likely not coordinating to the tin center. Polystannanes containing a hypercoordinating ligand typically show a resonance of > 200 ppm. ${ }^{51-52,62}$

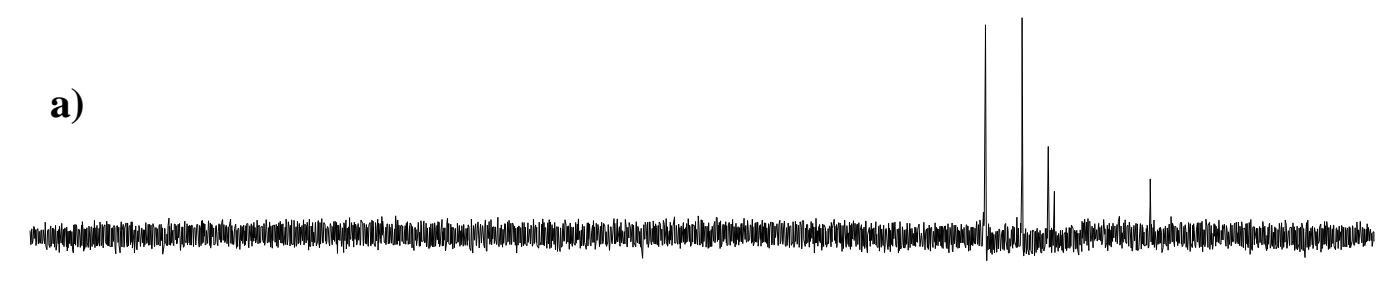

b)

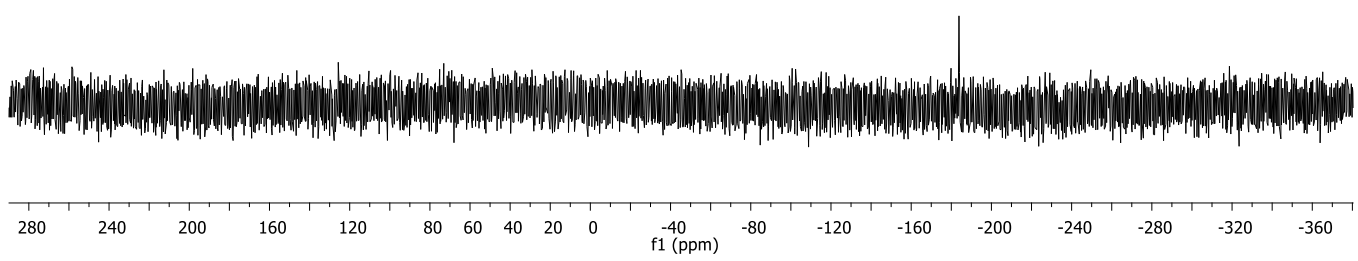

Figure 27: Crude (a) and clean (b) ${ }^{119} \mathrm{Sn}$ NMR spectrum of 22 in $\mathrm{C}_{6} \mathrm{D}_{6}$.

Preliminary GPC analysis of this crude mixture showed three different signals (Figure 28: top). One at approximately $18.00 \mathrm{~mL}$ and a second at $20.00 \mathrm{~mL}$. The peak at $18.00 \mathrm{~mL}$ is indicative of a higher molecular weight polymer which has a molecular weight of approximately $15,400 \mathrm{Da}$ with a PDI value of 1.03. Together both signals within the GPC showed a molecular weight of $24,400 \mathrm{Da}$ and a PDI value 1.82 . These values are rough estimates and will change after cleaning of the polymer. After cleaning, the GPC chromatograph (Figure 28: bottom) showed the disappearance of the signal at 20.00 retention volume, and a bimodal distribution at about 18.00 $\mathrm{mL}$. However, GPC analysis showed a molecular weight of 3,200 Da, which corresponds to 
approximately seven repeat units, with a PDI value of 1.56 . This molecular weight is lower than that obtained with polymer 16.
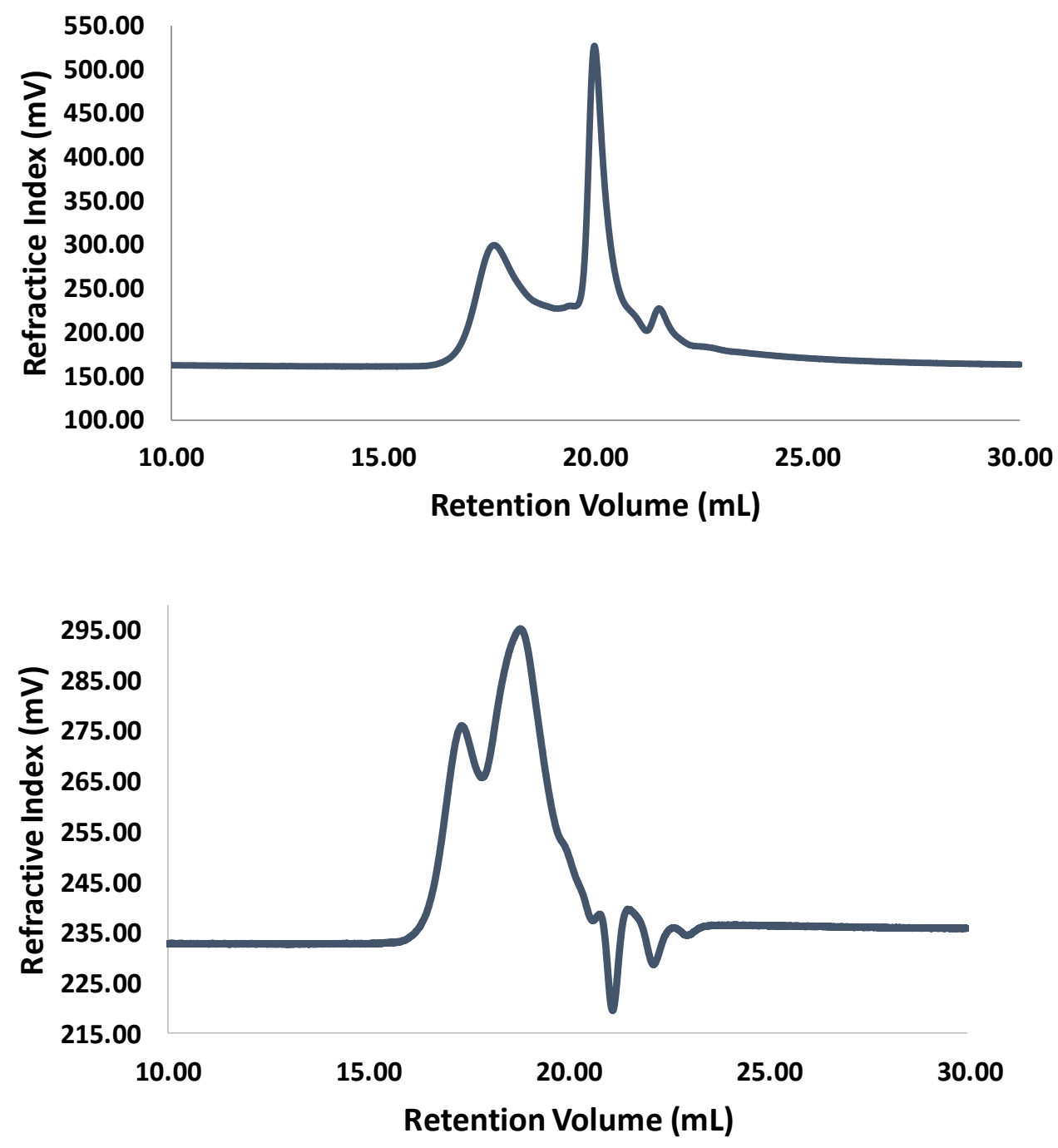

Figure 28: Crude GPC (top), after cleaning GPC (bottom) chromatogram of 22.

\subsection{Synthesis of of 2-(2-(triphenylstannyl)ethyl)pyridine 23:}

Molloy et al. ${ }^{18}$ previously reported the synthesis of 2-(2-(triphenylstannyl)ethyl)pyridine through the addition of 2-vinylpyridine in a slight excess to triphenyltin hydride, neat and heated to $100{ }^{\circ} \mathrm{C}$ for $2 \mathrm{~h}$ (Scheme 12). This results in a couple of by-products as seen in the ${ }^{119} \mathrm{Sn}$ NMR 
spectrum, one being hexaphenyl distannane. This can be removed through recrystallization to yield 23 as a white coloured powder. Alternate routes including the addition of AIBN, a radical initiator was used in different ratios to try to prevent the unwanted by-products. However, this proved ineffective therefore the reaction was performed without AIBN. After purification, the ${ }^{1} \mathrm{H},{ }^{13} \mathrm{C}$ and ${ }^{119}$ Sn NMR (Figure 30a) spectra of $\mathbf{2 3}$ agreed with that reported by Molloy et al. ${ }^{18}$
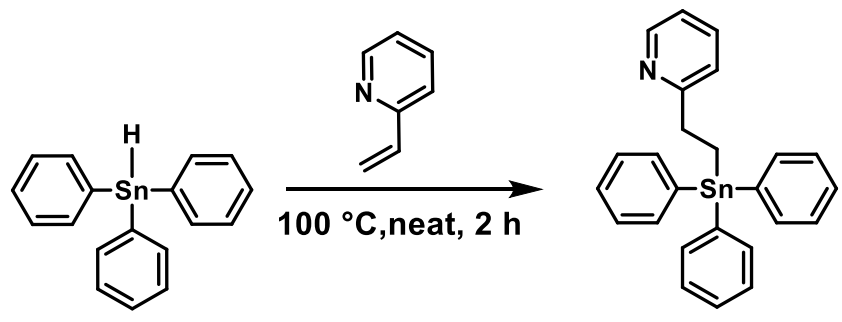

23

Yield $=76.3 \%$

Scheme 14: Reaction scheme for the synthesis of compound 23.

A crystal of compound $\mathbf{2 3}$ suitable for single crystal X-ray diffraction was obtained (Figure 29). The geometry of this molecule around tin is distorted trigonal bipyramidal $\left(\tau_{5}=0.74\right)$ with equatorial bond angles around the tin center between $102.4^{\circ}$ and $120.8^{\circ}$ and an axial bond angle of 165.14(7) ${ }^{\circ}$. The bond length between Sn1 and C20 is longer than the other tin carbon bonds (Table 6) due to these atoms being in the axial position along with the nitrogen atom, presumably resulting in $3 \mathrm{c}-4 \mathrm{e}^{-}$sharing. The tin nitrogen bond distance is $2.888 \AA$ which is slightly longer than what is present in the solid state structure of $\mathbf{1 0}(\mathrm{Sn}-\mathrm{N}: 2.762 \AA)$ but shorter than the bond distances found in the solid state structures of $\mathbf{1 8}$ (Sn-N: $3.176 \AA, 3.234 \AA$ ). The shorter Sn-N bond distance seen in $\mathbf{2 3}$ relative to $\mathbf{1 8}$, despite there being a flexible ethyl chain which allows the pyridine ring to extend away from the tin center, is likely a result of the pyridine ring being less sterically encumbering than the oxazoline ring in $\mathbf{1 8}$. This allows the ring nitrogen of the pyridine ring to be drawn closer to the Lewis acidic tin. 


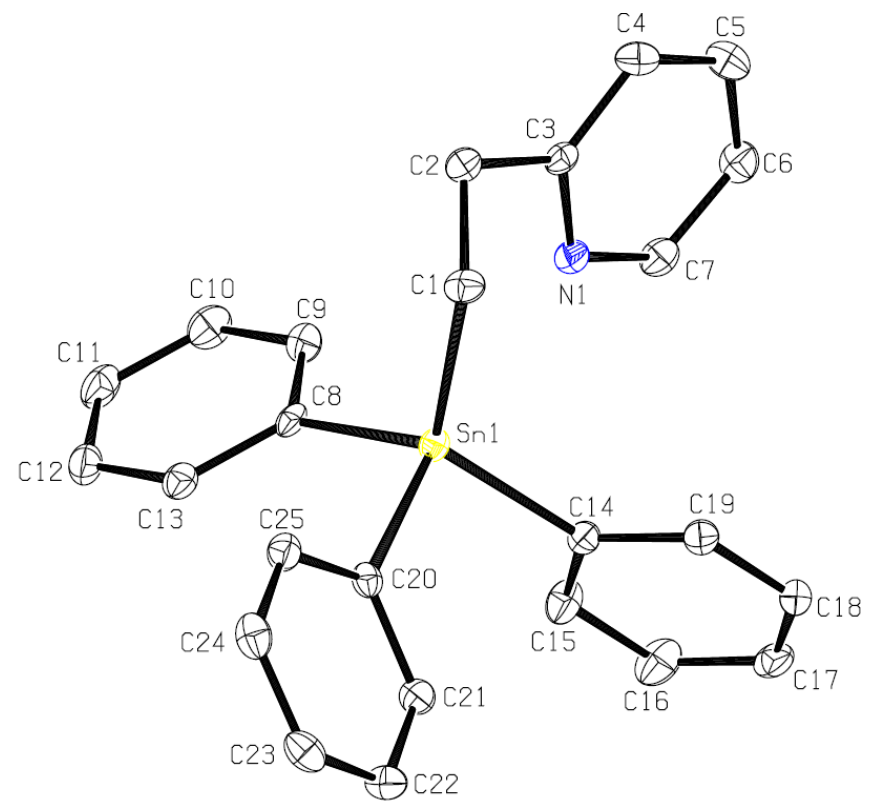

Figure 29: ORTEP representation of unit cell molecule of 23. Thermal ellipsoids drawn at the 30 $\%$ level.

Table 6: Relevant parameters obtained from the crystal data analysis of $\mathbf{2 3}$.

\begin{tabular}{|c|c|}
\hline Bond & Bond Lengths $(\AA)$ \\
\hline Sn1-N1 & 2.888 \\
\hline Sn1-C8 & $2.154(2)$ \\
\hline Sn1-C14 & $2.144(2)$ \\
\hline Sn1-C20 & $2.162(2)$ \\
\hline Angle & Bond Angle $\left(^{\circ}\right)$ \\
\hline N1-Sn1-C20 & 165.14 \\
\hline
\end{tabular}

2.7 Synthesis of 2-(2-(dibromo(phenyl)stannyl)ethyl)pyridine 24:

Molloy et al. ${ }^{18}$ reported the reaction between compound $23\left({ }^{119} \mathrm{Sn} \delta=-108.5 \mathrm{ppm}\right.$ : Figure 30a) and one equivalent of $\mathrm{Br}_{2}$ to yield the monobromide species after recrystallization; a compound yielding a single ${ }^{119} \mathrm{Sn}$ tin resonance at $-143.5 \mathrm{ppm}$. However, no dihalides of these compounds have been reported in the literature. 


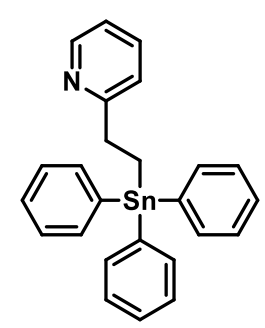

23

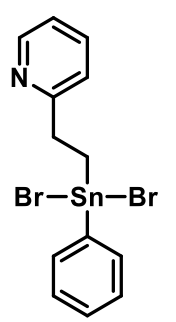

24

Yield $=81.6 \%$

Scheme 15: Reaction scheme for the synthesis of compound 24.

The synthesis of the monobromide was not attempted and two equivalents of $\mathrm{Br}_{2}$ were added directly to compound 23. This resulted in a mixture of four tin resonances in the ${ }^{119} \mathrm{Sn}$ NMR spectrum: $-60,-75,-143$, and $-184 \mathrm{ppm}$ (major). Due to the presence of a signal at $-143 \mathrm{ppm}$, reported as the chemical shift of the monobromide species, another equivalent of $\mathrm{Br}_{2}$ was added which resulted in two tin resonances of $\left(\delta_{119 \mathrm{Sn}}=-73\right.$ and $\left.-184 \mathrm{ppm}\right)$ being observed by NMR. This mixture was isolated as a viscous dark orange gel and was recrystallized with the method as reported by Molloy of the monobromide using a mixture of petroleum ether and ethyl acetate. This resulted in compound $\mathbf{2 4}$ being isolated as a white coloured powder. The integration of the ${ }^{1} \mathrm{H}$ NMR matches to what is expected of the dibromide species; a single tin resonance is also present in the ${ }^{119} \mathrm{Sn}$ NMR spectra $\left(\delta_{119 \mathrm{Sn}}=-184 \mathrm{ppm}\right.$ : Figure 30b). A crystal of 24 suitable for single crystal X-ray diffraction was obtained (Figure 31) 


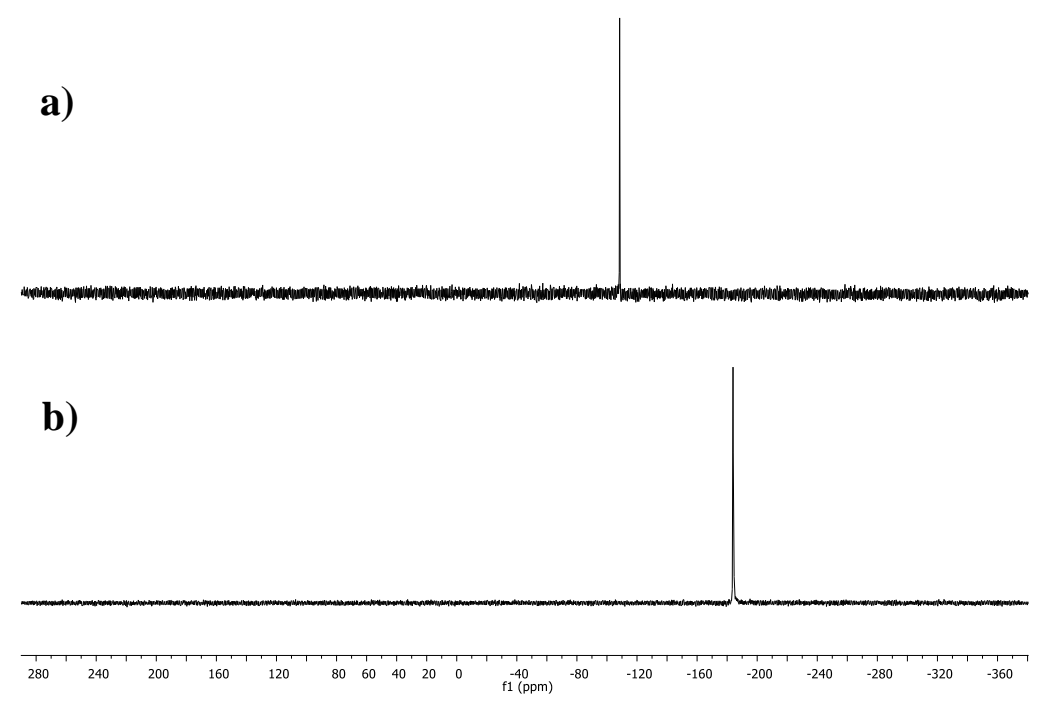

Figure 30: ${ }^{119}$ Sn NMR spectra of compounds 23(a) and 24(b).

Two unique molecules of $\mathbf{2 4}$ were formed within the unit cell, differing slightly in bond lengths and angles (Figure 31) The geometry around the tin center of both these molecules is distorted trigonal bipyramidal $\left(\tau_{5}=0.56, \tau_{5}=0.59\right.$ respectively). Equatorial angles around the tin center range between $76.7(2)$ and $136.9(2)^{\circ}$. The Sn-N bond lengths are considerably shorter than the triphenyl analogue 23. This is likely a result of the withdrawing effect of the bromine atoms, causing the tin center to be more electropositive than the tin center in $\mathbf{2 3}$, resulting in the nitrogen atom being drawn closer to the tin center. After the synthesis of the monobromide species, Molloy et al. reported substitution of the bromine atom with a $N, N$ - dimethyldithiocarbamate substituent. A solid-state structure of this molecule revealed a Sn-N bond length of 2.486(7) $\AA$. The $3 \mathrm{c}-4 \mathrm{e}^{-}$ sharing is evident between the nitrogen, tin and bromine atoms. The $\mathrm{Sn} 1-\mathrm{Br} 1$ atoms in both molecules are present in the axial positions, presumably participating in the $3 \mathrm{c}-4 \mathrm{e}^{-}$sharing. This causes the Sn1-Br1 bond length to be elongated relative to the $\mathrm{Sn} 1-\mathrm{Br} 2$ bonds which are in the equatorial positions and therefore, presumably not participating in the $3 \mathrm{c}-4 \mathrm{e}^{-}$sharing (Table 7). 
a)

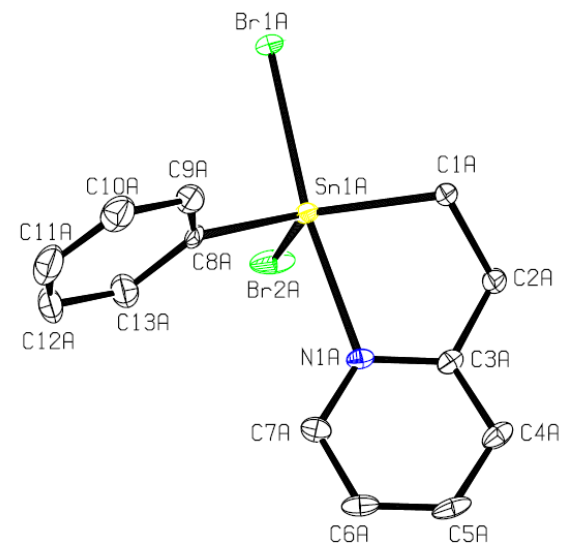

b)

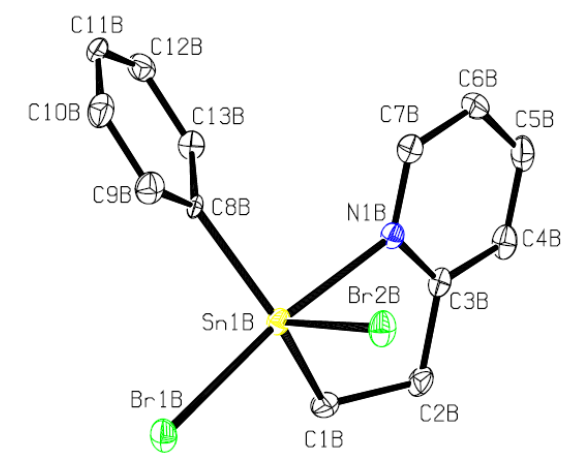

Figure 31: ORTEP representation of two molecules of compound $\mathbf{2 4}$ found in the unit cell.

Thermal ellipsoids shown at the $30 \%$ level.

Table 7: Relevant parameters obtained from the crystal data analysis of $\mathbf{2 4}$.

\begin{tabular}{|c|c|c|c|}
\hline Bond & Bond Lengths of A $(\AA)$ & Bond & Bond Lengths of B $(\AA)$ \\
\hline Sn1A-N1A & $2.382(5)$ & Sn1B-N1B & $2.363(5)$ \\
\hline Sn1A-C1A & $2.120(6)$ & Sn1B-C1B & $2.115(6)$ \\
\hline Sn1A-C8A & $2.131(7)$ & Sn1B-C8B & $2.138(6)$ \\
\hline Sn1A-Br1A & $2.6298(7)$ & Sn1B-Br1B & $2.6176(8)$ \\
\hline Sn1A-Br2A & $2.5058(8)$ & Sn1B-Br2B & $2.5223(8)$ \\
\hline
\end{tabular}

In the future, compound $\mathbf{2 4}$ will be synthesized into the corresponding dihydride and further undergo dehydropolymerziation to synthesize the polymer which will be further investigated. 


\subsection{Conclusions}

A series of novel rigid hypercoordinate organotin compounds containing a chelating oxazoline ring $(10,11,13,14)$ were synthesized and characterized by NMR spectroscopy $\left({ }^{1} \mathrm{H},{ }^{13} \mathrm{C}\right.$, ${ }^{119} \mathrm{Sn}, \mathrm{HSQC}, \mathrm{COSY}$ and HMBC). These compounds were also characterized by HRMS and/or Xray crystallography. X-ray crystallography of compounds 10,11 , and 13 showed relatively short tin-nitrogen bond distances, the distance becoming shorter with the addition of electronegative atoms $(\mathrm{Cl}, \mathrm{Br})$. The synthesis of compound $\mathbf{1 4}$ proved quite difficult as a result of the product being quite reactive at temperatures above $-20{ }^{\circ} \mathrm{C}$. The dehydropolymerization of this compound was attempted with a variety of conditions, however synthesis of high molecular weight polymers proved difficult. This is likely a result of the steric hindrance around the tin center and the close proximity of the chelating oxazoline ring causing interaction with Wilkinson's catalyst troublesome. The Wurtz coupling of $\mathbf{1 3}$ was also explored, however the synthesis of polymer from this method also proved quite difficult. The addition of a methylene group between the chelating oxazoline and tin was explored in hopes of producing higher molecular weight polymers.

The novel semi-flexible organotin compounds containing a chelating oxazoline ring (18, 20, and 21) were synthesized and characterized by NMR spectroscopy $\left({ }^{1} \mathrm{H},{ }^{13} \mathrm{C},{ }^{119} \mathrm{Sn}\right.$, HSQC, COSY and HMBC). These compounds were also characterized by HRMS and/or X-ray crystallography. X-ray crystallography of $\mathbf{1 8}$ revealed a larger tin-nitrogen bond distance from the ring nitrogen to the tin compared to that of $\mathbf{1 0}$ which was expected due to the methylene bridge. The synthesis of $\mathbf{2 1}$ was relatively easy and more stable than dihydride $\mathbf{1 4}$ which resulted in a low molecular weight polymer in the preliminary GPC analysis.

Organotin compounds containing a flexible ethyl pyridine chain (23 and $\mathbf{2 4})$ were also explored. These compounds were also characterized by NMR spectroscopy $\left({ }^{1} \mathrm{H},{ }^{13} \mathrm{C},{ }^{119} \mathrm{Sn}, \mathrm{HSQC}\right.$, 
COSY and HMBC). These compounds were also characterized by HRMS and/or X-ray crystallography. X-ray crystallography revealed a relatively short tin-nitrogen bond distance in between that of $\mathbf{1 0}$ and 13. Due to time restrictions, and focus on the oxazoline projects, the tin dihydrides of the pyridine analogues was not attempted. 


\subsection{Future Work}

In this work, novel organotin compounds containing chelating nitrogen donors were explored. It is likely in the case of polymer $\mathbf{1 6}$ that the dative interaction is preserved due to the upfield chemical shift $\left(\delta_{119 \mathrm{Sn}}=-268 \mathrm{ppm}\right)$ relative to known 4-coordinate polystannanes which typically resonate around $-190--200 \mathrm{ppm}$. Other catalysts should be explored in the polymerization of $\mathbf{1 6}$ in hopes of producing higher molecular weight polymers. The more flexible chelating oxazoline showed greater promise in the synthesis of a polymer and should be further explored. An organotin compound containing an ethyl bridge between the tin atom and the oxazoline might offer more flexibility and even higher molecular weights with the stability of the three polymers being compared. This monomer can be synthesized by lithiating 9 and further reacting this compound with allyl bromide ${ }^{56}$ to yield an ortho allyl group. This can further undergo a hydrostannaylation reaction. The organotin compounds containing the ethyl pyridyl compounds show promise in synthesizing stabilized polystannanes through hypercoordination and should further be explored. 


\subsection{Experimental}

\section{General Considerations}

All reagents and solvents were obtained from Sigma-Aldrich and used as received, unless otherwise indicated. Solvents were dried either through an MBraun solvent drying system, or through vacuum distillation and stored under an inert nitrogen atmosphere. All reactions were carried out under nitrogen atmosphere using Schlenk techniques unless otherwise noted. Nuclear magnetic resonance (NMR) spectroscopic experiments were carried out on a Bruker $400 \mathrm{MHz}$ Spectrometer using $\mathrm{CDCl}_{3}$ or $\mathrm{C}_{6} \mathrm{D}_{6}$ as the solvent. ${ }^{1} \mathrm{H}$ NMR $(400 \mathrm{MHz})$ and ${ }^{13} \mathrm{C}$ NMR $(100.6 \mathrm{MHz})$ spectra were referenced to the residual proton and central carbon resonance of the solvent. The

${ }^{119}$ Sn NMR (149 MHz) was referenced to $\mathrm{SnMe}_{4}$, respectively as internal standards. All the chemical shifts are given in $\delta(\mathrm{ppm})$ relative to the solvent and assigned to atoms. All NMR spectra were analyzed on MestReNova v6.0.2 software. High-resolution mass spectrometry was performed using an accuTOF DART-MS at the University of Toronto. Molecular weights of polymers were determined by gel permeation chromatography (GPC) using a Viscotek Triple Model 302 Detector system equipped with a Refractive Index Detector (RI), a four capillary differential viscometer (VISC), a right angle $\left(90^{\circ}\right)$ laser light scattering detector. GPC columns were calibrated versus polystyrene standards (American Polymer Standards). A flow rate of 1.0 $\mathrm{mL} \min ^{-1}$ was used with ACS grade THF as eluent. GPC sample were prepared using 10-15 $\mathrm{mg}$ of polymers per $\mathrm{mL}$ THF, and filtered using a $0.45 \mu \mathrm{m}$ filter. All reactions were carried out under a nitrogen atmosphere using Schlenk techniques unless otherwise described. A Bruker-Nonius Kappa-CCD diffractometer at the University of Toronto was used to obtain the X-ray diffraction data for crystal structures. 


\subsection{Synthesis of 2-(2-bromophenyl)-4,4-dimethyl-4,5-dihydrooxazole (8):}

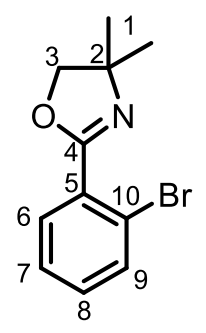

\section{Method 155:}

Thionyl chloride $(3.60 \mathrm{~mL}, 49.8 \mathrm{mmol})$ and 3 drops of DMF were added to a $250 \mathrm{~mL}$ round bottom flask containing 2-bromobenzoic acid $(5.00 \mathrm{~g}, 24.9 \mathrm{mmol})$ in $100 \mathrm{~mL}$ of dry DCM. The reaction mixture was heated to reflux temperature for $2 \mathrm{~h}$. The solvent and excess thionyl chloride were then removed under reduced pressure to afford a yellow coloured liquid. The product was dissolved in $30 \mathrm{~mL}$ of dry DCM and then added dropwise to a $250 \mathrm{~mL}$ round bottom flask containing a stirring solution of distilled 2-amino-2-methyl-1-propanol (2.66 g, $29.9 \mathrm{mmol})$ and triethylamine $(5.20 \mathrm{~mL}, 37.3 \mathrm{mmol})$ in $100 \mathrm{~mL}$ of dry $\mathrm{DCM}$ at $0{ }^{\circ} \mathrm{C}$. The reaction mixture was then stirred for $4 \mathrm{~h}$ at RT. The crude sample was washed once with $30 \mathrm{~mL}$ of $1 \mathrm{M}$ solution of aqueous $\mathrm{HCl}$ and $2 \times 30 \mathrm{~mL}$ of a saturated aqueous brine solution. The organic layer was then dried over anhydrous $\mathrm{MgSO}_{4}$, filtered and the solvent removed under reduced pressure to afford 2-bromo-N-(1-hydroxy-2-methylpropan-2-yl)benzamide as a white coloured powder in a $82.0 \%$ yield. The benzamide $(5.55 \mathrm{~g}, 20.4 \mathrm{~mol})$ was dissolved in $\mathrm{SOCl}_{2}(15.0 \mathrm{~mL}, 206 \mathrm{mmol})$ at $0{ }^{\circ} \mathrm{C}$. The solution was stirred at room temperature for $24 \mathrm{~h}$, after which $100 \mathrm{~mL}$ of $\mathrm{Et}_{2} \mathrm{O}$ was added and the precipitate collected via vacuum filtration and dissolved in $50 \mathrm{~mL}$ of DCM. The DCM mixture was washed with a saturated aqueous solution of $\mathrm{NaHCO}_{3}$ until the organic layer was neutral and then dried over anhydrous $\mathrm{MgSO}_{4}$. After filtration, the solvent was removed under reduced pressure to yield 2-(2-bromophenyl)-4,4-dimethyl-2-oxazoline as a white coloured powder. Yield: $4.75 \mathrm{~g}, 75.2 \%$. NMR data $\left({ }^{1} \mathrm{H},{ }^{13} \mathrm{C}\right)$ matches reported literature data within experimental error. ${ }^{55}$ 


\section{Method 253:}

A solution containing 2-bromobenzonitrile (0.50 g, $2.75 \mathrm{mmol})$, 2-amino-2-methyl-1-propanol $(0.37 \mathrm{~g}, 4.12 \mathrm{mmol})$ and anhydrous $\mathrm{ZnCl}_{2}(0.037 \mathrm{~g}, 0.27 \mathrm{mmol})$ were heated to reflux temperature in $15 \mathrm{~mL}$ of chlorobenzene for $24 \mathrm{~h}$. The solvent was then removed under reduced pressure. The crude product was purified via flash chromatography (EtOAc/Hex (1:1)) to yield 2-(2bromophenyl)-4,4-dimethyl-2-oxazoline as a white coloured powder. Yield: 0.52 g, $74.2 \%$. m.p. 39-40 ${ }^{\circ} \mathrm{C}$ (Lit. 36-38 $\left.{ }^{\circ} \mathrm{C}\right) \mathrm{NMR}$ data $\left({ }^{1} \mathrm{H},{ }^{13} \mathrm{C}\right)$ matches reported literature data within experimental error. ${ }^{2}{ }^{1} \mathbf{H}$ NMR $\left(400.13 \mathrm{MHz}, \mathrm{CDCl}_{3}, \delta\right): 7.66\left(\mathrm{dd}, 1 \mathrm{H}, \mathrm{H} 6,{ }^{3} J_{1 \mathrm{H}-1 \mathrm{H}}=7.78 \mathrm{~Hz},{ }^{4} J_{1 \mathrm{H}-1 \mathrm{H}}=1.51 \mathrm{~Hz}\right)$, $7.63\left(\mathrm{dd}, 1 \mathrm{H}, \mathrm{H} 9,{ }^{3} J_{1 \mathrm{H}-1 \mathrm{H}}=7.78 \mathrm{~Hz},{ }^{4} J_{1 \mathrm{H}-1 \mathrm{H}}=1.00 \mathrm{~Hz}\right), 7.34\left(\mathrm{ddd}, 1 \mathrm{H}, \mathrm{H} 7,{ }^{3} J_{1 \mathrm{H}-1 \mathrm{H}}=7.53 \mathrm{~Hz},{ }^{4} J_{1 \mathrm{H}-}\right.$ $1 \mathrm{H}=1.00 \mathrm{~Hz}), 7.28\left(\mathrm{ddd}, 1 \mathrm{H}, \mathrm{H} 8,{ }^{3} J_{1 \mathrm{H}-1 \mathrm{H}}=7.53 \mathrm{~Hz},{ }^{4} J_{1 \mathrm{H}-1 \mathrm{H}}=1.76 \mathrm{~Hz}\right), 4.16(\mathrm{~s}, 2 \mathrm{H}, \mathrm{H} 3), 1.43(\mathrm{~s}$, 6H, H1) ppm. ${ }^{13} \mathbf{C}\left\{{ }^{1} \mathbf{H}\right\}$ NMR (100.61 MHz, $\left.\mathrm{CDCl}_{3}, \delta\right): 161.79$ (C4), 133.59 (C9), 131.56 (C8), 131.26 (C6), 130.27 (C10), 127.07 (C7), 121.82 (C5), 79.44 (C3), 68.05 (C2), 28.25 (C1) ppm. 


\subsection{Synthesis of 4,4-dimethyl-2-(2-(triphenylstannyl)phenyl)-4,5-dihydrooxazole (10):}

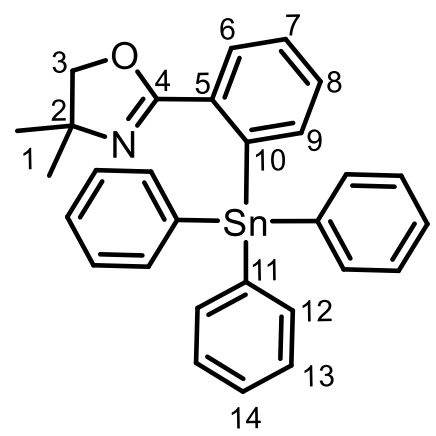

\section{Method 1:}

2-(2-bromophenyl)-4,4-dimethyl-4,5-dihydrooxazole (0.565 g, $2.22 \mathrm{mmol})$ and $15 \mathrm{~mL}$ of dry $\mathrm{Et}_{2} \mathrm{O}$ were added to a dry $100 \mathrm{~mL}$ Schlenk flask. The solution was cooled to $-84{ }^{\circ} \mathrm{C}$ and $1.6 \mathrm{M} \mathrm{n}$-BuLi/ hexane $(1.52 \mathrm{~mL}, 2.45 \mathrm{mmol})$ was added dropwise. The reaction mixture stirred for $2 \mathrm{~h}$ at $-84{ }^{\circ} \mathrm{C}$ then allowed to warm up to $0{ }^{\circ} \mathrm{C}$ before the addition of triphenyltin chloride $(0.857 \mathrm{~g}, 2.22 \mathrm{mmol})$ in $20 \mathrm{~mL}$ of $\mathrm{Et}_{2} \mathrm{O}$ was added dropwise. The reaction mixture was stirred for $1 \mathrm{~h}$ at $0{ }^{\circ} \mathrm{C}$. The solvent was removed under reduced pressure and $20 \mathrm{~mL}$ of toluene was added. The mixture was filtered via gravity filtration and the solvent was removed under reduced pressure to yield a pale yellow coloured powder. The crude product was triturated with $\mathrm{MeOH}$ and the yellow solution was decanted off. The residual solvent was removed under reduced pressure to yield the product as a white coloured powder. Yield: $0.86 \mathrm{~g}, 73.9 \%$.

\section{Method 2:}

4,4-dimethyl-2-phenyl-2-oxazoline $(5.00 \mathrm{~g}, 28.5 \mathrm{mmol})$ and $50 \mathrm{~mL}$ of dry $\mathrm{Et}_{2} \mathrm{O}$ were added to a dry $250 \mathrm{~mL}$ Schlenk flask. The solution was cooled to $-84{ }^{\circ} \mathrm{C}$ and $1.3 \mathrm{M} \mathrm{sec-BuLi/cyclohexane}$ (24.14 $\mathrm{mL}, 31.39 \mathrm{mmol}$ ) was added dropwise. The reaction mixture stirred for $1.5 \mathrm{~h}$ at $-84{ }^{\circ} \mathrm{C}$ then allowed to warm up to $0{ }^{\circ} \mathrm{C}$ before the addition of triphenyltin chloride $(11.0 \mathrm{~g}, 28.5 \mathrm{mmol})$ in 20 
$\mathrm{mL}$ of $\mathrm{Et}_{2} \mathrm{O}$ was added dropwise. The reaction mixture was stirred for $1 \mathrm{~h}$ at $0{ }^{\circ} \mathrm{C}$. The solvent was then removed under reduced pressure and $40 \mathrm{~mL}$ of toluene was added. The mixture was filtered via gravity filtration and the solvent was removed under reduced pressure to yield a pale yellow coloured powder. The crude product was triturated with methanol and the yellow solution was decanted off. The residual solvent was removed under reduced pressure to yield the product as a white coloured powder. Yield: 11.42 g, $76.3 \%$. m.p. $139-141{ }^{\circ} \mathrm{C} .{ }^{1} \mathbf{H}$ NMR $\left(400.13, \mathrm{CDCl}_{3}, \delta\right)$ : $8.05\left(\mathrm{~d}, 1 \mathrm{H}, \mathrm{H} 9,{ }^{3} J_{1 \mathrm{H}-1 \mathrm{H}}=7.78 \mathrm{~Hz},{ }^{3} J_{1 \mathrm{H}-119 \mathrm{Sn}}=24.59 \mathrm{~Hz}\right), 7.61-7.59(\mathrm{~m}, 6 \mathrm{H}, \mathrm{H} 12), 7.54-7.52(\mathrm{~m}$, 1H, H6), 7.50-7.48 (m, 1H, H7), 7.45- 7.42 (m, 1H, H8), 7.36-7.34 (m, 9H, H13 \& H14), 3.93 (s, 2H, H3), 0.77 (s, 6H, H1) ppm. ${ }^{13} \mathbf{C}\left\{{ }^{1} \mathbf{H}\right\}$ NMR (100.61 MHz, $\left.\mathrm{CDCl}_{3}, \delta\right): 163.19$ (C4), 143.19

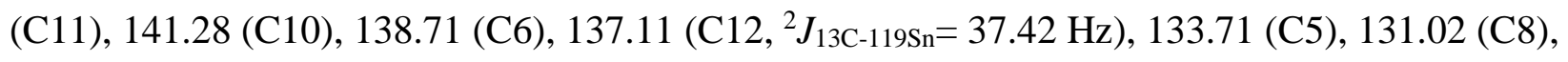
129.08 (C7), 128.10 (C14), 128.04 (C13), 127.80 (C9), 80.05 (C3), 67.49 (C2), 27.62 (C1) ppm. ${ }^{119} \mathrm{Sn}\left\{{ }^{1} \mathbf{H}\right\}$ NMR $\left(149.21 \mathrm{MHz}, \mathrm{CDCl}_{3}, \delta\right):-157.13 \mathrm{ppm}$. HRMS-DART $(\mathrm{m} / \mathrm{z})=448.07234(\mathrm{M}-$ $\mathrm{C}_{6} \mathrm{H}_{6}$ ) calculated for ${ }^{12} \mathrm{C}_{23}{ }^{1} \mathrm{H}_{22}{ }^{14} \mathrm{~N}_{1}{ }^{16} \mathrm{O}_{1}{ }^{120} \mathrm{Sn}_{1}$; found 448.07136. 


\subsection{Synthesis of 2-(2-(chlorodiphenylstannyl)phenyl)-4,4-dimethyl-4,5-dihydrooxazole (11):}

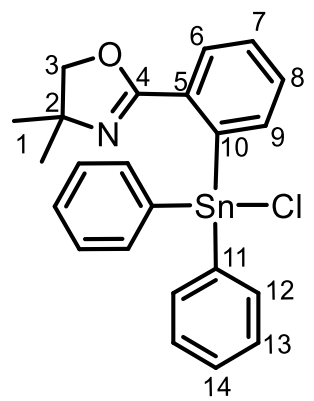

4,4-dimethyl-2-(2-(triphenylstannyl)phenyl)-4,5-dihydrooxazole $(0.250 \mathrm{~g}, 0.477 \mathrm{mmol})$ and 10 $\mathrm{mL}$ of benzene were added to a dry $100 \mathrm{~mL}$ Schlenk flask. $\mathrm{HCl} / \mathrm{Et}_{2} \mathrm{O}(0.47 \mathrm{~mL}, 0.477 \mathrm{mmol})$ was added and the solution was stirred for $1 \mathrm{~h}$ at RT. The solvent was removed under reduced pressure to yield 2-(2-(chlorodiphenylstannyl)phenyl)-4,4-dimethyl-4,5-dihydrooxazole. The crude product was triturated with hexanes and the cloudy solution was decanted off and residual solvent was then removed under reduced pressure to afford 2-(2-(chlorodiphenylstannyl)phenyl)-4,4dimethyl-4,5-dihydrooxazole as a white coloured powder. Yield: 0.192 g, $83.6 \%$. M.p: 222-223 ${ }^{\circ} \mathrm{C} .{ }^{1} \mathbf{H}$ NMR $\left(400.13, \mathrm{CDCl}_{3}, \delta\right): 8.57\left(\mathrm{~d}, 1 \mathrm{H}, \mathrm{H} 9,{ }^{3} J_{1 \mathrm{H}-1 \mathrm{H}}=7.03 \mathrm{~Hz},{ }^{3} J_{1 \mathrm{H}-117 \mathrm{Sn}}=25.85 \mathrm{~Hz},{ }^{3} J_{1 \mathrm{H}-}\right.$ $119 \mathrm{Sn}=74.54 \mathrm{~Hz}), 7.95\left(\mathrm{~d}, 1 \mathrm{H}, \mathrm{H} 6,{ }^{3} \mathrm{~J}_{1 \mathrm{H}-1 \mathrm{H}}=7.53 \mathrm{~Hz}\right), 7.79-7.75(\mathrm{~m}, 1 \mathrm{H}, \mathrm{H} 8), 7.74-7.71(\mathrm{~m}, 4 \mathrm{H}$, H12), 7.63-7.61 (m, 1H, H7), 7.39- 7.37 (m, 6H, H13 \& H14), 4.27 (s, 2H, H3), 0.86 (s, 6H, H1) ppm. ${ }^{13} \mathbf{C}\left\{{ }^{1} \mathbf{H}\right\}$ NMR (100.61 MHz, $\left.\mathrm{CDCl}_{3}, \delta\right): 168.90$ (C4), 143.23 (C11), 143.02 (C10), 138.42

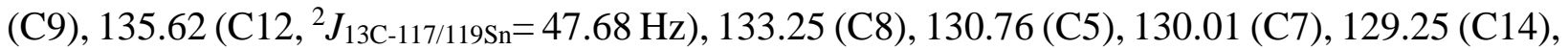

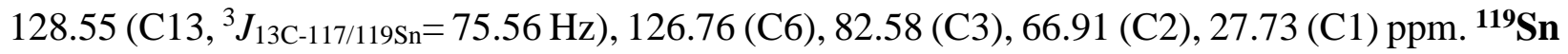
$\left\{{ }^{1} \mathbf{H}\right\}$ NMR $\left(149.21 \mathrm{MHz}, \mathrm{CDCl}_{3}, \delta\right):-225.99 \mathrm{ppm}$. 


\subsection{Synthesis of 2-(2-(dibromo(phenyl)stannyl)phenyl)-4,4-dimethyl-4,5-dihydrooxazole}

(13):

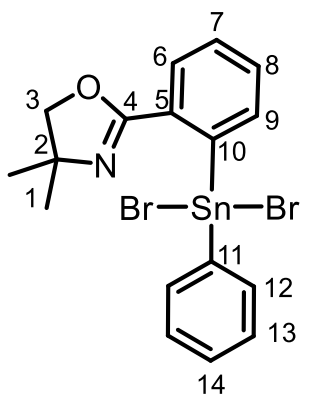

4,4-dimethyl-2-(2-(triphenylstannyl)phenyl)-4,5-dihydrooxazole (8.224 g, $15.69 \mathrm{mmol})$ and 50 $\mathrm{mL}$ of $\mathrm{C}_{6} \mathrm{H}_{6}$ was added to a $250 \mathrm{~mL}$ Schlenk flask and cooled to $0{ }^{\circ} \mathrm{C} . \mathrm{Br}_{2}(1.61 \mathrm{~mL}, 31.45 \mathrm{mmol})$ was added dropwise and the reaction mixture stirred for $1 \mathrm{~h}$. The solvent was removed under reduced pressure to yield a brown-yellow coloured powder. The crude product was triturated with $\mathrm{MeOH}$ and the yellow solution was decanted off. The residual solvent was removed under reduced pressure to afford the product as a white coloured powder. Yield $=6.60$ g, $79.4 \%$. M.p. 197-198 ${ }^{\circ} \mathrm{C} .{ }^{1} \mathbf{H}$ NMR $\left(400.13, \mathrm{CDCl}_{3}, \delta\right): 8.51\left(\mathrm{~d}, 1 \mathrm{H}, \mathrm{H} 9,{ }^{3} J_{1 \mathrm{H}-1 \mathrm{H}}=7.28 \mathrm{~Hz},{ }^{3} J_{1 \mathrm{H}-117 \mathrm{Sn}}=86.33 \mathrm{~Hz},{ }^{3} J_{1 \mathrm{H}-}\right.$ $119 \mathrm{Sn}=101.39 \mathrm{~Hz}), 7.92\left(\mathrm{~d}, 1 \mathrm{H}, \mathrm{H} 6,{ }^{3} J_{1 \mathrm{H}-1 \mathrm{H}}=7.53 \mathrm{~Hz}\right), 7.81\left(\mathrm{dd}, 1 \mathrm{H}, \mathrm{H} 8,{ }^{3} J_{1 \mathrm{H}-1 \mathrm{H}}=7.53 \mathrm{~Hz},{ }^{3} J_{1 \mathrm{H}-1 \mathrm{H}}=\right.$ 7.03 Hz), 7.68-7.63 (m, 3H, H7 \& H12), 7.45-7.38 (m, 3H, H13 \& H14), 4.38 (s, 2H, H3), 1.15 (s, 6H, H1) ppm. ${ }^{13} \mathbf{C}\left\{{ }^{1} \mathbf{H}\right\}$ NMR (100.61 MHz, $\left.\mathrm{CDCl}_{3}, \delta\right): 168.52$ (C4), 144.62 (C11), 140.58 (C10), $137.81(\mathrm{C} 9), 133.88(\mathrm{C} 7), 133.34\left(\mathrm{C} 12,{ }^{2} J_{13 \mathrm{C}-119 \mathrm{Sn}=}=68.22 \mathrm{~Hz}\right), 131.41(\mathrm{C} 8), 130.20\left(\mathrm{C} 14,{ }^{4} J_{13 \mathrm{C}-}\right.$ $\left.{ }_{119 \mathrm{Sn}}=20.54 \mathrm{~Hz}\right), 129.16(\mathrm{C} 5), 129.01\left(\mathrm{C} 13,{ }^{3} J_{13 \mathrm{C}-117 \mathrm{Sn}}=96.83 \mathrm{~Hz},{ }^{3} J_{13 \mathrm{C}-119 \mathrm{Sn}}=101.24 \mathrm{~Hz}\right), 126.95$ (C6), 83.69 (C3), 67.09 (C2), 27.98 (C1) ppm. ${ }^{119}$ Sn $\left\{{ }^{1} \mathbf{H}\right\}$ NMR (149.21 MHz, $\left.\mathrm{CDCl}_{3}, \delta\right):-290.63$ ppm. HRMS-DART (m/z): [M+] calculated for ${ }^{12} \mathrm{C}_{17}{ }^{1} \mathrm{H}_{18}{ }^{79} \mathrm{Br}_{2}{ }^{14} \mathrm{~N}_{1}{ }^{16} \mathrm{O}_{1}{ }^{120} \mathrm{Sn}_{1}$ : 529.87771; found 529.87682 . 


\subsection{Synthesis of 4,4-dimethyl-2-(2-(phenylstannyl)phenyl)-4,5-dihydrooxazole (14):}

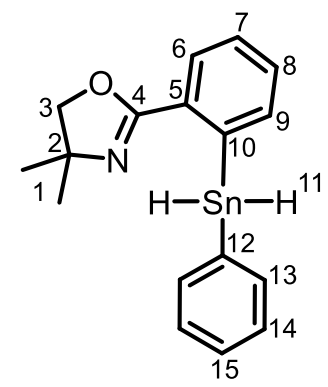

A suspension of 2-(2-(dibromo(phenyl)stannyl)phenyl)-4,4-dimethyl-4,5-dihydrooxazole (0.50 g, $0.94 \mathrm{mmol})$ in $15 \mathrm{~mL}$ of dry $\mathrm{EtOH}$ was added dropwise to a solution of $\mathrm{NaBH}_{4}(0.053 \mathrm{~g}, 1.42$ $\mathrm{mmol}$ ) in $5 \mathrm{~mL}$ of dry EtOH at $-84{ }^{\circ} \mathrm{C}$. The solution continued to stir at $-84{ }^{\circ} \mathrm{C}$ for $1 \mathrm{~h}$. Cold hexane (15 mL) was added to the solution and then quenched with $5 \mathrm{~mL}$ of chilled degassed distilled water. The mixture was extracted and the organic layer was dried over anhydrous $\mathrm{MgSO}_{4}$. The solution was filtered and the solvent was removed under reduced pressure to yield the product as a colourless viscous oil. Yield $=0.151 \mathrm{~g}, 43 \% .{ }^{1} \mathrm{H}$ NMR $\left(400.13, \mathrm{CDCl}_{3}, \delta\right): 8.01-7.99(\mathrm{~m}, 1 \mathrm{H}$, H6 ), 7.77-7.75 (m, 1H, H9), 7.70-7.68 (m, 1H, H7), 7.21-7.18 (m, 3H, H14 \& H15), 7.15-7.14 (m, 1H, H8), 7.12-7.08 (m, 2H, H13), 6.79 (s, H, H11), 3.59 (s, 2H, H3), 0.98 (s, 6H, 1H) ppm. ${ }^{13} \mathrm{C}\left\{{ }^{1} \mathrm{H}\right\}$ NMR (100.61 MHz, $\left.\mathrm{CDCl}_{3}, \delta\right): 164.22$ (C4), 141.60 (C10) 141.56 (C12), 138.68 (C9), 137.28 (C13), 137.21 (C5), 133.21 (C7), 130.97 (C8), 128.88 (C14), 128.15 (C15), 128.03(C6), 79.82 (C3), 67.07 (C2) 28.28 (C1) ppm. ${ }^{119} \mathrm{Sn}\left\{{ }^{1} \mathrm{H}\right\}$ NMR (149.21 MHz, $\left.\mathrm{CDCl}_{3}, \delta\right):-249.52$ ppm. HRMS-DART (m/z): [M-H] calculated for ${ }^{12} \mathrm{C}_{17}{ }^{1} \mathrm{H}_{18}{ }^{7914} \mathrm{~N}_{1}{ }^{16} \mathrm{O}_{1}{ }^{120} \mathrm{Sn}_{1}$ : 372.04451; found 372.04104 . 


\subsection{Synthesis of polymer (16):}

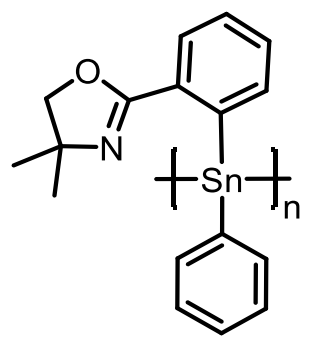

A solution of 4,4-dimethyl-2-(2-(phenylstannyl)phenyl)-4,5-dihydrooxazole $(0.327 \mathrm{~g}, \quad 0.879$ $\mathrm{mmol}$ ) in $3 \mathrm{~mL}$ of dry toluene was added dropwise to a dry Schlenk wrapped in aluminum foil containing Wilkinson's catalyst $(0.033 \mathrm{~g}, 0.035 \mathrm{mmol})$ in $10 \mathrm{~mL}$ of dry toluene at $0{ }^{\circ} \mathrm{C}$. The solution continued to be stirred at $0{ }^{\circ} \mathrm{C}$ for $4 \mathrm{~h}$ then the solvent was removed under reduced pressure. The crude product was dissolved in minimal dry THF (2 mL) and added dropwise to cold stirring hexanes $(3 \times 75 \mathrm{~mL})$ and heptane $(1 \times 75 \mathrm{~mL})$ and the residual solvent was then removed under reduced pressure to yield a pale-yellow powder. Yield $=0.052 \mathrm{~g}, 15.9 \% .{ }^{1} \mathrm{H}$ NMR $(400.13$, $\left.\mathrm{C}_{6} \mathrm{D}_{6}, \delta\right): 7.74-7.69(\mathrm{~m}, 4 \mathrm{H}), 7.09-7.00(\mathrm{~m}, 5 \mathrm{H}), 3.57(\mathrm{~m}, 2 \mathrm{H}) .{ }^{119} \mathrm{Sn}\left\{{ }^{1} \mathrm{H}\right\} \mathrm{NMR}(149.21 \mathrm{MHz}$, $\left.\mathrm{C}_{6} \mathrm{D}_{6}, \delta\right):-268.09 \mathrm{ppm}$. 


\subsection{Synthesis of 4,4-dimethyl-2-(o-tolyl)-4,5-dihydrooxazole (17):}

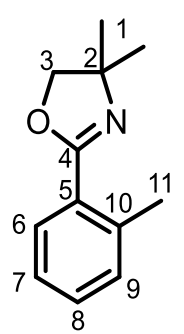

Thionyl chloride $(5.35 \mathrm{~mL}, 73.4 \mathrm{mmol})$ and 3 drops of DMF were added to a $250 \mathrm{~mL}$ round bottom flask containing $o$ - toluic acid $(5.00 \mathrm{~g}, 36.7 \mathrm{mmol})$ in $100 \mathrm{~mL}$ of dry DCM. The reaction mixture was heated to reflux temperature for $2 \mathrm{~h}$. The solvent and excess $\mathrm{SOCl}_{2}$ were then removed under reduced pressure to afford a yellow coloured liquid. The product was dissolved in $30 \mathrm{~mL}$ of dry DCM and then added dropwise to a $250 \mathrm{~mL}$ round bottom flask containing a stirring solution of distilled 2-amino-2-methyl-1-propanol (4.26 g, $47.7 \mathrm{mmol})$ and triethylamine $(7.68 \mathrm{~mL}, 55.1$ mmol) in $100 \mathrm{~mL}$ of dry $\mathrm{DCM}$ at $0{ }^{\circ} \mathrm{C}$. The reaction mixture was then stirred for $4 \mathrm{~h}$ at $\mathrm{RT}$. The crude sample was washed once with $30 \mathrm{~mL}$ of $1 \mathrm{M}$ solution of aqueous $\mathrm{HCl}$ and $2 \times 30 \mathrm{~mL}$ of a saturated aqueous brine solution. The organic layer was then dried over anhydrous $\mathrm{MgSO}_{4}$, filtered and the solvent was then removed under reduced pressure to afford $N$-(1-hydroxy-2-methylpropan2-yl)-2-methylbenzamide as a white coloured powder in an $69.9 \%$ yield. The benzamide (5.32 g, $25.7 \mathrm{mmol})$ was dissolved in thionyl chloride $(15.0 \mathrm{~mL}, 206 \mathrm{mmol})$ at $0{ }^{\circ} \mathrm{C}$. The solution was stirred at room temperature for $24 \mathrm{~h} .100 \mathrm{~mL}$ of $\mathrm{Et}_{2} \mathrm{O}$ was added and the precipitate was collected via vacuum filtration and dissolved in $50 \mathrm{~mL}$ of DCM. The solution was washed with a saturated aqueous solution of $\mathrm{NaHCO}_{3}$ until the organic layer was neutral and then dried over anhydrous $\mathrm{MgSO}_{4}$. After filtration, the solvent was removed under reduced pressure to yield 4,4-dimethyl-2(o-tolyl)-4,5-dihydrooxazole as a yellow coloured liquid. Yield: 4.07 g, $58.6 \%$. NMR data $\left({ }^{1} \mathrm{H}\right.$, $\left.{ }^{13} \mathrm{C}\right)$ matches reported literature data within experimental error. 
${ }^{1} \mathbf{H}$ NMR (400.13 MHz, $\left.\mathrm{CDCl}_{3}, \delta\right): 7.86$ (d, 1H, H6, $\left.{ }^{3} J_{1 \mathrm{H}-1 \mathrm{H}}=7.78\right), 7.33-7.29$ (m, 1H, H9), 7.217.17 (m, 2H, H7 \& H8) 4.15 (s, 2H, H3), 2.53 (s, 3H, H11) 1.42 (s, 6H, H1) ppm. ${ }^{13} \mathbf{C}\left\{{ }^{1} \mathbf{H}\right\}$ NMR (100.61 MHz, $\mathrm{CDCl}_{3}, \delta$ ): 164.45 (C4), 138.92 (C10), 131.42 (C9), 131.27 (C8), 130.36 (C6), 125.93 (C5), 125.78 (C7), 79.52 (C3), 66.85 (C2), 28.06 (C1), 21.44 (C11) ppm. 


\subsection{Synthesis of 4,4-dimethyl-2-(2-((triphenylstannyl)methyl)phenyl)-4,5-dihydrooxazole}

(18) :

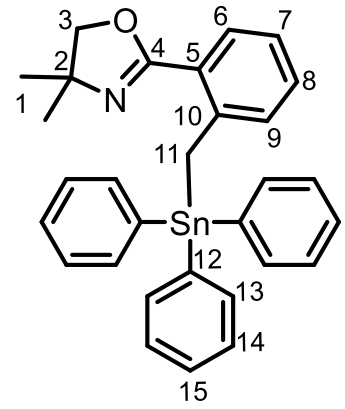

4,4-dimethyl-2-(o-tolyl)-4,5-dihydrooxazole $(0.50 \mathrm{~g}, 26.4 \mathrm{mmol})$ and $10 \mathrm{~mL}$ of dry $\mathrm{Et}_{2} \mathrm{O}$ were added to a dry $50 \mathrm{~mL}$ Schlenk flask. The solution was cooled down to $0{ }^{\circ} \mathrm{C}$ and $1.6 \mathrm{M} n$ BuLi/hexane $(1.82 \mathrm{~mL}, 2.91 \mathrm{mmol})$ was added dropwise to produce a dark red opaque solution and allowed to stir for 20 mins. A solution of triphenyltin chloride (1.02 g, $26.4 \mathrm{mmol})$ in $15 \mathrm{~mL}$ of $\mathrm{Et}_{2} \mathrm{O}$ was then added dropwise to produce a yellow opaque solution. The solution continued to be stirred for $1 \mathrm{~h}$ at $0{ }^{\circ} \mathrm{C}$. The solvent was removed under reduced pressure and $10 \mathrm{~mL}$ of toluene was added. The mixture was filtered via gravity filtration and the solvent was removed under reduced pressure to yield a pale yellow coloured powder. The crude product was triturated with methanol and the yellow solution was decanted off. The residual solvent was removed under reduced pressure to yield the product as white coloured crystals. Yield: $1.10 \mathrm{~g}, 77.4 \%$. ${ }^{1} \mathrm{H}$ NMR (400.13, $\left.\mathrm{CDCl}_{3}, \delta\right): 7.77\left(\mathrm{~d}, 1 \mathrm{H}, \mathrm{H} 9,{ }^{3} \mathrm{~J}_{1 \mathrm{H}-1 \mathrm{H}}=7.78 \mathrm{~Hz}\right), 7.46-7.44(\mathrm{~m}, 6 \mathrm{H}, \mathrm{H} 13), 7.36-7.31(\mathrm{~m}, 9 \mathrm{H}$, H14 \& H15), 7.29-7.28 (m, 2H, H6 \& H7), 7.12-7.10 (m, 1H, H8), 3.74 (s, 2H, H3), 3.57 (s, 2H, $\left.\mathrm{H} 11,{ }^{2} \mathrm{~J}_{1 \mathrm{H}-119 \mathrm{Sn}}=75.54 \mathrm{~Hz}\right), 1.11(\mathrm{~s}, 6 \mathrm{H}, \mathrm{H} 1) \mathrm{ppm} .{ }^{13} \mathrm{C}\left\{{ }^{1} \mathrm{H}\right\} \mathrm{NMR}\left(100.61 \mathrm{MHz}, \mathrm{CDCl}_{3}, \delta\right): 161.69$ (C4), 143.53 (C10), 140.10 (C12), 136.97 (C13), 130.62 (C6), 129.91 (C9), 129.34 (C7), 128.55 (C15), 128.12 (C14), 124.37 (C5), 123.72 (C8), 77.58 (C3), 68.20 (C2), 28.24 (C1), 23.34 (C11) ppm. ${ }^{119} \mathrm{Sn}\left\{{ }^{1} \mathrm{H}\right\}$ NMR $\left(149.21 \mathrm{MHz}, \mathrm{CDCl}_{3}, \delta\right):-125.96$ ppm. HRMS-DART (m/z): $\left(\mathrm{M}^{\left.-\mathrm{C}_{6} \mathrm{H}_{6}\right)}\right.$ calculated for ${ }^{12} \mathrm{C}_{24}{ }^{1} \mathrm{H}_{24}{ }^{14} \mathrm{~N}_{1}{ }^{16} \mathrm{O}_{1}{ }^{120} \mathrm{Sn}_{1}$ : 462.08799; found 462.08871 . 


\subsection{Synthesis of 2-(2-((dibromo(phenyl)stannyl)methyl)phenyl)-4,4-dimethyl-4,5- dihydrooxazole (20):}

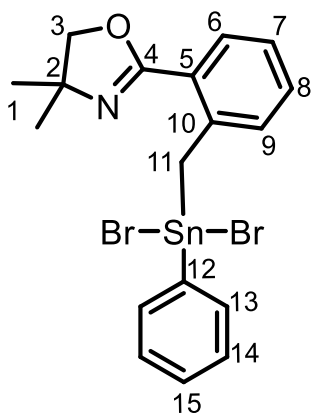

A solution of $\mathbf{1 8}(2.46 \mathrm{~g}, 4.57 \mathrm{mmol})$ and $20 \mathrm{~mL}$ of DCM was added to a $100 \mathrm{~mL}$ Schlenk flask and cooled to $0{ }^{\circ} \mathrm{C}$. A solution of $\mathrm{Br}_{2}(0.466 \mathrm{~mL}, 9.14 \mathrm{mmol})$ in $10 \mathrm{~mL}$ of DCM was added dropwise and the reaction mixture stirred for $1 \mathrm{~h}$ at $0{ }^{\circ} \mathrm{C}$. The solvent was removed under reduced pressure to yield a brown-yellow coloured powder. The crude product was triturated with $\mathrm{MeOH}$ and the yellow solution was decanted off. The residual solvent was removed under reduced pressure to afford the product as a white coloured powder. Yield $2.05 \mathrm{~g}, 82.3 \% .{ }^{1} \mathbf{H}$ NMR $(400.13$, $\left.\mathrm{CDCl}_{3}, \delta\right): 7.93\left(\mathrm{~d}, 1 \mathrm{H}, \mathrm{H} 6,{ }^{3} \mathrm{~J}_{1 \mathrm{H}-1 \mathrm{H}=}=7.64 \mathrm{~Hz}\right), 7.54-7.52(\mathrm{~m}, 2 \mathrm{H}, \mathrm{H} 8$ \& H9), 7.39-7.32 (m, 6H, H7, H13, H14 \& H15), 4.05 (s, 2H, H3), 3.63 (s, 2H, H11, $\left.{ }^{2} \mathrm{~J}_{1 \mathrm{H}-119 \mathrm{Sn}}=112.68 \mathrm{~Hz}\right), 1.25$ (s, 6H, H1) ppm. ${ }^{13} \mathbf{C}\left\{{ }^{1} \mathbf{H}\right\}$ NMR (100.61 MHz, $\left.\mathrm{CDCl}_{3}, \delta\right): 166.48$ (C4), 144.59(C12), 139.89 (C10), 133.91 (C13), 133.28 (C8), 130.54 (C9), 130.22 (C6), 130.18 (C7), 128.97 (C14), 126.80 (C15), 121.84(C5). 79.21 (C3). 69.27 (C2), 41.50 (C11), 27.67 (C1) ppm. ${ }^{119}$ Sn $\left\{{ }^{1} \mathbf{H}\right\}$ NMR (149.21 MHz, $\left.\mathrm{CDCl}_{3}, \quad \delta\right): \quad-248.24 \quad$ ppm. HRMS-DART $(\mathrm{m} / \mathrm{z}): \quad[\mathrm{M}+\mathrm{H}]$ calculated for ${ }^{12} \mathrm{C}_{18}{ }^{1} \mathrm{H}_{20}{ }^{79} \mathrm{Br}_{2}{ }^{14} \mathrm{~N}_{1}{ }^{16} \mathrm{O}_{1}{ }^{120} \mathrm{Sn}_{1}:$ 543.89336; found 543.89537. 
5.10 Synthesis of 4,4-dimethyl-2-(2-((tribromostannyl)methyl)phenyl)-4,5-dihydrooxazole (19):

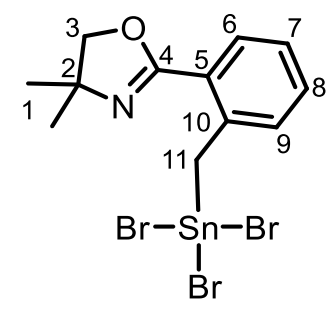

A solution of $18(0.250 \mathrm{~g}, 0.464 \mathrm{mmol})$ and $20 \mathrm{~mL}$ of $\mathrm{C}_{6} \mathrm{H}_{6}$ was added to a $100 \mathrm{~mL}$ Schlenk flask and cooled to $0{ }^{\circ} \mathrm{C}$. $\mathrm{Br}_{2}(0.047 \mathrm{~mL}, 0.929 \mathrm{mmol})$ was added dropwise and the reaction mixture stirred for $1 \mathrm{~h}$ at $0{ }^{\circ} \mathrm{C}$. The solvent was removed under reduced pressure to yield a brown-yellow coloured powder. The crude product was triturated with $\mathrm{MeOH}$ and the yellow solution was decanted off. The residual solvent was removed under reduced pressure to afford the product as a white coloured powder. Yield $=0.244 \mathrm{~g}, 96.2 \% .{ }^{1} \mathbf{H}$ NMR $\left(400.13, \mathrm{CDCl}_{3}, \delta\right): 7.96(\mathrm{~d}, 1 \mathrm{H}, \mathrm{H} 6$, $\left.{ }^{3} \mathrm{~J}_{1 \mathrm{H}-1 \mathrm{H}}=7.77 \mathrm{~Hz}\right), 7.60-7.56(\mathrm{~m}, 1 \mathrm{H}, \mathrm{H} 8), 7.50-7.43$ (m, 2H, H7 \& H9), 4.20 (s, 2H. H3), 3.70 (s, $\left.2 \mathrm{H}, \mathrm{H} 11,{ }^{2} \mathrm{~J}_{1 \mathrm{H}-119 \mathrm{Sn}}=121.53 \mathrm{~Hz}\right), 1.71(\mathrm{~s}, 6 \mathrm{H}, \mathrm{H} 1) \mathrm{ppm} .{ }^{\mathbf{1 3}} \mathbf{C}\left\{{ }^{\mathbf{1}} \mathbf{H}\right\} \mathbf{N M R} 167.11(\mathrm{C} 4), 138.35(\mathrm{C} 10)$, 133.73 (C8), 130.69 (C6), 130.47 (C9), 127.53 (C7), 121.05 (C5), 79.73 (C3), 69.83 (C2), 47.10 (C11), 27.93 (C1) ppm. ${ }^{119}$ Sn $\left\{{ }^{1} \mathbf{H}\right\}$ NMR (149.21 MHz, $\left.\mathrm{CDCl}_{3}, \delta\right):-448.6 \mathrm{ppm}$. 


\subsection{Synthesis of 4,4-dimethyl-2-(2-((phenylstannyl)methyl)phenyl)-4,5-dihydrooxazole}

(21):

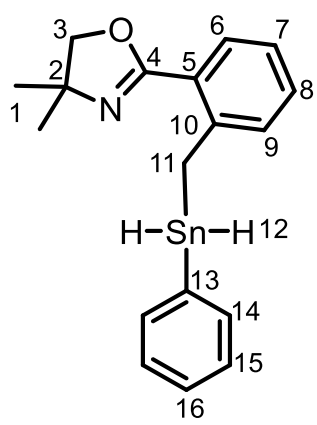

A suspension of $20(0.50 \mathrm{~g}, 0.919 \mathrm{mmol})$ in $15 \mathrm{~mL}$ of dry EtOH was added dropwise to a solution of $\mathrm{NaBH}_{4}(0.174 \mathrm{~g}, 4.70 \mathrm{mmol})$ in $5 \mathrm{~mL}$ of dry EtOH at $-0{ }^{\circ} \mathrm{C}$. The solution continued to stir at -0 ${ }^{\circ} \mathrm{C}$ for $1 \mathrm{~h}$. Cold hexane $(15 \mathrm{~mL})$ was added to the solution and then quenched with $5 \mathrm{~mL}$ of chilled degassed distilled water. The mixture was extracted, and the organic layer was dried over anhydrous $\mathrm{MgSO}_{4}$. The solution was filtered, and the solvent was removed under reduced pressure to yield the product as a colourless viscous oil. Yield $=0.305 \mathrm{~g}, 85.9 \% .{ }^{\mathbf{1}} \mathbf{H} \mathbf{~ N M R}\left(400.13, \mathrm{CDCl}_{3}\right.$,

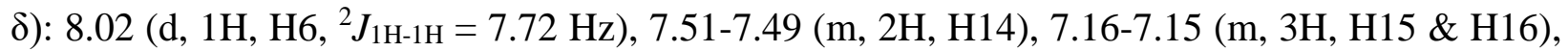
7.03-7.01 (m, 2H, H7 \& H8), 6.93-6.91 (m, 1H, H9), 5.94 (s, 2H, H12, ${ }^{1} J_{117 \mathrm{Sn}^{-1} \mathrm{H}}=1856.56 \mathrm{~Hz}$, $\left.{ }^{1} J_{119 \mathrm{Sn}-1 \mathrm{H}}=1942.82 \mathrm{~Hz}\right) 3.55(\mathrm{~s}, 2 \mathrm{H}, \mathrm{H} 3), 3.07\left(\mathrm{~s}, 2 \mathrm{H}, \mathrm{H} 11,{ }^{2} J_{119 \mathrm{Sn}-1 \mathrm{H}}=76.11 \mathrm{~Hz}\right) \mathrm{ppm} .{ }^{\mathbf{1 3}} \mathbf{C}\left\{{ }^{1} \mathbf{H}\right\}$ NMR 161.64 (C4), 145.43 (C10), 140.53 (C13), 137.03 (C14), 130.72 (C8), 129.81 (C6), 129.31 (C7), 128.22 (C16), 128.13 (C15), 77.25 (C3), 68.23 (C2), 27.88 (C1), 21.86 (C11) ppm. ${ }^{119}$ Sn $\left\{{ }^{1} \mathbf{H}\right\}$ NMR (149.21 MHz, $\left.\mathrm{CDCl}_{3}, \delta\right):-221.02 \mathrm{ppm}$. 


\subsection{Synthesis of polymer (22):}

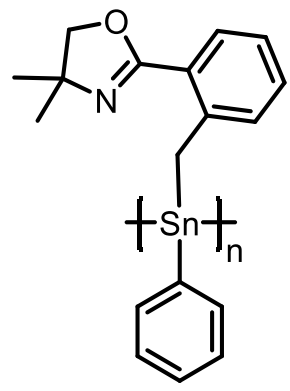

A solution of $21(0.432 \mathrm{~g}, 1.119 \mathrm{mmol})$ in $3 \mathrm{~mL}$ of dry toluene was added dropwise to a dry Schlenk wrapped in aluminum foil containing Wilkinson's catalyst $(0.0414 \mathrm{~g}, 0.045 \mathrm{mmol})$ in $10 \mathrm{~mL}$ of dry toluene at $0{ }^{\circ} \mathrm{C}$. The solution continued to be stirred at $0{ }^{\circ} \mathrm{C}$ for $4 \mathrm{~h}$ then the solvent was removed under reduced pressure. The crude product was dissolved in minimal dry THF (2 mL) and added dropwise to cold stirring hexanes $(3 \times 75 \mathrm{~mL})$ and heptane $(1 \times 75 \mathrm{~mL})$ and the residual solvent was then removed under reduced pressure to yield a pale-yellow powder. Yield $=0.096 \mathrm{~g}$, 22.2 \%. ${ }^{1} \mathrm{H}$ NMR $\left(400.13, \mathrm{C}_{6} \mathrm{D}_{6}, \delta\right): 7.96$ - $7.61(\mathrm{~m}, 4 \mathrm{H}), 7.10-7.6 .98(\mathrm{~m}, 5 \mathrm{H}), 3.58-3.25(\mathrm{~m}$, 4H). ${ }^{119} \mathrm{Sn}\left\{{ }^{1} \mathrm{H}\right\}$ NMR $\left(149.21 \mathrm{MHz}, \mathrm{C}_{6} \mathrm{D}_{6}, \delta\right):-183.84 \mathrm{ppm}$. 


\subsection{Synthesis of 2-(2-(triphenylstannyl)ethyl)pyridine (23):}

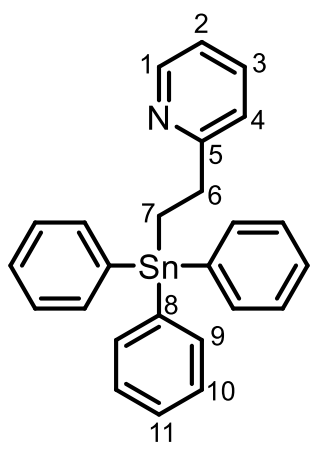

Triphenyltin hydride $(0.500 \mathrm{~g}, 1.42 \mathrm{mmol})$ and 2-vinylpyridine $(0.23 \mathrm{~mL}, 2.14 \mathrm{mmol})$ were added into a $50 \mathrm{~mL}$ dry Schlenk flask attached with a reflux condenser and heated to $100{ }^{\circ} \mathrm{C}$ for $2 \mathrm{~h}$. The solution was cooled down and recrystallized from petroleum ether (b.p. $60-95{ }^{\circ} \mathrm{C}$ ) and the mother liquor was removed under reduced pressure and the remaining solid was recrystallized from 1:1 $\mathrm{MeOH}$ : $\mathrm{Et}_{2} \mathrm{O}$ to yield the product as a white coloured powder. Yield: $0.496 \mathrm{~g}, 76.3 \%$. NMR data $\left({ }^{1} \mathrm{H},{ }^{13} \mathrm{C}\right)$ matches reported literature data within experimental error. ${ }^{18}{ }^{1} \mathrm{H} \mathrm{NMR}\left(400.13, \mathrm{CDCl}_{3}\right.$,

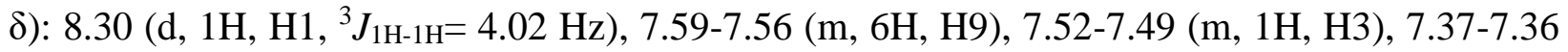
(m, 9H, H10 \& H11), 7.09 (d, 1H, H4, $\left.{ }^{3} J_{1 \mathrm{H}-1 \mathrm{H}}=7.78 \mathrm{~Hz}\right), 7.03-7.00(\mathrm{~m}, 1 \mathrm{H}, \mathrm{H} 2) 3.27$ (t, 2H, H6, $\left.{ }^{3} J_{1 \mathrm{H}-1 \mathrm{H}}=7.80 \mathrm{~Hz}\right), 1.91\left(\mathrm{t}, 2 \mathrm{H}, \mathrm{H} 7,{ }^{3} J_{1 \mathrm{H}-1 \mathrm{H}}=7.80 \mathrm{~Hz}\right) \mathrm{ppm} .{ }^{13} \mathrm{C}\left\{{ }^{1} \mathrm{H}\right\} \mathrm{NMR}\left(100.61 \mathrm{MHz}, \mathrm{CDCl}_{3}\right.$,

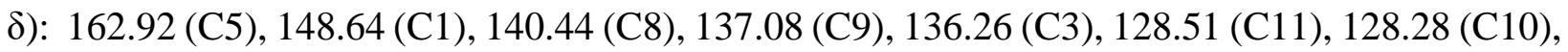
122.46 (C4), 121.13 (C2), 34.04 (C6), 10.60 (C7) ppm. ${ }^{119} \mathrm{Sn}\left\{{ }^{1} \mathrm{H}\right\}$ NMR (149.21 MHz, $\mathrm{CDCl}_{3}$,

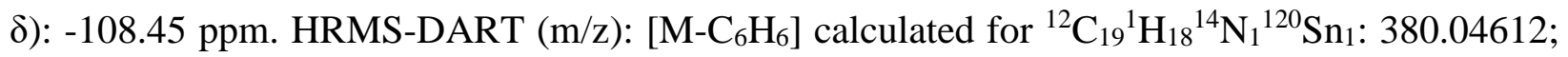
found 380.04610 . 


\subsection{Synthesis of 2-(2-(dibromo(phenyl)stannyl)ethyl)pyridine (24):}

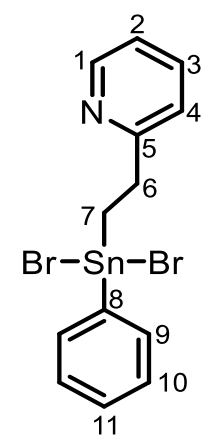

A solution of $23(0.500 \mathrm{~g}, 1.09 \mathrm{mmol}) 10 \mathrm{~mL}$ of $\mathrm{C}_{6} \mathrm{H}_{6}$ was added to a $50 \mathrm{~mL}$ Schlenk flask and cooled to $0{ }^{\circ} \mathrm{C}$. $\mathrm{Br}_{2}(0.350 \mathrm{~g}, 2.19 \mathrm{mmol})$ was added dropwise and the reaction mixture stirred for $1 \mathrm{~h}$. The solvent was removed under reduced pressure to yield a brown coloured gel. The crude product was recrystallized from 9:1 petroleum ether $\left(60-95^{\circ} \mathrm{C}\right)$ : ethyl acetate to yield the pure product as white coloured needles.Yield: $0.415 \mathrm{~g} \mathrm{82.0 \%}{ }^{1} \mathrm{H} \mathrm{NMR}\left(400.13, \mathrm{CDCl}_{3}, \delta\right): 8.15$ (d, $\left.1 \mathrm{H}, \mathrm{H} 1,{ }^{3} J_{1 \mathrm{H}-1 \mathrm{H}}=4.91 \mathrm{~Hz}\right), 7.86-7.84(\mathrm{~m}, 1 \mathrm{H}, \mathrm{H} 3), 7.64-7.62(\mathrm{~m}, 2 \mathrm{H}, \mathrm{H} 9), 7.42-7.39(\mathrm{~m}, 4 \mathrm{H}$, H10, H11, H4), 7.31-7.28 (m, 1H, H2), 3.47 (t, 2H, H7, $\left.{ }^{3} J_{1 \mathrm{H}-1 \mathrm{H}}=7.30 \mathrm{~Hz}\right), 2.22\left(\mathrm{t}, 2 \mathrm{H}, \mathrm{H} 6,{ }^{3} J_{1 \mathrm{H}-}\right.$ $1 \mathrm{H}=7.30 \mathrm{~Hz}) \mathrm{ppm} .{ }^{13} \mathrm{C}\left\{{ }^{1} \mathrm{H}\right\} \mathrm{NMR}\left(100.61 \mathrm{MHz}, \mathrm{CDCl}_{3}, \delta\right): 158.37(\mathrm{C} 5), 145.90(\mathrm{C} 1), 142.23$ (C8), 139.81 (C3), 134.69 (C9), 130.26 (C11), 128.91 (C1), 124.82 (C4), 123.49 (C2), 30.69 (C6), $21.68(\mathrm{C} 7) \mathrm{ppm} .{ }^{119} \mathrm{Sn}\left\{{ }^{1} \mathrm{H}\right\}$ NMR $\left(149.21 \mathrm{MHz}, \mathrm{CDCl}_{3}, \delta\right):-183.92 \mathrm{ppm}$. HRMS-DART (m/z): [M-Br] calculated for ${ }^{12} \mathrm{C}_{13}{ }^{1} \mathrm{H}_{13}{ }^{79} \mathrm{Br}_{1}{ }^{14} \mathrm{~N}_{1}{ }^{1120} \mathrm{Sn}_{1}$ : 381.92534 ; found 381.92478 . 


\section{References}

1. Meyers, A. I.; Mihelich, E. D., Angew. Chem. Int. Ed. 1976, 15, 270-281.

2. Gómez, M.; Muller, G.; Rocamora, M., Coord. Chem. Rev. 1999, 193-195, 769-835.

3. Helmut, W.; Wolfgang, S., Angew. Chem. Int. Ed. 1972, 11, 287-288.

4. Schwekendiek, K.; Glorius, F., Synthesis 2006, 2006, 2996-3002.

5. Vorbrüggen, H.; Krolikiewicz, K., Tetrahedron 1993, 49, 9353-9372.

6. Gant, T. G.; Meyers, A. I., Tetrahedron 1994, 50, 2297-2360.

7. Sharma, R.; Vadivel, S. K.; Duclos, R. I.; Makriyannis, A., Tetrahedron Lett. 2009, 50, 57805782.

8. Adams, N.; Schubert, U. S., Adv. Drug Deliv. Rev. 2007, 59, 1504-1520.

9. Arii, H.; Matsuo, M.; Nakadate, F.; Mochida, K.; Kawashima, T., Dalton Trans. 2012, 41, 11195-11200.

10. Lee, J.-D.; Kim, H.-S.; Han, W.-S.; Kang, S. O., J. Organomet. Chem. 2010, 695, 463-468.

11. Selvaratnam, S.; Lo, K. M.; Das, V. G. K., J. Organomet. Chem. 1994, 464, 143-148.

12. Stol, M.; Snelders, D. J. M.; de Pater, J. J. M.; van Klink, G. P. M.; Kooijman, H.; Spek, A. L.; van Koten, G., Organometallics 2005, 24, 743-749.

13. Jastrzebski, J. T. B. H.; Wehman, E.; Boersma, J.; van Koten, G.; Goubitz, K.; Heijdenrijk, D., J. Organomet. Chem. 1991, 409, 157-162.

14. Cmoch, P.; Urbańczyk-Lipkowska, Z.; Petrosyan, A.; Stępień, A.; Staliński, K., J. Mol. Struct. 2005, 733, 29-39.

15. Staliński, K.; Urbańczyk-Lipkowska, Z.; Cmoch, P.; Rupnicki, L.; Grachev, A., J. Organomet. Chem. 2006, 691, 2394-2402. 
16. Rupnicki, L.; Urbańczyk-Lipkowska, Z.; Stępień, A.; Cmoch, P.; Pianowski, Z.; Staliński, K., J. Organomet. Chem. 2005, 690, 3690-3696.

17. Matkowska, D.; Gola, M.; Śnieżek, M.; Cmoch, P.; Staliński, K., J. Organomet. Chem. 2007, 692, 2036-2045.

18. Mahon, M. F.; Molloy, K. C.; Waterfield, P. C., Organometallics 1993, 12, 769-774.

19. Musher, J. I., Angew. Chem. Int. Ed. 1969, 8, 54-68.

20. Khan, A.; Foucher, D., Coord. Chem. Rev. 2016, 312, 41-66.

21. Minyaev, R. M.; Gribanova, T.; Minkin, V., Hyperbonding and Hypercoordination in MainGroup Chemistry. 2013; Vol. 9, p 109-132.

22. van Koten, G.; Noltes, J. G.; Spek, A. L., J. Organomet. Chem. 1976, 118, 183-189.

23. Boyer, J.; Breliere, C.; Corriu, R. J. P.; Kpoton, A.; Poirier, M.; Royo, G., J. Organomet. Chem. 1986, 311, C39-C43.

24. Breliere, C.; Carre, F.; Corriu, R. J. P.; De Saxce, A.; Poirier, M.; Royo, G., J. Organomet. Chem. 1981, 205, C1-C3.

25. De Wit, P. P.; Van Der Kooi, H. O.; Wolters, J., J. Organomet. Chem. 1981, 216, C9-C11.

26. Caseri, W., Chem. Soc. Rev. 2016, 45, 5187-5199.

27. Deacon, P. R.; Devylder, N.; Hill, M. S.; Mahon, M. F.; Molloy, K. C.; Price, G. J., J. Organomet. Chem. 2003, 687, 46-56.

28. Lu, V. Y.; Tilley, T. D., Macromolecules 2000, 33, 2403-2412.

29. Harrypersad, S.; Liao, L.; Khan, A.; Wylie, R. S.; Foucher, D. A., J. Inorg. Organomet. Polymer. Mater. 2015, 25, 515-528.

30. Takeda, K.; Shiraishi, K., Chem. Phys. Lett. 1992, 195, 121-126.

31. Imori, T.; Lu, V.; Cai, H.; Tilley, T. D., J. Am. Chem. Soc. 1995, 117, 9931-9940. 
32. Choffat, F.; Buchmüller, Y.; Mensing, C.; Smith, P.; Caseri, W., J. Inorg. Organomet. Polymer. Mater. 2009, 19, 166-175.

33. Ciccioli, A.; Gigli, G., J. Phys. Chem. A 2012, 116, 7107-7122.

34. Fabien, C.; Pascal, W.; Paul, S.; Walter, C., Macromol. Mater. Eng. 2010, 295, 210-221.

35. Trummer, M.; Nauser, T.; Lechner, M.-L.; Uhlig, F.; Caseri, W., Poly. Degrad. Stab. 2011, $96,1841-1846$.

36. Trummer, M.; Choffat, F.; Smith, P.; Caseri, W., Macromol. Rapid Commun. 2012, 33, 448460.

37. Okano, M.; Matsumoto, N.; Arakawa, M.; Tsuruta, T.; Hamano, H., Chem. Commun. 1998, 1799-1800.

38. Okano, M.; Watanabe, K., Electrochem. Commun. 2000, 2, 471-474.

39. Okano, M.; Takeda, K.-i.; Toriumi, T.; Hamano, H., Electrochim. Acta 1998, 44, 659-666.

40. Devylder, N.; Hill, M.; Molloy, K. C.; Price, G. J., Chem. Commun. 1996, 711-712.

41. Miles, D.; Burrow, T.; Lough, A.; Foucher, D., J. Inorg. Organomet. Polymer. Mater. 2010, 20, 544-553.

42. Imori, T.; Tilley, T. D., J. Chem. Soc., Chem. Commun. 1993, 1607-1609.

43. Babcock, J. R.; Sita, L. R., J. Am. Chem. Soc. 1996, 118, 12481-12482.

44. Woo, H. G.; Park, J. M.; Song, S. J.; Yang, S. Y.; Kim, I.-S.; Kim, W. G., Bull. Korean Chem. 1997, 18, 1291-1295.

45. Neale, N. R.; Tilley, T. D., Tetrahedron 2004, 60, 7247-7260.

46. Thompson, S. M.; Schubert, U., Inorg. Chim. Acta 2004, 357, 1959-1964.

47. Choffat, F.; Smith, P.; Caseri, W., J. Chem. Mat. 2005, 15, 1789-1792. 
48. Choffat, F.; Käser, S.; Wolfer, P.; Schmid, D.; Mezzenga, R.; Smith, P.; Caseri, W., Macromolecules 2007, 40, 7878-7889.

49. Choffat, F.; Smith, P.; Caseri, W., Adv. Mater. 2008, 20, 2225-2229.

50. Harrypersad, S.; Foucher, D., Chem. Commun. 2015, 51, 7120-7123.

51. Pau, J.; Lough, A. J.; Wylie, R. S.; Gossage, R. A.; Foucher, D. A., Chem. Eur. J. 2017, 23, 14367-14374.

52. D'Amaral, G. Synthesis of Macromolecular Intermediates and Intermolecularly Coordinated Stannanes (Unpublished results). Ryerson University, 2018.

53. Sedelmeier, J.; Hammerer, T.; Bolm, C., Org. Lett. 2008, 10, 917-920.

54. Kurti, L.; Czako, B., Strategic Applications of Named Reactions in Organic Synthesis. Elsevier Inc.: 2005; p 758.

55. Scholer, S.; Wahl, M. H.; Wurster, N. I. C.; Puls, A.; Hattig, C.; Dyker, G., Chem. Commun. 2014, 50, 5909-5911.

56. Gschwend, H. W.; Hamdan, A., J. Org. Chem. 1975, 40, 2008-2009.

57. Addison, A. W.; Rao, T. N.; Reedijk, J.; van Rijn, J.; Verschoor, G. C., J. Chem. Soc., Dalton Trans. 1984, 1349-1356.

58. Baukov, Y. I.; Tandura, S. N., The Chemistry of Organic Germanium, Tin and Lead Compounds. John Wiley \& Sons: 2003; Vol. 2.

59. Loungxay, J., К2-C,O- and C,N - chelated polystannanes. Ryerson Univesity: 2018.

60. Novák, P.; Padělková, Z.; Kolářová, L.; Císařová, I.; Rûžička, A.; Holeček, J., Appl. Organometal. Chem. 2005, 19, 1101-1108.

61. Švec, P.; Růžičková, Z.; Vlasák, P.; Turek, J.; De Proft, F.; Růžička, A., J. Organomet. Chem. 2016, 801, 14-23. 
62. Khan, A.; Komejan, S.; Patel, A.; Lombardi, C.; Lough, A. J.; Foucher, D. A., J. Organomet. Chem. 2015, 776, 180-191.

63. Dhindsa, J. Synthesis and Characterization of Push-Pull Polystannanes. Ryerson University, Toronto, 2017. 


\section{Appendix}

\section{List of Appendix Tables}

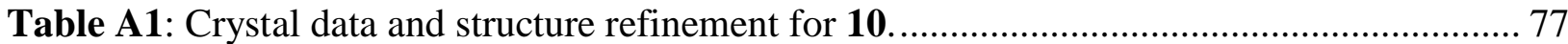

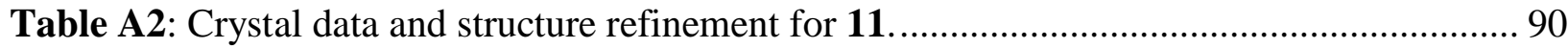

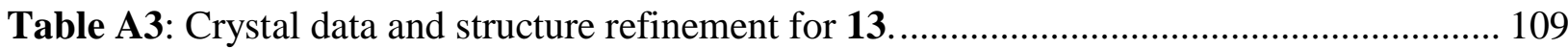

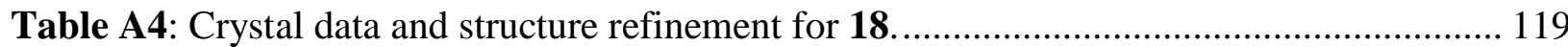

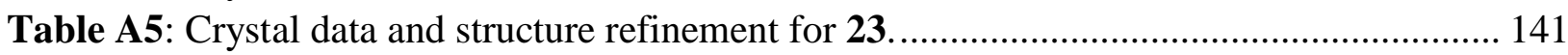

Table A6:Crystal data and structure refinement for 24....................................................... 152

\section{List of Appendix Figures}

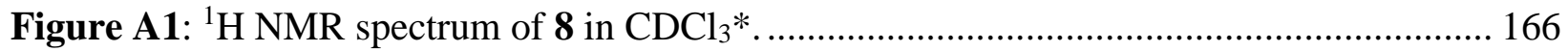

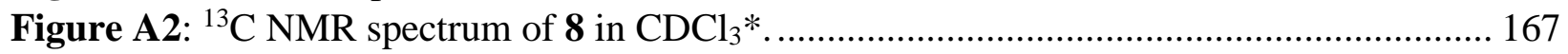

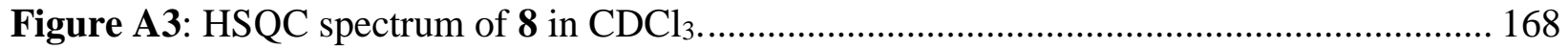

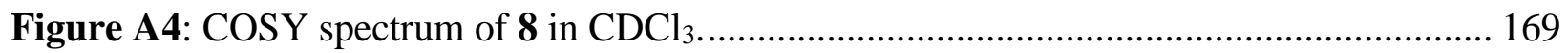

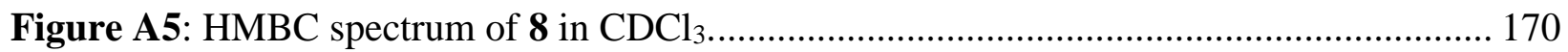

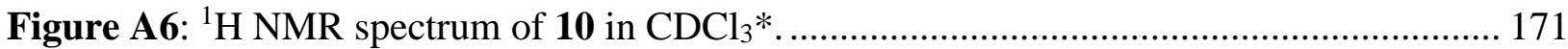

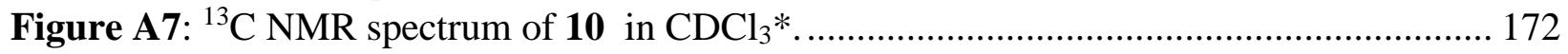

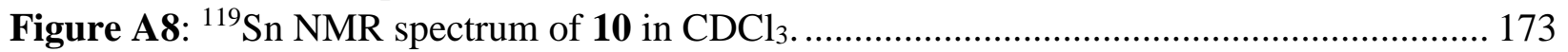

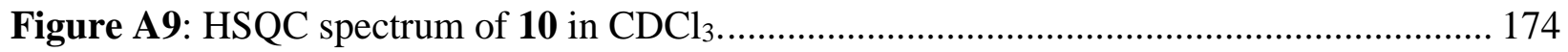

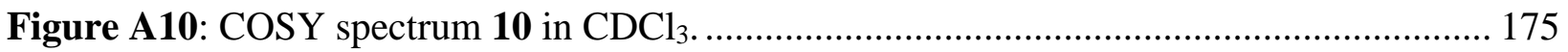

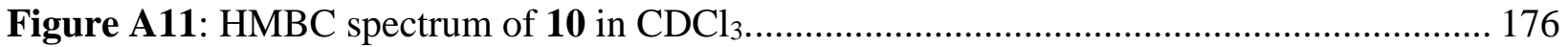

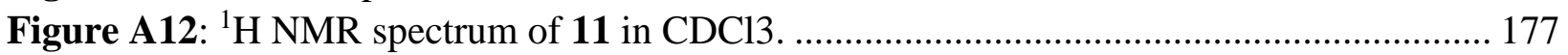

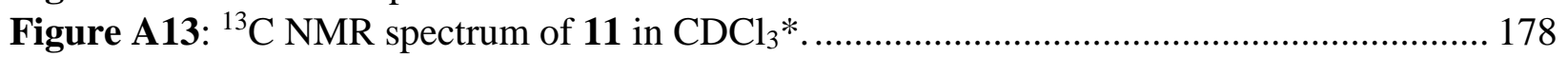

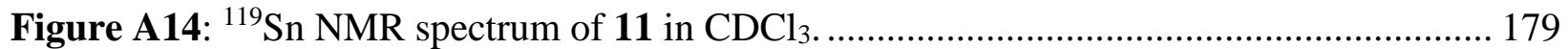

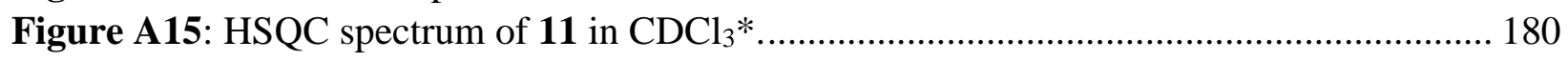

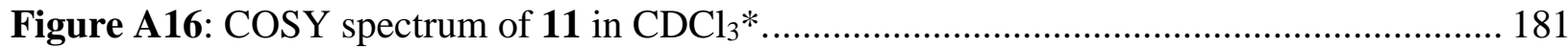

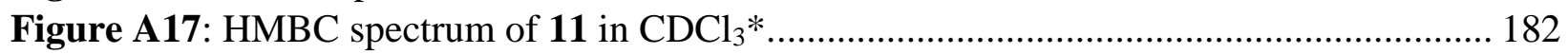

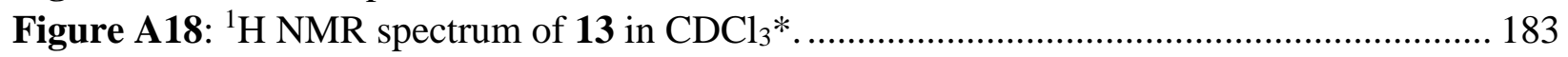

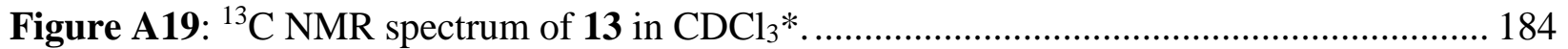

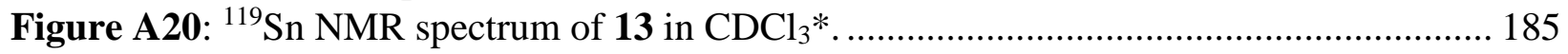

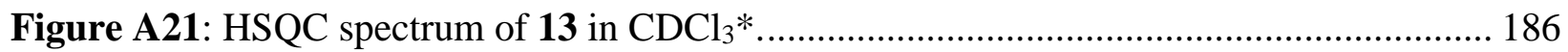

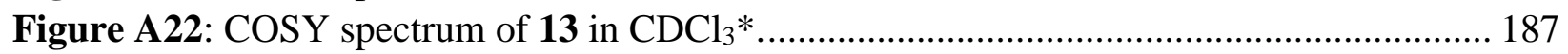

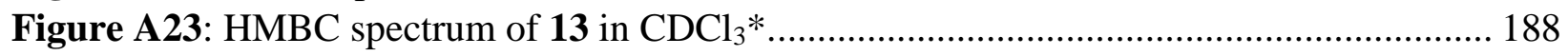

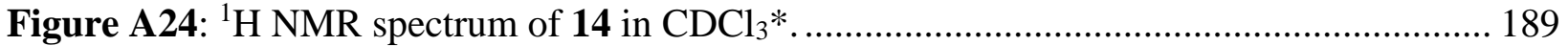

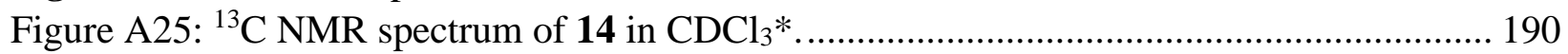

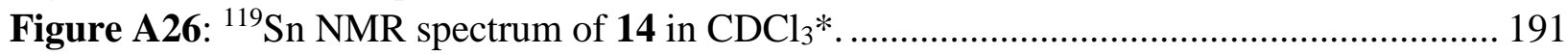

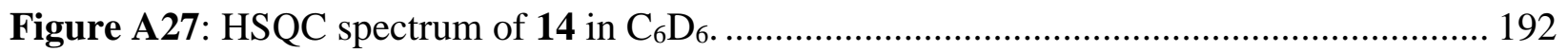

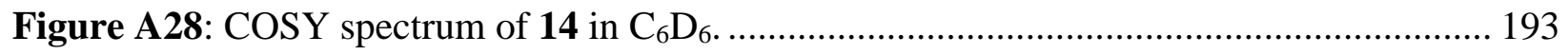

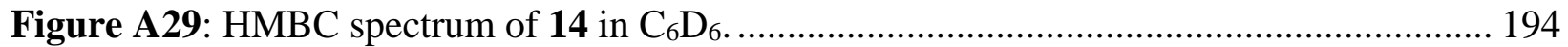

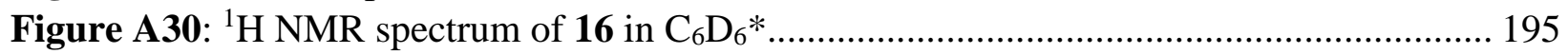

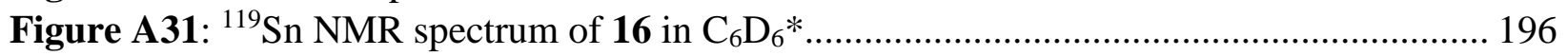

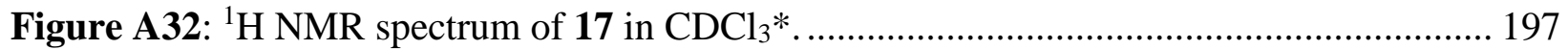




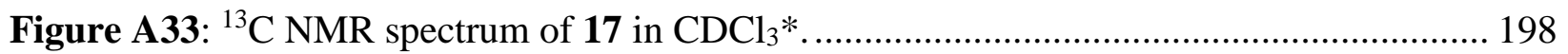

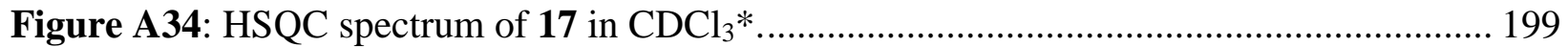

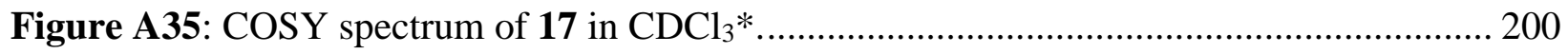

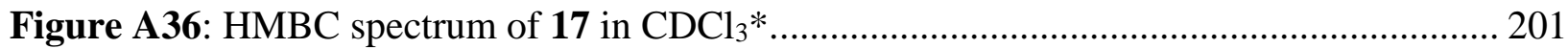

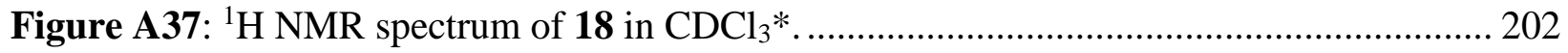

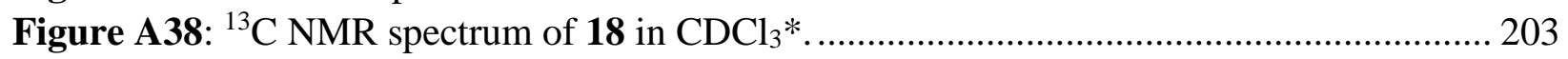

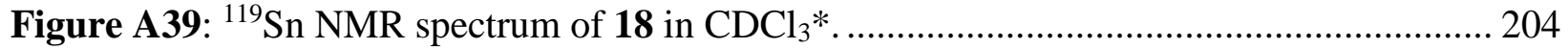

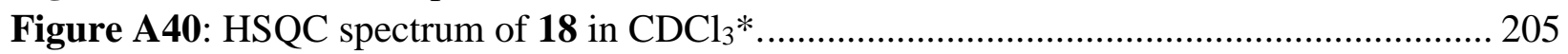

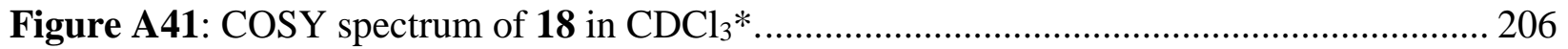

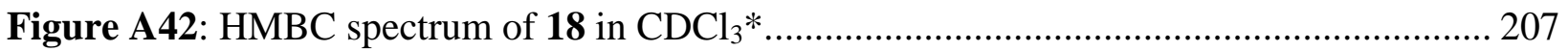

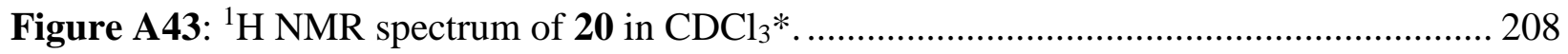

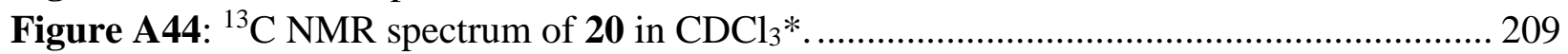

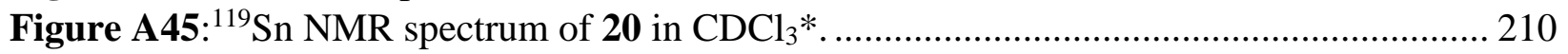

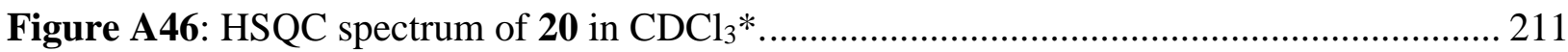

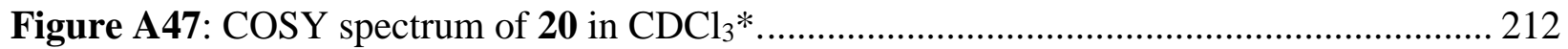

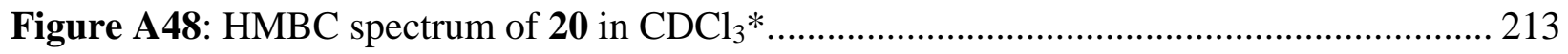

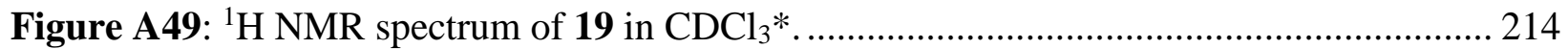

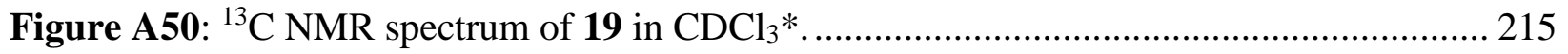

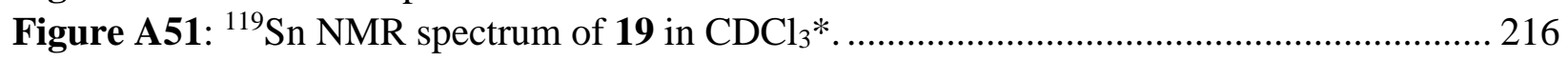

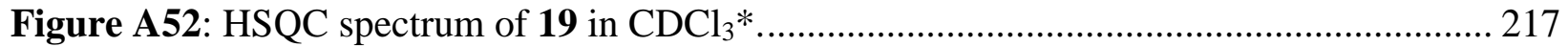

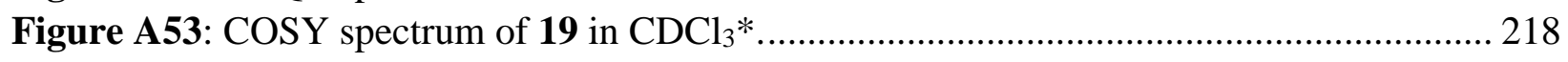

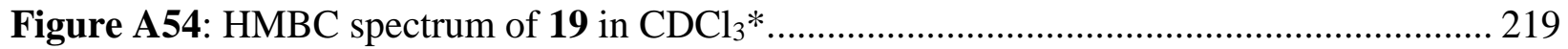

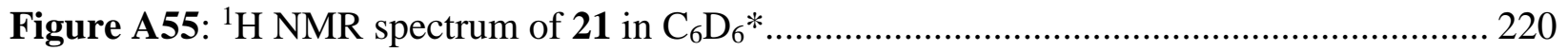

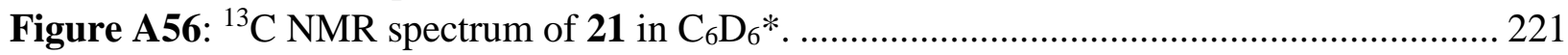

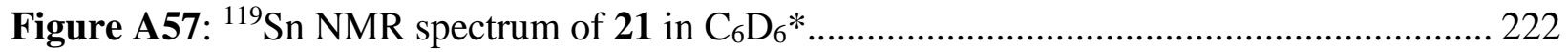

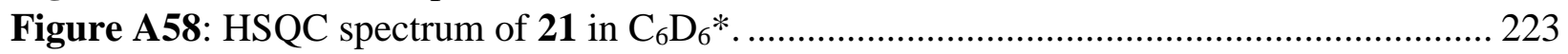

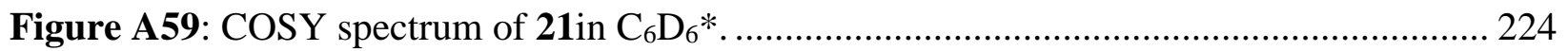

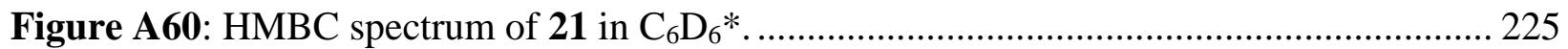

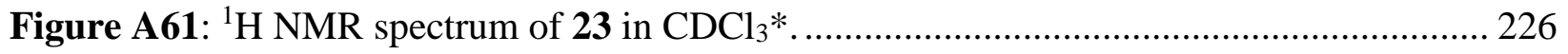

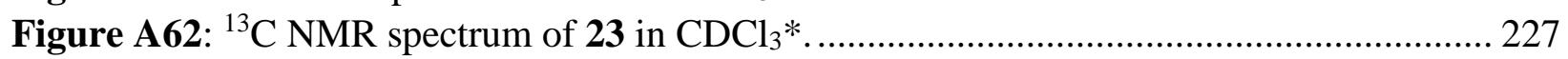

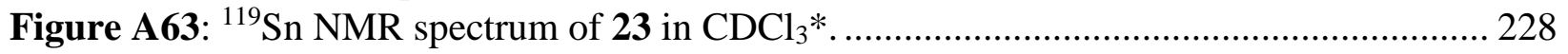

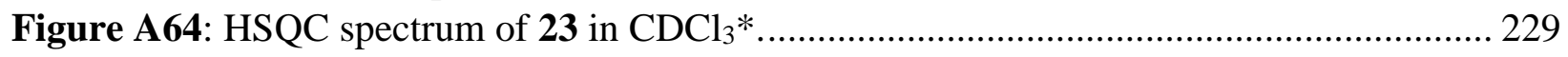

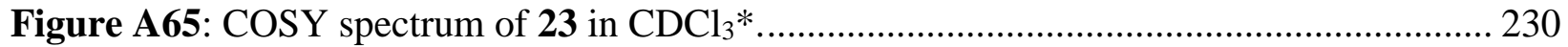

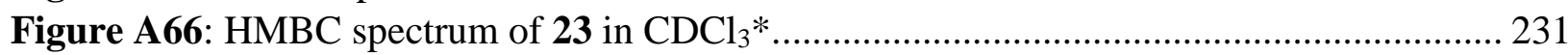

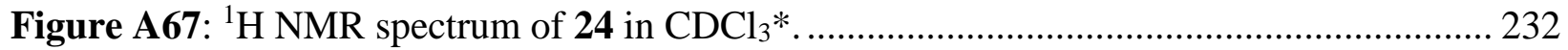

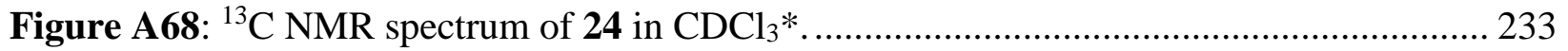

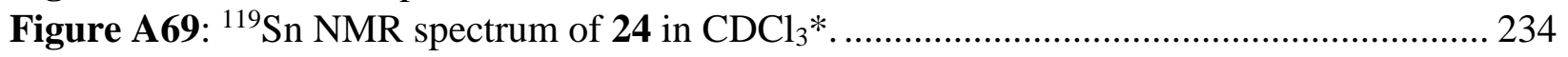

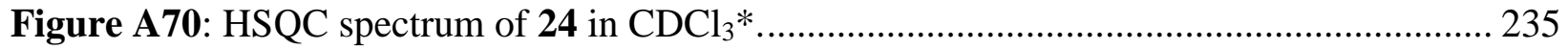

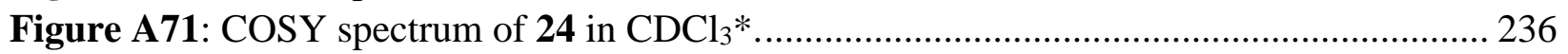

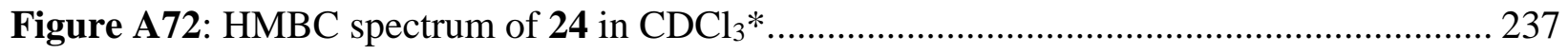


Table A1: Crystal data and structure refinement for $\mathbf{1 0 .}$

Identification code

Empirical formula

Formula weight

Temperature

Wavelength

Crystal system

Space group

Unit cell dimensions

Volume

Z

Density (calculated)

Absorption coefficient

$\mathrm{F}(000)$

Crystal size

Theta range for data collection

Index ranges

Reflections collected

Independent reflections

Completeness to theta $=25.242^{\circ}$

Absorption correction

Max. and min. transmission

Refinement method

Data / restraints / parameters

Goodness-of-fit on $\mathrm{F}^{2}$

Final $\mathrm{R}$ indices [I>2sigma(I)]

$\mathrm{R}$ indices (all data)

Extinction coefficient

Largest diff. peak and hole d17146_a

C29 H27 N O Sn

524.20

150(2) K

$0.71073 \AA$

Monoclinic

$\mathrm{P} 21 / \mathrm{n}$

$\mathrm{a}=9.3351(5) \AA \quad \square=90^{\circ}$.

$\mathrm{b}=18.4709(9) \AA$

$\square=93.8460(10)^{\circ}$.

$\mathrm{c}=14.3598(7) \AA$

2470.5(2) $\AA^{3}$

4

$1.409 \mathrm{Mg} / \mathrm{m}^{3}$

$1.054 \mathrm{~mm}^{-1}$

1064

$0.290 \times 0.190 \times 0.080 \mathrm{~mm}^{3}$

1.799 to $27.517^{\circ}$.

$-12<=\mathrm{h}<=12,-24<=\mathrm{k}<=24,-18<=1<=17$

39843

$5684[\mathrm{R}(\mathrm{int})=0.0229]$

$100.0 \%$

Semi-empirical from equivalents

0.7456 and 0.7028

Full-matrix least-squares on $\mathrm{F}^{2}$

5684 / 0 / 291

1.105

$\mathrm{R} 1=0.0212, \mathrm{wR} 2=0.0423$

$\mathrm{R} 1=0.0281, \mathrm{wR} 2=0.0452$

$\mathrm{n} / \mathrm{a}$

0.542 and -0.459 e. $\AA^{-3}$ 
Atomic coordinates ( $\left.\mathrm{x} 10^{4}\right)$ and equivalent isotropic displacement parameters $\left(\AA^{2} \times 10^{3}\right)$ for 10. $\mathrm{U}(\mathrm{eq})$ is defined as one third of the trace of the orthogonalized $\mathrm{Uij}^{\mathrm{ij}}$ tensor.

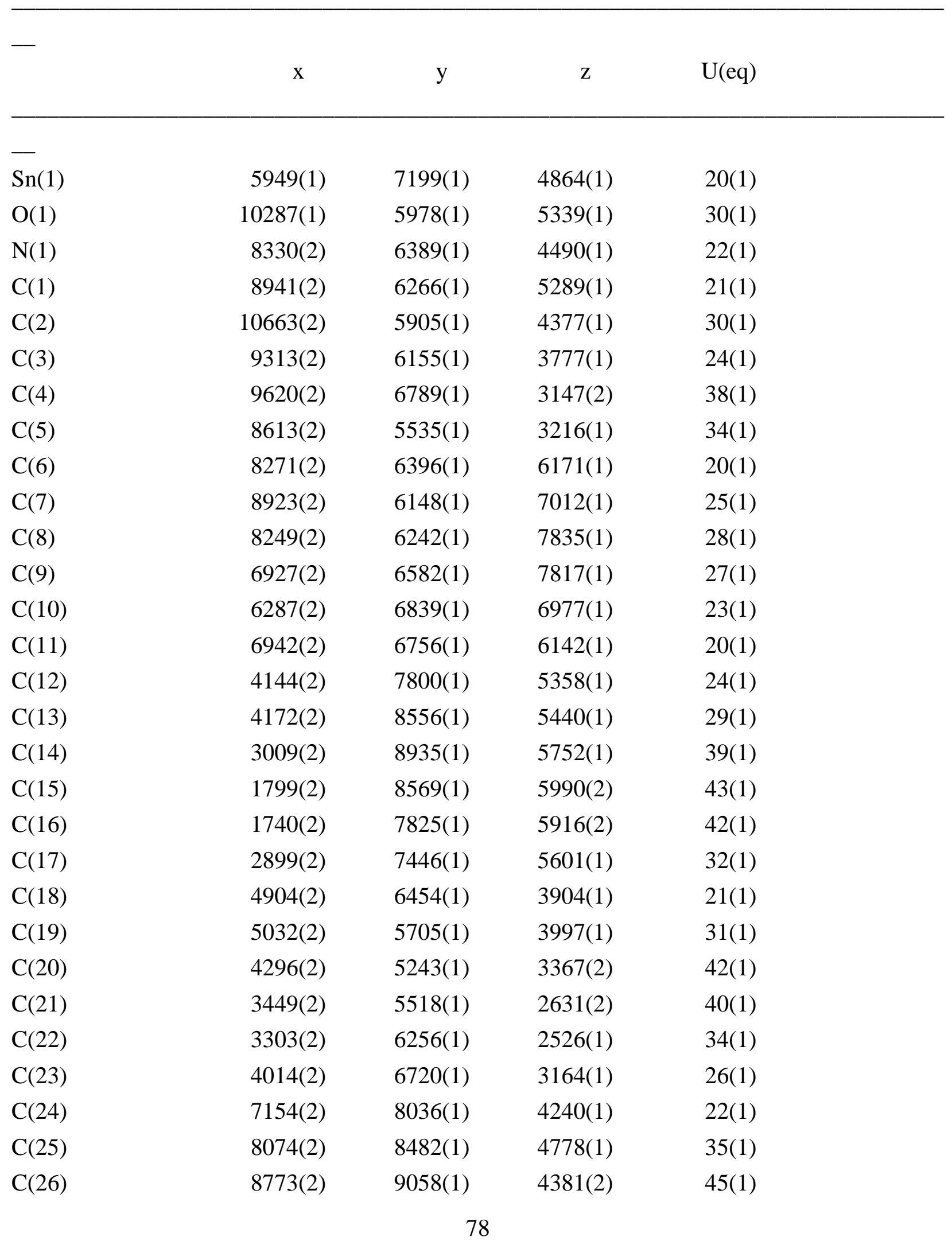


C(27)

C(28)

C(29)
8578(2)

7694(2)

6981(2)
9191(1)

8749(1)

8176(1)
3440(2)

2892(2)

3288(1)
38(1)

36(1)

29(1) 
Bond lengths $[\AA]$ and angles $\left[{ }^{\circ}\right]$ for $\mathbf{1 0 .}$

\begin{tabular}{|c|c|}
\hline $\operatorname{Sn}(1)-C(18)$ & $2.1378(16)$ \\
\hline $\operatorname{Sn}(1)-C(24)$ & $2.1425(17)$ \\
\hline $\operatorname{Sn}(1)-C(11)$ & $2.1602(16)$ \\
\hline $\operatorname{Sn}(1)-C(12)$ & $2.1752(17)$ \\
\hline $\mathrm{O}(1)-\mathrm{C}(1)$ & $1.361(2)$ \\
\hline $\mathrm{O}(1)-\mathrm{C}(2)$ & $1.455(2)$ \\
\hline $\mathrm{N}(1)-\mathrm{C}(1)$ & $1.268(2)$ \\
\hline $\mathrm{N}(1)-\mathrm{C}(3)$ & $1.485(2)$ \\
\hline$C(1)-C(6)$ & $1.469(2)$ \\
\hline$C(2)-C(3)$ & $1.549(3)$ \\
\hline $\mathrm{C}(2)-\mathrm{H}(2 \mathrm{~A})$ & 0.9900 \\
\hline $\mathrm{C}(2)-\mathrm{H}(2 \mathrm{~B})$ & 0.9900 \\
\hline$C(3)-C(4)$ & $1.520(2)$ \\
\hline$C(3)-C(5)$ & $1.522(3)$ \\
\hline $\mathrm{C}(4)-\mathrm{H}(4 \mathrm{~A})$ & 0.9800 \\
\hline $\mathrm{C}(4)-\mathrm{H}(4 \mathrm{~B})$ & 0.9800 \\
\hline $\mathrm{C}(4)-\mathrm{H}(4 \mathrm{C})$ & 0.9800 \\
\hline $\mathrm{C}(5)-\mathrm{H}(5 \mathrm{~A})$ & 0.9800 \\
\hline $\mathrm{C}(5)-\mathrm{H}(5 \mathrm{~B})$ & 0.9800 \\
\hline $\mathrm{C}(5)-\mathrm{H}(5 \mathrm{C})$ & 0.9800 \\
\hline$C(6)-C(7)$ & $1.393(2)$ \\
\hline $\mathrm{C}(6)-\mathrm{C}(11)$ & $1.406(2)$ \\
\hline$C(7)-C(8)$ & $1.387(3)$ \\
\hline $\mathrm{C}(7)-\mathrm{H}(7 \mathrm{~A})$ & 0.9500 \\
\hline $\mathrm{C}(8)-\mathrm{C}(9)$ & $1.383(3)$ \\
\hline $\mathrm{C}(8)-\mathrm{H}(8 \mathrm{~A})$ & 0.9500 \\
\hline $\mathrm{C}(9)-\mathrm{C}(10)$ & $1.393(2)$ \\
\hline $\mathrm{C}(9)-\mathrm{H}(9 \mathrm{~A})$ & 0.9500 \\
\hline $\mathrm{C}(10)-\mathrm{C}(11)$ & $1.391(2)$ \\
\hline $\mathrm{C}(10)-\mathrm{H}(10 \mathrm{~A})$ & 0.9500 \\
\hline $\mathrm{C}(12)-\mathrm{C}(17)$ & $1.398(3)$ \\
\hline $\mathrm{C}(12)-\mathrm{C}(13)$ & $1.401(2)$ \\
\hline $\mathrm{C}(13)-\mathrm{C}(14)$ & $1.391(3)$ \\
\hline $\mathrm{C}(13)-\mathrm{H}(13 \mathrm{~A})$ & 0.9500 \\
\hline
\end{tabular}




\begin{tabular}{|c|c|}
\hline$C(14)-C(15)$ & $1.378(3)$ \\
\hline $\mathrm{C}(14)-\mathrm{H}(14 \mathrm{~A})$ & 0.9500 \\
\hline$C(15)-C(16)$ & $1.381(3)$ \\
\hline $\mathrm{C}(15)-\mathrm{H}(15 \mathrm{~A})$ & 0.9500 \\
\hline$C(16)-C(17)$ & $1.389(3)$ \\
\hline $\mathrm{C}(16)-\mathrm{H}(16 \mathrm{~A})$ & 0.9500 \\
\hline $\mathrm{C}(17)-\mathrm{H}(17 \mathrm{~A})$ & 0.9500 \\
\hline C(18)-C(19) & $1.394(2)$ \\
\hline $\mathrm{C}(18)-\mathrm{C}(23)$ & $1.394(2)$ \\
\hline C(19)-C(20) & $1.391(3)$ \\
\hline $\mathrm{C}(19)-\mathrm{H}(19 \mathrm{~A})$ & 0.9500 \\
\hline $\mathrm{C}(20)-\mathrm{C}(21)$ & $1.374(3)$ \\
\hline $\mathrm{C}(20)-\mathrm{H}(20 \mathrm{~A})$ & 0.9500 \\
\hline $\mathrm{C}(21)-\mathrm{C}(22)$ & $1.377(3)$ \\
\hline $\mathrm{C}(21)-\mathrm{H}(21 \mathrm{~A})$ & 0.9500 \\
\hline$C(22)-C(23)$ & $1.389(3)$ \\
\hline $\mathrm{C}(22)-\mathrm{H}(22 \mathrm{~A})$ & 0.9500 \\
\hline $\mathrm{C}(23)-\mathrm{H}(23 \mathrm{~A})$ & 0.9500 \\
\hline $\mathrm{C}(24)-\mathrm{C}(25)$ & $1.388(3)$ \\
\hline $\mathrm{C}(24)-\mathrm{C}(29)$ & $1.390(2)$ \\
\hline$C(25)-C(26)$ & $1.389(3)$ \\
\hline $\mathrm{C}(25)-\mathrm{H}(25 \mathrm{~A})$ & 0.9500 \\
\hline$C(26)-C(27)$ & $1.374(3)$ \\
\hline $\mathrm{C}(26)-\mathrm{H}(26 \mathrm{~A})$ & 0.9500 \\
\hline $\mathrm{C}(27)-\mathrm{C}(28)$ & $1.370(3)$ \\
\hline $\mathrm{C}(27)-\mathrm{H}(27 \mathrm{~A})$ & 0.9500 \\
\hline $\mathrm{C}(28)-\mathrm{C}(29)$ & $1.392(3)$ \\
\hline $\mathrm{C}(28)-\mathrm{H}(28 \mathrm{~A})$ & 0.9500 \\
\hline $\mathrm{C}(29)-\mathrm{H}(29 \mathrm{~A})$ & 0.9500 \\
\hline $\mathrm{C}(18)-\mathrm{Sn}(1)-\mathrm{C}(24)$ & $115.10(6)$ \\
\hline $\mathrm{C}(18)-\mathrm{Sn}(1)-\mathrm{C}(11)$ & $117.09(6)$ \\
\hline $\mathrm{C}(24)-\operatorname{Sn}(1)-\mathrm{C}(11)$ & $114.92(6)$ \\
\hline $\mathrm{C}(18)-\mathrm{Sn}(1)-\mathrm{C}(12)$ & $102.03(6)$ \\
\hline $\mathrm{C}(24)-\operatorname{Sn}(1)-\mathrm{C}(12)$ & $102.00(7)$ \\
\hline $\mathrm{C}(11)-\operatorname{Sn}(1)-\mathrm{C}(12)$ & $102.36(6)$ \\
\hline
\end{tabular}




\begin{tabular}{|c|c|}
\hline $\mathrm{C}(1)-\mathrm{O}(1)-\mathrm{C}(2)$ & $105.48(13)$ \\
\hline $\mathrm{C}(1)-\mathrm{N}(1)-\mathrm{C}(3)$ & $108.09(14)$ \\
\hline $\mathrm{N}(1)-\mathrm{C}(1)-\mathrm{O}(1)$ & $118.41(15)$ \\
\hline $\mathrm{N}(1)-\mathrm{C}(1)-\mathrm{C}(6)$ & $123.97(16)$ \\
\hline $\mathrm{O}(1)-\mathrm{C}(1)-\mathrm{C}(6)$ & $117.60(15)$ \\
\hline $\mathrm{O}(1)-\mathrm{C}(2)-\mathrm{C}(3)$ & $105.17(14)$ \\
\hline $\mathrm{O}(1)-\mathrm{C}(2)-\mathrm{H}(2 \mathrm{~A})$ & 110.7 \\
\hline $\mathrm{C}(3)-\mathrm{C}(2)-\mathrm{H}(2 \mathrm{~A})$ & 110.7 \\
\hline $\mathrm{O}(1)-\mathrm{C}(2)-\mathrm{H}(2 \mathrm{~B})$ & 110.7 \\
\hline $\mathrm{C}(3)-\mathrm{C}(2)-\mathrm{H}(2 \mathrm{~B})$ & 110.7 \\
\hline $\mathrm{H}(2 \mathrm{~A})-\mathrm{C}(2)-\mathrm{H}(2 \mathrm{~B})$ & 108.8 \\
\hline $\mathrm{N}(1)-\mathrm{C}(3)-\mathrm{C}(4)$ & $109.58(14)$ \\
\hline $\mathrm{N}(1)-\mathrm{C}(3)-\mathrm{C}(5)$ & $108.74(15)$ \\
\hline $\mathrm{C}(4)-\mathrm{C}(3)-\mathrm{C}(5)$ & $110.91(16)$ \\
\hline $\mathrm{N}(1)-\mathrm{C}(3)-\mathrm{C}(2)$ & $102.73(14)$ \\
\hline $\mathrm{C}(4)-\mathrm{C}(3)-\mathrm{C}(2)$ & $112.51(16)$ \\
\hline$C(5)-C(3)-C(2)$ & $111.99(15)$ \\
\hline $\mathrm{C}(3)-\mathrm{C}(4)-\mathrm{H}(4 \mathrm{~A})$ & 109.5 \\
\hline $\mathrm{C}(3)-\mathrm{C}(4)-\mathrm{H}(4 \mathrm{~B})$ & 109.5 \\
\hline $\mathrm{H}(4 \mathrm{~A})-\mathrm{C}(4)-\mathrm{H}(4 \mathrm{~B})$ & 109.5 \\
\hline $\mathrm{C}(3)-\mathrm{C}(4)-\mathrm{H}(4 \mathrm{C})$ & 109.5 \\
\hline $\mathrm{H}(4 \mathrm{~A})-\mathrm{C}(4)-\mathrm{H}(4 \mathrm{C})$ & 109.5 \\
\hline $\mathrm{H}(4 \mathrm{~B})-\mathrm{C}(4)-\mathrm{H}(4 \mathrm{C})$ & 109.5 \\
\hline $\mathrm{C}(3)-\mathrm{C}(5)-\mathrm{H}(5 \mathrm{~A})$ & 109.5 \\
\hline $\mathrm{C}(3)-\mathrm{C}(5)-\mathrm{H}(5 \mathrm{~B})$ & 109.5 \\
\hline $\mathrm{H}(5 \mathrm{~A})-\mathrm{C}(5)-\mathrm{H}(5 \mathrm{~B})$ & 109.5 \\
\hline $\mathrm{C}(3)-\mathrm{C}(5)-\mathrm{H}(5 \mathrm{C})$ & 109.5 \\
\hline $\mathrm{H}(5 \mathrm{~A})-\mathrm{C}(5)-\mathrm{H}(5 \mathrm{C})$ & 109.5 \\
\hline$H(5 B)-C(5)-H(5 C)$ & 109.5 \\
\hline$C(7)-C(6)-C(11)$ & $121.02(16)$ \\
\hline $\mathrm{C}(7)-\mathrm{C}(6)-\mathrm{C}(1)$ & $120.39(16)$ \\
\hline$C(11)-C(6)-C(1)$ & $118.56(15)$ \\
\hline$C(8)-C(7)-C(6)$ & $119.99(17)$ \\
\hline $\mathrm{C}(8)-\mathrm{C}(7)-\mathrm{H}(7 \mathrm{~A})$ & 120.0 \\
\hline $\mathrm{C}(6)-\mathrm{C}(7)-\mathrm{H}(7 \mathrm{~A})$ & 120.0 \\
\hline$C(9)-C(8)-C(7)$ & $119.80(17)$ \\
\hline
\end{tabular}




$\begin{array}{ll}\mathrm{C}(9)-\mathrm{C}(8)-\mathrm{H}(8 \mathrm{~A}) & 120.1 \\ \mathrm{C}(7)-\mathrm{C}(8)-\mathrm{H}(8 \mathrm{~A}) & 120.1 \\ \mathrm{C}(8)-\mathrm{C}(9)-\mathrm{C}(10) & 120.06(17) \\ \mathrm{C}(8)-\mathrm{C}(9)-\mathrm{H}(9 \mathrm{~A}) & 120.0 \\ \mathrm{C}(10)-\mathrm{C}(9)-\mathrm{H}(9 \mathrm{~A}) & 120.0 \\ \mathrm{C}(11)-\mathrm{C}(10)-\mathrm{C}(9) & 121.43(17) \\ \mathrm{C}(11)-\mathrm{C}(10)-\mathrm{H}(10 \mathrm{~A}) & 119.3 \\ \mathrm{C}(9)-\mathrm{C}(10)-\mathrm{H}(10 \mathrm{~A}) & 119.3 \\ \mathrm{C}(10)-\mathrm{C}(11)-\mathrm{C}(6) & 117.67(16) \\ \mathrm{C}(10)-\mathrm{C}(11)-\mathrm{Sn}(1) & 120.17(13) \\ \mathrm{C}(6)-\mathrm{C}(11)-\mathrm{Sn}(1) & 122.14(12) \\ \mathrm{C}(17)-\mathrm{C}(12)-\mathrm{C}(13) & 117.09(17) \\ \mathrm{C}(17)-\mathrm{C}(12)-\mathrm{Sn}(1) & 121.20(13) \\ \mathrm{C}(13)-\mathrm{C}(12)-\mathrm{Sn}(1) & 121.71(14) \\ \mathrm{C}(14)-\mathrm{C}(13)-\mathrm{C}(12) & 121.24(19) \\ \mathrm{C}(14)-\mathrm{C}(13)-\mathrm{H}(13 \mathrm{~A}) & 119.4 \\ \mathrm{C}(12)-\mathrm{C}(13)-\mathrm{H}(13 \mathrm{~A}) & 119.4 \\ \mathrm{C}(15)-\mathrm{C}(14)-\mathrm{C}(13) & 120.2(2) \\ \mathrm{C}(15)-\mathrm{C}(14)-\mathrm{H}(14 \mathrm{~A}) & 119.9 \\ \mathrm{C}(13)-\mathrm{C}(14)-\mathrm{H}(14 \mathrm{~A}) & 119.9 \\ \mathrm{C}(14)-\mathrm{C}(15)-\mathrm{C}(16) & 119.86(19) \\ \mathrm{C}(14)-\mathrm{C}(15)-\mathrm{H}(15 \mathrm{~A}) & 120.1 \\ \mathrm{C}(16)-\mathrm{C}(15)-\mathrm{H}(15 \mathrm{~A}) & 120.1 \\ \mathrm{C}(15)-\mathrm{C}(16)-\mathrm{C}(17) & 119.9(2) \\ \mathrm{C}(15)-\mathrm{C}(16)-\mathrm{H}(16 \mathrm{~A}) & 120.0 \\ \mathrm{C}(17)-\mathrm{C}(16)-\mathrm{H}(16 \mathrm{~A}) & 120.0 \\ \mathrm{C}(16)-\mathrm{C}(17)-\mathrm{C}(12) & 121.7(2) \\ \mathrm{C}(16)-\mathrm{C}(17)-\mathrm{H}(17 \mathrm{~A}) & 119.2 \\ \mathrm{C}(12)-\mathrm{C}(17)-\mathrm{H}(17 \mathrm{~A}) & 119.2 \\ \mathrm{C}(19)-\mathrm{C}(18)-\mathrm{C}(23) & 117.78(16) \\ \mathrm{C}(19)-\mathrm{C}(18)-\mathrm{Sn}(1) & 122.99(14) \\ \mathrm{C}(23)-\mathrm{C}(18)-\mathrm{Sn}(1) & 119.21(12) \\ \mathrm{C}(20)-\mathrm{C}(19)-\mathrm{C}(18) & 120.72(19) \\ \mathrm{C}(20)-\mathrm{C}(19)-\mathrm{H}(19 \mathrm{~A}) & 119.6 \\ \mathrm{C}(18)-\mathrm{C}(19)-\mathrm{H}(19 \mathrm{~A}) & 119.6 \\ \mathrm{C}(21)-\mathrm{C}(20)-\mathrm{C}(19) & 120.43(19) \\ & \end{array}$




$\begin{array}{ll}\mathrm{C}(21)-\mathrm{C}(20)-\mathrm{H}(20 \mathrm{~A}) & 119.8 \\ \mathrm{C}(19)-\mathrm{C}(20)-\mathrm{H}(20 \mathrm{~A}) & 119.8 \\ \mathrm{C}(20)-\mathrm{C}(21)-\mathrm{C}(22) & 119.86(19) \\ \mathrm{C}(20)-\mathrm{C}(21)-\mathrm{H}(21 \mathrm{~A}) & 120.1 \\ \mathrm{C}(22)-\mathrm{C}(21)-\mathrm{H}(21 \mathrm{~A}) & 120.1 \\ \mathrm{C}(21)-\mathrm{C}(22)-\mathrm{C}(23) & 119.9(2) \\ \mathrm{C}(21)-\mathrm{C}(22)-\mathrm{H}(22 \mathrm{~A}) & 120.0 \\ \mathrm{C}(23)-\mathrm{C}(22)-\mathrm{H}(22 \mathrm{~A}) & 120.0 \\ \mathrm{C}(22)-\mathrm{C}(23)-\mathrm{C}(18) & 121.26(18) \\ \mathrm{C}(22)-\mathrm{C}(23)-\mathrm{H}(23 \mathrm{~A}) & 119.4 \\ \mathrm{C}(18)-\mathrm{C}(23)-\mathrm{H}(23 \mathrm{~A}) & 119.4 \\ \mathrm{C}(25)-\mathrm{C}(24)-\mathrm{C}(29) & 117.59(17) \\ \mathrm{C}(25)-\mathrm{C}(24)-\mathrm{Sn}(1) & 121.23(13) \\ \mathrm{C}(29)-\mathrm{C}(24)-\mathrm{Sn}(1) & 121.09(13) \\ \mathrm{C}(24)-\mathrm{C}(25)-\mathrm{C}(26) & 121.09(19) \\ \mathrm{C}(24)-\mathrm{C}(25)-\mathrm{H}(25 \mathrm{~A}) & 119.5 \\ \mathrm{C}(26)-\mathrm{C}(25)-\mathrm{H}(25 \mathrm{~A}) & 119.5 \\ \mathrm{C}(27)-\mathrm{C}(26)-\mathrm{C}(25) & 120.4(2) \\ \mathrm{C}(27)-\mathrm{C}(26)-\mathrm{H}(26 \mathrm{~A}) & 119.8 \\ \mathrm{C}(25)-\mathrm{C}(26)-\mathrm{H}(26 \mathrm{~A}) & 119.8 \\ \mathrm{C}(28)-\mathrm{C}(27)-\mathrm{C}(26) & 119.56(19) \\ \mathrm{C}(28)-\mathrm{C}(27)-\mathrm{H}(27 \mathrm{~A}) & 120.2 \\ \mathrm{C}(26)-\mathrm{C}(27)-\mathrm{H}(27 \mathrm{~A}) & 120.2 \\ \mathrm{C}(27)-\mathrm{C}(28)-\mathrm{C}(29) & 120.23(19) \\ \mathrm{C}(27)-\mathrm{C}(28)-\mathrm{H}(28 \mathrm{~A}) & 119.9 \\ \mathrm{C}(29)-\mathrm{C}(28)-\mathrm{H}(28 \mathrm{~A}) & 119.9 \\ \mathrm{C}(24)-\mathrm{C}(29)-\mathrm{C}(28) & 121.11(18) \\ \mathrm{C}(24)-\mathrm{C}(29)-\mathrm{H}(29 \mathrm{~A}) & 119.4 \\ \mathrm{C}(28)-\mathrm{C}(29)-\mathrm{H}(29 \mathrm{~A}) & 119.4 \\ & \\ & \\ & \end{array}$

Symmetry transformations used to generate equivalent atoms: 
Anisotropic displacement parameters $\left(\AA^{2} \times 10^{3}\right)$ for 10. The anisotropic

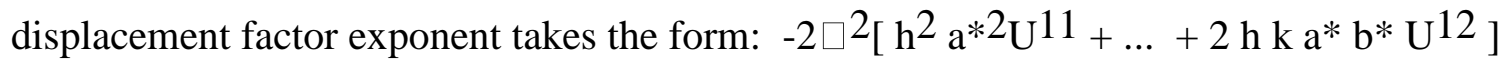

\begin{tabular}{|c|c|c|c|c|c|c|}
\hline & U11 & $\mathrm{U}^{22}$ & $\mathrm{U}^{33}$ & $\mathrm{U}^{23}$ & $\mathrm{U}^{13}$ & $\mathrm{U}^{12}$ \\
\hline $\operatorname{Sn}(1)$ & $23(1)$ & $18(1)$ & $19(1)$ & $0(1)$ & 1(1) & $-1(1)$ \\
\hline $\mathrm{O}(1)$ & $25(1)$ & $38(1)$ & $27(1)$ & $6(1)$ & $5(1)$ & $9(1)$ \\
\hline $\mathrm{N}(1)$ & $23(1)$ & $22(1)$ & $22(1)$ & $0(1)$ & $5(1)$ & $0(1)$ \\
\hline $\mathrm{C}(1)$ & 21(1) & $16(1)$ & $26(1)$ & $1(1)$ & $5(1)$ & $0(1)$ \\
\hline$C(2)$ & $27(1)$ & $35(1)$ & $29(1)$ & $0(1)$ & $9(1)$ & $5(1)$ \\
\hline $\mathrm{C}(3)$ & $26(1)$ & $24(1)$ & $23(1)$ & $3(1)$ & $8(1)$ & $4(1)$ \\
\hline C(4) & $42(1)$ & $33(1)$ & $40(1)$ & $13(1)$ & $19(1)$ & $7(1)$ \\
\hline$C(5)$ & $43(1)$ & $32(1)$ & $26(1)$ & $-4(1)$ & $3(1)$ & $7(1)$ \\
\hline$C(6)$ & $24(1)$ & $16(1)$ & $22(1)$ & $-1(1)$ & $2(1)$ & $-3(1)$ \\
\hline$C(7)$ & $28(1)$ & $22(1)$ & $24(1)$ & $0(1)$ & $-2(1)$ & $0(1)$ \\
\hline $\mathrm{C}(8)$ & $39(1)$ & $24(1)$ & $20(1)$ & 1(1) & $-5(1)$ & $-2(1)$ \\
\hline C(9) & $38(1)$ & $24(1)$ & $19(1)$ & $-3(1)$ & $6(1)$ & $-5(1)$ \\
\hline$C(10)$ & $28(1)$ & $20(1)$ & $23(1)$ & $-4(1)$ & $4(1)$ & $-3(1)$ \\
\hline $\mathrm{C}(11)$ & $24(1)$ & $16(1)$ & $19(1)$ & $-1(1)$ & $0(1)$ & $-3(1)$ \\
\hline$C(12)$ & $26(1)$ & $27(1)$ & $18(1)$ & $-2(1)$ & $-1(1)$ & $3(1)$ \\
\hline$C(13)$ & $34(1)$ & $27(1)$ & $27(1)$ & $-2(1)$ & $1(1)$ & $4(1)$ \\
\hline$C(14)$ & $46(1)$ & $35(1)$ & $34(1)$ & $-7(1)$ & $-1(1)$ & $16(1)$ \\
\hline$C(15)$ & $32(1)$ & $61(2)$ & $38(1)$ & $-9(1)$ & $2(1)$ & $18(1)$ \\
\hline$C(16)$ & $24(1)$ & $63(2)$ & $39(1)$ & $-6(1)$ & $4(1)$ & $0(1)$ \\
\hline$C(17)$ & $28(1)$ & $37(1)$ & $31(1)$ & $-4(1)$ & $0(1)$ & $-1(1)$ \\
\hline $\mathrm{C}(18)$ & $20(1)$ & $21(1)$ & $22(1)$ & $-4(1)$ & $6(1)$ & $-2(1)$ \\
\hline$C(19)$ & $33(1)$ & $23(1)$ & $38(1)$ & $3(1)$ & $4(1)$ & $-2(1)$ \\
\hline $\mathrm{C}(20)$ & $47(1)$ & $21(1)$ & $58(2)$ & $-12(1)$ & $18(1)$ & $-10(1)$ \\
\hline$C(21)$ & $37(1)$ & $45(1)$ & $39(1)$ & $-21(1)$ & 11(1) & $-18(1)$ \\
\hline$C(22)$ & $27(1)$ & $51(1)$ & $24(1)$ & $-6(1)$ & $2(1)$ & $-9(1)$ \\
\hline $\mathrm{C}(23)$ & $25(1)$ & $27(1)$ & $27(1)$ & $-1(1)$ & $3(1)$ & $-1(1)$ \\
\hline $\mathrm{C}(24)$ & $22(1)$ & $18(1)$ & $25(1)$ & $2(1)$ & $3(1)$ & $3(1)$ \\
\hline$C(25)$ & $41(1)$ & $35(1)$ & $29(1)$ & $-1(1)$ & 1(1) & $-12(1)$ \\
\hline$C(26)$ & $44(1)$ & $36(1)$ & $53(1)$ & $-1(1)$ & $0(1)$ & $-19(1)$ \\
\hline $\mathrm{C}(27)$ & $31(1)$ & $29(1)$ & $56(1)$ & $16(1)$ & $12(1)$ & $-1(1)$ \\
\hline$C(28)$ & $35(1)$ & $38(1)$ & $34(1)$ & $15(1)$ & $6(1)$ & $6(1)$ \\
\hline
\end{tabular}


C(29)

30(1)

30(1)

26(1)

4(1)

$-2(1)$

1(1) 
Hydrogen coordinates ( $\times 10^{4}$ ) and isotropic displacement parameters $\left(\AA^{2} \times 10^{3}\right)$ for $\mathbf{1 0}$.

\begin{tabular}{|c|c|c|c|c|}
\hline & $\mathrm{x}$ & $\mathrm{y}$ & $\mathrm{z}$ & $\mathrm{U}(\mathrm{eq})$ \\
\hline \multicolumn{5}{|l|}{-} \\
\hline $\mathrm{H}(2 \mathrm{~A})$ & 10899 & 5395 & 4237 & 36 \\
\hline $\mathrm{H}(2 \mathrm{~B})$ & 11499 & 6213 & 4258 & 36 \\
\hline $\mathrm{H}(4 \mathrm{~A})$ & 8725 & 6947 & 2811 & 57 \\
\hline $\mathrm{H}(4 \mathrm{~B})$ & 10308 & 6640 & 2697 & 57 \\
\hline $\mathrm{H}(4 \mathrm{C})$ & 10024 & 7191 & 3526 & 57 \\
\hline $\mathrm{H}(5 \mathrm{~A})$ & 7704 & 5700 & 2907 & 50 \\
\hline $\mathrm{H}(5 \mathrm{~B})$ & 8430 & 5132 & 3635 & 50 \\
\hline $\mathrm{H}(5 \mathrm{C})$ & 9255 & 5374 & 2745 & 50 \\
\hline $\mathrm{H}(7 \mathrm{~A})$ & 9831 & 5914 & 7021 & 30 \\
\hline $\mathrm{H}(8 \mathrm{~A})$ & 8693 & 6073 & 8409 & 34 \\
\hline $\mathrm{H}(9 \mathrm{~A})$ & 6456 & 6640 & 8379 & 33 \\
\hline $\mathrm{H}(10 \mathrm{~A})$ & 5383 & 7075 & 6975 & 28 \\
\hline $\mathrm{H}(13 \mathrm{~A})$ & 5000 & 8814 & 5279 & 35 \\
\hline $\mathrm{H}(14 \mathrm{~A})$ & 3049 & 9447 & 5801 & 46 \\
\hline $\mathrm{H}(15 \mathrm{~A})$ & 1008 & 8830 & 6205 & 52 \\
\hline $\mathrm{H}(16 \mathrm{~A})$ & 908 & 7571 & 6079 & 51 \\
\hline $\mathrm{H}(17 \mathrm{~A})$ & 2845 & 6934 & 5550 & 39 \\
\hline $\mathrm{H}(19 \mathrm{~A})$ & 5629 & 5508 & 4496 & 37 \\
\hline $\mathrm{H}(20 \mathrm{~A})$ & 4381 & 4734 & 3446 & 50 \\
\hline $\mathrm{H}(21 \mathrm{~A})$ & 2964 & 5200 & 2196 & 48 \\
\hline $\mathrm{H}(22 \mathrm{~A})$ & 2717 & 6448 & 2019 & 41 \\
\hline $\mathrm{H}(23 \mathrm{~A})$ & 3892 & 7228 & 3093 & 31 \\
\hline $\mathrm{H}(25 \mathrm{~A})$ & 8229 & 8393 & 5428 & 42 \\
\hline $\mathrm{H}(26 \mathrm{~A})$ & 9389 & 9361 & 4762 & 53 \\
\hline $\mathrm{H}(27 \mathrm{~A})$ & 9053 & 9586 & 3170 & 46 \\
\hline $\mathrm{H}(28 \mathrm{~A})$ & 7568 & 8834 & 2239 & 43 \\
\hline $\mathrm{H}(29 \mathrm{~A})$ & 6366 & 7876 & 2901 & 35 \\
\hline
\end{tabular}


Table 6. Torsion angles $\left[{ }^{\circ}\right]$ for $\mathbf{1 0}$.

\begin{tabular}{lc}
\hline $\mathrm{C}(3)-\mathrm{N}(1)-\mathrm{C}(1)-\mathrm{O}(1)$ & $1.3(2)$ \\
$\mathrm{C}(3)-\mathrm{N}(1)-\mathrm{C}(1)-\mathrm{C}(6)$ & $-177.08(15)$ \\
$\mathrm{C}(2)-\mathrm{O}(1)-\mathrm{C}(1)-\mathrm{N}(1)$ & $1.0(2)$ \\
$\mathrm{C}(2)-\mathrm{O}(1)-\mathrm{C}(1)-\mathrm{C}(6)$ & $179.51(14)$ \\
$\mathrm{C}(1)-\mathrm{O}(1)-\mathrm{C}(2)-\mathrm{C}(3)$ & $-2.74(18)$ \\
$\mathrm{C}(1)-\mathrm{N}(1)-\mathrm{C}(3)-\mathrm{C}(4)$ & $-122.64(17)$ \\
$\mathrm{C}(1)-\mathrm{N}(1)-\mathrm{C}(3)-\mathrm{C}(5)$ & $115.98(16)$ \\
$\mathrm{C}(1)-\mathrm{N}(1)-\mathrm{C}(3)-\mathrm{C}(2)$ & $-2.84(18)$ \\
$\mathrm{O}(1)-\mathrm{C}(2)-\mathrm{C}(3)-\mathrm{N}(1)$ & $3.34(18)$ \\
$\mathrm{O}(1)-\mathrm{C}(2)-\mathrm{C}(3)-\mathrm{C}(4)$ & $121.09(17)$ \\
$\mathrm{O}(1)-\mathrm{C}(2)-\mathrm{C}(3)-\mathrm{C}(5)$ & $-113.17(17)$ \\
$\mathrm{N}(1)-\mathrm{C}(1)-\mathrm{C}(6)-\mathrm{C}(7)$ & $170.47(16)$ \\
$\mathrm{O}(1)-\mathrm{C}(1)-\mathrm{C}(6)-\mathrm{C}(7)$ & $-7.9(2)$ \\
$\mathrm{N}(1)-\mathrm{C}(1)-\mathrm{C}(6)-\mathrm{C}(11)$ & $-7.7(2)$ \\
$\mathrm{O}(1)-\mathrm{C}(1)-\mathrm{C}(6)-\mathrm{C}(11)$ & $173.89(14)$ \\
$\mathrm{C}(11)-\mathrm{C}(6)-\mathrm{C}(7)-\mathrm{C}(8)$ & $1.3(3)$ \\
$\mathrm{C}(1)-\mathrm{C}(6)-\mathrm{C}(7)-\mathrm{C}(8)$ & $-176.86(16)$ \\
$\mathrm{C}(6)-\mathrm{C}(7)-\mathrm{C}(8)-\mathrm{C}(9)$ & $0.1(3)$ \\
$\mathrm{C}(7)-\mathrm{C}(8)-\mathrm{C}(9)-\mathrm{C}(10)$ & $-1.0(3)$ \\
$\mathrm{C}(8)-\mathrm{C}(9)-\mathrm{C}(10)-\mathrm{C}(11)$ & $0.6(3)$ \\
$\mathrm{C}(9)-\mathrm{C}(10)-\mathrm{C}(11)-\mathrm{C}(6)$ & $0.8(2)$ \\
$\mathrm{C}(9)-\mathrm{C}(10)-\mathrm{C}(11)-\mathrm{Sn}(1)$ & $-177.65(13)$ \\
$\mathrm{C}(7)-\mathrm{C}(6)-\mathrm{C}(11)-\mathrm{C}(10)$ & $-1.7(2)$ \\
$\mathrm{C}(1)-\mathrm{C}(6)-\mathrm{C}(11)-\mathrm{C}(10)$ & $176.50(15)$ \\
$\mathrm{C}(7)-\mathrm{C}(6)-\mathrm{C}(11)-\mathrm{Sn}(1)$ & $176.69(12)$ \\
$\mathrm{C}(1)-\mathrm{C}(6)-\mathrm{C}(11)-\mathrm{Sn}(1)$ & $-5.1(2)$ \\
$\mathrm{C}(17)-\mathrm{C}(12)-\mathrm{C}(13)-\mathrm{C}(14)$ & $0.1(3)$ \\
$\mathrm{Sn}(1)-\mathrm{C}(12)-\mathrm{C}(13)-\mathrm{C}(14)$ & $179.71(14)$ \\
$\mathrm{C}(12)-\mathrm{C}(13)-\mathrm{C}(14)-\mathrm{C}(15)$ & $0.1(3)$ \\
$\mathrm{C}(13)-\mathrm{C}(14)-\mathrm{C}(15)-\mathrm{C}(16)$ & $-0.2(3)$ \\
$\mathrm{C}(14)-\mathrm{C}(15)-\mathrm{C}(16)-\mathrm{C}(17)$ & $0.0(3)$ \\
$\mathrm{C}(15)-\mathrm{C}(16)-\mathrm{C}(17)-\mathrm{C}(12)$ & $0.3(3)$ \\
$\mathrm{C}(13)-\mathrm{C}(12)-\mathrm{C}(17)-\mathrm{C}(16)$ & \\
$\mathrm{Sn}(1)-\mathrm{C}(12)-\mathrm{C}(17)-\mathrm{C}(16)$ & \\
& \\
&
\end{tabular}




$\begin{array}{lc}\mathrm{C}(23)-\mathrm{C}(18)-\mathrm{C}(19)-\mathrm{C}(20) & 0.2(3) \\ \mathrm{Sn}(1)-\mathrm{C}(18)-\mathrm{C}(19)-\mathrm{C}(20) & 178.18(15) \\ \mathrm{C}(18)-\mathrm{C}(19)-\mathrm{C}(20)-\mathrm{C}(21) & 1.1(3) \\ \mathrm{C}(19)-\mathrm{C}(20)-\mathrm{C}(21)-\mathrm{C}(22) & -1.3(3) \\ \mathrm{C}(20)-\mathrm{C}(21)-\mathrm{C}(22)-\mathrm{C}(23) & 0.0(3) \\ \mathrm{C}(21)-\mathrm{C}(22)-\mathrm{C}(23)-\mathrm{C}(18) & 1.3(3) \\ \mathrm{C}(19)-\mathrm{C}(18)-\mathrm{C}(23)-\mathrm{C}(22) & -1.4(3) \\ \mathrm{Sn}(1)-\mathrm{C}(18)-\mathrm{C}(23)-\mathrm{C}(22) & -179.47(14) \\ \mathrm{C}(29)-\mathrm{C}(24)-\mathrm{C}(25)-\mathrm{C}(26) & 1.3(3) \\ \mathrm{Sn}(1)-\mathrm{C}(24)-\mathrm{C}(25)-\mathrm{C}(26) & -175.25(17) \\ \mathrm{C}(24)-\mathrm{C}(25)-\mathrm{C}(26)-\mathrm{C}(27) & -0.8(4) \\ \mathrm{C}(25)-\mathrm{C}(26)-\mathrm{C}(27)-\mathrm{C}(28) & -0.4(3) \\ \mathrm{C}(26)-\mathrm{C}(27)-\mathrm{C}(28)-\mathrm{C}(29) & 1.0(3) \\ \mathrm{C}(25)-\mathrm{C}(24)-\mathrm{C}(29)-\mathrm{C}(28) & -0.7(3) \\ \mathrm{Sn}(1)-\mathrm{C}(24)-\mathrm{C}(29)-\mathrm{C}(28) & 175.86(14) \\ \mathrm{C}(27)-\mathrm{C}(28)-\mathrm{C}(29)-\mathrm{C}(24) & -0.4(3)\end{array}$

Symmetry transformations used to generate equivalent atoms: 
Table A2: Crystal data and structure refinement for 11.

Identification code

Empirical formula

Formula weight

Temperature

Wavelength

Crystal system

Space group

Unit cell dimensions

Volume

$\mathrm{Z}$

Density (calculated)

Absorption coefficient

$\mathrm{F}(000)$

Crystal size

Theta range for data collection

Index ranges

Reflections collected

Independent reflections

Completeness to theta $=25.242^{\circ}$

Absorption correction

Max. and min. transmission

Refinement method

Data / restraints / parameters

Goodness-of-fit on $\mathrm{F}^{2}$

Final $\mathrm{R}$ indices [I $>2 \operatorname{sigma}(\mathrm{I})]$

$\mathrm{R}$ indices (all data)

Extinction coefficient

Largest diff. peak and hole d17148_a

$\mathrm{C} 23 \mathrm{H} 22 \mathrm{Cl}$ N O Sn

482.55

150(2) K

$0.71073 \AA$

Triclinic

P-1

$\mathrm{a}=9.1303(4) \AA \quad \square=90.942(1)^{\circ}$.

$\mathrm{b}=9.3020(4) \AA$

$\square=91.775(1)^{\circ}$.

$\mathrm{c}=24.2461(11) \AA \quad \square=91.724(1)^{\circ}$.

2056.99(16) $\AA^{3}$

4

$1.558 \mathrm{Mg} / \mathrm{m}^{3}$

$1.384 \mathrm{~mm}^{-1}$

968

$0.250 \times 0.150 \times 0.030 \mathrm{~mm}^{3}$

0.840 to $27.599^{\circ}$.

$-11<=\mathrm{h}<=11,-12<=\mathrm{k}<=12,-31<=\mathrm{l}<=31$

66519

$9482[\mathrm{R}(\mathrm{int})=0.0237]$

$100.0 \%$

Semi-empirical from equivalents

0.7456 and 0.6724

Full-matrix least-squares on $\mathrm{F}^{2}$

9482 / 0 / 491

1.096

$\mathrm{R} 1=0.0205, \mathrm{wR} 2=0.0398$

$\mathrm{R} 1=0.0255, \mathrm{wR} 2=0.0413$

$\mathrm{n} / \mathrm{a}$

0.429 and -0.600 e. $\AA^{-3}$ 
Atomic coordinates ( x $\left.10^{4}\right)$ and equivalent isotropic displacement parameters $\left(\AA^{2} \times 10^{3}\right)$ for $\mathbf{1 1}$. $\mathrm{U}(\mathrm{eq})$ is defined as one third of the trace of the orthogonalized $\mathrm{Uij}^{\mathrm{ij}}$ tensor.

\begin{tabular}{|c|c|c|c|c|}
\hline & $\mathrm{X}$ & $\mathrm{y}$ & $\mathrm{z}$ & $\mathrm{U}(\mathrm{eq})$ \\
\hline \multicolumn{5}{|l|}{-} \\
\hline $\operatorname{Sn}(1 \mathrm{~A})$ & $7188(1)$ & $2414(1)$ & $3954(1)$ & $16(1)$ \\
\hline $\mathrm{Cl}(1 \mathrm{~A})$ & $4808(1)$ & $3539(1)$ & $4124(1)$ & $25(1)$ \\
\hline $\mathrm{O}(1 \mathrm{~A})$ & $11520(1)$ & $1080(2)$ & $4575(1)$ & $24(1)$ \\
\hline $\mathrm{N}(1 \mathrm{~A})$ & $9666(2)$ & $1430(2)$ & $3963(1)$ & $16(1)$ \\
\hline$C(1 \mathrm{~A})$ & $10233(2)$ & $1673(2)$ & $4447(1)$ & $17(1)$ \\
\hline $\mathrm{C}(2 \mathrm{~A})$ & $11838(2)$ & $155(2)$ & $4103(1)$ & $23(1)$ \\
\hline$C(3 \mathrm{~A})$ & $10746(2)$ & $609(2)$ & $3644(1)$ & $20(1)$ \\
\hline $\mathrm{C}(4 \mathrm{~A})$ & $11495(2)$ & $1640(2)$ & $3249(1)$ & $30(1)$ \\
\hline $\mathrm{C}(5 \mathrm{~A})$ & $9997(2)$ & $-665(2)$ & $3340(1)$ & $30(1)$ \\
\hline$C(6 A)$ & $9560(2)$ & $2570(2)$ & $4864(1)$ & $17(1)$ \\
\hline $\mathrm{C}(7 \mathrm{~A})$ & $10305(2)$ & $2980(2)$ & $5354(1)$ & $22(1)$ \\
\hline $\mathrm{C}(8 \mathrm{~A})$ & $9639(2)$ & $3890(2)$ & $5723(1)$ & $24(1)$ \\
\hline $\mathrm{C}(9 \mathrm{~A})$ & $8248(2)$ & $4371(2)$ & $5607(1)$ & $23(1)$ \\
\hline $\mathrm{C}(10 \mathrm{~A})$ & $7501(2)$ & $3957(2)$ & $5117(1)$ & $20(1)$ \\
\hline $\mathrm{C}(11 \mathrm{~A})$ & $8151(2)$ & $3059(2)$ & $4738(1)$ & $16(1)$ \\
\hline $\mathrm{C}(12 \mathrm{~A})$ & $7611(2)$ & $3616(2)$ & $3231(1)$ & $17(1)$ \\
\hline $\mathrm{C}(13 \mathrm{~A})$ & $7960(2)$ & $2955(2)$ & $2736(1)$ & $24(1)$ \\
\hline $\mathrm{C}(14 \mathrm{~A})$ & $8217(2)$ & $3756(2)$ & $2268(1)$ & $30(1)$ \\
\hline $\mathrm{C}(15 \mathrm{~A})$ & $8151(2)$ & $5240(2)$ & 2291(1) & $33(1)$ \\
\hline $\mathrm{C}(16 \mathrm{~A})$ & $7795(2)$ & $5921(2)$ & $2780(1)$ & $31(1)$ \\
\hline $\mathrm{C}(17 \mathrm{~A})$ & $7510(2)$ & $5118(2)$ & $3244(1)$ & $23(1)$ \\
\hline $\mathrm{C}(18 \mathrm{~A})$ & $6248(2)$ & $306(2)$ & $3848(1)$ & $18(1)$ \\
\hline $\mathrm{C}(19 \mathrm{~A})$ & $6237(2)$ & $-619(2)$ & $4292(1)$ & $27(1)$ \\
\hline$C(20 A)$ & $5548(2)$ & $-1971(2)$ & $4245(1)$ & $34(1)$ \\
\hline $\mathrm{C}(21 \mathrm{~A})$ & $4871(2)$ & $-2411(2)$ & $3751(1)$ & $32(1)$ \\
\hline$C(22 A)$ & $4866(2)$ & $-1505(2)$ & $3305(1)$ & $31(1)$ \\
\hline$C(23 A)$ & $5553(2)$ & $-146(2)$ & $3354(1)$ & $24(1)$ \\
\hline $\operatorname{Sn}(1 B)$ & $2362(1)$ & $7896(1)$ & 1101(1) & $16(1)$ \\
\hline $\mathrm{Cl}(1 \mathrm{~B})$ & $-182(1)$ & $6888(1)$ & $938(1)$ & $26(1)$ \\
\hline
\end{tabular}




\begin{tabular}{|c|c|c|c|c|}
\hline $\mathrm{O}(1 \mathrm{~B})$ & $6667(1)$ & $9152(2)$ & $477(1)$ & $25(1)$ \\
\hline $\mathrm{N}(1 \mathrm{~B})$ & $4906(2)$ & $8811(2)$ & 1096(1) & $17(1)$ \\
\hline $\mathrm{C}(1 \mathrm{~B})$ & $5385(2)$ & $8538(2)$ & $614(1)$ & $17(1)$ \\
\hline $\mathrm{C}(2 \mathrm{~B})$ & $7088(2)$ & $10139(2)$ & 931(1) & $24(1)$ \\
\hline$C(3 B)$ & $6043(2)$ & $9731(2)$ & 1398(1) & $21(1)$ \\
\hline $\mathrm{C}(4 \mathrm{~B})$ & $6815(2)$ & $8821(2)$ & $1829(1)$ & $31(1)$ \\
\hline$C(5 B)$ & $5355(2)$ & $11033(2)$ & 1661(1) & $30(1)$ \\
\hline$C(6 B)$ & $4608(2)$ & $7566(2)$ & $212(1)$ & $18(1)$ \\
\hline$C(7 B)$ & $5273(2)$ & $7106(2)$ & $-264(1)$ & $23(1)$ \\
\hline$C(8 B)$ & $4516(2)$ & $6140(2)$ & $-617(1)$ & $27(1)$ \\
\hline $\mathrm{C}(9 \mathrm{~B})$ & $3115(2)$ & $5655(2)$ & $-498(1)$ & $28(1)$ \\
\hline$C(10 B)$ & $2448(2)$ & $6129(2)$ & $-21(1)$ & $22(1)$ \\
\hline$C(11 B)$ & $3191(2)$ & $7091(2)$ & $343(1)$ & $17(1)$ \\
\hline$C(12 B)$ & $2769(2)$ & $6728(2)$ & $1837(1)$ & $17(1)$ \\
\hline$C(13 B)$ & $1709(2)$ & $6614(2)$ & $2237(1)$ & $25(1)$ \\
\hline$C(14 B)$ & $1923(2)$ & $5755(2)$ & $2695(1)$ & $31(1)$ \\
\hline$C(15 B)$ & $3186(2)$ & $4978(2)$ & $2752(1)$ & $29(1)$ \\
\hline$C(16 B)$ & $4236(2)$ & $5060(2)$ & $2354(1)$ & $26(1)$ \\
\hline$C(17 B)$ & $4035(2)$ & $5942(2)$ & 1903(1) & $21(1)$ \\
\hline$C(18 B)$ & $1660(2)$ & $10051(2)$ & $1130(1)$ & $18(1)$ \\
\hline$C(19 B)$ & $1266(2)$ & $10711(2)$ & $638(1)$ & $23(1)$ \\
\hline$C(20 B)$ & $861(2)$ & $12139(2)$ & $635(1)$ & $33(1)$ \\
\hline$C(21 B)$ & $860(2)$ & $12926(2)$ & $1124(1)$ & $40(1)$ \\
\hline$C(22 B)$ & $1242(3)$ & $12279(2)$ & $1615(1)$ & $40(1)$ \\
\hline$C(23 B)$ & $1624(2)$ & $10851(2)$ & 1619(1) & $31(1)$ \\
\hline
\end{tabular}


Bond lengths $[\AA]$ and angles $\left[{ }^{\circ}\right]$ for $\mathbf{1 1}$.

\begin{tabular}{|c|c|}
\hline $\operatorname{Sn}(1 \mathrm{~A})-\mathrm{C}(18 \mathrm{~A})$ & $2.1250(17)$ \\
\hline $\operatorname{Sn}(1 \mathrm{~A})-\mathrm{C}(12 \mathrm{~A})$ & $2.1322(16)$ \\
\hline $\operatorname{Sn}(1 \mathrm{~A})-\mathrm{C}(11 \mathrm{~A})$ & $2.1401(16)$ \\
\hline $\operatorname{Sn}(1 \mathrm{~A})-\mathrm{N}(1 \mathrm{~A})$ & $2.4658(14)$ \\
\hline $\operatorname{Sn}(1 \mathrm{~A})-\mathrm{Cl}(1 \mathrm{~A})$ & $2.4832(5)$ \\
\hline $\mathrm{O}(1 \mathrm{~A})-\mathrm{C}(1 \mathrm{~A})$ & $1.343(2)$ \\
\hline $\mathrm{O}(1 \mathrm{~A})-\mathrm{C}(2 \mathrm{~A})$ & $1.462(2)$ \\
\hline $\mathrm{N}(1 \mathrm{~A})-\mathrm{C}(1 \mathrm{~A})$ & $1.282(2)$ \\
\hline $\mathrm{N}(1 \mathrm{~A})-\mathrm{C}(3 \mathrm{~A})$ & $1.493(2)$ \\
\hline$C(1 A)-C(6 A)$ & $1.461(2)$ \\
\hline $\mathrm{C}(2 \mathrm{~A})-\mathrm{C}(3 \mathrm{~A})$ & $1.544(2)$ \\
\hline $\mathrm{C}(2 \mathrm{~A})-\mathrm{H}(2 \mathrm{AA})$ & 0.9900 \\
\hline $\mathrm{C}(2 \mathrm{~A})-\mathrm{H}(2 \mathrm{AB})$ & 0.9900 \\
\hline$C(3 A)-C(5 A)$ & $1.519(3)$ \\
\hline$C(3 A)-C(4 A)$ & $1.528(3)$ \\
\hline $\mathrm{C}(4 \mathrm{~A})-\mathrm{H}(4 \mathrm{AA})$ & 0.9800 \\
\hline $\mathrm{C}(4 \mathrm{~A})-\mathrm{H}(4 \mathrm{AB})$ & 0.9800 \\
\hline $\mathrm{C}(4 \mathrm{~A})-\mathrm{H}(4 \mathrm{AC})$ & 0.9800 \\
\hline $\mathrm{C}(5 \mathrm{~A})-\mathrm{H}(5 \mathrm{AA})$ & 0.9800 \\
\hline $\mathrm{C}(5 \mathrm{~A})-\mathrm{H}(5 \mathrm{AB})$ & 0.9800 \\
\hline $\mathrm{C}(5 \mathrm{~A})-\mathrm{H}(5 \mathrm{AC})$ & 0.9800 \\
\hline$C(6 A)-C(7 A)$ & $1.394(2)$ \\
\hline$C(6 A)-C(11 A)$ & $1.403(2)$ \\
\hline $\mathrm{C}(7 \mathrm{~A})-\mathrm{C}(8 \mathrm{~A})$ & $1.388(3)$ \\
\hline $\mathrm{C}(7 \mathrm{~A})-\mathrm{H}(7 \mathrm{AA})$ & 0.9500 \\
\hline $\mathrm{C}(8 \mathrm{~A})-\mathrm{C}(9 \mathrm{~A})$ & $1.381(3)$ \\
\hline $\mathrm{C}(8 \mathrm{~A})-\mathrm{H}(8 \mathrm{AA})$ & 0.9500 \\
\hline$C(9 A)-C(10 A)$ & $1.394(2)$ \\
\hline $\mathrm{C}(9 \mathrm{~A})-\mathrm{H}(9 \mathrm{AA})$ & 0.9500 \\
\hline$C(10 A)-C(11 A)$ & $1.390(2)$ \\
\hline $\mathrm{C}(10 \mathrm{~A})-\mathrm{H}(10 \mathrm{~A})$ & 0.9500 \\
\hline $\mathrm{C}(12 \mathrm{~A})-\mathrm{C}(13 \mathrm{~A})$ & $1.391(3)$ \\
\hline $\mathrm{C}(12 \mathrm{~A})-\mathrm{C}(17 \mathrm{~A})$ & $1.403(2)$ \\
\hline$C(13 A)-C(14 A)$ & $1.389(3)$ \\
\hline
\end{tabular}




\begin{tabular}{|c|c|}
\hline $\mathrm{C}(13 \mathrm{~A})-\mathrm{H}(13 \mathrm{~A})$ & 0.9500 \\
\hline$C(14 A)-C(15 A)$ & $1.383(3)$ \\
\hline $\mathrm{C}(14 \mathrm{~A})-\mathrm{H}(14 \mathrm{~A})$ & 0.9500 \\
\hline$C(15 A)-C(16 A)$ & $1.386(3)$ \\
\hline $\mathrm{C}(15 \mathrm{~A})-\mathrm{H}(15 \mathrm{~A})$ & 0.9500 \\
\hline$C(16 A)-C(17 A)$ & $1.389(3)$ \\
\hline $\mathrm{C}(16 \mathrm{~A})-\mathrm{H}(16 \mathrm{~A})$ & 0.9500 \\
\hline $\mathrm{C}(17 \mathrm{~A})-\mathrm{H}(17 \mathrm{~A})$ & 0.9500 \\
\hline $\mathrm{C}(18 \mathrm{~A})-\mathrm{C}(19 \mathrm{~A})$ & $1.390(3)$ \\
\hline $\mathrm{C}(18 \mathrm{~A})-\mathrm{C}(23 \mathrm{~A})$ & $1.391(2)$ \\
\hline$C(19 A)-C(20 A)$ & $1.391(3)$ \\
\hline C(19A)-H(19A) & 0.9500 \\
\hline$C(20 A)-C(21 A)$ & $1.382(3)$ \\
\hline $\mathrm{C}(20 \mathrm{~A})-\mathrm{H}(20 \mathrm{~A})$ & 0.9500 \\
\hline$C(21 A)-C(22 A)$ & $1.380(3)$ \\
\hline $\mathrm{C}(21 \mathrm{~A})-\mathrm{H}(21 \mathrm{~A})$ & 0.9500 \\
\hline $\mathrm{C}(22 \mathrm{~A})-\mathrm{C}(23 \mathrm{~A})$ & $1.396(3)$ \\
\hline $\mathrm{C}(22 \mathrm{~A})-\mathrm{H}(22 \mathrm{~A})$ & 0.9500 \\
\hline $\mathrm{C}(23 \mathrm{~A})-\mathrm{H}(23 \mathrm{~A})$ & 0.9500 \\
\hline $\operatorname{Sn}(1 \mathrm{~B})-\mathrm{C}(18 \mathrm{~B})$ & $2.1232(17)$ \\
\hline $\operatorname{Sn}(1 B)-C(12 B)$ & $2.1330(17)$ \\
\hline $\operatorname{Sn}(1 B)-C(11 B)$ & $2.1422(17)$ \\
\hline $\operatorname{Sn}(1 \mathrm{~B})-\mathrm{N}(1 \mathrm{~B})$ & $2.4502(14)$ \\
\hline $\operatorname{Sn}(1 \mathrm{~B})-\mathrm{Cl}(1 \mathrm{~B})$ & $2.4955(5)$ \\
\hline $\mathrm{O}(1 \mathrm{~B})-\mathrm{C}(1 \mathrm{~B})$ & $1.340(2)$ \\
\hline $\mathrm{O}(1 \mathrm{~B})-\mathrm{C}(2 \mathrm{~B})$ & $1.457(2)$ \\
\hline $\mathrm{N}(1 \mathrm{~B})-\mathrm{C}(1 \mathrm{~B})$ & $1.285(2)$ \\
\hline $\mathrm{N}(1 \mathrm{~B})-\mathrm{C}(3 \mathrm{~B})$ & $1.492(2)$ \\
\hline $\mathrm{C}(1 \mathrm{~B})-\mathrm{C}(6 \mathrm{~B})$ & $1.469(2)$ \\
\hline $\mathrm{C}(2 \mathrm{~B})-\mathrm{C}(3 \mathrm{~B})$ & $1.547(2)$ \\
\hline $\mathrm{C}(2 \mathrm{~B})-\mathrm{H}(2 \mathrm{BA})$ & 0.9900 \\
\hline $\mathrm{C}(2 \mathrm{~B})-\mathrm{H}(2 \mathrm{BB})$ & 0.9900 \\
\hline $\mathrm{C}(3 \mathrm{~B})-\mathrm{C}(5 \mathrm{~B})$ & $1.522(3)$ \\
\hline $\mathrm{C}(3 \mathrm{~B})-\mathrm{C}(4 \mathrm{~B})$ & $1.526(3)$ \\
\hline $\mathrm{C}(4 \mathrm{~B})-\mathrm{H}(4 \mathrm{BA})$ & 0.9800 \\
\hline $\mathrm{C}(4 \mathrm{~B})-\mathrm{H}(4 \mathrm{BB})$ & 0.9800 \\
\hline
\end{tabular}




\begin{tabular}{|c|c|}
\hline $\mathrm{C}(4 \mathrm{~B})-\mathrm{H}(4 \mathrm{BC})$ & 0.9800 \\
\hline $\mathrm{C}(5 \mathrm{~B})-\mathrm{H}(5 \mathrm{BA})$ & 0.9800 \\
\hline $\mathrm{C}(5 \mathrm{~B})-\mathrm{H}(5 \mathrm{BB})$ & 0.9800 \\
\hline $\mathrm{C}(5 \mathrm{~B})-\mathrm{H}(5 \mathrm{BC})$ & 0.9800 \\
\hline $\mathrm{C}(6 \mathrm{~B})-\mathrm{C}(7 \mathrm{~B})$ & $1.389(2)$ \\
\hline$C(6 B)-C(11 B)$ & $1.402(2)$ \\
\hline $\mathrm{C}(7 \mathrm{~B})-\mathrm{C}(8 \mathrm{~B})$ & $1.386(3)$ \\
\hline $\mathrm{C}(7 \mathrm{~B})-\mathrm{H}(7 \mathrm{BA})$ & 0.9500 \\
\hline $\mathrm{C}(8 \mathrm{~B})-\mathrm{C}(9 \mathrm{~B})$ & $1.385(3)$ \\
\hline $\mathrm{C}(8 \mathrm{~B})-\mathrm{H}(8 \mathrm{BA})$ & 0.9500 \\
\hline $\mathrm{C}(9 \mathrm{~B})-\mathrm{C}(10 \mathrm{~B})$ & $1.396(3)$ \\
\hline $\mathrm{C}(9 \mathrm{~B})-\mathrm{H}(9 \mathrm{BA})$ & 0.9500 \\
\hline$C(10 B)-C(11 B)$ & $1.392(2)$ \\
\hline $\mathrm{C}(10 \mathrm{~B})-\mathrm{H}(10 \mathrm{~B})$ & 0.9500 \\
\hline$C(12 B)-C(17 B)$ & $1.392(2)$ \\
\hline $\mathrm{C}(12 \mathrm{~B})-\mathrm{C}(13 \mathrm{~B})$ & $1.395(2)$ \\
\hline $\mathrm{C}(13 \mathrm{~B})-\mathrm{C}(14 \mathrm{~B})$ & $1.390(3)$ \\
\hline $\mathrm{C}(13 \mathrm{~B})-\mathrm{H}(13 \mathrm{~B})$ & 0.9500 \\
\hline$C(14 B)-C(15 B)$ & $1.383(3)$ \\
\hline $\mathrm{C}(14 \mathrm{~B})-\mathrm{H}(14 \mathrm{~B})$ & 0.9500 \\
\hline$C(15 B)-C(16 B)$ & $1.383(3)$ \\
\hline $\mathrm{C}(15 \mathrm{~B})-\mathrm{H}(15 \mathrm{~B})$ & 0.9500 \\
\hline$C(16 B)-C(17 B)$ & $1.389(3)$ \\
\hline $\mathrm{C}(16 \mathrm{~B})-\mathrm{H}(16 \mathrm{~B})$ & 0.9500 \\
\hline $\mathrm{C}(17 \mathrm{~B})-\mathrm{H}(17 \mathrm{~B})$ & 0.9500 \\
\hline$C(18 B)-C(23 B)$ & $1.391(3)$ \\
\hline$C(18 B)-C(19 B)$ & $1.391(2)$ \\
\hline$C(19 B)-C(20 B)$ & $1.389(3)$ \\
\hline C(19B)-H(19B) & 0.9500 \\
\hline$C(20 B)-C(21 B)$ & $1.382(3)$ \\
\hline $\mathrm{C}(20 \mathrm{~B})-\mathrm{H}(20 \mathrm{~B})$ & 0.9500 \\
\hline$C(21 B)-C(22 B)$ & $1.383(3)$ \\
\hline $\mathrm{C}(21 \mathrm{~B})-\mathrm{H}(21 \mathrm{~B})$ & 0.9500 \\
\hline $\mathrm{C}(22 \mathrm{~B})-\mathrm{C}(23 \mathrm{~B})$ & $1.383(3)$ \\
\hline $\mathrm{C}(22 \mathrm{~B})-\mathrm{H}(22 \mathrm{~B})$ & 0.9500 \\
\hline $\mathrm{C}(23 \mathrm{~B})-\mathrm{H}(23 \mathrm{~B})$ & 0.9500 \\
\hline
\end{tabular}




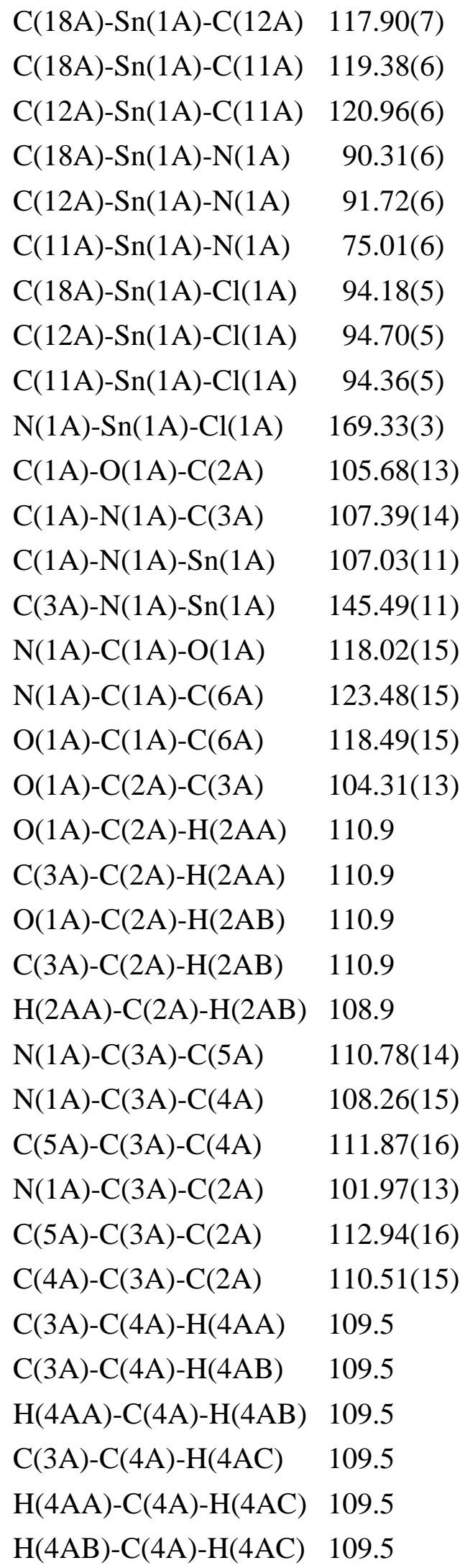




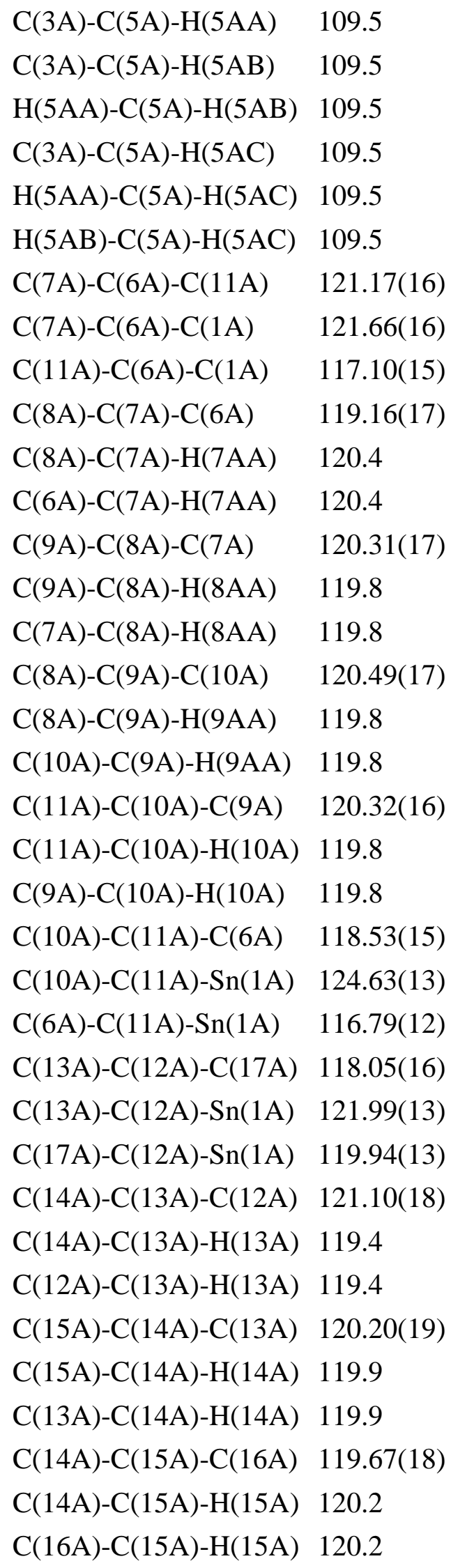




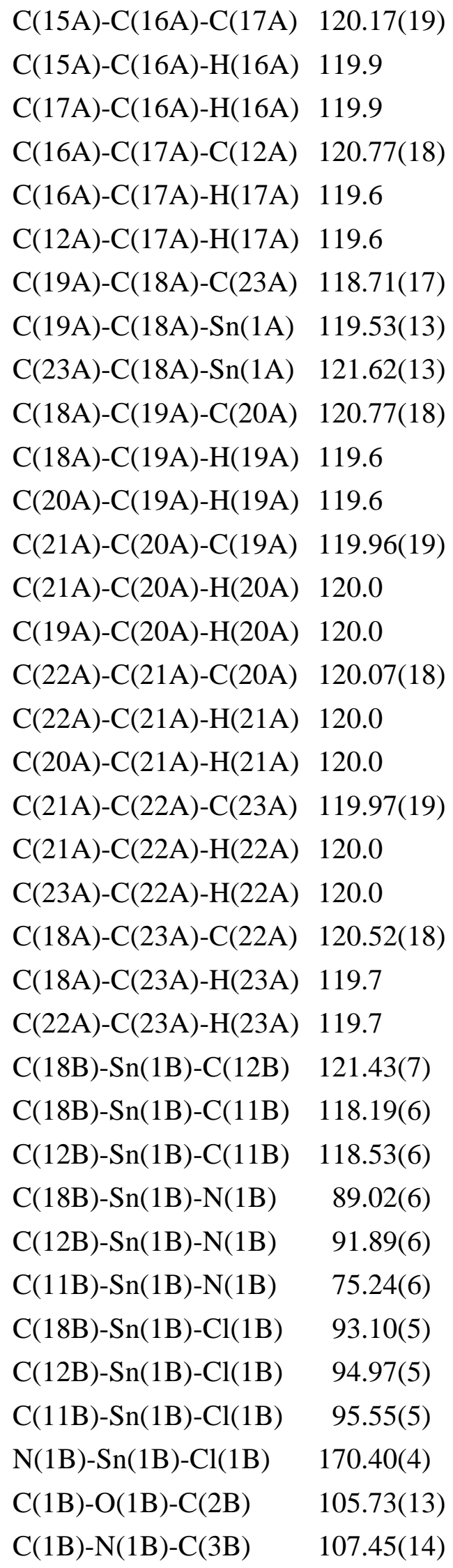




\begin{tabular}{|c|c|}
\hline $\mathrm{C}(1 \mathrm{~B})-\mathrm{N}(1 \mathrm{~B})-\mathrm{Sn}(1 \mathrm{~B})$ & $107.06(11)$ \\
\hline $\mathrm{C}(3 \mathrm{~B})-\mathrm{N}(1 \mathrm{~B})-\mathrm{Sn}(1 \mathrm{~B})$ & $144.67(11)$ \\
\hline $\mathrm{N}(1 \mathrm{~B})-\mathrm{C}(1 \mathrm{~B})-\mathrm{O}(1 \mathrm{~B})$ & $118.17(15)$ \\
\hline $\mathrm{N}(1 \mathrm{~B})-\mathrm{C}(1 \mathrm{~B})-\mathrm{C}(6 \mathrm{~B})$ & $123.05(15)$ \\
\hline $\mathrm{O}(1 \mathrm{~B})-\mathrm{C}(1 \mathrm{~B})-\mathrm{C}(6 \mathrm{~B})$ & $118.76(15)$ \\
\hline $\mathrm{O}(1 \mathrm{~B})-\mathrm{C}(2 \mathrm{~B})-\mathrm{C}(3 \mathrm{~B})$ & $104.63(14)$ \\
\hline $\mathrm{O}(1 \mathrm{~B})-\mathrm{C}(2 \mathrm{~B})-\mathrm{H}(2 \mathrm{BA})$ & \\
\hline $\mathrm{C}(3 \mathrm{~B})-\mathrm{C}(2 \mathrm{~B})-\mathrm{H}(2 \mathrm{BA})$ & \\
\hline $\mathrm{O}(1 \mathrm{~B})-\mathrm{C}(2 \mathrm{~B})-\mathrm{H}(2 \mathrm{BB})$ & \\
\hline $\mathrm{C}(3 \mathrm{~B})-\mathrm{C}(2 \mathrm{~B})-\mathrm{H}(2 \mathrm{BB})$ & \\
\hline $\mathrm{H}(2 \mathrm{BA})-\mathrm{C}(2 \mathrm{~B})-\mathrm{H}(2 \mathrm{BB})$ & 108.9 \\
\hline $\mathrm{N}(1 \mathrm{~B})-\mathrm{C}(3 \mathrm{~B})-\mathrm{C}(5 \mathrm{~B})$ & $110.63(15)$ \\
\hline$N(1 B)-C(3 B)-C(4 B)$ & $108.65(15)$ \\
\hline $\mathrm{C}(5 \mathrm{~B})-\mathrm{C}(3 \mathrm{~B})-\mathrm{C}(4 \mathrm{~B})$ & $6(16)$ \\
\hline $\mathrm{N}(1 \mathrm{~B})-\mathrm{C}(3 \mathrm{~B})-\mathrm{C}(2 \mathrm{~B})$ & $101.91(13)$ \\
\hline $\mathrm{C}(5 \mathrm{~B})-\mathrm{C}(3 \mathrm{~B})-\mathrm{C}(2 \mathrm{~B})$ & \\
\hline $\mathrm{C}(4 \mathrm{~B})-\mathrm{C}(3 \mathrm{~B})-\mathrm{C}(2 \mathrm{~B})$ & $111.01(16)$ \\
\hline $\mathrm{C}(3 \mathrm{~B})-\mathrm{C}(4 \mathrm{~B})-\mathrm{H}(4 \mathrm{BA})$ & \\
\hline $\mathrm{C}(3 \mathrm{~B})-\mathrm{C}(4 \mathrm{~B})-\mathrm{H}(4 \mathrm{BB})$ & \\
\hline $\mathrm{H}(4 \mathrm{BA})-\mathrm{C}(4 \mathrm{~B})-\mathrm{H}(4 \mathrm{BB})$ & \\
\hline $\mathrm{C}(3 \mathrm{~B})-\mathrm{C}(4 \mathrm{~B})-\mathrm{H}(4 \mathrm{BC})$ & 109.5 \\
\hline $\mathrm{H}(4 \mathrm{BA})-\mathrm{C}(4 \mathrm{~B})-\mathrm{H}(4 \mathrm{BC})$ & 109.5 \\
\hline $\mathrm{H}(4 \mathrm{BB})-\mathrm{C}(4 \mathrm{~B})-\mathrm{H}(4 \mathrm{BC})$ & 109.5 \\
\hline $\mathrm{C}(3 \mathrm{~B})-\mathrm{C}(5 \mathrm{~B})-\mathrm{H}(5 \mathrm{BA})$ & 109.5 \\
\hline $\mathrm{C}(3 \mathrm{~B})-\mathrm{C}(5 \mathrm{~B})-\mathrm{H}(5 \mathrm{BB})$ & 109.5 \\
\hline $\mathrm{H}(5 \mathrm{BA})-\mathrm{C}(5 \mathrm{~B})-\mathrm{H}(5 \mathrm{BB})$ & 109.5 \\
\hline $\mathrm{C}(3 \mathrm{~B})-\mathrm{C}(5 \mathrm{~B})-\mathrm{H}(5 \mathrm{BC})$ & 109.5 \\
\hline $\mathrm{H}(5 \mathrm{BA})-\mathrm{C}(5 \mathrm{~B})-\mathrm{H}(5 \mathrm{BC})$ & 109.5 \\
\hline $\mathrm{H}(5 \mathrm{BB})-\mathrm{C}(5 \mathrm{~B})-\mathrm{H}(5 \mathrm{BC})$ & 109.5 \\
\hline$C(7 B)-C(6 B)-C(11 B)$ & $121.93(16)$ \\
\hline$C(7 B)-C(6 B)-C(1 B)$ & 121.19(16) \\
\hline$C(11 B)-C(6 B)-C(1 B)$ & $116.85(15)$ \\
\hline $\mathrm{C}(8 \mathrm{~B})-\mathrm{C}(7 \mathrm{~B})-\mathrm{C}(6 \mathrm{~B})$ & $118.92(17)$ \\
\hline $\mathrm{C}(8 \mathrm{~B})-\mathrm{C}(7 \mathrm{~B})-\mathrm{H}(7 \mathrm{BA})$ & 120.5 \\
\hline $\mathrm{C}(6 \mathrm{~B})-\mathrm{C}(7 \mathrm{~B})-\mathrm{H}(7 \mathrm{BA})$ & 120.5 \\
\hline $\mathrm{C}(9 \mathrm{~B})-\mathrm{C}(8 \mathrm{~B})-\mathrm{C}(7 \mathrm{~B})$ & $120.30(17)$ \\
\hline
\end{tabular}




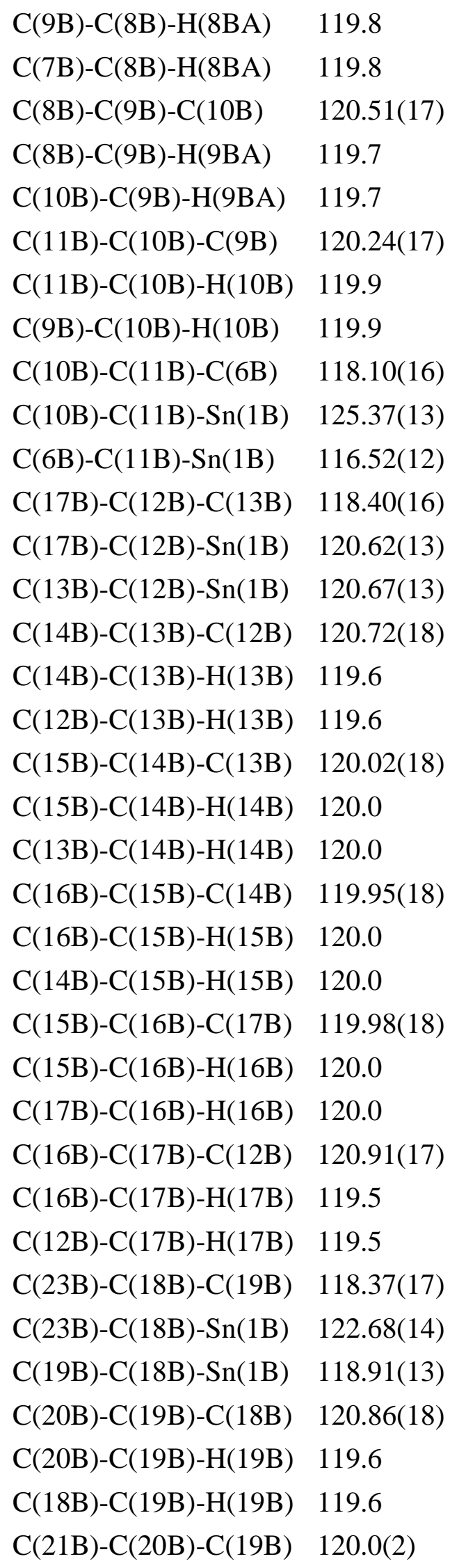




$\begin{array}{ll}\mathrm{C}(21 \mathrm{~B})-\mathrm{C}(20 \mathrm{~B})-\mathrm{H}(20 \mathrm{~B}) & 120.0 \\ \mathrm{C}(19 \mathrm{~B})-\mathrm{C}(20 \mathrm{~B})-\mathrm{H}(20 \mathrm{~B}) & 120.0 \\ \mathrm{C}(20 \mathrm{~B})-\mathrm{C}(21 \mathrm{~B})-\mathrm{C}(22 \mathrm{~B}) & 119.7(2) \\ \mathrm{C}(20 \mathrm{~B})-\mathrm{C}(21 \mathrm{~B})-\mathrm{H}(21 \mathrm{~B}) & 120.2 \\ \mathrm{C}(22 \mathrm{~B})-\mathrm{C}(21 \mathrm{~B})-\mathrm{H}(21 \mathrm{~B}) & 120.2 \\ \mathrm{C}(23 \mathrm{~B})-\mathrm{C}(22 \mathrm{~B})-\mathrm{C}(21 \mathrm{~B}) & 120.3(2) \\ \mathrm{C}(23 \mathrm{~B})-\mathrm{C}(22 \mathrm{~B})-\mathrm{H}(22 \mathrm{~B}) & 119.9 \\ \mathrm{C}(21 \mathrm{~B})-\mathrm{C}(22 \mathrm{~B})-\mathrm{H}(22 \mathrm{~B}) & 119.9 \\ \mathrm{C}(22 \mathrm{~B})-\mathrm{C}(23 \mathrm{~B})-\mathrm{C}(18 \mathrm{~B}) & 120.8(2) \\ \mathrm{C}(22 \mathrm{~B})-\mathrm{C}(23 \mathrm{~B})-\mathrm{H}(23 \mathrm{~B}) & 119.6 \\ \mathrm{C}(18 \mathrm{~B})-\mathrm{C}(23 \mathrm{~B})-\mathrm{H}(23 \mathrm{~B}) & 119.6\end{array}$

Symmetry transformations used to generate equivalent atoms: 
Anisotropic displacement parameters $\left(\AA^{2} \times 10^{3}\right)$ for 11. The anisotropic displacement factor exponent takes the form: $-2 \square^{2}\left[h^{2} a^{* 2} U^{11}+\ldots+2 h k a^{*} b^{*} U^{12}\right]$

\begin{tabular}{|c|c|c|c|c|c|c|}
\hline & U11 & $\mathrm{U}^{22}$ & $\mathrm{U}^{33}$ & $\mathrm{U}^{23}$ & $\mathrm{U}^{13}$ & $\mathrm{U}^{12}$ \\
\hline $\operatorname{Sn}(1 \mathrm{~A})$ & $16(1)$ & $16(1)$ & $14(1)$ & $1(1)$ & $-2(1)$ & $0(1)$ \\
\hline $\mathrm{Cl}(1 \mathrm{~A})$ & $20(1)$ & $30(1)$ & $27(1)$ & $-1(1)$ & $-2(1)$ & $8(1)$ \\
\hline $\mathrm{O}(1 \mathrm{~A})$ & $19(1)$ & $36(1)$ & $19(1)$ & $-2(1)$ & $-2(1)$ & $10(1)$ \\
\hline $\mathrm{N}(1 \mathrm{~A})$ & $14(1)$ & $17(1)$ & $17(1)$ & $1(1)$ & 1(1) & $0(1)$ \\
\hline$C(1 \mathrm{~A})$ & $13(1)$ & $20(1)$ & $18(1)$ & $5(1)$ & $1(1)$ & $-1(1)$ \\
\hline$C(2 A)$ & $21(1)$ & $29(1)$ & $20(1)$ & $-1(1)$ & $2(1)$ & $9(1)$ \\
\hline$C(3 A)$ & $18(1)$ & $23(1)$ & $19(1)$ & $0(1)$ & $3(1)$ & $5(1)$ \\
\hline$C(4 A)$ & $25(1)$ & $43(1)$ & $23(1)$ & $9(1)$ & $5(1)$ & $2(1)$ \\
\hline$C(5 A)$ & $34(1)$ & $26(1)$ & $29(1)$ & $-8(1)$ & $-5(1)$ & $8(1)$ \\
\hline$C(6 A)$ & $17(1)$ & $19(1)$ & $15(1)$ & $3(1)$ & $2(1)$ & $-2(1)$ \\
\hline$C(7 A)$ & $18(1)$ & $29(1)$ & $18(1)$ & $2(1)$ & $-2(1)$ & $-1(1)$ \\
\hline $\mathrm{C}(8 \mathrm{~A})$ & $24(1)$ & $30(1)$ & $18(1)$ & $-3(1)$ & $-3(1)$ & $-6(1)$ \\
\hline $\mathrm{C}(9 \mathrm{~A})$ & $26(1)$ & $23(1)$ & $21(1)$ & $-5(1)$ & $3(1)$ & $-1(1)$ \\
\hline $\mathrm{C}(10 \mathrm{~A})$ & $18(1)$ & $21(1)$ & $20(1)$ & $0(1)$ & $1(1)$ & $1(1)$ \\
\hline $\mathrm{C}(11 \mathrm{~A})$ & $18(1)$ & $16(1)$ & $14(1)$ & $2(1)$ & $0(1)$ & $-3(1)$ \\
\hline $\mathrm{C}(12 \mathrm{~A})$ & $15(1)$ & $19(1)$ & $15(1)$ & $4(1)$ & $-4(1)$ & $-2(1)$ \\
\hline$C(13 A)$ & $21(1)$ & $27(1)$ & $24(1)$ & $2(1)$ & $-1(1)$ & $2(1)$ \\
\hline $\mathrm{C}(14 \mathrm{~A})$ & $21(1)$ & $48(1)$ & $22(1)$ & $4(1)$ & $2(1)$ & $2(1)$ \\
\hline$C(15 A)$ & $22(1)$ & $45(1)$ & $31(1)$ & $20(1)$ & $-2(1)$ & $-6(1)$ \\
\hline$C(16 A)$ & $27(1)$ & $25(1)$ & $39(1)$ & $13(1)$ & $-9(1)$ & $-5(1)$ \\
\hline $\mathrm{C}(17 \mathrm{~A})$ & $20(1)$ & $23(1)$ & $26(1)$ & $2(1)$ & $-6(1)$ & $0(1)$ \\
\hline $\mathrm{C}(18 \mathrm{~A})$ & $13(1)$ & $17(1)$ & $22(1)$ & $0(1)$ & $1(1)$ & $1(1)$ \\
\hline$C(19 A)$ & $24(1)$ & $28(1)$ & $28(1)$ & $6(1)$ & $-7(1)$ & $-2(1)$ \\
\hline$C(20 A)$ & $31(1)$ & $26(1)$ & $45(1)$ & $16(1)$ & $-1(1)$ & $-2(1)$ \\
\hline$C(21 A)$ & $28(1)$ & $19(1)$ & $50(1)$ & $-4(1)$ & $8(1)$ & $-4(1)$ \\
\hline $\mathrm{C}(22 \mathrm{~A})$ & $32(1)$ & $31(1)$ & $30(1)$ & $-13(1)$ & $5(1)$ & $-9(1)$ \\
\hline$C(23 A)$ & $26(1)$ & $26(1)$ & $18(1)$ & $-1(1)$ & $4(1)$ & $-4(1)$ \\
\hline $\operatorname{Sn}(1 B)$ & $17(1)$ & $16(1)$ & $16(1)$ & $2(1)$ & $2(1)$ & $2(1)$ \\
\hline $\mathrm{Cl}(1 \mathrm{~B})$ & $17(1)$ & $28(1)$ & $32(1)$ & $4(1)$ & $0(1)$ & $-3(1)$ \\
\hline $\mathrm{O}(1 \mathrm{~B})$ & $20(1)$ & $32(1)$ & $22(1)$ & $-2(1)$ & $5(1)$ & $-6(1)$ \\
\hline $\mathrm{N}(1 \mathrm{~B})$ & $17(1)$ & $17(1)$ & $18(1)$ & $1(1)$ & $0(1)$ & $-1(1)$ \\
\hline & & & & 102 & & \\
\hline
\end{tabular}




\begin{tabular}{|c|c|c|c|c|c|c|}
\hline$C(1 B)$ & $16(1)$ & $17(1)$ & $18(1)$ & $4(1)$ & $0(1)$ & $2(1)$ \\
\hline $\mathrm{C}(2 \mathrm{~B})$ & $22(1)$ & $26(1)$ & $25(1)$ & $-1(1)$ & $-1(1)$ & $-5(1)$ \\
\hline $\mathrm{C}(3 \mathrm{~B})$ & $21(1)$ & $23(1)$ & $19(1)$ & $1(1)$ & $-2(1)$ & $-4(1)$ \\
\hline $\mathrm{C}(4 \mathrm{~B})$ & $32(1)$ & $36(1)$ & $24(1)$ & $6(1)$ & $-7(1)$ & $-3(1)$ \\
\hline$C(5 B)$ & $33(1)$ & $26(1)$ & $30(1)$ & $-5(1)$ & $2(1)$ & $-4(1)$ \\
\hline $\mathrm{C}(6 \mathrm{~B})$ & $21(1)$ & $17(1)$ & $16(1)$ & $2(1)$ & $1(1)$ & $3(1)$ \\
\hline $\mathrm{C}(7 \mathrm{~B})$ & $24(1)$ & $24(1)$ & $21(1)$ & $0(1)$ & $4(1)$ & $3(1)$ \\
\hline $\mathrm{C}(8 \mathrm{~B})$ & $38(1)$ & $24(1)$ & $21(1)$ & $-4(1)$ & $5(1)$ & $6(1)$ \\
\hline $\mathrm{C}(9 \mathrm{~B})$ & $37(1)$ & $21(1)$ & $24(1)$ & $-6(1)$ & $-5(1)$ & $1(1)$ \\
\hline$C(10 B)$ & $23(1)$ & $18(1)$ & $24(1)$ & $0(1)$ & $-2(1)$ & $2(1)$ \\
\hline $\mathrm{C}(11 \mathrm{~B})$ & $20(1)$ & $15(1)$ & $16(1)$ & $2(1)$ & $-1(1)$ & $4(1)$ \\
\hline $\mathrm{C}(12 \mathrm{~B})$ & $18(1)$ & $17(1)$ & $15(1)$ & $2(1)$ & $-1(1)$ & $-2(1)$ \\
\hline$C(13 B)$ & $21(1)$ & $29(1)$ & $25(1)$ & $3(1)$ & $4(1)$ & $2(1)$ \\
\hline $\mathrm{C}(14 \mathrm{~B})$ & $30(1)$ & $40(1)$ & $23(1)$ & $7(1)$ & $4(1)$ & $-6(1)$ \\
\hline$C(15 B)$ & $35(1)$ & $27(1)$ & $24(1)$ & $9(1)$ & $-8(1)$ & $-9(1)$ \\
\hline$C(16 B)$ & $24(1)$ & $20(1)$ & $33(1)$ & $4(1)$ & $-8(1)$ & $-1(1)$ \\
\hline$C(17 B)$ & $20(1)$ & $19(1)$ & $23(1)$ & $-1(1)$ & $1(1)$ & $0(1)$ \\
\hline $\mathrm{C}(18 \mathrm{~B})$ & $14(1)$ & $18(1)$ & $22(1)$ & $1(1)$ & $3(1)$ & $2(1)$ \\
\hline$C(19 B)$ & $22(1)$ & $28(1)$ & $21(1)$ & $5(1)$ & $5(1)$ & $3(1)$ \\
\hline$C(20 B)$ & $27(1)$ & $32(1)$ & $42(1)$ & $19(1)$ & $8(1)$ & $8(1)$ \\
\hline$C(21 B)$ & $34(1)$ & 21(1) & $66(2)$ & $2(1)$ & 11(1) & $10(1)$ \\
\hline $\mathrm{C}(22 \mathrm{~B})$ & $40(1)$ & $36(1)$ & $46(1)$ & $-18(1)$ & $0(1)$ & $14(1)$ \\
\hline$C(23 B)$ & $34(1)$ & $33(1)$ & $25(1)$ & $-4(1)$ & $-1(1)$ & $13(1)$ \\
\hline
\end{tabular}


Hydrogen coordinates $\left(\times 10^{4}\right)$ and isotropic displacement parameters $\left(\AA^{2} \times 10^{3}\right)$ for $\mathbf{1 1}$.

\begin{tabular}{|c|c|c|c|c|}
\hline- & $\mathrm{x}$ & $\mathrm{y}$ & $\mathrm{z}$ & $\mathrm{U}(\mathrm{eq})$ \\
\hline \multicolumn{5}{|l|}{-} \\
\hline $\mathrm{H}(2 \mathrm{AA})$ & 11681 & -872 & 4192 & 28 \\
\hline $\mathrm{H}(2 \mathrm{AB})$ & 12862 & 313 & 3990 & 28 \\
\hline $\mathrm{H}(4 \mathrm{AA})$ & 10759 & 2031 & 2995 & 45 \\
\hline $\mathrm{H}(4 \mathrm{AB})$ & 12217 & 1121 & 3038 & 45 \\
\hline $\mathrm{H}(4 \mathrm{AC})$ & 11990 & 2429 & 3461 & 45 \\
\hline $\mathrm{H}(5 \mathrm{AA})$ & 9319 & -316 & 3054 & 45 \\
\hline $\mathrm{H}(5 \mathrm{AB})$ & 9451 & -1250 & 3601 & 45 \\
\hline $\mathrm{H}(5 \mathrm{AC})$ & 10738 & -1251 & 3167 & 45 \\
\hline $\mathrm{H}(7 \mathrm{AA})$ & 11257 & 2640 & 5435 & 26 \\
\hline $\mathrm{H}(8 \mathrm{AA})$ & 10142 & 4184 & 6057 & 29 \\
\hline $\mathrm{H}(9 \mathrm{AA})$ & 7797 & 4989 & 5863 & 28 \\
\hline $\mathrm{H}(10 \mathrm{~A})$ & 6543 & 4291 & 5042 & 23 \\
\hline $\mathrm{H}(13 \mathrm{~A})$ & 8025 & 1938 & 2717 & 29 \\
\hline $\mathrm{H}(14 \mathrm{~A})$ & 8438 & 3284 & 1932 & 36 \\
\hline $\mathrm{H}(15 \mathrm{~A})$ & 8350 & 5789 & 1974 & 39 \\
\hline $\mathrm{H}(16 \mathrm{~A})$ & 7746 & 6939 & 2796 & 37 \\
\hline $\mathrm{H}(17 \mathrm{~A})$ & 7242 & 5592 & 3575 & 28 \\
\hline $\mathrm{H}(19 \mathrm{~A})$ & 6705 & -323 & 4633 & 32 \\
\hline $\mathrm{H}(20 \mathrm{~A})$ & 5544 & -2592 & 4552 & 41 \\
\hline $\mathrm{H}(21 \mathrm{~A})$ & 4408 & -3338 & 3717 & 39 \\
\hline $\mathrm{H}(22 \mathrm{~A})$ & 4395 & -1806 & 2966 & 37 \\
\hline $\mathrm{H}(23 \mathrm{~A})$ & 5546 & 475 & 3046 & 28 \\
\hline $\mathrm{H}(2 \mathrm{BA})$ & 6962 & 11150 & 821 & 29 \\
\hline $\mathrm{H}(2 \mathrm{BB})$ & 8123 & 10016 & 1050 & 29 \\
\hline $\mathrm{H}(4 \mathrm{BA})$ & 6099 & 8462 & 2091 & 46 \\
\hline $\mathrm{H}(4 \mathrm{BB})$ & 7574 & 9411 & 2028 & 46 \\
\hline $\mathrm{H}(4 \mathrm{BC})$ & 7267 & 8006 & 1647 & 46 \\
\hline $\mathrm{H}(5 \mathrm{BA})$ & 4736 & 10719 & 1962 & 45 \\
\hline $\mathrm{H}(5 \mathrm{BB})$ & 4756 & 11521 & 1384 & 45 \\
\hline
\end{tabular}




\begin{tabular}{lrrrr}
$\mathrm{H}(5 \mathrm{BC})$ & 6130 & 11698 & 1808 & 45 \\
$\mathrm{H}(7 \mathrm{BA})$ & 6231 & 7449 & -346 & 27 \\
$\mathrm{H}(8 \mathrm{BA})$ & 4961 & 5808 & -943 & 33 \\
$\mathrm{H}(9 \mathrm{BA})$ & 2603 & 4994 & -743 & 33 \\
$\mathrm{H}(10 \mathrm{~B})$ & 1483 & 5795 & 56 & 26 \\
$\mathrm{H}(13 \mathrm{~B})$ & 830 & 7129 & 2197 & 30 \\
$\mathrm{H}(14 \mathrm{~B})$ & 1202 & 5701 & 2968 & 37 \\
$\mathrm{H}(15 \mathrm{~B})$ & 3331 & 4389 & 3064 & 35 \\
$\mathrm{H}(16 \mathrm{~B})$ & 5095 & 4513 & 2389 & 31 \\
$\mathrm{H}(17 \mathrm{~B})$ & 4772 & 6011 & 1635 & 25 \\
$\mathrm{H}(19 \mathrm{~B})$ & 1273 & 10178 & 301 & 28 \\
$\mathrm{H}(20 \mathrm{~B})$ & 586 & 12574 & 297 & 40 \\
$\mathrm{H}(21 \mathrm{~B})$ & 597 & 13906 & 1122 & 48 \\
$\mathrm{H}(22 \mathrm{~B})$ & 1244 & 12818 & 1951 & 49 \\
$\mathrm{H}(23 \mathrm{~B})$ & 1863 & 10412 & 1959 & 37 \\
& & & & \\
\hline
\end{tabular}


Torsion angles $\left[^{\circ}\right]$ for $\mathbf{1 1}$.

\begin{tabular}{|c|c|}
\hline $\mathrm{C}(3 \mathrm{~A})-\mathrm{N}(1 \mathrm{~A})-\mathrm{C}(1 \mathrm{~A})-\mathrm{O}(1 \mathrm{~A})$ & $-5.4(2)$ \\
\hline $\operatorname{Sn}(1 \mathrm{~A})-\mathrm{N}(1 \mathrm{~A})-\mathrm{C}(1 \mathrm{~A})-\mathrm{O}(1 \mathrm{~A})$ & $172.06(12)$ \\
\hline$C(3 A)-N(1 A)-C(1 A)-C(6 A)$ & $174.04(15)$ \\
\hline $\operatorname{Sn}(1 \mathrm{~A})-\mathrm{N}(1 \mathrm{~A})-\mathrm{C}(1 \mathrm{~A})-\mathrm{C}(6 \mathrm{~A})$ & $-8.55(19)$ \\
\hline $\mathrm{C}(2 \mathrm{~A})-\mathrm{O}(1 \mathrm{~A})-\mathrm{C}(1 \mathrm{~A})-\mathrm{N}(1 \mathrm{~A})$ & $-5.6(2)$ \\
\hline $\mathrm{C}(2 \mathrm{~A})-\mathrm{O}(1 \mathrm{~A})-\mathrm{C}(1 \mathrm{~A})-\mathrm{C}(6 \mathrm{~A})$ & $174.93(15)$ \\
\hline $\mathrm{C}(1 \mathrm{~A})-\mathrm{O}(1 \mathrm{~A})-\mathrm{C}(2 \mathrm{~A})-\mathrm{C}(3 \mathrm{~A})$ & $13.44(18)$ \\
\hline $\mathrm{C}(1 \mathrm{~A})-\mathrm{N}(1 \mathrm{~A})-\mathrm{C}(3 \mathrm{~A})-\mathrm{C}(5 \mathrm{~A})$ & $133.53(16)$ \\
\hline $\operatorname{Sn}(1 \mathrm{~A})-\mathrm{N}(1 \mathrm{~A})-\mathrm{C}(3 \mathrm{~A})-\mathrm{C}(5 \mathrm{~A})$ & $-42.1(3)$ \\
\hline $\mathrm{C}(1 \mathrm{~A})-\mathrm{N}(1 \mathrm{~A})-\mathrm{C}(3 \mathrm{~A})-\mathrm{C}(4 \mathrm{~A})$ & $-103.46(17)$ \\
\hline $\operatorname{Sn}(1 \mathrm{~A})-\mathrm{N}(1 \mathrm{~A})-\mathrm{C}(3 \mathrm{~A})-\mathrm{C}(4 \mathrm{~A})$ & $80.9(2)$ \\
\hline $\mathrm{C}(1 \mathrm{~A})-\mathrm{N}(1 \mathrm{~A})-\mathrm{C}(3 \mathrm{~A})-\mathrm{C}(2 \mathrm{~A})$ & $13.10(18)$ \\
\hline $\operatorname{Sn}(1 \mathrm{~A})-\mathrm{N}(1 \mathrm{~A})-\mathrm{C}(3 \mathrm{~A})-\mathrm{C}(2 \mathrm{~A})$ & $-162.52(15)$ \\
\hline $\mathrm{O}(1 \mathrm{~A})-\mathrm{C}(2 \mathrm{~A})-\mathrm{C}(3 \mathrm{~A})-\mathrm{N}(1 \mathrm{~A})$ & $-15.81(17)$ \\
\hline $\mathrm{O}(1 \mathrm{~A})-\mathrm{C}(2 \mathrm{~A})-\mathrm{C}(3 \mathrm{~A})-\mathrm{C}(5 \mathrm{~A})$ & $-134.72(16)$ \\
\hline $\mathrm{O}(1 \mathrm{~A})-\mathrm{C}(2 \mathrm{~A})-\mathrm{C}(3 \mathrm{~A})-\mathrm{C}(4 \mathrm{~A})$ & $99.11(17)$ \\
\hline $\mathrm{N}(1 \mathrm{~A})-\mathrm{C}(1 \mathrm{~A})-\mathrm{C}(6 \mathrm{~A})-\mathrm{C}(7 \mathrm{~A})$ & $-170.49(17)$ \\
\hline $\mathrm{O}(1 \mathrm{~A})-\mathrm{C}(1 \mathrm{~A})-\mathrm{C}(6 \mathrm{~A})-\mathrm{C}(7 \mathrm{~A})$ & $8.9(2)$ \\
\hline $\mathrm{N}(1 \mathrm{~A})-\mathrm{C}(1 \mathrm{~A})-\mathrm{C}(6 \mathrm{~A})-\mathrm{C}(11 \mathrm{~A})$ & $6.6(3)$ \\
\hline $\mathrm{O}(1 \mathrm{~A})-\mathrm{C}(1 \mathrm{~A})-\mathrm{C}(6 \mathrm{~A})-\mathrm{C}(11 \mathrm{~A})$ & $-173.96(15)$ \\
\hline $\mathrm{C}(11 \mathrm{~A})-\mathrm{C}(6 \mathrm{~A})-\mathrm{C}(7 \mathrm{~A})-\mathrm{C}(8 \mathrm{~A})$ & $-0.1(3)$ \\
\hline$C(1 A)-C(6 A)-C(7 A)-C(8 A)$ & $176.88(16)$ \\
\hline$C(6 A)-C(7 A)-C(8 A)-C(9 A)$ & $0.6(3)$ \\
\hline $\mathrm{C}(7 \mathrm{~A})-\mathrm{C}(8 \mathrm{~A})-\mathrm{C}(9 \mathrm{~A})-\mathrm{C}(10 \mathrm{~A})$ & $-0.4(3)$ \\
\hline$C(8 A)-C(9 A)-C(10 A)-C(11 A)$ & $-0.3(3)$ \\
\hline$C(9 A)-C(10 A)-C(11 A)-C(6 A)$ & $0.8(3)$ \\
\hline$C(9 A)-C(10 A)-C(11 A)-S n(1 A)$ & $-176.94(13)$ \\
\hline$C(7 A)-C(6 A)-C(11 A)-C(10 A)$ & $-0.6(3)$ \\
\hline$C(1 A)-C(6 A)-C(11 A)-C(10 A)$ & $-177.72(15)$ \\
\hline$C(7 A)-C(6 A)-C(11 A)-S n(1 A)$ & 177.33(13) \\
\hline$C(1 A)-C(6 A)-C(11 A)-S n(1 A)$ & $0.2(2)$ \\
\hline $\mathrm{C}(17 \mathrm{~A})-\mathrm{C}(12 \mathrm{~A})-\mathrm{C}(13 \mathrm{~A})-\mathrm{C}(14 \mathrm{~A})$ & $0.7(3)$ \\
\hline $\operatorname{Sn}(1 \mathrm{~A})-\mathrm{C}(12 \mathrm{~A})-\mathrm{C}(13 \mathrm{~A})-\mathrm{C}(14 \mathrm{~A})$ & $179.27(14)$ \\
\hline$C(12 A)-C(13 A)-C(14 A)-C(15 A)$ & $1.0(3)$ \\
\hline
\end{tabular}




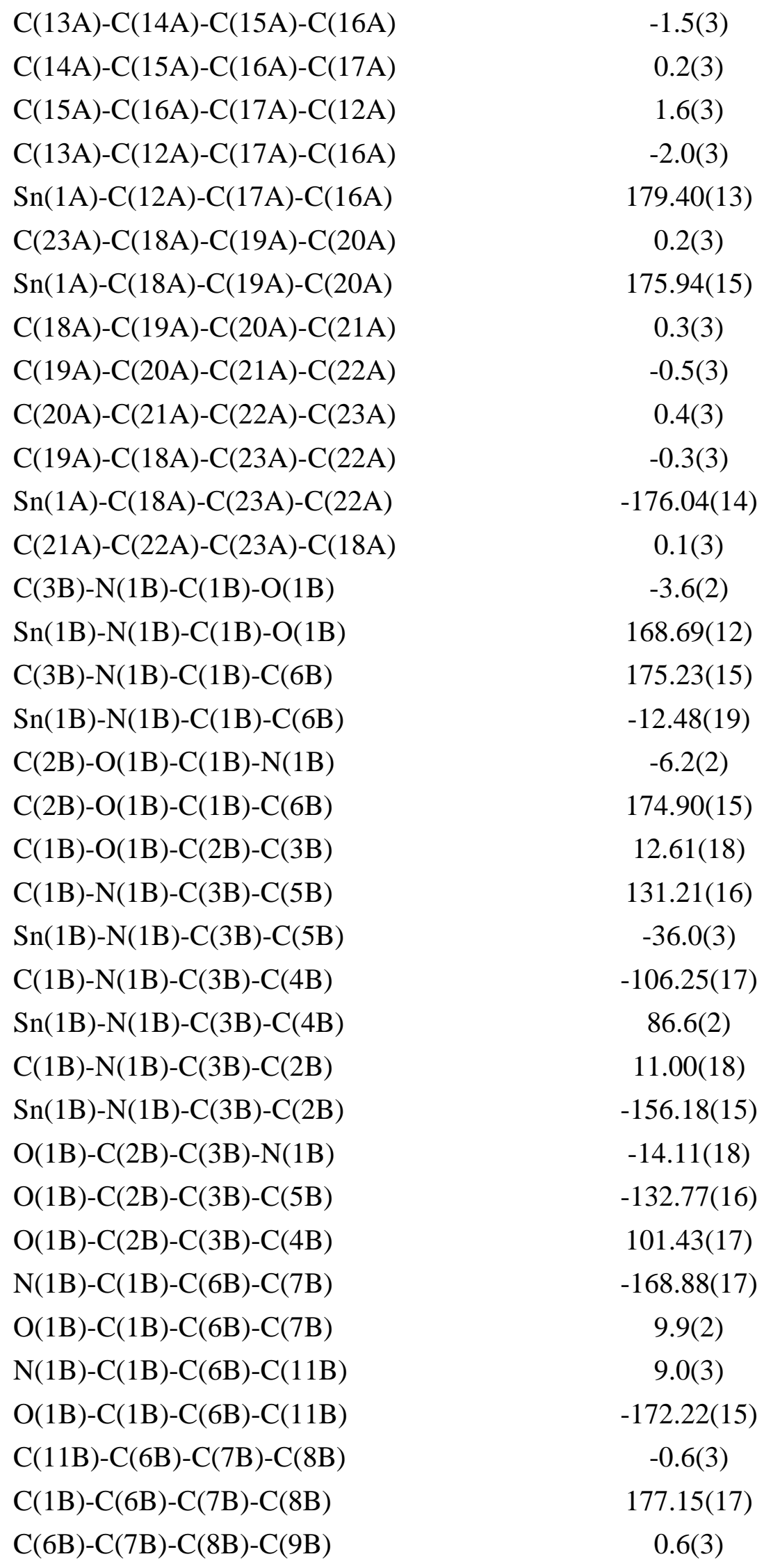




$\begin{array}{lc}\mathrm{C}(7 \mathrm{~B})-\mathrm{C}(8 \mathrm{~B})-\mathrm{C}(9 \mathrm{~B})-\mathrm{C}(10 \mathrm{~B}) & -0.2(3) \\ \mathrm{C}(8 \mathrm{~B})-\mathrm{C}(9 \mathrm{~B})-\mathrm{C}(10 \mathrm{~B})-\mathrm{C}(11 \mathrm{~B}) & -0.4(3) \\ \mathrm{C}(9 \mathrm{~B})-\mathrm{C}(10 \mathrm{~B})-\mathrm{C}(11 \mathrm{~B})-\mathrm{C}(6 \mathrm{~B}) & 0.4(3) \\ \mathrm{C}(9 \mathrm{~B})-\mathrm{C}(10 \mathrm{~B})-\mathrm{C}(11 \mathrm{~B})-\mathrm{Sn}(1 \mathrm{~B}) & -178.58(13) \\ \mathrm{C}(7 \mathrm{~B})-\mathrm{C}(6 \mathrm{~B})-\mathrm{C}(11 \mathrm{~B})-\mathrm{C}(10 \mathrm{~B}) & 0.0(3) \\ \mathrm{C}(1 \mathrm{~B})-\mathrm{C}(6 \mathrm{~B})-\mathrm{C}(11 \mathrm{~B})-\mathrm{C}(10 \mathrm{~B}) & -177.78(15) \\ \mathrm{C}(7 \mathrm{~B})-\mathrm{C}(6 \mathrm{~B})-\mathrm{C}(11 \mathrm{~B})-\mathrm{Sn}(1 \mathrm{~B}) & 179.15(13) \\ \mathrm{C}(1 \mathrm{~B})-\mathrm{C}(6 \mathrm{~B})-\mathrm{C}(11 \mathrm{~B})-\mathrm{Sn}(1 \mathrm{~B}) & 1.3(2) \\ \mathrm{C}(17 \mathrm{~B})-\mathrm{C}(12 \mathrm{~B})-\mathrm{C}(13 \mathrm{~B})-\mathrm{C}(14 \mathrm{~B}) & 1.0(3) \\ \mathrm{Sn}(1 \mathrm{~B})-\mathrm{C}(12 \mathrm{~B})-\mathrm{C}(13 \mathrm{~B})-\mathrm{C}(14 \mathrm{~B}) & 174.59(15) \\ \mathrm{C}(12 \mathrm{~B})-\mathrm{C}(13 \mathrm{~B})-\mathrm{C}(14 \mathrm{~B})-\mathrm{C}(15 \mathrm{~B}) & -1.3(3) \\ \mathrm{C}(13 \mathrm{~B})-\mathrm{C}(14 \mathrm{~B})-\mathrm{C}(15 \mathrm{~B})-\mathrm{C}(16 \mathrm{~B}) & 0.1(3) \\ \mathrm{C}(14 \mathrm{~B})-\mathrm{C}(15 \mathrm{~B})-\mathrm{C}(16 \mathrm{~B})-\mathrm{C}(17 \mathrm{~B}) & 1.2(3) \\ \mathrm{C}(15 \mathrm{~B})-\mathrm{C}(16 \mathrm{~B})-\mathrm{C}(17 \mathrm{~B})-\mathrm{C}(12 \mathrm{~B}) & -1.5(3) \\ \mathrm{C}(13 \mathrm{~B})-\mathrm{C}(12 \mathrm{~B})-\mathrm{C}(17 \mathrm{~B})-\mathrm{C}(16 \mathrm{~B}) & 0.4(3) \\ \mathrm{Sn}(1 \mathrm{~B})-\mathrm{C}(12 \mathrm{~B})-\mathrm{C}(17 \mathrm{~B})-\mathrm{C}(16 \mathrm{~B}) & -173.23(13) \\ \mathrm{C}(23 \mathrm{~B})-\mathrm{C}(18 \mathrm{~B})-\mathrm{C}(19 \mathrm{~B})-\mathrm{C}(20 \mathrm{~B}) & 0.8(3) \\ \mathrm{Sn}(1 \mathrm{~B})-\mathrm{C}(18 \mathrm{~B})-\mathrm{C}(19 \mathrm{~B})-\mathrm{C}(20 \mathrm{~B}) & -177.19(14) \\ \mathrm{C}(18 \mathrm{~B})-\mathrm{C}(19 \mathrm{~B})-\mathrm{C}(20 \mathrm{~B})-\mathrm{C}(21 \mathrm{~B}) & 0.5(3) \\ \mathrm{C}(19 \mathrm{~B})-\mathrm{C}(20 \mathrm{~B})-\mathrm{C}(21 \mathrm{~B})-\mathrm{C}(22 \mathrm{~B}) & -0.9(3) \\ \mathrm{C}(20 \mathrm{~B})-\mathrm{C}(21 \mathrm{~B})-\mathrm{C}(22 \mathrm{~B})-\mathrm{C}(23 \mathrm{~B}) & -0.1(3) \\ \mathrm{C}(21 \mathrm{~B})-\mathrm{C}(22 \mathrm{~B})-\mathrm{C}(23 \mathrm{~B})-\mathrm{C}(18 \mathrm{~B}) & 1.4(3) \\ \mathrm{C}(19 \mathrm{~B})-\mathrm{C}(18 \mathrm{~B})-\mathrm{C}(23 \mathrm{~B})-\mathrm{C}(22 \mathrm{~B}) & -1.7(3) \\ \mathrm{Sn}(1 \mathrm{~B})-\mathrm{C}(18 \mathrm{~B})-\mathrm{C}(23 \mathrm{~B})-\mathrm{C}(22 \mathrm{~B}) & 176.13(16) \\ & \end{array}$

Symmetry transformations used to generate equivalent atoms: 
Table A3: Crystal data and structure refinement for 13.

Identification code

Empirical formula

Formula weight

Temperature

Wavelength

Crystal system

Space group

Unit cell dimensions

Volume

$\mathrm{Z}$

Density (calculated)

Absorption coefficient

$\mathrm{F}(000)$

Crystal size

Theta range for data collection

Index ranges

Reflections collected

Independent reflections

Completeness to theta $=25.242^{\circ}$

Absorption correction

Max. and min. transmission

Refinement method

Data / restraints / parameters

Goodness-of-fit on $\mathrm{F}^{2}$

Final $\mathrm{R}$ indices [I $>2 \operatorname{sigma}(\mathrm{I})]$

$\mathrm{R}$ indices (all data)

Extinction coefficient

Largest diff. peak and hole d17164_a

C17 H17 Br2 N O Sn

529.82

150(2) K

$0.71073 \AA$

Monoclinic

$\mathrm{P} 21 / \mathrm{n}$

$\mathrm{a}=10.5295(7) \AA \quad \square=90^{\circ}$.

$\mathrm{b}=10.0336(5) \AA \quad \square=96.677(2)^{\circ}$.

c $=17.1396(11) \AA \quad \square=90^{\circ}$.

1798.50(19) $\AA^{3}$

4

$1.957 \mathrm{Mg} / \mathrm{m}^{3}$

$5.865 \mathrm{~mm}^{-1}$

1016

$0.120 \times 0.090 \times 0.050 \mathrm{~mm}^{3}$

2.164 to $27.535^{\circ}$.

$-13<=\mathrm{h}<=13,-12<=\mathrm{k}<=13,-22<=\mathrm{l}<=22$

38637

$4135[\mathrm{R}(\mathrm{int})=0.0364]$

$100.0 \%$

Semi-empirical from equivalents

0.7456 and 0.5610

Full-matrix least-squares on $\mathrm{F}^{2}$

4135 / 54 / 220

1.052

$\mathrm{R} 1=0.0219, \mathrm{wR} 2=0.0383$

$\mathrm{R} 1=0.0358, \mathrm{wR} 2=0.0422$

$\mathrm{n} / \mathrm{a}$

0.553 and -0.467 e. $\AA^{-3}$ 
Atomic coordinates ( $\left.\mathrm{x} 10^{4}\right)$ and equivalent isotropic displacement parameters $\left(\AA^{2} \times 10^{3}\right)$ for 13. $U(e q)$ is defined as one third of the trace of the orthogonalized $U^{i j}$ tensor.

\begin{tabular}{|c|c|c|c|c|}
\hline & $\mathrm{x}$ & $\mathrm{y}$ & $\mathrm{z}$ & $\mathrm{U}(\mathrm{eq})$ \\
\hline \multicolumn{5}{|l|}{-} \\
\hline $\operatorname{Sn}(1)$ & $6822(1)$ & $2886(1)$ & $4710(1)$ & $17(1)$ \\
\hline $\operatorname{Br}(1)$ & $8038(1)$ & $944(1)$ & $5321(1)$ & $29(1)$ \\
\hline $\operatorname{Br}(2)$ & $5466(1)$ & $3086(1)$ & $5892(1)$ & $28(1)$ \\
\hline $\mathrm{O}(1)$ & $9820(30)$ & $4220(40)$ & $3340(20)$ & $20(4)$ \\
\hline $\mathrm{O}(1 \mathrm{~A})$ & $9640(17)$ & $4319(18)$ & $3239(10)$ & $24(3)$ \\
\hline $\mathrm{N}(1)$ & $8278(2)$ & $2927(2)$ & $3744(1)$ & $18(1)$ \\
\hline$C(1)$ & $7681(2)$ & $4814(2)$ & $4841(1)$ & $16(1)$ \\
\hline$C(2)$ & $7364(2)$ & $5779(2)$ & $5362(2)$ & $23(1)$ \\
\hline$C(3)$ & $7910(3)$ & $7042(3)$ & $5350(2)$ & $29(1)$ \\
\hline$C(4)$ & $8800(3)$ & $7324(3)$ & $4840(2)$ & $27(1)$ \\
\hline$C(5)$ & $9152(2)$ & $6360(2)$ & $4327(1)$ & $21(1)$ \\
\hline$C(6)$ & $8577(2)$ & $5112(2)$ & $4325(1)$ & $16(1)$ \\
\hline$C(7)$ & $8849(2)$ & $4062(2)$ & $3778(1)$ & $19(1)$ \\
\hline $\mathrm{C}(8)$ & $9670(30)$ & $3130(30)$ & $2770(20)$ & $31(5)$ \\
\hline $\mathrm{C}(8 \mathrm{~A})$ & $9849(16)$ & $3015(15)$ & $2877(11)$ & $39(3)$ \\
\hline $\mathrm{C}(9)$ & $8732(2)$ & $2142(3)$ & $3090(1)$ & $24(1)$ \\
\hline$C(10)$ & $9242(3)$ & 798(3) & $3378(2)$ & $46(1)$ \\
\hline $\mathrm{C}(11)$ & $7644(3)$ & 1994(3) & $2431(2)$ & $38(1)$ \\
\hline $\mathrm{C}(12)$ & $5330(2)$ & $2290(2)$ & $3836(1)$ & $18(1)$ \\
\hline$C(13)$ & $4863(2)$ & $3196(3)$ & $3261(2)$ & $24(1)$ \\
\hline$C(14)$ & $3912(3)$ & $2824(3)$ & $2668(2)$ & $32(1)$ \\
\hline$C(15)$ & $3436(3)$ & $1537(3)$ & $2654(2)$ & $33(1)$ \\
\hline$C(16)$ & 3888(3) & $632(3)$ & $3224(2)$ & $30(1)$ \\
\hline$C(17)$ & $4838(2)$ & $1008(3)$ & $3817(2)$ & $24(1)$ \\
\hline
\end{tabular}


Bond lengths $[\AA]$ and angles $\left[{ }^{\circ}\right]$ for $\mathbf{1 3}$.

\begin{tabular}{|c|c|}
\hline $\operatorname{Sn}(1)-C(12)$ & $2.127(2)$ \\
\hline $\operatorname{Sn}(1)-C(1)$ & $2.137(2)$ \\
\hline $\operatorname{Sn}(1)-N(1)$ & $2.383(2)$ \\
\hline $\operatorname{Sn}(1)-\operatorname{Br}(1)$ & $2.4943(3)$ \\
\hline $\operatorname{Sn}(1)-\operatorname{Br}(2)$ & $2.6180(3)$ \\
\hline $\mathrm{O}(1)-\mathrm{C}(7)$ & $1.339(8)$ \\
\hline $\mathrm{O}(1)-\mathrm{C}(8)$ & $1.475(11)$ \\
\hline $\mathrm{O}(1 \mathrm{~A})-\mathrm{C}(7)$ & $1.339(5)$ \\
\hline $\mathrm{O}(1 \mathrm{~A})-\mathrm{C}(8 \mathrm{~A})$ & $1.476(9)$ \\
\hline $\mathrm{N}(1)-\mathrm{C}(7)$ & $1.286(3)$ \\
\hline $\mathrm{N}(1)-\mathrm{C}(9)$ & $1.493(3)$ \\
\hline $\mathrm{C}(1)-\mathrm{C}(2)$ & $1.383(3)$ \\
\hline$C(1)-C(6)$ & $1.399(3)$ \\
\hline $\mathrm{C}(2)-\mathrm{C}(3)$ & $1.393(4)$ \\
\hline $\mathrm{C}(2)-\mathrm{H}(2 \mathrm{~A})$ & 0.9500 \\
\hline$C(3)-C(4)$ & $1.384(4)$ \\
\hline $\mathrm{C}(3)-\mathrm{H}(3 \mathrm{~A})$ & 0.9500 \\
\hline$C(4)-C(5)$ & $1.386(4)$ \\
\hline $\mathrm{C}(4)-\mathrm{H}(4 \mathrm{~A})$ & 0.9500 \\
\hline$C(5)-C(6)$ & 1.391(3) \\
\hline $\mathrm{C}(5)-\mathrm{H}(5 \mathrm{~A})$ & 0.9500 \\
\hline$C(6)-C(7)$ & $1.460(3)$ \\
\hline $\mathrm{C}(8)-\mathrm{C}(9)$ & $1.546(8)$ \\
\hline $\mathrm{C}(8)-\mathrm{H}(8 \mathrm{~A})$ & 0.9900 \\
\hline $\mathrm{C}(8)-\mathrm{H}(8 \mathrm{~B})$ & 0.9900 \\
\hline $\mathrm{C}(8 \mathrm{~A})-\mathrm{C}(9)$ & $1.544(6)$ \\
\hline $\mathrm{C}(8 \mathrm{~A})-\mathrm{H}(8 \mathrm{AA})$ & 0.9900 \\
\hline $\mathrm{C}(8 \mathrm{~A})-\mathrm{H}(8 \mathrm{AB})$ & 0.9900 \\
\hline $\mathrm{C}(9)-\mathrm{C}(10)$ & $1.513(4)$ \\
\hline $\mathrm{C}(9)-\mathrm{C}(11)$ & $1.520(4)$ \\
\hline $\mathrm{C}(10)-\mathrm{H}(10 \mathrm{~A})$ & 0.9800 \\
\hline $\mathrm{C}(10)-\mathrm{H}(10 \mathrm{~B})$ & 0.9800 \\
\hline $\mathrm{C}(10)-\mathrm{H}(10 \mathrm{C})$ & 0.9800 \\
\hline $\mathrm{C}(11)-\mathrm{H}(11 \mathrm{~A})$ & 0.9800 \\
\hline
\end{tabular}




\begin{tabular}{|c|c|}
\hline $\mathrm{C}(11)-\mathrm{H}(11 \mathrm{~B})$ & 0.9800 \\
\hline $\mathrm{C}(11)-\mathrm{H}(11 \mathrm{C})$ & 0.9800 \\
\hline$C(12)-C(17)$ & $1.385(3)$ \\
\hline$C(12)-C(13)$ & $1.388(3)$ \\
\hline$C(13)-C(14)$ & $1.392(4)$ \\
\hline $\mathrm{C}(13)-\mathrm{H}(13 \mathrm{~A})$ & 0.9500 \\
\hline$C(14)-C(15)$ & $1.385(4)$ \\
\hline $\mathrm{C}(14)-\mathrm{H}(14 \mathrm{~A})$ & 0.9500 \\
\hline$C(15)-C(16)$ & $1.378(4)$ \\
\hline $\mathrm{C}(15)-\mathrm{H}(15 \mathrm{~A})$ & 0.9500 \\
\hline$C(16)-C(17)$ & $1.392(4)$ \\
\hline$C(16)-H(16 A)$ & 0.9500 \\
\hline $\mathrm{C}(17)-\mathrm{H}(17 \mathrm{~A})$ & 0.9500 \\
\hline$C(12)-\operatorname{Sn}(1)-C(1)$ & $126.73(9)$ \\
\hline $\mathrm{C}(12)-\mathrm{Sn}(1)-\mathrm{N}(1)$ & $89.86(8)$ \\
\hline $\mathrm{C}(1)-\mathrm{Sn}(1)-\mathrm{N}(1)$ & $76.06(8)$ \\
\hline$C(12)-\operatorname{Sn}(1)-\operatorname{Br}(1)$ & $112.14(7)$ \\
\hline $\mathrm{C}(1)-\operatorname{Sn}(1)-\mathrm{Br}(1)$ & $118.23(6)$ \\
\hline $\mathrm{N}(1)-\mathrm{Sn}(1)-\mathrm{Br}(1)$ & $87.98(5)$ \\
\hline$C(12)-\operatorname{Sn}(1)-\operatorname{Br}(2)$ & $98.14(6)$ \\
\hline $\mathrm{C}(1)-\operatorname{Sn}(1)-\mathrm{Br}(2)$ & $96.41(6)$ \\
\hline $\mathrm{N}(1)-\mathrm{Sn}(1)-\mathrm{Br}(2)$ & $171.36(5)$ \\
\hline $\operatorname{Br}(1)-\operatorname{Sn}(1)-\operatorname{Br}(2)$ & 91.994(11 \\
\hline $\mathrm{C}(7)-\mathrm{O}(1)-\mathrm{C}(8)$ & $105(2)$ \\
\hline $\mathrm{C}(7)-\mathrm{O}(1 \mathrm{~A})-\mathrm{C}(8 \mathrm{~A})$ & $104.7(11)$ \\
\hline $\mathrm{C}(7)-\mathrm{N}(1)-\mathrm{C}(9)$ & $108.2(2)$ \\
\hline $\mathrm{C}(7)-\mathrm{N}(1)-\mathrm{Sn}(1)$ & $108.60(15)$ \\
\hline $\mathrm{C}(9)-\mathrm{N}(1)-\mathrm{Sn}(1)$ & $143.15(16)$ \\
\hline$C(2)-C(1)-C(6)$ & $119.4(2)$ \\
\hline$C(2)-C(1)-\operatorname{Sn}(1)$ & $124.76(18)$ \\
\hline$C(6)-C(1)-\operatorname{Sn}(1)$ & $115.79(16)$ \\
\hline $\mathrm{C}(1)-\mathrm{C}(2)-\mathrm{C}(3)$ & $119.7(2)$ \\
\hline $\mathrm{C}(1)-\mathrm{C}(2)-\mathrm{H}(2 \mathrm{~A})$ & 120.1 \\
\hline $\mathrm{C}(3)-\mathrm{C}(2)-\mathrm{H}(2 \mathrm{~A})$ & 120.1 \\
\hline $\mathrm{C}(4)-\mathrm{C}(3)-\mathrm{C}(2)$ & $120.4(2)$ \\
\hline
\end{tabular}




\begin{tabular}{|c|c|}
\hline $\mathrm{C}(4)-\mathrm{C}(3)-\mathrm{H}(3 \mathrm{~A})$ & 119.8 \\
\hline $\mathrm{C}(2)-\mathrm{C}(3)-\mathrm{H}(3 \mathrm{~A})$ & 119.8 \\
\hline$C(3)-C(4)-C(5)$ & $120.6(2)$ \\
\hline $\mathrm{C}(3)-\mathrm{C}(4)-\mathrm{H}(4 \mathrm{~A})$ & 119.7 \\
\hline $\mathrm{C}(5)-\mathrm{C}(4)-\mathrm{H}(4 \mathrm{~A})$ & 119.7 \\
\hline$C(4)-C(5)-C(6)$ & $118.7(2)$ \\
\hline $\mathrm{C}(4)-\mathrm{C}(5)-\mathrm{H}(5 \mathrm{~A})$ & 120.6 \\
\hline $\mathrm{C}(6)-\mathrm{C}(5)-\mathrm{H}(5 \mathrm{~A})$ & 120.6 \\
\hline$C(5)-C(6)-C(1)$ & $121.1(2)$ \\
\hline$C(5)-C(6)-C(7)$ & $122.3(2)$ \\
\hline$C(1)-C(6)-C(7)$ & $116.7(2)$ \\
\hline $\mathrm{N}(1)-\mathrm{C}(7)-\mathrm{O}(1)$ & $117.7(16)$ \\
\hline $\mathrm{N}(1)-\mathrm{C}(7)-\mathrm{O}(1 \mathrm{~A})$ & 117.7(7) \\
\hline $\mathrm{N}(1)-\mathrm{C}(7)-\mathrm{C}(6)$ & $122.9(2)$ \\
\hline $\mathrm{O}(1)-\mathrm{C}(7)-\mathrm{C}(6)$ & $119.1(16)$ \\
\hline $\mathrm{O}(1 \mathrm{~A})-\mathrm{C}(7)-\mathrm{C}(6)$ & 119.1(7) \\
\hline $\mathrm{O}(1)-\mathrm{C}(8)-\mathrm{C}(9)$ & $105(2)$ \\
\hline $\mathrm{O}(1)-\mathrm{C}(8)-\mathrm{H}(8 \mathrm{~A})$ & 110.8 \\
\hline $\mathrm{C}(9)-\mathrm{C}(8)-\mathrm{H}(8 \mathrm{~A})$ & 110.8 \\
\hline $\mathrm{O}(1)-\mathrm{C}(8)-\mathrm{H}(8 \mathrm{~B})$ & 110.8 \\
\hline $\mathrm{C}(9)-\mathrm{C}(8)-\mathrm{H}(8 \mathrm{~B})$ & 110.8 \\
\hline $\mathrm{H}(8 \mathrm{~A})-\mathrm{C}(8)-\mathrm{H}(8 \mathrm{~B})$ & 108.8 \\
\hline $\mathrm{O}(1 \mathrm{~A})-\mathrm{C}(8 \mathrm{~A})-\mathrm{C}(9)$ & $104.4(10)$ \\
\hline $\mathrm{O}(1 \mathrm{~A})-\mathrm{C}(8 \mathrm{~A})-\mathrm{H}(8 \mathrm{AA})$ & 110.9 \\
\hline $\mathrm{C}(9)-\mathrm{C}(8 \mathrm{~A})-\mathrm{H}(8 \mathrm{AA})$ & 110.9 \\
\hline $\mathrm{O}(1 \mathrm{~A})-\mathrm{C}(8 \mathrm{~A})-\mathrm{H}(8 \mathrm{AB})$ & 110.9 \\
\hline $\mathrm{C}(9)-\mathrm{C}(8 \mathrm{~A})-\mathrm{H}(8 \mathrm{AB})$ & 110.9 \\
\hline $\mathrm{H}(8 \mathrm{AA})-\mathrm{C}(8 \mathrm{~A})-\mathrm{H}(8 \mathrm{AB})$ & 108.9 \\
\hline N(1)-C(9)-C(10) & $111.0(2)$ \\
\hline $\mathrm{N}(1)-\mathrm{C}(9)-\mathrm{C}(11)$ & $109.3(2)$ \\
\hline $\mathrm{C}(10)-\mathrm{C}(9)-\mathrm{C}(11)$ & $111.3(2)$ \\
\hline $\mathrm{N}(1)-\mathrm{C}(9)-\mathrm{C}(8 \mathrm{~A})$ & $101.4(6)$ \\
\hline$C(10)-C(9)-C(8 A)$ & 109.3(8) \\
\hline$C(11)-C(9)-C(8 A)$ & $114.1(8)$ \\
\hline $\mathrm{N}(1)-\mathrm{C}(9)-\mathrm{C}(8)$ & $101.9(13)$ \\
\hline C(10)-C(9)-C(8) & $117.8(17)$ \\
\hline
\end{tabular}




$\begin{array}{ll}\mathrm{C}(11)-\mathrm{C}(9)-\mathrm{C}(8) & 104.9(17) \\ \mathrm{C}(9)-\mathrm{C}(10)-\mathrm{H}(10 \mathrm{~A}) & 109.5 \\ \mathrm{C}(9)-\mathrm{C}(10)-\mathrm{H}(10 \mathrm{~B}) & 109.5 \\ \mathrm{H}(10 \mathrm{~A})-\mathrm{C}(10)-\mathrm{H}(10 \mathrm{~B}) & 109.5 \\ \mathrm{C}(9)-\mathrm{C}(10)-\mathrm{H}(10 \mathrm{C}) & 109.5 \\ \mathrm{H}(10 \mathrm{~A})-\mathrm{C}(10)-\mathrm{H}(10 \mathrm{C}) & 109.5 \\ \mathrm{H}(10 \mathrm{~B})-\mathrm{C}(10)-\mathrm{H}(10 \mathrm{C}) & 109.5 \\ \mathrm{C}(9)-\mathrm{C}(11)-\mathrm{H}(11 \mathrm{~A}) & 109.5 \\ \mathrm{C}(9)-\mathrm{C}(11)-\mathrm{H}(11 \mathrm{~B}) & 109.5 \\ \mathrm{H}(11 \mathrm{~A})-\mathrm{C}(11)-\mathrm{H}(11 \mathrm{~B}) & 109.5 \\ \mathrm{C}(9)-\mathrm{C}(11)-\mathrm{H}(11 \mathrm{C}) & 109.5 \\ \mathrm{H}(11 \mathrm{~A})-\mathrm{C}(11)-\mathrm{H}(11 \mathrm{C}) & 109.5 \\ \mathrm{H}(11 \mathrm{~B})-\mathrm{C}(11)-\mathrm{H}(11 \mathrm{C}) & 109.5 \\ \mathrm{C}(17)-\mathrm{C}(12)-\mathrm{C}(13) & 119.4(2) \\ \mathrm{C}(17)-\mathrm{C}(12)-\mathrm{Sn}(1) & 121.44(18) \\ \mathrm{C}(13)-\mathrm{C}(12)-\mathrm{Sn}(1) & 119.16(18) \\ \mathrm{C}(12)-\mathrm{C}(13)-\mathrm{C}(14) & 120.5(2) \\ \mathrm{C}(12)-\mathrm{C}(13)-\mathrm{H}(13 \mathrm{~A}) & 119.7 \\ \mathrm{C}(14)-\mathrm{C}(13)-\mathrm{H}(13 \mathrm{~A}) & 119.7 \\ \mathrm{C}(15)-\mathrm{C}(14)-\mathrm{C}(13) & 119.5(3) \\ \mathrm{C}(15)-\mathrm{C}(14)-\mathrm{H}(14 \mathrm{~A}) & 120.3 \\ \mathrm{C}(13)-\mathrm{C}(14)-\mathrm{H}(14 \mathrm{~A}) & 120.3 \\ \mathrm{C}(16)-\mathrm{C}(15)-\mathrm{C}(14) & 120.5(3) \\ \mathrm{C}(16)-\mathrm{C}(15)-\mathrm{H}(15 \mathrm{~A}) & 119.8 \\ \mathrm{C}(14)-\mathrm{C}(15)-\mathrm{H}(15 \mathrm{~A}) & 119.8 \\ \mathrm{C}(15)-\mathrm{C}(16)-\mathrm{C}(17) & 119.9(3) \\ \mathrm{C}(15)-\mathrm{C}(16)-\mathrm{H}(16 \mathrm{~A}) & 120.0 \\ \mathrm{C}(17)-\mathrm{C}(16)-\mathrm{H}(16 \mathrm{~A}) & 120.0 \\ \mathrm{C}(12)-\mathrm{C}(17)-\mathrm{C}(16) & 120.3(2) \\ \mathrm{C}(12)-\mathrm{C}(17)-\mathrm{H}(17 \mathrm{~A}) & 119.9 \\ \mathrm{C}(16)-\mathrm{C}(17)-\mathrm{H}(17 \mathrm{~A}) & 119.9 \\ & \\ & \end{array}$

Symmetry transformations used to generate equivalent atoms: 
Anisotropic displacement parameters $\left(\AA^{2} \times 10^{3}\right)$ for 13. The anisotropic displacement factor exponent takes the form: $-2 \square^{2}\left[\mathrm{~h}^{2} \mathrm{a}^{* 2} \mathrm{U}^{11}+\ldots+2 \mathrm{~h} \mathrm{k} \mathrm{a}^{*} \mathrm{~b}^{*} \mathrm{U}^{12}\right]$

\begin{tabular}{|c|c|c|c|c|c|c|}
\hline & $\mathrm{U}^{11}$ & $\mathrm{U}^{22}$ & $\mathrm{U}^{33}$ & $\mathrm{U}^{23}$ & U13 & $\mathrm{U}^{12}$ \\
\hline $\operatorname{Sn}(1)$ & $17(1)$ & $17(1)$ & $15(1)$ & $1(1)$ & $1(1)$ & $-1(1)$ \\
\hline $\operatorname{Br}(1)$ & $30(1)$ & $25(1)$ & $33(1)$ & 11(1) & $4(1)$ & $5(1)$ \\
\hline $\operatorname{Br}(2)$ & $27(1)$ & $38(1)$ & $19(1)$ & $3(1)$ & $8(1)$ & $-1(1)$ \\
\hline $\mathrm{O}(1)$ & $14(6)$ & $34(7)$ & $11(6)$ & $1(5)$ & $-1(5)$ & $-2(5)$ \\
\hline $\mathrm{O}(1 \mathrm{~A})$ & $25(5)$ & $31(3)$ & $19(5)$ & $-3(3)$ & $8(4)$ & $-2(3)$ \\
\hline $\mathrm{N}(1)$ & $17(1)$ & $20(1)$ & $18(1)$ & $-3(1)$ & $3(1)$ & $2(1)$ \\
\hline $\mathrm{C}(1)$ & $15(1)$ & $17(1)$ & $15(1)$ & $0(1)$ & $-1(1)$ & $1(1)$ \\
\hline$C(2)$ & $19(1)$ & $26(1)$ & $25(1)$ & $-6(1)$ & $3(1)$ & $1(1)$ \\
\hline$C(3)$ & $26(2)$ & $24(1)$ & $36(2)$ & $-14(1)$ & $2(1)$ & $2(1)$ \\
\hline C(4) & $27(2)$ & $17(1)$ & $33(2)$ & $-2(1)$ & $-6(1)$ & $-2(1)$ \\
\hline$C(5)$ & $16(1)$ & $25(1)$ & $21(1)$ & $3(1)$ & $0(1)$ & $-1(1)$ \\
\hline$C(6)$ & $16(1)$ & $19(1)$ & $13(1)$ & $1(1)$ & $-3(1)$ & $2(1)$ \\
\hline$C(7)$ & $17(1)$ & $25(1)$ & $14(1)$ & $1(1)$ & $1(1)$ & $1(1)$ \\
\hline$C(8)$ & $34(10)$ & $35(7)$ & $28(8)$ & $-11(5)$ & $17(7)$ & $2(6)$ \\
\hline $\mathrm{C}(8 \mathrm{~A})$ & $32(4)$ & $53(5)$ & $34(6)$ & $-24(4)$ & $14(4)$ & $-6(4)$ \\
\hline $\mathrm{C}(9)$ & $24(1)$ & $29(1)$ & $19(1)$ & $-9(1)$ & $4(1)$ & $4(1)$ \\
\hline$C(10)$ & $64(2)$ & $39(2)$ & $34(2)$ & $-14(1)$ & $3(2)$ & $24(2)$ \\
\hline $\mathrm{C}(11)$ & $32(2)$ & $59(2)$ & $23(2)$ & $-14(1)$ & $-1(1)$ & $1(2)$ \\
\hline$C(12)$ & $14(1)$ & $23(1)$ & $16(1)$ & $-4(1)$ & $2(1)$ & $-1(1)$ \\
\hline$C(13)$ & $24(1)$ & $25(1)$ & $23(1)$ & $1(1)$ & $2(1)$ & $1(1)$ \\
\hline$C(14)$ & $27(2)$ & $44(2)$ & $24(1)$ & $2(1)$ & $-2(1)$ & $8(1)$ \\
\hline$C(15)$ & $21(1)$ & $52(2)$ & $26(2)$ & $-14(1)$ & $-1(1)$ & $-2(1)$ \\
\hline$C(16)$ & $26(2)$ & $32(2)$ & $31(2)$ & $-11(1)$ & $5(1)$ & $-9(1)$ \\
\hline$C(17)$ & $25(1)$ & $26(1)$ & $21(1)$ & $0(1)$ & $5(1)$ & $-3(1)$ \\
\hline
\end{tabular}


Hydrogen coordinates ( $\left.x 10^{4}\right)$ and isotropic displacement parameters $\left(\AA^{2} \times 10^{3}\right)$ for 13 .

\begin{tabular}{|c|c|c|c|c|}
\hline & $\mathrm{x}$ & $\mathrm{y}$ & $\mathrm{z}$ & $\mathrm{U}(\mathrm{eq})$ \\
\hline \multicolumn{5}{|l|}{ - } \\
\hline $\mathrm{H}(2 \mathrm{~A})$ & 6775 & 5580 & 5726 & 28 \\
\hline $\mathrm{H}(3 \mathrm{~A})$ & 7670 & 7714 & 5695 & 35 \\
\hline $\mathrm{H}(4 \mathrm{~A})$ & 9172 & 8186 & 4840 & 32 \\
\hline $\mathrm{H}(5 \mathrm{~A})$ & 9775 & 6548 & 3983 & 25 \\
\hline $\mathrm{H}(8 \mathrm{~A})$ & 10508 & 2690 & 2729 & 38 \\
\hline $\mathrm{H}(8 \mathrm{~B})$ & 9326 & 3458 & 2243 & 38 \\
\hline $\mathrm{H}(8 \mathrm{AA})$ & 10682 & 2630 & 3094 & 47 \\
\hline $\mathrm{H}(8 \mathrm{AB})$ & 9828 & 3100 & 2300 & 47 \\
\hline $\mathrm{H}(10 \mathrm{~A})$ & 8539 & 254 & 3531 & 69 \\
\hline $\mathrm{H}(10 \mathrm{~B})$ & 9887 & 922 & 3832 & 69 \\
\hline $\mathrm{H}(10 \mathrm{C})$ & 9629 & 348 & 2956 & 69 \\
\hline $\mathrm{H}(11 \mathrm{~A})$ & 6965 & 1446 & 2612 & 58 \\
\hline $\mathrm{H}(11 \mathrm{~B})$ & 7963 & 1565 & 1978 & 58 \\
\hline $\mathrm{H}(11 \mathrm{C})$ & 7302 & 2876 & 2277 & 58 \\
\hline $\mathrm{H}(13 \mathrm{~A})$ & 5195 & 4077 & 3272 & 29 \\
\hline $\mathrm{H}(14 \mathrm{~A})$ & 3592 & 3448 & 2277 & 38 \\
\hline $\mathrm{H}(15 \mathrm{~A})$ & 2793 & 1275 & 2247 & 40 \\
\hline $\mathrm{H}(16 \mathrm{~A})$ & 3553 & -247 & 3213 & 36 \\
\hline $\mathrm{H}(17 \mathrm{~A})$ & 5149 & 384 & 4210 & 28 \\
\hline
\end{tabular}


Torsion angles $\left[{ }^{\circ}\right]$ for $\mathbf{1 3}$.

\begin{tabular}{lc}
\hline $\mathrm{C}(6)-\mathrm{C}(1)-\mathrm{C}(2)-\mathrm{C}(3)$ & $1.9(4)$ \\
$\mathrm{Sn}(1)-\mathrm{C}(1)-\mathrm{C}(2)-\mathrm{C}(3)$ & $-174.54(19)$ \\
$\mathrm{C}(1)-\mathrm{C}(2)-\mathrm{C}(3)-\mathrm{C}(4)$ & $-2.2(4)$ \\
$\mathrm{C}(2)-\mathrm{C}(3)-\mathrm{C}(4)-\mathrm{C}(5)$ & $0.6(4)$ \\
$\mathrm{C}(3)-\mathrm{C}(4)-\mathrm{C}(5)-\mathrm{C}(6)$ & $1.2(4)$ \\
$\mathrm{C}(4)-\mathrm{C}(5)-\mathrm{C}(6)-\mathrm{C}(1)$ & $-1.5(3)$ \\
$\mathrm{C}(4)-\mathrm{C}(5)-\mathrm{C}(6)-\mathrm{C}(7)$ & $177.0(2)$ \\
$\mathrm{C}(2)-\mathrm{C}(1)-\mathrm{C}(6)-\mathrm{C}(5)$ & $0.0(3)$ \\
$\mathrm{Sn}(1)-\mathrm{C}(1)-\mathrm{C}(6)-\mathrm{C}(5)$ & $176.70(17)$ \\
$\mathrm{C}(2)-\mathrm{C}(1)-\mathrm{C}(6)-\mathrm{C}(7)$ & $-178.6(2)$ \\
$\mathrm{Sn}(1)-\mathrm{C}(1)-\mathrm{C}(6)-\mathrm{C}(7)$ & $-1.9(3)$ \\
$\mathrm{C}(9)-\mathrm{N}(1)-\mathrm{C}(7)-\mathrm{O}(1)$ & $-10(2)$ \\
$\mathrm{Sn}(1)-\mathrm{N}(1)-\mathrm{C}(7)-\mathrm{O}(1)$ & $172(2)$ \\
$\mathrm{C}(9)-\mathrm{N}(1)-\mathrm{C}(7)-\mathrm{O}(1 \mathrm{~A})$ & $2.5(12)$ \\
$\mathrm{Sn}(1)-\mathrm{N}(1)-\mathrm{C}(7)-\mathrm{O}(1 \mathrm{~A})$ & $-175.1(12)$ \\
$\mathrm{C}(9)-\mathrm{N}(1)-\mathrm{C}(7)-\mathrm{C}(6)$ & $176.5(2)$ \\
$\mathrm{Sn}(1)-\mathrm{N}(1)-\mathrm{C}(7)-\mathrm{C}(6)$ & $-1.1(3)$ \\
$\mathrm{C}(8)-\mathrm{O}(1)-\mathrm{C}(7)-\mathrm{N}(1)$ & $16(4)$ \\
$\mathrm{C}(8)-\mathrm{O}(1)-\mathrm{C}(7)-\mathrm{C}(6)$ & $-170(3)$ \\
$\mathrm{C}(8 \mathrm{~A})-\mathrm{O}(1 \mathrm{~A})-\mathrm{C}(7)-\mathrm{N}(1)$ & $-14(2)$ \\
$\mathrm{C}(8 \mathrm{~A})-\mathrm{O}(1 \mathrm{~A})-\mathrm{C}(7)-\mathrm{C}(6)$ & $171.7(13)$ \\
$\mathrm{C}(5)-\mathrm{C}(6)-\mathrm{C}(7)-\mathrm{N}(1)$ & $-176.5(2)$ \\
$\mathrm{C}(1)-\mathrm{C}(6)-\mathrm{C}(7)-\mathrm{N}(1)$ & $2.1(3)$ \\
$\mathrm{C}(5)-\mathrm{C}(6)-\mathrm{C}(7)-\mathrm{O}(1)$ & $10(2)$ \\
$\mathrm{C}(1)-\mathrm{C}(6)-\mathrm{C}(7)-\mathrm{O}(1)$ & $-171(2)$ \\
$\mathrm{C}(5)-\mathrm{C}(6)-\mathrm{C}(7)-\mathrm{O}(1 \mathrm{~A})$ & $-2.6(12)$ \\
$\mathrm{C}(1)-\mathrm{C}(6)-\mathrm{C}(7)-\mathrm{O}(1 \mathrm{~A})$ & $176.0(12)$ \\
$\mathrm{C}(7)-\mathrm{O}(1)-\mathrm{C}(8)-\mathrm{C}(9)$ & $-15(5)$ \\
$\mathrm{C}(7)-\mathrm{O}(1 \mathrm{~A})-\mathrm{C}(8 \mathrm{~A})-\mathrm{C}(9)$ & $19(2)$ \\
$\mathrm{C}(7)-\mathrm{N}(1)-\mathrm{C}(9)-\mathrm{C}(10)$ & $125.6(2)$ \\
$\mathrm{Sn}(1)-\mathrm{N}(1)-\mathrm{C}(9)-\mathrm{C}(10)$ & $-58.2(3)$ \\
$\mathrm{C}(7)-\mathrm{N}(1)-\mathrm{C}(9)-\mathrm{C}(11)$ & $-111.2(2)$ \\
$\mathrm{Sn}(1)-\mathrm{N}(1)-\mathrm{C}(9)-\mathrm{C}(11)$ & $65.0(3)$ \\
$\mathrm{C}(7)-\mathrm{N}(1)-\mathrm{C}(9)-\mathrm{C}(8 \mathrm{~A})$ & \\
& \\
&
\end{tabular}




$\begin{array}{lc}\mathrm{Sn}(1)-\mathrm{N}(1)-\mathrm{C}(9)-\mathrm{C}(8 \mathrm{~A}) & -174.2(9) \\ \mathrm{C}(7)-\mathrm{N}(1)-\mathrm{C}(9)-\mathrm{C}(8) & -0.7(19) \\ \mathrm{Sn}(1)-\mathrm{N}(1)-\mathrm{C}(9)-\mathrm{C}(8) & 175.6(19) \\ \mathrm{O}(1 \mathrm{~A})-\mathrm{C}(8 \mathrm{~A})-\mathrm{C}(9)-\mathrm{N}(1) & -16.8(18) \\ \mathrm{O}(1 \mathrm{~A})-\mathrm{C}(8 \mathrm{~A})-\mathrm{C}(9)-\mathrm{C}(10) & -134.1(15) \\ \mathrm{O}(1 \mathrm{~A})-\mathrm{C}(8 \mathrm{~A})-\mathrm{C}(9)-\mathrm{C}(11) & 100.5(16) \\ \mathrm{O}(1)-\mathrm{C}(8)-\mathrm{C}(9)-\mathrm{N}(1) & 9(4) \\ \mathrm{O}(1)-\mathrm{C}(8)-\mathrm{C}(9)-\mathrm{C}(10) & -112(3) \\ \mathrm{O}(1)-\mathrm{C}(8)-\mathrm{C}(9)-\mathrm{C}(11) & 123(3) \\ \mathrm{C}(17)-\mathrm{C}(12)-\mathrm{C}(13)-\mathrm{C}(14) & -0.2(4) \\ \mathrm{Sn}(1)-\mathrm{C}(12)-\mathrm{C}(13)-\mathrm{C}(14) & 178.2(2) \\ \mathrm{C}(12)-\mathrm{C}(13)-\mathrm{C}(14)-\mathrm{C}(15) & -0.3(4) \\ \mathrm{C}(13)-\mathrm{C}(14)-\mathrm{C}(15)-\mathrm{C}(16) & 0.7(4) \\ \mathrm{C}(14)-\mathrm{C}(15)-\mathrm{C}(16)-\mathrm{C}(17) & -0.5(4) \\ \mathrm{C}(13)-\mathrm{C}(12)-\mathrm{C}(17)-\mathrm{C}(16) & 0.4(4) \\ \mathrm{Sn}(1)-\mathrm{C}(12)-\mathrm{C}(17)-\mathrm{C}(16) & -178.03(19) \\ \mathrm{C}(15)-\mathrm{C}(16)-\mathrm{C}(17)-\mathrm{C}(12) & 0.0(4) \\ & \end{array}$

Symmetry transformations used to generate equivalent atoms: 
Table A4: Crystal data and structure refinement for 18 .

Identification code

Empirical formula

Formula weight

Temperature

Wavelength

Crystal system

Space group

Unit cell dimensions

Volume

$\mathrm{Z}$

Density (calculated)

Absorption coefficient

$\mathrm{F}(000)$

Crystal size

Theta range for data collection

Index ranges

Reflections collected

Independent reflections

Completeness to theta $=25.242^{\circ}$

Absorption correction

Max. and min. transmission

Refinement method

Data / restraints / parameters

Goodness-of-fit on $\mathrm{F}^{2}$

Final $\mathrm{R}$ indices [I>2sigma(I)]

$\mathrm{R}$ indices (all data)

Absolute structure parameter

Extinction coefficient

Largest diff. peak and hole d1887_a

C30 H29 N O Sn

538.23

150(2) K

$0.71073 \AA$

Orthorhombic

$\mathrm{P} 212121$

$\mathrm{a}=8.4502(2) \AA \quad \square=90^{\circ}$.

$\mathrm{b}=18.9557(5) \AA \quad \square=90^{\circ}$.

$\mathrm{c}=31.5231(9) \AA \quad \square=90^{\circ}$.

5049.4(2) $\AA^{3}$

8

$1.416 \mathrm{Mg} / \mathrm{m}^{3}$

$1.034 \mathrm{~mm}^{-1}$

2192

$0.400 \times 0.080 \times 0.080 \mathrm{~mm}^{3}$

1.680 to $27.489^{\circ}$.

$-10<=\mathrm{h}<=8,-24<=\mathrm{k}<=21,-40<=\mathrm{l}<=40$

27514

$11499[\mathrm{R}(\mathrm{int})=0.0346]$

$99.5 \%$

Semi-empirical from equivalents

0.7456 and 0.6836

Full-matrix least-squares on $\mathrm{F}^{2}$

11499 / 0 / 599

0.987

$\mathrm{R} 1=0.0316, \mathrm{wR} 2=0.0485$

$\mathrm{R} 1=0.0449, \mathrm{wR} 2=0.0517$

$0.008(11)$

$\mathrm{n} / \mathrm{a}$

0.473 and -0.414 e. $\AA^{-3}$ 
Atomic coordinates ( $\left.\mathrm{x} 10^{4}\right)$ and equivalent isotropic displacement parameters $\left(\AA^{2} \times 10^{3}\right)$ for 18. $\mathrm{U}(\mathrm{eq})$ is defined as one third of the trace of the orthogonalized $\mathrm{Uij}^{\mathrm{ij}}$ tensor.

\begin{tabular}{|c|c|c|c|c|}
\hline - & $\mathrm{X}$ & $\mathrm{y}$ & $\mathrm{z}$ & $\mathrm{U}(\mathrm{eq})$ \\
\hline \multicolumn{5}{|l|}{ - } \\
\hline $\operatorname{Sn}(1 \mathrm{~A})$ & $7729(1)$ & $6447(1)$ & $3679(1)$ & $19(1)$ \\
\hline $\mathrm{O}(1 \mathrm{~A})$ & $9605(3)$ & 3999(2) & $3330(1)$ & $29(1)$ \\
\hline $\mathrm{N}(1 \mathrm{~A})$ & $9128(4)$ & $5142(2)$ & $3171(1)$ & $21(1)$ \\
\hline$C(1 \mathrm{~A})$ & $6114(4)$ & $5689(2)$ & $3405(1)$ & $22(1)$ \\
\hline$C(2 A)$ & $6100(4)$ & $5032(2)$ & $3665(2)$ & $20(1)$ \\
\hline$C(3 \mathrm{~A})$ & $4897(5)$ & 4933(2) & $3963(2)$ & $27(1)$ \\
\hline $\mathrm{C}(4 \mathrm{~A})$ & $4861(5)$ & $4371(3)$ & $4235(2)$ & $34(1)$ \\
\hline$C(5 A)$ & $6025(5)$ & $3847(3)$ & $4208(2)$ & $33(1)$ \\
\hline$C(6 A)$ & $7217(5)$ & $3922(2)$ & $3911(2)$ & $29(1)$ \\
\hline$C(7 A)$ & $7289(4)$ & $4506(2)$ & $3643(1)$ & $20(1)$ \\
\hline $\mathrm{C}(8 \mathrm{~A})$ & $8677(4)$ & $4587(2)$ & $3365(1)$ & $21(1)$ \\
\hline $\mathrm{C}(9 \mathrm{~A})$ & $11042(5)$ & $4238(3)$ & $3130(2)$ & $30(1)$ \\
\hline$C(10 A)$ & $10624(5)$ & $4964(2)$ & 2949(1) & $22(1)$ \\
\hline$C(11 A)$ & $10309(5)$ & $4941(3)$ & $2475(2)$ & $32(1)$ \\
\hline $\mathrm{C}(12 \mathrm{~A})$ & $11864(5)$ & $5519(2)$ & $3056(2)$ & $31(1)$ \\
\hline$C(13 A)$ & $6209(5)$ & $7123(2)$ & $4050(1)$ & $20(1)$ \\
\hline $\mathrm{C}(14 \mathrm{~A})$ & $6579(5)$ & $7281(3)$ & $4471(2)$ & $28(1)$ \\
\hline$C(15 A)$ & $5609(6)$ & $7704(3)$ & $4715(2)$ & $38(1)$ \\
\hline$C(16 A)$ & $4263(6)$ & 7990(3) & $4540(2)$ & $39(1)$ \\
\hline $\mathrm{C}(17 \mathrm{~A})$ & $3869(5)$ & 7841(3) & $4130(2)$ & $35(1)$ \\
\hline $\mathrm{C}(18 \mathrm{~A})$ & $4827(5)$ & $7408(2)$ & $3881(2)$ & $29(1)$ \\
\hline $\mathrm{C}(19 \mathrm{~A})$ & 8923(4) & $7085(2)$ & $3215(1)$ & $20(1)$ \\
\hline $\mathrm{C}(20 \mathrm{~A})$ & $8750(5)$ & $6976(2)$ & $2784(1)$ & $23(1)$ \\
\hline $\mathrm{C}(21 \mathrm{~A})$ & $9505(5)$ & $7407(2)$ & 2493(2) & $30(1)$ \\
\hline $\mathrm{C}(22 \mathrm{~A})$ & $10484(5)$ & $7943(2)$ & $2628(2)$ & $31(1)$ \\
\hline $\mathrm{C}(23 \mathrm{~A})$ & $10700(5)$ & $8055(2)$ & $3057(2)$ & $29(1)$ \\
\hline $\mathrm{C}(24 \mathrm{~A})$ & $9908(5)$ & $7632(2)$ & $3349(2)$ & $26(1)$ \\
\hline $\mathrm{C}(25 \mathrm{~A})$ & $9395(5)$ & $6027(2)$ & $4126(1)$ & $20(1)$ \\
\hline $\mathrm{C}(26 \mathrm{~A})$ & $10918(5)$ & $6308(2)$ & $4148(1)$ & $22(1)$ \\
\hline
\end{tabular}




\begin{tabular}{|c|c|c|c|c|}
\hline $\mathrm{C}(27 \mathrm{~A})$ & $12009(5)$ & $6063(2)$ & $4442(1)$ & $26(1)$ \\
\hline$C(28 A)$ & $11609(5)$ & $5522(2)$ & $4715(1)$ & $28(1)$ \\
\hline$C(29 A)$ & $10108(5)$ & $5234(3)$ & $4697(2)$ & $28(1)$ \\
\hline$C(30 A)$ & $9003(5)$ & $5495(2)$ & $4410(1)$ & $21(1)$ \\
\hline $\operatorname{Sn}(1 \mathrm{~B})$ & $2962(1)$ & $374(1)$ & $3700(1)$ & $21(1)$ \\
\hline $\mathrm{O}(1 \mathrm{~B})$ & $4814(3)$ & $2834(2)$ & $3327(1)$ & $33(1)$ \\
\hline $\mathrm{N}(1 \mathrm{~B})$ & $4352(4)$ & $1690(2)$ & $3164(1)$ & $23(1)$ \\
\hline$C(1 B)$ & $1372(5)$ & $1115(2)$ & $3406(1)$ & $22(1)$ \\
\hline $\mathrm{C}(2 \mathrm{~B})$ & $1310(4)$ & $1793(2)$ & $3650(2)$ & $20(1)$ \\
\hline $\mathrm{C}(3 \mathrm{~B})$ & $69(5)$ & $1904(2)$ & $3935(2)$ & $25(1)$ \\
\hline$C(4 B)$ & $-34(5)$ & $2506(3)$ & $4180(2)$ & $29(1)$ \\
\hline $\mathrm{C}(5 \mathrm{~B})$ & $1097(5)$ & $3026(3)$ & $4149(2)$ & $29(1)$ \\
\hline$C(6 B)$ & $2341(5)$ & $2934(2)$ & $3870(1)$ & $24(1)$ \\
\hline$C(7 B)$ & 2481(4) & $2329(2)$ & $3624(1)$ & $21(1)$ \\
\hline $\mathrm{C}(8 \mathrm{~B})$ & $3883(5)$ & $2241(2)$ & $3354(1)$ & $20(1)$ \\
\hline $\mathrm{C}(9 \mathrm{~B})$ & $6241(5)$ & $2610(2)$ & $3113(2)$ & $31(1)$ \\
\hline $\mathrm{C}(10 \mathrm{~B})$ & $5854(5)$ & $1866(2)$ & $2944(2)$ & $23(1)$ \\
\hline $\mathrm{C}(11 \mathrm{~B})$ & $5574(5)$ & $1868(3)$ & $2466(2)$ & $31(1)$ \\
\hline $\mathrm{C}(12 \mathrm{~B})$ & $7105(5)$ & $1326(3)$ & $3063(2)$ & $34(1)$ \\
\hline$C(13 B)$ & $1408(5)$ & $-284(2)$ & $4069(1)$ & $23(1)$ \\
\hline$C(14 B)$ & $1671(5)$ & $-401(3)$ & $4498(2)$ & $32(1)$ \\
\hline $\mathrm{C}(15 \mathrm{~B})$ & $682(5)$ & $-841(3)$ & $4734(2)$ & $38(1)$ \\
\hline$C(16 B)$ & $-581(6)$ & $-1155(3)$ & $4545(2)$ & $36(1)$ \\
\hline$C(17 B)$ & $-900(5)$ & $-1040(3)$ & $4119(2)$ & $35(1)$ \\
\hline $\mathrm{C}(18 \mathrm{~B})$ & $84(5)$ & $-605(2)$ & $3884(2)$ & $30(1)$ \\
\hline$C(19 B)$ & $4144(4)$ & $-273(2)$ & $3243(1)$ & $21(1)$ \\
\hline $\mathrm{C}(20 \mathrm{~B})$ & $3993(5)$ & $-156(2)$ & 2811(1) & $25(1)$ \\
\hline$C(21 B)$ & $4727(5)$ & $-594(2)$ & $2516(2)$ & $29(1)$ \\
\hline $\mathrm{C}(22 \mathrm{~B})$ & $5647(5)$ & $-1145(3)$ & $2652(2)$ & $32(1)$ \\
\hline$C(23 B)$ & $5822(5)$ & $-1270(3)$ & $3080(2)$ & $33(1)$ \\
\hline$C(24 B)$ & $5062(5)$ & $-843(2)$ & $3376(2)$ & $29(1)$ \\
\hline$C(25 B)$ & $4631(5)$ & $808(2)$ & $4141(2)$ & $22(1)$ \\
\hline$C(26 B)$ & $6162(5)$ & $530(3)$ & $4169(1)$ & $26(1)$ \\
\hline$C(27 B)$ & $7244(5)$ & $786(3)$ & $4459(1)$ & $34(1)$ \\
\hline$C(28 B)$ & $6840(6)$ & $1342(3)$ & $4721(2)$ & $40(1)$ \\
\hline $\mathrm{C}(29 \mathrm{~B})$ & $5337(6)$ & $1629(3)$ & $4698(2)$ & $39(1)$ \\
\hline
\end{tabular}


Bond lengths $[\AA]$ and angles $\left[{ }^{\circ}\right]$ for $\mathbf{1 8}$.

\begin{tabular}{|c|c|}
\hline $\operatorname{Sn}(1 \mathrm{~A})-\mathrm{C}(25 \mathrm{~A})$ & $2.143(4)$ \\
\hline $\operatorname{Sn}(1 A)-C(19 A)$ & $2.150(4)$ \\
\hline $\operatorname{Sn}(1 \mathrm{~A})-\mathrm{C}(13 \mathrm{~A})$ & $2.158(4)$ \\
\hline $\operatorname{Sn}(1 \mathrm{~A})-\mathrm{C}(1 \mathrm{~A})$ & $2.162(4)$ \\
\hline $\mathrm{O}(1 \mathrm{~A})-\mathrm{C}(8 \mathrm{~A})$ & $1.367(5)$ \\
\hline $\mathrm{O}(1 \mathrm{~A})-\mathrm{C}(9 \mathrm{~A})$ & $1.441(5)$ \\
\hline $\mathrm{N}(1 \mathrm{~A})-\mathrm{C}(8 \mathrm{~A})$ & $1.275(5)$ \\
\hline $\mathrm{N}(1 \mathrm{~A})-\mathrm{C}(10 \mathrm{~A})$ & $1.484(5)$ \\
\hline $\mathrm{C}(1 \mathrm{~A})-\mathrm{C}(2 \mathrm{~A})$ & $1.490(6)$ \\
\hline $\mathrm{C}(1 \mathrm{~A})-\mathrm{H}(1 \mathrm{AA})$ & 0.9900 \\
\hline $\mathrm{C}(1 \mathrm{~A})-\mathrm{H}(1 \mathrm{AB})$ & 0.9900 \\
\hline$C(2 A)-C(3 A)$ & $1.397(6)$ \\
\hline $\mathrm{C}(2 \mathrm{~A})-\mathrm{C}(7 \mathrm{~A})$ & $1.418(5)$ \\
\hline$C(3 A)-C(4 A)$ & $1.368(7)$ \\
\hline $\mathrm{C}(3 \mathrm{~A})-\mathrm{H}(3 \mathrm{AA})$ & 0.9500 \\
\hline$C(4 A)-C(5 A)$ & $1.400(7)$ \\
\hline $\mathrm{C}(4 \mathrm{~A})-\mathrm{H}(4 \mathrm{AA})$ & 0.9500 \\
\hline$C(5 A)-C(6 A)$ & $1.383(6)$ \\
\hline $\mathrm{C}(5 \mathrm{~A})-\mathrm{H}(5 \mathrm{AA})$ & 0.9500 \\
\hline$C(6 A)-C(7 A)$ & $1.393(6)$ \\
\hline $\mathrm{C}(6 \mathrm{~A})-\mathrm{H}(6 \mathrm{AA})$ & 0.9500 \\
\hline $\mathrm{C}(7 \mathrm{~A})-\mathrm{C}(8 \mathrm{~A})$ & $1.473(5)$ \\
\hline$C(9 A)-C(10 A)$ & $1.532(6)$ \\
\hline $\mathrm{C}(9 \mathrm{~A})-\mathrm{H}(9 \mathrm{AA})$ & 0.9900 \\
\hline $\mathrm{C}(9 \mathrm{~A})-\mathrm{H}(9 \mathrm{AB})$ & 0.9900 \\
\hline$C(10 A)-C(11 A)$ & $1.519(6)$ \\
\hline$C(10 A)-C(12 A)$ & $1.522(6)$ \\
\hline $\mathrm{C}(11 \mathrm{~A})-\mathrm{H}(11 \mathrm{~A})$ & 0.9800 \\
\hline $\mathrm{C}(11 \mathrm{~A})-\mathrm{H}(11 \mathrm{~B})$ & 0.9800 \\
\hline $\mathrm{C}(11 \mathrm{~A})-\mathrm{H}(11 \mathrm{C})$ & 0.9800 \\
\hline $\mathrm{C}(12 \mathrm{~A})-\mathrm{H}(12 \mathrm{~A})$ & 0.9800 \\
\hline $\mathrm{C}(12 \mathrm{~A})-\mathrm{H}(12 \mathrm{~B})$ & 0.9800 \\
\hline $\mathrm{C}(12 \mathrm{~A})-\mathrm{H}(12 \mathrm{C})$ & 0.9800 \\
\hline $\mathrm{C}(13 \mathrm{~A})-\mathrm{C}(18 \mathrm{~A})$ & $1.392(6)$ \\
\hline
\end{tabular}




\begin{tabular}{|c|c|}
\hline$C(13 A)-C(14 A)$ & $1.396(6)$ \\
\hline$C(14 A)-C(15 A)$ & $1.381(6)$ \\
\hline $\mathrm{C}(14 \mathrm{~A})-\mathrm{H}(14 \mathrm{~A})$ & 0.9500 \\
\hline$C(15 A)-C(16 A)$ & $1.374(7)$ \\
\hline $\mathrm{C}(15 \mathrm{~A})-\mathrm{H}(15 \mathrm{~A})$ & 0.9500 \\
\hline$C(16 A)-C(17 A)$ & $1.364(7)$ \\
\hline $\mathrm{C}(16 \mathrm{~A})-\mathrm{H}(16 \mathrm{~A})$ & 0.9500 \\
\hline $\mathrm{C}(17 \mathrm{~A})-\mathrm{C}(18 \mathrm{~A})$ & $1.394(6)$ \\
\hline $\mathrm{C}(17 \mathrm{~A})-\mathrm{H}(17 \mathrm{~A})$ & 0.9500 \\
\hline $\mathrm{C}(18 \mathrm{~A})-\mathrm{H}(18 \mathrm{~A})$ & 0.9500 \\
\hline$C(19 A)-C(20 A)$ & $1.383(6)$ \\
\hline$C(19 A)-C(24 A)$ & $1.395(6)$ \\
\hline$C(20 A)-C(21 A)$ & $1.383(6)$ \\
\hline $\mathrm{C}(20 \mathrm{~A})-\mathrm{H}(20 \mathrm{~A})$ & 0.9500 \\
\hline $\mathrm{C}(21 \mathrm{~A})-\mathrm{C}(22 \mathrm{~A})$ & $1.377(6)$ \\
\hline $\mathrm{C}(21 \mathrm{~A})-\mathrm{H}(21 \mathrm{~A})$ & 0.9500 \\
\hline $\mathrm{C}(22 \mathrm{~A})-\mathrm{C}(23 \mathrm{~A})$ & $1.382(7)$ \\
\hline $\mathrm{C}(22 \mathrm{~A})-\mathrm{H}(22 \mathrm{~A})$ & 0.9500 \\
\hline $\mathrm{C}(23 \mathrm{~A})-\mathrm{C}(24 \mathrm{~A})$ & $1.393(6)$ \\
\hline $\mathrm{C}(23 \mathrm{~A})-\mathrm{H}(23 \mathrm{~A})$ & 0.9500 \\
\hline $\mathrm{C}(24 \mathrm{~A})-\mathrm{H}(24 \mathrm{~A})$ & 0.9500 \\
\hline$C(25 A)-C(30 A)$ & $1.389(6)$ \\
\hline$C(25 A)-C(26 A)$ & $1.395(6)$ \\
\hline$C(26 A)-C(27 A)$ & $1.388(6)$ \\
\hline $\mathrm{C}(26 \mathrm{~A})-\mathrm{H}(26 \mathrm{~A})$ & 0.9500 \\
\hline $\mathrm{C}(27 \mathrm{~A})-\mathrm{C}(28 \mathrm{~A})$ & $1.381(6)$ \\
\hline $\mathrm{C}(27 \mathrm{~A})-\mathrm{H}(27 \mathrm{~A})$ & 0.9500 \\
\hline $\mathrm{C}(28 \mathrm{~A})-\mathrm{C}(29 \mathrm{~A})$ & $1.382(6)$ \\
\hline $\mathrm{C}(28 \mathrm{~A})-\mathrm{H}(28 \mathrm{~A})$ & 0.9500 \\
\hline$C(29 A)-C(30 A)$ & $1.392(6)$ \\
\hline $\mathrm{C}(29 \mathrm{~A})-\mathrm{H}(29 \mathrm{~A})$ & 0.9500 \\
\hline $\mathrm{C}(30 \mathrm{~A})-\mathrm{H}(30 \mathrm{~A})$ & 0.9500 \\
\hline $\operatorname{Sn}(1 B)-C(19 B)$ & $2.139(4)$ \\
\hline $\operatorname{Sn}(1 B)-C(25 B)$ & $2.144(4)$ \\
\hline $\operatorname{Sn}(1 \mathrm{~B})-\mathrm{C}(1 \mathrm{~B})$ & $2.153(4)$ \\
\hline $\operatorname{Sn}(1 B)-C(13 B)$ & $2.155(4)$ \\
\hline
\end{tabular}




\begin{tabular}{|c|c|}
\hline $\mathrm{O}(1 \mathrm{~B})-\mathrm{C}(8 \mathrm{~B})$ & $1.375(5)$ \\
\hline $\mathrm{O}(1 \mathrm{~B})-\mathrm{C}(9 \mathrm{~B})$ & $1.446(5)$ \\
\hline $\mathrm{N}(1 \mathrm{~B})-\mathrm{C}(8 \mathrm{~B})$ & $1.267(5)$ \\
\hline $\mathrm{N}(1 \mathrm{~B})-\mathrm{C}(10 \mathrm{~B})$ & $1.483(5)$ \\
\hline $\mathrm{C}(1 \mathrm{~B})-\mathrm{C}(2 \mathrm{~B})$ & $1.500(6)$ \\
\hline $\mathrm{C}(1 \mathrm{~B})-\mathrm{H}(1 \mathrm{BA})$ & 0.9900 \\
\hline $\mathrm{C}(1 \mathrm{~B})-\mathrm{H}(1 \mathrm{BB})$ & 0.9900 \\
\hline $\mathrm{C}(2 \mathrm{~B})-\mathrm{C}(3 \mathrm{~B})$ & $1.397(6)$ \\
\hline $\mathrm{C}(2 \mathrm{~B})-\mathrm{C}(7 \mathrm{~B})$ & $1.421(5)$ \\
\hline$C(3 B)-C(4 B)$ & $1.380(6)$ \\
\hline $\mathrm{C}(3 \mathrm{~B})-\mathrm{H}(3 \mathrm{BA})$ & 0.9500 \\
\hline $\mathrm{C}(4 \mathrm{~B})-\mathrm{C}(5 \mathrm{~B})$ & $1.376(6)$ \\
\hline $\mathrm{C}(4 \mathrm{~B})-\mathrm{H}(4 \mathrm{BA})$ & 0.9500 \\
\hline$C(5 B)-C(6 B)$ & $1.381(6)$ \\
\hline $\mathrm{C}(5 \mathrm{~B})-\mathrm{H}(5 \mathrm{BA})$ & 0.9500 \\
\hline $\mathrm{C}(6 \mathrm{~B})-\mathrm{C}(7 \mathrm{~B})$ & $1.389(5)$ \\
\hline $\mathrm{C}(6 \mathrm{~B})-\mathrm{H}(6 \mathrm{BA})$ & 0.9500 \\
\hline C(7B)-C(8B) & $1.468(5)$ \\
\hline $\mathrm{C}(9 \mathrm{~B})-\mathrm{C}(10 \mathrm{~B})$ & $1.543(6)$ \\
\hline C(9B)-H(9BA) & 0.9900 \\
\hline $\mathrm{C}(9 \mathrm{~B})-\mathrm{H}(9 \mathrm{BB})$ & 0.9900 \\
\hline $\mathrm{C}(10 \mathrm{~B})-\mathrm{C}(12 \mathrm{~B})$ & $1.518(6)$ \\
\hline$C(10 B)-C(11 B)$ & $1.525(6)$ \\
\hline$C(11 B)-H(11 D)$ & 0.9800 \\
\hline $\mathrm{C}(11 \mathrm{~B})-\mathrm{H}(11 \mathrm{E})$ & 0.9800 \\
\hline $\mathrm{C}(11 \mathrm{~B})-\mathrm{H}(11 \mathrm{~F})$ & 0.9800 \\
\hline $\mathrm{C}(12 \mathrm{~B})-\mathrm{H}(12 \mathrm{D})$ & 0.9800 \\
\hline $\mathrm{C}(12 \mathrm{~B})-\mathrm{H}(12 \mathrm{E})$ & 0.9800 \\
\hline $\mathrm{C}(12 \mathrm{~B})-\mathrm{H}(12 \mathrm{~F})$ & 0.9800 \\
\hline$C(13 B)-C(14 B)$ & $1.388(6)$ \\
\hline $\mathrm{C}(13 \mathrm{~B})-\mathrm{C}(18 \mathrm{~B})$ & $1.400(6)$ \\
\hline$C(14 B)-C(15 B)$ & $1.394(6)$ \\
\hline $\mathrm{C}(14 \mathrm{~B})-\mathrm{H}(14 \mathrm{~B})$ & 0.9500 \\
\hline$C(15 B)-C(16 B)$ & $1.359(7)$ \\
\hline $\mathrm{C}(15 \mathrm{~B})-\mathrm{H}(15 \mathrm{~B})$ & 0.9500 \\
\hline $\mathrm{C}(16 \mathrm{~B})-\mathrm{C}(17 \mathrm{~B})$ & $1.386(7)$ \\
\hline
\end{tabular}




\begin{tabular}{|c|c|}
\hline $\mathrm{C}(16 \mathrm{~B})-\mathrm{H}(16 \mathrm{~B})$ & 0.9500 \\
\hline $\mathrm{C}(17 \mathrm{~B})-\mathrm{C}(18 \mathrm{~B})$ & $1.385(6)$ \\
\hline $\mathrm{C}(17 \mathrm{~B})-\mathrm{H}(17 \mathrm{~B})$ & 0.9500 \\
\hline $\mathrm{C}(18 \mathrm{~B})-\mathrm{H}(18 \mathrm{~B})$ & 0.9500 \\
\hline$C(19 B)-C(20 B)$ & $1.386(6)$ \\
\hline $\mathrm{C}(19 \mathrm{~B})-\mathrm{C}(24 \mathrm{~B})$ & $1.394(6)$ \\
\hline$C(20 B)-C(21 B)$ & $1.394(6)$ \\
\hline $\mathrm{C}(20 \mathrm{~B})-\mathrm{H}(20 \mathrm{~B})$ & 0.9500 \\
\hline $\mathrm{C}(21 \mathrm{~B})-\mathrm{C}(22 \mathrm{~B})$ & $1.370(6)$ \\
\hline $\mathrm{C}(21 \mathrm{~B})-\mathrm{H}(21 \mathrm{~B})$ & 0.9500 \\
\hline $\mathrm{C}(22 \mathrm{~B})-\mathrm{C}(23 \mathrm{~B})$ & $1.379(7)$ \\
\hline $\mathrm{C}(22 \mathrm{~B})-\mathrm{H}(22 \mathrm{~B})$ & 0.9500 \\
\hline$C(23 B)-C(24 B)$ & $1.391(7)$ \\
\hline $\mathrm{C}(23 \mathrm{~B})-\mathrm{H}(23 \mathrm{~B})$ & 0.9500 \\
\hline $\mathrm{C}(24 \mathrm{~B})-\mathrm{H}(24 \mathrm{~B})$ & 0.9500 \\
\hline $\mathrm{C}(25 \mathrm{~B})-\mathrm{C}(30 \mathrm{~B})$ & $1.393(6)$ \\
\hline$C(25 B)-C(26 B)$ & $1.400(6)$ \\
\hline$C(26 B)-C(27 B)$ & $1.382(6)$ \\
\hline $\mathrm{C}(26 \mathrm{~B})-\mathrm{H}(26 \mathrm{~B})$ & 0.9500 \\
\hline $\mathrm{C}(27 \mathrm{~B})-\mathrm{C}(28 \mathrm{~B})$ & $1.380(7)$ \\
\hline $\mathrm{C}(27 \mathrm{~B})-\mathrm{H}(27 \mathrm{~B})$ & 0.9500 \\
\hline $\mathrm{C}(28 \mathrm{~B})-\mathrm{C}(29 \mathrm{~B})$ & $1.384(6)$ \\
\hline $\mathrm{C}(28 \mathrm{~B})-\mathrm{H}(28 \mathrm{~B})$ & 0.9500 \\
\hline$C(29 B)-C(30 B)$ & $1.387(6)$ \\
\hline C(29B)-H(29B) & 0.9500 \\
\hline $\mathrm{C}(30 \mathrm{~B})-\mathrm{H}(30 \mathrm{~B})$ & 0.9500 \\
\hline$C(25 A)-S n(1 A)-C(19 A)$ & $110.34(15)$ \\
\hline$C(25 A)-S n(1 A)-C(13 A)$ & $104.86(16)$ \\
\hline$C(19 A)-S n(1 A)-C(13 A)$ & $108.28(16)$ \\
\hline$C(25 A)-S n(1 A)-C(1 A)$ & $115.46(16)$ \\
\hline$C(19 A)-S n(1 A)-C(1 A)$ & $113.46(17)$ \\
\hline$C(13 \mathrm{~A})-\mathrm{Sn}(1 \mathrm{~A})-\mathrm{C}(1 \mathrm{~A})$ & $103.61(16)$ \\
\hline $\mathrm{C}(8 \mathrm{~A})-\mathrm{O}(1 \mathrm{~A})-\mathrm{C}(9 \mathrm{~A})$ & $105.2(3)$ \\
\hline $\mathrm{C}(8 \mathrm{~A})-\mathrm{N}(1 \mathrm{~A})-\mathrm{C}(10 \mathrm{~A})$ & $107.1(3)$ \\
\hline$C(2 A)-C(1 A)-S n(1 A)$ & $109.9(3)$ \\
\hline
\end{tabular}




\begin{tabular}{|c|c|}
\hline $\mathrm{C}(2 \mathrm{~A})-\mathrm{C}(1 \mathrm{~A})-\mathrm{H}(1 \mathrm{AA})$ & 109.7 \\
\hline $\operatorname{Sn}(1 \mathrm{~A})-\mathrm{C}(1 \mathrm{~A})-\mathrm{H}(1 \mathrm{AA})$ & 109.7 \\
\hline $\mathrm{C}(2 \mathrm{~A})-\mathrm{C}(1 \mathrm{~A})-\mathrm{H}(1 \mathrm{AB})$ & 109.7 \\
\hline $\operatorname{Sn}(1 \mathrm{~A})-\mathrm{C}(1 \mathrm{~A})-\mathrm{H}(1 \mathrm{AB})$ & 109.7 \\
\hline $\mathrm{H}(1 \mathrm{AA})-\mathrm{C}(1 \mathrm{~A})-\mathrm{H}(1 \mathrm{AB})$ & 108.2 \\
\hline $\mathrm{C}(3 \mathrm{~A})-\mathrm{C}(2 \mathrm{~A})-\mathrm{C}(7 \mathrm{~A})$ & $117.0(4)$ \\
\hline $\mathrm{C}(3 \mathrm{~A})-\mathrm{C}(2 \mathrm{~A})-\mathrm{C}(1 \mathrm{~A})$ & $119.2(4)$ \\
\hline$C(7 A)-C(2 A)-C(1 A)$ & $123.7(4)$ \\
\hline $\mathrm{C}(4 \mathrm{~A})-\mathrm{C}(3 \mathrm{~A})-\mathrm{C}(2 \mathrm{~A})$ & $122.8(4)$ \\
\hline $\mathrm{C}(4 \mathrm{~A})-\mathrm{C}(3 \mathrm{~A})-\mathrm{H}(3 \mathrm{AA})$ & 118.6 \\
\hline $\mathrm{C}(2 \mathrm{~A})-\mathrm{C}(3 \mathrm{~A})-\mathrm{H}(3 \mathrm{AA})$ & 118.6 \\
\hline $\mathrm{C}(3 \mathrm{~A})-\mathrm{C}(4 \mathrm{~A})-\mathrm{C}(5 \mathrm{~A})$ & $119.9(4)$ \\
\hline $\mathrm{C}(3 \mathrm{~A})-\mathrm{C}(4 \mathrm{~A})-\mathrm{H}(4 \mathrm{AA})$ & 120.1 \\
\hline $\mathrm{C}(5 \mathrm{~A})-\mathrm{C}(4 \mathrm{~A})-\mathrm{H}(4 \mathrm{AA})$ & 120.1 \\
\hline$C(6 A)-C(5 A)-C(4 A)$ & $118.7(5)$ \\
\hline $\mathrm{C}(6 \mathrm{~A})-\mathrm{C}(5 \mathrm{~A})-\mathrm{H}(5 \mathrm{AA})$ & 120.6 \\
\hline $\mathrm{C}(4 \mathrm{~A})-\mathrm{C}(5 \mathrm{~A})-\mathrm{H}(5 \mathrm{AA})$ & 120.6 \\
\hline$C(5 A)-C(6 A)-C(7 A)$ & $121.5(4)$ \\
\hline $\mathrm{C}(5 \mathrm{~A})-\mathrm{C}(6 \mathrm{~A})-\mathrm{H}(6 \mathrm{AA})$ & 119.2 \\
\hline $\mathrm{C}(7 \mathrm{~A})-\mathrm{C}(6 \mathrm{~A})-\mathrm{H}(6 \mathrm{AA})$ & 119.2 \\
\hline $\mathrm{C}(6 \mathrm{~A})-\mathrm{C}(7 \mathrm{~A})-\mathrm{C}(2 \mathrm{~A})$ & $119.9(4)$ \\
\hline$C(6 A)-C(7 A)-C(8 A)$ & $118.6(3)$ \\
\hline $\mathrm{C}(2 \mathrm{~A})-\mathrm{C}(7 \mathrm{~A})-\mathrm{C}(8 \mathrm{~A})$ & $121.3(4)$ \\
\hline $\mathrm{N}(1 \mathrm{~A})-\mathrm{C}(8 \mathrm{~A})-\mathrm{O}(1 \mathrm{~A})$ & $117.6(4)$ \\
\hline$N(1 A)-C(8 A)-C(7 A)$ & $127.5(4)$ \\
\hline $\mathrm{O}(1 \mathrm{~A})-\mathrm{C}(8 \mathrm{~A})-\mathrm{C}(7 \mathrm{~A})$ & $114.8(4)$ \\
\hline $\mathrm{O}(1 \mathrm{~A})-\mathrm{C}(9 \mathrm{~A})-\mathrm{C}(10 \mathrm{~A})$ & $104.6(3)$ \\
\hline $\mathrm{O}(1 \mathrm{~A})-\mathrm{C}(9 \mathrm{~A})-\mathrm{H}(9 \mathrm{AA})$ & 110.8 \\
\hline $\mathrm{C}(10 \mathrm{~A})-\mathrm{C}(9 \mathrm{~A})-\mathrm{H}(9 \mathrm{AA})$ & 110.8 \\
\hline $\mathrm{O}(1 \mathrm{~A})-\mathrm{C}(9 \mathrm{~A})-\mathrm{H}(9 \mathrm{AB})$ & 110.8 \\
\hline$C(10 A)-C(9 A)-H(9 A B)$ & 110.8 \\
\hline $\mathrm{H}(9 \mathrm{AA})-\mathrm{C}(9 \mathrm{~A})-\mathrm{H}(9 \mathrm{AB})$ & 108.9 \\
\hline $\mathrm{N}(1 \mathrm{~A})-\mathrm{C}(10 \mathrm{~A})-\mathrm{C}(11 \mathrm{~A})$ & $108.8(3)$ \\
\hline $\mathrm{N}(1 \mathrm{~A})-\mathrm{C}(10 \mathrm{~A})-\mathrm{C}(12 \mathrm{~A})$ & $109.0(4)$ \\
\hline $\mathrm{C}(11 \mathrm{~A})-\mathrm{C}(10 \mathrm{~A})-\mathrm{C}(12 \mathrm{~A})$ & $111.0(4)$ \\
\hline $\mathrm{N}(1 \mathrm{~A})-\mathrm{C}(10 \mathrm{~A})-\mathrm{C}(9 \mathrm{~A})$ & $102.9(3)$ \\
\hline
\end{tabular}




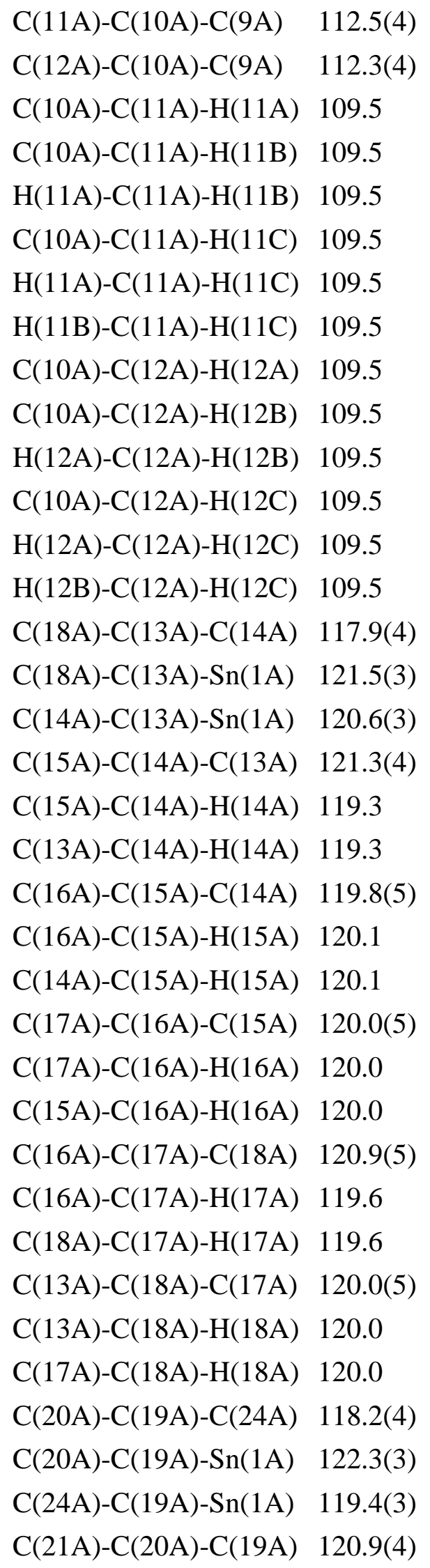




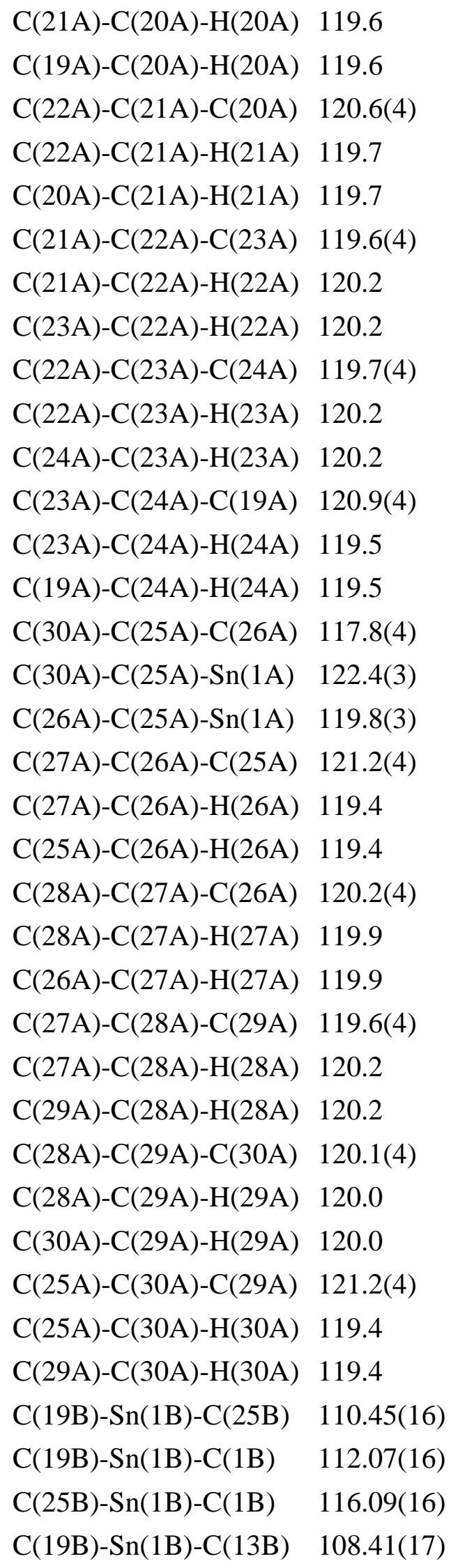




\begin{tabular}{|c|c|}
\hline$C(25 B)-S n(1 B)-C(13 B)$ & $105.81(17)$ \\
\hline $\mathrm{C}(1 \mathrm{~B})-\mathrm{Sn}(1 \mathrm{~B})-\mathrm{C}(13 \mathrm{~B})$ & $103.30(16)$ \\
\hline $\mathrm{C}(8 \mathrm{~B})-\mathrm{O}(1 \mathrm{~B})-\mathrm{C}(9 \mathrm{~B})$ & $105.4(3)$ \\
\hline $\mathrm{C}(8 \mathrm{~B})-\mathrm{N}(1 \mathrm{~B})-\mathrm{C}(10 \mathrm{~B})$ & $107.7(4)$ \\
\hline C(2B)-C(1B)-Sn(1B) & $111.0(3)$ \\
\hline $\mathrm{C}(2 \mathrm{~B})-\mathrm{C}(1 \mathrm{~B})-\mathrm{H}(1 \mathrm{BA})$ & 109.4 \\
\hline $\operatorname{Sn}(1 \mathrm{~B})-\mathrm{C}(1 \mathrm{~B})-\mathrm{H}(1 \mathrm{BA})$ & 109.4 \\
\hline $\mathrm{C}(2 \mathrm{~B})-\mathrm{C}(1 \mathrm{~B})-\mathrm{H}(1 \mathrm{BB})$ & 109.4 \\
\hline $\mathrm{Sn}(1 \mathrm{~B})-\mathrm{C}(1 \mathrm{~B})-\mathrm{H}(1 \mathrm{BB})$ & 109.4 \\
\hline $\mathrm{H}(1 \mathrm{BA})-\mathrm{C}(1 \mathrm{~B})-\mathrm{H}(1 \mathrm{BB})$ & 108.0 \\
\hline $\mathrm{C}(3 \mathrm{~B})-\mathrm{C}(2 \mathrm{~B})-\mathrm{C}(7 \mathrm{~B})$ & $117.0(4)$ \\
\hline $\mathrm{C}(3 \mathrm{~B})-\mathrm{C}(2 \mathrm{~B})-\mathrm{C}(1 \mathrm{~B})$ & $119.1(4)$ \\
\hline $\mathrm{C}(7 \mathrm{~B})-\mathrm{C}(2 \mathrm{~B})-\mathrm{C}(1 \mathrm{~B})$ & $123.9(4)$ \\
\hline$C(4 B)-C(3 B)-C(2 B)$ & $122.0(4)$ \\
\hline $\mathrm{C}(4 \mathrm{~B})-\mathrm{C}(3 \mathrm{~B})-\mathrm{H}(3 \mathrm{BA})$ & 119.0 \\
\hline $\mathrm{C}(2 \mathrm{~B})-\mathrm{C}(3 \mathrm{~B})-\mathrm{H}(3 \mathrm{BA})$ & 119.0 \\
\hline $\mathrm{C}(5 \mathrm{~B})-\mathrm{C}(4 \mathrm{~B})-\mathrm{C}(3 \mathrm{~B})$ & $120.6(4)$ \\
\hline $\mathrm{C}(5 \mathrm{~B})-\mathrm{C}(4 \mathrm{~B})-\mathrm{H}(4 \mathrm{BA})$ & 119.7 \\
\hline $\mathrm{C}(3 \mathrm{~B})-\mathrm{C}(4 \mathrm{~B})-\mathrm{H}(4 \mathrm{BA})$ & 119.7 \\
\hline$C(4 B)-C(5 B)-C(6 B)$ & $118.9(4)$ \\
\hline $\mathrm{C}(4 \mathrm{~B})-\mathrm{C}(5 \mathrm{~B})-\mathrm{H}(5 \mathrm{BA})$ & 120.6 \\
\hline $\mathrm{C}(6 \mathrm{~B})-\mathrm{C}(5 \mathrm{~B})-\mathrm{H}(5 \mathrm{BA})$ & 120.6 \\
\hline $\mathrm{C}(5 \mathrm{~B})-\mathrm{C}(6 \mathrm{~B})-\mathrm{C}(7 \mathrm{~B})$ & $121.6(4)$ \\
\hline $\mathrm{C}(5 \mathrm{~B})-\mathrm{C}(6 \mathrm{~B})-\mathrm{H}(6 \mathrm{BA})$ & 119.2 \\
\hline $\mathrm{C}(7 \mathrm{~B})-\mathrm{C}(6 \mathrm{~B})-\mathrm{H}(6 \mathrm{BA})$ & 119.2 \\
\hline $\mathrm{C}(6 \mathrm{~B})-\mathrm{C}(7 \mathrm{~B})-\mathrm{C}(2 \mathrm{~B})$ & $119.8(4)$ \\
\hline $\mathrm{C}(6 \mathrm{~B})-\mathrm{C}(7 \mathrm{~B})-\mathrm{C}(8 \mathrm{~B})$ & 119.1(4) \\
\hline $\mathrm{C}(2 \mathrm{~B})-\mathrm{C}(7 \mathrm{~B})-\mathrm{C}(8 \mathrm{~B})$ & $121.0(4)$ \\
\hline $\mathrm{N}(1 \mathrm{~B})-\mathrm{C}(8 \mathrm{~B})-\mathrm{O}(1 \mathrm{~B})$ & $117.7(4)$ \\
\hline $\mathrm{N}(1 \mathrm{~B})-\mathrm{C}(8 \mathrm{~B})-\mathrm{C}(7 \mathrm{~B})$ & $128.3(4)$ \\
\hline $\mathrm{O}(1 \mathrm{~B})-\mathrm{C}(8 \mathrm{~B})-\mathrm{C}(7 \mathrm{~B})$ & $113.9(4)$ \\
\hline $\mathrm{O}(1 \mathrm{~B})-\mathrm{C}(9 \mathrm{~B})-\mathrm{C}(10 \mathrm{~B})$ & $104.6(3)$ \\
\hline $\mathrm{O}(1 \mathrm{~B})-\mathrm{C}(9 \mathrm{~B})-\mathrm{H}(9 \mathrm{BA})$ & 110.8 \\
\hline $\mathrm{C}(10 \mathrm{~B})-\mathrm{C}(9 \mathrm{~B})-\mathrm{H}(9 \mathrm{BA})$ & 110.8 \\
\hline $\mathrm{O}(1 \mathrm{~B})-\mathrm{C}(9 \mathrm{~B})-\mathrm{H}(9 \mathrm{BB})$ & 110.8 \\
\hline $\mathrm{C}(10 \mathrm{~B})-\mathrm{C}(9 \mathrm{~B})-\mathrm{H}(9 \mathrm{BB})$ & 110.8 \\
\hline
\end{tabular}




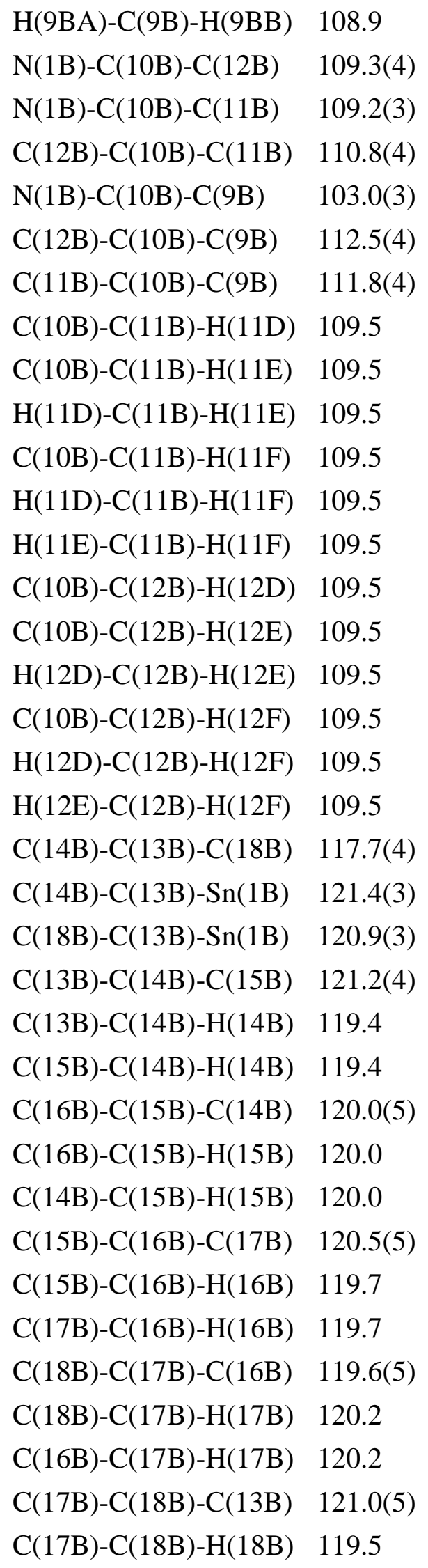




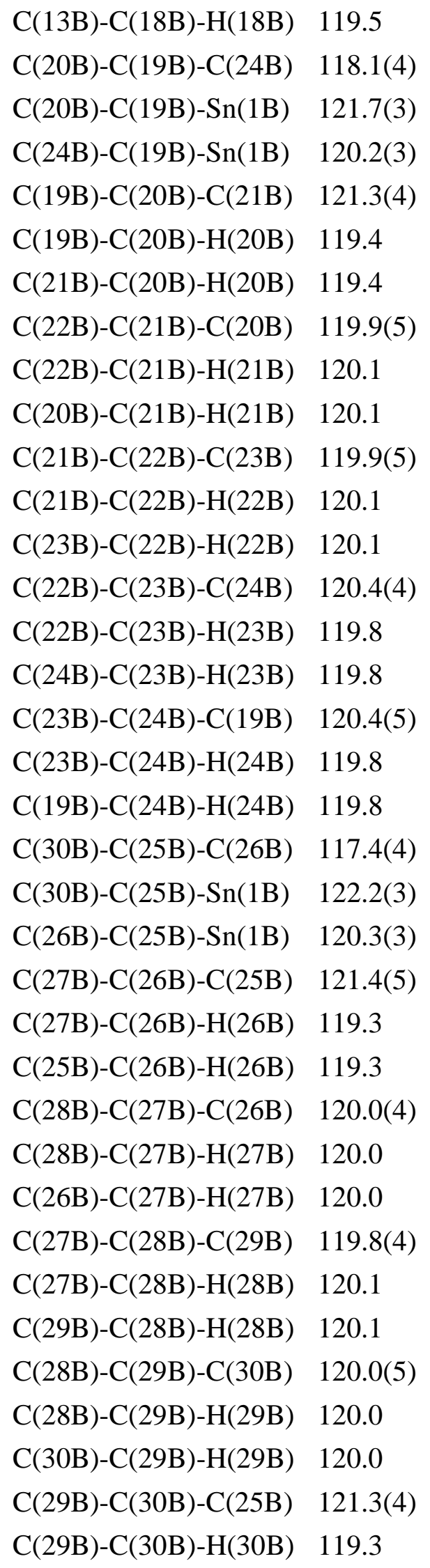


C(25B)-C(30B)-H(30B) 119.3

Symmetry transformations used to generate equivalent atoms: 
Anisotropic displacement parameters $\left(\AA^{2} \times 10^{3}\right)$ for 18. The anisotropic displacement factor exponent takes the form: $-2 \square^{2}\left[h^{2} a^{* 2} U^{11}+\ldots+2 h k a^{*} b^{*} U^{12}\right]$

\begin{tabular}{|c|c|c|c|c|c|c|}
\hline & U11 & $\mathrm{U}^{22}$ & $\mathrm{U}^{33}$ & $\mathrm{U}^{23}$ & $\mathrm{U}^{13}$ & $\mathrm{U}^{12}$ \\
\hline $\operatorname{Sn}(1 \mathrm{~A})$ & $18(1)$ & $20(1)$ & $18(1)$ & $0(1)$ & $-2(1)$ & $0(1)$ \\
\hline $\mathrm{O}(1 \mathrm{~A})$ & $30(2)$ & $23(2)$ & $36(2)$ & $7(2)$ & $8(2)$ & $8(1)$ \\
\hline $\mathrm{N}(1 \mathrm{~A})$ & $17(2)$ & $21(2)$ & $26(2)$ & $0(2)$ & $0(2)$ & $0(2)$ \\
\hline$C(1 \mathrm{~A})$ & $15(2)$ & $24(3)$ & $27(3)$ & $-4(2)$ & $-4(2)$ & $1(2)$ \\
\hline$C(2 A)$ & $17(2)$ & $21(2)$ & $23(2)$ & $-5(2)$ & $-5(2)$ & $-2(2)$ \\
\hline$C(3 A)$ & $21(2)$ & $29(3)$ & $31(3)$ & $-6(2)$ & $1(2)$ & $-2(2)$ \\
\hline$C(4 A)$ & $27(3)$ & $38(3)$ & $37(3)$ & $-4(3)$ & $12(2)$ & $-9(2)$ \\
\hline$C(5 A)$ & $35(3)$ & $32(3)$ & $33(3)$ & $8(2)$ & $5(2)$ & $-6(2)$ \\
\hline$C(6 A)$ & $29(2)$ & $24(2)$ & $35(3)$ & $-2(2)$ & $-2(2)$ & $1(2)$ \\
\hline$C(7 A)$ & $18(2)$ & $18(2)$ & $25(2)$ & $-5(2)$ & $-2(2)$ & $-4(2)$ \\
\hline$C(8 A)$ & $19(2)$ & $19(2)$ & $23(2)$ & $-4(2)$ & $-4(2)$ & $4(2)$ \\
\hline $\mathrm{C}(9 \mathrm{~A})$ & $19(2)$ & $36(3)$ & $35(3)$ & $4(2)$ & $4(2)$ & $8(2)$ \\
\hline $\mathrm{C}(10 \mathrm{~A})$ & $16(2)$ & $25(3)$ & $25(3)$ & $1(2)$ & $-2(2)$ & $1(2)$ \\
\hline $\mathrm{C}(11 \mathrm{~A})$ & $30(3)$ & $38(3)$ & $27(3)$ & $2(2)$ & $-4(2)$ & $-1(2)$ \\
\hline $\mathrm{C}(12 \mathrm{~A})$ & $21(2)$ & $36(3)$ & $37(3)$ & $-2(2)$ & $2(2)$ & $-3(2)$ \\
\hline $\mathrm{C}(13 \mathrm{~A})$ & $22(2)$ & $18(2)$ & $19(2)$ & $1(2)$ & $2(2)$ & $-5(2)$ \\
\hline $\mathrm{C}(14 \mathrm{~A})$ & $32(3)$ & $29(3)$ & $24(3)$ & $-4(2)$ & $-5(2)$ & $0(2)$ \\
\hline $\mathrm{C}(15 \mathrm{~A})$ & $57(3)$ & $34(3)$ & $25(3)$ & $-6(2)$ & $6(3)$ & $-3(3)$ \\
\hline$C(16 A)$ & $45(3)$ & $26(3)$ & $45(4)$ & $-1(3)$ & $26(3)$ & $4(2)$ \\
\hline $\mathrm{C}(17 \mathrm{~A})$ & $29(3)$ & $31(3)$ & $45(3)$ & $6(3)$ & $10(2)$ & $7(2)$ \\
\hline $\mathrm{C}(18 \mathrm{~A})$ & $27(2)$ & $29(3)$ & $29(3)$ & $4(2)$ & $1(2)$ & $4(2)$ \\
\hline $\mathrm{C}(19 \mathrm{~A})$ & $17(2)$ & $21(2)$ & $21(2)$ & $2(2)$ & $-1(2)$ & $4(2)$ \\
\hline$C(20 A)$ & $25(2)$ & $25(3)$ & $20(2)$ & $-1(2)$ & $0(2)$ & $3(2)$ \\
\hline$C(21 \mathrm{~A})$ & $37(3)$ & $32(3)$ & $20(3)$ & $-2(2)$ & $2(2)$ & $9(2)$ \\
\hline$C(22 A)$ & $28(2)$ & $25(3)$ & $38(3)$ & $10(2)$ & $12(2)$ & $3(2)$ \\
\hline$C(23 A)$ & $32(3)$ & $17(3)$ & $38(3)$ & $3(2)$ & $3(2)$ & $-5(2)$ \\
\hline $\mathrm{C}(24 \mathrm{~A})$ & $31(2)$ & $21(3)$ & $25(3)$ & $0(2)$ & $-4(2)$ & $3(2)$ \\
\hline $\mathrm{C}(25 \mathrm{~A})$ & $20(2)$ & $20(3)$ & $21(2)$ & $-5(2)$ & $-4(2)$ & $6(2)$ \\
\hline$C(26 A)$ & $23(2)$ & $20(3)$ & $24(3)$ & $1(2)$ & $-1(2)$ & $2(2)$ \\
\hline $\mathrm{C}(27 \mathrm{~A})$ & $18(2)$ & $29(3)$ & $31(3)$ & $-5(2)$ & $-5(2)$ & $1(2)$ \\
\hline $\mathrm{C}(28 \mathrm{~A})$ & $27(2)$ & $31(3)$ & $25(3)$ & $0(2)$ & $-9(2)$ & $7(2)$ \\
\hline
\end{tabular}




\begin{tabular}{|c|c|c|c|c|c|c|}
\hline$C(29 A)$ & $33(3)$ & $28(3)$ & $23(3)$ & $9(2)$ & $-2(2)$ & $-1(2)$ \\
\hline$C(30 A)$ & $21(2)$ & $24(3)$ & $19(2)$ & $2(2)$ & $0(2)$ & $1(2)$ \\
\hline $\operatorname{Sn}(1 B)$ & $21(1)$ & $21(1)$ & $20(1)$ & $1(1)$ & $-1(1)$ & $1(1)$ \\
\hline $\mathrm{O}(1 \mathrm{~B})$ & $32(2)$ & $27(2)$ & $40(2)$ & $-10(2)$ & $15(2)$ & $-8(1)$ \\
\hline $\mathrm{N}(1 \mathrm{~B})$ & $17(2)$ & $26(2)$ & $27(2)$ & $-3(2)$ & $2(2)$ & $1(2)$ \\
\hline$C(1 B)$ & $22(2)$ & $21(2)$ & $22(2)$ & $1(2)$ & $-1(2)$ & $-2(2)$ \\
\hline $\mathrm{C}(2 \mathrm{~B})$ & $18(2)$ & $24(2)$ & $17(2)$ & $3(2)$ & $-2(2)$ & $5(2)$ \\
\hline$C(3 B)$ & $23(2)$ & $27(3)$ & $25(3)$ & $7(2)$ & $-2(2)$ & $2(2)$ \\
\hline$C(4 B)$ & $25(2)$ & $37(3)$ & $25(3)$ & $2(2)$ & $6(2)$ & $6(2)$ \\
\hline$C(5 B)$ & $34(3)$ & $28(3)$ & $26(3)$ & $-5(2)$ & $0(2)$ & $11(2)$ \\
\hline$C(6 B)$ & $26(2)$ & $24(2)$ & $21(2)$ & $2(2)$ & $-1(2)$ & $3(2)$ \\
\hline$C(7 B)$ & $23(2)$ & $23(2)$ & $16(2)$ & $4(2)$ & $-2(2)$ & $5(2)$ \\
\hline$C(8 B)$ & $21(2)$ & $18(2)$ & $21(2)$ & $-1(2)$ & $-1(2)$ & $2(2)$ \\
\hline$C(9 B)$ & $26(2)$ & $32(3)$ & $36(3)$ & $-8(2)$ & $9(2)$ & $-5(2)$ \\
\hline$C(10 B)$ & $16(2)$ & $29(3)$ & $25(3)$ & $-4(2)$ & $5(2)$ & $-1(2)$ \\
\hline$C(11 B)$ & $28(2)$ & $35(3)$ & $30(3)$ & $-1(2)$ & $-3(2)$ & $3(2)$ \\
\hline $\mathrm{C}(12 \mathrm{~B})$ & $21(2)$ & $44(3)$ & $37(3)$ & $4(2)$ & $3(2)$ & $7(2)$ \\
\hline$C(13 B)$ & $24(2)$ & $21(3)$ & $25(3)$ & $3(2)$ & $4(2)$ & $7(2)$ \\
\hline$C(14 B)$ & $28(2)$ & $37(3)$ & $31(3)$ & $5(2)$ & $-3(2)$ & $-5(2)$ \\
\hline$C(15 B)$ & $35(3)$ & $47(4)$ & $32(3)$ & $14(3)$ & $5(2)$ & $-3(2)$ \\
\hline$C(16 B)$ & $34(3)$ & $29(3)$ & $45(4)$ & $4(3)$ & $17(3)$ & $-1(2)$ \\
\hline $\mathrm{C}(17 \mathrm{~B})$ & $25(3)$ & $30(3)$ & $50(4)$ & $-8(3)$ & $3(2)$ & $-4(2)$ \\
\hline $\mathrm{C}(18 \mathrm{~B})$ & $34(3)$ & $28(3)$ & $28(3)$ & $-5(2)$ & $-4(2)$ & $-3(2)$ \\
\hline $\mathrm{C}(19 \mathrm{~B})$ & $19(2)$ & $17(2)$ & $26(3)$ & $2(2)$ & $-3(2)$ & $-3(2)$ \\
\hline$C(20 B)$ & $21(2)$ & $26(3)$ & $28(3)$ & $1(2)$ & $0(2)$ & $1(2)$ \\
\hline$C(21 B)$ & $34(3)$ & $29(3)$ & $23(3)$ & $0(2)$ & $2(2)$ & $-5(2)$ \\
\hline $\mathrm{C}(22 \mathrm{~B})$ & $28(2)$ & $30(3)$ & $40(3)$ & $-5(2)$ & $15(2)$ & $-3(2)$ \\
\hline$C(23 B)$ & $30(3)$ & $24(3)$ & $45(3)$ & $2(2)$ & $-1(2)$ & $11(2)$ \\
\hline$C(24 B)$ & $35(3)$ & $26(3)$ & $26(3)$ & $3(2)$ & $-3(2)$ & $3(2)$ \\
\hline $\mathrm{C}(25 \mathrm{~B})$ & $26(2)$ & $21(3)$ & $20(3)$ & $3(2)$ & $-2(2)$ & $-2(2)$ \\
\hline$C(26 B)$ & $27(2)$ & $30(3)$ & $21(3)$ & $5(2)$ & $0(2)$ & $-1(2)$ \\
\hline$C(27 B)$ & $26(2)$ & $46(3)$ & $30(3)$ & $14(2)$ & $-4(2)$ & $-9(2)$ \\
\hline$C(28 B)$ & $44(3)$ & $48(3)$ & $26(3)$ & $8(2)$ & $-15(2)$ & $-20(3)$ \\
\hline$C(29 B)$ & $59(3)$ & $32(3)$ & $26(3)$ & $-2(2)$ & $-9(3)$ & $-3(2)$ \\
\hline$C(30 B)$ & $34(3)$ & $35(3)$ & $25(3)$ & $5(2)$ & $-3(2)$ & $9(2)$ \\
\hline
\end{tabular}


Hydrogen coordinates ( $\times 10^{4}$ ) and isotropic displacement parameters $\left(\AA^{2} \times 10^{3}\right)$ for $\mathbf{1 8}$.

\begin{tabular}{|c|c|c|c|c|}
\hline- & $\mathrm{x}$ & $\mathrm{y}$ & z & $\mathrm{U}(\mathrm{eq})$ \\
\hline \multicolumn{5}{|l|}{-} \\
\hline $\mathrm{H}(1 \mathrm{AA})$ & 5036 & 5892 & 3394 & 26 \\
\hline $\mathrm{H}(1 \mathrm{AB})$ & 6447 & 5577 & 3112 & 26 \\
\hline $\mathrm{H}(3 \mathrm{AA})$ & 4068 & 5271 & 3977 & 32 \\
\hline $\mathrm{H}(4 \mathrm{AA})$ & 4047 & 4336 & 4442 & 41 \\
\hline $\mathrm{H}(5 \mathrm{AA})$ & 5998 & 3449 & 4391 & 40 \\
\hline $\mathrm{H}(6 \mathrm{AA})$ & 8004 & 3566 & 3888 & 35 \\
\hline $\mathrm{H}(9 \mathrm{AA})$ & 11370 & 3911 & 2902 & 36 \\
\hline $\mathrm{H}(9 \mathrm{AB})$ & 11910 & 4276 & 3340 & 36 \\
\hline $\mathrm{H}(11 \mathrm{~A})$ & 9948 & 5406 & 2378 & 48 \\
\hline $\mathrm{H}(11 \mathrm{~B})$ & 9492 & 4588 & 2415 & 48 \\
\hline $\mathrm{H}(11 \mathrm{C})$ & 11285 & 4814 & 2325 & 48 \\
\hline $\mathrm{H}(12 \mathrm{~A})$ & 11525 & 5978 & 2945 & 47 \\
\hline $\mathrm{H}(12 \mathrm{~B})$ & 12877 & 5388 & 2926 & 47 \\
\hline $\mathrm{H}(12 \mathrm{C})$ & 11990 & 5548 & 3364 & 47 \\
\hline $\mathrm{H}(14 \mathrm{~A})$ & 7518 & 7093 & 4592 & 34 \\
\hline $\mathrm{H}(15 \mathrm{~A})$ & 5870 & 7798 & 5002 & 46 \\
\hline $\mathrm{H}(16 \mathrm{~A})$ & 3609 & 8292 & 4704 & 46 \\
\hline $\mathrm{H}(17 \mathrm{~A})$ & 2929 & 8034 & 4012 & 42 \\
\hline $\mathrm{H}(18 \mathrm{~A})$ & 4537 & 7307 & 3596 & 34 \\
\hline $\mathrm{H}(20 \mathrm{~A})$ & 8103 & 6599 & 2686 & 28 \\
\hline $\mathrm{H}(21 \mathrm{~A})$ & 9347 & 7332 & 2198 & 35 \\
\hline $\mathrm{H}(22 \mathrm{~A})$ & 11007 & 8234 & 2426 & 37 \\
\hline $\mathrm{H}(23 \mathrm{~A})$ & 11386 & 8419 & 3152 & 35 \\
\hline $\mathrm{H}(24 \mathrm{~A})$ & 10040 & 7717 & 3644 & 31 \\
\hline $\mathrm{H}(26 \mathrm{~A})$ & 11214 & 6674 & 3958 & 27 \\
\hline $\mathrm{H}(27 \mathrm{~A})$ & 13033 & 6269 & 4456 & 31 \\
\hline $\mathrm{H}(28 \mathrm{~A})$ & 12361 & 5349 & 4913 & 33 \\
\hline $\mathrm{H}(29 \mathrm{~A})$ & 9831 & 4857 & 4882 & 34 \\
\hline $\mathrm{H}(30 \mathrm{~A})$ & 7961 & 5306 & 4408 & 25 \\
\hline
\end{tabular}




\begin{tabular}{|c|c|c|c|c|}
\hline $\mathrm{H}(1 \mathrm{BA})$ & 1729 & 1211 & 3112 & 26 \\
\hline $\mathrm{H}(1 \mathrm{BB})$ & 298 & 907 & 3391 & 26 \\
\hline $\mathrm{H}(3 \mathrm{BA})$ & -729 & 1553 & 3962 & 30 \\
\hline $\mathrm{H}(4 \mathrm{BA})$ & -893 & 2563 & 4371 & 35 \\
\hline $\mathrm{H}(5 \mathrm{BA})$ & 1023 & 3441 & 4316 & 35 \\
\hline $\mathrm{H}(6 \mathrm{BA})$ & 3120 & 3293 & 3846 & 29 \\
\hline H(9BA) & 7145 & 2594 & 3313 & 37 \\
\hline $\mathrm{H}(9 \mathrm{BB})$ & 6504 & 2934 & 2877 & 37 \\
\hline $\mathrm{H}(11 \mathrm{D})$ & 5197 & 1403 & 2376 & 47 \\
\hline $\mathrm{H}(11 \mathrm{E})$ & 6566 & 1978 & 2320 & 47 \\
\hline $\mathrm{H}(11 \mathrm{~F})$ & 4777 & 2225 & 2396 & 47 \\
\hline $\mathrm{H}(12 \mathrm{D})$ & 6789 & 861 & 2958 & 51 \\
\hline $\mathrm{H}(12 \mathrm{E})$ & 7214 & 1310 & 3373 & 51 \\
\hline $\mathrm{H}(12 \mathrm{~F})$ & 8119 & 1460 & 2936 & 51 \\
\hline $\mathrm{H}(14 \mathrm{~B})$ & 2541 & -178 & 4634 & 38 \\
\hline $\mathrm{H}(15 \mathrm{~B})$ & 892 & -922 & 5026 & 46 \\
\hline $\mathrm{H}(16 \mathrm{~B})$ & -1251 & -1455 & 4706 & 43 \\
\hline $\mathrm{H}(17 \mathrm{~B})$ & -1788 & -1259 & 3989 & 42 \\
\hline $\mathrm{H}(18 \mathrm{~B})$ & -143 & -522 & 3593 & 36 \\
\hline $\mathrm{H}(20 \mathrm{~B})$ & 3376 & 231 & 2714 & 30 \\
\hline $\mathrm{H}(21 \mathrm{~B})$ & 4591 & -512 & 2221 & 35 \\
\hline $\mathrm{H}(22 \mathrm{~B})$ & 6164 & -1440 & 2451 & 39 \\
\hline $\mathrm{H}(23 \mathrm{~B})$ & 6466 & -1650 & 3174 & 39 \\
\hline $\mathrm{H}(24 \mathrm{~B})$ & 5169 & -941 & 3670 & 35 \\
\hline$H(26 B)$ & 6464 & 157 & 3985 & 31 \\
\hline $\mathrm{H}(27 \mathrm{~B})$ & 8266 & 580 & 4479 & 41 \\
\hline $\mathrm{H}(28 \mathrm{~B})$ & 7592 & 1526 & 4915 & 47 \\
\hline $\mathrm{H}(29 B)$ & 5053 & 2009 & 4879 & 47 \\
\hline $\mathrm{H}(30 \mathrm{~B})$ & 3213 & 1559 & 4401 & 38 \\
\hline
\end{tabular}


Torsion angles $\left[{ }^{\circ}\right]$ for $\mathbf{1 8}$.

\begin{tabular}{|c|c|}
\hline $\operatorname{Sn}(1 \mathrm{~A})-\mathrm{C}(1 \mathrm{~A})-\mathrm{C}(2 \mathrm{~A})-\mathrm{C}(3 \mathrm{~A})$ & $98.0(4)$ \\
\hline $\operatorname{Sn}(1 \mathrm{~A})-\mathrm{C}(1 \mathrm{~A})-\mathrm{C}(2 \mathrm{~A})-\mathrm{C}(7 \mathrm{~A})$ & $-79.1(5)$ \\
\hline $\mathrm{C}(7 \mathrm{~A})-\mathrm{C}(2 \mathrm{~A})-\mathrm{C}(3 \mathrm{~A})-\mathrm{C}(4 \mathrm{~A})$ & $2.1(6)$ \\
\hline$C(1 A)-C(2 A)-C(3 A)-C(4 A)$ & $-175.2(4)$ \\
\hline$C(2 A)-C(3 A)-C(4 A)-C(5 A)$ & $-3.0(7)$ \\
\hline$C(3 A)-C(4 A)-C(5 A)-C(6 A)$ & $1.6(7)$ \\
\hline$C(4 A)-C(5 A)-C(6 A)-C(7 A)$ & $0.7(7)$ \\
\hline$C(5 A)-C(6 A)-C(7 A)-C(2 A)$ & $-1.6(6)$ \\
\hline$C(5 A)-C(6 A)-C(7 A)-C(8 A)$ & $173.8(4)$ \\
\hline$C(3 A)-C(2 A)-C(7 A)-C(6 A)$ & $0.2(6)$ \\
\hline$C(1 A)-C(2 A)-C(7 A)-C(6 A)$ & $177.4(4)$ \\
\hline $\mathrm{C}(3 \mathrm{~A})-\mathrm{C}(2 \mathrm{~A})-\mathrm{C}(7 \mathrm{~A})-\mathrm{C}(8 \mathrm{~A})$ & $-175.0(4)$ \\
\hline$C(1 A)-C(2 A)-C(7 A)-C(8 A)$ & $2.1(6)$ \\
\hline $\mathrm{C}(10 \mathrm{~A})-\mathrm{N}(1 \mathrm{~A})-\mathrm{C}(8 \mathrm{~A})-\mathrm{O}(1 \mathrm{~A})$ & $0.4(5)$ \\
\hline $\mathrm{C}(10 \mathrm{~A})-\mathrm{N}(1 \mathrm{~A})-\mathrm{C}(8 \mathrm{~A})-\mathrm{C}(7 \mathrm{~A})$ & $177.4(4)$ \\
\hline $\mathrm{C}(9 \mathrm{~A})-\mathrm{O}(1 \mathrm{~A})-\mathrm{C}(8 \mathrm{~A})-\mathrm{N}(1 \mathrm{~A})$ & $10.2(5)$ \\
\hline $\mathrm{C}(9 \mathrm{~A})-\mathrm{O}(1 \mathrm{~A})-\mathrm{C}(8 \mathrm{~A})-\mathrm{C}(7 \mathrm{~A})$ & $-167.2(4)$ \\
\hline$C(6 A)-C(7 A)-C(8 A)-N(1 A)$ & $-163.5(4)$ \\
\hline $\mathrm{C}(2 \mathrm{~A})-\mathrm{C}(7 \mathrm{~A})-\mathrm{C}(8 \mathrm{~A})-\mathrm{N}(1 \mathrm{~A})$ & $11.8(6)$ \\
\hline$C(6 A)-C(7 A)-C(8 A)-O(1 A)$ & $13.6(5)$ \\
\hline$C(2 A)-C(7 A)-C(8 A)-O(1 A)$ & $-171.1(4)$ \\
\hline $\mathrm{C}(8 \mathrm{~A})-\mathrm{O}(1 \mathrm{~A})-\mathrm{C}(9 \mathrm{~A})-\mathrm{C}(10 \mathrm{~A})$ & $-15.4(4)$ \\
\hline $\mathrm{C}(8 \mathrm{~A})-\mathrm{N}(1 \mathrm{~A})-\mathrm{C}(10 \mathrm{~A})-\mathrm{C}(11 \mathrm{~A})$ & $109.4(4)$ \\
\hline$C(8 A)-N(1 A)-C(10 A)-C(12 A)$ & $-129.4(4)$ \\
\hline $\mathrm{C}(8 \mathrm{~A})-\mathrm{N}(1 \mathrm{~A})-\mathrm{C}(10 \mathrm{~A})-\mathrm{C}(9 \mathrm{~A})$ & $-10.0(4)$ \\
\hline $\mathrm{O}(1 \mathrm{~A})-\mathrm{C}(9 \mathrm{~A})-\mathrm{C}(10 \mathrm{~A})-\mathrm{N}(1 \mathrm{~A})$ & $15.5(4)$ \\
\hline $\mathrm{O}(1 \mathrm{~A})-\mathrm{C}(9 \mathrm{~A})-\mathrm{C}(10 \mathrm{~A})-\mathrm{C}(11 \mathrm{~A})$ & $-101.4(4)$ \\
\hline $\mathrm{O}(1 \mathrm{~A})-\mathrm{C}(9 \mathrm{~A})-\mathrm{C}(10 \mathrm{~A})-\mathrm{C}(12 \mathrm{~A})$ & $132.6(4)$ \\
\hline$C(18 A)-C(13 A)-C(14 A)-C(15 A)$ & $0.2(7)$ \\
\hline $\operatorname{Sn}(1 \mathrm{~A})-\mathrm{C}(13 \mathrm{~A})-\mathrm{C}(14 \mathrm{~A})-\mathrm{C}(15 \mathrm{~A})$ & $-179.1(4)$ \\
\hline$C(13 A)-C(14 A)-C(15 A)-C(16 A)$ & $-1.3(8)$ \\
\hline$C(14 A)-C(15 A)-C(16 A)-C(17 A)$ & $1.7(8)$ \\
\hline$C(15 A)-C(16 A)-C(17 A)-C(18 A)$ & $-1.0(8)$ \\
\hline$C(14 A)-C(13 A)-C(18 A)-C(17 A)$ & $0.5(6)$ \\
\hline
\end{tabular}




\begin{tabular}{|c|c|}
\hline $\operatorname{Sn}(1 \mathrm{~A})-\mathrm{C}(13 \mathrm{~A})-\mathrm{C}(18 \mathrm{~A})-\mathrm{C}(17 \mathrm{~A})$ & $179.8(3)$ \\
\hline$C(16 A)-C(17 A)-C(18 A)-C(13 A)$ & $-0.1(7)$ \\
\hline$C(24 A)-C(19 A)-C(20 A)-C(21 A)$ & $-1.4(6)$ \\
\hline $\operatorname{Sn}(1 \mathrm{~A})-\mathrm{C}(19 \mathrm{~A})-\mathrm{C}(20 \mathrm{~A})-\mathrm{C}(21 \mathrm{~A})$ & $178.4(3)$ \\
\hline$C(19 A)-C(20 A)-C(21 A)-C(22 A)$ & $1.9(7)$ \\
\hline$C(20 A)-C(21 A)-C(22 A)-C(23 A)$ & $-0.7(7)$ \\
\hline$C(21 A)-C(22 A)-C(23 A)-C(24 A)$ & $-1.0(7)$ \\
\hline$C(22 A)-C(23 A)-C(24 A)-C(19 A)$ & $1.4(7)$ \\
\hline$C(20 A)-C(19 A)-C(24 A)-C(23 A)$ & $-0.2(6)$ \\
\hline $\operatorname{Sn}(1 \mathrm{~A})-\mathrm{C}(19 \mathrm{~A})-\mathrm{C}(24 \mathrm{~A})-\mathrm{C}(23 \mathrm{~A})$ & $179.9(3)$ \\
\hline$C(30 A)-C(25 A)-C(26 A)-C(27 A)$ & $0.3(6)$ \\
\hline $\operatorname{Sn}(1 \mathrm{~A})-\mathrm{C}(25 \mathrm{~A})-\mathrm{C}(26 \mathrm{~A})-\mathrm{C}(27 \mathrm{~A})$ & $177.9(3)$ \\
\hline $\mathrm{C}(25 \mathrm{~A})-\mathrm{C}(26 \mathrm{~A})-\mathrm{C}(27 \mathrm{~A})-\mathrm{C}(28 \mathrm{~A})$ & $1.3(7)$ \\
\hline$C(26 A)-C(27 A)-C(28 A)-C(29 A)$ & $-1.0(7)$ \\
\hline$C(27 A)-C(28 A)-C(29 A)-C(30 A)$ & $-0.8(7)$ \\
\hline$C(26 A)-C(25 A)-C(30 A)-C(29 A)$ & $-2.2(7)$ \\
\hline $\operatorname{Sn}(1 \mathrm{~A})-\mathrm{C}(25 \mathrm{~A})-\mathrm{C}(30 \mathrm{~A})-\mathrm{C}(29 \mathrm{~A})$ & $-179.7(3)$ \\
\hline$C(28 A)-C(29 A)-C(30 A)-C(25 A)$ & $2.5(7)$ \\
\hline $\mathrm{Sn}(1 \mathrm{~B})-\mathrm{C}(1 \mathrm{~B})-\mathrm{C}(2 \mathrm{~B})-\mathrm{C}(3 \mathrm{~B})$ & $-98.2(4)$ \\
\hline $\mathrm{Sn}(1 \mathrm{~B})-\mathrm{C}(1 \mathrm{~B})-\mathrm{C}(2 \mathrm{~B})-\mathrm{C}(7 \mathrm{~B})$ & $79.4(5)$ \\
\hline $\mathrm{C}(7 \mathrm{~B})-\mathrm{C}(2 \mathrm{~B})-\mathrm{C}(3 \mathrm{~B})-\mathrm{C}(4 \mathrm{~B})$ & $0.4(6)$ \\
\hline $\mathrm{C}(1 \mathrm{~B})-\mathrm{C}(2 \mathrm{~B})-\mathrm{C}(3 \mathrm{~B})-\mathrm{C}(4 \mathrm{~B})$ & $178.1(4)$ \\
\hline $\mathrm{C}(2 \mathrm{~B})-\mathrm{C}(3 \mathrm{~B})-\mathrm{C}(4 \mathrm{~B})-\mathrm{C}(5 \mathrm{~B})$ & $0.2(7)$ \\
\hline$C(3 B)-C(4 B)-C(5 B)-C(6 B)$ & $-0.2(7)$ \\
\hline $\mathrm{C}(4 \mathrm{~B})-\mathrm{C}(5 \mathrm{~B})-\mathrm{C}(6 \mathrm{~B})-\mathrm{C}(7 \mathrm{~B})$ & $-0.5(6)$ \\
\hline $\mathrm{C}(5 \mathrm{~B})-\mathrm{C}(6 \mathrm{~B})-\mathrm{C}(7 \mathrm{~B})-\mathrm{C}(2 \mathrm{~B})$ & $1.2(6)$ \\
\hline $\mathrm{C}(5 \mathrm{~B})-\mathrm{C}(6 \mathrm{~B})-\mathrm{C}(7 \mathrm{~B})-\mathrm{C}(8 \mathrm{~B})$ & $-176.0(4)$ \\
\hline $\mathrm{C}(3 \mathrm{~B})-\mathrm{C}(2 \mathrm{~B})-\mathrm{C}(7 \mathrm{~B})-\mathrm{C}(6 \mathrm{~B})$ & $-1.1(6)$ \\
\hline $\mathrm{C}(1 \mathrm{~B})-\mathrm{C}(2 \mathrm{~B})-\mathrm{C}(7 \mathrm{~B})-\mathrm{C}(6 \mathrm{~B})$ & $-178.6(4)$ \\
\hline $\mathrm{C}(3 \mathrm{~B})-\mathrm{C}(2 \mathrm{~B})-\mathrm{C}(7 \mathrm{~B})-\mathrm{C}(8 \mathrm{~B})$ & $176.1(4)$ \\
\hline$C(1 B)-C(2 B)-C(7 B)-C(8 B)$ & $-1.5(6)$ \\
\hline $\mathrm{C}(10 \mathrm{~B})-\mathrm{N}(1 \mathrm{~B})-\mathrm{C}(8 \mathrm{~B})-\mathrm{O}(1 \mathrm{~B})$ & $-1.4(5)$ \\
\hline$C(10 B)-N(1 B)-C(8 B)-C(7 B)$ & $-178.2(4)$ \\
\hline $\mathrm{C}(9 \mathrm{~B})-\mathrm{O}(1 \mathrm{~B})-\mathrm{C}(8 \mathrm{~B})-\mathrm{N}(1 \mathrm{~B})$ & $-6.8(5)$ \\
\hline $\mathrm{C}(9 \mathrm{~B})-\mathrm{O}(1 \mathrm{~B})-\mathrm{C}(8 \mathrm{~B})-\mathrm{C}(7 \mathrm{~B})$ & $170.5(4)$ \\
\hline $\mathrm{C}(6 \mathrm{~B})-\mathrm{C}(7 \mathrm{~B})-\mathrm{C}(8 \mathrm{~B})-\mathrm{N}(1 \mathrm{~B})$ & $167.5(4)$ \\
\hline
\end{tabular}




\begin{tabular}{|c|c|}
\hline $\mathrm{C}(2 \mathrm{~B})-\mathrm{C}(7 \mathrm{~B})-\mathrm{C}(8 \mathrm{~B})-\mathrm{N}(1 \mathrm{~B})$ & $-9.7(7)$ \\
\hline $\mathrm{C}(6 \mathrm{~B})-\mathrm{C}(7 \mathrm{~B})-\mathrm{C}(8 \mathrm{~B})-\mathrm{O}(1 \mathrm{~B})$ & $-9.5(5)$ \\
\hline $\mathrm{C}(2 \mathrm{~B})-\mathrm{C}(7 \mathrm{~B})-\mathrm{C}(8 \mathrm{~B})-\mathrm{O}(1 \mathrm{~B})$ & $173.4(4)$ \\
\hline $\mathrm{C}(8 \mathrm{~B})-\mathrm{O}(1 \mathrm{~B})-\mathrm{C}(9 \mathrm{~B})-\mathrm{C}(10 \mathrm{~B})$ & $11.2(5)$ \\
\hline $\mathrm{C}(8 \mathrm{~B})-\mathrm{N}(1 \mathrm{~B})-\mathrm{C}(10 \mathrm{~B})-\mathrm{C}(12 \mathrm{~B})$ & $128.1(4)$ \\
\hline $\mathrm{C}(8 \mathrm{~B})-\mathrm{N}(1 \mathrm{~B})-\mathrm{C}(10 \mathrm{~B})-\mathrm{C}(11 \mathrm{~B})$ & $-110.7(4)$ \\
\hline $\mathrm{C}(8 \mathrm{~B})-\mathrm{N}(1 \mathrm{~B})-\mathrm{C}(10 \mathrm{~B})-\mathrm{C}(9 \mathrm{~B})$ & $8.3(5)$ \\
\hline $\mathrm{O}(1 \mathrm{~B})-\mathrm{C}(9 \mathrm{~B})-\mathrm{C}(10 \mathrm{~B})-\mathrm{N}(1 \mathrm{~B})$ & $-11.8(5)$ \\
\hline $\mathrm{O}(1 \mathrm{~B})-\mathrm{C}(9 \mathrm{~B})-\mathrm{C}(10 \mathrm{~B})-\mathrm{C}(12 \mathrm{~B})$ & $-129.3(4)$ \\
\hline $\mathrm{O}(1 \mathrm{~B})-\mathrm{C}(9 \mathrm{~B})-\mathrm{C}(10 \mathrm{~B})-\mathrm{C}(11 \mathrm{~B})$ & $105.3(4)$ \\
\hline $\mathrm{C}(18 \mathrm{~B})-\mathrm{C}(13 \mathrm{~B})-\mathrm{C}(14 \mathrm{~B})-\mathrm{C}(15 \mathrm{~B})$ & $2.1(7)$ \\
\hline $\mathrm{Sn}(1 \mathrm{~B})-\mathrm{C}(13 \mathrm{~B})-\mathrm{C}(14 \mathrm{~B})-\mathrm{C}(15 \mathrm{~B})$ & $-178.5(4)$ \\
\hline$C(13 B)-C(14 B)-C(15 B)-C(16 B)$ & $-1.1(8)$ \\
\hline $\mathrm{C}(14 \mathrm{~B})-\mathrm{C}(15 \mathrm{~B})-\mathrm{C}(16 \mathrm{~B})-\mathrm{C}(17 \mathrm{~B})$ & $-0.1(8)$ \\
\hline $\mathrm{C}(15 \mathrm{~B})-\mathrm{C}(16 \mathrm{~B})-\mathrm{C}(17 \mathrm{~B})-\mathrm{C}(18 \mathrm{~B})$ & $0.3(8)$ \\
\hline $\mathrm{C}(16 \mathrm{~B})-\mathrm{C}(17 \mathrm{~B})-\mathrm{C}(18 \mathrm{~B})-\mathrm{C}(13 \mathrm{~B})$ & $0.7(7)$ \\
\hline $\mathrm{C}(14 \mathrm{~B})-\mathrm{C}(13 \mathrm{~B})-\mathrm{C}(18 \mathrm{~B})-\mathrm{C}(17 \mathrm{~B})$ & $-1.9(7)$ \\
\hline $\mathrm{Sn}(1 \mathrm{~B})-\mathrm{C}(13 \mathrm{~B})-\mathrm{C}(18 \mathrm{~B})-\mathrm{C}(17 \mathrm{~B})$ & $178.7(3)$ \\
\hline$C(24 B)-C(19 B)-C(20 B)-C(21 B)$ & $0.3(6)$ \\
\hline $\operatorname{Sn}(1 \mathrm{~B})-\mathrm{C}(19 \mathrm{~B})-\mathrm{C}(20 \mathrm{~B})-\mathrm{C}(21 \mathrm{~B})$ & $-178.0(3)$ \\
\hline$C(19 B)-C(20 B)-C(21 B)-C(22 B)$ & $-1.4(7)$ \\
\hline $\mathrm{C}(20 \mathrm{~B})-\mathrm{C}(21 \mathrm{~B})-\mathrm{C}(22 \mathrm{~B})-\mathrm{C}(23 \mathrm{~B})$ & $1.0(7)$ \\
\hline $\mathrm{C}(21 \mathrm{~B})-\mathrm{C}(22 \mathrm{~B})-\mathrm{C}(23 \mathrm{~B})-\mathrm{C}(24 \mathrm{~B})$ & $0.4(7)$ \\
\hline $\mathrm{C}(22 \mathrm{~B})-\mathrm{C}(23 \mathrm{~B})-\mathrm{C}(24 \mathrm{~B})-\mathrm{C}(19 \mathrm{~B})$ & $-1.5(7)$ \\
\hline$C(20 B)-C(19 B)-C(24 B)-C(23 B)$ & $1.1(6)$ \\
\hline $\mathrm{Sn}(1 \mathrm{~B})-\mathrm{C}(19 \mathrm{~B})-\mathrm{C}(24 \mathrm{~B})-\mathrm{C}(23 \mathrm{~B})$ & $179.4(3)$ \\
\hline $\mathrm{C}(30 \mathrm{~B})-\mathrm{C}(25 \mathrm{~B})-\mathrm{C}(26 \mathrm{~B})-\mathrm{C}(27 \mathrm{~B})$ & $1.0(7)$ \\
\hline $\mathrm{Sn}(1 \mathrm{~B})-\mathrm{C}(25 \mathrm{~B})-\mathrm{C}(26 \mathrm{~B})-\mathrm{C}(27 \mathrm{~B})$ & $-178.1(3)$ \\
\hline $\mathrm{C}(25 \mathrm{~B})-\mathrm{C}(26 \mathrm{~B})-\mathrm{C}(27 \mathrm{~B})-\mathrm{C}(28 \mathrm{~B})$ & $-1.9(7)$ \\
\hline $\mathrm{C}(26 \mathrm{~B})-\mathrm{C}(27 \mathrm{~B})-\mathrm{C}(28 \mathrm{~B})-\mathrm{C}(29 \mathrm{~B})$ & $1.6(7)$ \\
\hline $\mathrm{C}(27 \mathrm{~B})-\mathrm{C}(28 \mathrm{~B})-\mathrm{C}(29 \mathrm{~B})-\mathrm{C}(30 \mathrm{~B})$ & $-0.4(8)$ \\
\hline$C(28 B)-C(29 B)-C(30 B)-C(25 B)$ & $-0.6(8)$ \\
\hline $\mathrm{C}(26 \mathrm{~B})-\mathrm{C}(25 \mathrm{~B})-\mathrm{C}(30 \mathrm{~B})-\mathrm{C}(29 \mathrm{~B})$ & $0.3(7)$ \\
\hline $\mathrm{Sn}(1 \mathrm{~B})-\mathrm{C}(25 \mathrm{~B})-\mathrm{C}(30 \mathrm{~B})-\mathrm{C}(29 \mathrm{~B})$ & $179.3(4)$ \\
\hline
\end{tabular}

Symmetry transformations used to generate equivalent atoms: 
Table A5: Crystal data and structure refinement for $\mathbf{2 3}$.

Identification code

Empirical formula

Formula weight

Temperature

Wavelength

Crystal system

Space group

Unit cell dimensions

Volume

$\mathrm{Z}$

Density (calculated)

Absorption coefficient

$\mathrm{F}(000)$

Crystal size

Theta range for data collection

Index ranges

Reflections collected

Independent reflections

Completeness to theta $=25.242^{\circ}$

Absorption correction

Max. and min. transmission

Refinement method

Data / restraints / parameters

Goodness-of-fit on $\mathrm{F}^{2}$

Final R indices [I $>2 \operatorname{sigma}(\mathrm{I})]$

$\mathrm{R}$ indices (all data)

Extinction coefficient

Largest diff. peak and hole d18125_a

C25 H23 N Sn

456.13

150(2) K

$0.71073 \AA$

Monoclinic

$\mathrm{P} 21 / \mathrm{n}$

$\mathrm{a}=15.3986(9) \AA \quad \mathrm{a}=90^{\circ}$.

$\mathrm{b}=7.9119(5) \AA$

$\mathrm{b}=97.734(2)^{\circ}$.

$\mathrm{c}=17.214(11) \AA$

$\mathrm{g}=90^{\circ}$.

2078.1(2) $\AA^{3}$

4

$1.458 \mathrm{Mg} / \mathrm{m}^{3}$

$1.238 \mathrm{~mm}^{-1}$

920

$0.27 \times 0.20 \times 0.07 \mathrm{~mm}^{3}$

1.667 to $27.523^{\circ}$.

$-19<=\mathrm{h}<=20,-10<=\mathrm{k}<=10,-22<=\mathrm{l}<=22$

30756

$4785[\mathrm{R}(\mathrm{int})=0.0463]$

$100.0 \%$

Semi-empirical from equivalents

0.7456 and 0.6806

Full-matrix least-squares on $\mathrm{F}^{2}$

4785 / 0 / 244

1.025

$\mathrm{R} 1=0.0240, \mathrm{wR} 2=0.0407$

$\mathrm{R} 1=0.0456, \mathrm{wR} 2=0.0471$

$\mathrm{n} / \mathrm{a}$

0.833 and -0.437 e. $\AA^{-3}$ 
Atomic coordinates ( $\left.\mathrm{x} 10^{4}\right)$ and equivalent isotropic displacement parameters $\left(\AA^{2} \times 10^{3}\right)$ for 23. $\mathrm{U}(\mathrm{eq})$ is defined as one third of the trace of the orthogonalized $\mathrm{Uij}^{\mathrm{ij}}$ tensor.

\begin{tabular}{|c|c|c|c|c|}
\hline & $\mathrm{X}$ & $\mathrm{y}$ & $\mathrm{z}$ & $\mathrm{U}(\mathrm{eq})$ \\
\hline \multicolumn{5}{|l|}{-} \\
\hline $\operatorname{Sn}(1)$ & $5621(1)$ & $4202(1)$ & $3355(1)$ & $21(1)$ \\
\hline $\mathrm{N}(1)$ & 4694(1) & $5729(2)$ & $1960(1)$ & $25(1)$ \\
\hline $\mathrm{C}(1)$ & $5456(2)$ & $6900(3)$ & $3469(1)$ & $28(1)$ \\
\hline $\mathrm{C}(2)$ & $4596(2)$ & $7599(3)$ & $3050(1)$ & $29(1)$ \\
\hline $\mathrm{C}(3)$ & 4499(1) & $7293(3)$ & 2181(1) & $23(1)$ \\
\hline $\mathrm{C}(4)$ & $4234(2)$ & $8537(3)$ & $1634(2)$ & $31(1)$ \\
\hline $\mathrm{C}(5)$ & $4185(2)$ & $8174(3)$ & $843(2)$ & $37(1)$ \\
\hline$C(6)$ & $4390(2)$ & $6570(3)$ & $616(1)$ & $33(1)$ \\
\hline $\mathrm{C}(7)$ & $4638(2)$ & $5394(3)$ & $1192(1)$ & $31(1)$ \\
\hline $\mathrm{C}(8)$ & $4457(1)$ & $2779(3)$ & $3484(1)$ & $22(1)$ \\
\hline $\mathrm{C}(9)$ & $3715(2)$ & 2807(3) & $2918(1)$ & $29(1)$ \\
\hline$C(10)$ & 2971(2) & 1903(3) & $3024(2)$ & $37(1)$ \\
\hline $\mathrm{C}(11)$ & $2944(2)$ & $960(3)$ & $3690(2)$ & $38(1)$ \\
\hline $\mathrm{C}(12)$ & $3670(2)$ & $896(3)$ & $4256(2)$ & $35(1)$ \\
\hline$C(13)$ & $4421(2)$ & 1797(3) & $4152(1)$ & $28(1)$ \\
\hline $\mathrm{C}(14)$ & $6217(1)$ & $3174(3)$ & $2402(1)$ & $22(1)$ \\
\hline$C(15)$ & $5999(2)$ & 1551(3) & $2143(2)$ & $34(1)$ \\
\hline$C(16)$ & $6358(2)$ & $837(4)$ & $1523(2)$ & $41(1)$ \\
\hline $\mathrm{C}(17)$ & $6948(2)$ & 1734(3) & $1156(1)$ & $33(1)$ \\
\hline $\mathrm{C}(18)$ & $7177(2)$ & $3349(3)$ & $1404(1)$ & $33(1)$ \\
\hline C(19) & $6816(2)$ & 4061(3) & $2025(1)$ & $28(1)$ \\
\hline$C(20)$ & $6561(1)$ & $3562(3)$ & $4360(1)$ & $22(1)$ \\
\hline $\mathrm{C}(21)$ & $7286(2)$ & $2571(3)$ & $4268(1)$ & $27(1)$ \\
\hline$C(22)$ & $7956(2)$ & $2276(3)$ & $4883(1)$ & $32(1)$ \\
\hline$C(23)$ & $7911(2)$ & $3000(3)$ & $5603(1)$ & $33(1)$ \\
\hline$C(24)$ & $7200(2)$ & $3996(3)$ & $5717(1)$ & $32(1)$ \\
\hline$C(25)$ & $6534(2)$ & 4263(3) & $5104(1)$ & $28(1)$ \\
\hline
\end{tabular}


Bond lengths $[\AA]$ and angles $\left[{ }^{\circ}\right]$ for 23 .

\begin{tabular}{|c|c|}
\hline $\operatorname{Sn}(1)-C(14)$ & $2.144(2)$ \\
\hline $\operatorname{Sn}(1)-C(8)$ & $2.154(2)$ \\
\hline $\operatorname{Sn}(1)-C(20)$ & $2.162(2)$ \\
\hline $\operatorname{Sn}(1)-C(1)$ & $2.162(2)$ \\
\hline $\mathrm{N}(1)-\mathrm{C}(7)$ & $1.340(3)$ \\
\hline $\mathrm{N}(1)-\mathrm{C}(3)$ & $1.341(3)$ \\
\hline $\mathrm{C}(1)-\mathrm{C}(2)$ & $1.524(3)$ \\
\hline $\mathrm{C}(1)-\mathrm{H}(1 \mathrm{~A})$ & 0.9900 \\
\hline $\mathrm{C}(1)-\mathrm{H}(1 \mathrm{~B})$ & 0.9900 \\
\hline$C(2)-C(3)$ & $1.502(3)$ \\
\hline $\mathrm{C}(2)-\mathrm{H}(2 \mathrm{~A})$ & 0.9900 \\
\hline $\mathrm{C}(2)-\mathrm{H}(2 \mathrm{~B})$ & 0.9900 \\
\hline$C(3)-C(4)$ & $1.386(3)$ \\
\hline$C(4)-C(5)$ & $1.383(3)$ \\
\hline $\mathrm{C}(4)-\mathrm{H}(4 \mathrm{~A})$ & 0.9500 \\
\hline$C(5)-C(6)$ & $1.377(3)$ \\
\hline $\mathrm{C}(5)-\mathrm{H}(5 \mathrm{~A})$ & 0.9500 \\
\hline$C(6)-C(7)$ & $1.375(3)$ \\
\hline $\mathrm{C}(6)-\mathrm{H}(6 \mathrm{~A})$ & 0.9500 \\
\hline $\mathrm{C}(7)-\mathrm{H}(7 \mathrm{~A})$ & 0.9500 \\
\hline$C(8)-C(13)$ & $1.396(3)$ \\
\hline $\mathrm{C}(8)-\mathrm{C}(9)$ & $1.397(3)$ \\
\hline$C(9)-C(10)$ & $1.384(3)$ \\
\hline $\mathrm{C}(9)-\mathrm{H}(9 \mathrm{~A})$ & 0.9500 \\
\hline$C(10)-C(11)$ & $1.373(4)$ \\
\hline $\mathrm{C}(10)-\mathrm{H}(10 \mathrm{~A})$ & 0.9500 \\
\hline $\mathrm{C}(11)-\mathrm{C}(12)$ & $1.381(4)$ \\
\hline $\mathrm{C}(11)-\mathrm{H}(11 \mathrm{~A})$ & 0.9500 \\
\hline$C(12)-C(13)$ & $1.390(3)$ \\
\hline $\mathrm{C}(12)-\mathrm{H}(12 \mathrm{~A})$ & 0.9500 \\
\hline $\mathrm{C}(13)-\mathrm{H}(13 \mathrm{~A})$ & 0.9500 \\
\hline$C(14)-C(15)$ & $1.386(3)$ \\
\hline $\mathrm{C}(14)-\mathrm{C}(19)$ & $1.388(3)$ \\
\hline$C(15)-C(16)$ & $1.387(3)$ \\
\hline
\end{tabular}




\begin{tabular}{|c|c|}
\hline $\mathrm{C}(15)-\mathrm{H}(15 \mathrm{~A})$ & 0.9500 \\
\hline$C(16)-C(17)$ & $1.371(4)$ \\
\hline $\mathrm{C}(16)-\mathrm{H}(16 \mathrm{~A})$ & 0.9500 \\
\hline $\mathrm{C}(17)-\mathrm{C}(18)$ & $1.378(4)$ \\
\hline $\mathrm{C}(17)-\mathrm{H}(17 \mathrm{~A})$ & 0.9500 \\
\hline C(18)-C(19) & $1.388(3)$ \\
\hline $\mathrm{C}(18)-\mathrm{H}(18 \mathrm{~A})$ & 0.9500 \\
\hline $\mathrm{C}(19)-\mathrm{H}(19 \mathrm{~A})$ & 0.9500 \\
\hline $\mathrm{C}(20)-\mathrm{C}(21)$ & $1.391(3)$ \\
\hline$C(20)-C(25)$ & $1.401(3)$ \\
\hline $\mathrm{C}(21)-\mathrm{C}(22)$ & $1.395(3)$ \\
\hline $\mathrm{C}(21)-\mathrm{H}(21 \mathrm{~A})$ & 0.9500 \\
\hline $\mathrm{C}(22)-\mathrm{C}(23)$ & $1.376(3)$ \\
\hline $\mathrm{C}(22)-\mathrm{H}(22 \mathrm{~A})$ & 0.9500 \\
\hline $\mathrm{C}(23)-\mathrm{C}(24)$ & $1.384(3)$ \\
\hline $\mathrm{C}(23)-\mathrm{H}(23 \mathrm{~A})$ & 0.9500 \\
\hline$C(24)-C(25)$ & $1.385(3)$ \\
\hline $\mathrm{C}(24)-\mathrm{H}(24 \mathrm{~A})$ & 0.9500 \\
\hline $\mathrm{C}(25)-\mathrm{H}(25 \mathrm{~A})$ & 0.9500 \\
\hline $\mathrm{C}(14)-\mathrm{Sn}(1)-\mathrm{C}(8)$ & $109.18(8)$ \\
\hline $\mathrm{C}(14)-\mathrm{Sn}(1)-\mathrm{C}(20)$ & $102.38(8)$ \\
\hline$C(8)-\operatorname{Sn}(1)-C(20)$ & $105.77(8)$ \\
\hline$C(14)-\operatorname{Sn}(1)-C(1)$ & $120.81(9)$ \\
\hline$C(8)-\operatorname{Sn}(1)-C(1)$ & $113.38(9)$ \\
\hline$C(20)-\operatorname{Sn}(1)-C(1)$ & $103.44(8)$ \\
\hline $\mathrm{C}(7)-\mathrm{N}(1)-\mathrm{C}(3)$ & $118.4(2)$ \\
\hline$C(2)-C(1)-\operatorname{Sn}(1)$ & $114.87(16)$ \\
\hline $\mathrm{C}(2)-\mathrm{C}(1)-\mathrm{H}(1 \mathrm{~A})$ & 108.6 \\
\hline $\operatorname{Sn}(1)-C(1)-H(1 A)$ & 108.6 \\
\hline $\mathrm{C}(2)-\mathrm{C}(1)-\mathrm{H}(1 \mathrm{~B})$ & 108.6 \\
\hline $\mathrm{Sn}(1)-\mathrm{C}(1)-\mathrm{H}(1 \mathrm{~B})$ & 108.6 \\
\hline $\mathrm{H}(1 \mathrm{~A})-\mathrm{C}(1)-\mathrm{H}(1 \mathrm{~B})$ & 107.5 \\
\hline $\mathrm{C}(3)-\mathrm{C}(2)-\mathrm{C}(1)$ & $112.15(19)$ \\
\hline $\mathrm{C}(3)-\mathrm{C}(2)-\mathrm{H}(2 \mathrm{~A})$ & 109.2 \\
\hline $\mathrm{C}(1)-\mathrm{C}(2)-\mathrm{H}(2 \mathrm{~A})$ & 109.2 \\
\hline
\end{tabular}




\begin{tabular}{|c|c|}
\hline $\mathrm{C}(3)-\mathrm{C}(2)-\mathrm{H}(2 \mathrm{~B})$ & 109.2 \\
\hline $\mathrm{C}(1)-\mathrm{C}(2)-\mathrm{H}(2 \mathrm{~B})$ & 109.2 \\
\hline $\mathrm{H}(2 \mathrm{~A})-\mathrm{C}(2)-\mathrm{H}(2 \mathrm{~B})$ & 107.9 \\
\hline $\mathrm{N}(1)-\mathrm{C}(3)-\mathrm{C}(4)$ & $121.3(2)$ \\
\hline $\mathrm{N}(1)-\mathrm{C}(3)-\mathrm{C}(2)$ & $115.8(2)$ \\
\hline $\mathrm{C}(4)-\mathrm{C}(3)-\mathrm{C}(2)$ & $122.9(2)$ \\
\hline$C(5)-C(4)-C(3)$ & $119.6(2)$ \\
\hline $\mathrm{C}(5)-\mathrm{C}(4)-\mathrm{H}(4 \mathrm{~A})$ & 120.2 \\
\hline $\mathrm{C}(3)-\mathrm{C}(4)-\mathrm{H}(4 \mathrm{~A})$ & 120.2 \\
\hline$C(6)-C(5)-C(4)$ & $119.1(2)$ \\
\hline $\mathrm{C}(6)-\mathrm{C}(5)-\mathrm{H}(5 \mathrm{~A})$ & 120.4 \\
\hline $\mathrm{C}(4)-\mathrm{C}(5)-\mathrm{H}(5 \mathrm{~A})$ & 120.4 \\
\hline $\mathrm{C}(7)-\mathrm{C}(6)-\mathrm{C}(5)$ & $118.1(2)$ \\
\hline $\mathrm{C}(7)-\mathrm{C}(6)-\mathrm{H}(6 \mathrm{~A})$ & 121.0 \\
\hline $\mathrm{C}(5)-\mathrm{C}(6)-\mathrm{H}(6 \mathrm{~A})$ & 121.0 \\
\hline $\mathrm{N}(1)-\mathrm{C}(7)-\mathrm{C}(6)$ & $123.5(2)$ \\
\hline $\mathrm{N}(1)-\mathrm{C}(7)-\mathrm{H}(7 \mathrm{~A})$ & 118.2 \\
\hline $\mathrm{C}(6)-\mathrm{C}(7)-\mathrm{H}(7 \mathrm{~A})$ & 118.2 \\
\hline C(13)-C(8)-C(9) & $117.7(2)$ \\
\hline$C(13)-C(8)-\operatorname{Sn}(1)$ & $120.10(16)$ \\
\hline $\mathrm{C}(9)-\mathrm{C}(8)-\mathrm{Sn}(1)$ & $122.22(17)$ \\
\hline$C(10)-C(9)-C(8)$ & $120.9(2)$ \\
\hline $\mathrm{C}(10)-\mathrm{C}(9)-\mathrm{H}(9 \mathrm{~A})$ & 119.5 \\
\hline $\mathrm{C}(8)-\mathrm{C}(9)-\mathrm{H}(9 \mathrm{~A})$ & 119.5 \\
\hline $\mathrm{C}(11)-\mathrm{C}(10)-\mathrm{C}(9)$ & $120.6(2)$ \\
\hline $\mathrm{C}(11)-\mathrm{C}(10)-\mathrm{H}(10 \mathrm{~A})$ & 119.7 \\
\hline $\mathrm{C}(9)-\mathrm{C}(10)-\mathrm{H}(10 \mathrm{~A})$ & 119.7 \\
\hline $\mathrm{C}(10)-\mathrm{C}(11)-\mathrm{C}(12)$ & $119.8(2)$ \\
\hline$C(10)-C(11)-H(11 A)$ & 120.1 \\
\hline $\mathrm{C}(12)-\mathrm{C}(11)-\mathrm{H}(11 \mathrm{~A})$ & 120.1 \\
\hline $\mathrm{C}(11)-\mathrm{C}(12)-\mathrm{C}(13)$ & $120.0(2)$ \\
\hline $\mathrm{C}(11)-\mathrm{C}(12)-\mathrm{H}(12 \mathrm{~A})$ & 120.0 \\
\hline $\mathrm{C}(13)-\mathrm{C}(12)-\mathrm{H}(12 \mathrm{~A})$ & 120.0 \\
\hline $\mathrm{C}(12)-\mathrm{C}(13)-\mathrm{C}(8)$ & $121.1(2)$ \\
\hline $\mathrm{C}(12)-\mathrm{C}(13)-\mathrm{H}(13 \mathrm{~A})$ & 119.5 \\
\hline $\mathrm{C}(8)-\mathrm{C}(13)-\mathrm{H}(13 \mathrm{~A})$ & 119.5 \\
\hline
\end{tabular}




\begin{tabular}{|c|c|}
\hline $\mathrm{C}(15)-\mathrm{C}(14)-\mathrm{C}(19)$ & $117.8(2)$ \\
\hline C(15)-C(14)-Sn(1) & $119.17(17)$ \\
\hline C(19)-C(14)-Sn(1) & $123.08(17)$ \\
\hline $\mathrm{C}(14)-\mathrm{C}(15)-\mathrm{C}(16)$ & $121.3(2)$ \\
\hline $\mathrm{C}(14)-\mathrm{C}(15)-\mathrm{H}(15 \mathrm{~A})$ & 119.3 \\
\hline $\mathrm{C}(16)-\mathrm{C}(15)-\mathrm{H}(15 \mathrm{~A})$ & 119.3 \\
\hline $\mathrm{C}(17)-\mathrm{C}(16)-\mathrm{C}(15)$ & $120.1(3)$ \\
\hline $\mathrm{C}(17)-\mathrm{C}(16)-\mathrm{H}(16 \mathrm{~A})$ & 119.9 \\
\hline $\mathrm{C}(15)-\mathrm{C}(16)-\mathrm{H}(16 \mathrm{~A})$ & 119.9 \\
\hline $\mathrm{C}(16)-\mathrm{C}(17)-\mathrm{C}(18)$ & $119.6(2)$ \\
\hline $\mathrm{C}(16)-\mathrm{C}(17)-\mathrm{H}(17 \mathrm{~A})$ & 120.2 \\
\hline $\mathrm{C}(18)-\mathrm{C}(17)-\mathrm{H}(17 \mathrm{~A})$ & 120.2 \\
\hline C(17)-C(18)-C(19) & $120.2(2)$ \\
\hline $\mathrm{C}(17)-\mathrm{C}(18)-\mathrm{H}(18 \mathrm{~A})$ & 119.9 \\
\hline $\mathrm{C}(19)-\mathrm{C}(18)-\mathrm{H}(18 \mathrm{~A})$ & 119.9 \\
\hline C(14)-C(19)-C(18) & $121.0(2)$ \\
\hline $\mathrm{C}(14)-\mathrm{C}(19)-\mathrm{H}(19 \mathrm{~A})$ & 119.5 \\
\hline $\mathrm{C}(18)-\mathrm{C}(19)-\mathrm{H}(19 \mathrm{~A})$ & 119.5 \\
\hline$C(21)-C(20)-C(25)$ & $116.8(2)$ \\
\hline $\mathrm{C}(21)-\mathrm{C}(20)-\mathrm{Sn}(1)$ & $120.12(16)$ \\
\hline $\mathrm{C}(25)-\mathrm{C}(20)-\mathrm{Sn}(1)$ & $122.70(17)$ \\
\hline $\mathrm{C}(20)-\mathrm{C}(21)-\mathrm{C}(22)$ & $122.1(2)$ \\
\hline $\mathrm{C}(20)-\mathrm{C}(21)-\mathrm{H}(21 \mathrm{~A})$ & 119.0 \\
\hline $\mathrm{C}(22)-\mathrm{C}(21)-\mathrm{H}(21 \mathrm{~A})$ & 119.0 \\
\hline $\mathrm{C}(23)-\mathrm{C}(22)-\mathrm{C}(21)$ & $119.5(2)$ \\
\hline $\mathrm{C}(23)-\mathrm{C}(22)-\mathrm{H}(22 \mathrm{~A})$ & 120.2 \\
\hline $\mathrm{C}(21)-\mathrm{C}(22)-\mathrm{H}(22 \mathrm{~A})$ & 120.2 \\
\hline $\mathrm{C}(22)-\mathrm{C}(23)-\mathrm{C}(24)$ & $120.0(2)$ \\
\hline $\mathrm{C}(22)-\mathrm{C}(23)-\mathrm{H}(23 \mathrm{~A})$ & 120.0 \\
\hline $\mathrm{C}(24)-\mathrm{C}(23)-\mathrm{H}(23 \mathrm{~A})$ & 120.0 \\
\hline $\mathrm{C}(23)-\mathrm{C}(24)-\mathrm{C}(25)$ & $119.9(2)$ \\
\hline $\mathrm{C}(23)-\mathrm{C}(24)-\mathrm{H}(24 \mathrm{~A})$ & 120.0 \\
\hline $\mathrm{C}(25)-\mathrm{C}(24)-\mathrm{H}(24 \mathrm{~A})$ & 120.0 \\
\hline $\mathrm{C}(24)-\mathrm{C}(25)-\mathrm{C}(20)$ & $121.7(2)$ \\
\hline $\mathrm{C}(24)-\mathrm{C}(25)-\mathrm{H}(25 \mathrm{~A})$ & 119.2 \\
\hline $\mathrm{C}(20)-\mathrm{C}(25)-\mathrm{H}(25 \mathrm{~A})$ & 119.2 \\
\hline
\end{tabular}


Symmetry transformations used to generate equivalent atoms: 
Anisotropic displacement parameters $\left(\AA^{2} \times 10^{3}\right)$ for 13. The anisotropic displacement factor exponent takes the form: $-2 \mathrm{p}^{2}\left[\mathrm{~h}^{2} \mathrm{a}^{* 2} \mathrm{U}^{11}+\ldots+2 \mathrm{~h} \mathrm{k} \mathrm{a}^{*} \mathrm{~b}^{*} \mathrm{U}^{12}\right]$

\begin{tabular}{|c|c|c|c|c|c|c|}
\hline & U11 & $\mathrm{U}^{22}$ & $\mathrm{U}^{33}$ & $\mathrm{U}^{23}$ & U13 & $\mathrm{U}^{12}$ \\
\hline $\operatorname{Sn}(1)$ & $22(1)$ & $22(1)$ & $20(1)$ & $-3(1)$ & $5(1)$ & $-1(1)$ \\
\hline $\mathrm{N}(1)$ & $26(1)$ & $25(1)$ & $26(1)$ & $-2(1)$ & $6(1)$ & $2(1)$ \\
\hline $\mathrm{C}(1)$ & $32(1)$ & $25(1)$ & $25(1)$ & $-7(1)$ & $1(1)$ & $4(1)$ \\
\hline $\mathrm{C}(2)$ & $32(1)$ & $27(1)$ & $29(1)$ & $-2(1)$ & $9(1)$ & $5(1)$ \\
\hline$C(3)$ & $16(1)$ & $24(1)$ & $28(1)$ & $-2(1)$ & $5(1)$ & $-1(1)$ \\
\hline C(4) & $30(1)$ & $24(1)$ & $38(1)$ & $-2(1)$ & $-1(1)$ & $4(1)$ \\
\hline$C(5)$ & $40(2)$ & $35(2)$ & $33(2)$ & $6(1)$ & $-3(1)$ & $3(1)$ \\
\hline$C(6)$ & $33(1)$ & $41(2)$ & $23(1)$ & $-4(1)$ & $1(1)$ & $1(1)$ \\
\hline$C(7)$ & $32(1)$ & $30(1)$ & $31(1)$ & $-8(1)$ & $7(1)$ & $2(1)$ \\
\hline$C(8)$ & $22(1)$ & $21(1)$ & $26(1)$ & $-7(1)$ & $11(1)$ & $0(1)$ \\
\hline $\mathrm{C}(9)$ & $28(1)$ & $31(1)$ & $29(1)$ & $-2(1)$ & $6(1)$ & $-3(1)$ \\
\hline$C(10)$ & $26(1)$ & $42(2)$ & $44(2)$ & $-6(1)$ & $4(1)$ & $-4(1)$ \\
\hline $\mathrm{C}(11)$ & $29(1)$ & $33(2)$ & $55(2)$ & $-5(1)$ & $19(1)$ & $-6(1)$ \\
\hline$C(12)$ & $39(1)$ & $29(1)$ & $41(2)$ & $3(1)$ & $20(1)$ & $0(1)$ \\
\hline$C(13)$ & $29(1)$ & $27(1)$ & $27(1)$ & $-4(1)$ & $8(1)$ & $2(1)$ \\
\hline$C(14)$ & 21(1) & $28(1)$ & $19(1)$ & $-1(1)$ & $1(1)$ & $1(1)$ \\
\hline$C(15)$ & $34(1)$ & $32(1)$ & $37(2)$ & $-9(1)$ & $14(1)$ & $-7(1)$ \\
\hline$C(16)$ & $43(2)$ & $37(2)$ & $44(2)$ & $-20(1)$ & $12(1)$ & $-3(1)$ \\
\hline$C(17)$ & $34(1)$ & $44(2)$ & $23(1)$ & $-4(1)$ & $5(1)$ & $15(1)$ \\
\hline$C(18)$ & $34(1)$ & $37(2)$ & $32(1)$ & $10(1)$ & $14(1)$ & $9(1)$ \\
\hline C(19) & $32(1)$ & $24(1)$ & $30(1)$ & 1(1) & $9(1)$ & $2(1)$ \\
\hline$C(20)$ & $25(1)$ & $19(1)$ & $23(1)$ & $1(1)$ & $5(1)$ & $-5(1)$ \\
\hline $\mathrm{C}(21)$ & $34(1)$ & $24(1)$ & $22(1)$ & $-3(1)$ & $5(1)$ & $3(1)$ \\
\hline $\mathrm{C}(22)$ & $32(1)$ & $28(1)$ & $36(1)$ & $1(1)$ & $3(1)$ & $6(1)$ \\
\hline $\mathrm{C}(23)$ & $37(2)$ & $30(1)$ & $28(1)$ & $4(1)$ & $-6(1)$ & $-6(1)$ \\
\hline $\mathrm{C}(24)$ & $43(2)$ & $32(1)$ & $21(1)$ & $-4(1)$ & $4(1)$ & $-8(1)$ \\
\hline$C(25)$ & $30(1)$ & $27(1)$ & $28(1)$ & $-1(1)$ & $9(1)$ & $-1(1)$ \\
\hline
\end{tabular}


Hydrogen coordinates $\left(\mathrm{x} 10^{4}\right)$ and isotropic displacement parameters $\left(\AA^{2} \times 10^{3}\right)$ for $\mathbf{1 3}$.

\begin{tabular}{|c|c|c|c|c|}
\hline & $\mathrm{x}$ & $\mathrm{y}$ & $\mathrm{z}$ & $\mathrm{U}(\mathrm{eq})$ \\
\hline \multicolumn{5}{|l|}{-} \\
\hline $\mathrm{H}(1 \mathrm{~A})$ & 5495 & 7179 & 4034 & 33 \\
\hline $\mathrm{H}(1 \mathrm{~B})$ & 5946 & 7478 & 3262 & 33 \\
\hline $\mathrm{H}(2 \mathrm{~A})$ & 4101 & 7059 & 3267 & 34 \\
\hline $\mathrm{H}(2 \mathrm{~B})$ & 4570 & 8829 & 3149 & 34 \\
\hline $\mathrm{H}(4 \mathrm{~A})$ & 4086 & 9632 & 1800 & 37 \\
\hline $\mathrm{H}(5 \mathrm{~A})$ & 4014 & 9020 & 462 & 44 \\
\hline $\mathrm{H}(6 \mathrm{~A})$ & 4361 & 6283 & 77 & 39 \\
\hline $\mathrm{H}(7 \mathrm{~A})$ & 4777 & 4285 & 1037 & 37 \\
\hline $\mathrm{H}(9 \mathrm{~A})$ & 3722 & 3456 & 2455 & 35 \\
\hline $\mathrm{H}(10 \mathrm{~A})$ & 2474 & 1936 & 2632 & 45 \\
\hline $\mathrm{H}(11 \mathrm{~A})$ & 2429 & 352 & 3761 & 45 \\
\hline $\mathrm{H}(12 \mathrm{~A})$ & 3656 & 238 & 4715 & 42 \\
\hline $\mathrm{H}(13 \mathrm{~A})$ & 4919 & 1742 & 4543 & 33 \\
\hline $\mathrm{H}(15 \mathrm{~A})$ & 5595 & 913 & 2396 & 40 \\
\hline $\mathrm{H}(16 \mathrm{~A})$ & 6196 & -274 & 1352 & 49 \\
\hline $\mathrm{H}(17 \mathrm{~A})$ & 7198 & 1244 & 733 & 40 \\
\hline $\mathrm{H}(18 \mathrm{~A})$ & 7583 & 3978 & 1150 & 40 \\
\hline $\mathrm{H}(19 \mathrm{~A})$ & 6982 & 5172 & 2194 & 34 \\
\hline $\mathrm{H}(21 \mathrm{~A})$ & 7326 & 2081 & 3770 & 32 \\
\hline $\mathrm{H}(22 \mathrm{~A})$ & 8440 & 1580 & 4805 & 39 \\
\hline $\mathrm{H}(23 \mathrm{~A})$ & 8369 & 2815 & 6023 & 39 \\
\hline $\mathrm{H}(24 \mathrm{~A})$ & 7170 & 4496 & 6214 & 38 \\
\hline $\mathrm{H}(25 \mathrm{~A})$ & 6046 & 4939 & 5191 & 33 \\
\hline
\end{tabular}


Torsion angles $\left[{ }^{\circ}\right]$ for $\mathbf{1 3}$.

\begin{tabular}{|c|c|}
\hline $\mathrm{Sn}(1)-\mathrm{C}(1)-\mathrm{C}(2)-\mathrm{C}(3)$ & $-60.7(2)$ \\
\hline $\mathrm{C}(7)-\mathrm{N}(1)-\mathrm{C}(3)-\mathrm{C}(4)$ & $1.0(3)$ \\
\hline $\mathrm{C}(7)-\mathrm{N}(1)-\mathrm{C}(3)-\mathrm{C}(2)$ & $-178.5(2)$ \\
\hline $\mathrm{C}(1)-\mathrm{C}(2)-\mathrm{C}(3)-\mathrm{N}(1)$ & $46.2(3)$ \\
\hline$C(1)-C(2)-C(3)-C(4)$ & $-133.3(2)$ \\
\hline $\mathrm{N}(1)-\mathrm{C}(3)-\mathrm{C}(4)-\mathrm{C}(5)$ & $-1.4(4)$ \\
\hline$C(2)-C(3)-C(4)-C(5)$ & $178.0(2)$ \\
\hline$C(3)-C(4)-C(5)-C(6)$ & $1.0(4)$ \\
\hline$C(4)-C(5)-C(6)-C(7)$ & $-0.2(4)$ \\
\hline $\mathrm{C}(3)-\mathrm{N}(1)-\mathrm{C}(7)-\mathrm{C}(6)$ & $-0.1(3)$ \\
\hline $\mathrm{C}(5)-\mathrm{C}(6)-\mathrm{C}(7)-\mathrm{N}(1)$ & $-0.2(4)$ \\
\hline $\mathrm{C}(13)-\mathrm{C}(8)-\mathrm{C}(9)-\mathrm{C}(10)$ & $0.6(3)$ \\
\hline $\operatorname{Sn}(1)-C(8)-C(9)-C(10)$ & $-178.83(18)$ \\
\hline $\mathrm{C}(8)-\mathrm{C}(9)-\mathrm{C}(10)-\mathrm{C}(11)$ & $0.2(4)$ \\
\hline $\mathrm{C}(9)-\mathrm{C}(10)-\mathrm{C}(11)-\mathrm{C}(12)$ & $-0.7(4)$ \\
\hline$C(10)-C(11)-C(12)-C(13)$ & $0.5(4)$ \\
\hline $\mathrm{C}(11)-\mathrm{C}(12)-\mathrm{C}(13)-\mathrm{C}(8)$ & $0.3(4)$ \\
\hline $\mathrm{C}(9)-\mathrm{C}(8)-\mathrm{C}(13)-\mathrm{C}(12)$ & $-0.8(3)$ \\
\hline $\operatorname{Sn}(1)-C(8)-C(13)-C(12)$ & $178.62(17)$ \\
\hline$C(19)-C(14)-C(15)-C(16)$ & $-0.7(4)$ \\
\hline $\mathrm{Sn}(1)-\mathrm{C}(14)-\mathrm{C}(15)-\mathrm{C}(16)$ & $179.2(2)$ \\
\hline$C(14)-C(15)-C(16)-C(17)$ & $0.6(4)$ \\
\hline $\mathrm{C}(15)-\mathrm{C}(16)-\mathrm{C}(17)-\mathrm{C}(18)$ & $-0.4(4)$ \\
\hline $\mathrm{C}(16)-\mathrm{C}(17)-\mathrm{C}(18)-\mathrm{C}(19)$ & $0.4(4)$ \\
\hline $\mathrm{C}(15)-\mathrm{C}(14)-\mathrm{C}(19)-\mathrm{C}(18)$ & $0.7(3)$ \\
\hline $\operatorname{Sn}(1)-C(14)-C(19)-C(18)$ & $-179.21(18)$ \\
\hline $\mathrm{C}(17)-\mathrm{C}(18)-\mathrm{C}(19)-\mathrm{C}(14)$ & $-0.5(4)$ \\
\hline $\mathrm{C}(25)-\mathrm{C}(20)-\mathrm{C}(21)-\mathrm{C}(22)$ & $0.3(3)$ \\
\hline $\operatorname{Sn}(1)-C(20)-C(21)-C(22)$ & $173.06(18)$ \\
\hline$C(20)-C(21)-C(22)-C(23)$ & $-0.9(4)$ \\
\hline$C(21)-C(22)-C(23)-C(24)$ & $0.8(4)$ \\
\hline $\mathrm{C}(22)-\mathrm{C}(23)-\mathrm{C}(24)-\mathrm{C}(25)$ & $0.0(4)$ \\
\hline $\mathrm{C}(23)-\mathrm{C}(24)-\mathrm{C}(25)-\mathrm{C}(20)$ & $-0.7(4)$ \\
\hline$C(21)-C(20)-C(25)-C(24)$ & $0.5(3)$ \\
\hline
\end{tabular}


Symmetry transformations used to generate equivalent atoms: 
Table A6:Crystal data and structure refinement for $\mathbf{2 4}$.

Identification code

Empirical formula

Formula weight

Temperature

Wavelength

Crystal system

Space group

Unit cell dimensions

Volume

Z

Density (calculated)

Absorption coefficient

$\mathrm{F}(000)$

Crystal size

Theta range for data collection

Index ranges

Reflections collected

Independent reflections

Completeness to theta $=25.242^{\circ}$

Absorption correction

Max. and min. transmission

Refinement method

Data / restraints / parameters

Goodness-of-fit on $\mathrm{F}^{2}$

Final $\mathrm{R}$ indices [I>2sigma(I)]

$\mathrm{R}$ indices (all data)

Extinction coefficient

Largest diff. peak and hole d18128_a

C13 H13 Br2 N Sn

461.75

150(2) K

$0.71073 \AA$

Monoclinic

$\mathrm{P} 21 / \mathrm{n}$

$\mathrm{a}=15.4702(11) \AA \quad \mathrm{a}=90^{\circ}$.

$\mathrm{b}=10.7758(7) \AA$

$\mathrm{b}=100.386(2)^{\circ}$.

$\mathrm{c}=17.9533(12) \AA$

2943.8(3) $\AA^{3}$

8

$2.084 \mathrm{Mg} / \mathrm{m}^{3}$

$7.144 \mathrm{~mm}^{-1}$

1744

$0.350 \times 0.200 \times 0.020 \mathrm{~mm}^{3}$

1.601 to $27.562^{\circ}$.

$-19<=\mathrm{h}<=20,-14<=\mathrm{k}<=13,-23<=1<=21$

39833

$6786[\mathrm{R}(\mathrm{int})=0.0683]$

$100.0 \%$

Semi-empirical from equivalents

0.7456 and 0.4499

Full-matrix least-squares on $\mathrm{F}^{2}$

6786 / 0 / 307

1.103

$\mathrm{R} 1=0.0503, \mathrm{wR} 2=0.0870$

$\mathrm{R} 1=0.0883, \mathrm{wR} 2=0.0995$

$\mathrm{n} / \mathrm{a}$

1.781 and -1.270 e. $\AA^{-3}$ 
Atomic coordinates ( $\left.\mathrm{x} 10^{4}\right)$ and equivalent isotropic displacement parameters $\left(\AA^{2} \times 10^{3}\right)$ for 24. $\mathrm{U}(\mathrm{eq})$ is defined as one third of the trace of the orthogonalized $\mathrm{Uij}^{\mathrm{ij}}$ tensor.

\begin{tabular}{|c|c|c|c|c|}
\hline & $\mathrm{x}$ & $\mathrm{y}$ & $\mathrm{z}$ & $\mathrm{U}(\mathrm{eq})$ \\
\hline \multicolumn{5}{|l|}{-} \\
\hline $\operatorname{Sn}(1 \mathrm{~A})$ & $2652(1)$ & $4622(1)$ & $8106(1)$ & $20(1)$ \\
\hline $\operatorname{Br}(1 \mathrm{~A})$ & $1406(1)$ & $3727(1)$ & $7051(1)$ & $27(1)$ \\
\hline $\operatorname{Br}(2 \mathrm{~A})$ & $3080(1)$ & $2536(1)$ & $8671(1)$ & $45(1)$ \\
\hline $\mathrm{N}(1 \mathrm{~A})$ & $3872(3)$ & $5529(4)$ & $8923(3)$ & $21(1)$ \\
\hline $\mathrm{C}(1 \mathrm{~A})$ & $3519(4)$ & $5089(6)$ & $7360(3)$ & $23(1)$ \\
\hline $\mathrm{C}(2 \mathrm{~A})$ & $4468(4)$ & $5059(6)$ & $7792(3)$ & $28(2)$ \\
\hline $\mathrm{C}(3 \mathrm{~A})$ & $4557(4)$ & $5675(5)$ & $8558(3)$ & $22(1)$ \\
\hline$C(4 A)$ & $5296(4)$ & $6327(6)$ & $8881(4)$ & $30(2)$ \\
\hline$C(5 A)$ & $5336(5)$ & $6819(6)$ & $9594(4)$ & $34(2)$ \\
\hline$C(6 A)$ & $4646(5)$ & $6668(6)$ & $9969(4)$ & $30(2)$ \\
\hline$C(7 A)$ & $3917(5)$ & $6010(5)$ & $9618(4)$ & $28(2)$ \\
\hline$C(8 A)$ & $1787(4)$ & $5527(6)$ & $8730(4)$ & $29(2)$ \\
\hline $\mathrm{C}(9 \mathrm{~A})$ & $1325(5)$ & $6545(7)$ & $8442(4)$ & $38(2)$ \\
\hline$C(10 A)$ & 761(6) & $7144(8)$ & $8840(5)$ & $52(2)$ \\
\hline$C(11 A)$ & $645(6)$ & $6705(10)$ & $9524(6)$ & $61(3)$ \\
\hline $\mathrm{C}(12 \mathrm{~A})$ & 1106(6) & $5686(9)$ & $9840(5)$ & $58(3)$ \\
\hline$C(13 A)$ & $1688(6)$ & $5077(8)$ & $9439(4)$ & $46(2)$ \\
\hline $\mathrm{Sn}(1 \mathrm{~B})$ & $7599(1)$ & $7094(1)$ & $7180(1)$ & $23(1)$ \\
\hline $\operatorname{Br}(1 \mathrm{~B})$ & $7321(1)$ & $7949(1)$ & $8480(1)$ & $36(1)$ \\
\hline $\operatorname{Br}(2 \mathrm{~B})$ & $8083(1)$ & $9153(1)$ & $6728(1)$ & $36(1)$ \\
\hline $\mathrm{N}(1 \mathrm{~B})$ & $8046(3)$ & $6291(4)$ & $6084(3)$ & $23(1)$ \\
\hline$C(1 B)$ & $8702(4)$ & 5989(6) & $7626(4)$ & $31(2)$ \\
\hline $\mathrm{C}(2 \mathrm{~B})$ & $9309(4)$ & $5828(7)$ & $7052(4)$ & $32(2)$ \\
\hline$C(3 B)$ & $8822(4)$ & $5713(5)$ & $6244(4)$ & $25(1)$ \\
\hline$C(4 B)$ & $9160(5)$ & $5104(6)$ & $5690(4)$ & $31(2)$ \\
\hline$C(5 B)$ & $8709(5)$ & $5113(6)$ & $4960(4)$ & $38(2)$ \\
\hline$C(6 B)$ & $7921(5)$ & $5737(7)$ & $4793(4)$ & $39(2)$ \\
\hline$C(7 B)$ & $7602(5)$ & $6315(7)$ & $5369(4)$ & $34(2)$ \\
\hline $\mathrm{C}(8 \mathrm{~B})$ & $6249(4)$ & $6790(5)$ & $6696(3)$ & $16(1)$ \\
\hline
\end{tabular}




$\begin{array}{lllll}\mathrm{C}(9 \mathrm{~B}) & 5624(5) & 7655(6) & 6725(4) & 35(2) \\ \mathrm{C}(10 \mathrm{~B}) & 4765(5) & 7479(7) & 6368(4) & 37(2) \\ \mathrm{C}(11 \mathrm{~B}) & 4525(5) & 6411(7) & 5968(4) & 36(2) \\ \mathrm{C}(12 \mathrm{~B}) & 5141(5) & 5494(6) & 5938(4) & 34(2) \\ \mathrm{C}(13 \mathrm{~B}) & 6010(5) & 5671(6) & 6293(4) & 27(2)\end{array}$


Bond lengths $[\AA]$ and angles $\left[{ }^{\circ}\right]$ for 24.

\begin{tabular}{|c|c|}
\hline $\operatorname{Sn}(1 \mathrm{~A})-\mathrm{C}(1 \mathrm{~A})$ & $2.120(6)$ \\
\hline $\operatorname{Sn}(1 \mathrm{~A})-\mathrm{C}(8 \mathrm{~A})$ & $2.131(7)$ \\
\hline $\operatorname{Sn}(1 \mathrm{~A})-\mathrm{N}(1 \mathrm{~A})$ & $2.382(5)$ \\
\hline $\operatorname{Sn}(1 \mathrm{~A})-\mathrm{Br}(2 \mathrm{~A})$ & $2.5058(8)$ \\
\hline $\operatorname{Sn}(1 \mathrm{~A})-\mathrm{Br}(1 \mathrm{~A})$ & $2.6298(7)$ \\
\hline $\mathrm{N}(1 \mathrm{~A})-\mathrm{C}(7 \mathrm{~A})$ & $1.340(8)$ \\
\hline $\mathrm{N}(1 \mathrm{~A})-\mathrm{C}(3 \mathrm{~A})$ & $1.351(8)$ \\
\hline$C(1 \mathrm{~A})-\mathrm{C}(2 \mathrm{~A})$ & $1.532(9)$ \\
\hline $\mathrm{C}(1 \mathrm{~A})-\mathrm{H}(1 \mathrm{AA})$ & 0.9900 \\
\hline $\mathrm{C}(1 \mathrm{~A})-\mathrm{H}(1 \mathrm{AB})$ & 0.9900 \\
\hline $\mathrm{C}(2 \mathrm{~A})-\mathrm{C}(3 \mathrm{~A})$ & $1.509(9)$ \\
\hline $\mathrm{C}(2 \mathrm{~A})-\mathrm{H}(2 \mathrm{AA})$ & 0.9900 \\
\hline $\mathrm{C}(2 \mathrm{~A})-\mathrm{H}(2 \mathrm{AB})$ & 0.9900 \\
\hline$C(3 A)-C(4 A)$ & $1.378(9)$ \\
\hline$C(4 A)-C(5 A)$ & $1.378(10)$ \\
\hline $\mathrm{C}(4 \mathrm{~A})-\mathrm{H}(4 \mathrm{AA})$ & 0.9500 \\
\hline$C(5 A)-C(6 A)$ & $1.370(10)$ \\
\hline $\mathrm{C}(5 \mathrm{~A})-\mathrm{H}(5 \mathrm{AA})$ & 0.9500 \\
\hline$C(6 A)-C(7 A)$ & $1.384(9)$ \\
\hline $\mathrm{C}(6 \mathrm{~A})-\mathrm{H}(6 \mathrm{AA})$ & 0.9500 \\
\hline $\mathrm{C}(7 \mathrm{~A})-\mathrm{H}(7 \mathrm{AA})$ & 0.9500 \\
\hline $\mathrm{C}(8 \mathrm{~A})-\mathrm{C}(9 \mathrm{~A})$ & $1.359(10)$ \\
\hline$C(8 A)-C(13 A)$ & $1.397(10)$ \\
\hline $\mathrm{C}(9 \mathrm{~A})-\mathrm{C}(10 \mathrm{~A})$ & $1.384(11)$ \\
\hline $\mathrm{C}(9 \mathrm{~A})-\mathrm{H}(9 \mathrm{AA})$ & 0.9500 \\
\hline$C(10 A)-C(11 A)$ & $1.357(13)$ \\
\hline $\mathrm{C}(10 \mathrm{~A})-\mathrm{H}(10 \mathrm{~A})$ & 0.9500 \\
\hline $\mathrm{C}(11 \mathrm{~A})-\mathrm{C}(12 \mathrm{~A})$ & $1.375(13)$ \\
\hline $\mathrm{C}(11 \mathrm{~A})-\mathrm{H}(11 \mathrm{~A})$ & 0.9500 \\
\hline $\mathrm{C}(12 \mathrm{~A})-\mathrm{C}(13 \mathrm{~A})$ & $1.411(12)$ \\
\hline $\mathrm{C}(12 \mathrm{~A})-\mathrm{H}(12 \mathrm{~A})$ & 0.9500 \\
\hline $\mathrm{C}(13 \mathrm{~A})-\mathrm{H}(13 \mathrm{~A})$ & 0.9500 \\
\hline $\operatorname{Sn}(1 \mathrm{~B})-\mathrm{C}(1 \mathrm{~B})$ & $2.115(6)$ \\
\hline $\operatorname{Sn}(1 B)-C(8 B)$ & $2.138(6)$ \\
\hline
\end{tabular}




\begin{tabular}{|c|c|}
\hline $\operatorname{Sn}(1 \mathrm{~B})-\mathrm{N}(1 \mathrm{~B})$ & $2.363(5)$ \\
\hline $\operatorname{Sn}(1 \mathrm{~B})-\mathrm{Br}(2 \mathrm{~B})$ & $2.5223(8)$ \\
\hline $\operatorname{Sn}(1 \mathrm{~B})-\mathrm{Br}(1 \mathrm{~B})$ & $2.6176(8)$ \\
\hline $\mathrm{N}(1 \mathrm{~B})-\mathrm{C}(3 \mathrm{~B})$ & $1.336(8)$ \\
\hline $\mathrm{N}(1 \mathrm{~B})-\mathrm{C}(7 \mathrm{~B})$ & $1.342(8)$ \\
\hline$C(1 B)-C(2 B)$ & $1.524(9)$ \\
\hline $\mathrm{C}(1 \mathrm{~B})-\mathrm{H}(1 \mathrm{BA})$ & 0.9900 \\
\hline $\mathrm{C}(1 \mathrm{~B})-\mathrm{H}(1 \mathrm{BB})$ & 0.9900 \\
\hline $\mathrm{C}(2 \mathrm{~B})-\mathrm{C}(3 \mathrm{~B})$ & $1.515(9)$ \\
\hline $\mathrm{C}(2 \mathrm{~B})-\mathrm{H}(2 \mathrm{BA})$ & 0.9900 \\
\hline $\mathrm{C}(2 \mathrm{~B})-\mathrm{H}(2 \mathrm{BB})$ & 0.9900 \\
\hline$C(3 B)-C(4 B)$ & $1.371(9)$ \\
\hline $\mathrm{C}(4 \mathrm{~B})-\mathrm{C}(5 \mathrm{~B})$ & $1.371(10)$ \\
\hline $\mathrm{C}(4 \mathrm{~B})-\mathrm{H}(4 \mathrm{BA})$ & 0.9500 \\
\hline $\mathrm{C}(5 \mathrm{~B})-\mathrm{C}(6 \mathrm{~B})$ & $1.376(11)$ \\
\hline $\mathrm{C}(5 \mathrm{~B})-\mathrm{H}(5 \mathrm{BA})$ & 0.9500 \\
\hline $\mathrm{C}(6 \mathrm{~B})-\mathrm{C}(7 \mathrm{~B})$ & $1.373(10)$ \\
\hline $\mathrm{C}(6 \mathrm{~B})-\mathrm{H}(6 \mathrm{BA})$ & 0.9500 \\
\hline $\mathrm{C}(7 \mathrm{~B})-\mathrm{H}(7 \mathrm{BA})$ & 0.9500 \\
\hline $\mathrm{C}(8 \mathrm{~B})-\mathrm{C}(9 \mathrm{~B})$ & $1.351(9)$ \\
\hline $\mathrm{C}(8 \mathrm{~B})-\mathrm{C}(13 \mathrm{~B})$ & $1.421(8)$ \\
\hline $\mathrm{C}(9 \mathrm{~B})-\mathrm{C}(10 \mathrm{~B})$ & $1.381(10)$ \\
\hline C(9B)-H(9BA) & 0.9500 \\
\hline $\mathrm{C}(10 \mathrm{~B})-\mathrm{C}(11 \mathrm{~B})$ & $1.372(10)$ \\
\hline $\mathrm{C}(10 \mathrm{~B})-\mathrm{H}(10 \mathrm{~B})$ & 0.9500 \\
\hline$C(11 B)-C(12 B)$ & $1.380(10)$ \\
\hline $\mathrm{C}(11 \mathrm{~B})-\mathrm{H}(11 \mathrm{~B})$ & 0.9500 \\
\hline $\mathrm{C}(12 \mathrm{~B})-\mathrm{C}(13 \mathrm{~B})$ & $1.393(10)$ \\
\hline $\mathrm{C}(12 \mathrm{~B})-\mathrm{H}(12 \mathrm{~B})$ & 0.9500 \\
\hline $\mathrm{C}(13 \mathrm{~B})-\mathrm{H}(13 \mathrm{~B})$ & 0.9500 \\
\hline$C(1 A)-\operatorname{Sn}(1 A)-C(8 A)$ & $138.8(3)$ \\
\hline$C(1 \mathrm{~A})-\operatorname{Sn}(1 \mathrm{~A})-\mathrm{N}(1 \mathrm{~A})$ & $76.7(2)$ \\
\hline $\mathrm{C}(8 \mathrm{~A})-\mathrm{Sn}(1 \mathrm{~A})-\mathrm{N}(1 \mathrm{~A})$ & $89.5(2)$ \\
\hline $\mathrm{C}(1 \mathrm{~A})-\operatorname{Sn}(1 \mathrm{~A})-\mathrm{Br}(2 \mathrm{~A})$ & $108.53(17)$ \\
\hline $\mathrm{C}(8 \mathrm{~A})-\mathrm{Sn}(1 \mathrm{~A})-\mathrm{Br}(2 \mathrm{~A})$ & $110.05(19)$ \\
\hline
\end{tabular}




\begin{tabular}{|c|c|}
\hline$N(1 A)-S n(1 A)-B r(2 A)$ & $89.80(11)$ \\
\hline$C(1 \mathrm{~A})-\operatorname{Sn}(1 \mathrm{~A})-\mathrm{Br}(1 \mathrm{~A})$ & $95.55(16)$ \\
\hline $\mathrm{C}(8 \mathrm{~A})-\mathrm{Sn}(1 \mathrm{~A})-\mathrm{Br}(1 \mathrm{~A})$ & $95.62(16)$ \\
\hline $\mathrm{N}(1 \mathrm{~A})-\operatorname{Sn}(1 \mathrm{~A})-\mathrm{Br}(1 \mathrm{~A})$ & $172.19(13)$ \\
\hline $\operatorname{Br}(2 \mathrm{~A})-\operatorname{Sn}(1 \mathrm{~A})-\mathrm{Br}(1 \mathrm{~A})$ & $93.91(3)$ \\
\hline C(7A)-N(1A)-C(3A) & $119.6(5)$ \\
\hline$C(7 A)-N(1 A)-S n(1 A)$ & $129.3(5)$ \\
\hline $\mathrm{C}(3 \mathrm{~A})-\mathrm{N}(1 \mathrm{~A})-\mathrm{Sn}(1 \mathrm{~A})$ & $110.6(4)$ \\
\hline$C(2 A)-C(1 A)-S n(1 A)$ & $109.4(4)$ \\
\hline $\mathrm{C}(2 \mathrm{~A})-\mathrm{C}(1 \mathrm{~A})-\mathrm{H}(1 \mathrm{AA})$ & 109.8 \\
\hline $\operatorname{Sn}(1 \mathrm{~A})-\mathrm{C}(1 \mathrm{~A})-\mathrm{H}(1 \mathrm{AA})$ & 109.8 \\
\hline $\mathrm{C}(2 \mathrm{~A})-\mathrm{C}(1 \mathrm{~A})-\mathrm{H}(1 \mathrm{AB})$ & 109.8 \\
\hline $\operatorname{Sn}(1 \mathrm{~A})-\mathrm{C}(1 \mathrm{~A})-\mathrm{H}(1 \mathrm{AB})$ & 109.8 \\
\hline $\mathrm{H}(1 \mathrm{AA})-\mathrm{C}(1 \mathrm{~A})-\mathrm{H}(1 \mathrm{AB})$ & 108.2 \\
\hline $\mathrm{C}(3 \mathrm{~A})-\mathrm{C}(2 \mathrm{~A})-\mathrm{C}(1 \mathrm{~A})$ & $112.0(5)$ \\
\hline $\mathrm{C}(3 \mathrm{~A})-\mathrm{C}(2 \mathrm{~A})-\mathrm{H}(2 \mathrm{AA})$ & 109.2 \\
\hline $\mathrm{C}(1 \mathrm{~A})-\mathrm{C}(2 \mathrm{~A})-\mathrm{H}(2 \mathrm{AA})$ & 109.2 \\
\hline $\mathrm{C}(3 \mathrm{~A})-\mathrm{C}(2 \mathrm{~A})-\mathrm{H}(2 \mathrm{AB})$ & 109.2 \\
\hline $\mathrm{C}(1 \mathrm{~A})-\mathrm{C}(2 \mathrm{~A})-\mathrm{H}(2 \mathrm{AB})$ & 109.2 \\
\hline $\mathrm{H}(2 \mathrm{AA})-\mathrm{C}(2 \mathrm{~A})-\mathrm{H}(2 \mathrm{AB})$ & 107.9 \\
\hline $\mathrm{N}(1 \mathrm{~A})-\mathrm{C}(3 \mathrm{~A})-\mathrm{C}(4 \mathrm{~A})$ & $121.2(6)$ \\
\hline $\mathrm{N}(1 \mathrm{~A})-\mathrm{C}(3 \mathrm{~A})-\mathrm{C}(2 \mathrm{~A})$ & $116.1(5)$ \\
\hline $\mathrm{C}(4 \mathrm{~A})-\mathrm{C}(3 \mathrm{~A})-\mathrm{C}(2 \mathrm{~A})$ & $122.7(6)$ \\
\hline$C(3 A)-C(4 A)-C(5 A)$ & $118.9(7)$ \\
\hline $\mathrm{C}(3 \mathrm{~A})-\mathrm{C}(4 \mathrm{~A})-\mathrm{H}(4 \mathrm{AA})$ & 120.6 \\
\hline $\mathrm{C}(5 \mathrm{~A})-\mathrm{C}(4 \mathrm{~A})-\mathrm{H}(4 \mathrm{AA})$ & 120.6 \\
\hline$C(6 A)-C(5 A)-C(4 A)$ & $120.1(6)$ \\
\hline$C(6 A)-C(5 A)-H(5 A A)$ & 119.9 \\
\hline$C(4 A)-C(5 A)-H(5 A A)$ & 119.9 \\
\hline$C(5 A)-C(6 A)-C(7 A)$ & $118.7(6)$ \\
\hline$C(5 A)-C(6 A)-H(6 A A)$ & 120.6 \\
\hline$C(7 A)-C(6 A)-H(6 A A)$ & 120.6 \\
\hline $\mathrm{N}(1 \mathrm{~A})-\mathrm{C}(7 \mathrm{~A})-\mathrm{C}(6 \mathrm{~A})$ & $121.5(7)$ \\
\hline $\mathrm{N}(1 \mathrm{~A})-\mathrm{C}(7 \mathrm{~A})-\mathrm{H}(7 \mathrm{AA})$ & 119.2 \\
\hline $\mathrm{C}(6 \mathrm{~A})-\mathrm{C}(7 \mathrm{~A})-\mathrm{H}(7 \mathrm{AA})$ & 119.2 \\
\hline C(9A)-C(8A)-C(13A) & $119.4(7)$ \\
\hline
\end{tabular}




$$
\begin{aligned}
& \mathrm{C}(9 \mathrm{~A})-\mathrm{C}(8 \mathrm{~A})-\mathrm{Sn}(1 \mathrm{~A}) \quad 120.4(5) \\
& \mathrm{C}(13 \mathrm{~A})-\mathrm{C}(8 \mathrm{~A})-\mathrm{Sn}(1 \mathrm{~A}) \quad 120.2(6) \\
& \mathrm{C}(8 \mathrm{~A})-\mathrm{C}(9 \mathrm{~A})-\mathrm{C}(10 \mathrm{~A}) \quad 121.2(8) \\
& \text { C(8A)-C(9A)-H(9AA) } 119.4 \\
& \text { C(10A)-C(9A)-H(9AA) } 119.4 \\
& \text { C(11A)-C(10A)-C(9A) 120.2(9) } \\
& \text { C(11A)-C(10A)-H(10A) } 119.9 \\
& \text { C(9A)-C(10A)-H(10A) } 119.9 \\
& \text { C(10A)-C(11A)-C(12A) 120.6(9) } \\
& \text { C(10A)-C(11A)-H(11A) } 119.7 \\
& \text { C(12A)-C(11A)-H(11A) } 119.7 \\
& \text { C(11A)-C(12A)-C(13A) 119.5(8) } \\
& \text { C(11A)-C(12A)-H(12A) } 120.3 \\
& \text { C(13A)-C(12A)-H(12A) } 120.3 \\
& \mathrm{C}(8 \mathrm{~A})-\mathrm{C}(13 \mathrm{~A})-\mathrm{C}(12 \mathrm{~A}) \quad 119.2(8) \\
& \mathrm{C}(8 \mathrm{~A})-\mathrm{C}(13 \mathrm{~A})-\mathrm{H}(13 \mathrm{~A}) \quad 120.4 \\
& \text { C(12A)-C(13A)-H(13A) } 120.4 \\
& \mathrm{C}(1 \mathrm{~B})-\operatorname{Sn}(1 \mathrm{~B})-\mathrm{C}(8 \mathrm{~B}) \quad 136.9(2) \\
& \mathrm{C}(1 \mathrm{~B})-\mathrm{Sn}(1 \mathrm{~B})-\mathrm{N}(1 \mathrm{~B}) \quad 76.9(2) \\
& \mathrm{C}(8 \mathrm{~B})-\mathrm{Sn}(1 \mathrm{~B})-\mathrm{N}(1 \mathrm{~B}) \quad 91.0(2) \\
& \text { C(1B)-Sn(1B)-Br(2B) 110.6(2) } \\
& \mathrm{C}(8 \mathrm{~B})-\mathrm{Sn}(1 \mathrm{~B})-\mathrm{Br}(2 \mathrm{~B}) \quad \text { 109.21(14) } \\
& \mathrm{N}(1 \mathrm{~B})-\mathrm{Sn}(1 \mathrm{~B})-\mathrm{Br}(2 \mathrm{~B}) \quad \text { 84.61(12) } \\
& \text { C(1B)-Sn(1B)-Br(1B) 96.40(18) } \\
& \mathrm{C}(8 \mathrm{~B})-\mathrm{Sn}(1 \mathrm{~B})-\mathrm{Br}(1 \mathrm{~B}) \quad 96.33(16) \\
& \mathrm{N}(1 \mathrm{~B})-\mathrm{Sn}(1 \mathrm{~B})-\mathrm{Br}(1 \mathrm{~B}) \quad \text { 172.44(13) } \\
& \operatorname{Br}(2 \mathrm{~B})-\mathrm{Sn}(1 \mathrm{~B})-\mathrm{Br}(1 \mathrm{~B}) \quad 94.74(3) \\
& \mathrm{C}(3 \mathrm{~B})-\mathrm{N}(1 \mathrm{~B})-\mathrm{C}(7 \mathrm{~B}) \quad 120.0(6) \\
& \mathrm{C}(3 \mathrm{~B})-\mathrm{N}(1 \mathrm{~B})-\mathrm{Sn}(1 \mathrm{~B}) \quad 112.2(4) \\
& \mathrm{C}(7 \mathrm{~B})-\mathrm{N}(1 \mathrm{~B})-\mathrm{Sn}(1 \mathrm{~B}) \quad 127.8(4) \\
& \mathrm{C}(2 \mathrm{~B})-\mathrm{C}(1 \mathrm{~B})-\mathrm{Sn}(1 \mathrm{~B}) \quad 111.2(4) \\
& \text { C(2B)-C(1B)-H(1BA) } 109.4 \\
& \mathrm{Sn}(1 \mathrm{~B})-\mathrm{C}(1 \mathrm{~B})-\mathrm{H}(1 \mathrm{BA}) \quad 109.4 \\
& \text { C(2B)-C(1B)-H(1BB) } \quad 109.4 \\
& \mathrm{Sn}(1 \mathrm{~B})-\mathrm{C}(1 \mathrm{~B})-\mathrm{H}(1 \mathrm{BB}) \quad 109.4 \\
& \text { H(1BA)-C(1B)-H(1BB) } 108.0
\end{aligned}
$$




$$
\begin{aligned}
& \mathrm{C}(3 \mathrm{~B})-\mathrm{C}(2 \mathrm{~B})-\mathrm{C}(1 \mathrm{~B}) \quad 113.3(6) \\
& \mathrm{C}(3 \mathrm{~B})-\mathrm{C}(2 \mathrm{~B})-\mathrm{H}(2 \mathrm{BA}) \quad 108.9 \\
& \text { C(1B)-C(2B)-H(2BA) } 108.9 \\
& \text { C(3B)-C(2B)-H(2BB) } 108.9 \\
& \text { C(1B)-C(2B)-H(2BB) } 108.9 \\
& \text { H(2BA)-C(2B)-H(2BB) } 107.7 \\
& \mathrm{~N}(1 \mathrm{~B})-\mathrm{C}(3 \mathrm{~B})-\mathrm{C}(4 \mathrm{~B}) \quad 120.8(6) \\
& \mathrm{N}(1 \mathrm{~B})-\mathrm{C}(3 \mathrm{~B})-\mathrm{C}(2 \mathrm{~B}) \quad 116.1(6) \\
& \mathrm{C}(4 \mathrm{~B})-\mathrm{C}(3 \mathrm{~B})-\mathrm{C}(2 \mathrm{~B}) \quad 123.0(6) \\
& \mathrm{C}(3 \mathrm{~B})-\mathrm{C}(4 \mathrm{~B})-\mathrm{C}(5 \mathrm{~B}) \quad 119.7(7) \\
& \text { C(3B)-C(4B)-H(4BA) } 120.1 \\
& \text { C(5B)-C(4B)-H(4BA) } 120.1 \\
& \mathrm{C}(4 \mathrm{~B})-\mathrm{C}(5 \mathrm{~B})-\mathrm{C}(6 \mathrm{~B}) \quad 119.3(7) \\
& \text { C(4B)-C(5B)-H(5BA) } 120.4 \\
& \text { C(6B)-C(5B)-H(5BA) } 120.4 \\
& \text { C(7B)-C(6B)-C(5B) 118.9(7) } \\
& \mathrm{C}(7 \mathrm{~B})-\mathrm{C}(6 \mathrm{~B})-\mathrm{H}(6 \mathrm{BA}) \quad 120.6 \\
& \mathrm{C}(5 \mathrm{~B})-\mathrm{C}(6 \mathrm{~B})-\mathrm{H}(6 \mathrm{BA}) \quad 120.6 \\
& \mathrm{~N}(1 \mathrm{~B})-\mathrm{C}(7 \mathrm{~B})-\mathrm{C}(6 \mathrm{~B}) \quad 121.3(7) \\
& \mathrm{N}(1 \mathrm{~B})-\mathrm{C}(7 \mathrm{~B})-\mathrm{H}(7 \mathrm{BA}) \quad 119.4 \\
& \text { C(6B)-C(7B)-H(7BA) } 119.4 \\
& \mathrm{C}(9 \mathrm{~B})-\mathrm{C}(8 \mathrm{~B})-\mathrm{C}(13 \mathrm{~B}) \quad 118.9(6) \\
& \text { C(9B)-C(8B)-Sn(1B) 122.2(5) } \\
& \text { C(13B)-C(8B)-Sn(1B) 118.9(4) } \\
& \mathrm{C}(8 \mathrm{~B})-\mathrm{C}(9 \mathrm{~B})-\mathrm{C}(10 \mathrm{~B}) \quad 121.6(6) \\
& \text { C(8B)-C(9B)-H(9BA) } 119.2 \\
& \text { C(10B)-C(9B)-H(9BA) } 119.2 \\
& \mathrm{C}(11 \mathrm{~B})-\mathrm{C}(10 \mathrm{~B})-\mathrm{C}(9 \mathrm{~B}) \quad 120.3(7) \\
& \text { C(11B)-C(10B)-H(10B) } 119.9 \\
& \text { C(9B)-C(10B)-H(10B) } 119.9 \\
& \mathrm{C}(10 \mathrm{~B})-\mathrm{C}(11 \mathrm{~B})-\mathrm{C}(12 \mathrm{~B}) \quad 119.9(7) \\
& \text { C(10B)-C(11B)-H(11B) } 120.1 \\
& \text { C(12B)-C(11B)-H(11B) } 120.1 \\
& \text { C(11B)-C(12B)-C(13B) 120.0(6) } \\
& \text { C(11B)-C(12B)-H(12B) } 120.0 \\
& \text { C(13B)-C(12B)-H(12B) } 120.0
\end{aligned}
$$




$\begin{array}{ll}\mathrm{C}(12 \mathrm{~B})-\mathrm{C}(13 \mathrm{~B})-\mathrm{C}(8 \mathrm{~B}) & 119.4(6) \\ \mathrm{C}(12 \mathrm{~B})-\mathrm{C}(13 \mathrm{~B})-\mathrm{H}(13 \mathrm{~B}) & 120.3 \\ \mathrm{C}(8 \mathrm{~B})-\mathrm{C}(13 \mathrm{~B})-\mathrm{H}(13 \mathrm{~B}) & 120.3\end{array}$

Symmetry transformations used to generate equivalent atoms: 
Anisotropic displacement parameters $\left(\AA^{2} \times 10^{3}\right)$ for 24. The anisotropicdisplacement factor exponent takes the form: $-2 \mathrm{p}^{2}\left[\mathrm{~h}^{2} \mathrm{a}^{* 2} \mathrm{U}^{11}+\ldots+2 \mathrm{~h} \mathrm{k} \mathrm{a}^{*} \mathrm{~b}^{*} \mathrm{U}^{12}\right]$

\begin{tabular}{|c|c|c|c|c|c|c|}
\hline & U11 & $\mathrm{U}^{22}$ & $\mathrm{U}^{33}$ & $\mathrm{U}^{23}$ & $\mathrm{U}^{13}$ & $\mathrm{U}^{12}$ \\
\hline $\operatorname{Sn}(1 \mathrm{~A})$ & $19(1)$ & $22(1)$ & $19(1)$ & $-1(1)$ & $0(1)$ & $-3(1)$ \\
\hline $\operatorname{Br}(1 \mathrm{~A})$ & $21(1)$ & $34(1)$ & $24(1)$ & $-3(1)$ & $-3(1)$ & $-5(1)$ \\
\hline $\operatorname{Br}(2 \mathrm{~A})$ & $55(1)$ & $25(1)$ & $42(1)$ & $9(1)$ & $-23(1)$ & $-10(1)$ \\
\hline $\mathrm{N}(1 \mathrm{~A})$ & $21(3)$ & $18(2)$ & $21(3)$ & $1(2)$ & $-4(2)$ & $0(2)$ \\
\hline$C(1 \mathrm{~A})$ & $19(4)$ & $30(3)$ & $20(3)$ & $2(3)$ & $3(3)$ & $-1(3)$ \\
\hline$C(2 A)$ & $21(4)$ & $38(4)$ & $24(3)$ & $5(3)$ & $4(3)$ & $2(3)$ \\
\hline$C(3 A)$ & $20(4)$ & $18(3)$ & $28(3)$ & $4(2)$ & $0(3)$ & $-1(2)$ \\
\hline$C(4 A)$ & $22(4)$ & $23(3)$ & $42(4)$ & $8(3)$ & $-4(3)$ & $-5(3)$ \\
\hline$C(5 A)$ & $30(4)$ & $19(3)$ & $44(4)$ & $-1(3)$ & $-17(4)$ & $-7(3)$ \\
\hline$C(6 A)$ & $34(5)$ & $20(3)$ & $30(4)$ & $-5(3)$ & $-12(3)$ & $7(3)$ \\
\hline$C(7 A)$ & $33(4)$ & $24(3)$ & $25(3)$ & $-1(3)$ & $1(3)$ & $2(3)$ \\
\hline $\mathrm{C}(8 \mathrm{~A})$ & $19(4)$ & $44(4)$ & $26(3)$ & $-17(3)$ & $9(3)$ & $-19(3)$ \\
\hline $\mathrm{C}(9 \mathrm{~A})$ & $33(5)$ & $48(4)$ & $36(4)$ & $-20(3)$ & $11(3)$ & $-7(4)$ \\
\hline $\mathrm{C}(10 \mathrm{~A})$ & $39(5)$ & $57(5)$ & $61(6)$ & $-24(4)$ & $13(4)$ & $-7(4)$ \\
\hline $\mathrm{C}(11 \mathrm{~A})$ & $40(6)$ & $79(7)$ & $72(7)$ & $-40(6)$ & $28(5)$ & $-22(5)$ \\
\hline $\mathrm{C}(12 \mathrm{~A})$ & $60(6)$ & $82(7)$ & $39(5)$ & $-25(5)$ & $30(5)$ & $-40(5)$ \\
\hline$C(13 A)$ & $51(6)$ & $55(5)$ & $37(4)$ & $-13(4)$ & $19(4)$ & $-23(4)$ \\
\hline $\operatorname{Sn}(1 B)$ & $20(1)$ & $21(1)$ & $29(1)$ & $-4(1)$ & $7(1)$ & $0(1)$ \\
\hline $\operatorname{Br}(1 \mathrm{~B})$ & $41(1)$ & $32(1)$ & $39(1)$ & $-14(1)$ & $19(1)$ & $-11(1)$ \\
\hline $\mathrm{Br}(2 \mathrm{~B})$ & $40(1)$ & $24(1)$ & $47(1)$ & $-2(1)$ & $18(1)$ & $-6(1)$ \\
\hline $\mathrm{N}(1 \mathrm{~B})$ & $22(3)$ & $21(3)$ & $27(3)$ & $-3(2)$ & $7(2)$ & $-1(2)$ \\
\hline $\mathrm{C}(1 \mathrm{~B})$ & $24(4)$ & $38(4)$ & $29(4)$ & $0(3)$ & $1(3)$ & $3(3)$ \\
\hline$C(2 B)$ & $17(4)$ & $41(4)$ & $39(4)$ & $4(3)$ & $6(3)$ & $7(3)$ \\
\hline$C(3 B)$ & $21(4)$ & $22(3)$ & $34(4)$ & $3(3)$ & $9(3)$ & $0(3)$ \\
\hline$C(4 B)$ & $31(4)$ & $22(3)$ & $44(4)$ & $-4(3)$ & $17(3)$ & $0(3)$ \\
\hline$C(5 B)$ & $41(5)$ & $36(4)$ & $43(4)$ & $-13(3)$ & $25(4)$ & $-15(3)$ \\
\hline$C(6 B)$ & $38(5)$ & $54(5)$ & $24(4)$ & $-9(3)$ & $8(3)$ & $-12(4)$ \\
\hline $\mathrm{C}(7 \mathrm{~B})$ & $26(4)$ & $45(4)$ & $33(4)$ & $2(3)$ & $7(3)$ & $-2(3)$ \\
\hline $\mathrm{C}(8 \mathrm{~B})$ & $10(3)$ & $18(3)$ & $21(3)$ & $7(2)$ & $5(2)$ & $0(2)$ \\
\hline $\mathrm{C}(9 \mathrm{~B})$ & $37(5)$ & $28(4)$ & $41(4)$ & $-2(3)$ & $10(4)$ & $-6(3)$ \\
\hline \multirow[t]{2}{*}{$\mathrm{C}(10 \mathrm{~B})$} & $27(4)$ & $41(4)$ & $45(4)$ & $10(3)$ & $12(4)$ & $5(3)$ \\
\hline & & & & 161 & & \\
\hline
\end{tabular}




$\begin{array}{lllllll}\mathrm{C}(11 \mathrm{~B}) & 18(4) & 64(5) & 25(3) & 9(3) & 2(3) & -14(4) \\ \mathrm{C}(12 \mathrm{~B}) & 43(5) & 33(4) & 25(3) & -1(3) & 8(3) & -14(3) \\ \mathrm{C}(13 \mathrm{~B}) & 28(4) & 23(3) & 31(4) & 0(3) & 8(3) & 1(3)\end{array}$


Hydrogen coordinates ( $\left.\mathrm{x} 10^{4}\right)$ and isotropic displacement parameters $\left(\AA^{2} \times 10^{3}\right)$ for 25.

\begin{tabular}{|c|c|c|c|c|}
\hline & $\mathrm{x}$ & $\mathrm{y}$ & $\mathrm{z}$ & $\mathrm{U}(\mathrm{eq})$ \\
\hline \multicolumn{5}{|l|}{-} \\
\hline $\mathrm{H}(1 \mathrm{AA})$ & 3449 & 4490 & 6935 & 28 \\
\hline $\mathrm{H}(1 \mathrm{AB})$ & 3378 & 5928 & 7148 & 28 \\
\hline $\mathrm{H}(2 \mathrm{AA})$ & 4665 & 4186 & 7861 & 33 \\
\hline $\mathrm{H}(2 \mathrm{AB})$ & 4853 & 5487 & 7490 & 33 \\
\hline $\mathrm{H}(4 \mathrm{AA})$ & 5769 & 6435 & 8616 & 36 \\
\hline $\mathrm{H}(5 \mathrm{AA})$ & 5844 & 7264 & 9827 & 41 \\
\hline $\mathrm{H}(6 \mathrm{AA})$ & 4667 & 7009 & 10460 & 36 \\
\hline $\mathrm{H}(7 \mathrm{AA})$ & 3437 & 5896 & 9875 & 33 \\
\hline $\mathrm{H}(9 \mathrm{AA})$ & 1390 & 6850 & 7959 & 46 \\
\hline $\mathrm{H}(10 \mathrm{~A})$ & 454 & 7866 & 8635 & 62 \\
\hline $\mathrm{H}(11 \mathrm{~A})$ & 241 & 7104 & 9786 & 73 \\
\hline $\mathrm{H}(12 \mathrm{~A})$ & 1033 & 5394 & 10324 & 69 \\
\hline $\mathrm{H}(13 \mathrm{~A})$ & 2009 & 4370 & 9650 & 55 \\
\hline $\mathrm{H}(1 \mathrm{BA})$ & 9030 & 6384 & 8090 & 37 \\
\hline $\mathrm{H}(1 \mathrm{BB})$ & 8500 & 5164 & 7767 & 37 \\
\hline $\mathrm{H}(2 \mathrm{BA})$ & 9711 & 6548 & 7088 & 38 \\
\hline $\mathrm{H}(2 \mathrm{BB})$ & 9672 & 5075 & 7184 & 38 \\
\hline $\mathrm{H}(4 \mathrm{BA})$ & 9704 & 4677 & 5813 & 38 \\
\hline $\mathrm{H}(5 \mathrm{BA})$ & 8937 & 4693 & 4572 & 45 \\
\hline $\mathrm{H}(6 \mathrm{BA})$ & 7604 & 5767 & 4289 & 46 \\
\hline $\mathrm{H}(7 \mathrm{BA})$ & 7055 & 6740 & 5260 & 41 \\
\hline $\mathrm{H}(9 \mathrm{BA})$ & 5780 & 8403 & 6996 & 42 \\
\hline $\mathrm{H}(10 \mathrm{~B})$ & 4337 & 8100 & 6401 & 45 \\
\hline $\mathrm{H}(11 \mathrm{~B})$ & 3937 & 6303 & 5711 & 43 \\
\hline $\mathrm{H}(12 \mathrm{~B})$ & 4972 & 4743 & 5675 & 40 \\
\hline $\mathrm{H}(13 \mathrm{~B})$ & 6438 & 5049 & 6266 & 33 \\
\hline
\end{tabular}


Torsion angles $\left[{ }^{\circ}\right]$ for $\mathbf{2 4}$.

\begin{tabular}{|c|c|}
\hline $\operatorname{Sn}(1 \mathrm{~A})-\mathrm{C}(1 \mathrm{~A})-\mathrm{C}(2 \mathrm{~A})-\mathrm{C}(3 \mathrm{~A})$ & $-43.8(6)$ \\
\hline $\mathrm{C}(7 \mathrm{~A})-\mathrm{N}(1 \mathrm{~A})-\mathrm{C}(3 \mathrm{~A})-\mathrm{C}(4 \mathrm{~A})$ & $-1.1(8)$ \\
\hline $\operatorname{Sn}(1 \mathrm{~A})-\mathrm{N}(1 \mathrm{~A})-\mathrm{C}(3 \mathrm{~A})-\mathrm{C}(4 \mathrm{~A})$ & $171.4(4)$ \\
\hline$C(7 A)-N(1 A)-C(3 A)-C(2 A)$ & $177.5(5)$ \\
\hline $\operatorname{Sn}(1 \mathrm{~A})-\mathrm{N}(1 \mathrm{~A})-\mathrm{C}(3 \mathrm{~A})-\mathrm{C}(2 \mathrm{~A})$ & $-9.9(6)$ \\
\hline $\mathrm{C}(1 \mathrm{~A})-\mathrm{C}(2 \mathrm{~A})-\mathrm{C}(3 \mathrm{~A})-\mathrm{N}(1 \mathrm{~A})$ & $35.4(7)$ \\
\hline $\mathrm{C}(1 \mathrm{~A})-\mathrm{C}(2 \mathrm{~A})-\mathrm{C}(3 \mathrm{~A})-\mathrm{C}(4 \mathrm{~A})$ & $-146.0(6)$ \\
\hline$N(1 A)-C(3 A)-C(4 A)-C(5 A)$ & $1.0(9)$ \\
\hline$C(2 A)-C(3 A)-C(4 A)-C(5 A)$ & $-177.5(6)$ \\
\hline$C(3 A)-C(4 A)-C(5 A)-C(6 A)$ & $-0.6(9)$ \\
\hline$C(4 A)-C(5 A)-C(6 A)-C(7 A)$ & $0.3(9)$ \\
\hline$C(3 A)-N(1 A)-C(7 A)-C(6 A)$ & $0.8(9)$ \\
\hline $\operatorname{Sn}(1 \mathrm{~A})-\mathrm{N}(1 \mathrm{~A})-\mathrm{C}(7 \mathrm{~A})-\mathrm{C}(6 \mathrm{~A})$ & $-170.1(4)$ \\
\hline$C(5 A)-C(6 A)-C(7 A)-N(1 A)$ & $-0.4(9)$ \\
\hline$C(13 A)-C(8 A)-C(9 A)-C(10 A)$ & $0.2(10)$ \\
\hline $\operatorname{Sn}(1 \mathrm{~A})-\mathrm{C}(8 \mathrm{~A})-\mathrm{C}(9 \mathrm{~A})-\mathrm{C}(10 \mathrm{~A})$ & $-179.9(5)$ \\
\hline$C(8 A)-C(9 A)-C(10 A)-C(11 A)$ & $-1.4(12)$ \\
\hline $\mathrm{C}(9 \mathrm{~A})-\mathrm{C}(10 \mathrm{~A})-\mathrm{C}(11 \mathrm{~A})-\mathrm{C}(12 \mathrm{~A})$ & $2.1(13)$ \\
\hline$C(10 A)-C(11 A)-C(12 A)-C(13 A)$ & $-1.5(13)$ \\
\hline $\mathrm{C}(9 \mathrm{~A})-\mathrm{C}(8 \mathrm{~A})-\mathrm{C}(13 \mathrm{~A})-\mathrm{C}(12 \mathrm{~A})$ & $0.4(10)$ \\
\hline $\operatorname{Sn}(1 \mathrm{~A})-\mathrm{C}(8 \mathrm{~A})-\mathrm{C}(13 \mathrm{~A})-\mathrm{C}(12 \mathrm{~A})$ & $-179.5(5)$ \\
\hline $\mathrm{C}(11 \mathrm{~A})-\mathrm{C}(12 \mathrm{~A})-\mathrm{C}(13 \mathrm{~A})-\mathrm{C}(8 \mathrm{~A})$ & $0.3(11)$ \\
\hline $\operatorname{Sn}(1 \mathrm{~B})-\mathrm{C}(1 \mathrm{~B})-\mathrm{C}(2 \mathrm{~B})-\mathrm{C}(3 \mathrm{~B})$ & $-36.6(7)$ \\
\hline $\mathrm{C}(7 \mathrm{~B})-\mathrm{N}(1 \mathrm{~B})-\mathrm{C}(3 \mathrm{~B})-\mathrm{C}(4 \mathrm{~B})$ & $-2.1(9)$ \\
\hline $\operatorname{Sn}(1 B)-N(1 B)-C(3 B)-C(4 B)$ & $175.0(5)$ \\
\hline $\mathrm{C}(7 \mathrm{~B})-\mathrm{N}(1 \mathrm{~B})-\mathrm{C}(3 \mathrm{~B})-\mathrm{C}(2 \mathrm{~B})$ & $175.0(6)$ \\
\hline $\mathrm{Sn}(1 \mathrm{~B})-\mathrm{N}(1 \mathrm{~B})-\mathrm{C}(3 \mathrm{~B})-\mathrm{C}(2 \mathrm{~B})$ & $-7.8(7)$ \\
\hline $\mathrm{C}(1 \mathrm{~B})-\mathrm{C}(2 \mathrm{~B})-\mathrm{C}(3 \mathrm{~B})-\mathrm{N}(1 \mathrm{~B})$ & $29.1(8)$ \\
\hline $\mathrm{C}(1 \mathrm{~B})-\mathrm{C}(2 \mathrm{~B})-\mathrm{C}(3 \mathrm{~B})-\mathrm{C}(4 \mathrm{~B})$ & $-153.8(6)$ \\
\hline $\mathrm{N}(1 \mathrm{~B})-\mathrm{C}(3 \mathrm{~B})-\mathrm{C}(4 \mathrm{~B})-\mathrm{C}(5 \mathrm{~B})$ & $1.6(10)$ \\
\hline $\mathrm{C}(2 \mathrm{~B})-\mathrm{C}(3 \mathrm{~B})-\mathrm{C}(4 \mathrm{~B})-\mathrm{C}(5 \mathrm{~B})$ & $-175.3(6)$ \\
\hline $\mathrm{C}(3 \mathrm{~B})-\mathrm{C}(4 \mathrm{~B})-\mathrm{C}(5 \mathrm{~B})-\mathrm{C}(6 \mathrm{~B})$ & $0.1(10)$ \\
\hline$C(4 B)-C(5 B)-C(6 B)-C(7 B)$ & $-1.2(10)$ \\
\hline$C(3 B)-N(1 B)-C(7 B)-C(6 B)$ & $1.0(10)$ \\
\hline
\end{tabular}




$\begin{array}{lc}\mathrm{Sn}(1 \mathrm{~B})-\mathrm{N}(1 \mathrm{~B})-\mathrm{C}(7 \mathrm{~B})-\mathrm{C}(6 \mathrm{~B}) & -175.7(5) \\ \mathrm{C}(5 \mathrm{~B})-\mathrm{C}(6 \mathrm{~B})-\mathrm{C}(7 \mathrm{~B})-\mathrm{N}(1 \mathrm{~B}) & 0.7(11) \\ \mathrm{C}(13 \mathrm{~B})-\mathrm{C}(8 \mathrm{~B})-\mathrm{C}(9 \mathrm{~B})-\mathrm{C}(10 \mathrm{~B}) & -0.4(10) \\ \mathrm{Sn}(1 \mathrm{~B})-\mathrm{C}(8 \mathrm{~B})-\mathrm{C}(9 \mathrm{~B})-\mathrm{C}(10 \mathrm{~B}) & 175.8(5) \\ \mathrm{C}(8 \mathrm{~B})-\mathrm{C}(9 \mathrm{~B})-\mathrm{C}(10 \mathrm{~B})-\mathrm{C}(11 \mathrm{~B}) & -0.5(11) \\ \mathrm{C}(9 \mathrm{~B})-\mathrm{C}(10 \mathrm{~B})-\mathrm{C}(11 \mathrm{~B})-\mathrm{C}(12 \mathrm{~B}) & 1.8(11) \\ \mathrm{C}(10 \mathrm{~B})-\mathrm{C}(11 \mathrm{~B})-\mathrm{C}(12 \mathrm{~B})-\mathrm{C}(13 \mathrm{~B}) & -2.1(10) \\ \mathrm{C}(11 \mathrm{~B})-\mathrm{C}(12 \mathrm{~B})-\mathrm{C}(13 \mathrm{~B})-\mathrm{C}(8 \mathrm{~B}) & 1.2(10) \\ \mathrm{C}(9 \mathrm{~B})-\mathrm{C}(8 \mathrm{~B})-\mathrm{C}(13 \mathrm{~B})-\mathrm{C}(12 \mathrm{~B}) & 0.1(9) \\ \mathrm{Sn}(1 \mathrm{~B})-\mathrm{C}(8 \mathrm{~B})-\mathrm{C}(13 \mathrm{~B})-\mathrm{C}(12 \mathrm{~B}) & -176.3(5)\end{array}$

Symmetry transformations used to generate equivalent atoms: 


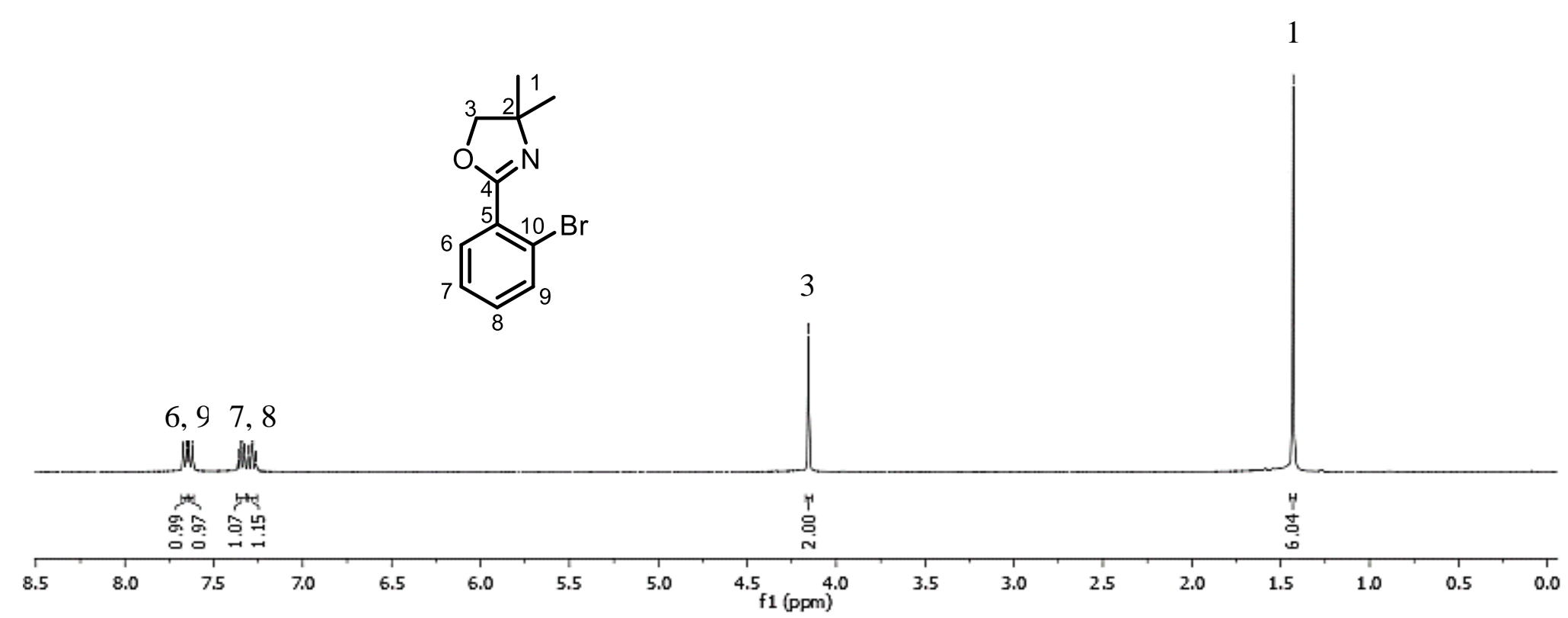

Figure A1: ${ }^{1} \mathrm{H}$ NMR spectrum of 8 in $\mathrm{CDCl}_{3}$ * 


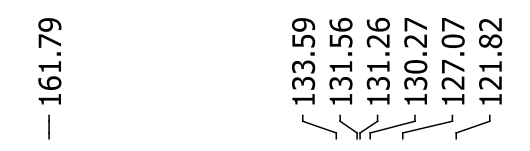

$\forall \infty$

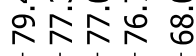

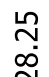

।
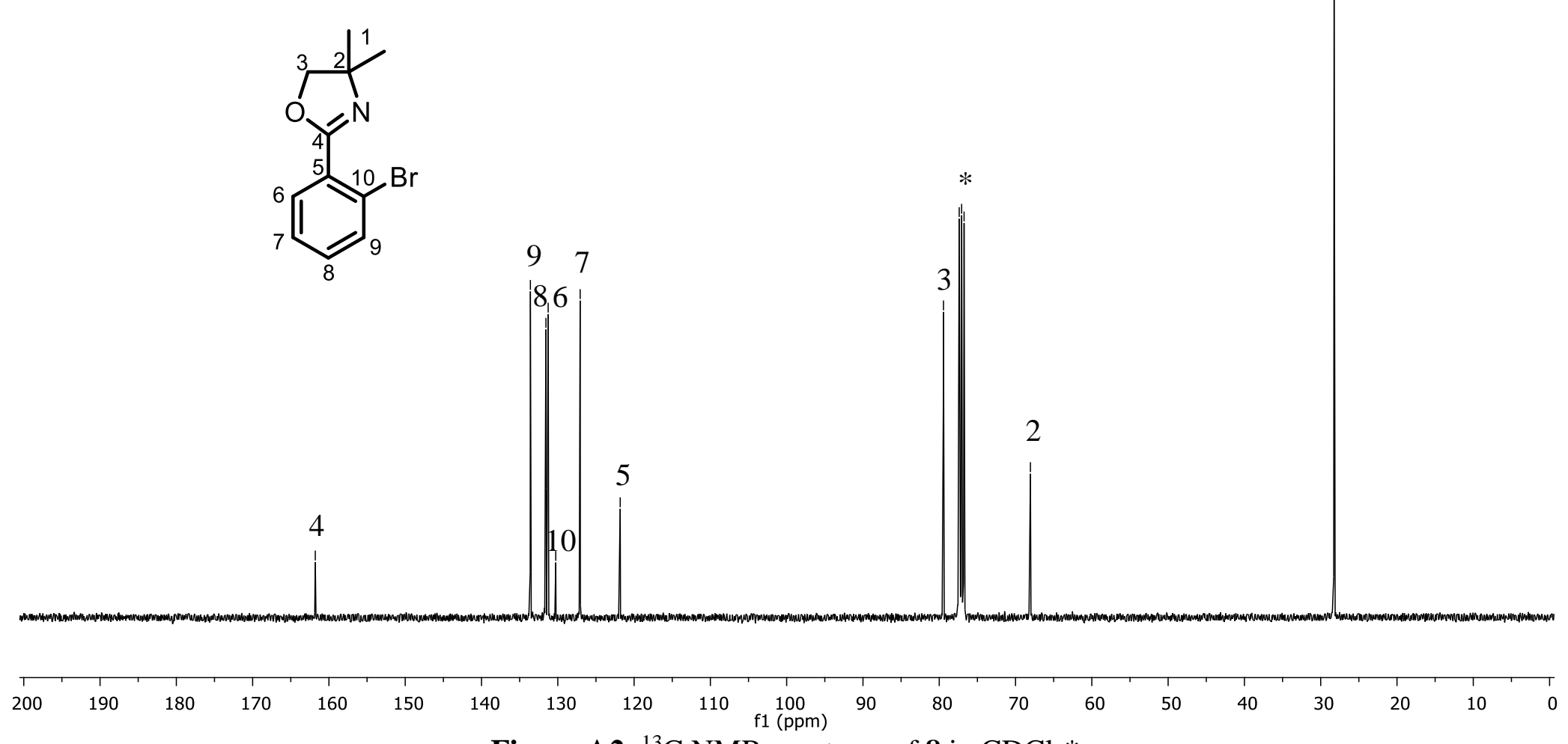

$\overline{3}$

Figure A2: ${ }^{13} \mathrm{C}$ NMR spectrum of $\mathbf{8}$ in $\mathrm{CDCl}_{3}{ }^{*}$. 


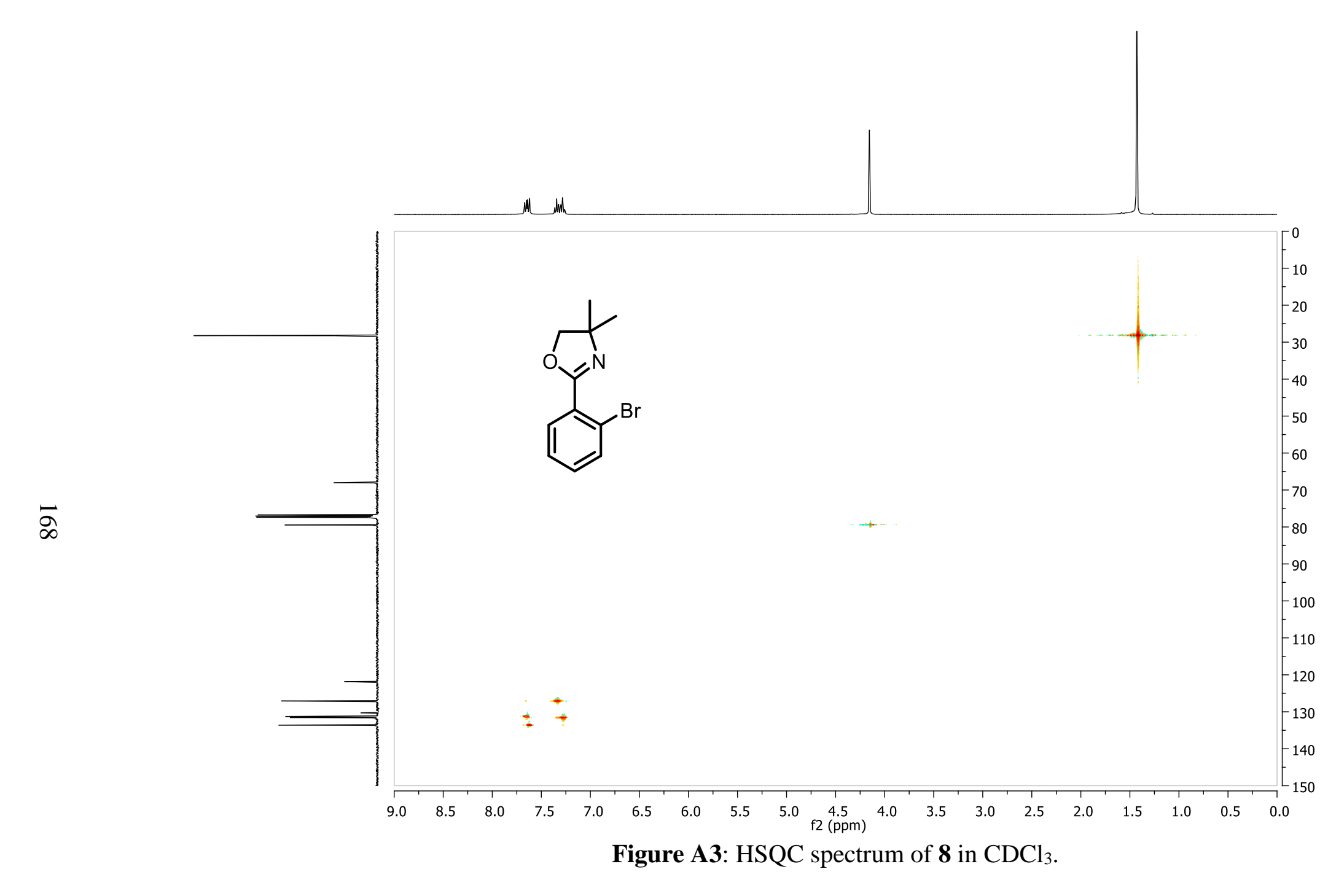




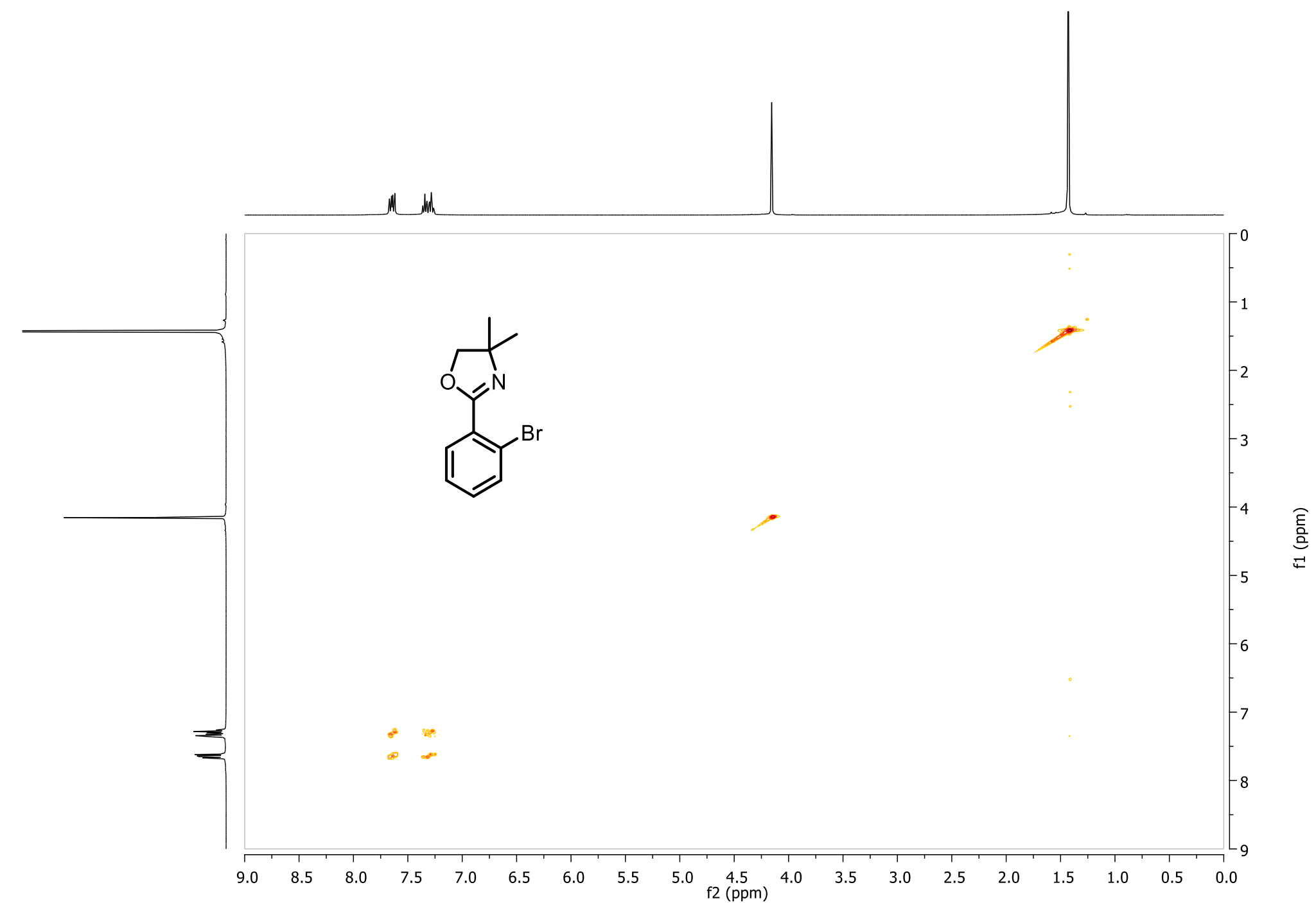

Figure A4: $\mathrm{COSY}$ spectrum of 8 in $\mathrm{CDCl}_{3}$. 


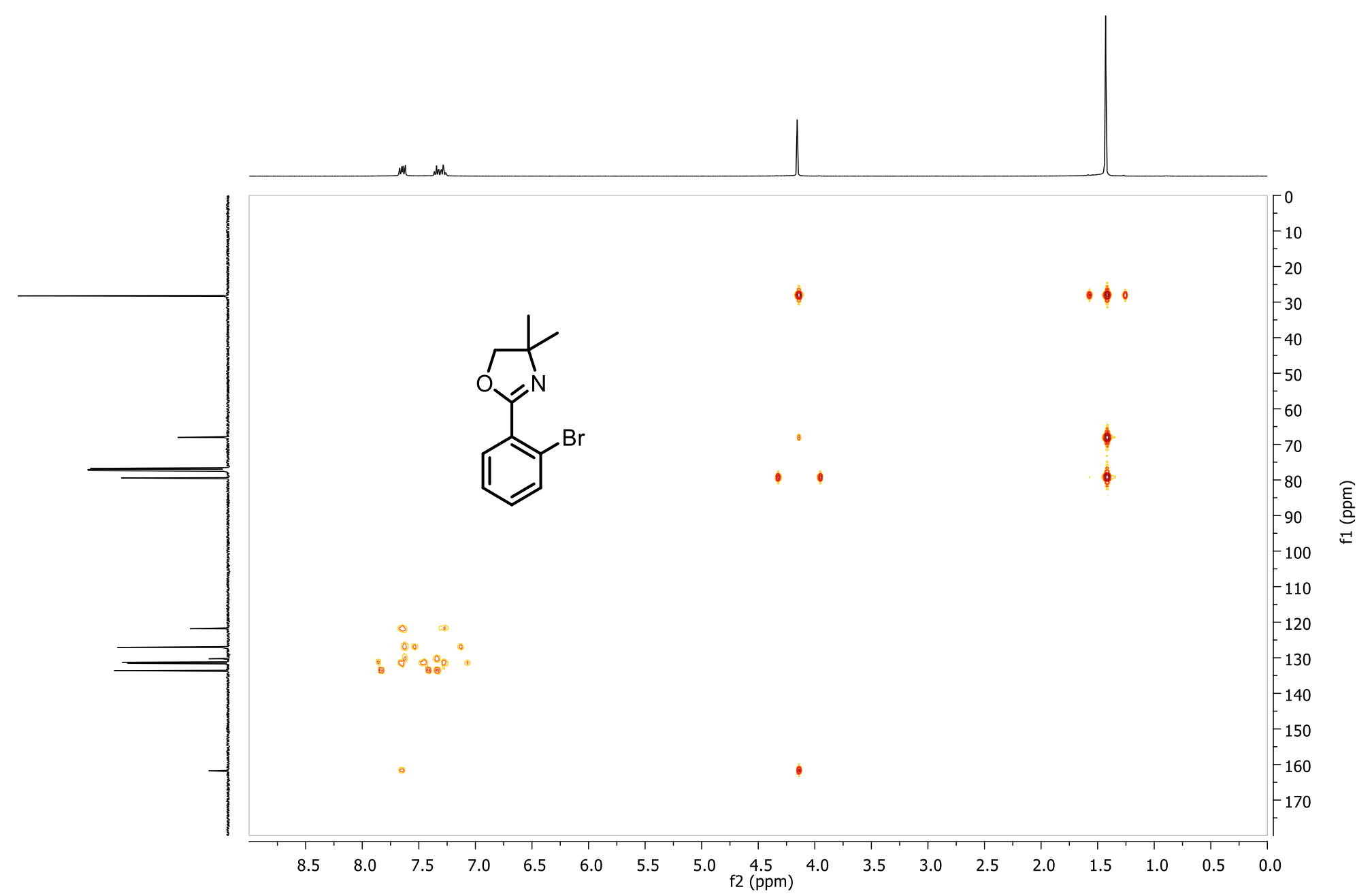

Figure A5: $\mathrm{HMBC}$ spectrum of $\mathbf{8}$ in $\mathrm{CDCl}_{3}$. 


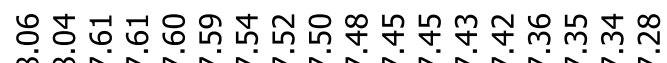
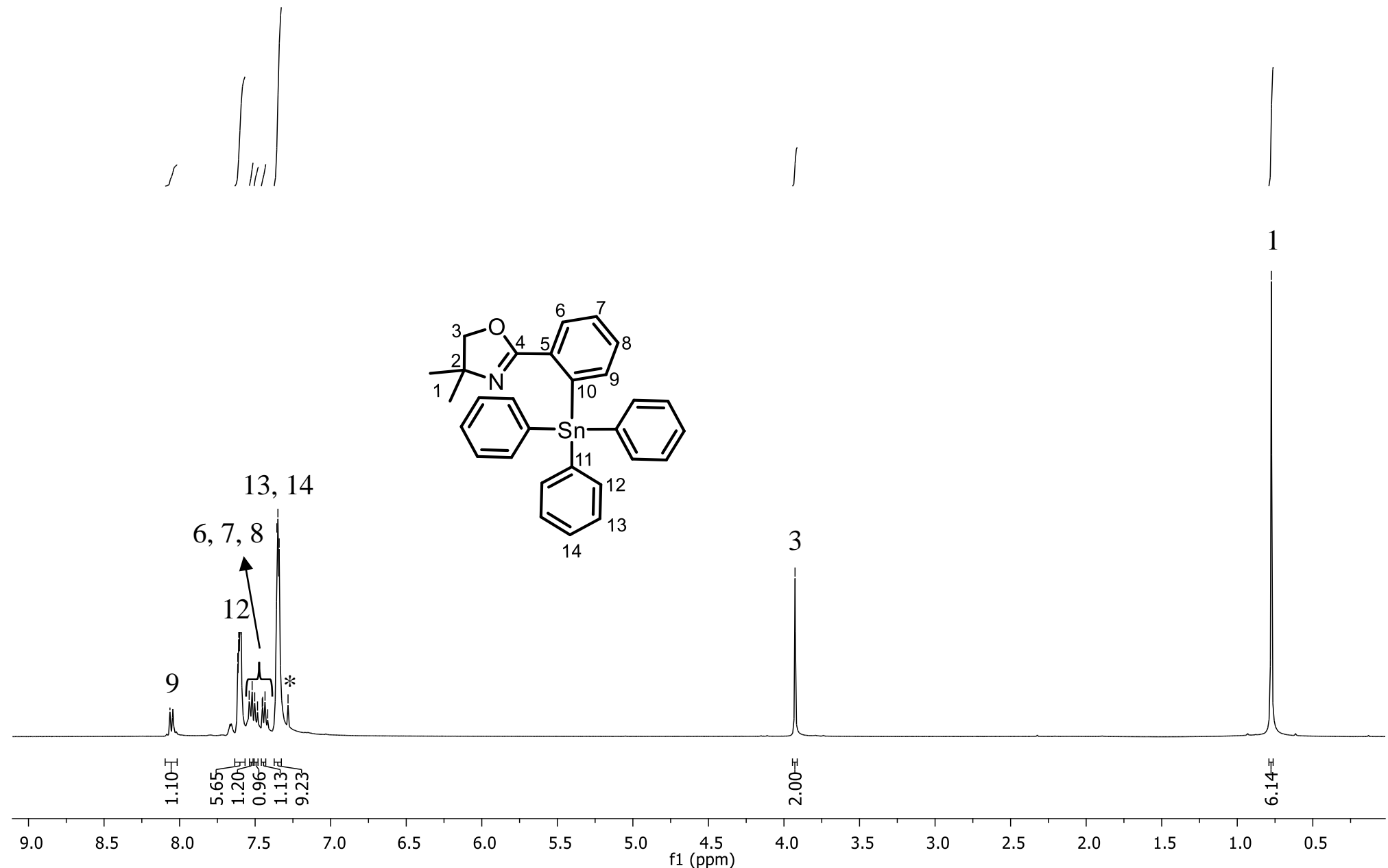

Figure A6: ${ }^{1} \mathrm{H}$ NMR spectrum of 10 in $\mathrm{CDCl}_{3}$ *. 


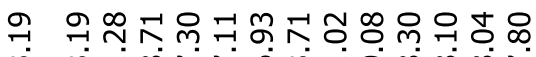

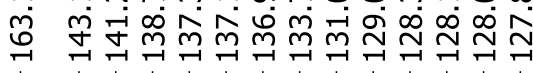

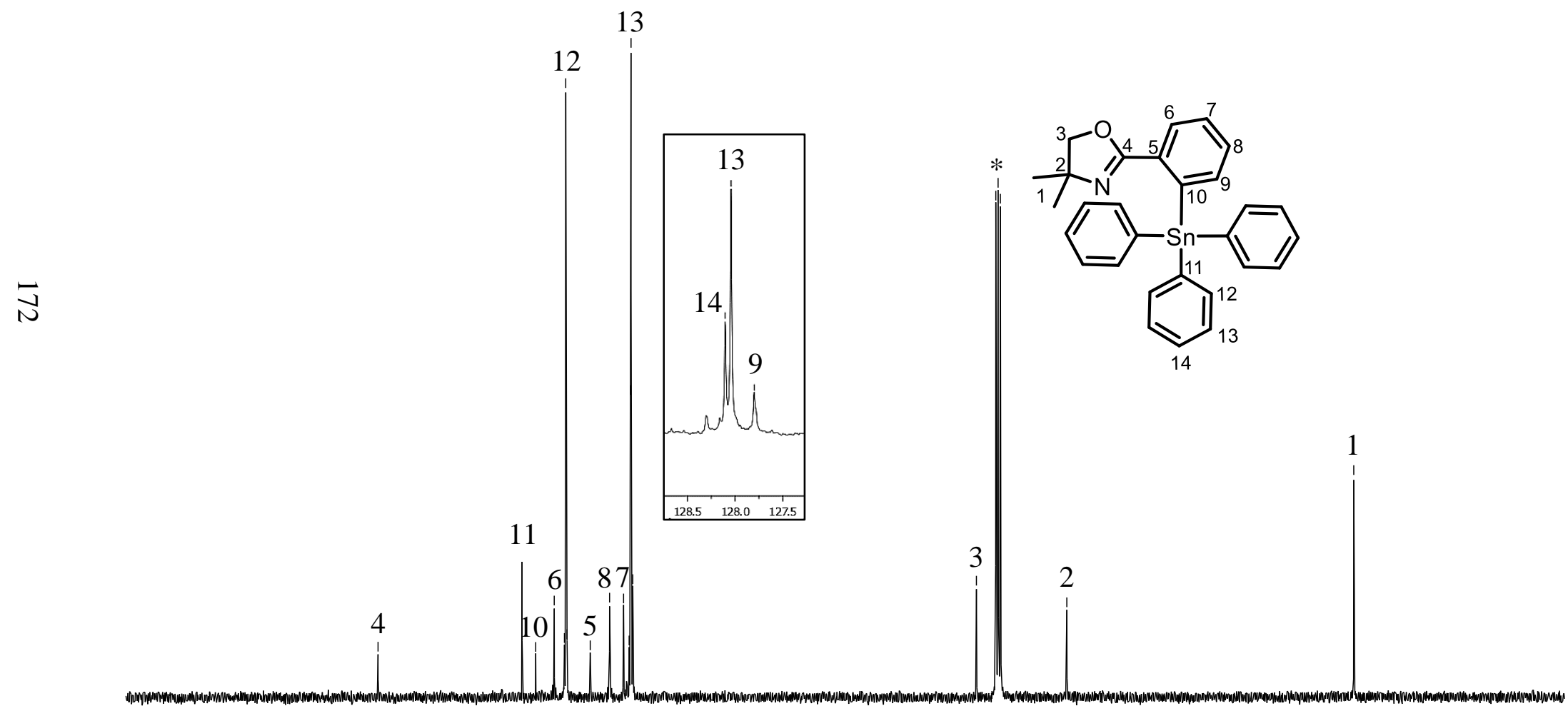

$\begin{array}{llll}190 & 180 & 170 & 160\end{array}$

Figure A7: ${ }^{13} \mathrm{C}$ NMR spectrum of $\mathbf{1 0}$ in $\mathrm{CDCl}_{3} *$. 


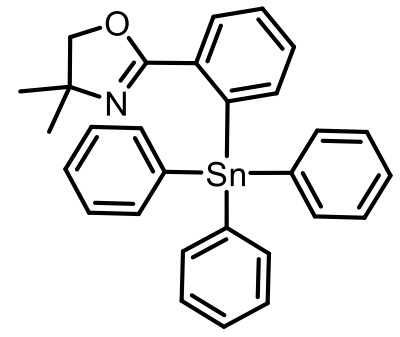

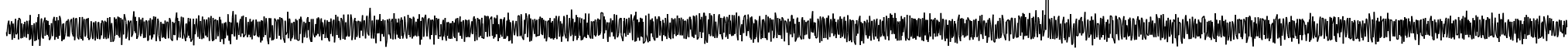
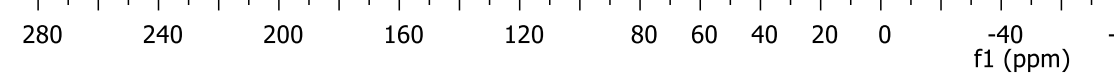

$-120$

$-160$

$-200$

$-240$

$-280$

Figure A8: ${ }^{119} \mathrm{Sn}$ NMR spectrum of $\mathbf{1 0}$ in $\mathrm{CDCl}_{3}$. 


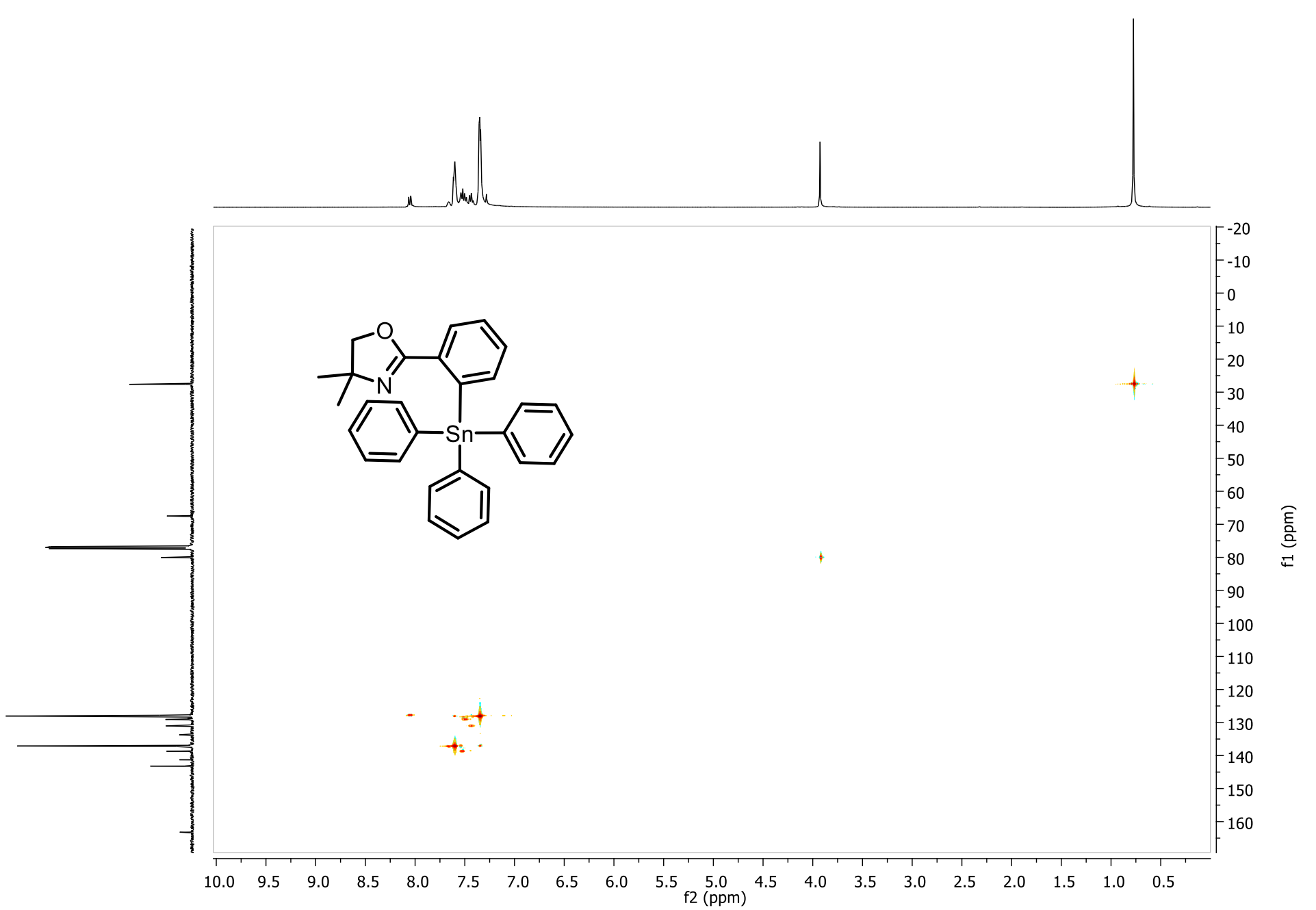

Figure A9: $\mathrm{HSQC}$ spectrum of $\mathbf{1 0}$ in $\mathrm{CDCl}_{3}$. 


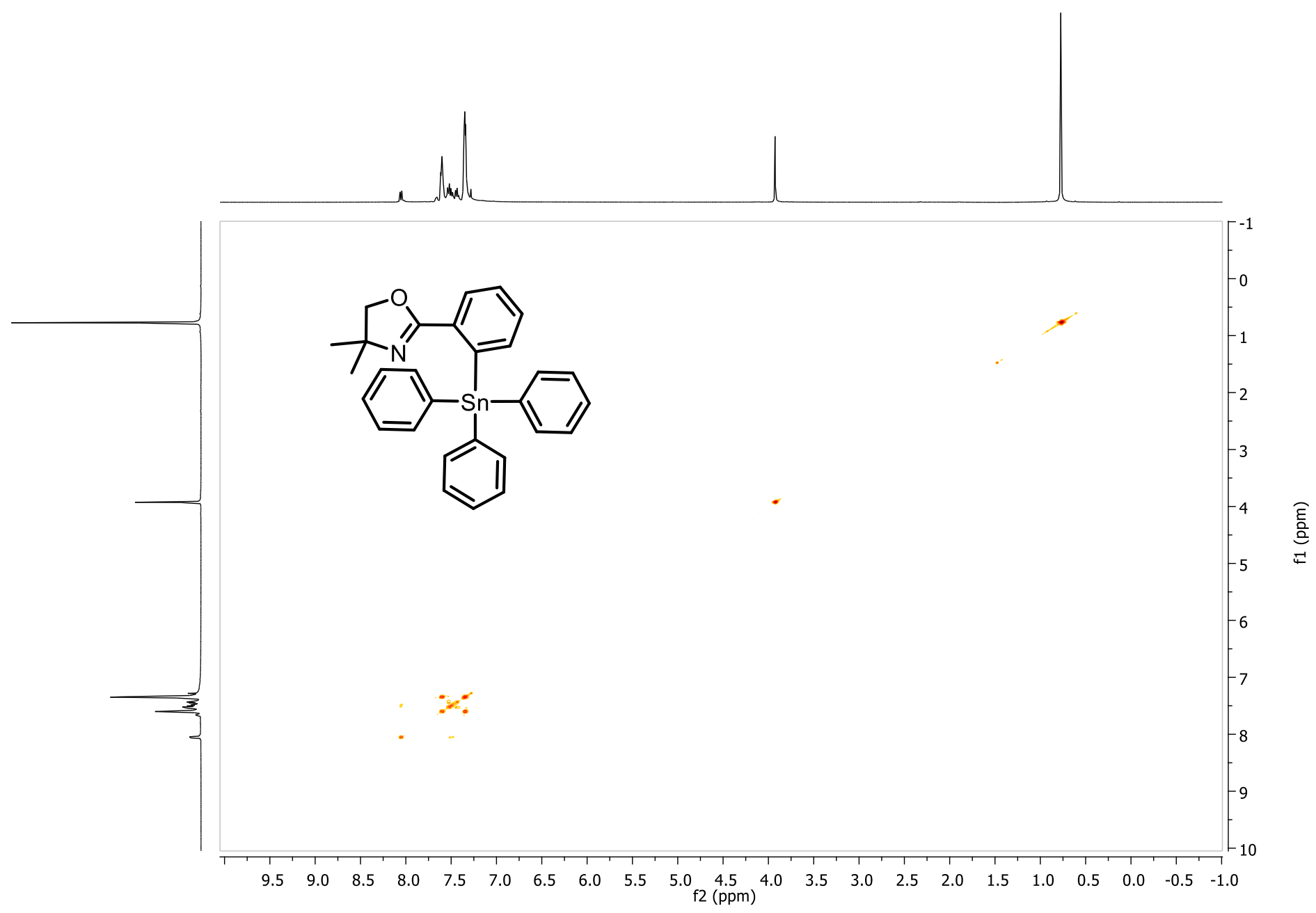

Figure A10: COSY spectrum 10 in $\mathrm{CDCl}_{3}$. 


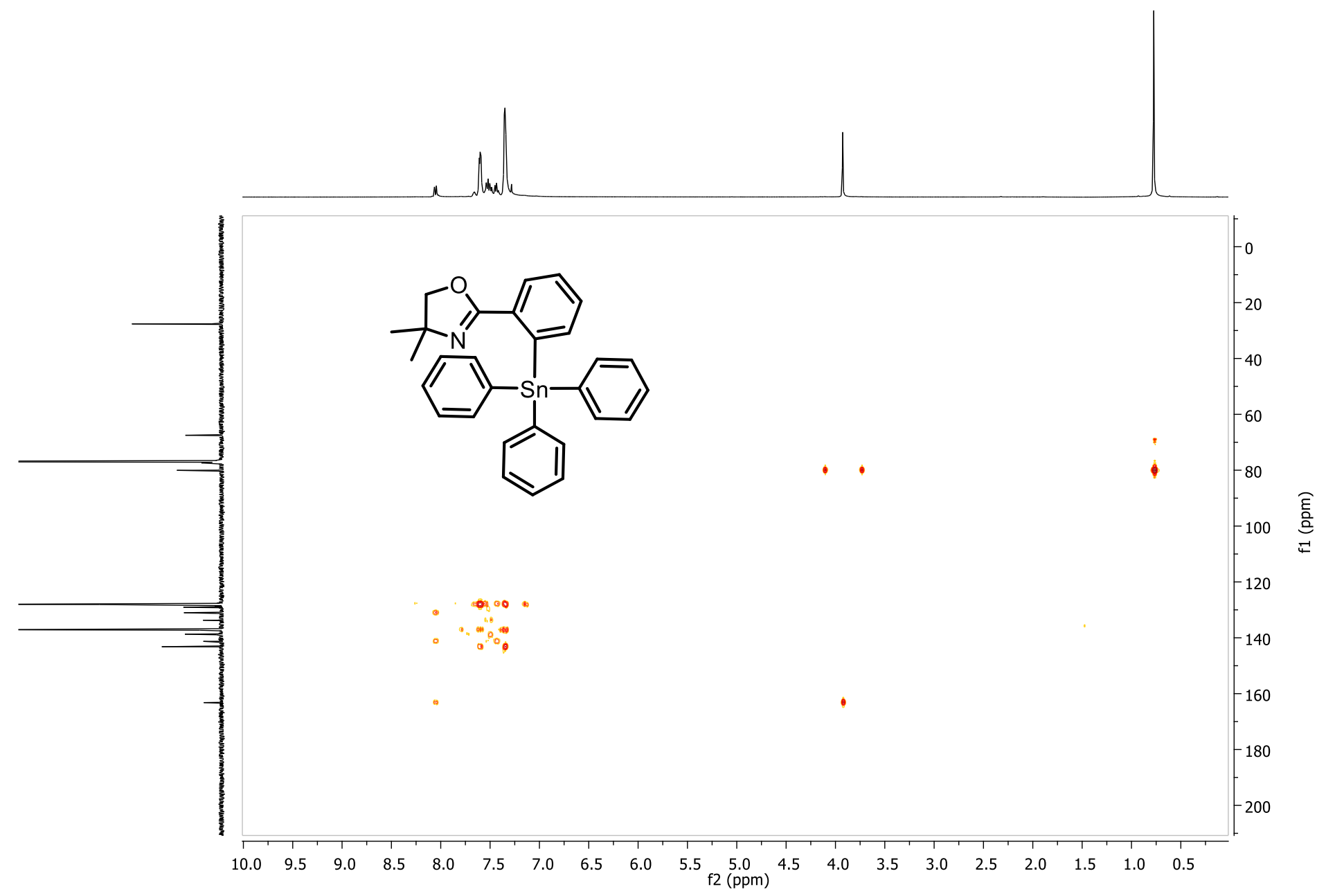

Figure A11: $\mathrm{HMBC}$ spectrum of 10 in $\mathrm{CDCl}_{3}$. 


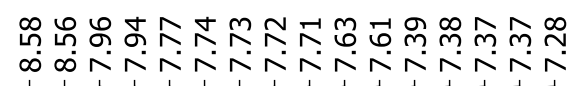

$\Xi$
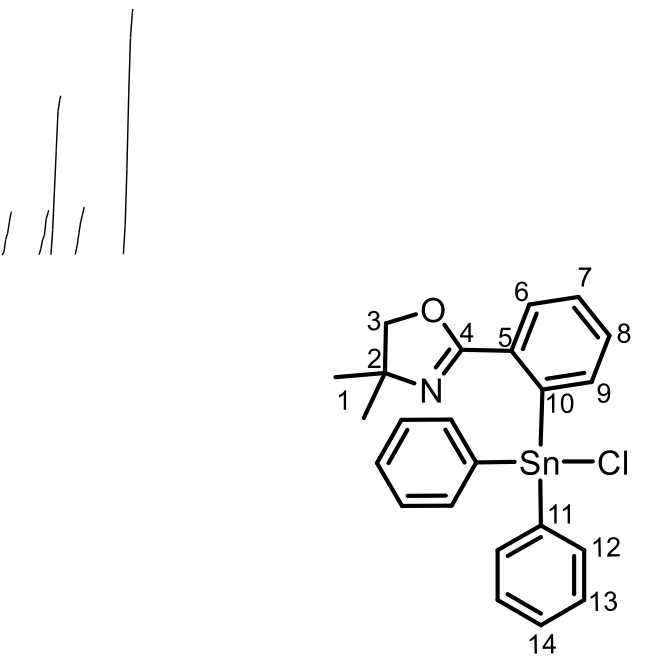

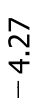

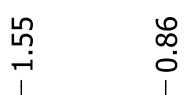

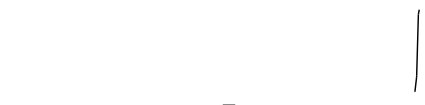

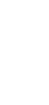
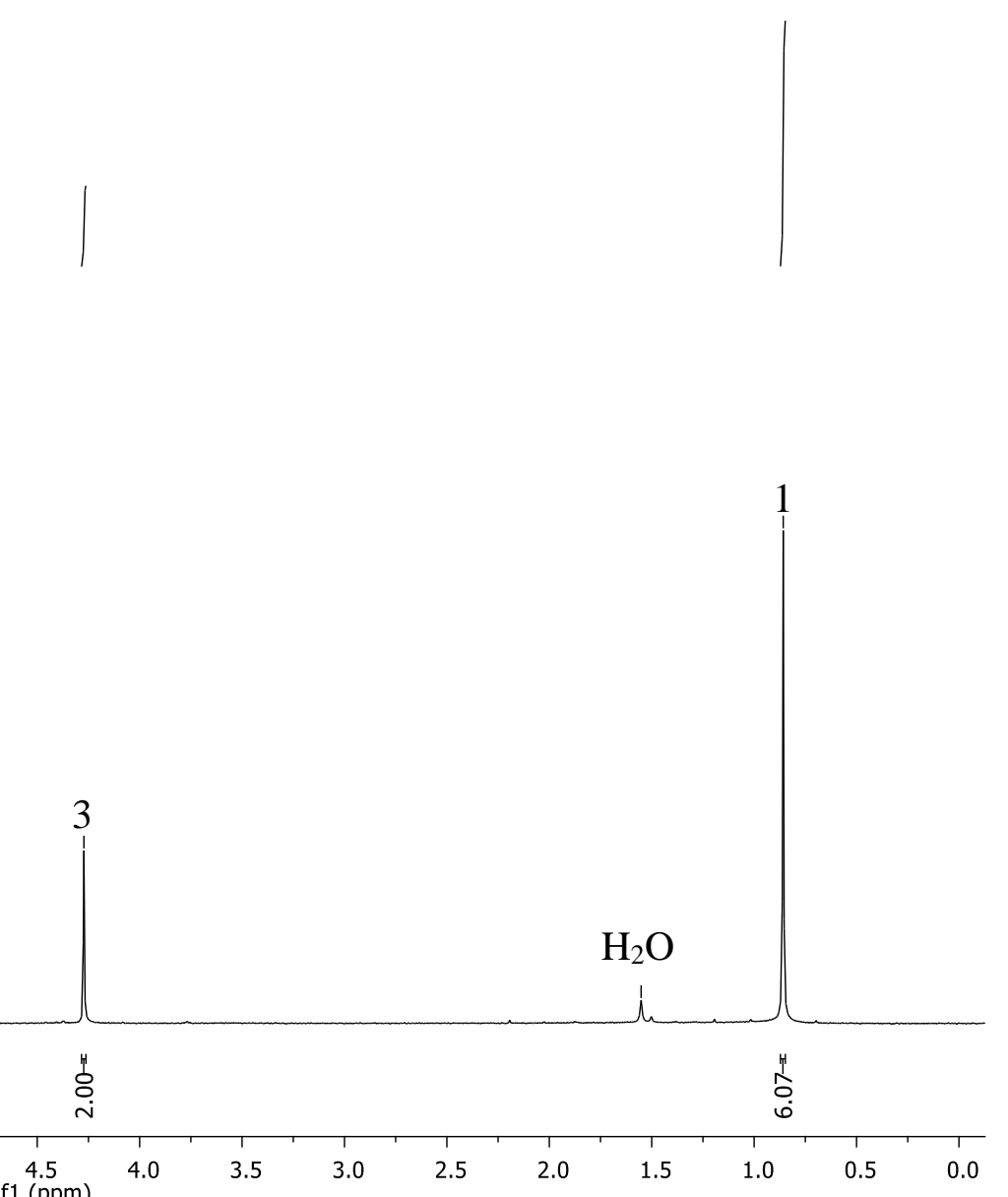

Figure A12: ${ }^{1} \mathrm{H}$ NMR spectrum of $\mathbf{1 1}$ in $\mathrm{CDCl} 3$. 


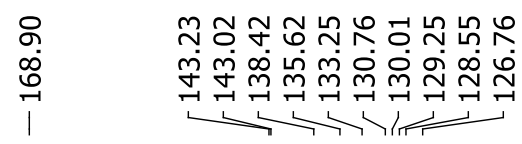

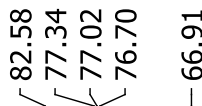
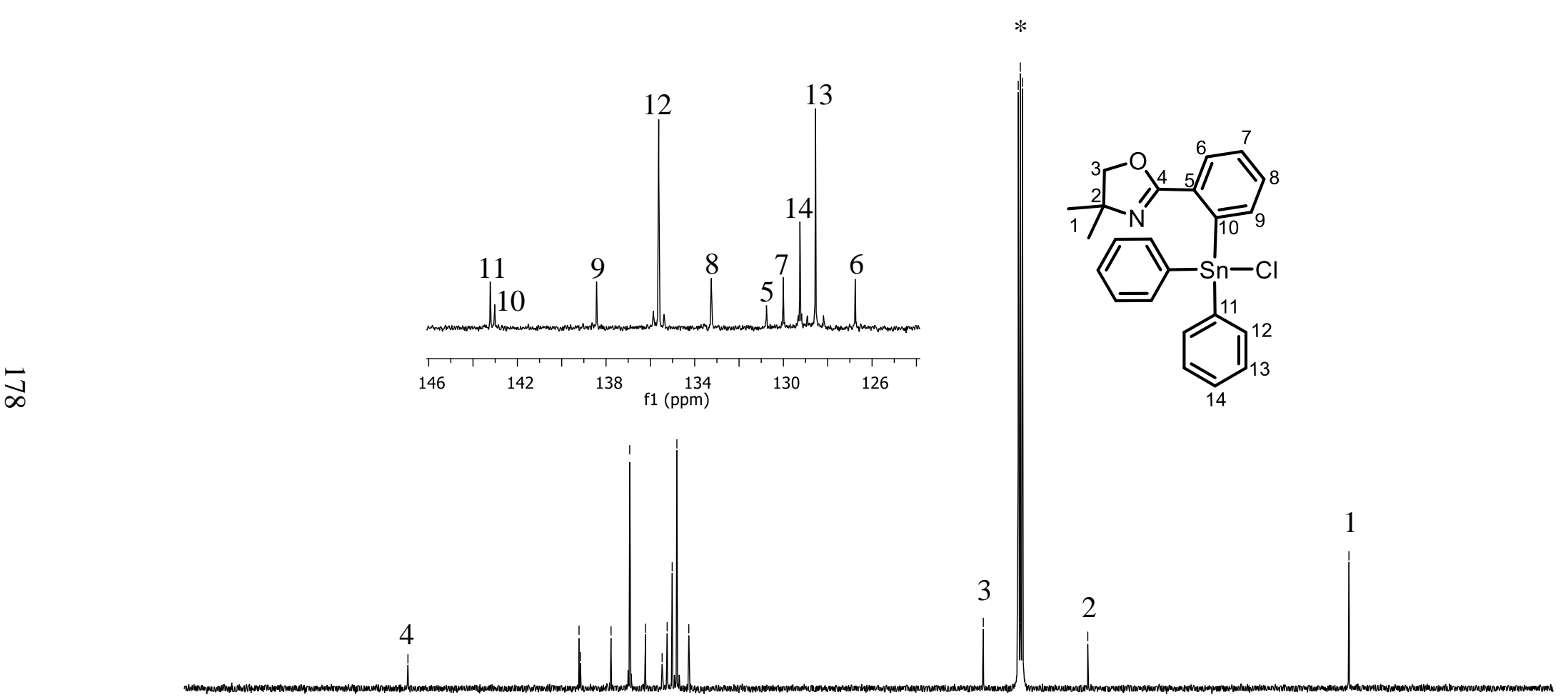

200

Figure A13: ${ }^{13} \mathrm{C}$ NMR spectrum of 11 in $\mathrm{CDCl}_{3} *$. 

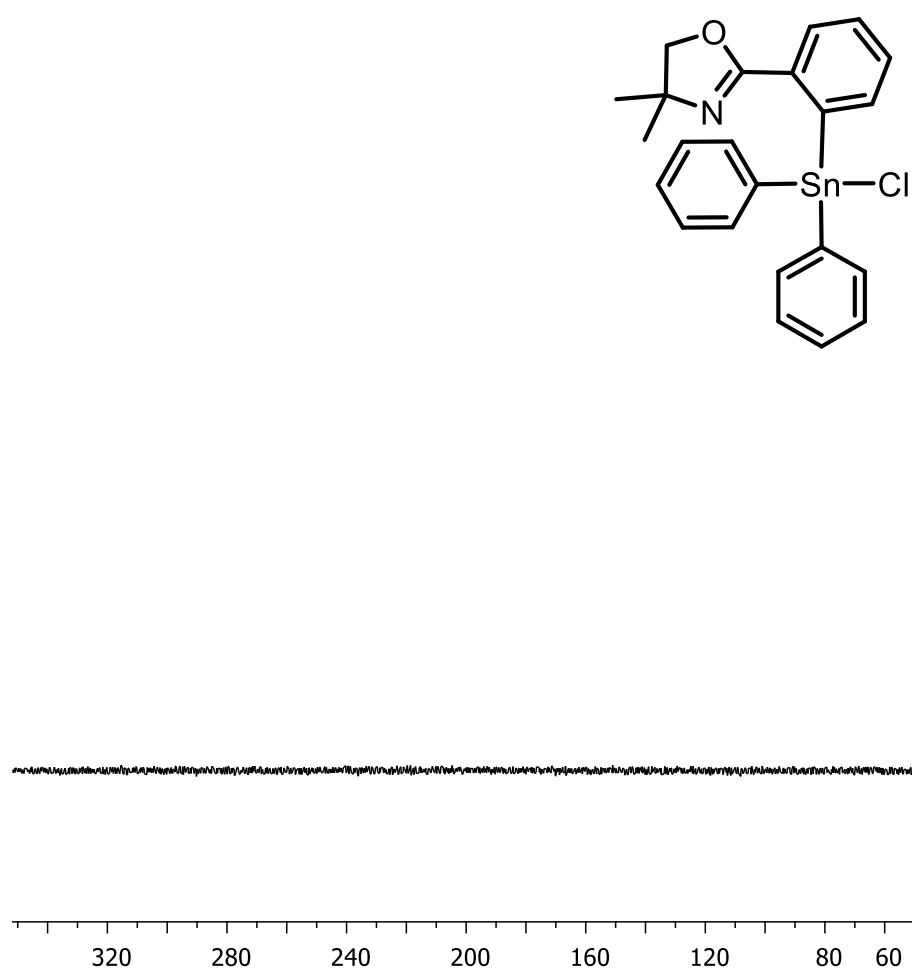

$60 \quad 120$

$\begin{array}{llll}80 & 60 & 40 & 20\end{array}$

Figure A14: ${ }^{119} \mathrm{Sn}$ NMR spectrum of 11 in $\mathrm{CDCl}_{3}$. 


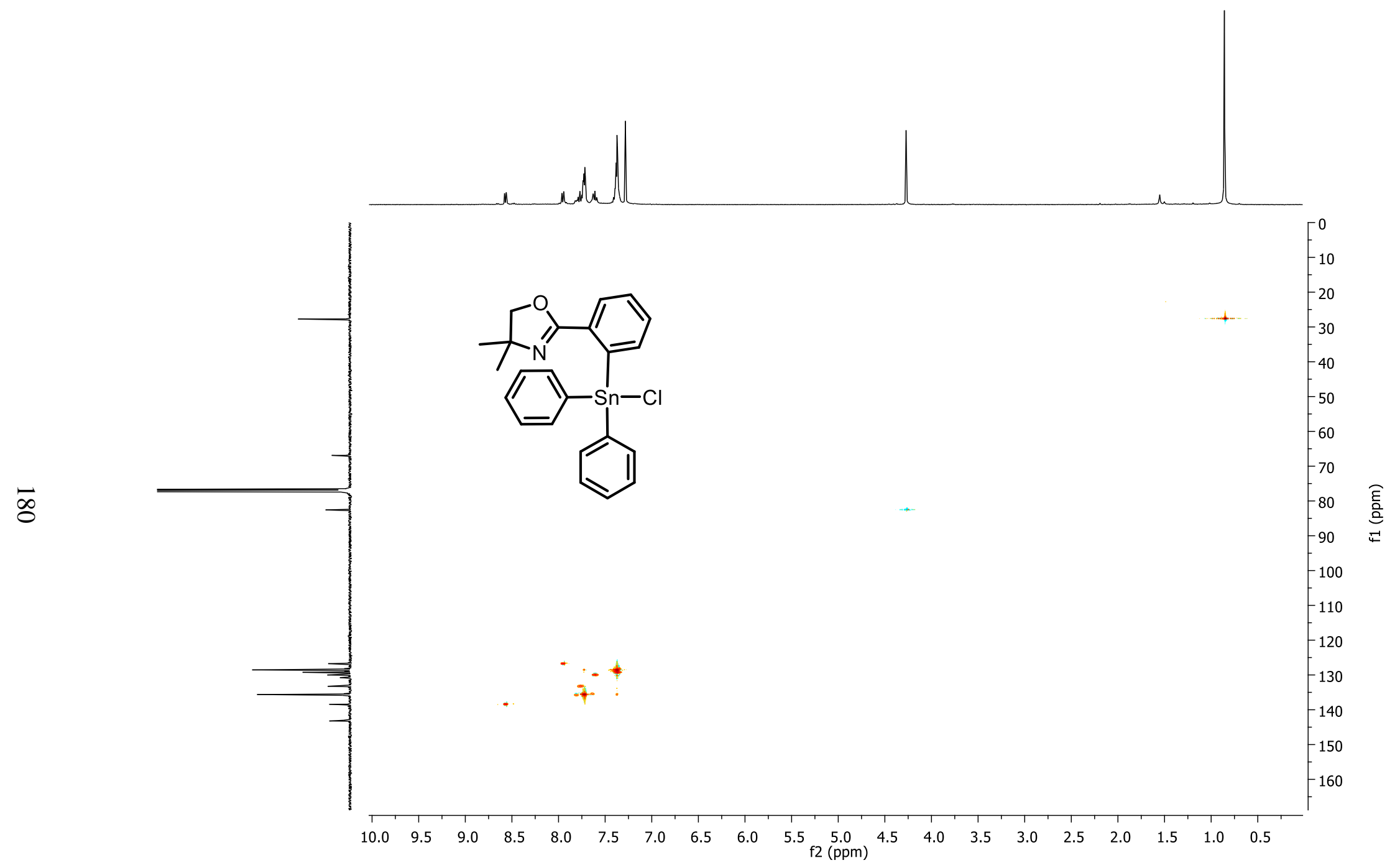

Figure A15: $\mathrm{HSQC}$ spectrum of $\mathbf{1 1}$ in $\mathrm{CDCl}_{3}$ *. 


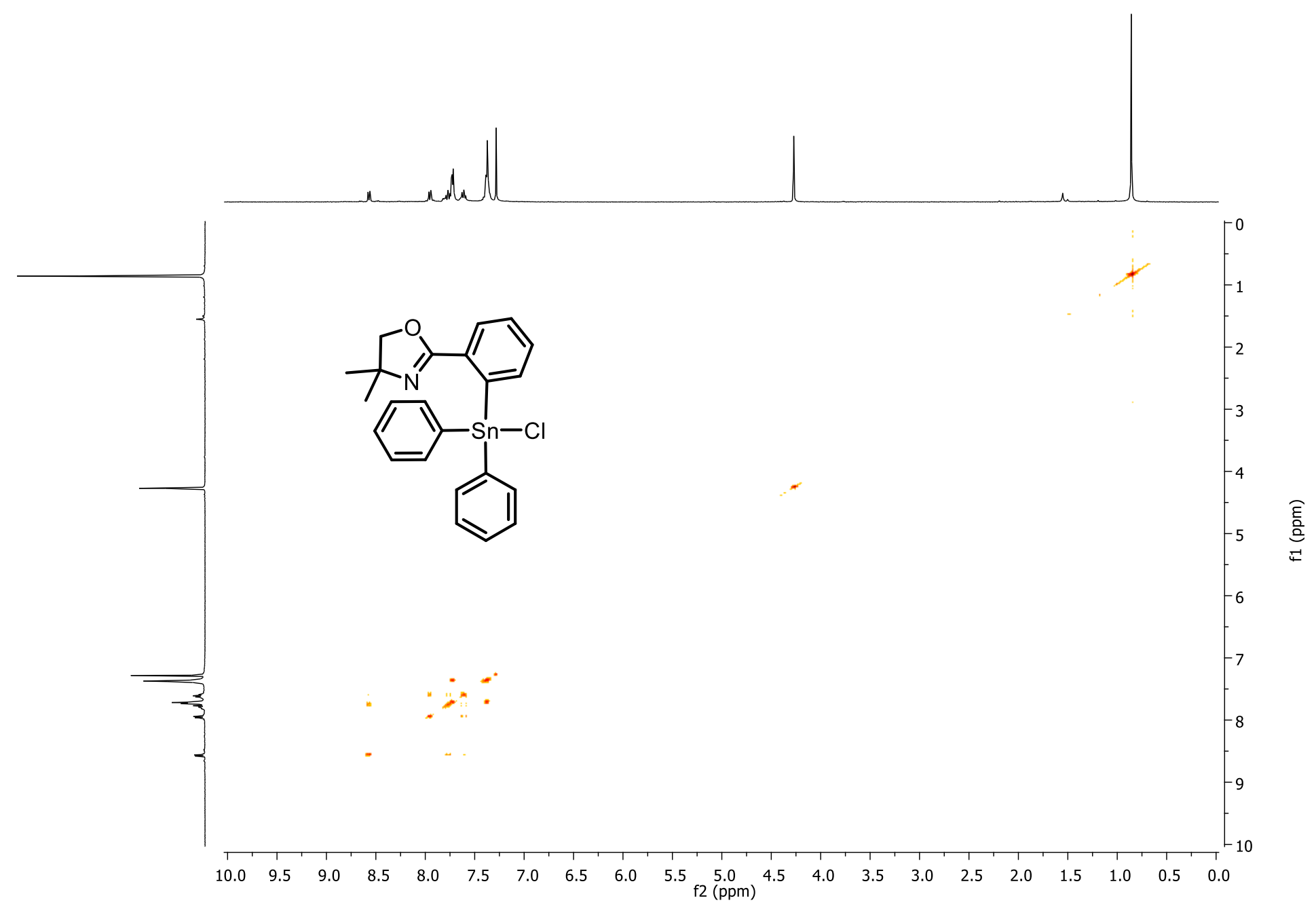

Figure A16: COSY spectrum of 11 in $\mathrm{CDCl}_{3} *$. 


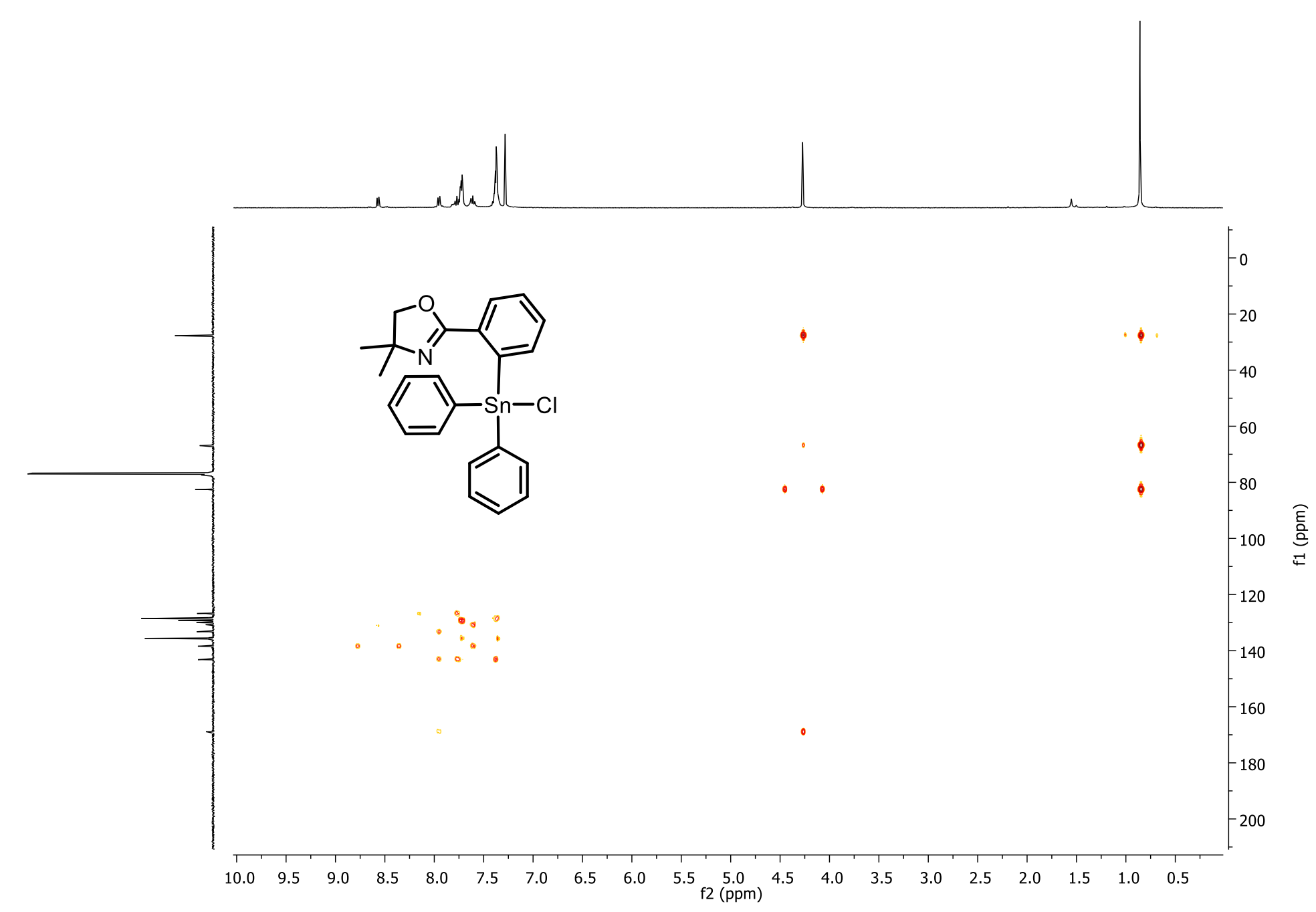

Figure A17: $\mathrm{HMBC}$ spectrum of 11 in $\mathrm{CDCl}_{3} *$. 


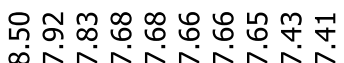

佂NNNNN
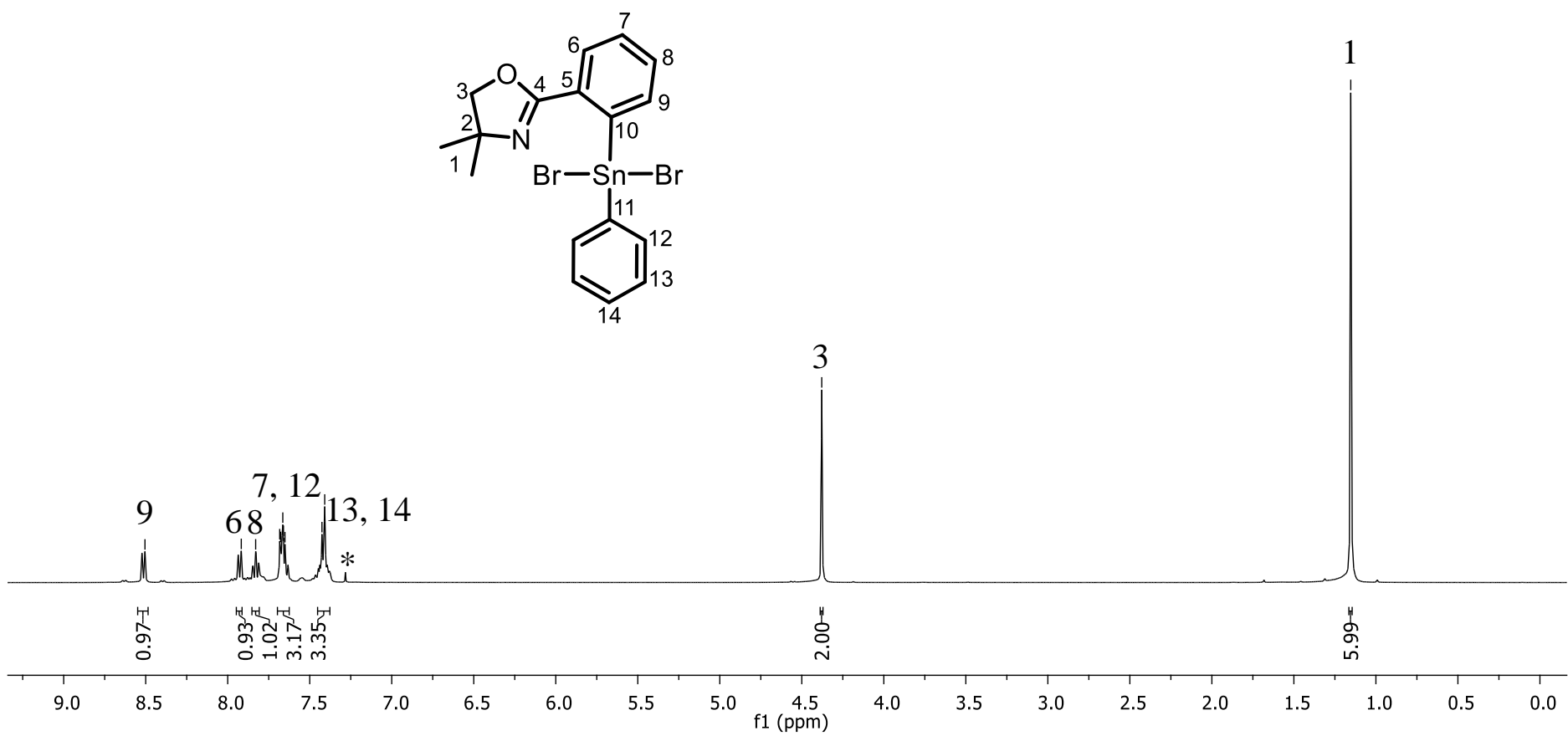

Figure A18: ${ }^{1} \mathrm{H}$ NMR spectrum of 13 in $\mathrm{CDCl}_{3}$ *. 

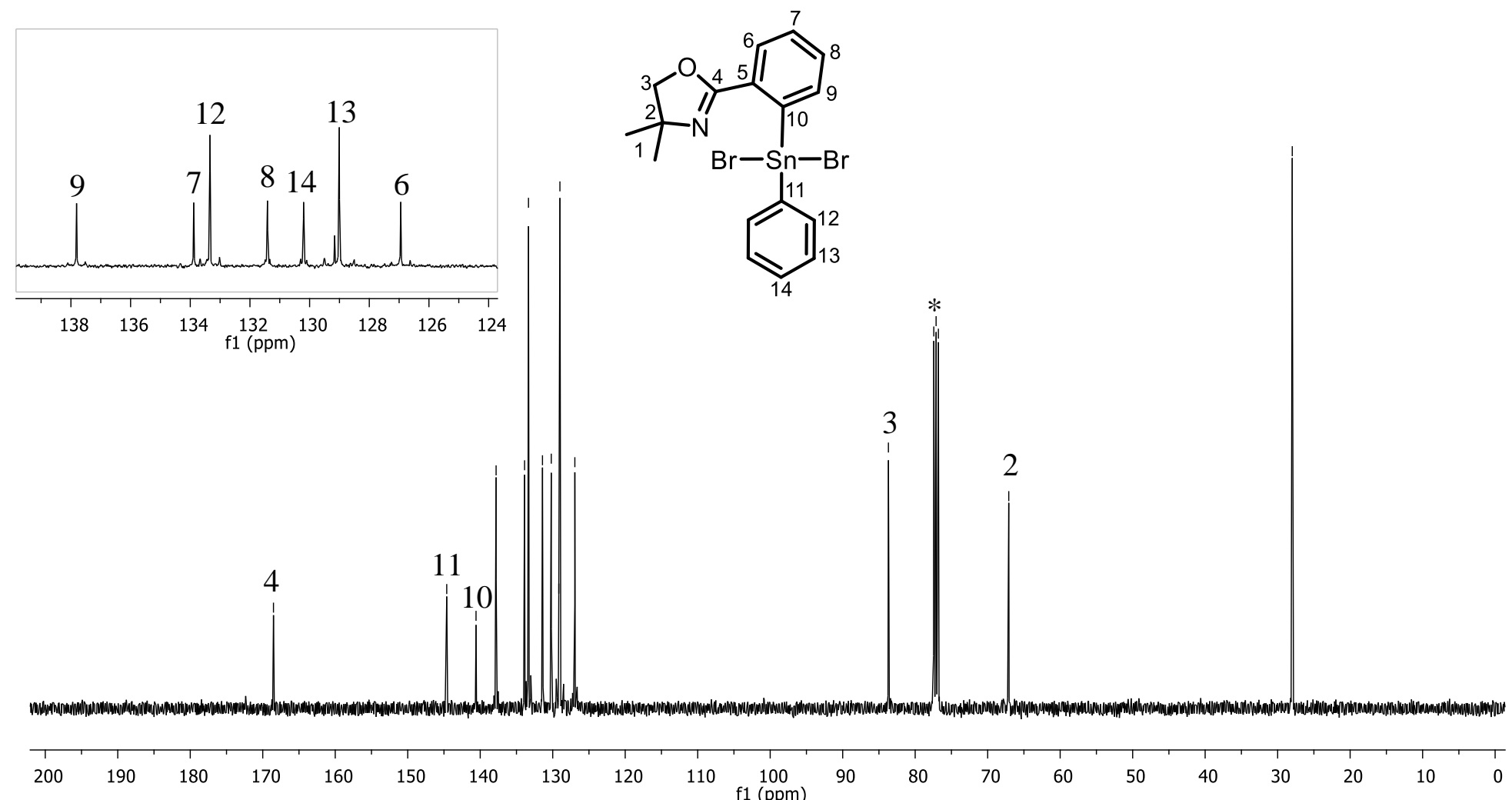

Figure A19: ${ }^{13} \mathrm{C}$ NMR spectrum of $\mathbf{1 3}$ in $\mathrm{CDCl}_{3}{ }^{*}$. 

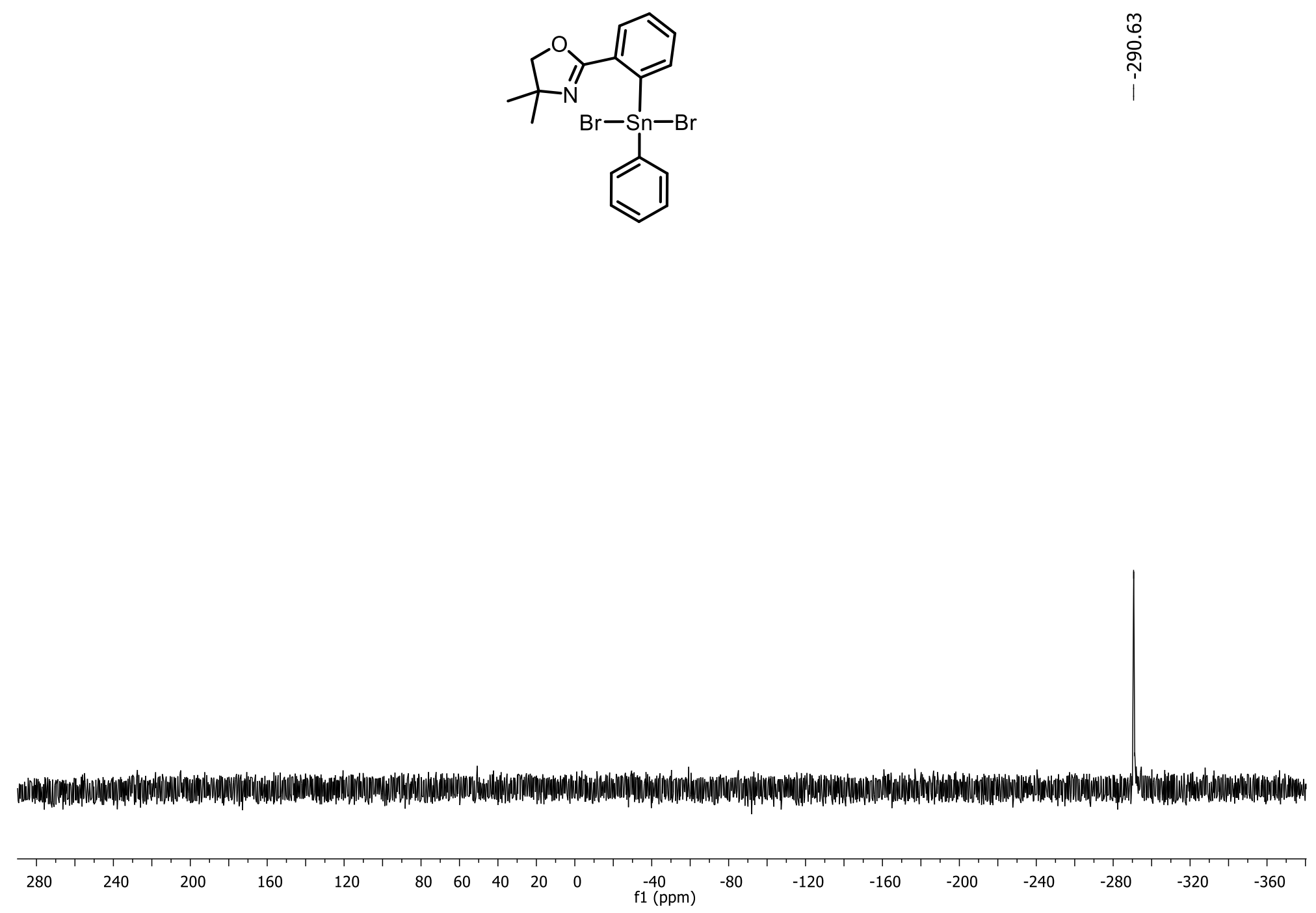

Figure A20: ${ }^{119} \mathrm{Sn}$ NMR spectrum of $\mathbf{1 3}$ in $\mathrm{CDCl}_{3} *$. 


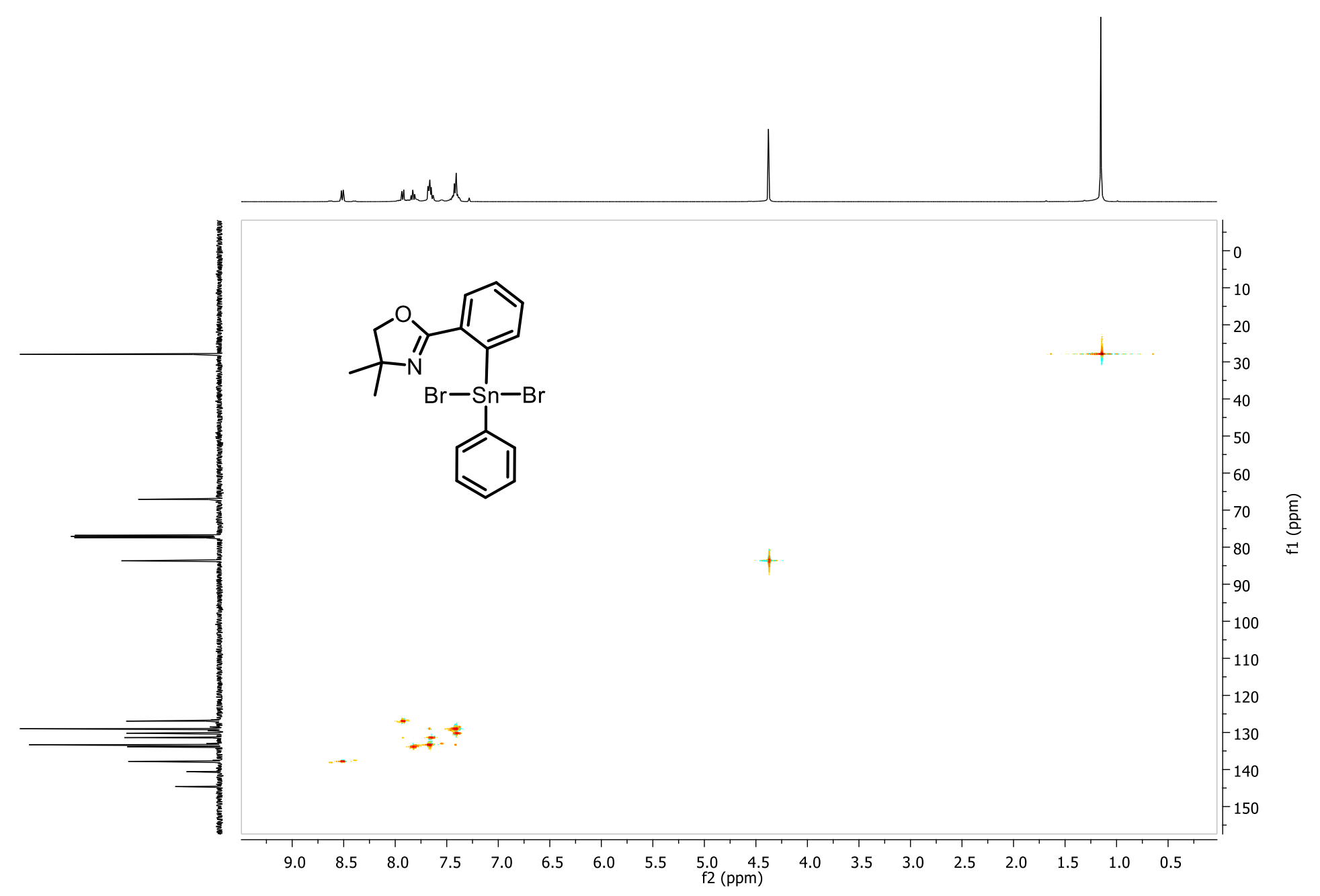

Figure A21: $\mathrm{HSQC}$ spectrum of 13 in $\mathrm{CDCl}_{3} *$. 


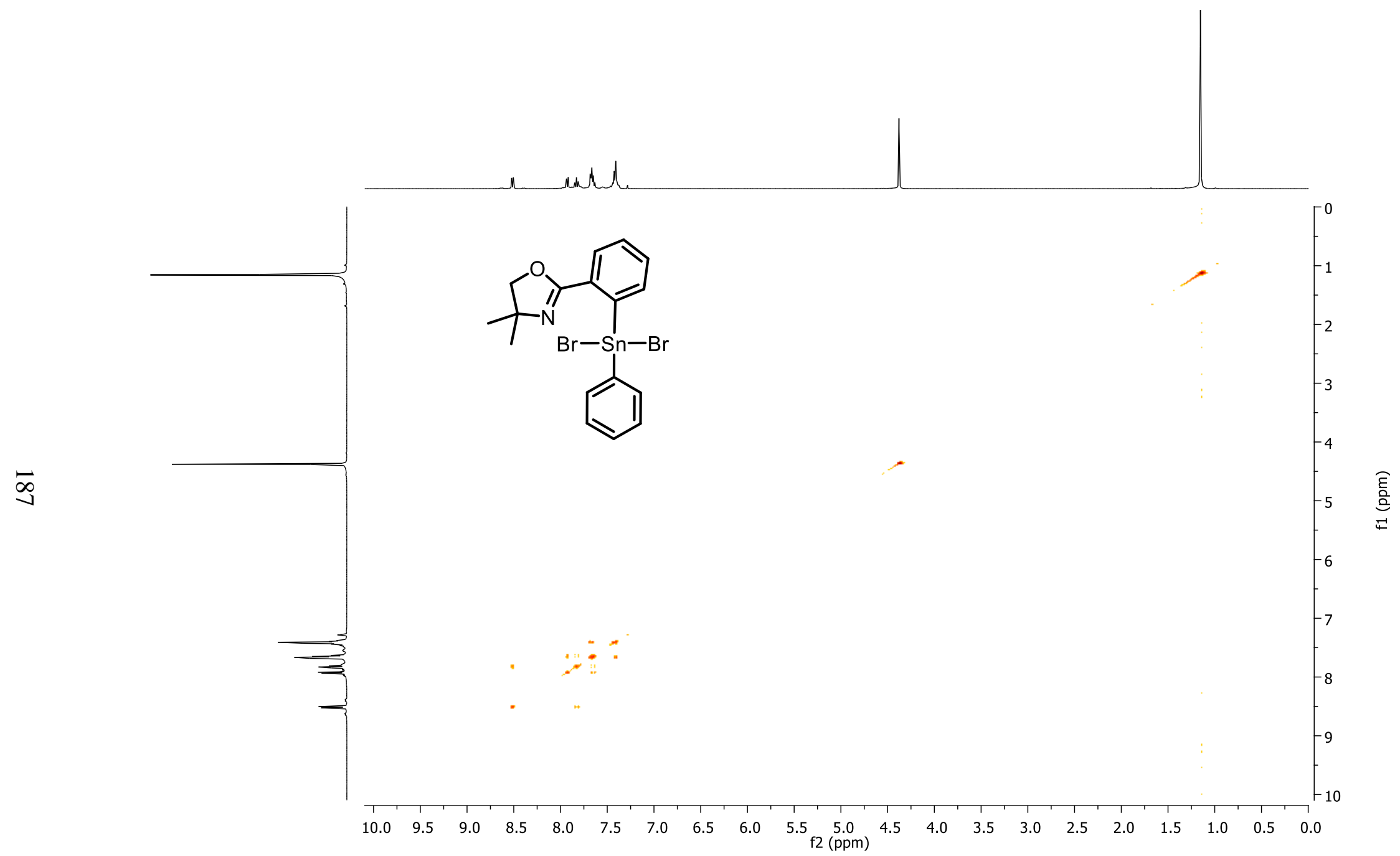

Figure A22: COSY spectrum of $\mathbf{1 3}$ in $\mathrm{CDCl}_{3}$ *. 


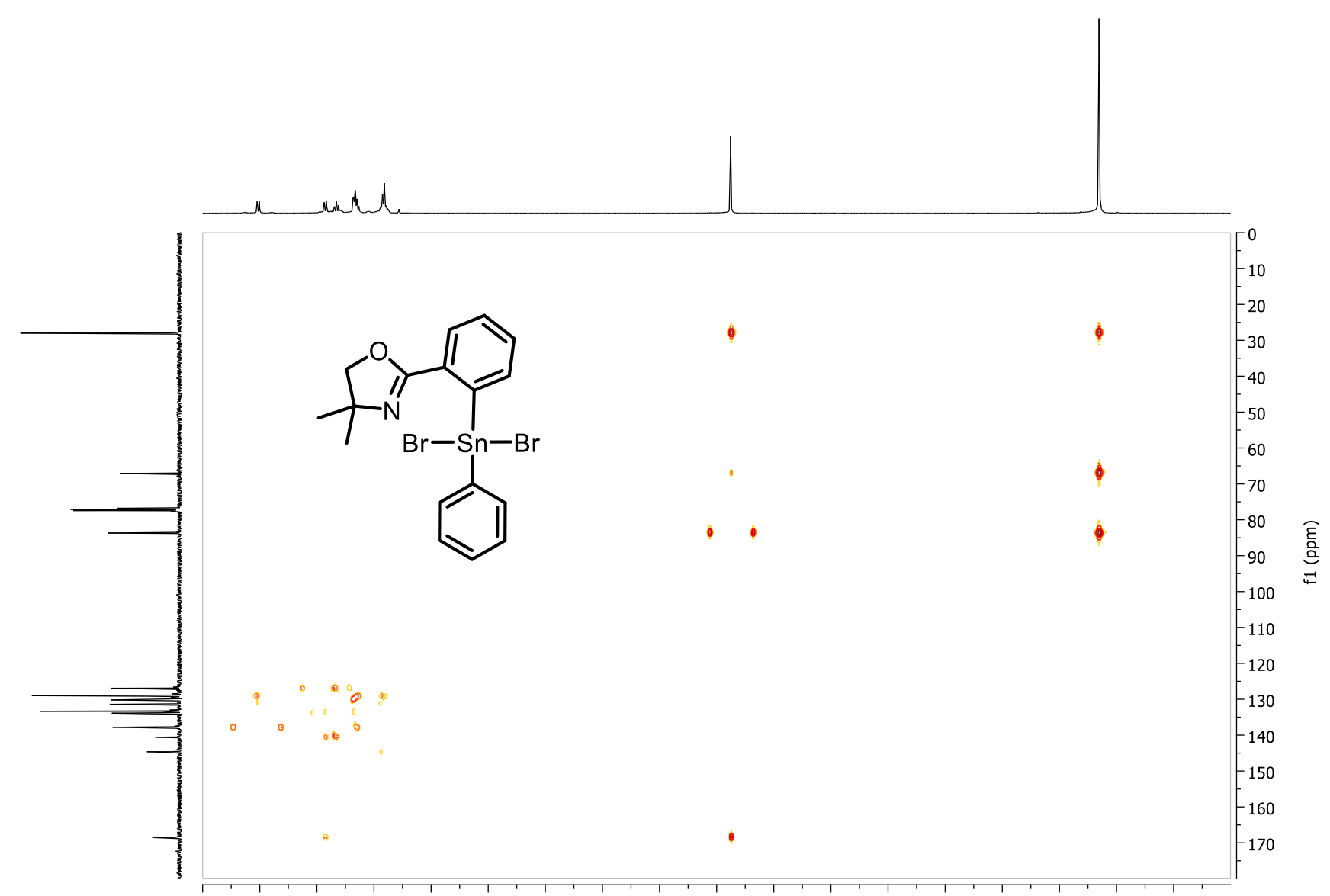

Figure A23: $\mathrm{HMBC}$ spectrum of 13 in $\mathrm{CDCl}_{3} *$. 


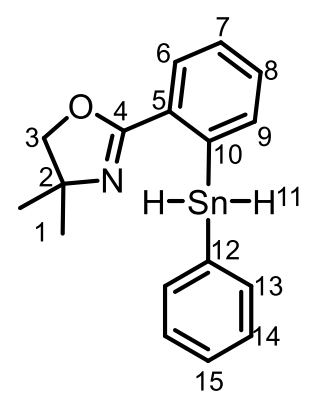

hexane

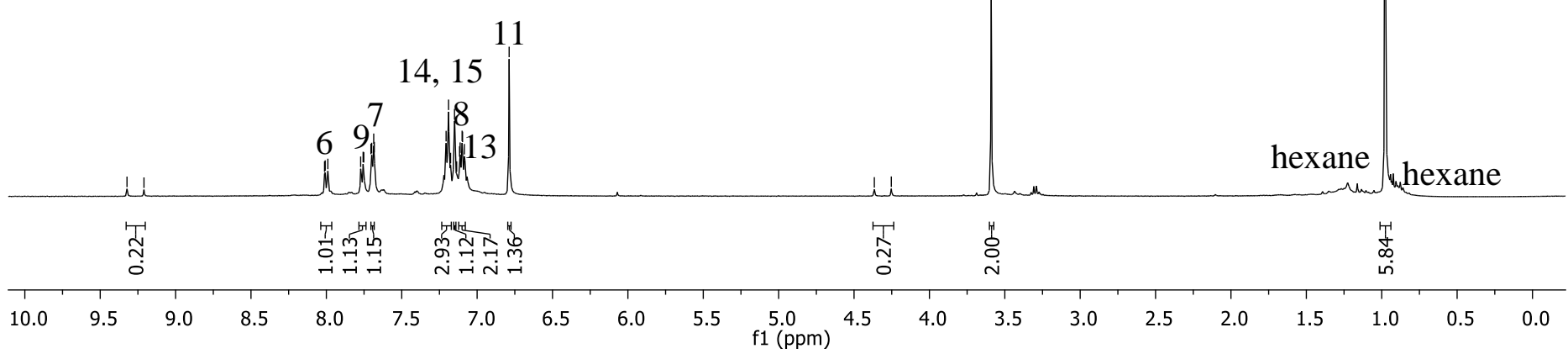

Figure A24: ${ }^{1} \mathrm{H}$ NMR spectrum of $\mathbf{1 4}$ in $\mathrm{CDCl}_{3}$ * 


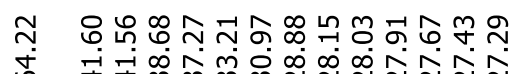

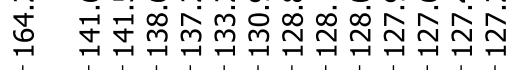

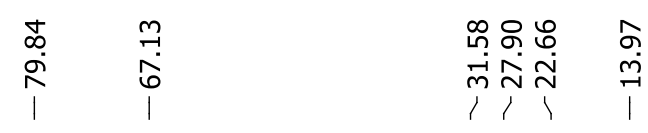
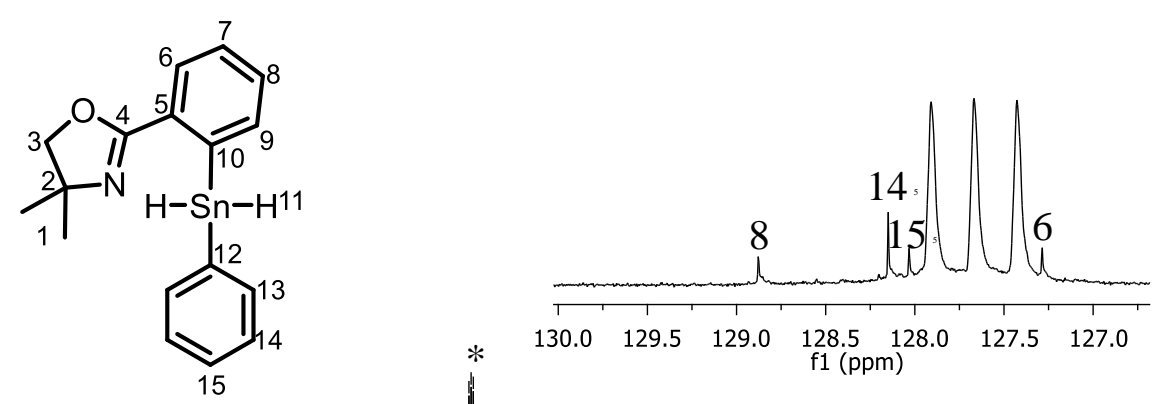

4

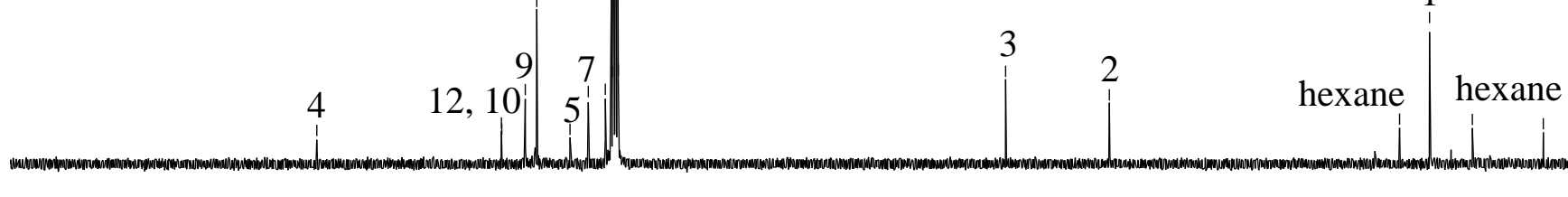

13

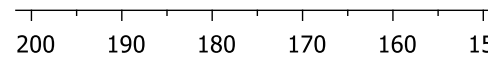

200

$90 \quad 18$

$\begin{array}{lll}170 & 160 & 150\end{array}$

$140 \quad 130$

120

100
$\mathrm{f} 1(\mathrm{ppm})$

Figure A25: ${ }^{13} \mathrm{C}$ NMR spectrum of $\mathbf{1 4}$ in $\mathrm{CDCl}_{3} *$. 

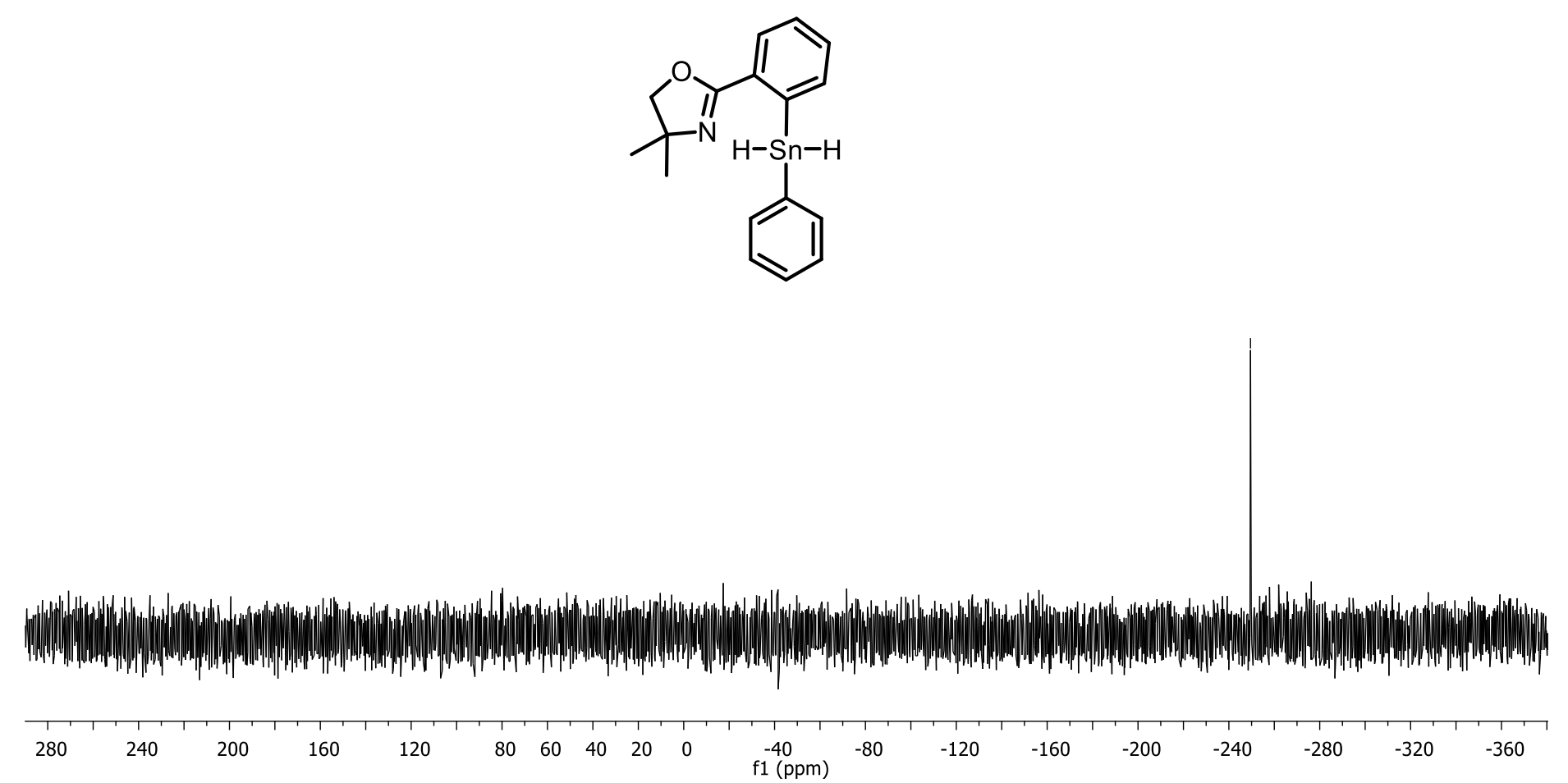

Figure A26: ${ }^{119} \mathrm{Sn} \mathrm{NMR}$ spectrum of $\mathbf{1 4}$ in $\mathrm{CDCl}_{3}$ *. 


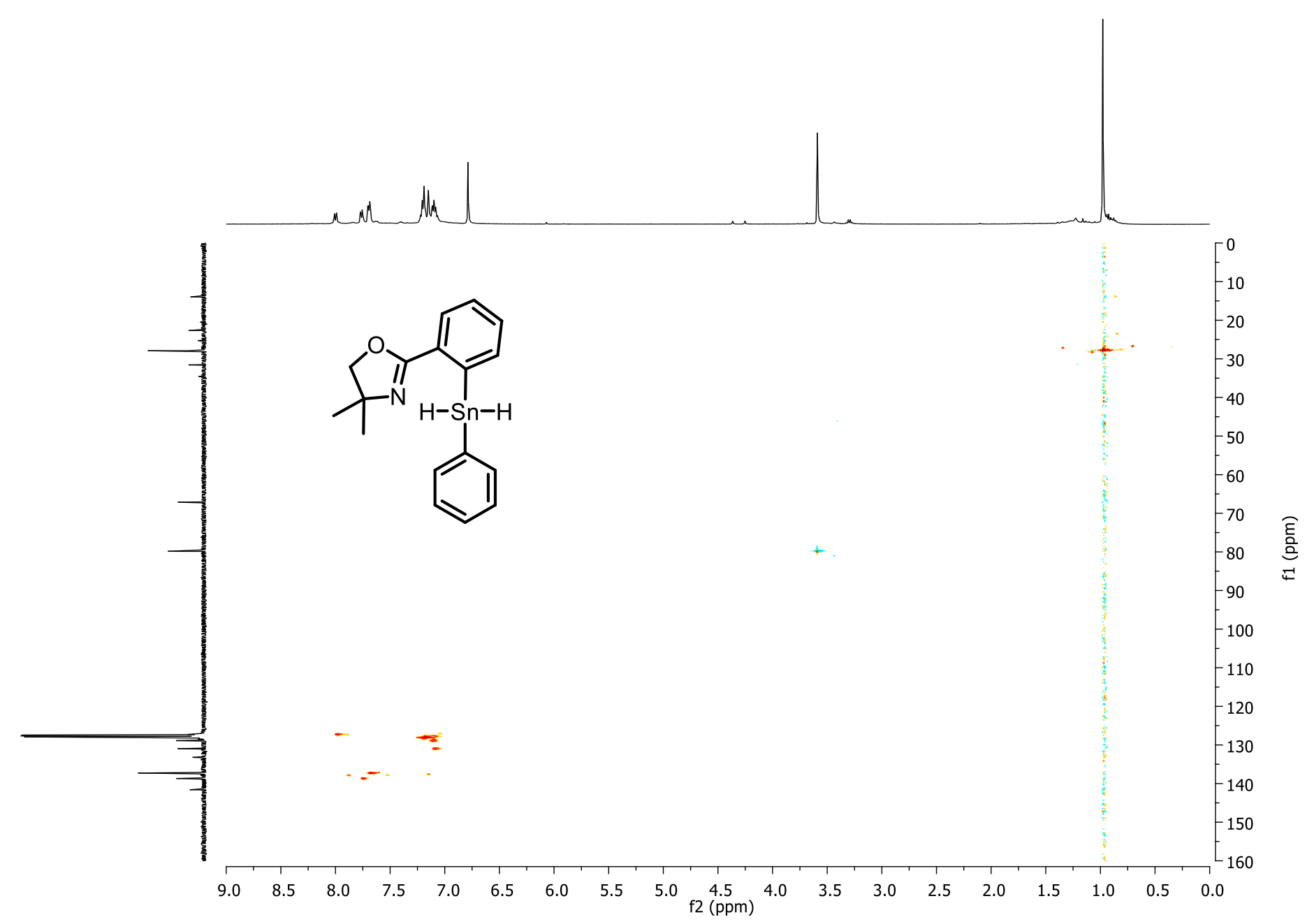

Figure A27: HSQC spectrum of 14 in $\mathrm{C}_{6} \mathrm{D}_{6}$. 


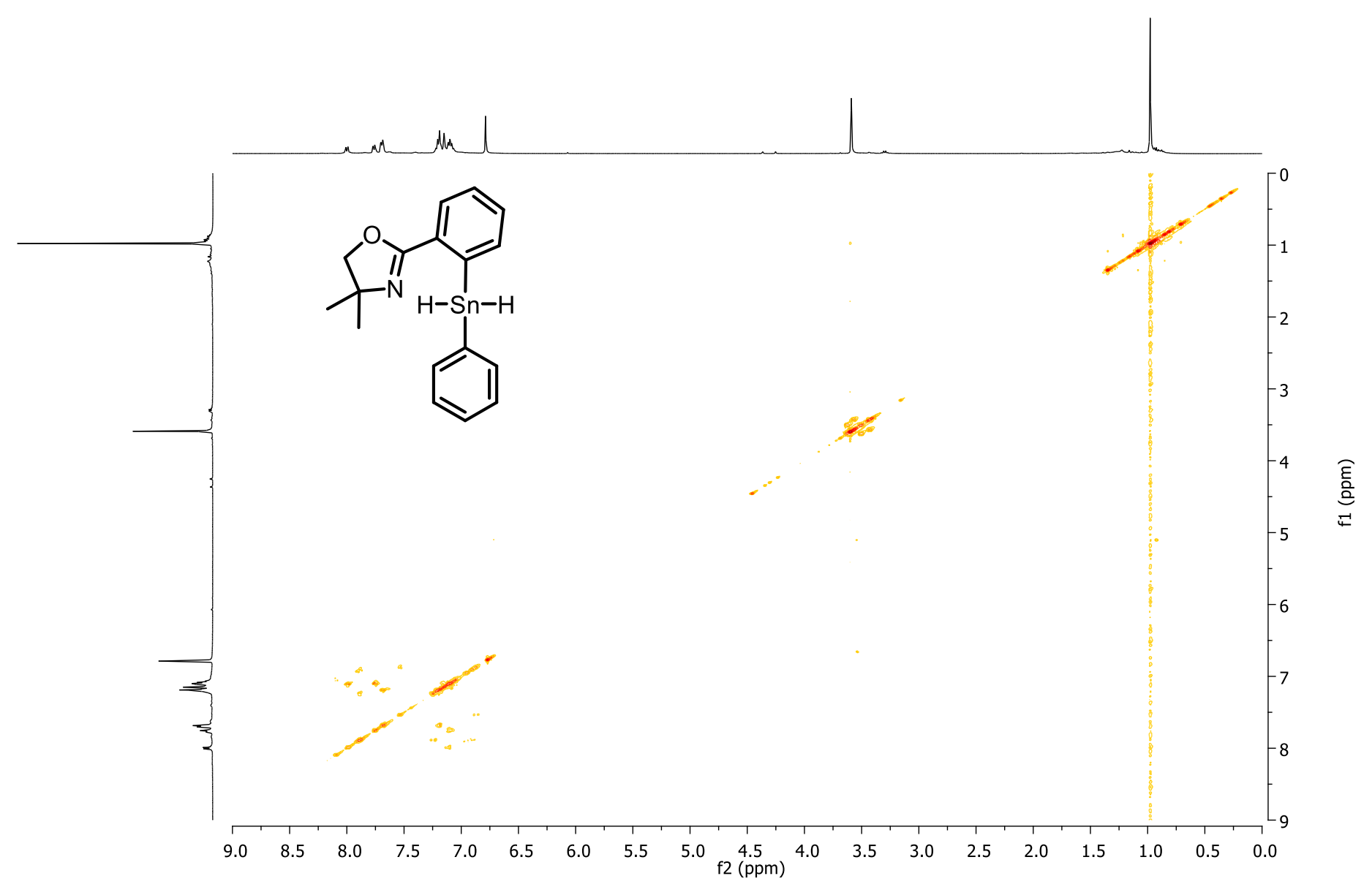

Figure A28: COSY spectrum of $\mathbf{1 4}$ in $\mathrm{C}_{6} \mathrm{D}_{6}$. 


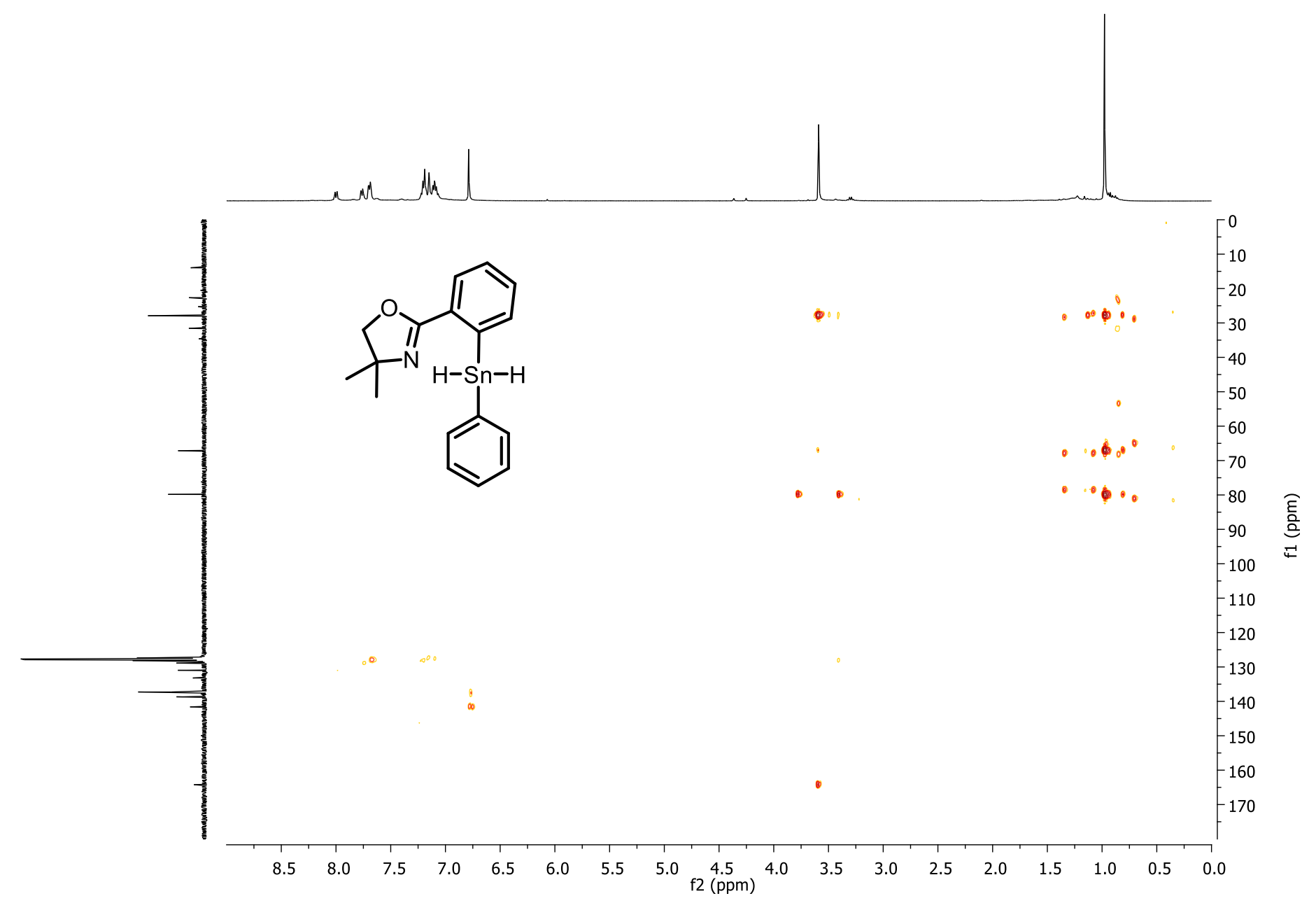

Figure A29: $\mathrm{HMBC}$ spectrum of $\mathbf{1 4}$ in $\mathrm{C}_{6} \mathrm{D}_{6}$. 

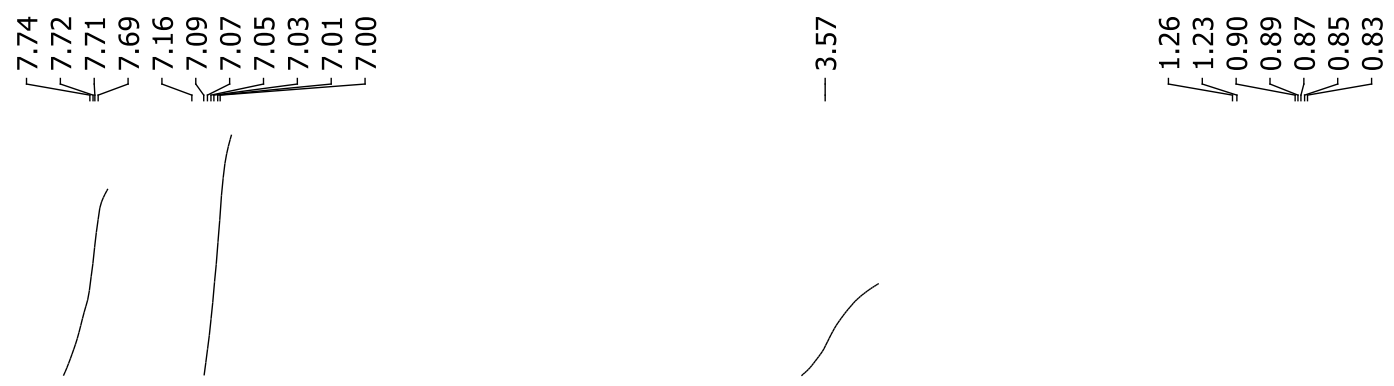

ర্

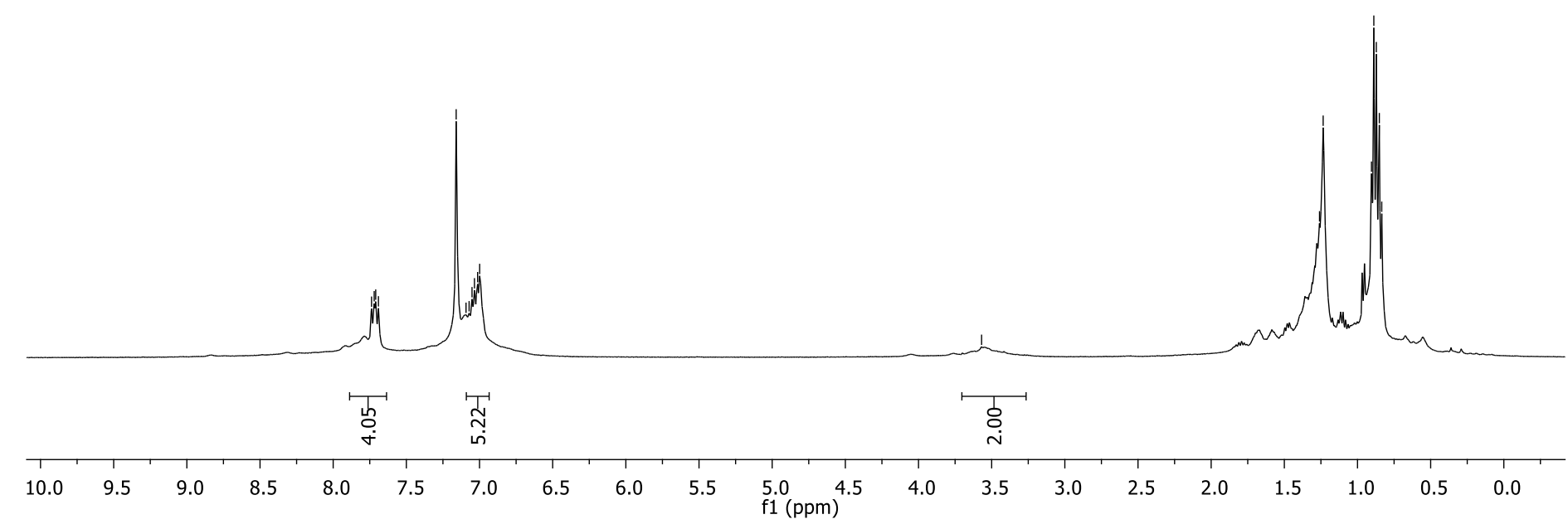

Figure A30: ${ }^{1} \mathrm{H}$ NMR spectrum of 16 in $\mathrm{C}_{6} \mathrm{D}_{6}$ *. 
8
0
0
0
$i$
$i$

$\circ$
0
0
0
$i$
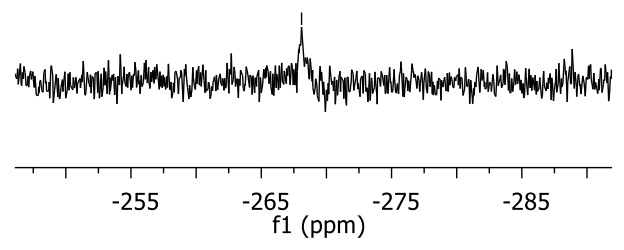

ธุ
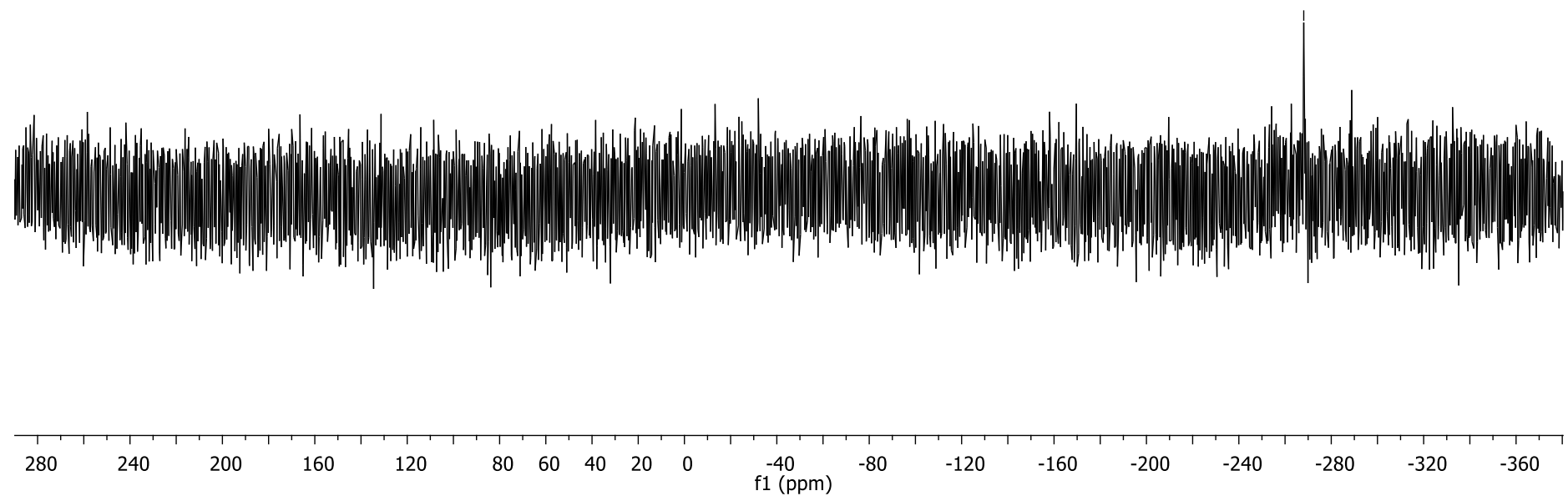

Figure A31: ${ }^{119} \mathrm{Sn}$ NMR spectrum of $\mathbf{1 6}$ in $\mathrm{C}_{6} \mathrm{D}_{6} *$. 


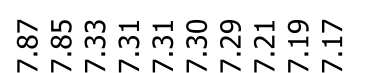

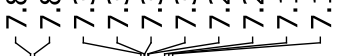

$\stackrel{\stackrel{?}{7}}{\stackrel{+}{+}}$

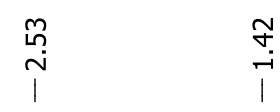

11

$\stackrel{0}{9}$
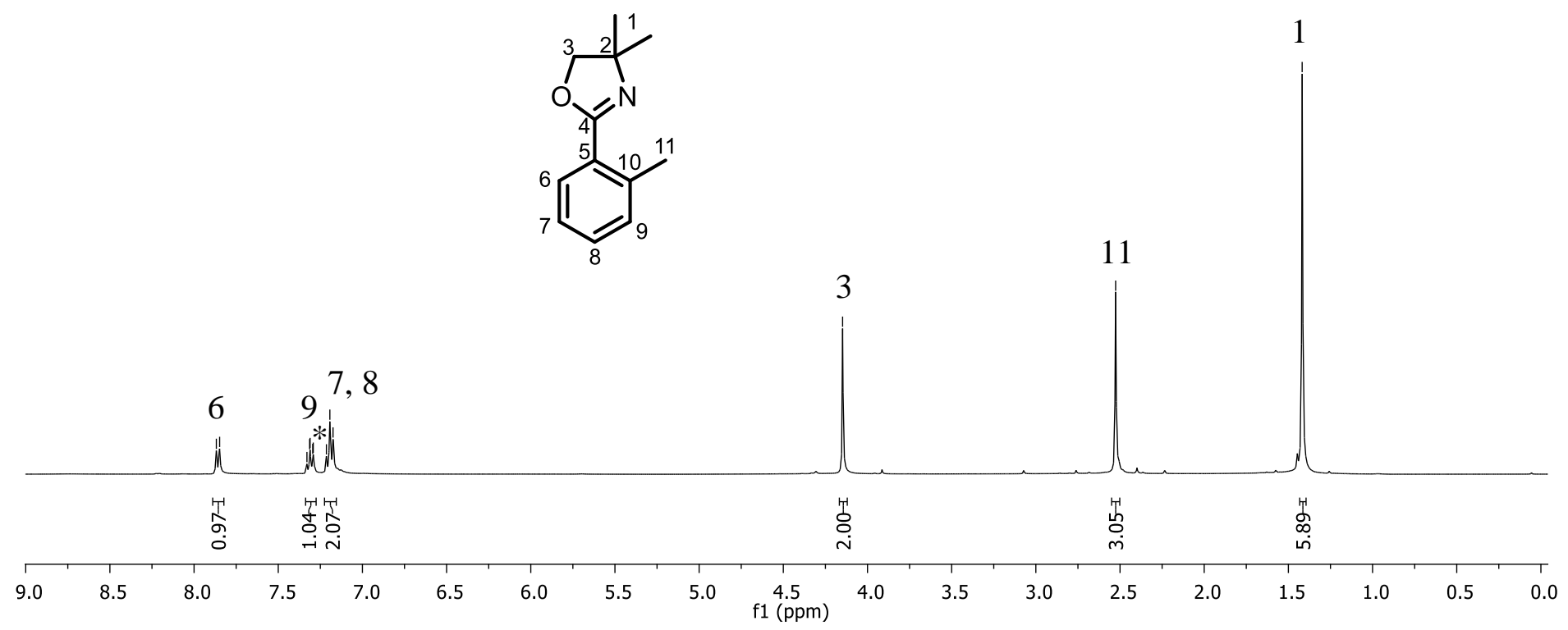

Figure A32: ${ }^{1} \mathrm{H}$ NMR spectrum of $\mathbf{1 7}$ in $\mathrm{CDCl}_{3}$ *. 


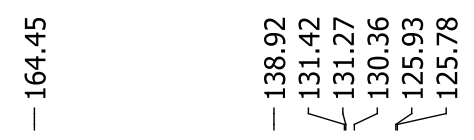

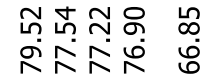

솟ํㅇ

$\stackrel{\substack{i \\ \stackrel{\infty}{0}}}{\stackrel{i}{+}}$
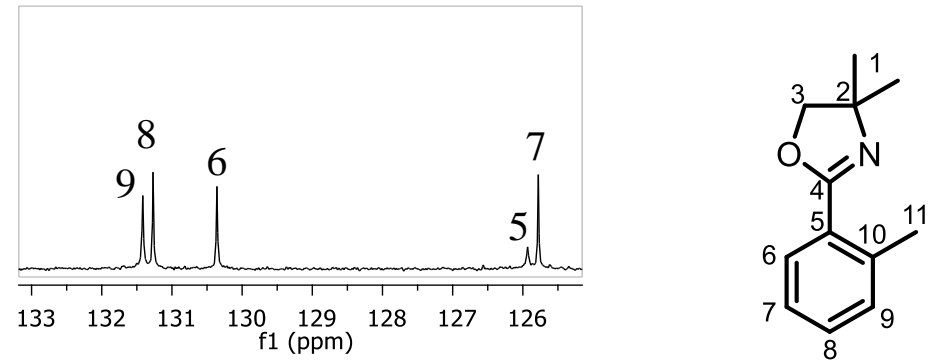

$\varpi$

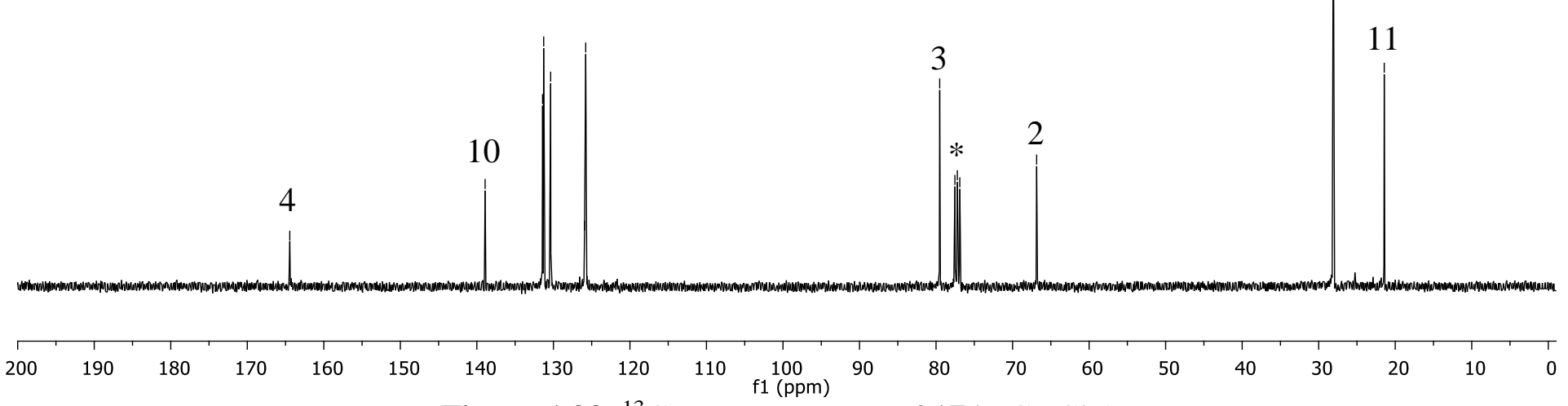

Figure A33: ${ }^{13} \mathrm{C}$ NMR spectrum of 17 in $\mathrm{CDCl}_{3}{ }^{*}$. 


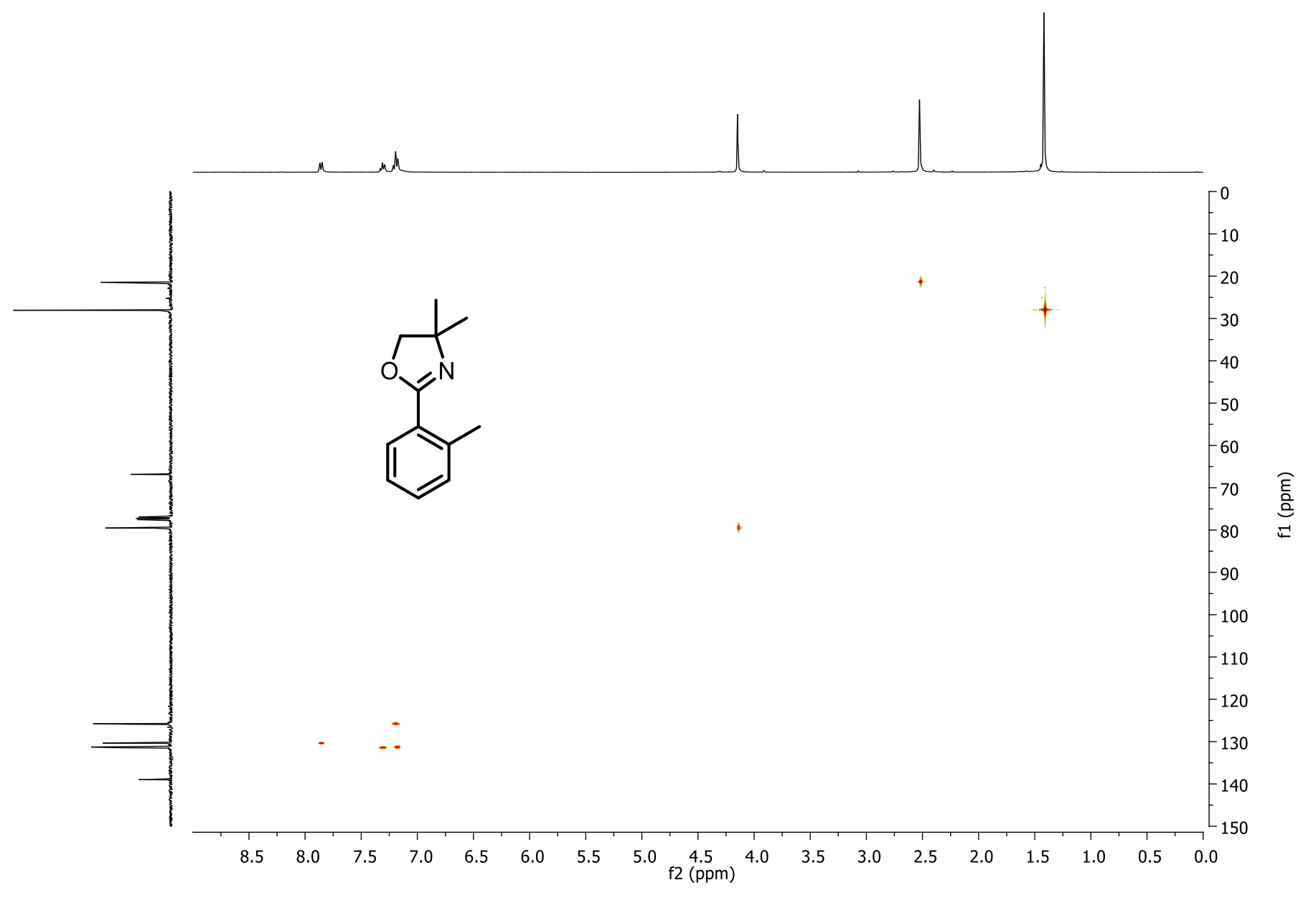

Figure A34: HSQC spectrum of 17 in $\mathrm{CDCl}_{3}$ * 


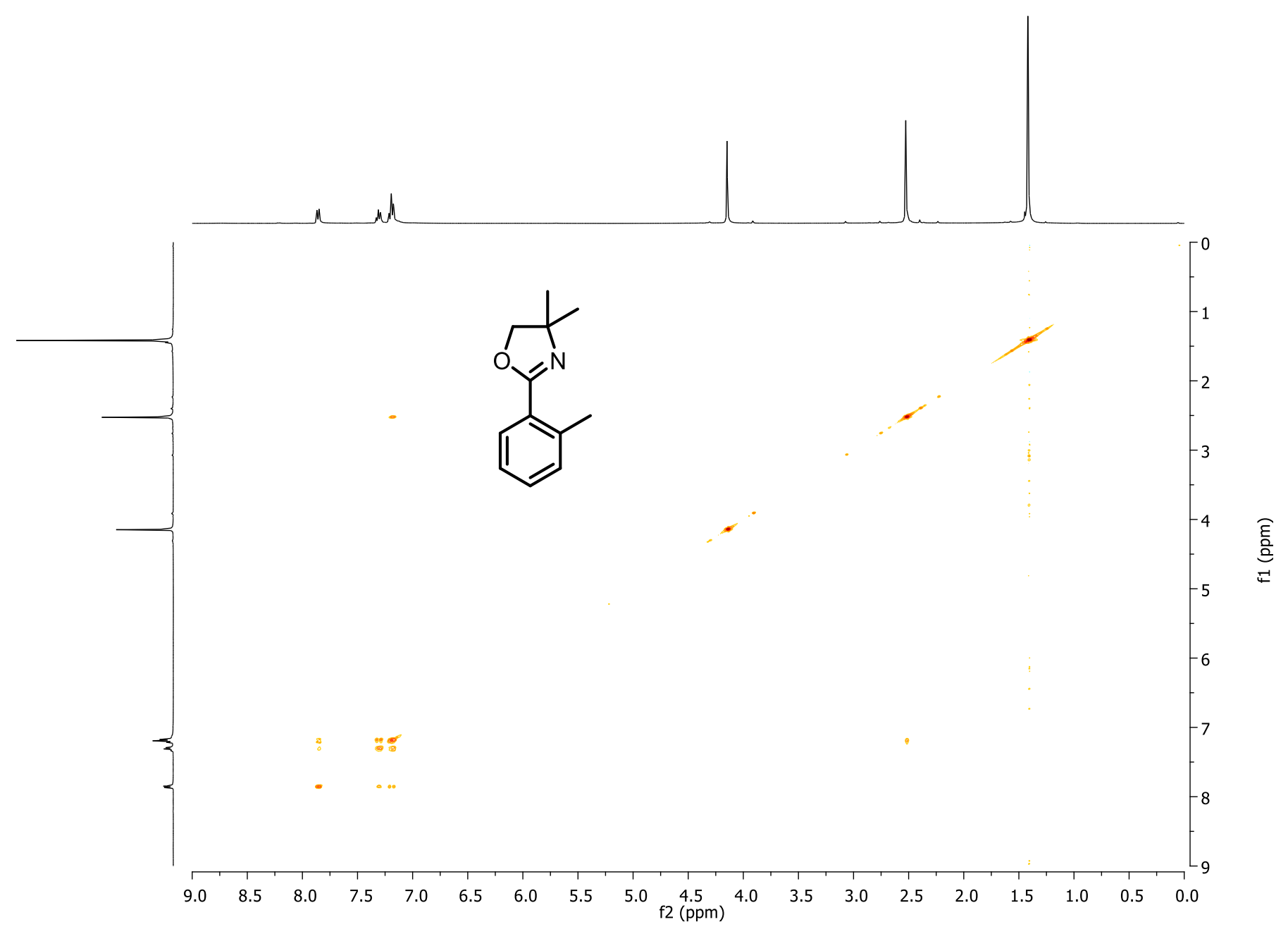

Figure A35: COSY spectrum of $\mathbf{1 7}$ in $\mathrm{CDCl}_{3} *$. 


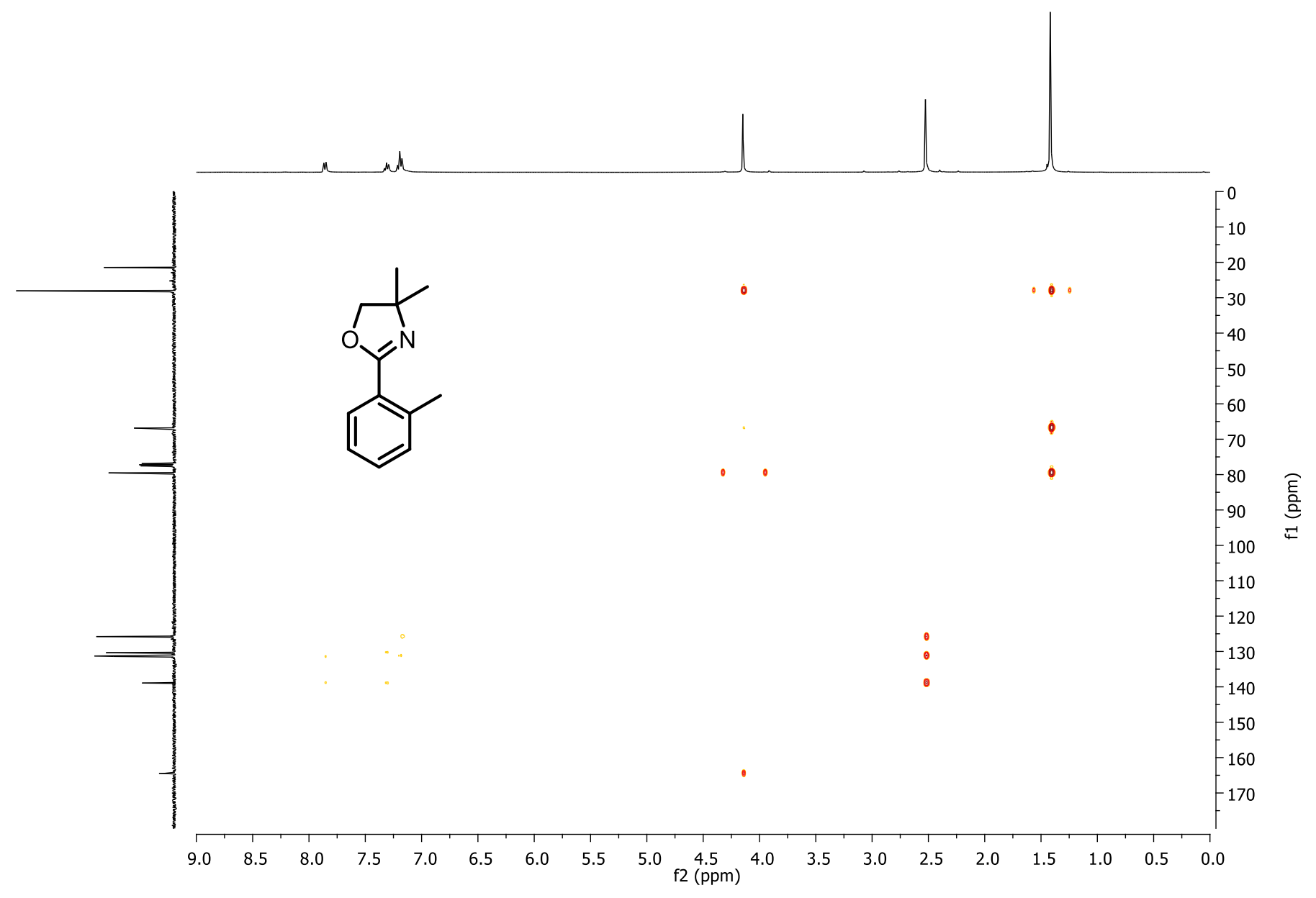

Figure A36: $\mathrm{HMBC}$ spectrum of 17 in $\mathrm{CDCl}_{3}$ * 


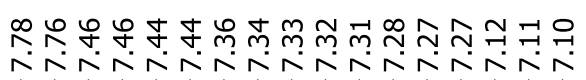

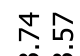

mल

Iㄱ
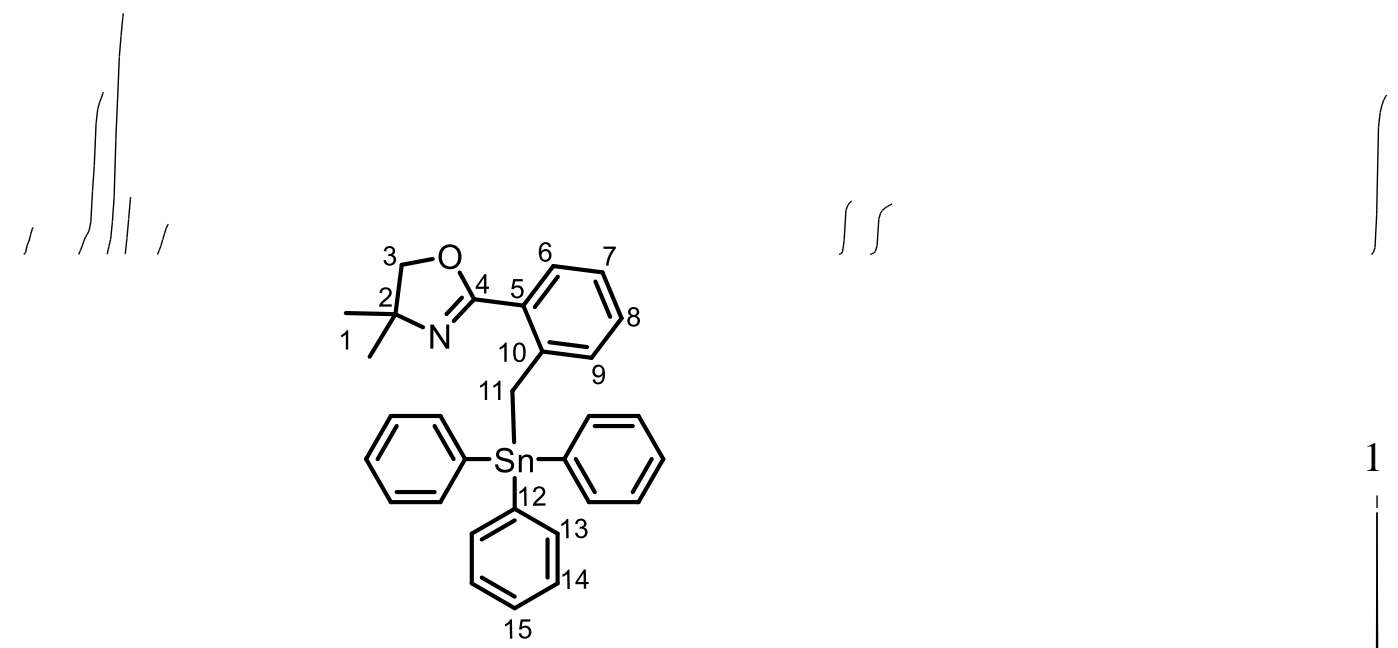

กับ

14,15

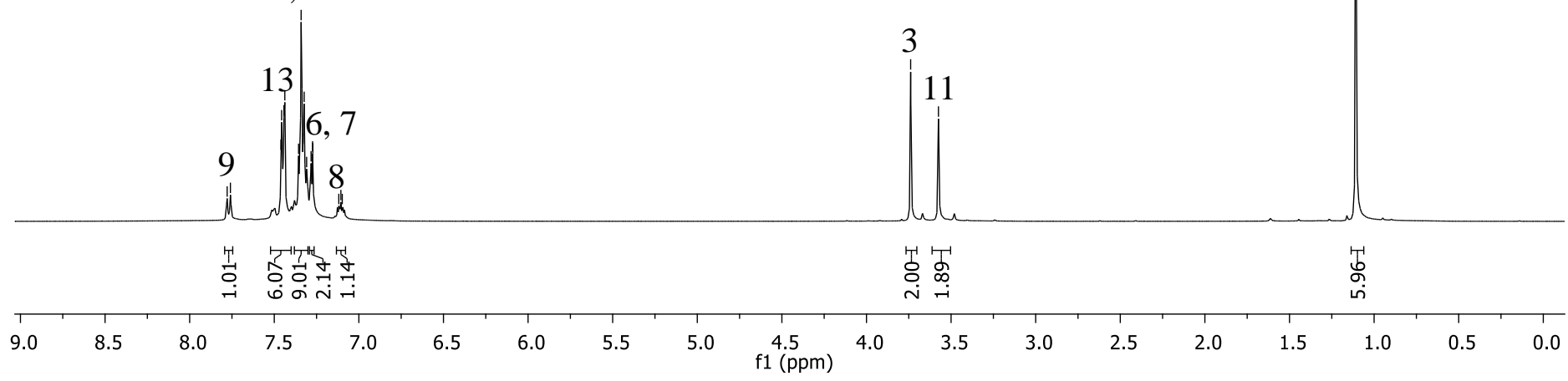

Figure A37: ${ }^{1} \mathrm{H} \mathrm{NMR}$ spectrum of $\mathbf{1 8}$ in $\mathrm{CDCl}_{3} *$. 

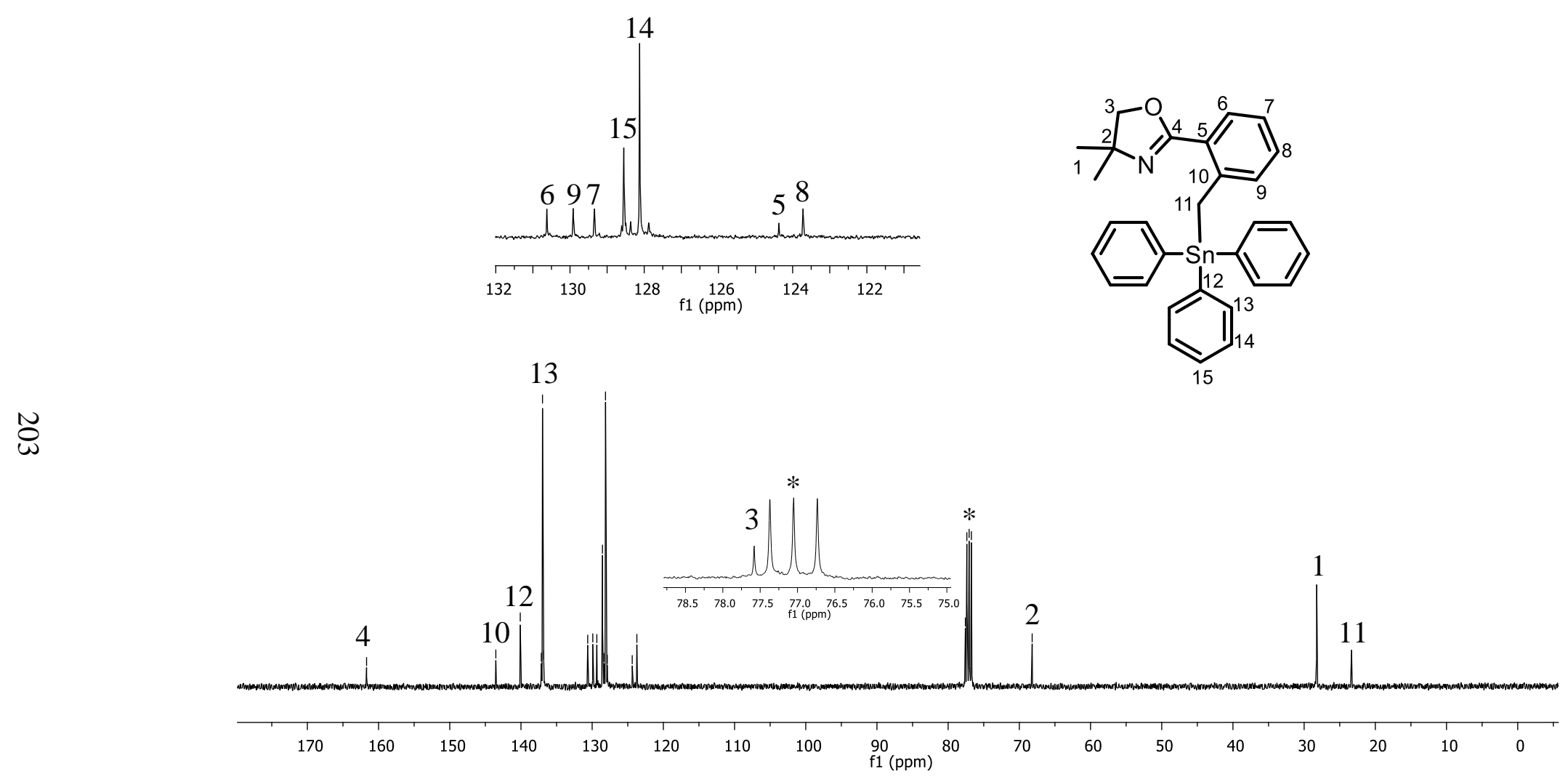

Figure A38: ${ }^{13} \mathrm{C}$ NMR spectrum of $\mathbf{1 8}$ in $\mathrm{CDCl}_{3}$ *. 


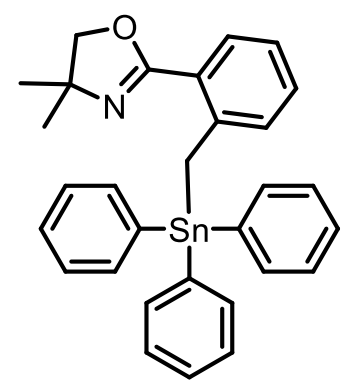

\begin{tabular}{lllllllllllllllllllllllllllllll}
\hline 280 & 240 & 200 & 160 & 120 & 80 & 60 & 40 & 20 & 0 & -40 & -80 & -120 & -160 & -200 & -240 & -280 & -320 & -360
\end{tabular}

Figure A39: ${ }^{119} \mathrm{Sn} \mathrm{NMR}$ spectrum of $\mathbf{1 8}$ in $\mathrm{CDCl}_{3} *$. 


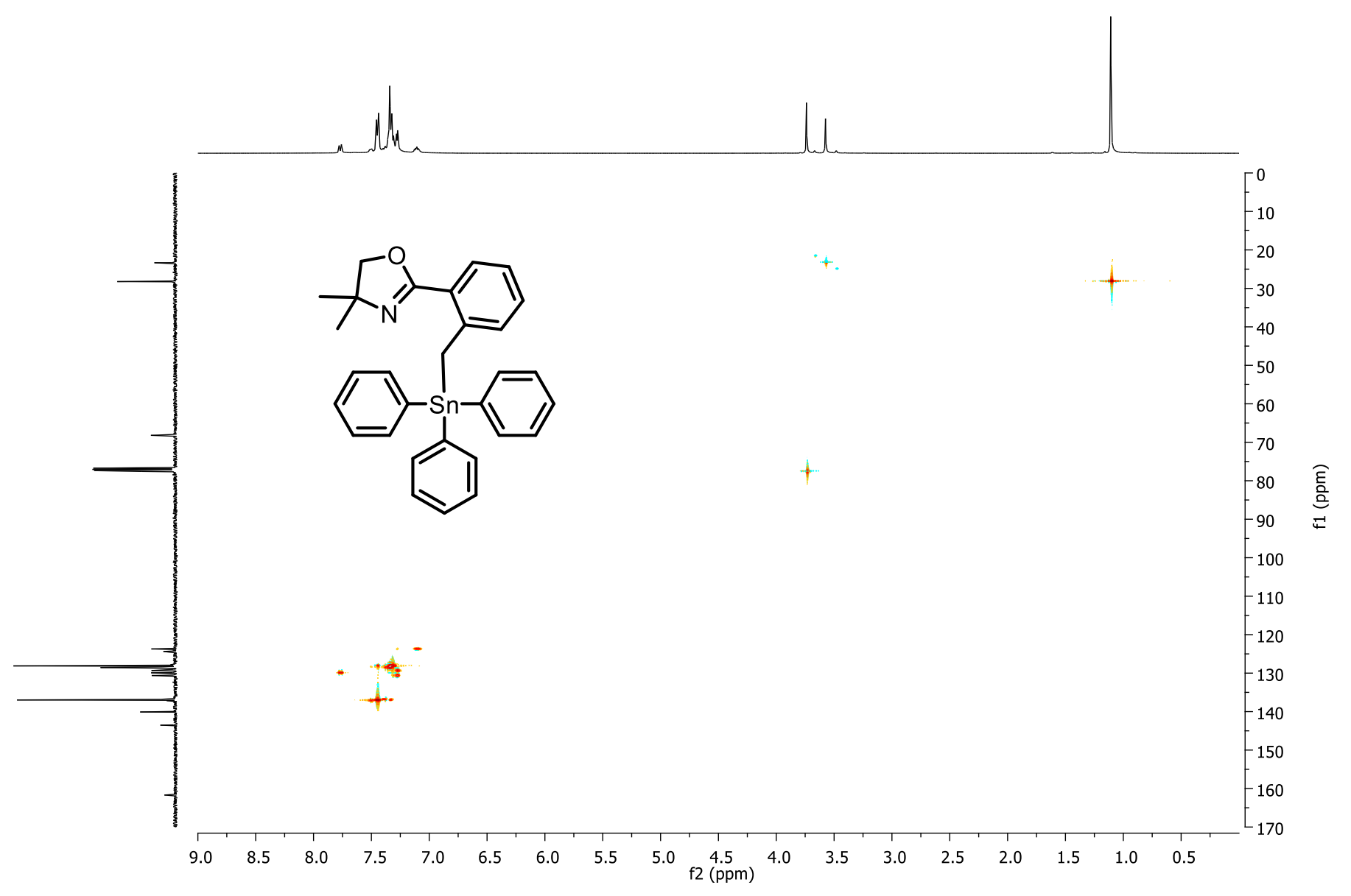

Figure A40: HSQC spectrum of 18 in $\mathrm{CDCl}_{3} *$. 


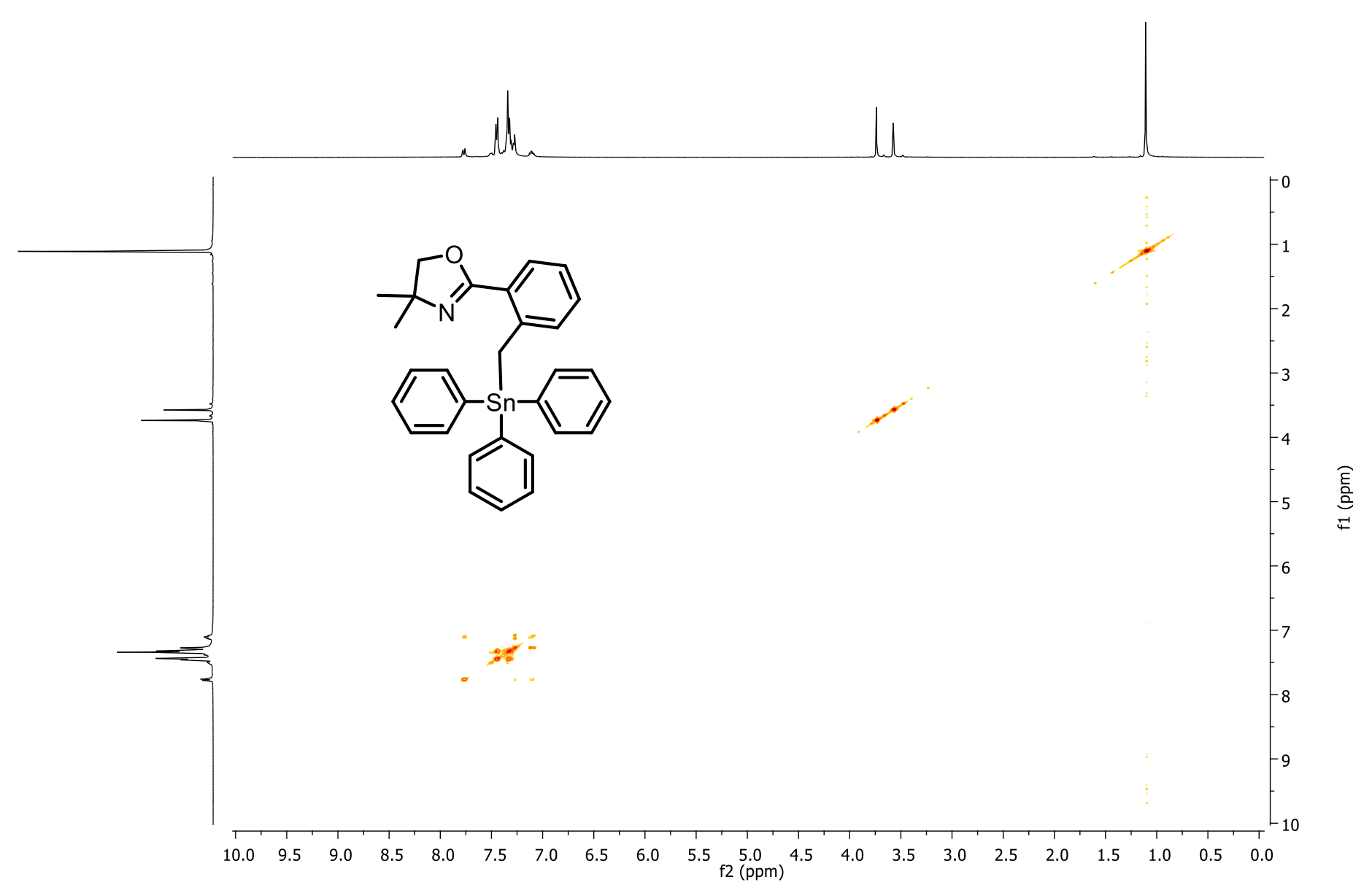

Figure A41: COSY spectrum of 18 in $\mathrm{CDCl}_{3}$ *. 


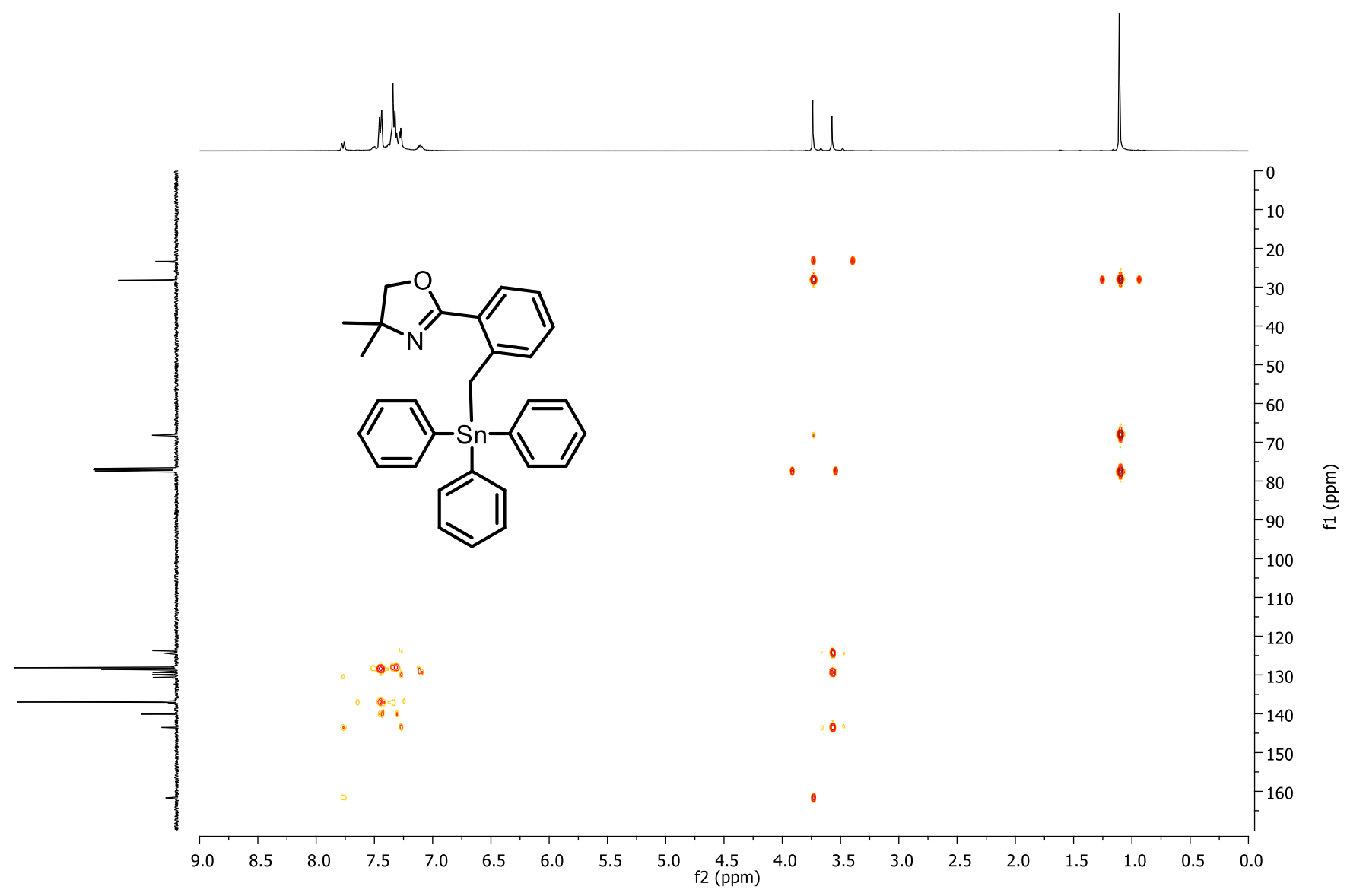

Figure A42: $\mathrm{HMBC}$ spectrum of 18 in $\mathrm{CDCl}_{3}$ *. 


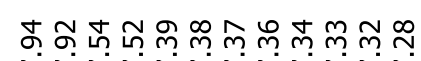

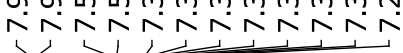

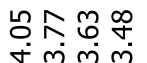

$\stackrel{\leftrightarrow}{\rightarrow}$

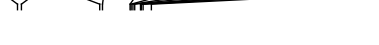

$1<1$

i

$\infty$

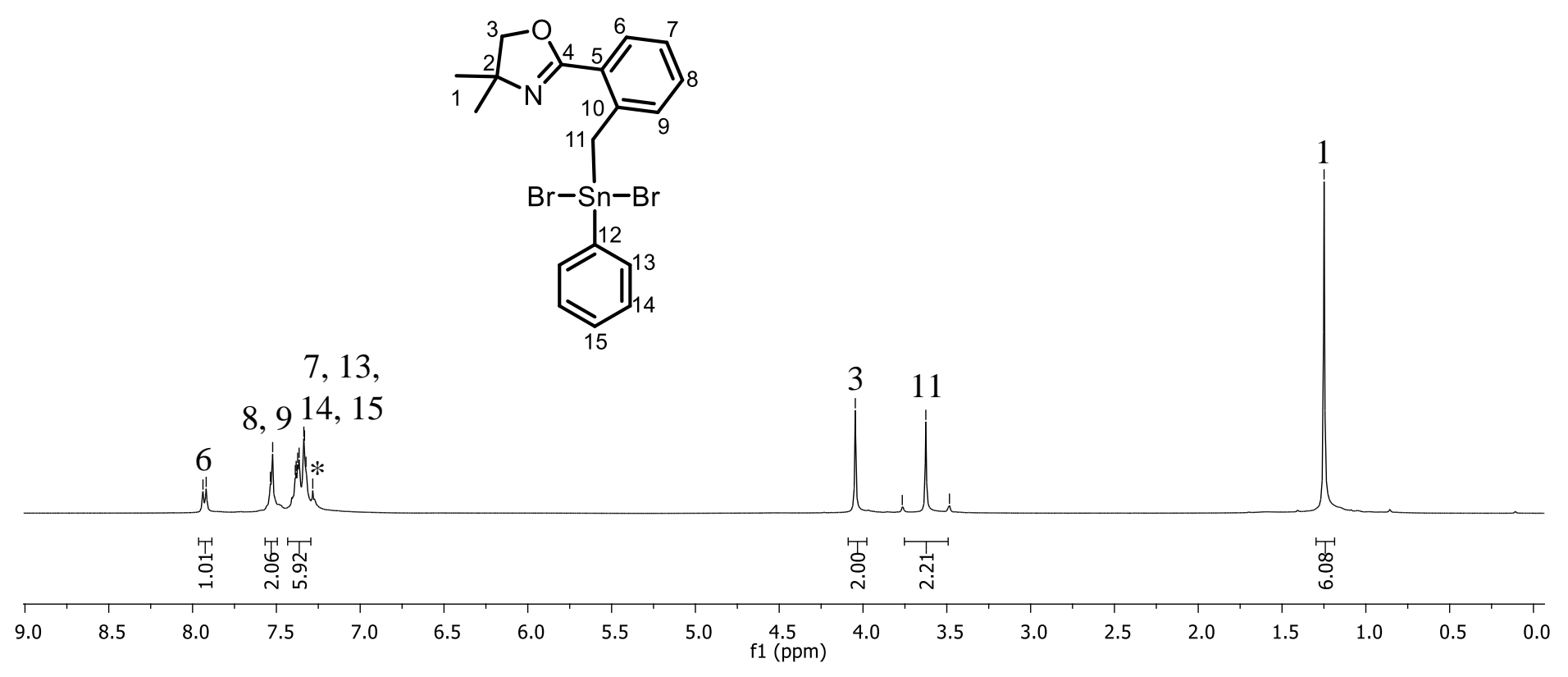

Figure A43: ${ }^{1} \mathrm{H}$ NMR spectrum of 20 in $\mathrm{CDCl}_{3}{ }^{*}$. 


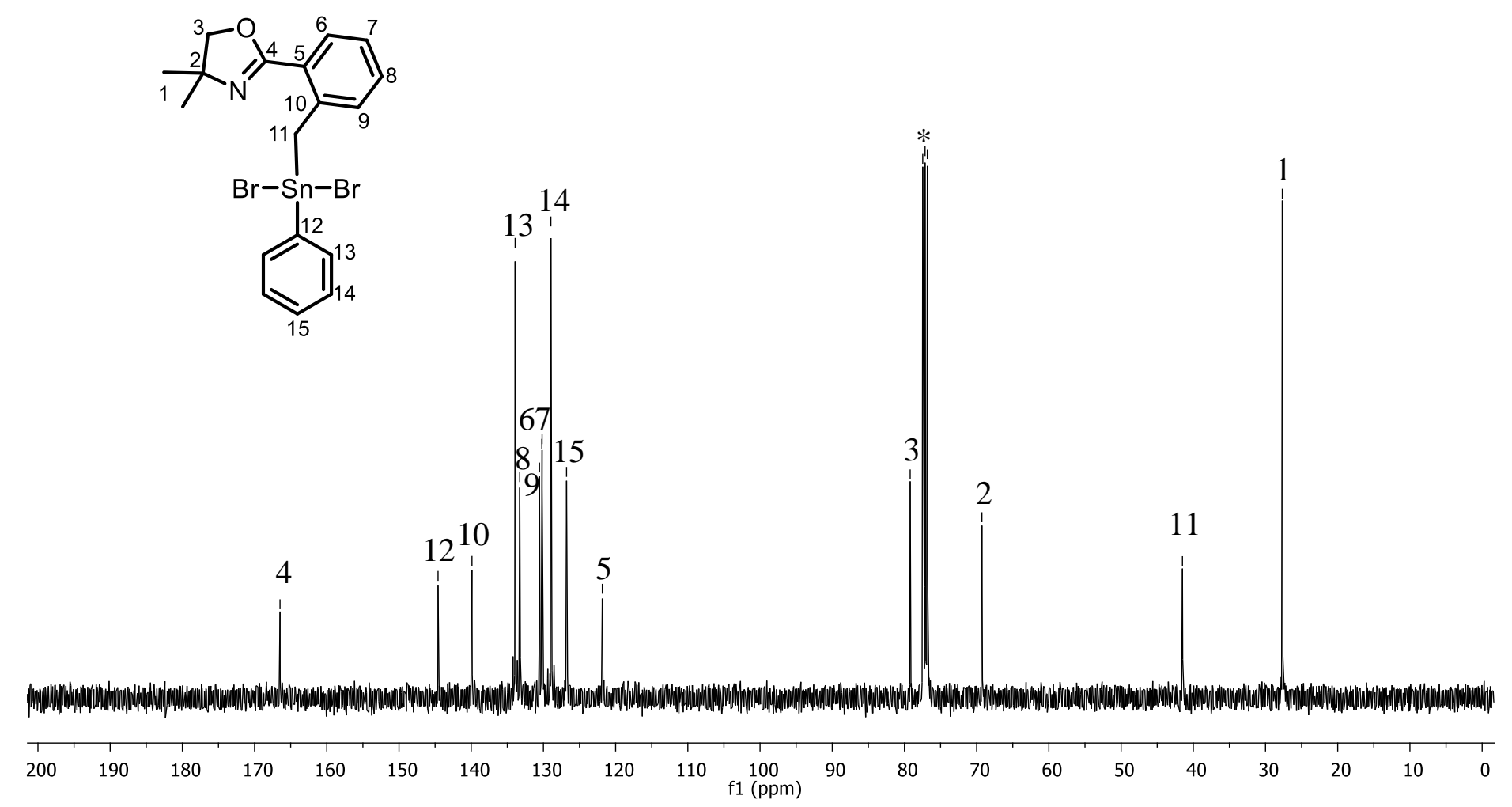

Figure A44: ${ }^{13} \mathrm{C}$ NMR spectrum of 20 in $\mathrm{CDCl}_{3} *$. 

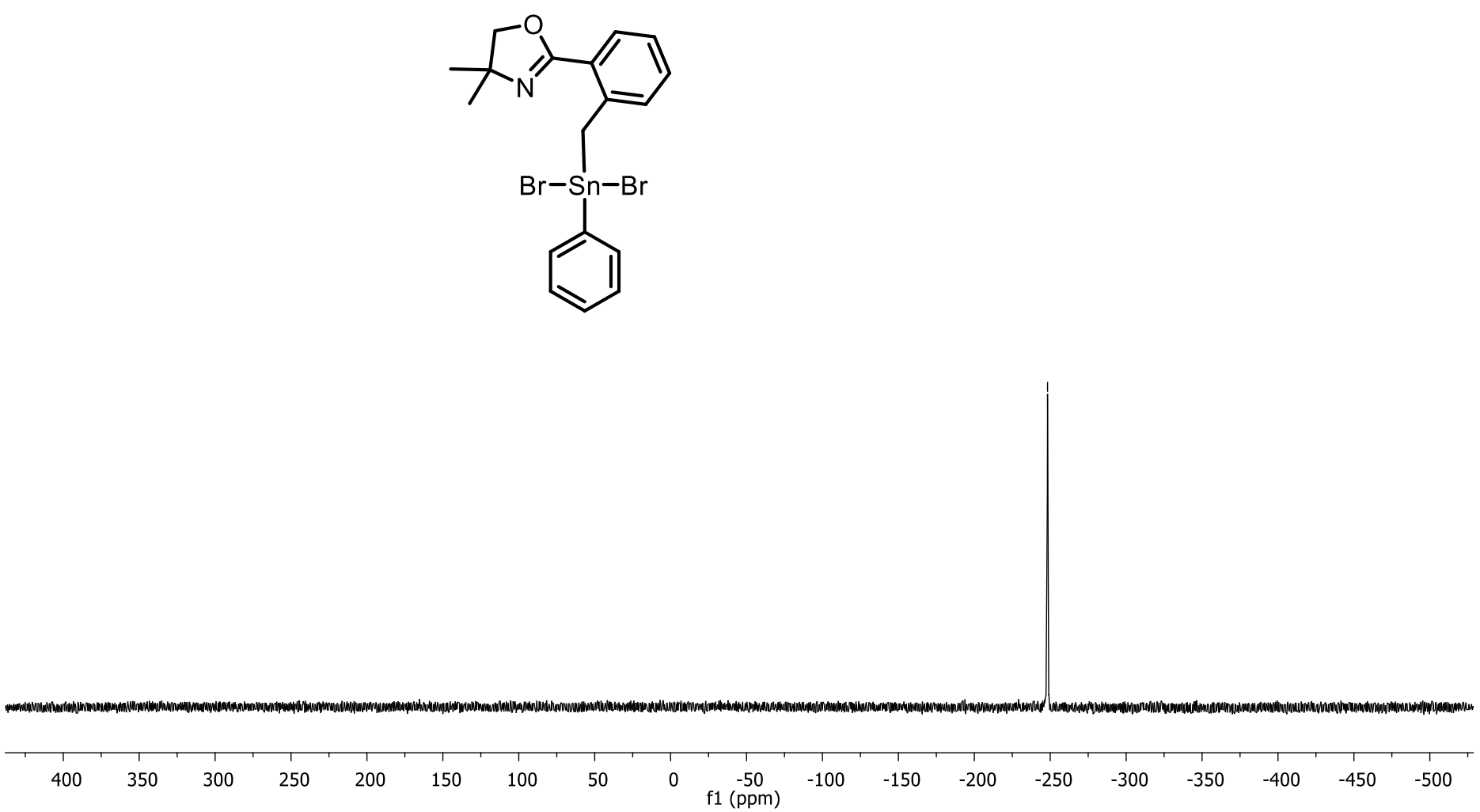

Figure A45: ${ }^{119} \mathrm{Sn}$ NMR spectrum of 20 in $\mathrm{CDCl}_{3} *$. 


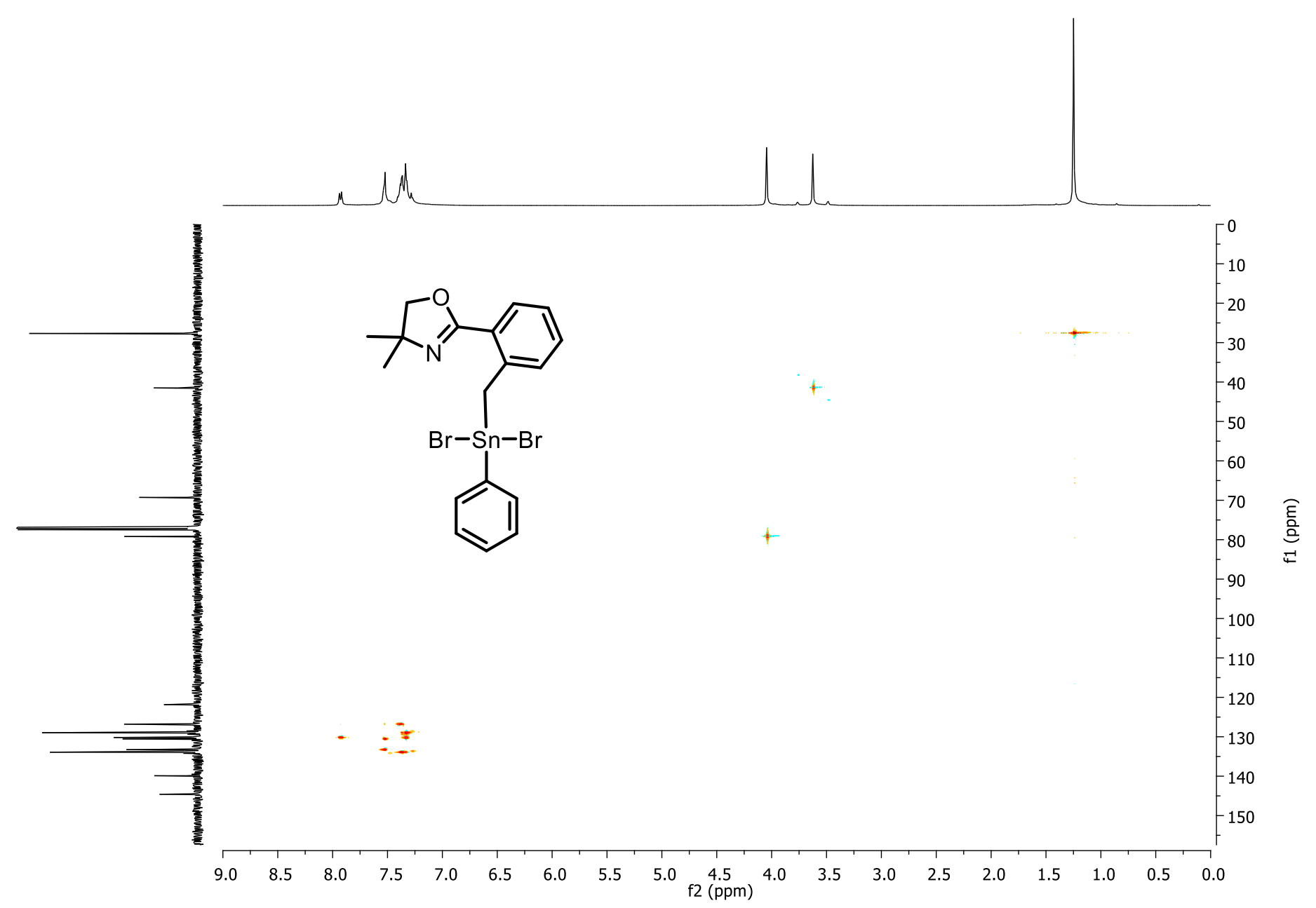

Figure A46: HSQC spectrum of 20 in $\mathrm{CDCl}_{3} *$. 


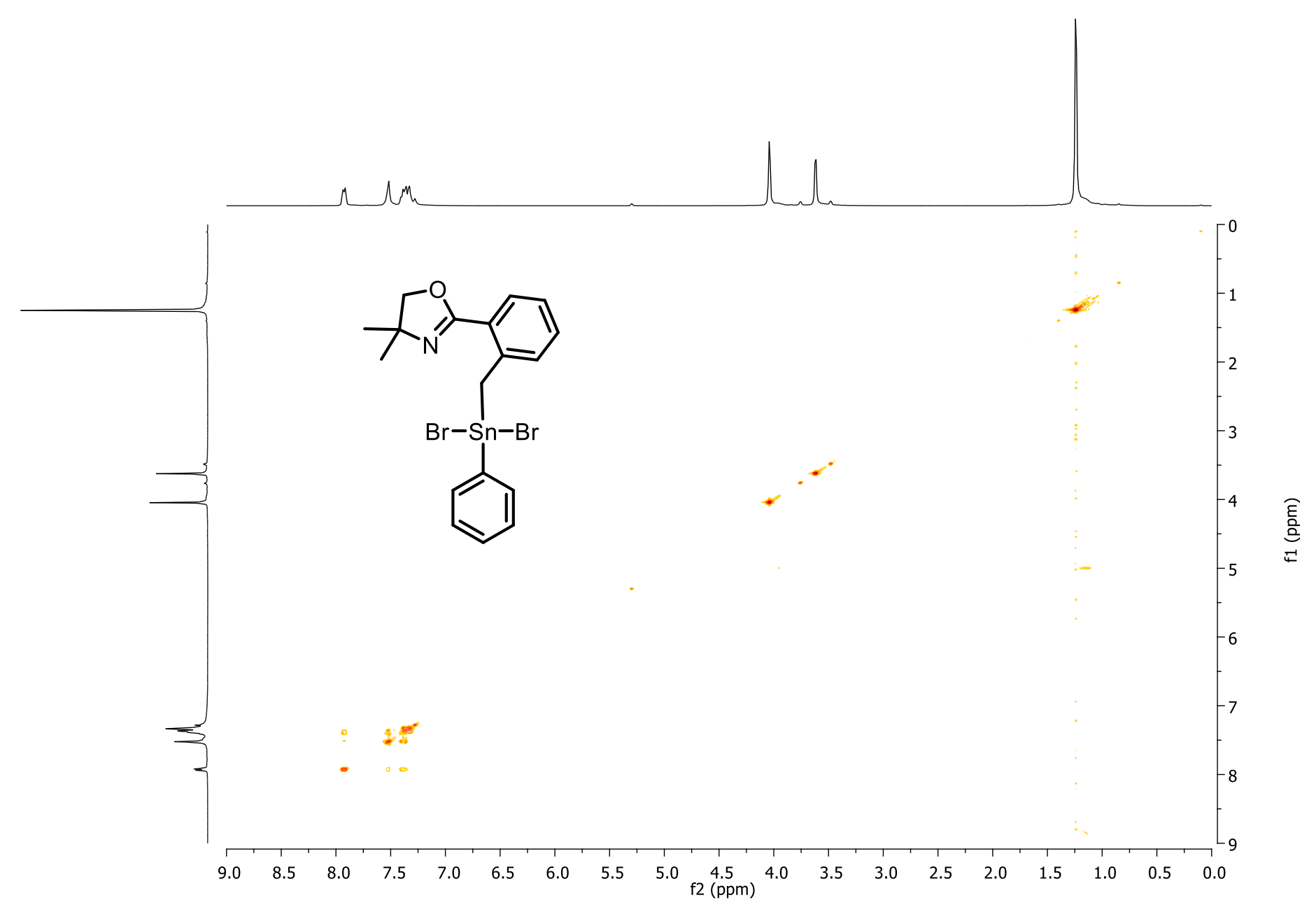

Figure A47: COSY spectrum of 20 in $\mathrm{CDCl}_{3} *$. 


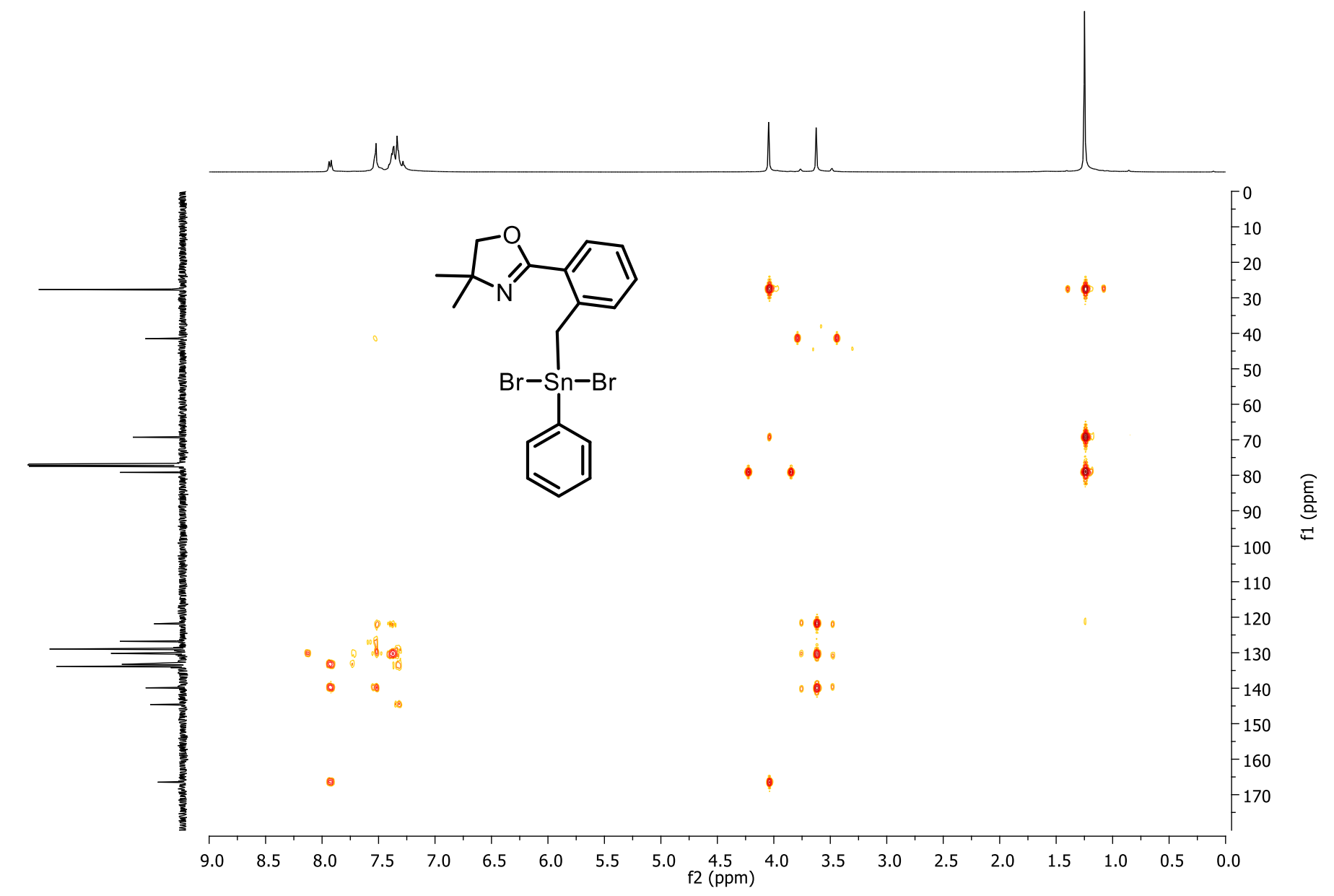

Figure A48: $\mathrm{HMBC}$ spectrum of 20 in $\mathrm{CDCl}_{3} *$. 

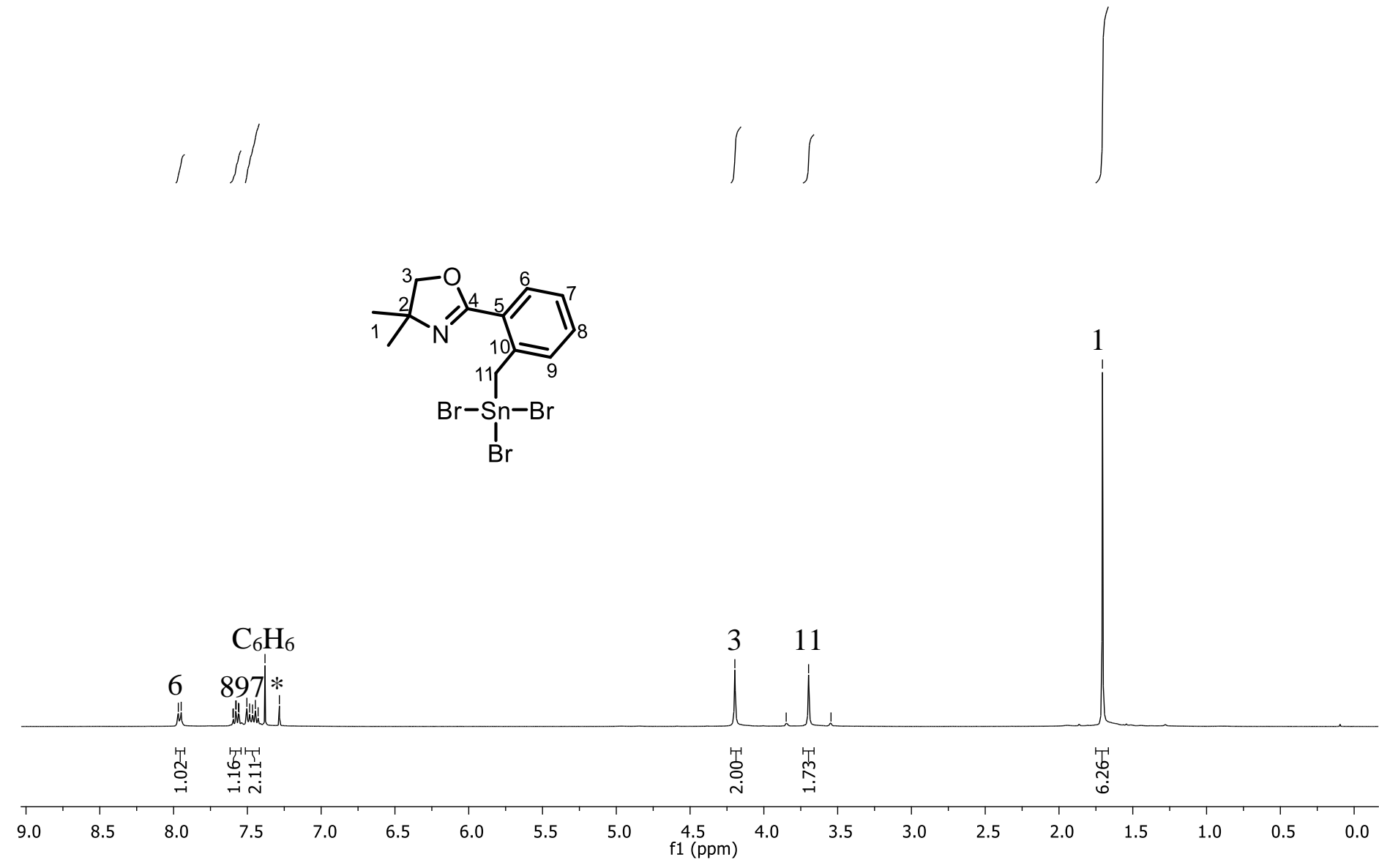

Figure A49: ${ }^{1} \mathrm{H}$ NMR spectrum of 19 in $\mathrm{CDCl}_{3}{ }^{*}$. 
$\stackrel{N}{u}$
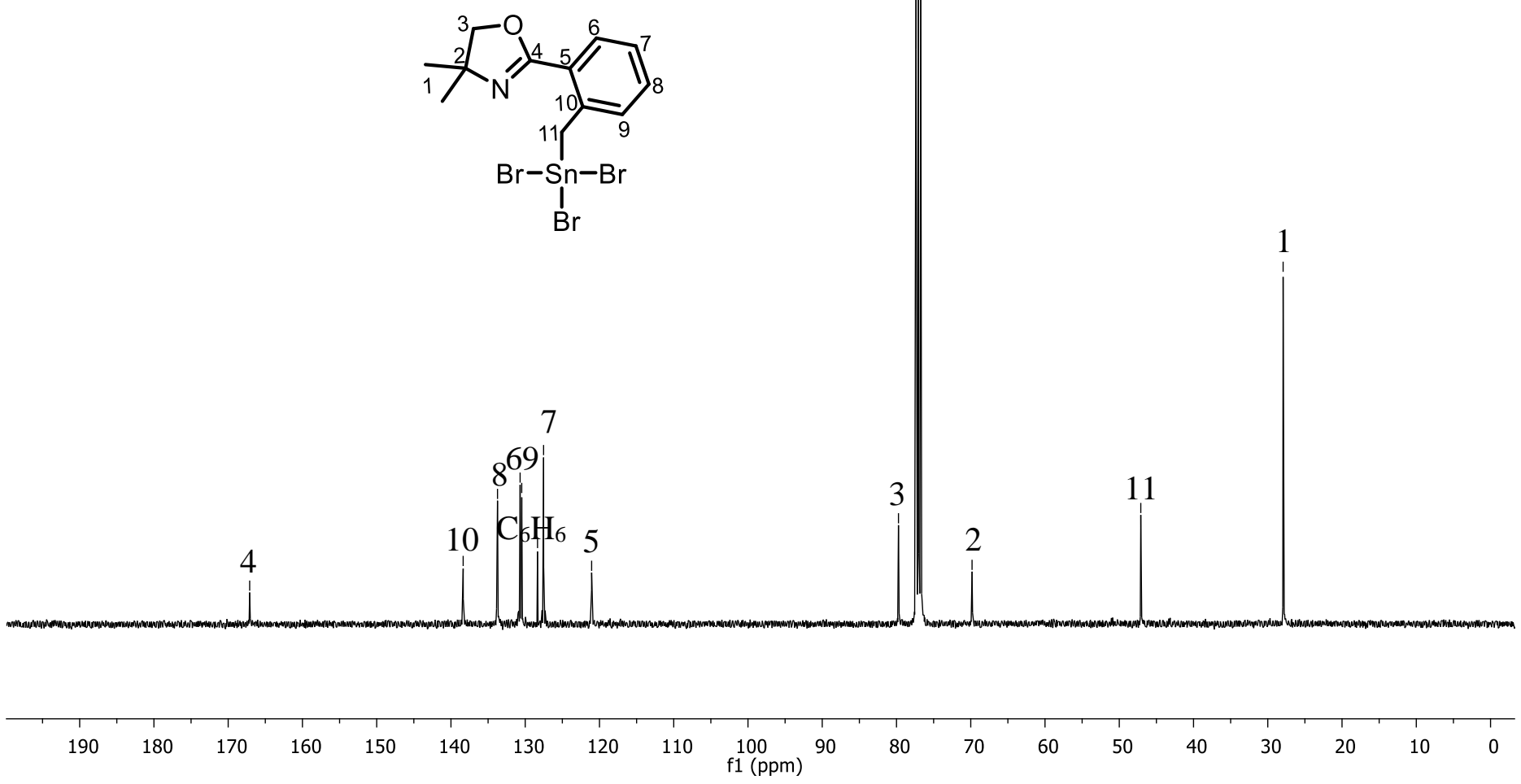

Figure A50: ${ }^{13} \mathrm{C}$ NMR spectrum of 19 in $\mathrm{CDCl}_{3}{ }^{*}$. 

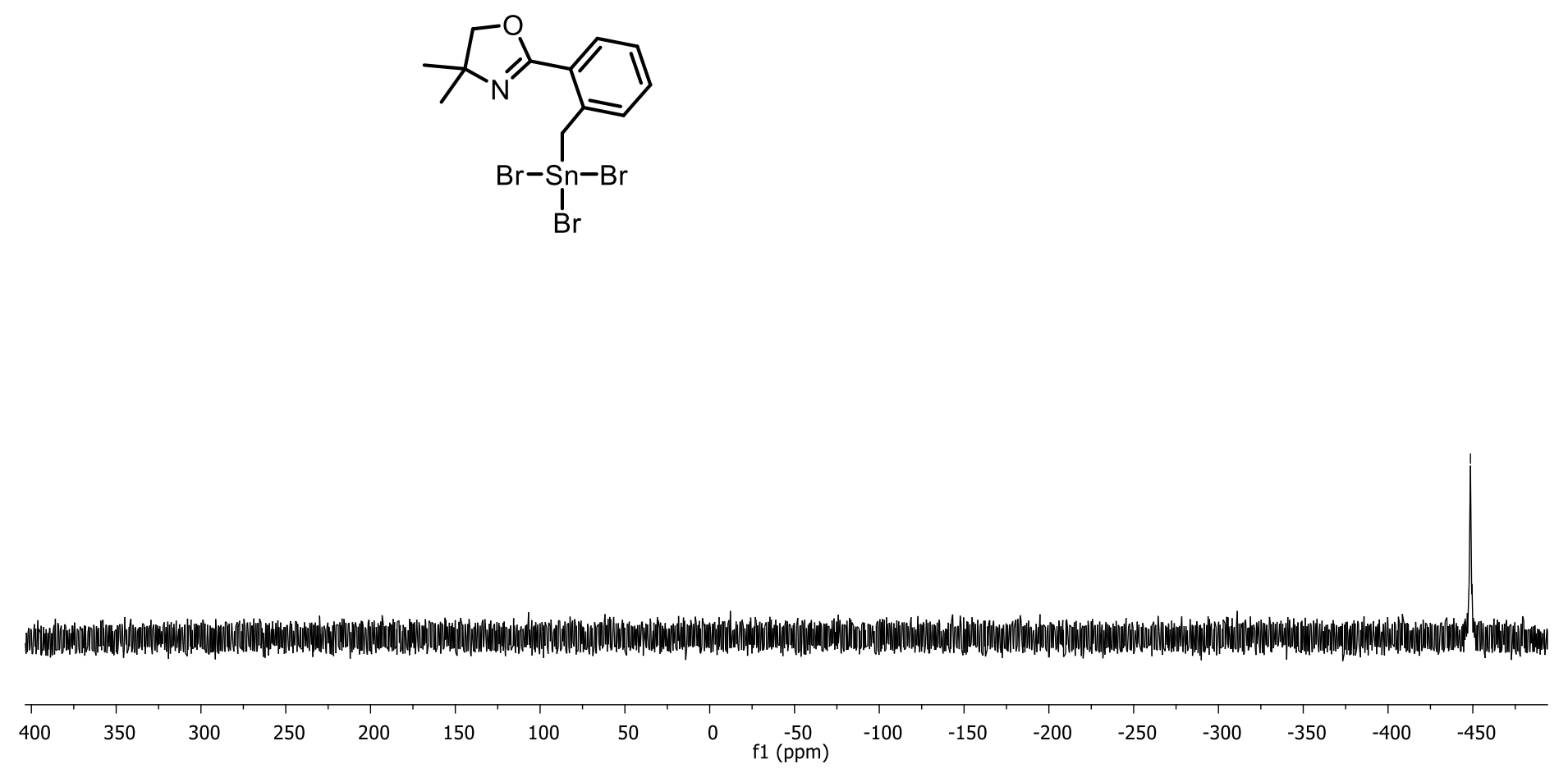

Figure A51: ${ }^{119} \mathrm{Sn}$ NMR spectrum of 19 in $\mathrm{CDCl}_{3}$ *. 


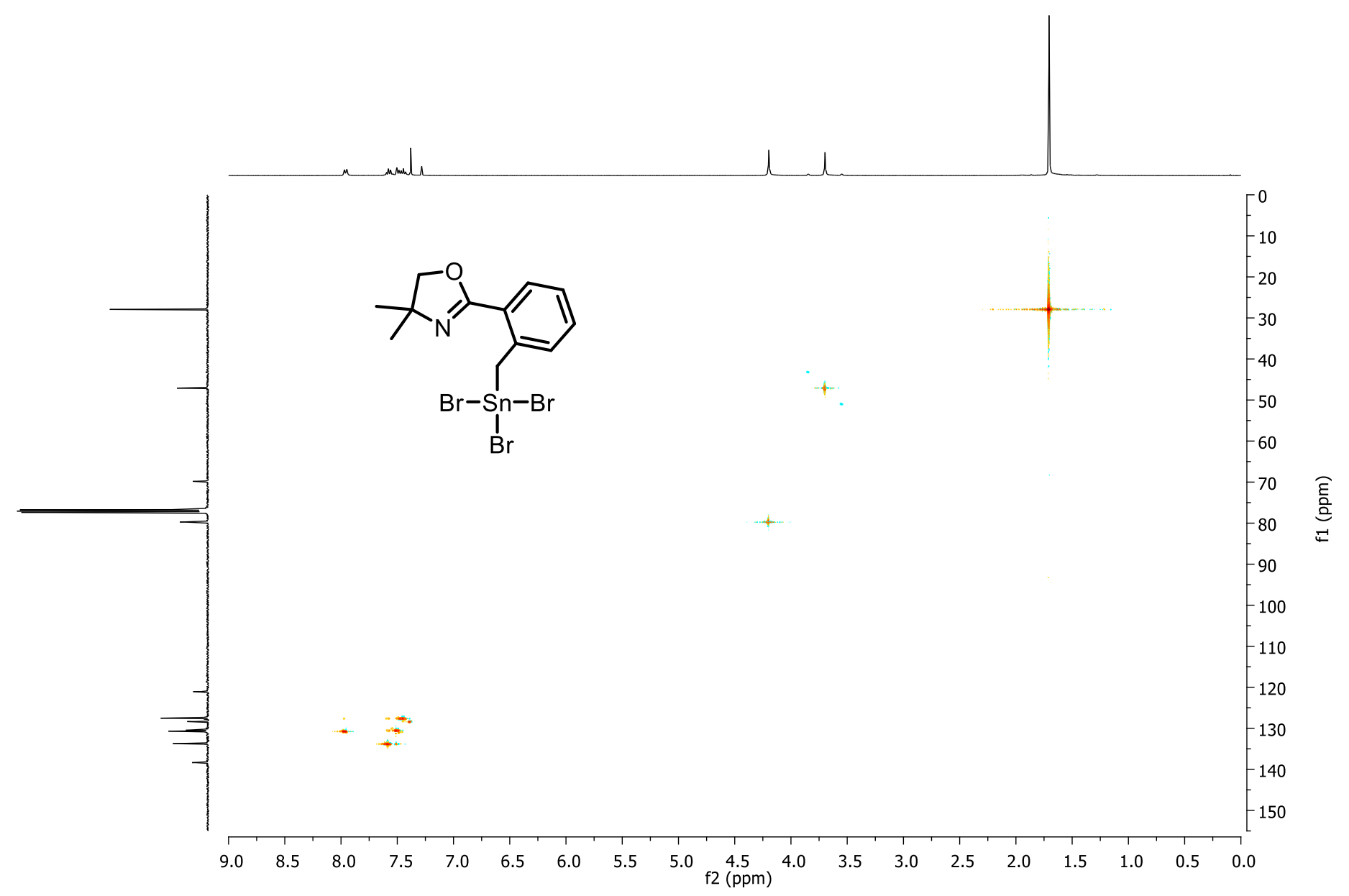

Figure A52: HSQC spectrum of 19 in $\mathrm{CDCl}_{3} *$. 


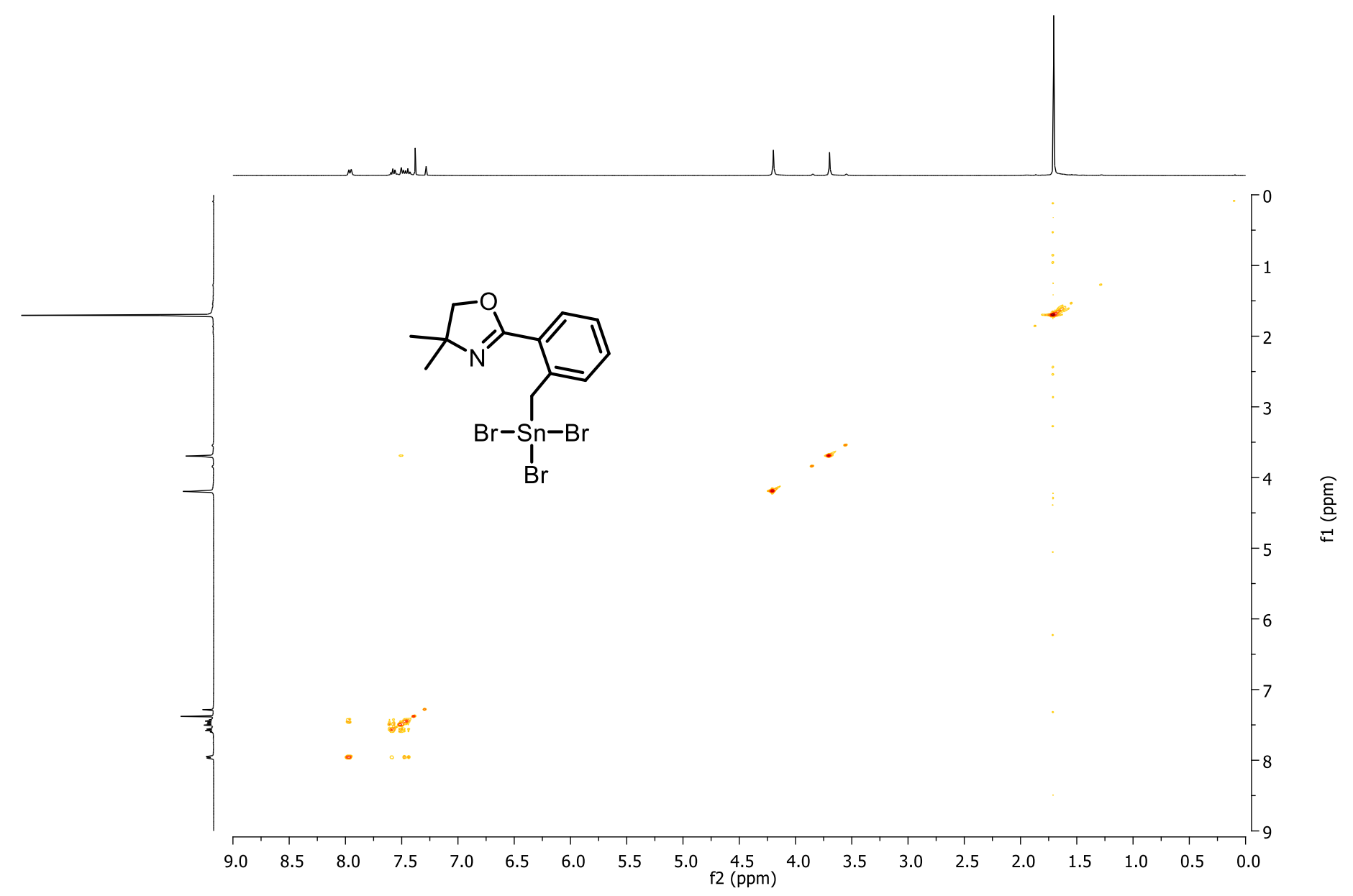

Figure A53: COSY spectrum of 19 in $\mathrm{CDCl}_{3} *$. 


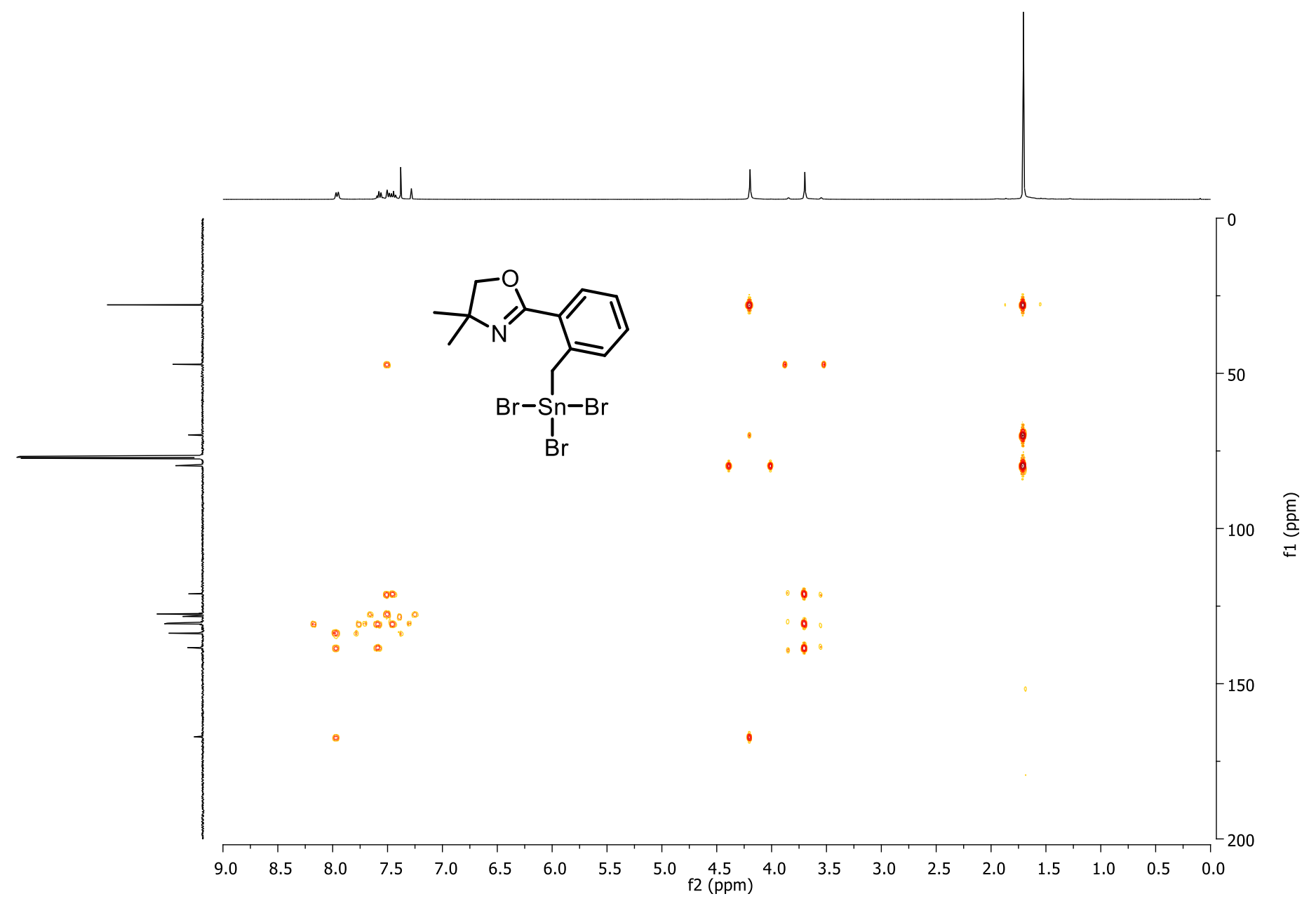

Figure A54: $\mathrm{HMBC}$ spectrum of 19 in $\mathrm{CDCl}_{3}$ * 


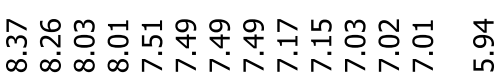

پْ

$\stackrel{ }{\stackrel{ }{ }}$

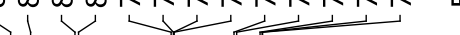
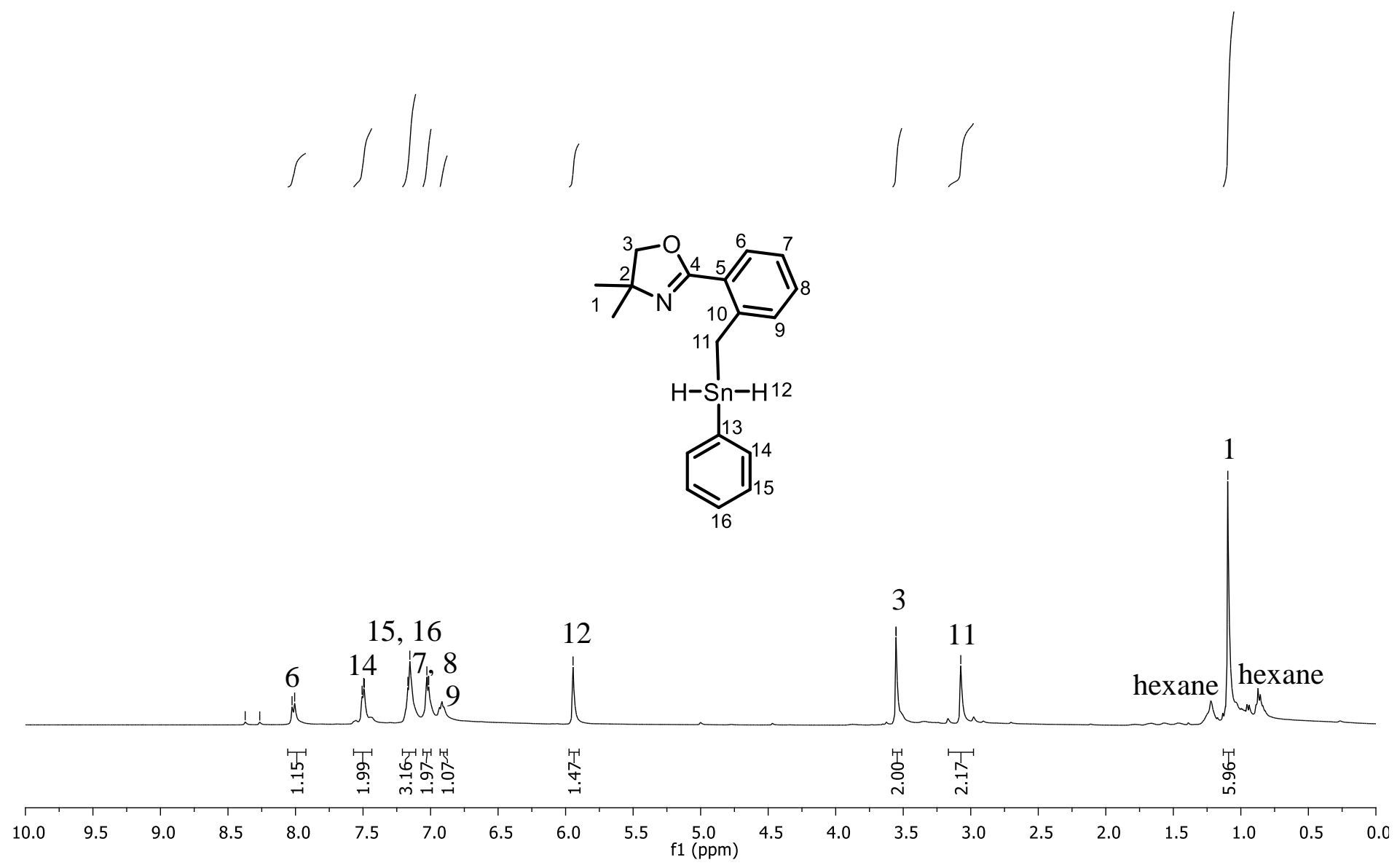

Figure A55: ${ }^{1} \mathrm{H}$ NMR spectrum of 21 in $\mathrm{C}_{6} \mathrm{D}_{6}$ *. 


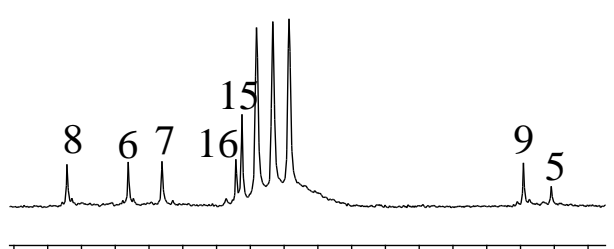

$\begin{array}{llllllll}131 & 130 & 129 & 128 & 127 \\ \text { f1 (ppm) } & 126 & 125 & 124 & 123\end{array}$

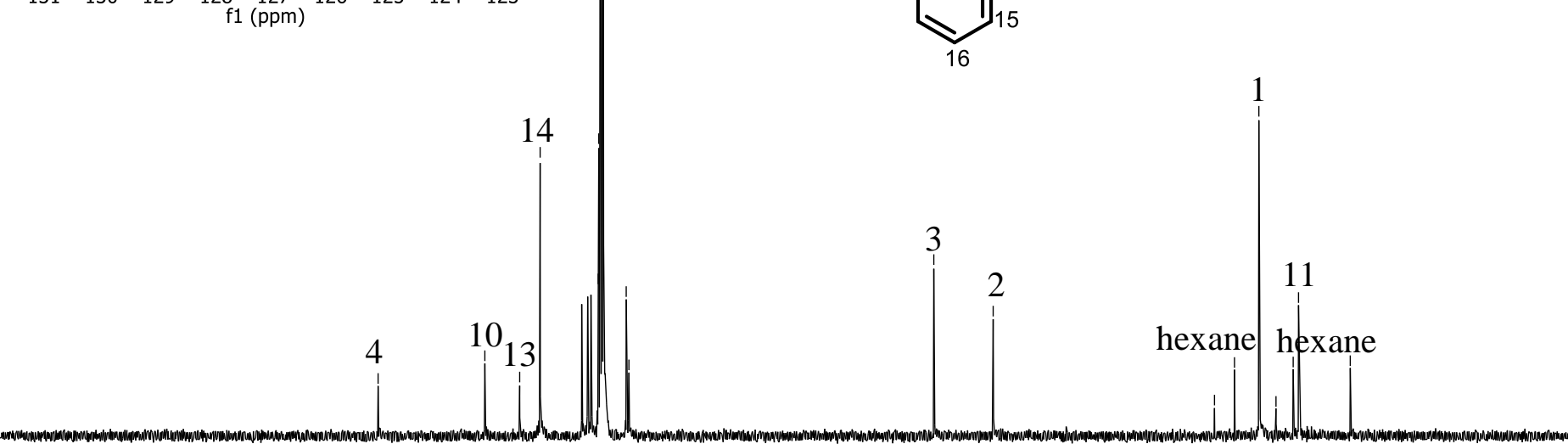

$\begin{array}{lllllllllll}210 & 200 & 190 & 180 & 170 & 160 & 150 & 140 & 130 & 120 & \left.110 \begin{array}{l}100 \\ \mathrm{f} 1(\mathrm{pp})\end{array}\right)\end{array}$

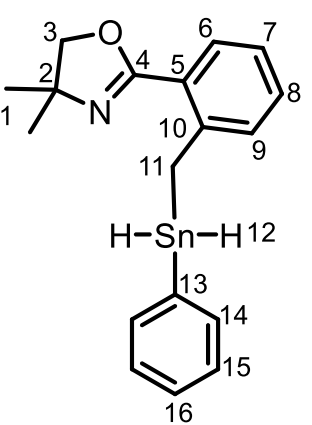

hexane hexane

Figure A56: ${ }^{13} \mathrm{C}$ NMR spectrum of 21 in $\mathrm{C}_{6} \mathrm{D}_{6} *$. 


\section{ๆ \\ ơं \\ 1 | 11}

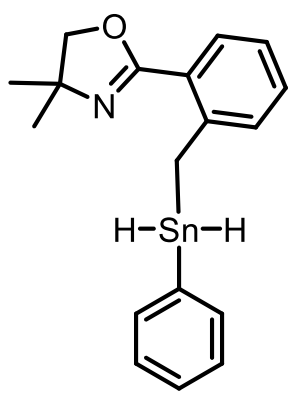

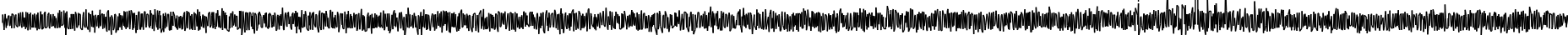

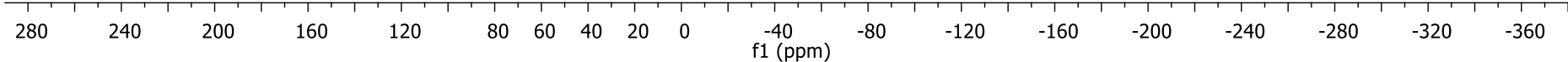

Figure A57: ${ }^{119} \mathrm{Sn}$ NMR spectrum of 21 in $\mathrm{C}_{6} \mathrm{D}_{6} *$. 


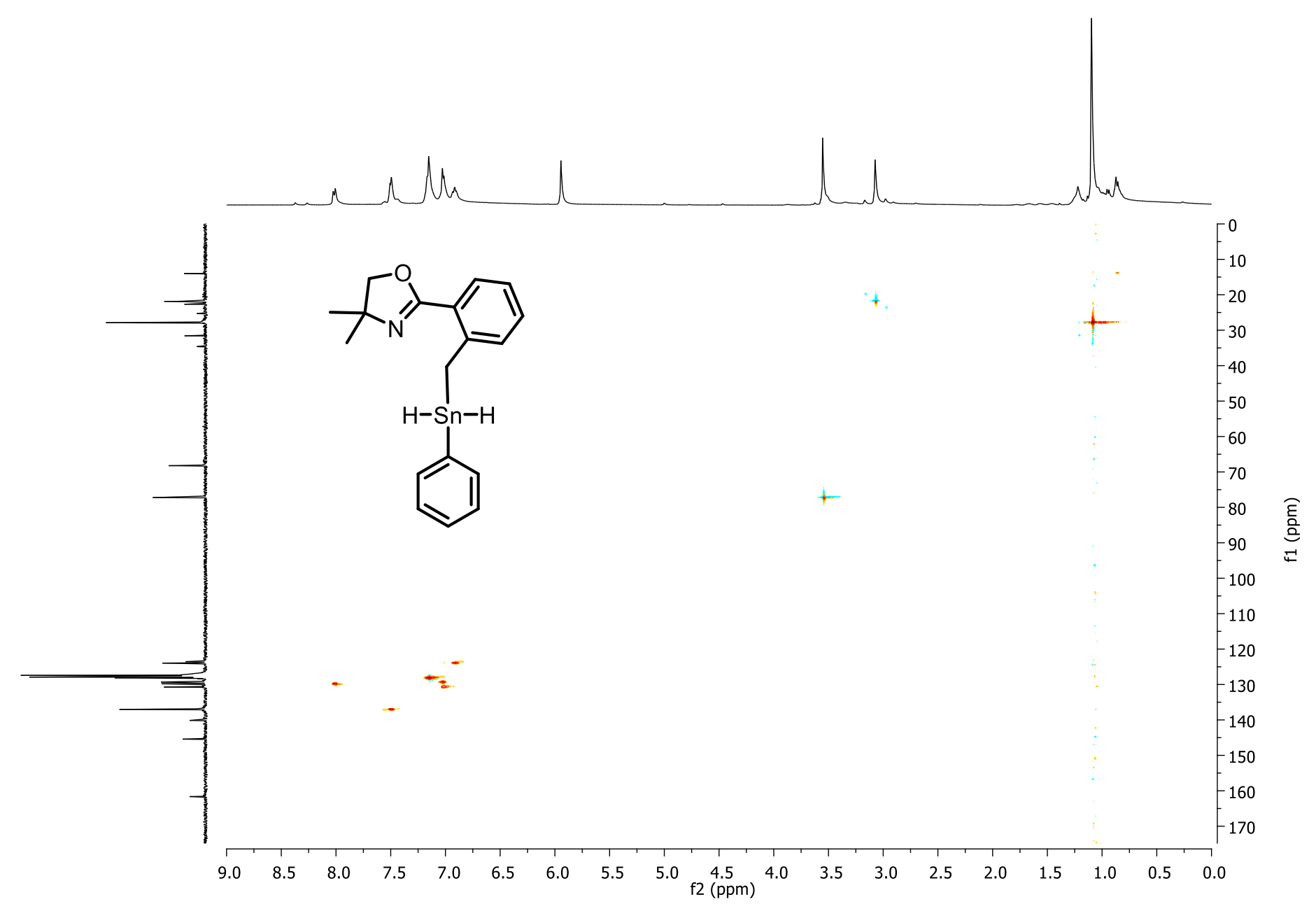

Figure A58: HSQC spectrum of 21 in $\mathrm{C}_{6} \mathrm{D}_{6}{ }^{*}$. 


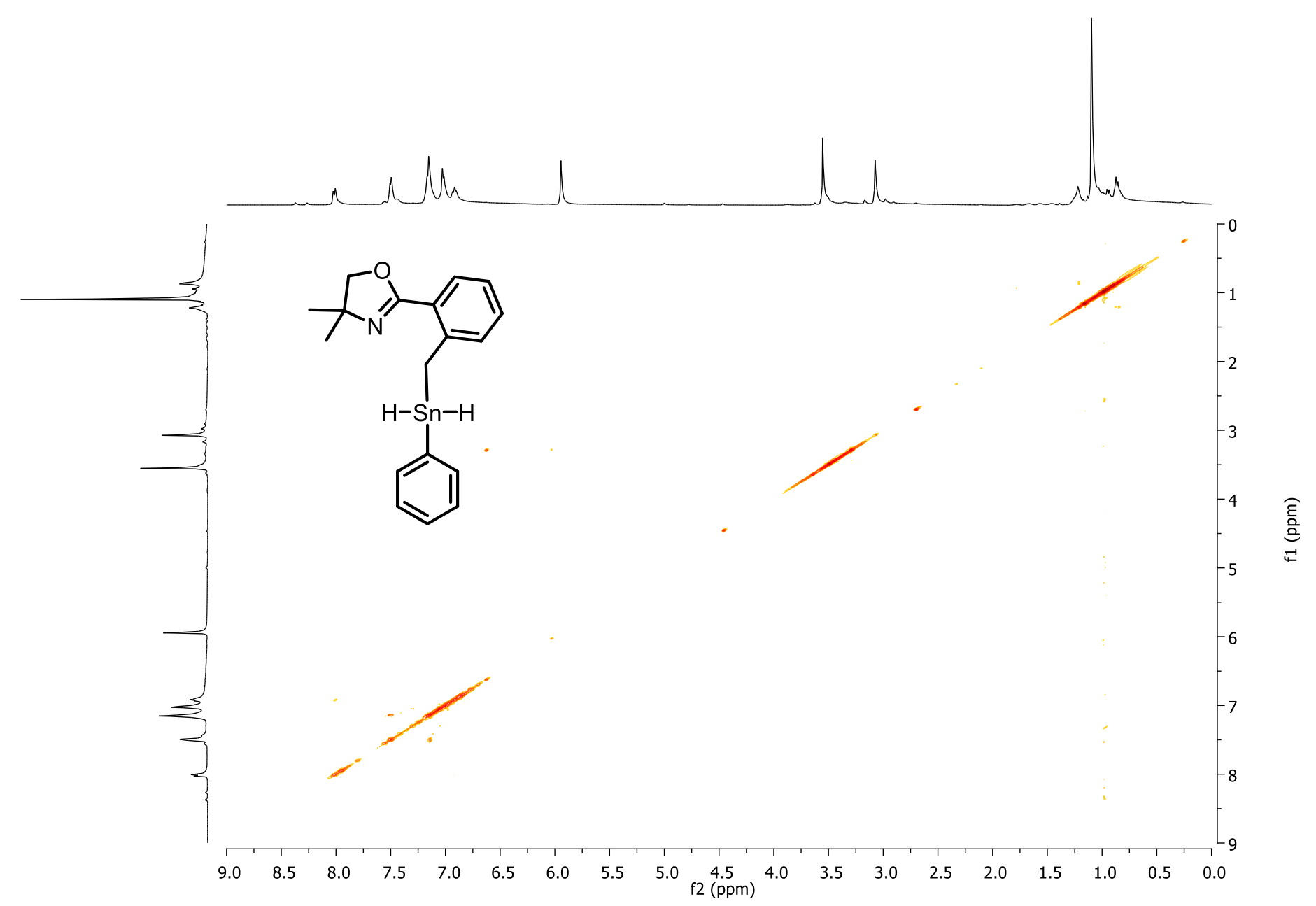

Figure A59: COSY spectrum of 21 in $\mathrm{C}_{6} \mathrm{D}_{6}{ }^{*}$. 


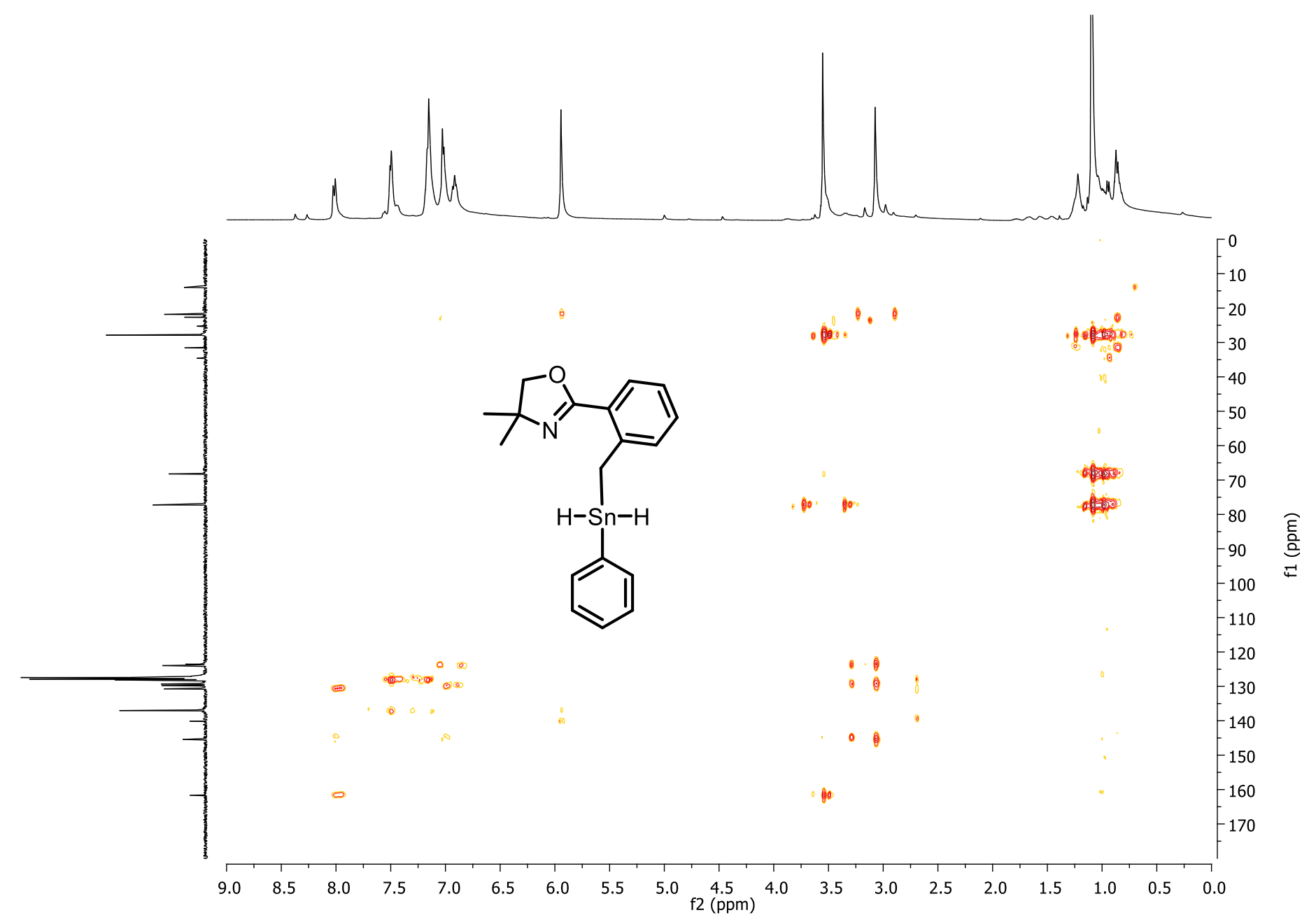

Figure A60: HMBC spectrum of 21 in $\mathrm{C}_{6} \mathrm{D}_{6} *$. 


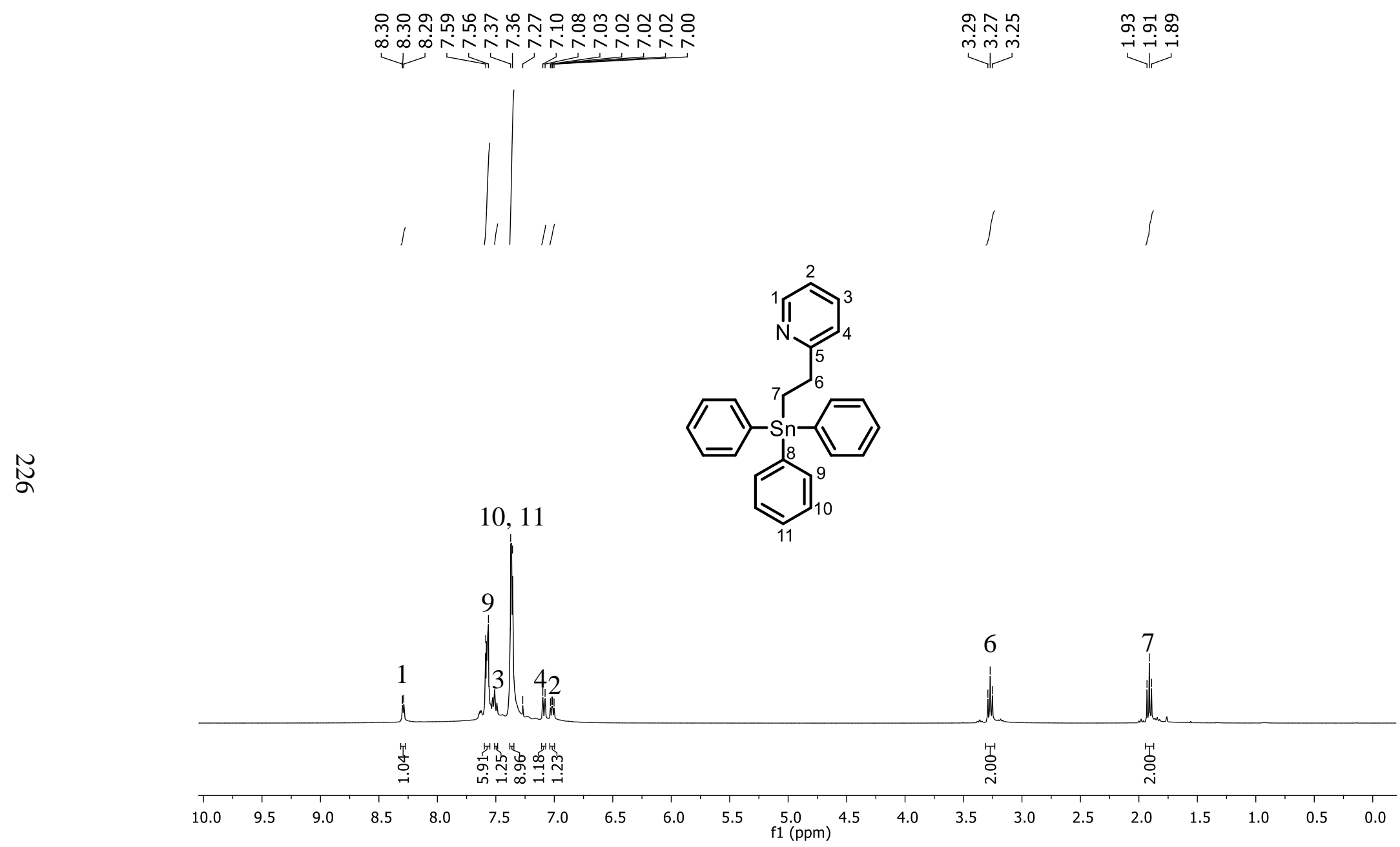

Figure A61: ${ }^{1} \mathrm{H}$ NMR spectrum of 23 in $\mathrm{CDCl}_{3}{ }^{*}$. 

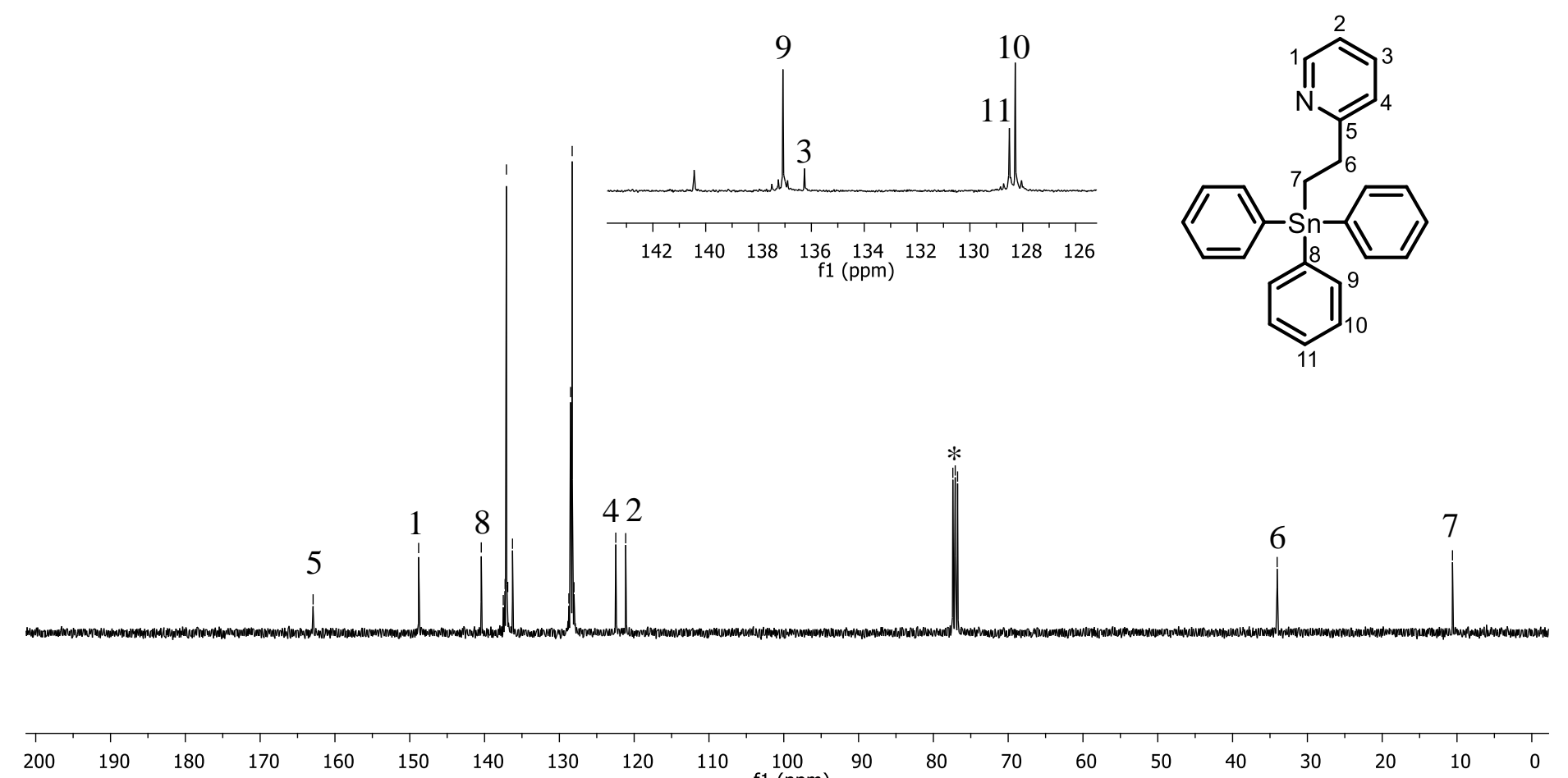

Figure A62: ${ }^{13} \mathrm{C}$ NMR spectrum of 23 in $\mathrm{CDCl}_{3}{ }^{*}$. 


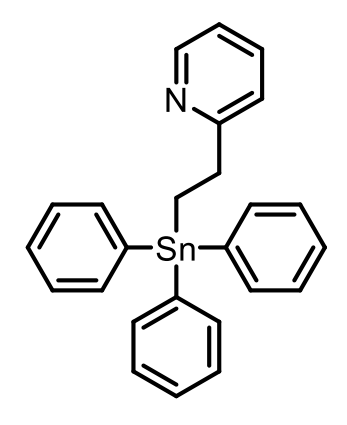

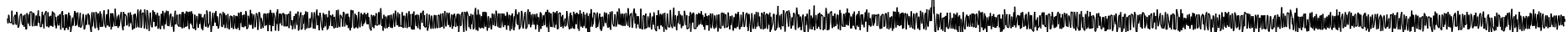

\begin{tabular}{lllllllllllllllllllll}
\hline 280 & 240 & 200 & 160 & 120 & 80 & 60 & 40 & 20 & 0 & -40 & -80 & -120 & -160 & -200 & -240 & -280 & -320 & -360
\end{tabular}

Figure A63: ${ }^{119} \mathrm{Sn} \mathrm{NMR}$ spectrum of 23 in $\mathrm{CDCl}_{3} *$. 


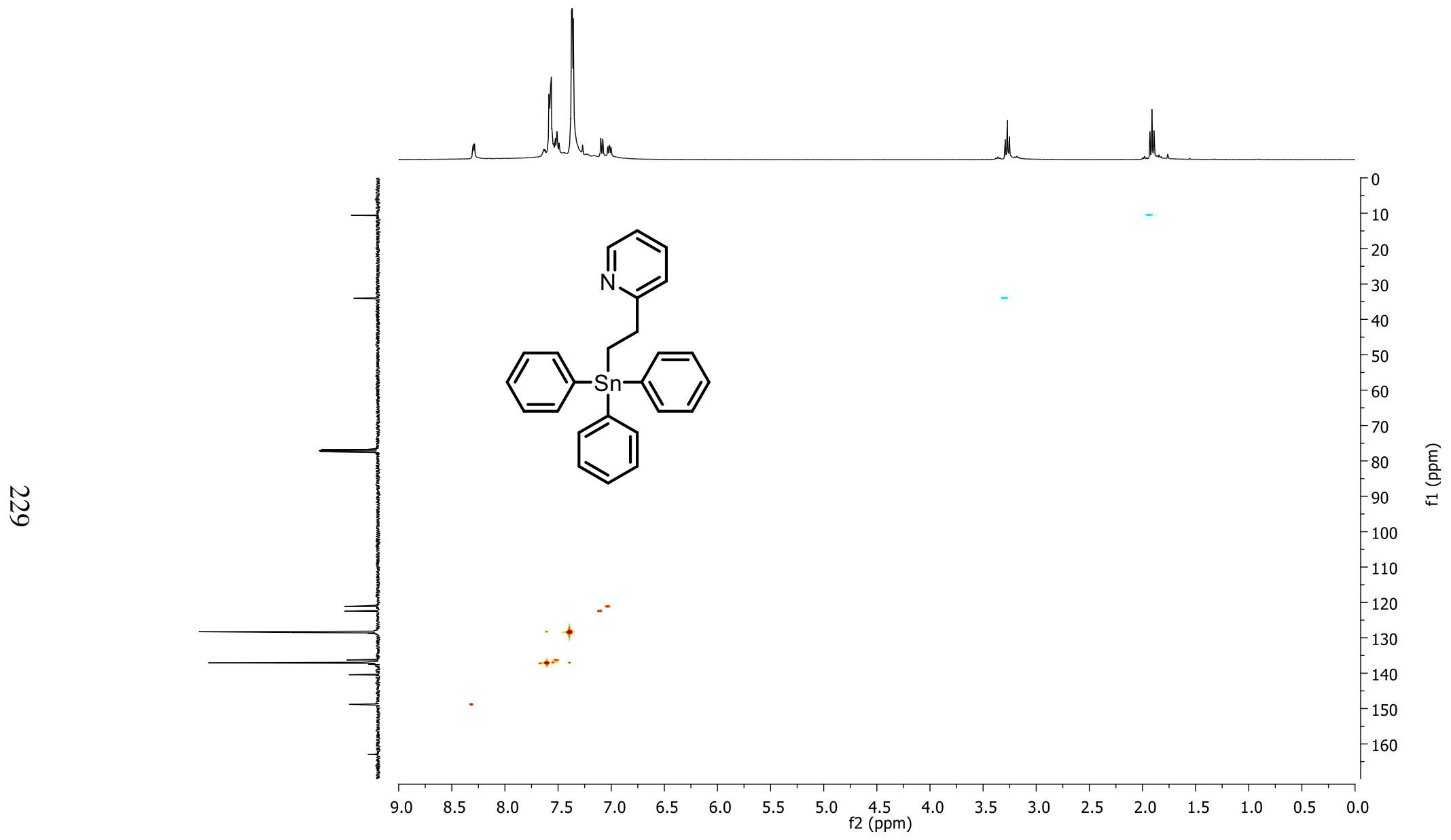

Figure A64: HSQC spectrum of 23 in $\mathrm{CDCl}_{3}$ *. 


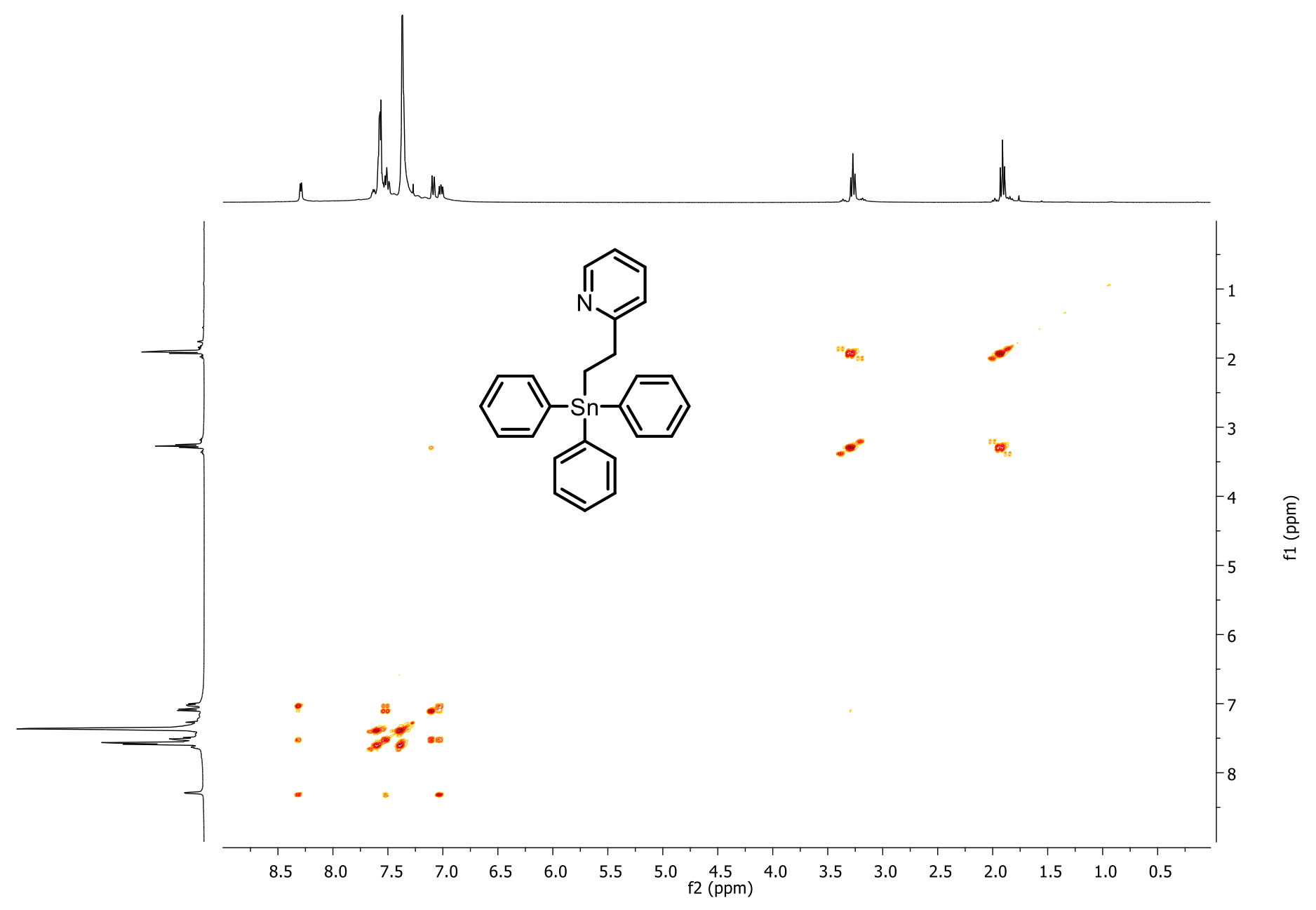

Figure A65: COSY spectrum of 23 in $\mathrm{CDCl}_{3} *$. 


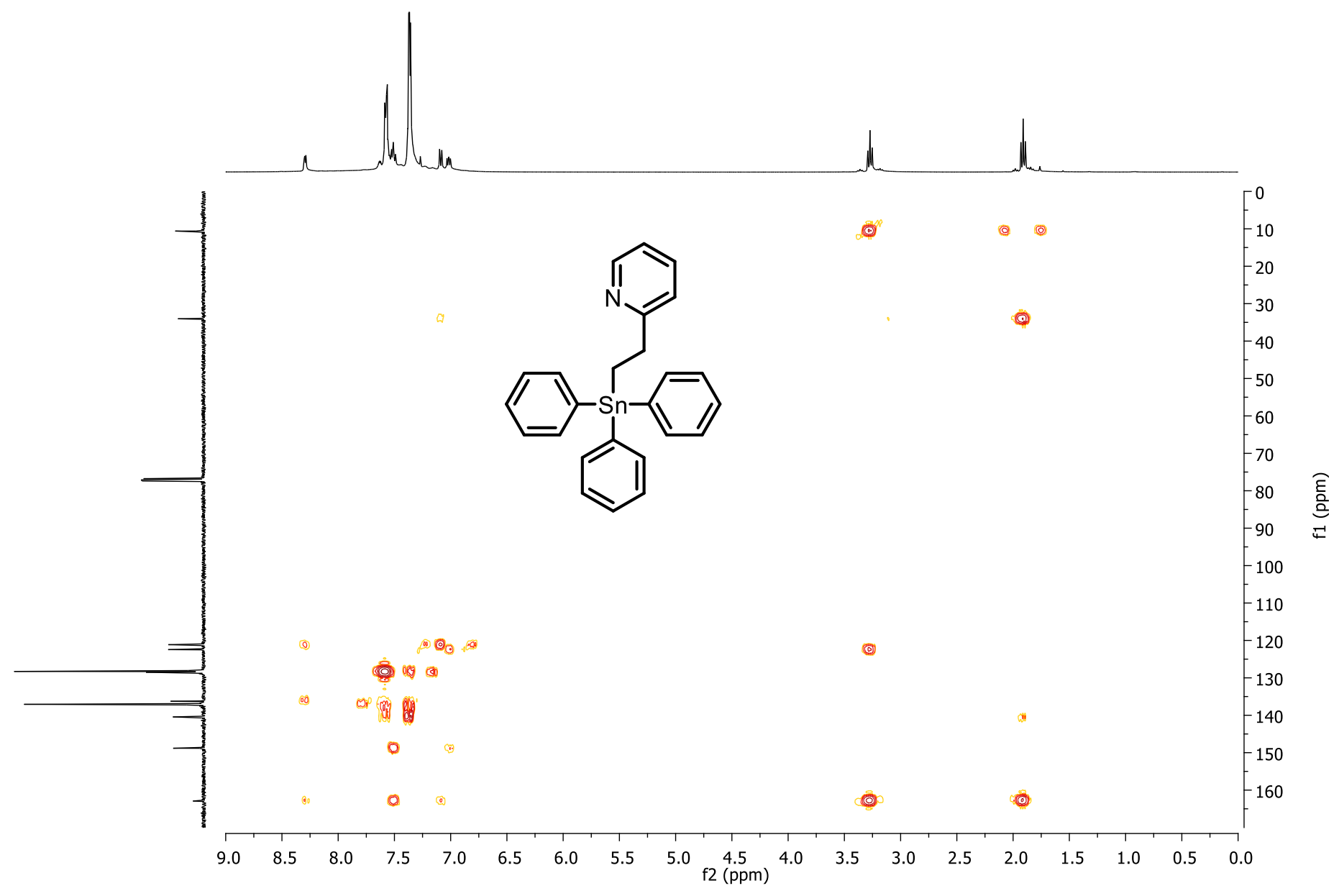

Figure A66: $\mathrm{HMBC}$ spectrum of 23 in $\mathrm{CDCl}_{3} *$. 
눔

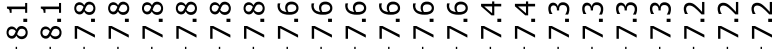

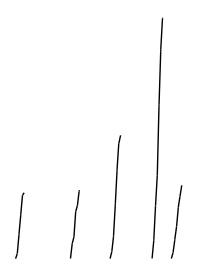

N

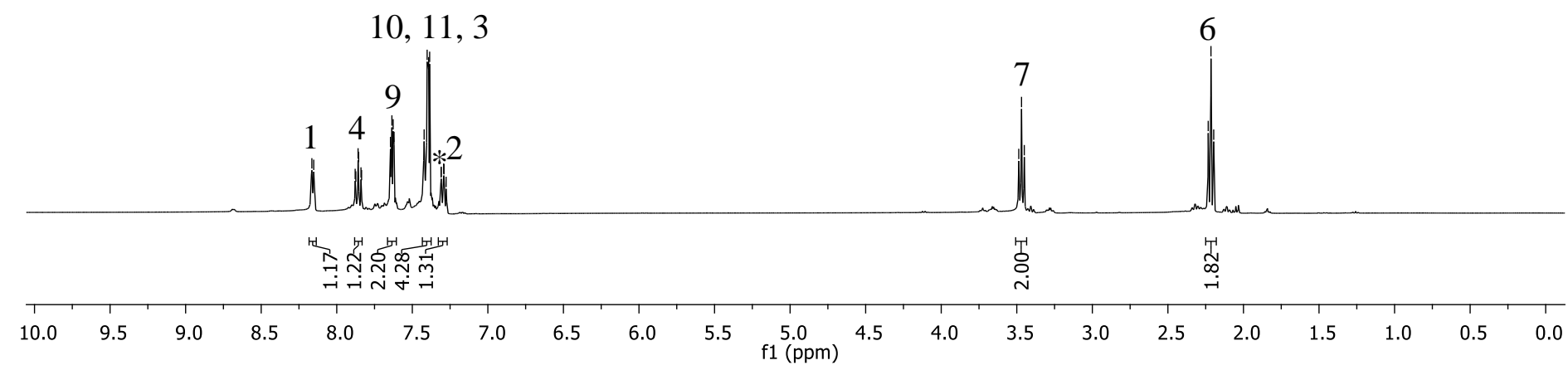

Figure A67: ${ }^{1} \mathrm{H}$ NMR spectrum of 24 in $\mathrm{CDCl}_{3}{ }^{*}$. 


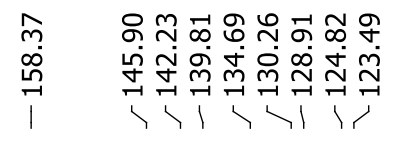

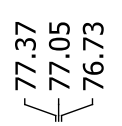
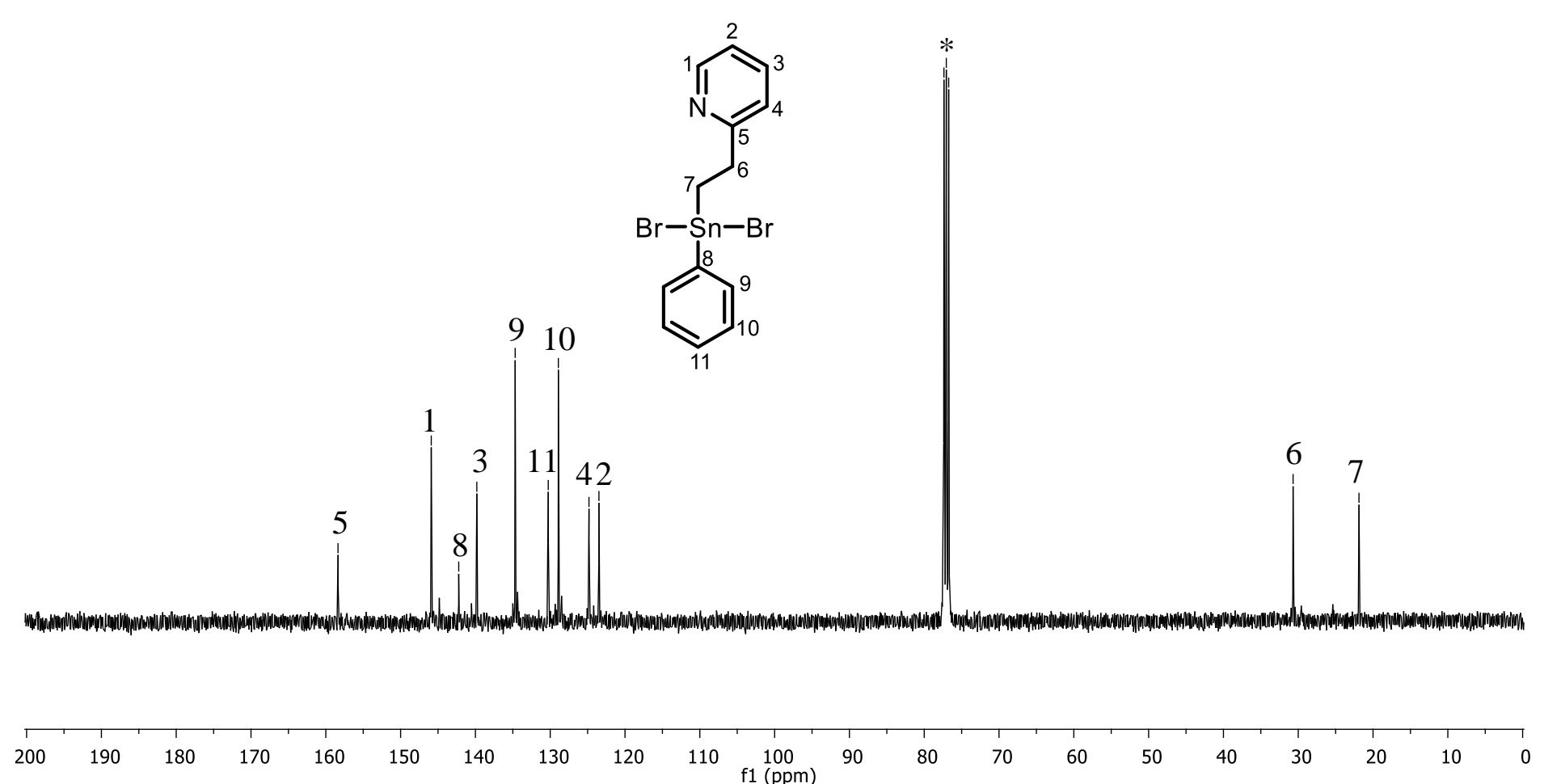

Figure A68: ${ }^{13} \mathrm{C}$ NMR spectrum of 24 in $\mathrm{CDCl}_{3} *$. 


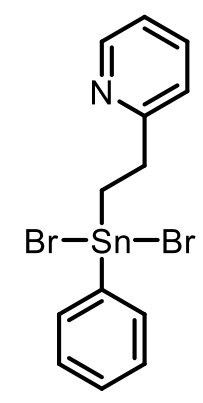

Figure A69: ${ }^{119} \mathrm{Sn} \mathrm{NMR}$ spectrum of 24 in $\mathrm{CDCl}_{3}{ }^{*}$. 


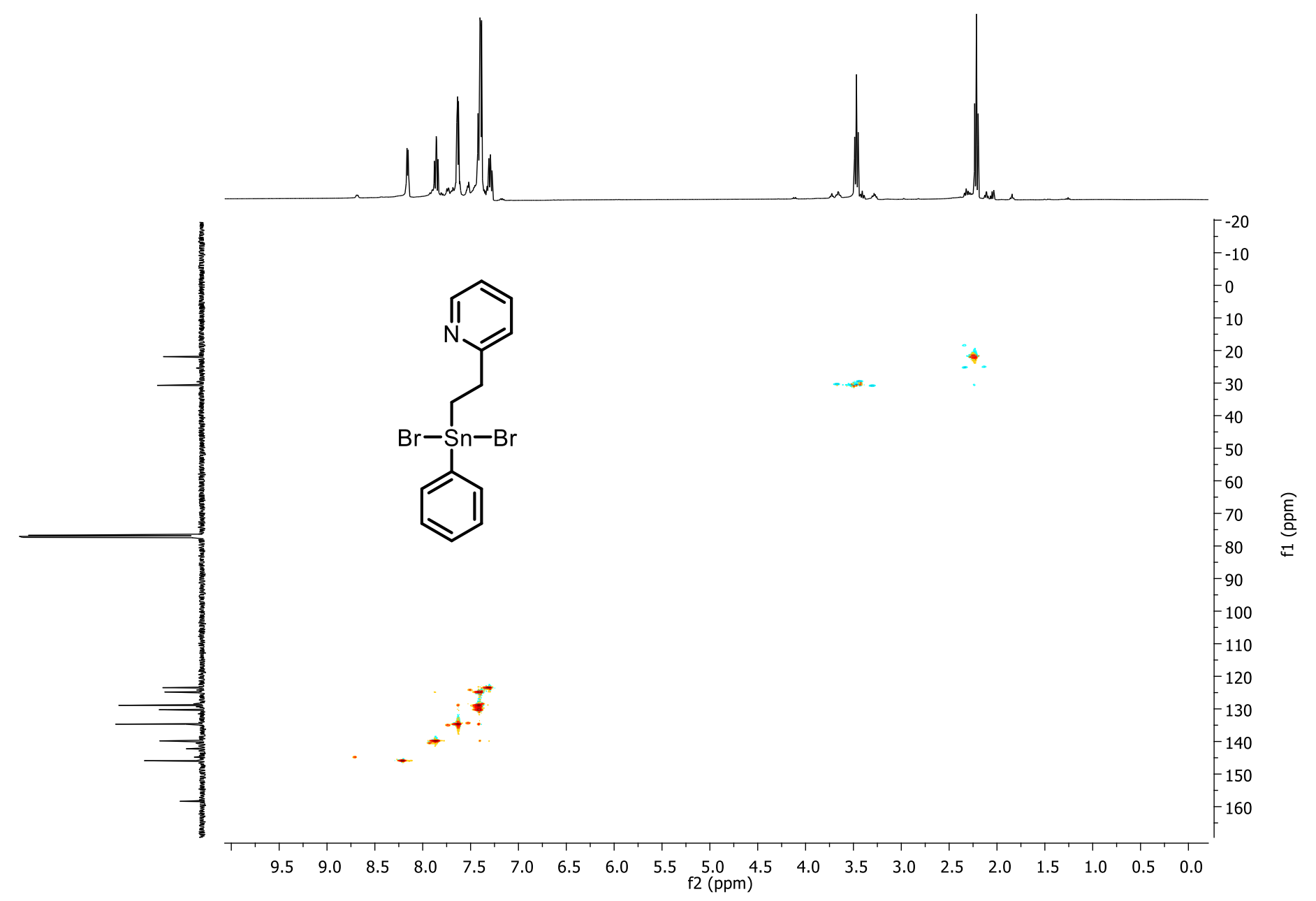

Figure A70: HSQC spectrum of 24 in $\mathrm{CDCl}_{3} *$. 


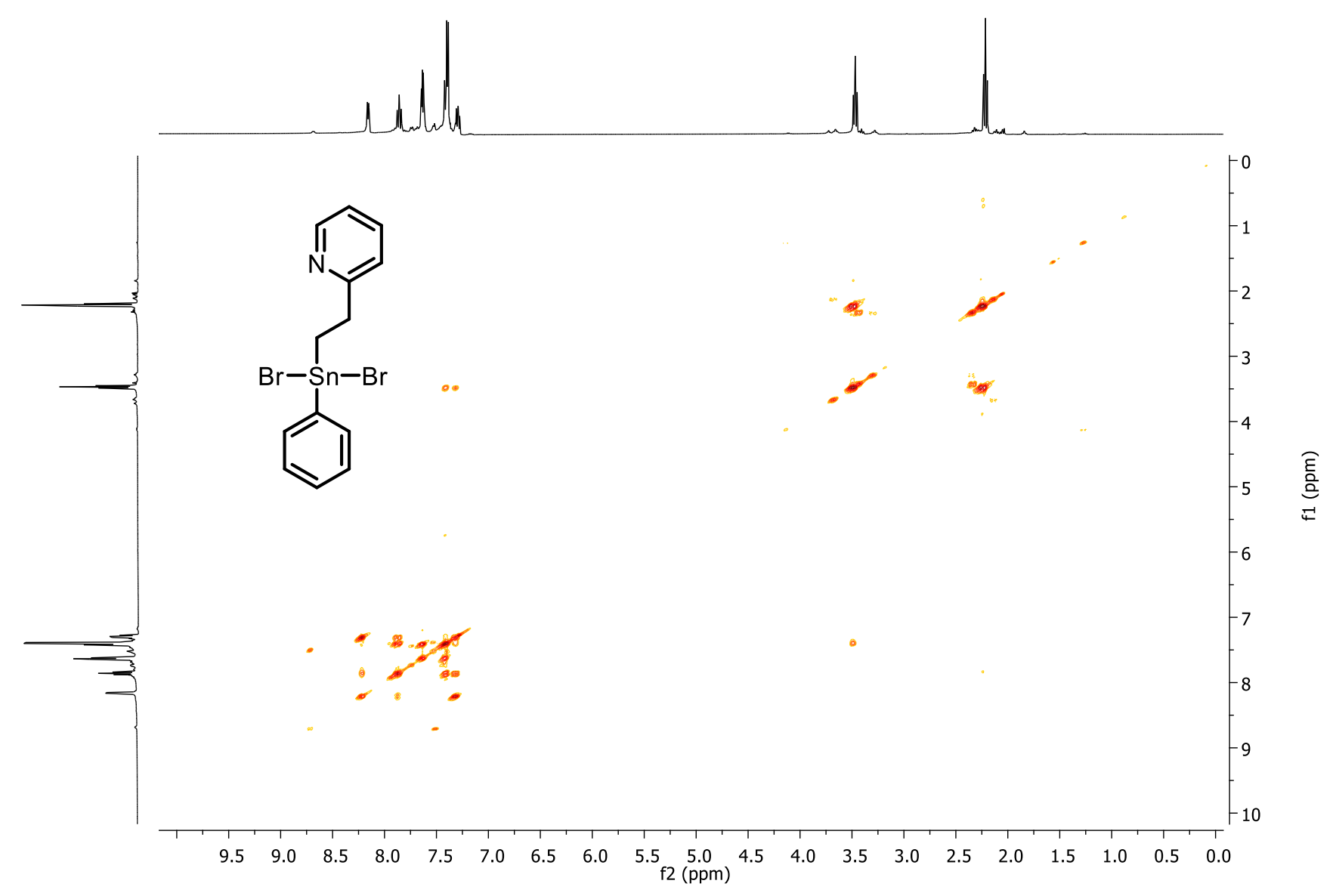

Figure A71: COSY spectrum of 24 in $\mathrm{CDCl}_{3} *$. 


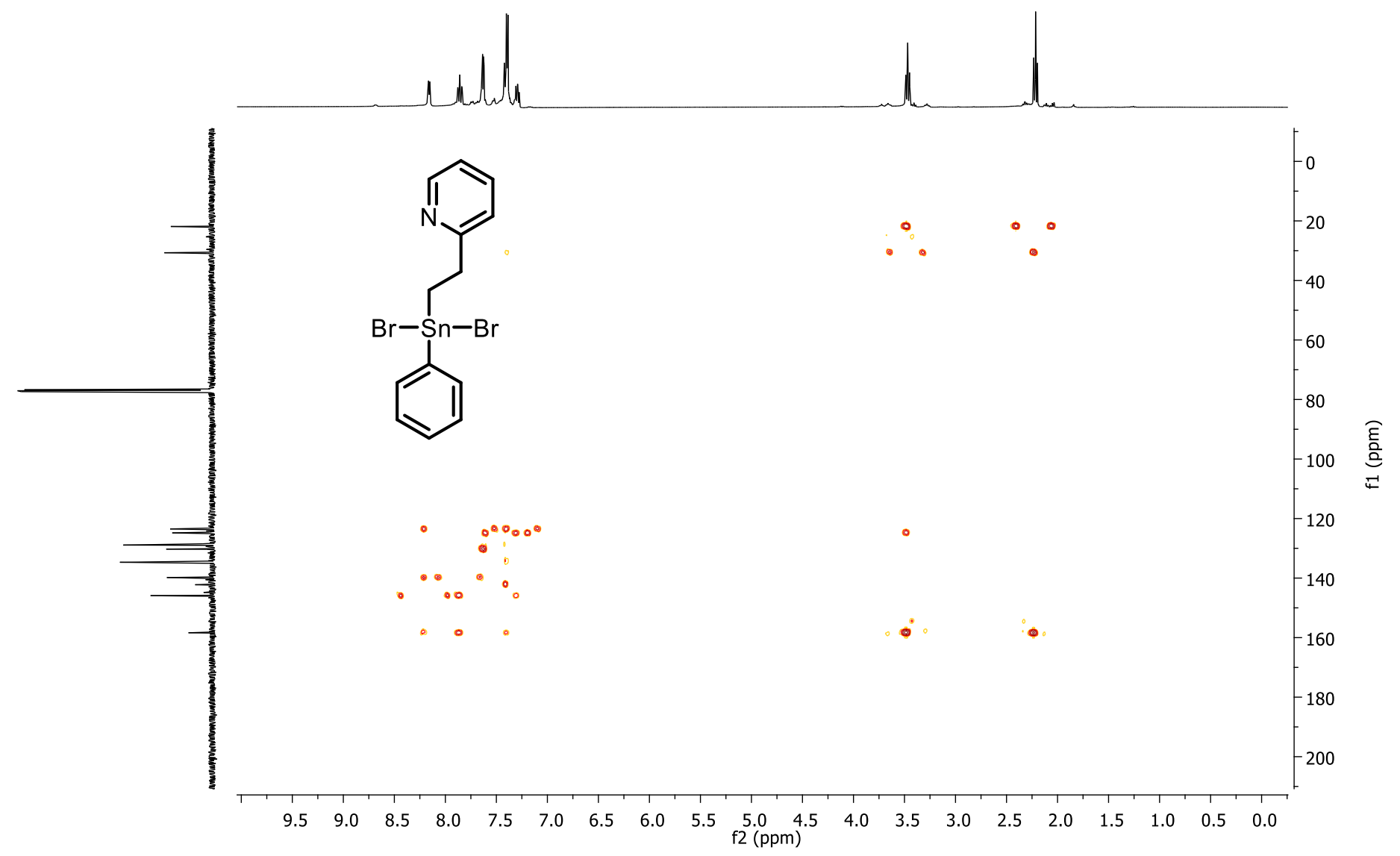

Figure A72: $\mathrm{HMBC}$ spectrum of $\mathbf{2 4}$ in $\mathrm{CDCl}_{3} *$. 